\title{
A GARANTIA INSTITUCIONAL DO MINISTÉRIO PÚBLICO EM FUNÇÃO DA PROTEÇÃO DOS DIREITOS HUMANOS
}

TESE DE DOUTORADO

Orientador: Prof. Titular Fábio Konder Comparato

FACULDADE DE DIREITO DA UNIVERSIDADE DE SÃO PAULO SÃO PAULO 2010 


\section{A GARANTIA INSTITUCIONAL DO MINISTÉRIO PÚBLICO EM FUNÇÃO DA PROTEÇÃO DOS DIREITOS HUMANOS}

Tese de Doutorado apresentada à Banca Examinadora da Faculdade de Direito da Universidade de São Paulo, como exigência parcial para a obtenção do título de Doutor em Direito, sob orientação do Prof. Titular Fábio Konder Comparato

FACULDADE DE DIREITO DA UNIVERSIDADE DE SÃO PAULO SÃO PAULO 


\section{RESUMO}

Esta tese volta-se à análise crítica da garantia institucional de independência do Ministério Público brasileiro sob dois aspectos: de um lado, a sua independência em relação às esferas organizacionais dos poderes clássicos do Estado; e, de outro, os limites da independência funcional que visa a assegurar, para os seus membros, o livre desenvolvimento das funções institucionais. Sob o influxo do processo de reconhecimento universal dos direitos humanos a partir da Declaração de 1948, o valor da dignidade da pessoa humana representa o fundamento central do Estado Democrático de Direito da Constituição Federal de 1988, constituindo a fonte jurídica do vasto conjunto de direitos fundamentais dela constante. A proteção dos direitos fundamentais da pessoa humana é indissociável de um regime político democrático, que não pode prescindir de um sistema eficaz de controle do exercício do poder político para a persecução de tal desiderato. Daí a importância da efetividade dos mecanismos de controle recíproco entre os órgãos estatais, no comando do princípio fundamental projetado por Montesquieu que, atualmente, não mais se reduz à formula tríplice de distribuição das funções legislativa, executiva e judicial. É nesse contexto que se pretende introduzir a análise da garantia institucional de independência do Ministério Público, à luz, especificamente, de determinadas funções que lhe foram atribuídas para o controle de decisões de outros órgãos estatais, sobretudo do Executivo, envolvendo a tutela dos direitos fundamentais de proteção da dignidade da pessoa humana. A hipótese é a da existência de aspectos organizacionais condicionando o funcionamento do Ministério Público em dissonância de sua plena afirmação como novo ator político; quais sejam: a) a ausência de limites precisos à garantia de independência funcional no desenvolvimento de suas atividades; b) um sistema autocrático de gestão orientando as decisões sobre todas as políticas institucionais; c) a manutenção dos vínculos que prendem a instituição ao Executivo do Estado, concebido como o ramo hegemônico do regime político brasileiro. O trabalho pretende investigar as causas das incorreções, correlacioná-las e apontar os seus equívocos, para a identificação dos pontos relevantes sujeitos a uma pronta alteração de cunho organizacional, de modo a serem reproduzidos no funcionamento do Ministério Público brasileiro os valores republicanos e democráticos que devem informar um regime político como Estado Democrático de Direito.

Unitermos: Ministério Público - princípio da dignidade da pessoa humana - direitos humanos - constituição - Estado Democrático de Direito - controle do poder político - princípio do controle recíproco entre os órgãos estatais - garantia institucional de independência 


\begin{abstract}
This thesis offers a critical analysis of the institutional guarantee of independence of the Brazilian Public Attorney's Office regarding two aspects: on one hand, its independence concerning the organizational spheres of the classical branches of the State; on the other hand, the limits of the functional independence that aims at securing free development of the institutional functions to the members of the Public Attorney's Office. Due to the process of universal acknowledgement of human rights since the Declaration of 1948 , the value of a human being's dignity represents the central basis of the Democratic Rule of Law of the 1988 Federal Constitution, establishing a legal source for the vast set of fundamental rights contained in it. The protection of the fundamental rights of a human being is intrinsic to a democratic political system, which cannot dispense with an efficient procedure to control the use of political power for pursuing such desideratum. Hence the importance of the efficiency of the mechanisms of checks and balances among state agencies, in carrying out the fundamental principle proposed by Montesquieu that is no longer limited nowadays to the triple distribution formula of legislative, executive and judiciary functions. It's in this context that the present work intends to introduce the analysis of the institutional guarantee of independence of the Public Attorney's Office, specifically examining certain functions attributed to it for the control over decisions by other state agencies, particularly in the executive branch, that involve the safeguarding of the fundamental rights of protection of a human being's dignity. The hypothesis is the existence of organizational aspects stipulating the operation of the Public Attorney's Office in discordance with its full role as new political agent, such as: a) absence of precise limits to guarantee functional independence in the development of its activities; b) an autocratic ruling system guiding decisions on all institutional policies; c) maintenance of the bonds linking the institution to the executive branch, which is conceived as the hegemonic branch of Brazil's political system. This work intends to investigate the causes of those problems, correlate them and pinpoint mistakes, in order to identify the relevant points that would be subject to a swift alteration in terms of organization, so the republican, democratic values that ought to conduct a political regime as a Democratic Rule of Law may be reproduced in the operations of the Brazilian Public Attorney's Office.
\end{abstract}

Keywords: Public Attorney's Office - principle of a human being's dignity - human rights - constitution - Democratic Rule of Law - control of political power principle of checks and balances among state agencies - institutional guarantee of independence 


\section{RÉSUMÉ}

Cette thèse est dirigée vers l'analyse critique de la garantie institutionnelle de l'indépendance du Ministère Public brésilien sous deux aspects: d'une part, son indépendance par rapport aux sphères organisationnelles des pouvoirs classiques de l'État, et d'autre part, les limites de l'indépendance fonctionnelle qui tend à assurer pour ses membres le libre développement des fonctions institutionnelles. Sous l'influx du processus de reconnaissance universelle des droits humains à partir de la Déclaration de 1948, la valeur de la dignité de la personne humaine représente le fondement central de l'État Démocratique de Droit de la Constitution Fédérale de 1988, constituant la source juridique du vaste ensemble de droits fondamentaux présents en elle. La protection des droits fondamentaux de la personne humaine est indissociable d'un régime politique démocratique qui ne peut pas renoncer à un système efficace de contrôle de l'exercice du pouvoir politique pour l'accomplissement d'un tel desideratum. De là l'importance de l'effectivité des mécanismes de contrôle réciproque entre les entités de l'état dans l'emploi du principe fondamental projeté par Montesquieu, qui à présent ne se réduit plus à la triple formule de distribution des fonctions législative, exécutive et judiciaire. C'est dans ce contexte qu'on prétend introduire l'analyse de la garantie institutionnelle de l'indépendance du Ministère Public sous la lumière, plus spécifiquement, de quelques fonctions lui ont été attribuées pour le contrôle de décisions d'autres entités de l'état, surtout de l'Exécutive, entraînant la tutelle des droits fondamentaux de protection de la dignité de la personne humaine. L'hypothèse est celle de l'existence d'aspects organisationnels qui conditionnent le fonctionnement du Ministère Public en dissonance avec sa pleine affirmation comme nouvel acteur politique, c'est à dire: a) l'absence de limites précises pour la garantie d'indépendance fonctionnelle dans le développement de ses activités; b) un système autocratique de gestion qui oriente les décisions de toutes les politiques institutionnelles; c) la manutention des liens qui attachent l'institution à l'Exécutive de l'État, conçu comme la branche hégémonique du régime politique brésilien. Le travail a l'intention d'investiguer les causes des incorrections, établir une relation entre elles, et indiquer leurs équivoques, pour identifier les points importants qui peuvent être soumises à une immédiate modification organisationnelle, de façon à reproduire dans le fonctionnement du Ministère Public brésilien les valeurs républicaines et démocratiques qui doivent informer un régime politique comme État Démocratique de Droit.

Unitermes: Ministère Public - principe de la dignité de la personne humaine - droits humains - constitution - État Démocratique de Droit - contrôle du pouvoir politique - principe du contrôle réciproque entre les entités de l'état - garantie institutionnelle de l'indépendance 


\section{SUMÁRIO}

INTRODUÇÃOO 8

\section{CAPítulo I. A ORganizaÇão do PODER POlítico No ESTAdo MODERNO E TRÊS CONGÊNERES DO MINISTÉRIO PÚBLICO} BRASILEIRO

1.1. A proposta de Montesquieu ................................................................................ 18

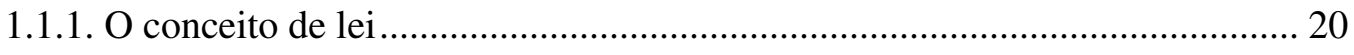

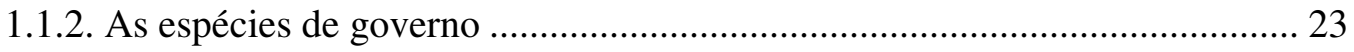

1.1.3. A teoria da liberdade política: a distribuição do poder estatal ..................... 29

1.2. A independência dos Estados Unidos da América: o marco do constitucionalismo moderno na origem do Attorney General ................................. 34

1.2.1. Os principais aspectos da figura do Attorney General .................................. 44

1.3. A Revolução Francesa e a Declaração dos Direitos do Homem e do Cidadão de 1789: o embrião do Estado-legislador na organização do Parquet.................... 49

1.3.1. Considerações gerais sobre o Parquet na França .......................................... 55

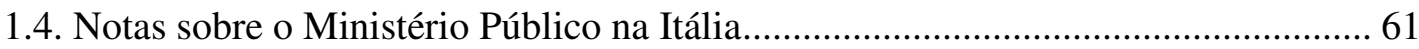

\section{CAPítulo II. O CENÁRIO de CONCENTRAÇÃo do PODER POLÍTICO NO} BRASIL E O PERCURSO HISTÓRICO DO MINISTÉRIO PÚBLICO .... 67

2.1. A formação do Estado patrimonial no Brasil colônia ................................................. 67

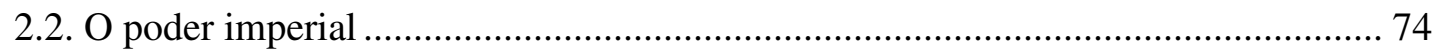

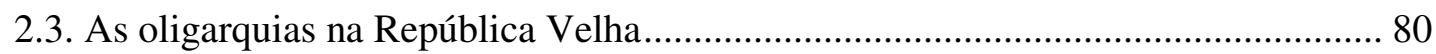

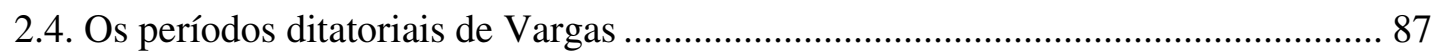

2.5. O efêmero período de um governo democrático....................................................... 97

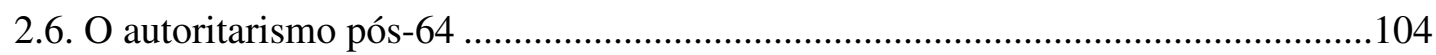

2.7. A fase de transição e a Constituinte de 1988 ............................................................110

CAPÍtUlo III. A CONSTITUIÇÃo FEDERAL DE 1998 NA DEFESA DOS DIREITOS FUNDAMENTAIS: O PAPEL DAS GARANTIAS INSTITUCIONAIS

3.1. A supremacia da vontade estatal na noção de direitos subjetivos 
3.1.1. O decisionismo de Carl Schmitt na definição de direitos fundamentais e o conceito de garantias institucionais

3.2. Os reflexos da Declaração Universal dos Direitos Humanos no constitucionalismo contemporâneo: o princípio da dignidade da pessoa humana

3.2.1. A redefinição do Estado de Direito

3.3. O Estado Democrático de Direito na Constituição de 1988: uma república democrática

3.3.1. As garantias institucionais no Estado Democrático de Direito: o princípio do controle recíproco entre os órgãos estatais.

\section{CAPÍTUlO IV. O MINISTÉRIO PÚBLICO NA CONSTITUIÇÃO FEDERAL DE 1988 COMO UM RAMO DO PODER POLÍTICO DO ESTADO}

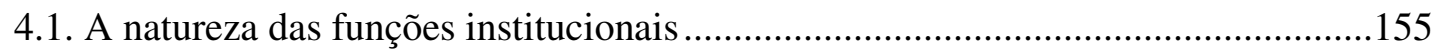

4.1.1. A repressão à criminalidade no Estado Democrático de Direito...................165

4.1.1.1. Os atos investigatórios.................................................................171

4.1.1.2. O controle externo da atividade policial ...........................................180

4.1.2. As características centrais do controle de constitucionalidade: uma breve apresentação de alguns mecanismos..................................................184

4.1.2.1. A inconstitucionalidade por ação .....................................................187

4.1.2.2. A inconstitucionalidade por omissão................................................189

4.1.2.3. A arguição de descumprimento de preceito fundamental.................192

4.1.2.4. A representação interventiva ...........................................................193

4.1.3. A afirmação de legítimo defensor dos interesses do povo e a ação civil pública

4.1.3.1. A essência do controle da legitimidade na gestão do patrimônio público

4.1.3.2. Considerações gerais sobre o controle das políticas públicas .........203

4.1.3.3. Notas sobre as políticas de ação afirmativa .....................................208

4.2. A organização do Ministério Público ......................................................................210

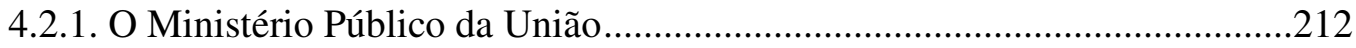

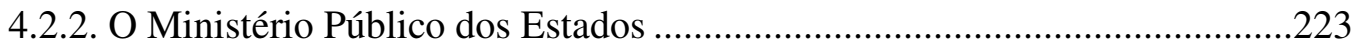

4.2.3. O Ministério Público Eleitoral..................................................................227

4.3. Os princípios da unidade, indivisibilidade e independência funcional...................228

4.3.1. Os corolários da inamovibilidade e do princípio do promotor natural ........231 
4.3.2. A construção de objetivos comuns: um desafio institucional do Ministério Público

\section{CAPÍtULO V. A INDEPENDÊNCIA DO MINISTÉRIO PÚBLICO E A REALIZAÇÃO DOS DIREITOS FUNDAMENTAIS NA} PERSPECTIVA DE UM REGIME POLÍTICO DEMOCRÁTICO

5.1. A garantia de independência funcional e a gestão democrática da instituição .......249

5.1.1. A democracia participativa e as decisões políticas institucionais ................252

5.1.2. O aprimoramento do sistema de representação democrática........................257

5.1.3. A legitimidade dos concursos públicos ....................................................263

5.1.3.1. Os concursos de ingresso ..........................................................266

5.1.3.2. Os concursos de movimentação nas carreiras ..................................269

5.1.2. O princípio democrático do controle recíproco entre os órgãos estatais e a garantia de independência funcional

5.2.1. A abrangência do sistema de incompatibilidades e o rompimento dos vínculos com o Executivo do Estado..........................................................281

5.2.2. A alteração da forma de escolha do Procurador-Geral................................28

5.2.3. A autonomia funcional, administrativa e financeira....................................291

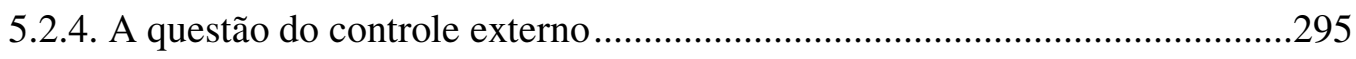

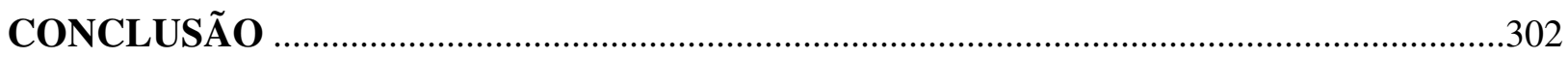

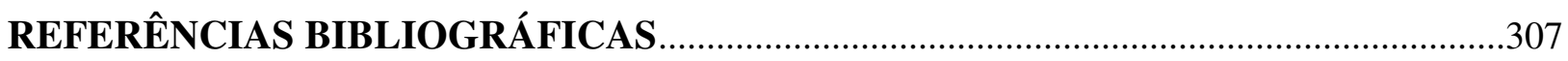




\section{INTRODUÇÃO}

À luz do sistema de proteção dos direitos humanos da Constituição Federal de 1988, o objetivo deste trabalho é investigar a organização e o funcionamento do Ministério Público sob dois aspectos: a análise crítica da garantia de sua independência em relação às esferas organizacionais dos poderes clássicos do Estado, de um lado; de outro, os limites do princípio de independência funcional, contemplado especificamente para assegurar o livre desenvolvimento de suas funções institucionais.

No atual cenário do constitucionalismo brasileiro, o Estado Democrático de Direito da República Federativa do Brasil funda-se no valor da dignidade da pessoa humana, que, além de alicerçar os seus objetivos essenciais, constitui a fonte jurídica de todos os direitos fundamentais da pessoa humana. Com a função de assegurá-los, o constituinte de 1988 explicitou algumas garantias institucionais como formas de organização e de atuação do Estado, certamente sobressaindo o princípio democrático do controle recíproco entre os órgãos que compõem a sua estrutura básica ${ }^{1}$.

Na qualidade de principal fundamento do Estado, o princípio da dignidade da pessoa humana é o vetor axiológico que deve dar sentido à organização e ao funcionamento das instituições estatais para a efetividade de um sistema de controle do exercício do poder político, que, caso esteja concentrado nas mãos de um só órgão ou pessoa, não condiz com processos decisórios tendentes à tutela dos direitos fundamentais da pessoa humana. E isso porque a função de controle social do Estado acaba incorporando a noção de domínio, afastando-se da ideia de uma incumbência que deve ocorrer em benefício de toda sociedade, em consideração a cada um de seus membros como partícipes de uma comunidade política. Há de sempre preponderar o princípio republicano que, em prol da união de todos em torno do bem comum, obriga o respeito incondicional à res publica por seus governantes. República e democracia andam juntas, com a atenção aos direitos humanos servindo de paradigma ao exercício da soberania popular. Impõe-se,

\footnotetext{
${ }^{1} \mathrm{O}$ art. $1^{\circ}$, III, da $\mathrm{CF}$, consagrou o princípio da dignidade da pessoa humana como um dos fundamentos do Estado, cujos objetivos consistem na construção de uma sociedade livre, justa e solidária; na garantia do desenvolvimento nacional; na erradicação da pobreza, da marginalização e da redução das desigualdades sociais e regionais; e na promoção do bem de todos, sem preconceitos de origem, raça, sexo, cor, idade e quaisquer outras formas de discriminação (art. $3^{\circ}$, I a IV, da CF). Não obstante tenha sido positivado em termos da clássica divisão tríplice, o princípio do controle recíproco entre os órgãos estatais está assegurado na norma do art. $2^{\circ}$, da $\mathrm{CF}$, como um dos princípios fundamentais do regime político brasileiro.
} 
portanto, um funcionamento eficaz dos instrumentos de controle do exercício do poder político no âmbito da estrutura organizacional do Estado Democrático de Direito, o que depende da real aptidão das instituições colocadas ao alcance de tal desiderato.

Enquanto instituição permanente e essencial à função jurisdicional do Estado, ao Ministério Público foi atribuída a defesa das mais relevantes densificações do princípio fundamental de proteção à dignidade humana, sob a égide das garantias institucionais da unidade, indivisibilidade e independência funcional. A natureza de uma instituição encarregada da defesa da ordem jurídica, do regime democrático e dos interesses sociais e individuais indisponíveis, aliada ao conjunto de suas funções constitucionais, revela o papel de corresponsável pelo exercício do poder político, especialmente a se ter em conta a ação de controle que lhe compete executar sobre algumas decisões de outros órgãos estatais no âmbito de tutela daquele princípio fundamental ${ }^{2}$. A noção de um órgão uno, indivisível e independente encarregado de relevantes funções de controle do exercício do poder político do Estado Democrático de Direito, com a atuação de cada um de seus membros amparada pela garantia de independência funcional, propõe repensar o Ministério Público em suas relações de reciprocidade com os demais órgãos estatais, também sugerindo a reflexão sobre os limites dessa garantia para agregá-la à ideia de responsabilidade no cumprimento de deveres de absoluta supremacia.

Nesse sentido, o trabalho pretende investigar a existência de fatores na estrutura organizacional e no funcionamento do Ministério Público dissonantes de sua plena afirmação como um novo ator político; quais sejam: a) a ausência de limites precisos à garantia de independência funcional no desenvolvimento de suas atividades, dissociando-a dos princípios da unidade e indivisibilidade; b) um sistema autocrático de gestão orientando as decisões sobre todas as políticas institucionais; c) a manutenção dos vínculos

\footnotetext{
${ }^{2} \mathrm{O}$ art. 127, caput, da CF, conceituou o Ministério Público como instituição permanente e essencial à função jurisdicional do Estado, encarregada da defesa da ordem jurídica, do regime democrático e dos interesses sociais e individuais indisponíveis. Os princípios da unidade, indivisibilidade e independência funcional foram expressamente contemplados como princípios institucionais do Ministério Público (art. 127, $\S 1^{\circ}$, da $\mathrm{CF}$ ). Ainda segundo a Constituição, ao Ministério Público cabe, privativamente, a promoção da ação penal e o exercício do controle externo da atividade policial; o zelo pelo efetivo respeito dos poderes públicos e dos serviços de relevância pública aos direitos assegurados na Constituição; a proteção do patrimônio público e social, do meio ambiente e de outros interesses difusos e coletivos, mediante a utilização da garantia da ação civil pública; a promoção da ação de inconstitucionalidade e da representação para fins de intervenção da União nos Estados; e a defesa judicial dos direitos e interesses das populações indígenas, além de outras atividades afins. No desenvolvimento de suas funções institucionais, a Constituição assegurou ao Ministério Público a possibilidade de expedição de notificações nos procedimentos administrativos de sua competência; a requisição de informações e documentos para instruí-los; e a requisição de diligências investigatórias e de instauração de inquérito policial, indicados os fundamentos jurídicos de suas manifestações (art. 129, I a IX, da CF).
} 
que prendem a instituição ao Executivo do Estado, concebido como o ramo hegemônico do regime político brasileiro.

Tendo em vista a natureza das funções do Ministério Público no âmbito do Estado Democrático de Direito da Constituição de 1988, para tratá-lo no comando do princípio fundamental do controle recíproco entre os órgãos estatais, revelou-se a necessidade de uma prévia abordagem histórica do reconhecimento dos direitos humanos no plano do constitucionalismo moderno e, em seguida, do constitucionalismo contemporâneo, cujos traços centrais repousam na introdução de uma variedade de princípios de justiça e de um amplo conjunto de direitos fundamentais da pessoa humana nos textos constitucionais da atualidade, sob o influxo da Declaração Universal de 1948.

Assim, não foi possível abrir mão da análise da evolução do sistema de proteção dos direitos humanos a partir dos movimentos revolucionários do século XVIII, quando a sua importância no interior das organizações políticas da era moderna ganhou contornos mais precisos com a fórmula de Montesquieu projetada para a preservação da liberdade individual. É com a exposição da doutrina desse autor que se dará início ao primeiro capítulo deste trabalho. Definida à luz das espécies de governo de Platão e Aristóteles, a engrenagem de distribuição do poder político projetada por Montesquieu corresponde à essência de um governo moderado, que traduz o equilíbrio gerado por diferentes forças políticas figurando na estrutura organizacional e no funcionamento do Estado. Daí a importância do papel dos corpos intermediários, além da dinâmica dos princípios de Montesquieu orientando a constituição e o funcionamento das sociedades estatais para colocá-las em movimento a serviço dos desígnios compartilhados por seus integrantes.

Ainda no primeiro capítulo, a atenção será dirigida aos movimentos revolucionários dos Estados Unidos da América e da França, que tiveram papéis decisivos na arquitetura de um sistema de proteção dos direitos humanos no plano do constitucionalismo moderno. Sob a influência de Rousseau, o constitucionalismo derivado da Revolução Francesa partiu da idealização do Estado-legislador, que acabou munindo-se de poderes mais vigorosos para a realização da vontade estatal, a despeito da solene proclamação do princípio da separação dos poderes na Declaração dos Direitos do Homem e do Cidadão de 1789. Ao contrário dos norte-americanos, a preocupação maior dos franceses foi a de firmar uma declaração de direitos humanos para elevá-la ao plano universal, mais do que discorrer sobre os instrumentos de controle do poder político que seriam capazes de assegurá-los de modo efetivo no interior das sociedades estatais. 
Firmaram-se, então, modelos diferenciados de organização e exercício do poder político, de que derivaram estruturas distintas de congêneres do Ministério Público brasileiro. Para fins de uma abordagem comparativa no decorrer do trabalho, a opção pela descrição dos principais aspectos dos sistemas do Attorney General dos Estados Unidos da América, do Parquet francês e do Ministério Público italiano deveu-se à inserção de cada qual em diferentes esferas da organização política dos respectivos Estados. A breve exposição da forma de funcionamento dos três sistemas pareceu necessária para demonstrar a conexão existente entre os fatores históricos que determinaram a formação de uma organização política e o universo jurídico-constitucional dispondo sobre o funcionamento de suas instituições.

A percepção das experiências pretéritas no curso da evolução da vida pública de uma comunidade política torna possível o olhar, nas palavras de Ortega y Gasset, para o que é "historicamente necessário"3. A natureza dinâmica que envolve qualquer sistema moldado para orientar o exercício do poder político em torno da tutela dos direitos fundamentais requer a compreensão de que hipóteses análogas nem sempre são capazes de produzir os mesmos resultados diante de cenários políticos distintos. E a reprodução de frutíferas experiências passadas pode gerar bons resultados frente à realidade do presente. É o que, aliás, não escapou à percepção de Montesquieu, para quem a observação das variações concomitantes dos fenômenos sociais foi de fundamental importância para o seu modelo de distribuição do poder político resultante na célebre fórmula tríplice.

Foram essas as premissas que determinaram o conteúdo do segundo capítulo deste trabalho, em atenção à evolução da vida pública brasileira, que, marcada por fortes aspectos oligárquicos e patrimonialistas, se caracterizou pela permanente concentração do poder político nas mãos do chefe do Executivo, não obstante a previsão do princípio do controle recíproco entre os órgãos estatais em todos os textos constitucionais, com ressalva apenas à Carta de 1937, no período ditatorial do Estado Novo. A possibilidade de alterações na estrutura e no funcionamento do Ministério Público depende, em larga medida, da apreensão das experiências vivenciadas pelas instituições estatais ao longo da História. A opção foi incluir o Ministério Público no cenário político brasileiro como um de seus elementos, de modo a priorizar a identificação da via que culminou na eclosão de

\footnotetext{
${ }^{3}$ ORTEGA Y GASSET, José. Obras completas. (1926-1931). Fundación José Ortega y Gasset, 2005. t. 4, p.
} 788. 
seu atual perfil constitucional, malgrado a manutenção de componentes cruciais prendendo-o, tal como outrora, à chefia do Executivo.

Por outro lado, como será visto no terceiro capítulo, durante todo o século XIX até meados do século XX, o desenvolvimento da teoria dos direitos humanos centrou-se no reconhecimento de direitos subjetivos no plano das organizações estatais. Não obstante o auspício de universalidade da Declaração dos Direitos do Homem e do Cidadão da Revolução Francesa, o predomínio foi de concessão dos direitos fundamentais derivada da vontade estatal, consoante permitirão depreender as breves considerações a respeito das doutrinas de Jellinek, Kelsen e Carl Schmitt. Sob a vigência da Constituição da República de Weimar (1919), este último jurista foi o primeiro a sistematizar a categoria das garantias institucionais no campo do constitucionalismo contemporâneo. Mas, ao fazê-lo, não vinculou os direitos fundamentais da pessoa humana a nenhuma forma de organização política apta a garanti-los.

Levando em conta a experiência do constitucionalismo estadunidense e do constitucionalismo francês, ficou sedimentada a possibilidade de duas abordagens divergentes em torno das garantias constitucionais dos direitos fundamentais da pessoa humana ${ }^{4}$. Sob a primeira perspectiva, de cunho liberal, resultou o condicionamento da atuação estatal, notadamente da produção legislativa, aos princípios concernentes aos direitos de liberdade, conaturais à pessoa humana. Ao Judiciário competiria a tarefa de assegurar a estabilidade dos fundamentos do Estado de Direito, freando os eventuais abusos dos outros órgãos. Já o modelo oriundo da experiência francesa realça a qualidade do poder constituinte como a fonte de legitimidade de toda produção constitucional. A defesa dos direitos fundamentais da pessoa humana não poderia depender do êxito de um equilíbrio formal e burocrático entre os órgãos estatais. Para a tutela das liberdades, seria preciso assegurar a permanente iniciativa popular capaz de permitir a renovação legislativa dos diplomas constitucionais e das declarações de direitos, de acordo com as exigências resultantes das progressivas transformações que permeiam as sociedades contemporâneas ${ }^{5}$.

A intenção é subverter qualquer dicotomia entre essas duas tendências, diante da concepção do Estado Democrático de Direito que resultou do processo de reconhecimento universal dos direitos humanos após a Declaração de 1948, por força da introdução do

\footnotetext{
${ }^{4}$ Cf. ZOLO, Danilo. Teoria e crítica do Estado de direito. In: COSTA, Pietro; ZOLO, Danilo (Orgs.). $O$ Estado de direito: história, teoria, critica. Tradução de Carlos Alberto Dastoli. São Paulo: Martins Fontes. 2006. p. 52 e ss.

${ }^{5}$ Id. Ibid., p. 57.
} 
princípio da dignidade da pessoa humana como fundamento do Estado nos principais textos constitucionais. Daí por que constitui um componente determinante na agenda constitucional da atualidade o funcionamento de um sistema eficaz de controle político nas organizações do Estado Democrático de Direito. Além do respeito à soberania popular condicionando a formação da vontade estatal para o advento de decisões políticas fundamentais, é imprescindível o funcionamento de um sistema de controle recíproco do exercício do poder político permeado pelo respectivo princípio fundamental para guiar as relações entre os órgãos estatais no âmbito de um regime político democrático.

É o contexto em que será incluído o exame do Ministério Público brasileiro, de sorte a estabelecer a condição de corresponsável pelo exercício do poder político do Estado, com a garantia institucional de independência figurando como uma proteção objetiva ou orgânica dos direitos fundamentais da pessoa humana. Nesse passo, terá início o quarto capítulo deste trabalho com a apresentação do Ministério Público na Constituição Federal de 1988. Desde logo, sobrelevou-se ressaltar a natureza de suas funções, que, reproduzindo a essência da instituição estatal, não permite afastá-la do conjunto dos direitos e garantias fundamentais declarados no ordenamento constitucional. Para confirmar a hipótese, haverá uma breve exposição das principais características das funções atribuídas ao Ministério Público, à luz dos instrumentos que foram destinados para assegurar o seu exercício.

$\mathrm{Na}$ qualidade de princípios organizacionais conformando o desenvolvimento das atividades da instituição, serão retratadas as garantias da unidade, indivisibilidade e independência funcional, com o fortalecimento desta última acentuado pelos princípios da inamovibilidade e do promotor natural ${ }^{6}$. No entanto, em dissonância de seu real papel na organização política brasileira, a noção dessas garantias institucionais subsiste atrelada aos imperativos de neutralidade, certeza e segurança forjados pelo positivismo jurídico com base no pressuposto da estrita legalidade formal. A intenção é enfatizar não ter sido incorporada a ideia de uma proteção objetiva relacionada à natureza das funções do Ministério Público, para o efeito de assegurar que elas sejam desenvolvidas na esteira dos bens e valores que constituem a essência da instituição estatal no Estado Democrático de

\footnotetext{
${ }^{6} \mathrm{~A}$ inamovibilidade, conjugada ao princípio do promotor natural, constitui desdobramento do princípio da independência funcional (art. 127, $\S 1^{\circ}, c / c$ o art. $128, \S 5^{\circ}, \mathrm{I}, b$, da $\mathrm{CF}$ ). São garantias da própria sociedade, como destinatária das funções institucionais, que determinam a sua distribuição entre as carreiras, setores e membros do Ministério Público na conformidade com regras preestabelecidas segundo critérios objetivos pautados pela matriz da impessoalidade. O princípio do promotor natural encontra ainda direta ressonância na garantia fundamental do devido processo legal, considerando as diretrizes centrais que servem para orientá-la (art. 5 XXXV, XXXVII, LIII e LIV, da CF).
} 
Direito da Constituição de 1988. É o que se entende alimentar, ao longo dos anos, a existência de uma estrutura organizacional estática e pouco flexível, de acentuado isolamento, em que desaparecem os canais de comunicação entre os integrantes das carreiras, inibindo a consolidação de projetos institucionais que reflitam objetivos comuns e, por conseguinte, apresentem aptidão para satisfazer as exigências decorrentes de uma atuação de controle do poder político. É a noção de telos envolvendo a garantia de independência funcional que permitiria efetivá-la em harmonia com a realização dos princípios da unidade e indivisibilidade, que, de idêntico modo, também deveriam conduzir o funcionamento da instituição.

A situação convive, em contrapartida, com um sistema autocrático de gestão que impera para determinar todas as decisões versando sobre as políticas institucionais do Ministério Público. Emanam dos órgãos da administração superior, que são integrados por agentes que oficiam junto aos tribunais, todas as decisões de cunho organizacional que orientam o seu funcionamento. $\mathrm{O}$ âmbito de incidência da garantia de independência funcional, sob os corolários da inamovibilidade e do princípio do promotor natural, costuma ser bastante comprometido, inclusive com o respaldo em permissivos contidos nos estatutos de organização das carreiras, sem em nada contribuir para a eficácia dos postulados de unidade e indivisibilidade no desenvolvimento das funções institucionais. $\mathrm{O}$ aparato gera um funcionamento de enorme ambiguidade, que acaba robustecendo sobremaneira os vínculos que, historicamente, ligam o Ministério Público ao Executivo do Estado, cujas funções são o alvo precípuo de suas atividades de limitação do poder político para a tutela do conjunto dos direitos fundamentais da pessoa humana.

Não é objeto da tese a projeção de mecanismos de controle externo de aplicação direta sobre o desenvolvimento das atividades-fins do Ministério Público ${ }^{7}$. Também não se pretende discorrer sobre formas de controle interno, como as que já se estabelecem na

\footnotetext{
${ }^{7}$ Sob essa ótica, é de considerar hipóteses como a da garantia fundamental da ação privada substitutiva, atenuando o monopólio da instituição para as decisões de exercício do ius puniendi (art. $5^{\circ}$, LIX, da CF), ou mesmo a possibilidade de extensão da legitimidade ativa para a propositura da ação de improbidade administrativa para o cidadão, tendo em conta a consonância com o conteúdo da garantia da ação popular constitucional. Cf. o art. $5^{\circ}$, LXXIII, da CF, e a Lei de 8.429, de 2.6.1992, que dispõe sobre as sanções aplicáveis aos agentes públicos nos casos de enriquecimento ilícito no exercício de mandato, cargo, emprego ou função na administração pública direta, indireta ou fundacional. Em cumprimento ao disposto no ordenamento constitucional, culminando severas sanções para os seus responsáveis por atos de improbidade administrativa (art. 37, $\S 4^{\circ}$, da CF), a Lei 8.429/92 atribuiu ao Ministério Público e à pessoa jurídica afetada pelos atos de improbidade administrativa a titularidade da ação civil contra os responsáveis (art. 17). Sob o princípio republicano que, juntamente com o da soberania popular, orienta a garantia fundamental da ação popular, o sistema jurídico de punição da improbidade administrativa poderia ser profundamente aperfeiçoado mediante a outorga a qualquer do povo de legitimidade para a propositura da ação por atos de improbidade.
} 
esfera correcional das carreiras do Ministério Público, ainda que de forma limitada pela garantia institucional de independência. A finalidade deste trabalho é acentuar a necessidade de algumas alterações na estrutura organizacional e no funcionamento do Ministério Público, sob pressupostos intransponíveis do regime político do Estado Democrático de Direito da Constituição de 1988, especialmente para a efetividade de seu papel no sistema de controle recíproco entre os órgãos estatais.

Em primeiro lugar, levando em conta o funcionamento interna corporis das carreiras que compõem o Ministério Público Nacional ${ }^{8}$, a abordagem do ultimo capítulo da tese centrar-se-á na extinção do modelo autocrático de gestão para a observância do princípio nuclear de qualquer democracia, de modo a buscar a compatibilidade entre as garantias institucionais de unidade e indivisibilidade e a de independência funcional. Para que as decisões concernentes às políticas institucionais possam exprimir uma vontade comum da classe, a primeira solução apresentada consiste na adoção de instrumentos que assegurem a participação de todos os seus membros em decisões de cunho organizacional versando sobre interesses comuns. Na perspectiva de propiciar a abertura dos canais de participação para o advento de decisões coletivas, a hipótese coaduna-se perfeitamente com o regime de representação democrática que já vigora para a composição dos órgãos da administração superior do Ministério Público. Ocorre que esse sistema de representação também apresenta a inaceitável distorção consistente em restringir a esfera de incidência do pressuposto do sufrágio universal para privilegiar, indevidamente, nos processos eleitorais, o direito de participação dos membros da instituição que oficiam junto aos tribunais. É de extrema relevância a correção dessa deficiência, de franco caráter oligárquico e, por conseguinte, altamente contrastante com a ideia de qualquer gestão democrática.

Ainda com referência à gestão democrática do Ministério Público, o ponto subsequente incide sobre a legitimidade dos concursos públicos de ingresso e de movimentação nas carreiras. Apenas uma instituição independente, com um regime de seleção de seus integrantes orientado pela garantia de acesso aos cargos públicos em igualdade de condições, é capaz de assegurar a preservação dos mecanismos de controle do poder político para conformar o seu exercício à tutela dos direitos fundamentais da pessoa

\footnotetext{
${ }^{8}$ Segundo o art. 128, I, $a$ a $d$, e II, da CF, o Ministério Público Nacional abrange os seguintes ramos: I - o Ministério Público da União, compreendendo o Ministério Público Federal, o Ministério Público do Trabalho, o Ministério Público Militar e o Ministério Público do Distrito Federal e Territórios; e II - os Ministérios Públicos dos Estados.
} 
humana. E é, sob essa ótica, que haverá o ulterior exame da estrutura organizacional do Ministério Público, considerando-o agora como parte integrante de todo o aparato da organização política brasileira. Para efetivar o seu funcionamento segundo os fundamentos do princípio democrático do controle recíproco entre os órgãos estatais, o destaque será, prioritariamente, à necessidade de ruptura dos vínculos mantidos com o Executivo do Estado. Daí o reconhecimento do grau de abrangência do sistema de incompatibilidades previsto na Constituição Federal, da iminência da alteração da forma de escolha da figura do Procurador-Geral, que ocupa o ápice da estrutura hierárquica das carreiras do Ministério Público; e, finalmente, da necessidade de ampliação de sua autonomia organizacional ${ }^{9}$. O último tópico procura responder à pergunta sobre quem deve controlar o órgão controlador, para preconizar o aperfeiçoamento do instrumento de controle do Ministério Público, por intermédio de alterações em determinantes aspectos das funções do Conselho Nacional e na forma de composição de seu quadro ${ }^{10}$.

A opção pelos três primeiros capítulos desta tese decorreu da necessidade de construir uma base teórica para introduzir a análise da estrutura organizacional e do funcionamento do Ministério Público, de modo a possibilitar a identificação das soluções para os problemas apresentados. Sob uma perspectiva histórica e interdisciplinar, além da doutrina de Montesquieu, também acompanharão o desenvolvimento do tema alguns pontos do pensamento clássico da Antiguidade, como de Cícero e Aristóteles. Haverá também referências às teorias do contrato social de Locke e Rousseau, porquanto

\footnotetext{
${ }^{9}$ Como vedações aos membros do Ministério Público, a Constituição estabelece o recebimento de honorários, percentagens ou custas processuais; o exercício da advocacia; o exercício de qualquer outra função pública, salvo uma de magistério; o exercício de atividade político-partidária; e, finalmente, o recebimento de auxílios ou contribuições de pessoas físicas, entidades públicas ou privadas (art. 128, II, $a$ a $f$, da CF). Muito embora para o Ministério Público dos Estados tenha sido reservada a formação de lista tríplice entre os integrantes das carreiras, a escolha do nome para a chefia da instituição cabe, respectivamente, ao Presidente da República e aos Governadores (art. 128, $\S \S 1^{\circ}$ e $3^{\circ}$, da CF). Por sua vez, a iniciativa para os estatutos de organização das carreiras é apenas facultada aos Procuradores-Gerais, concorrentemente com os chefes dos órgãos do Executivo (art. 128, $\S 5^{\circ}$, c/c o art. 61, § $1^{\circ}$, II, $d$, da CF).

${ }^{10} \mathrm{No}$ rol das medidas introduzidas no texto constitucional pela Emenda 45, de 8.12.2004, para as instituições do sistema de Justiça, incluiu-se a criação do Conselho Nacional do Ministério Público (art. 130-A, caput, I a VI, $\S 1^{\circ}$ e $\S 2^{\circ}$, I a V, $\S 3^{\circ}$, I a III, e $\S \S 4^{\circ}$ e $5^{\circ}$, da CF). O Conselho foi concebido para atuar no âmbito da organização das políticas institucionais e do controle de atos administrativos, além da esfera correcional. $\mathrm{O}$ Procurador-Geral da República, que é chefe do Ministério Público da União, figura como presidente do Conselho, que também deve ser integrado por quatro membros do Ministério Público da União, assegurada a representação de cada uma de suas carreiras; três membros do Ministério Público dos Estados, dois juízes, indicados um pelo Supremo Tribunal Federal e outro pelo Superior Tribunal de Justiça, dois advogados, indicados pelo Conselho Federal da Ordem dos Advogados do Brasil, e dois cidadãos de notável saber jurídico e reputação ilibada, indicados um pela Câmara dos deputados e outro pelo Senado Federal (art. 130-A, I a VI, da CF). As funções correcionais foram atribuídas ao Corregedor do Conselho Nacional, que deve ser escolhido dentre os membros do Ministério Público que o integram, em votação secreta (art. 130$\mathrm{A}, \S 3^{\circ}$, da CF).
} 
traduzirem simbolicamente a estrutura de governos democráticos que se firmaram com base no primado da soberania popular.

Considerou-se, igualmente, a necessidade de uma previa sistematização da categoria jurídica das garantias institucionais no sistema de proteção dos direitos fundamentais, em especial atenção ao princípio do controle recíproco entre os órgãos estatais. Foi indispensável recorrer à doutrina do constitucionalismo alemão, à qual, não obstante divergências conceituais, pode ser tributada a sistematização das categorias identificadas como princípios instrumentais e substanciais de interpretação constitucional. Em consideração aos fatores políticos que envolvem os ordenamentos constitucionais, a apreensão material dos conteúdos de suas normas é de vital importância para torná-los efetivos, sobretudo para condicionar a ação do Estado ao conjunto de bens e valores disciplinados na esteira da proteção da dignidade da pessoa humana. Nesse passo, mostrouse de grande valia, no plano do constitucionalismo contemporâneo, a paradigmática classificação de Karl Loewenstein identificando os elementos essenciais à estrutura e ao funcionamento de um regime político democrático.

A tese pautou-se, de forma primordial, pela diretriz da aproximação conceitual entre direito e moral, com críticas à autonomia da doutrina positivista para a correta compreensão do regime jurídico do Estado Democrático de Direito arquitetado na Constituição de 1988. Adotou-se uma linha de argumentação contrária aos fundamentos do positivismo jurídico, para defender a supremacia dos conteúdos principiológicos dos direitos e garantias fundamentais da pessoa humana. Incluindo os que consubstanciam as garantias institucionais incidentes sobre a atuação do Estado, princípios incorporam expressões valorativas cuja especificação de seus conceitos reclama do intérprete, necessariamente, uma posição moral condicionando a tarefa do legislador, da jurisdição e da própria ciência jurídica. Ao afastar do direito o universo axiológico reproduzido nas normas de princípios, o positivismo jurídico não se presta ao cumprimento dessa função, não sendo mais possível, do ponto de vista interno, uma análise do direito estranha aos valores estabelecidos nos textos constitucionais. Nessa linha de raciocínio, vale ressaltar o aproveitamento da lição de Alexy, que, com a técnica da proporcionalidade, apresentou uma significativa ferramenta para solucionar as hipóteses de colisão entre princípios fundamentais, suprimindo, assim, os entraves para o reconhecimento da efetividade de suas normas. 


\section{CAPÍtulo I. A ORGANIZAÇÃO DO PODER POLÍtico NO ESTADO MODERNO E TRÊS CONGÊNERES DO MINISTÉRIO PÚBLICO BRASILEIRO}

\subsection{A proposta de Montesquieu}

Considerando a organização do poder político no Estado moderno, na esteira da tradição iluminista, o direito tem por função a preservação da liberdade humana, de maneira a coibir a desordem do estado de natureza que, em virtude do risco da dominação dos mais fracos pelos mais fortes, exige a existência de um poder institucional ${ }^{11}$. Mas a conquista da liberdade humana também reclama a distribuição do poder em ramos diversos, com a disposição de meios que assegurem o controle recíproco entre eles para o advento de um cenário de equilíbrio e harmonia nas sociedades estatais. A concentração do poder em um só órgão ou pessoa viria sempre em detrimento do exercício da liberdade. É que, como observou Montesquieu, uma experiência eterna nos faz ver "que todo homem que tem poder tende a abusar dele; ele vai até onde encontra limites (...). Para que não se possa abusar do poder é preciso que, pela disposição das coisas, o poder limite o poder" ${ }^{\prime 2}$.

\footnotetext{
${ }^{11}$ Cf. COMPARATO, Fábio Konder. A garantia institucional contra o abuso de poder. In: BENEVIDES, Maria Victoria et al. (Orgs.). Reforma política e cidadania. São Paulo: Fundação Perseu Abramo, 2003. p. 44 e ss. O destaque é à doutrina jusnaturalista de Thomas Hobbes sobre a origem e fundamento do Estado, à luz da dicotomia estado (ou sociedade) de natureza e estado (ou sociedade) civil. Para sair do estado natural que representa um estado de "guerra de todos contra todos", os homens devem consentir em renunciar a seu próprio poder e força para transferi-los a uma única pessoa (uma pessoa física ou jurídica, como uma assembleia) que, coercitivamente, porquanto munida de um poder absoluto, há de reunir todas as condições necessárias para obrigar os indivíduos a atuarem em consonância com os ditames da razão e não segundo as suas paixões, necessidades e desejos. O pacto fundamental de Hobbes contém as características do pactum subiectionis e do pactum societatis. Cf. Leviathan. Penguin Classics, 1985. Part II, chap. XVII, p. 227.

${ }^{12}$ MONTESQUIEU, Charles de. De l'esprit des lois. Paris: Gallimard, 2003. Livro XI, cap. IV, p. 326. A doutrina da separação de poderes é frequentemente atribuída a Montesquieu, associada à teoria do governo misto de Platão e Aristóteles, em que se combinam as três formas tradicionais de governo: a monarquia, a aristocracia e a democracia. John Locke, filósofo inglês do século XVII, também é apontado como o criador da doutrina. No entanto, em seu Segundo tratado sobre o governo, o foco da atenção de Locke é o homem em seu estado natural para explicar a origem da sociedade civil, com ênfase à soberania do povo como fundamento do exercício do poder político. A principal função de todo e qualquer governo é a preservação dos direitos naturais do homem, sobretudo a propriedade. Ao ingressar no estado civil, a comunidade escolhe aqueles que deverão representá-la no órgão legislativo do Estado, que é o poder soberano (GOUGH, J. W. A separação de poderes e a soberania. In: SADEK, Maria Tereza; QUIRINO, Célia Galvão (Orgs.). O pensamento político clássico: Maquiavel, Hobbes, Locke, Montesquieu, Rousseau. 2. ed. São Paulo: Martins Fontes, 2003; e LASLETT, Peter. A teoria social e política dos "Dois tratados sobre o governo”. In: SADEK, Maria Tereza; QUIRINO, Célia Galvão (Orgs.). op. cit., p. 219 e ss.; e p. 274 e ss. Cf. também COMPARATO, Fábio Konder. Ética: direito, moral e religião no mundo moderno. São Paulo: Companhia das Letras, 2006. p. 217 e ss.).
} 
Com a morte de Luis XIV, aspirações liberais passaram a dominar todos os escalões da sociedade francesa, dissipando-se a convicção acerca da necessidade de uma divisão do poder político como forma de conter o despotismo real. Na busca de alternativas que evitassem a supremacia absoluta do poder do monarca, os parlamentares cogitavam do desmembramento da autoridade para mantê-la em termos moderados, preponderando também ideias sobre a criação de corpos oficiais para intermediarem as relações entre o rei e o povo ${ }^{13}$. As soluções diferiam na exata medida da contraposição entre os interesses dos agrupamentos sociais, cessando as possibilidades de consenso quando se tornava necessário determinar "a natureza, o domínio, o papel político, as relações mútuas e o tipo de dependência em relação ao soberano" ${ }^{\prime 14}$.

Até Montesquieu, não eram identificadas com clareza as esferas de abrangência dos poderes políticos: "só se concebia sua união nas mãos de um só ou, então, sua separação; ninguém se arriscava a apresentar, sob forma de sistema coerente, as consequências de conceitos diversos" $" 15$. Pensador francês do século XVIII, Montesquieu situa-se entre o racionalismo cartesiano e o empirismo de origem baconiana, não abandonando o rigor das certezas matemáticas em suas certezas morais ${ }^{16}$. Porém, refugindo às especulações metafísicas que, no plano da idealidade, serviram aos filósofos do pacto social para a explicação dos fundamentos do Estado ou da sociedade civil, ele procura ingressar no terreno dos fatos ${ }^{17}$.

Em seu De l'esprit des lois, reproduzindo uma série de investigações históricas, Montesquieu dá azo à pesquisa positiva para classificar racionalmente os fenômenos sociais. Mas, num segundo plano, "estes mesmos fatos sociais parecem refratados, como uma luz por um cristal, quer dizer, percebidos e interpretados, conforme dois sistemas

\footnotetext{
${ }^{13}$ Cf. DEDIEU, Joseph. As ideais políticas e morais de Montesquieu. In: SADEK, Maria Tereza; QUIRINO, Célia Galvão (Orgs.). op. cit., p. 310 e ss.

${ }^{14}$ Id. Ibid., p. 326. Segundo Dedieu, não faltavam projetos versando sobre a divisão do poder central: Grotius chegou a aconselhar uma repartição das funções políticas, conforme as diferenças de lugares, povos e costumes. Puffendorf indicou a existência de três poderes: o legislativo, que prescreve as leis; o judiciário, que se manifesta sobre os conflitos entre os cidadãos; e um terceiro poder para dispor sobre a guerra e paz, receber impostos e nomear magistrados. Mas esses poderes não poderiam recair em pessoas diversas, pois aquela que detivesse o poder de coerção acabaria exercendo o domínio sobre os demais. Além disso, quando surgissem divergências entre eles, não haveria como encontrar um árbitro para dirimi-las (cf. DEDIEU, Joseph. op. cit., p. 316-318).

${ }^{15}$ DEDIEU, Joseph. op. cit., p. 326.

${ }^{16}$ Segundo Paul Vernière, apesar de incompatível com o método experimental que estabelece leis a partir da observação de variações concomitantes dos fenômenos, Montesquieu não abandonou conceitos aristotélicos sobre a religião, a moral e o mundo material (cf. VERNIÈRE, Paul. Dois planos e duas leituras. In: SADEK, Maria Tereza; QUIRINO, Célia Galvão (Orgs.). op. cit., p. 371-372).

${ }^{17}$ DEDIEU, Joseph. op. cit., p. 296-297.
} 
diferentes. (...) De um lado, todos os fatos sociais são interpretados em função de um 'decodificador' político, a tipologia dos governos com o sistema tripartido da natureza e dos elementos que o colocam em marcha (...). Por outro lado, a partir do livro XI, uma nova perspectiva, a da liberdade política, que implica uma escolha de ordem ética, a do governo moderado, põe em marcha um sistema dos três poderes (...."18.

\subsubsection{O conceito de lei}

No início de sua famosa obra, Montesquieu introduz o conceito de leis como "as relações necessárias derivadas da natureza das coisas". Dessa forma, "todos os seres possuem suas leis; a divindade possui suas leis, o mundo material possui suas leis, as inteligências superiores ao homem possuem suas leis, os animais possuem suas leis, o homem possui suas leis"19. No entanto, se forem excluídas as leis divinas e de conservação do universo, as leis morais que na lei natural precedem a própria criação, "as leis físicas que regem a matéria e a vida, não resta senão o homem, livre, inteligente, mas limitado, ao mesmo tempo apto para compreender e para violar as leis, diante de um triplo código religioso, moral e social" ${ }^{\prime 20}$.

Ao definir leis como "relações necessárias que derivam da natureza das coisas", Montesquieu aponta para a ciência empírica, especialmente relacionada à física de Newton. Como nas relações entre os corpos físicos, é possível encontrar certa constância nos comportamentos e na forma de organização dos seres humanos. As leis que dispõem sobre as instituições também resultam da natureza das coisas. Envolvem, porém, relações de caráter social e político. Com isso, a política é conduzida ao campo das ciências, com contornos teóricos próprios.

A lei humana, se reproduzida em uma prescrição imposta por um código, “(...) uma religião, um legislador, ou simplesmente o costume (...), exprime também e sem contradição uma necessidade analisável e permeável à inteligência, uma ordem à qual nós nos submetemos a partir do momento em que a entendemos" ${ }^{\text {21 }}$. As leis constituem, assim, expressão da "razão humana, enquanto governa todos os povos da terra; e as leis políticas e

\footnotetext{
${ }^{18}$ VERNIÈRE, Paul. op. cit., p. 363. Diante da fecundidade de possíveis interpretações, para superar suas contradições e dificuldades metodológicas, o autor propõe um método de duas leituras para a obra de Montesquieu.

${ }^{19}$ MONTESQUIEU, Charles de. op. cit., I, livro I, cap. I, p. 87.

${ }^{20}$ VERNIÈRE, Paul. op. cit., p. 367.

${ }^{21}$ Id. Ibid., p. 368-369.
} 
civis de cada nação devem ser apenas casos particulares onde se aplica essa razão humana",22.

De outro turno, Montesquieu admira a pluralidade de elementos que envolve a natureza humana. Busca a distinção e a identidade entre as coisas, partindo da realidade viva, como produto da criação humana. Em todos os lugares a intervenção humana se fez presente. Os homens criaram usos, costumes, leis, Estados. Mas nunca estiverem dispersos; agruparam-se "em uniões, povos, nações, classes sociais; eles formam organizações. Montesquieu quer percorrer toda esta gama de formas de organização recobertas pela vida coletiva, compará-las, estabelecer as diferenças e as similitudes" ${ }^{, 23}$.

Nesse contexto, as leis são consideradas manifestações das necessidades dos indivíduos, derivadas da complexidade das relações e fenômenos sociais, como reflexos das condições físicas e morais dos povos. O valor das leis é sempre relativo, dependendo do grau de adaptação ao modo de agir das sociedades às quais elas se voltam. As leis conferidas a um povo devem respeitar as suas peculiaridades; devem se ajustar ao complexo de condições e dados morais, econômicos, religiosos e ambientais que o caracterizam $^{24}$.

Tendo em vista os elementos extraídos da história, Montesquieu procura comparar as leis que constituem diferentes formas de governo para alcançar as regras gerais de determinados tipos de legislação. Interessa-lhe "descobrir, na diversidade dos dados oferecidos pela história do mundo inteligente, o significado que tomam as individualidades coletivas criadas pelo espírito humano na perseguição de certos objetivos, e indagando-se sobre o seu valor relativo. O que está sujeito à mudança, o que é diverso, o que não tem sentido se tomado isoladamente, adquire um sentido nos agrupamentos coletivos construídos a partir de leis visando a atingir um objeto particular,"25.

Desse modo, compete ao legislador a organização das sociedades levando em conta que a união de um corpo político consiste na harmonia entre partes diversas que, por mais

\footnotetext{
${ }^{22}$ MONTESQUIEU, Charles de. op. cit., I, livro I, cap. III, p. 95.

${ }^{23}$ GROETHYSEN, Bernard. op. cit., p. 342.

${ }^{24}$ Segundo Montesquieu: as leis "devem ser relativas ao físico do país, ao clima gélido, tórrido ou temperado; à qualidade do terreno, a sua situação e grandeza; ao tipo de vida dos povos, agricultores, caçadores ou pastores; elas devem se relacionar com o grau de liberdade que sua constituição pode suportar; com a religião de seus habitantes, com suas inclinações, com suas riquezas, com seu número, com seu conteúdo, com seus costumes, com suas maneiras. Enfim, elas possuem relações entre si; possuem também relações com sua origem, com o objetivo do legislador, com a ordem das coisas sobre as quais foram estabelecidas. É sob todos esses aspectos que é preciso considerá-las" (MONTESQUIEU, Charles de. op. cit., I, livro I, cap. III, p. 95).

${ }^{25}$ GROETHYSEN, Bernard. op. cit., p. 349-350.
} 
que pareçam contrárias, "concorrem para o bem geral da sociedade, como as dissonâncias na música concorrem para o acorde geral" ${ }^{\text {26 }}$. Em atenção à estrutura teleológica do conjunto, o homem não deixa de intervir na realidade, de criá-la e recriá-la; e as leis servem para orientar as suas ações, a partir da definição do objeto de uma coletividade.

Afastando-se das discussões em torno da lei da natureza, do homem no estado natural e da origem do Estado ou da sociedade civil, a preocupação de Montesquieu recai nas leis positivas e nas instituições criadas pelos homens para reger as suas relações. E, como foi consignado, elas devem ser próprias à coletividade para a qual foram previstas; devem estar em consonância "com o princípio do governo que foi estabelecido, ou que se pretende estabelecer; quer o formem, como é caso das leis políticas, quer o mantenham, como é o caso das leis civis" 27 .

Assim, a lei fundamental, que Montesquieu denomina constituição, resulta da natureza das espécies de governo. "E desta constituição decorrem enfim as leis positivas" $^{, 28}$. Tanto a lei fundamental relativa à forma de governo como as que dela resultam para regular as relações entre os integrantes do ente político visam à realização do desígnio que lhe é próprio. Cada Estado representa um todo, com a sua estrutura voltada a determinados objetivos, “(...) um organismo em que todas as diferentes tendências que podem representar os homens encontram uma unidade de objeto nas leis, que servem ou para manter a coletividade" 29 , fazendo prosperar certos interesses comuns.

Montesquieu dedica-se aos tipos de organização dos povos a partir dos objetivos que eles procuram atingir, sempre guiados por um espírito que os comanda. Daí por que a primeira tarefa do legislador consiste em dar uma forma de governo aos povos, de acordo com a sua maneira específica de sentir, com o espírito que deve dominar todos os organismos coletivos, desde o momento em que são constituídos. Tal espírito reflete a disposição comum a todos aqueles que formam uma determinada comunidade, conferindolhe "uma unidade de sentimentos suficientemente eficaz para dar uma direção comum a

\footnotetext{
${ }^{26}$ GROETHYSEN, Bernard. op. cit., p. 346-347.

${ }^{27}$ MONTESQUIEU, Charles de. op. cit., I, livro I, cap. III, p. 95. Já em Locke, as leis produzidas pelo legislativo, o poder supremo do Estado, são manifestações da lei da natureza, que representa a lei da razão, como expressão da vontade de Deus. Mas, para evitar as inconveniências que "perturbam as propriedades dos homens no estado de natureza, eles se reúnem em sociedades, de modo que possam dispor da força reunida da sociedade como um todo para garantir e defender suas propriedades, e para disporem de regras fixas a delimitá-las e por cujo meio cada qual possa saber o que lhe pertence" (Segundo Tratado, § 136, in LOCKE, John. Dois tratados sobre o governo. Trad. Julio Fischer. 2. ed. São Paulo: Martins Fontes, 2005. p. 507).

${ }^{28}$ VERNIÈRE, Paul. op. cit., p. 373.

${ }^{29}$ GROETHYSEN, Bernard. op. cit., p. 346.
} 
todas as vontades diferentes, suscetíveis de serem inspiradas por motivos individuais. Todas as partes do todo devem obedecer a um mesmo impulso",30.

Segundo Montesquieu, os homens são guiados por várias coisas: "o clima, a religião, as leis, as máximas do governo, os exemplos das coisas passadas, os costumes, as maneiras; de onde se forma um espírito geral, que disso resulta" ${ }^{, 31}$. No instante em que surge a estrutura de unidade de um povo, segue-se a lei fundamental relativa à sua forma de governo. Todos os conflitos sociais ocorrem nos limites traçados pela lei fundamental, que arquitetou o ente coletivo com base no espírito informador do conjunto. As ações e reações dos elementos da sociedade nela se fundam, de modo que os conflitos que apareçam no decorrer dessa dinâmica dialética possam ser devidamente transpostos ${ }^{32}$.

\subsubsection{As espécies de governo}

Para descobrir a natureza das espécies de governo, Montesquieu supõe "três definições, ou melhor, três fatos: o governo republicano é aquele no qual o povo em seu conjunto ou apenas uma parte do povo possui o poder soberano; o monárquico, aquele onde um só governa, mas através de leis fixas e estabelecidas; ao passo que, no despótico, um só, sem lei e sem regra, determina tudo por sua vontade e seus caprichos"33.

A democracia e a aristocracia são desdobramentos da república. Na democracia, todos têm acesso ao governo, enquanto que, na aristocracia, ele é exercido apenas por uma parte dos cidadãos. Quanto à monarquia e ao governo despótico, muito embora recaiam sobre uma só pessoa, não há semelhanças entre eles, pois, na monarquia, as leis restringem o poder real.

Ao contrário de Aristóteles, Montesquieu não levou em conta somente o número de governantes e a forma de administração da coisa pública, mas tratou da natureza das sociedades governadas ${ }^{34}$. É que, enquanto Aristóteles e de seus seguidores extraem sua classificação de uma noção abstrata de Estado, Montesquieu a apreende "das próprias

\footnotetext{
${ }^{30}$ GROETHYSEN, Bernard. op. cit., p. 344.

${ }^{31}$ MONTESQUIEU, Charles de. op. cit., I, livro XIX, cap. IV, p. 567.

${ }^{32}$ Cf. GROETHYSEN, Bernard. op. cit., p. 345.

${ }^{33}$ MONTESQUIEU, Charles de. op. cit., I, livro II, cap. I, p. 97.

${ }^{34}$ Aristóteles apontou a monarquia, a aristocracia e a república como espécies de constituição dos Estados (cf. ARISTÓTELES. Ética a Nicômaco. Trad. Pietro Nassatti. São Paulo: Martin Claret, 2004. Livro VIII, p. 172-194; e Política. Trad. Therezinha Monteiro Deutsch e Baby Abrão. São Paulo: Nova Cultural, 2000. Livro III, p. 211-251. (Coleção Os pensadores). Cícero também indicou três formas de governo: "Quando a autoridade está nas mãos de um só, chamamos esse homem de rei e ao poder de monarquia; uma vez confiada a supremacia a alguns cidadãos escolhidos, a constituição se torna aristocrática; enfim, a sabedoria popular, conforme a expressão consagrada, é aquela em que todas as coisas residem no povo" (CÍCERO, Marco Túlio. Da República. Trad. Amador Cisneiro. Bauru-SP: EDIPRO, 1995. Livro Primeiro, XXVI, p. 27).
} 
coisas. Ele não infere esses três tipos de algum princípio estabelecido a priori; ele os criou pela comparação das sociedades que conheceu através da história ou dos relatos de viajantes, ou mesmo em suas próprias viagens" ${ }^{, 35}$. O abandono do esquema aristotélico, tão comum no pensamento europeu, sugere a opção metodológica de "partir de um mundo real, de sociedades vivas que podem ser observadas, e de sociedades mortas em que a cultura histórica supre a observação", para, destacando os mecanismos específicos dos vários regimes, explicar a variedade das instituições ${ }^{36}$.

No que toca à república, a alusão é às cidades gregas e itálicas da Antiguidade em que, muitas vezes, a aristocracia e a democracia tomaram conjugadamente a forma de governo. A república condiz com as pequenas cidades; a monarquia com nações de extensão média, como as da Europa moderna. Já os governos despóticos identificam-se com nações de grande extensão territorial, com um maior número de súditos; a referência aqui é às sociedades do Oriente, (turcos, persas e outros povos da Ásia) ${ }^{37}$.

Além do caráter histórico e concreto atribuído aos três tipos de governo, a originalidade do pensamento de Montesquieu revela-se à luz dos princípios que movimentam as forças sociais e políticas. A natureza do governo corresponde ao “mecanismo de sua estrutura. Seu princípio é o que o faz agir, mola invisível que põe em movimento as paixões dos cidadãos, determina correntes de opinião e molda um espírito geral, uma alma nacional"38. Trata-se de um fundamento psicológico extraído do seio das sociedades, responsável pela instituição de sua forma de governo que, por sua vez, fará eclodir a legislação do ente político.

São estruturalmente diversos os vínculos que unem os indivíduos nas sociedades em que imperam as diferentes formas de governo; assim como também o são os princípios que colocam em marcha as instituições estatais.

\footnotetext{
${ }^{35}$ DURKHEIM, Émile. Como Montesquieu classifica as sociedades por tipos e por espécies. In: SADEK, Maria Tereza; QUIRINO, Célia Galvão (Orgs.). O pensamento político clássico: Maquiavel, Hobbes, Locke, Montesquieu, Rousseau. 2. ed. São Paulo: Martins Fontes, 2003. p. 280.

${ }^{36}$ VERNIÈRE, Paul. op. cit., p. 368-369. Segundo o autor, Montesquieu substituiu "o critério tradicional do número pelo seguinte esquema categorial: o presente, o passado e o alhures, Desde então tudo se ordena: o governo republicano é o passando de Roma e Atenas, com o prolongamento, a sobrevivência das repúblicas aristocráticas italianas: Veneza e Gênova. O despotismo é o Oriente, o dos três grandes impérios mulçumanos, com a excrescência longínqua da China. Mas o presente é a Europa monárquica moderna nascida na Idade Média meio germânica, diversa, mas coerente" (VERNIÈRE, Paul. op. cit., p. 368-369).

${ }^{37}$ Cf. MONTESQUIEU, Charles de. op. cit., I, livro VIII, caps. XVI a XXI, p. 276-284. Ao tratar da origem das monarquias na Europa, cf. também livro XI, cap. VIII, p. 343-344.

${ }^{38}$ DEDIEU, Joseph. op. cit., p. 299.
} 
Na república, principalmente considerando uma república democrática, "todos zelam igualmente pela coisa comum; os que detêm a magistratura não são superiores aos outros, pois ocupam seus cargos somente por algum tempo"39. E mais, a igualdade é a essência de um regime democrático. Muito embora Montesquieu admita as dificuldades existentes para a supressão total das diferenças sociais, elas devem ser limitadas até certo ponto. É função das leis "nivelar, por assim dizer, as desigualdades por tributos que impõem aos ricos e alívio que concedem aos pobres" 40 .

Na democracia, o povo obedece a sua própria vontade, por meio de magistrados eleitos em sufrágios públicos. O legislador deve zelar pelos costumes públicos, com um Senado que seja o exemplo vivo do espírito republicano ${ }^{41}$. A virtude é o princípio que orienta o funcionamento de uma república; corresponde a um espírito cívico, à disposição moral de jamais sobrelevar os interesses pessoais aos do Estado. E, assim, os cidadãos, “(...) como resultado de um impulso natural, abandonam a si mesmos para se voltarem ao bem comum"42. A virtude política implica o amor às leis, o amor à pátria, o amor pela igualdade; pressupõe, enfim, um sentimento de reverência em relação às cidades ${ }^{43}$.

Pela virtude, premidos por um sentimento de moderação, os nobres, na aristocracia, admitem a submissão às leis tendentes a abolir os seus privilégios e prerrogativas para mitigar os quadros acentuados de desigualdade material ${ }^{44}$. É que, em uma república, os interesses e as prerrogativas do corpo dos nobres não podem levá-lo a reprimir o povo. E, em se tratando de uma aristocracia, a virtude deve, ao menos, tornar os integrantes da nobreza iguais entre si, para manter a sua conservação ${ }^{45}$. De qualquer forma, a república é tanto mais perfeita quanto mais próxima da democracia, pois é a virtude que a faz mover.

\footnotetext{
${ }^{39}$ DURKHEIM, Émile. op. cit., p. 282.

${ }^{40}$ MONTESQUIEU, Charles de. op. cit., I, livro V, cap. V, p. 155. A atenção de Montesquieu é a Roma e Atenas, onde "cada cidadão detinha muito pouco individualmente e que foi esta a causa que assegurou a unidade da sociedade" (DURKHEIM, Émile. op. cit., p. 290).

${ }^{41}$ Cf. DEDIEU, Joseph. op. cit., p. 304.

${ }^{42}$ DURKHEIM, Émile. op. cit., p. 284.

${ }^{43}$ Cf. VERNIÈRE, Paul. op. cit., p. 376; e MONTESQUIEU, Charles de. op. cit., I, livro III, cap. III; livro IV, cap. V; e livro V, cap. III; p. 115-119, 137-138 e 149-150. Cf. também COMPARATO, Fábio Konder. Ética: direito, moral e religião no mundo moderno, cit., p. 619-620. No mesmo sentido, cf. as referências de Quentin Skinner, em atenção aos escritos humanistas das Repúblicas Itálicas de Florença no início do século XVI (SKINNER, Quentin. As fundações do pensamento político moderno. Trad. Renato Janine Ribeiro e Laura Teixeira Motta. São Paulo: Companhia das Letras, 2003. p. 196).

${ }^{44}$ Cf. MONTESQUIEU, Charles de. op. cit., I, livro III, cap. IV, p. 119-120.

${ }^{45}$ Cf. Id. Ibid., I, livro III, cap. IV, p. 120.
} 
As leis comandam a todos; até aquele que faz executá-las deve sentir "que suportará seu peso" $^{, 46}$.

Outra é a natureza de um regime monárquico. As funções da vida pública e da vida privada são diversas e se encontram fragmentadas entre vários órgãos e extratos sociais. $\mathrm{Na}$ monarquia, "a sociedade poderia ser comparada a um ser vivo, cujos elementos ocupam diferentes funções de acordo com a sua natureza" ${ }^{47}$. O monarca governa sob o manto de leis fixas e contínuas. "Os poderes intermediários, subordinados e dependentes constituem a natureza do governo monárquico, isto é, daquele em que um só governa por leis fundamentais (...),48.

Muito embora constitua o príncipe a fonte primordial do poder político, as "leis fundamentais supõem necessariamente canais médios por onde flui o poder: pois, se existir num Estado apenas a vontade momentânea e caprichosa de um só, nada pode ser fixo e, consequentemente, nenhuma lei pode ser fundamental" ${ }^{\prime 4}$. Dos poderes que incorporam os organismos intermediários resultam os limites à autoridade do príncipe. Se não houvesse obstáculo ao poder real, não poderia haver lei que limitasse a "sua vontade, pois as próprias leis só dela dependeriam" ${ }^{, 50}$.

A sociedade monárquica é diversa da republicana, a qual se move em torno da realização do bem comum. Já o objetivo de cada um dos organismos sociais que integram uma monarquia é a conquista do que lhe é peculiar, ou seja, daquilo que atende aos seus interesses específicos. Por isso, a desigualdade entre as fortunas pessoais é um elemento intrínseco à constituição das monarquias em que "as riquezas estão distribuídas de forma desigual (...)" $)^{51}$.

O princípio que orienta as relações sociais e políticas em uma sociedade monárquica é a honra, que toma o lugar da virtude do regime republicano. O princípio é identificado com a ambição, o desejo de distinção, com as peculiaridades de uma classe privilegiada $^{52}$. Um governo exercido sob esse móvel deve curvar-se a preferências e diversidades. Enquanto a ambição é perniciosa numa república, ela "tem bons efeitos na

\footnotetext{
${ }^{46}$ MONTESQUIEU, Charles de. op. cit., I, livro III, cap. III, p. 116.

${ }^{47}$ DURKHEIM, Émile. op. cit., p. 285.

${ }^{48}$ MONTESQUIEU, Charles de. op. cit., I, livro II, cap. IV, p. 108.

${ }^{49}$ Id. Ibid., p. 109.

${ }^{50}$ DURKHEIM, Émile. op. cit., p. 285.

${ }^{51}$ MONTESQUIEU, Charles de. op. cit., I, livro VII, cap. IV, p. 236-237.

${ }^{52}$ Cf. VERNIËRE, Paul. op. cit., p. 377. Cf. MONTESQUIEU, Charles de. op. cit., I, livro III, cap. VI; livro IV, cap. II; e livro V, cap. IX; p. 122-123, 131-135 e 168-169.
} 
monarquia, dá vida a este governo (...). Dir-se-ia que é como o sistema do universo em que há uma força que afasta constantemente do centro todos os corpos, e uma força de gravidade que os traz de volta. A honra move todas as partes do corpo político; liga-as por sua própria ação; e assim todos se dirigem ao bem comum, pensando ir ao encalço de seus interesses particulares",53.

O governo despótico é de uma só pessoa, inexistindo qualquer força capaz de limitar o seu exercício; nele, “(...) um só, sem lei e sem regra, determina tudo por sua vontade e seus caprichos",54. E, como acontece no governo republicano, os homens são todos iguais “(...) no primeiro porque são tudo; no segundo, porque nada são" "55. Nada nesse governo é passível de ser objeto de lei ou de julgamento, pois "o despotismo basta a si mesmo; tudo fica vazio à sua volta. (...) Todas as oportunidades de disputa e de processo são, portanto, suprimidas" $" 56$.

Dessa forma, o princípio que rege a vida social no despotismo não é nem a virtude, pois o povo não participa dos negócios da comunidade, nem a honra, "pois não existe nenhuma diferença de condições. Se os homens são vinculados à sociedade é porque são tão poucos ativos que se submetem à vontade do príncipe sem resistência, isto é, unicamente pelo temor" ${ }^{257}$.

A dinâmica das forças sociais e políticas, expostas por Montesquieu, manifesta-se com bastante clareza quando de sua abordagem sobre a decadência dos regimes de governo. Um sistema decai quando o princípio se degenera. "Quando os princípios de governo se corrompem, as melhores leis tornam-se más e se voltam contra o Estado; quando os princípios estão sãos, as más leis têm o efeito das boas; a força do princípio sobrepõe-se a tudo" ${ }^{, 58}$. Daí por que um Estado pode mudar pelas seguintes razões: "ou porque a constituição se corrige ou porque ela se corrompe. Se ele tiver conservado seus

\footnotetext{
${ }^{53}$ MONTESQUIEU, Charles de. op. cit., I, livro III, cap. VII, p. 123-124. Teriam gerado problemas as expressões virtude e honra, utilizadas por Montesquieu para indicar, respectivamente, os princípios regentes da democracia e da monarquia. Reputou-se inviável dissociar o princípio da virtude da ideia de integridade moral dos particulares, não obstante a justificativa do autor de se tratar de uma virtude política voltada para o bem geral. Daí a conclusão pela preponderância de uma visão republicana de Montesquieu nos oito primeiros livros de De l'esprit des lois (cf. VERNIÈRE, Paul. op. cit., p. 380-381).

${ }^{54}$ MONTESQUIEU, Charles de. op. cit., I, livro II, cap. I, p. 97.

${ }^{55}$ Id. Ibid., I, livro VI, cap. II, p. 199.

${ }^{56}$ Id. Ibid., I, livro VI, cap. I, p. 197.

${ }^{57}$ DURKHEIM, Émile. op. cit., p. 288.

${ }^{58}$ MONTESQUIEU, Charles de. op. cit., I, livro VIII, cap. XI, p. 269-270.
} 
princípios e a constituição mudar, é porque ela se corrige; se tiver perdido seus princípios quando a constituição mudou é porque ela se corrompe" ${ }^{\text {"59 }}$.

A democracia não subsiste sem a virtude para movê-la. A perda do espírito de igualdade acarreta a transformação do regime em aristocracia ou em monarquia, enquanto que o extremo espírito de igualdade pode conduzi-la ao despotismo para impedir a anarquia entre os cidadãos. Na república de Montesquieu, excessos nos impulsos igualitários acabam reclamando a proteção de um tirano.

Por sua vez, as prerrogativas e os privilégios fazem parte do regime monárquico, que se corrompe quando ocorre sua supressão: "as monarquias se corrompem quando são abolidas, pouco a pouco, as prerrogativas dos corpos ou os privilégios das cidades. No primeiro caso, dirige-se ao despotismo de todos; no outro, ao despotismo de um só. (...) A monarquia perde-se quando o príncipe, tudo reduzindo a si mesmo, chama o Estado para sua capital, a capital para sua corte e a corte para sua pessoa" ${ }^{\prime 60}$.

Na visão de Montesquieu, a liberdade política é própria dos governos moderados, e a sua identificação com as monarquias se justifica na medida em que as forças da autoridade e dos organismos sociais tendem a uma limitação recíproca, sustentando-se mutuamente. É de ver a premissa do equilíbrio gravitacional que vai orientar a teoria da distribuição dos poderes do Estado, de modo a impedir a preponderância de qualquer deles: “para que não se possa abusar do poder, é preciso que, pela disposição das coisas, o poder limite o poder" ${ }^{\prime \prime}$.

Em inovadora análise, Montesquieu definiu as formas de governo à luz das diferenças no funcionamento dos sistemas que foram enunciados, com a ênfase na

\footnotetext{
${ }^{59}$ MONTESQUIEU, Charles de. op. cit., I, livro XI, cap. XIII, p. 352.

${ }^{60}$ Id. Ibid., I, livro VIII, cap. VI, p. 264-265. Para Aristóteles é a virtude o primado do Estado e da essência de um governo moderado: a “(...) finalidade de todo conhecimento e de toda atividade é a virtude. Isso é especialmente verdade em relação às atividades mais importantes, a do Estado e a do cidadão. No Estado, a virtude objetivada é a justiça; e isso significa justiça para toda comunidade. Está muito claro que a justiça, numa comunidade, significa igualdade para todos" (ARISTÓTELES. Política, cit., p. 234). Mas a referência é à igualdade proporcional; vale dizer: a justiça distributiva que envolve sempre o "meio-termo". Segundo Aristóteles: "o injusto é o que viola a proporção, pois proporcional é o intermediário, e o justo é o proporcional” (ARISTÓTELES. Ética a Nicômaco, cit., Livro V, p. 109). As hipóteses de desvios de governo no esquema de Aristóteles são “(...) da monarquia, a tirania; da aristocracia, a oligarquia; da politeia ou governo constitucional para muitos, a democracia. Porque a tirania é o governo único para o benefício de um único governante; a oligarquia, para o benefício dos homens de posses; a democracia, para o benefício dos homens sem posses. Nenhum dos três tem como objetivo o benefício de toda comunidade" (ARISTÓTELES. Política, cit., Livro III, p. 224. Cf. também Ética a Nicômaco, cit., Livro VIII, p. 186-187).

${ }^{61}$ MONTESQUIEU, Charles de. op. cit., I, livro XI, cap. VI, p. 326.
} 
reprodução da dinâmica social para justificar os vínculos que dão suporte ao exercício da autoridade.

\subsubsection{A teoria da liberdade política: a distribuição do poder estatal}

Montesquieu desdobrou o significado da liberdade política em duas vertentes: uma em relação à constituição e outra em relação ao cidadão ${ }^{62}$. A liberdade em relação à constituição é formada pela distribuição dos poderes estatais; e aquela que se verifica em relação aos cidadãos pressupõe a segurança, ou seja, a disposição de leis para assegurar os limites ao exercício da liberdade individual: "A liberdade é o direito de fazer o que as leis permitem; e se um cidadão pudesse fazer o que elas proíbem, não haveria mais liberdade, porque os outros também teriam esse poder"63.

Além de um aparato legal para regular a conduta dos cidadãos, avulta a fórmula política de uma constituição livre voltada à manutenção de corpos intermediários e ao estabelecimento da separação de poderes no seio governamental ${ }^{64}$. Como apontado acima, em um governo moderado, os corpos intermediários colocam-se como elemento mediador entre a autoridade suprema e o povo. Eles impõem-se “(...) ao povo e protegem-no contra os abusos do poder supremo. Respeitemo-lhes, portanto, suas prerrogativas: elas salvam a instituição, e a instituição, a liberdade" ${ }^{, 65}$.

Montesquieu defendeu a harmonia entre forças sociais contrastantes como sustentáculo à fusão das diferentes espécies de governo. O príncipe representa a forma monárquica; a nobreza, a aristocracia, enquanto ao povo correspondem as aspirações democráticas. O mecanismo que movimenta todas essas forças políticas resulta "de uma lei que dirigirá sua atividade, de uma polícia que garantirá a execução das leis, de um tribunal que punirá os delinquentes; em outros termos, de um poder legislativo, de um poder executivo, de um poder judiciário"66. O legislativo é o poder responsável pela elaboração das leis; o judiciário é aquele que pune os crimes e julga as controvérsias entre os

\footnotetext{
${ }^{62}$ MONTESQUIEU, Charles de. op. cit., I, livros XI e XII, p. 323 e ss., e 375 e ss.

${ }^{63}$ Id. Ibid., I, livro XI, cap. III, p. 325-326.

${ }^{64}$ Cf. DEDIEU, Joseph. op. cit., p. 326-327.

${ }^{65}$ Id. Ibid., p. 327.

${ }^{66}$ Id. Ibid., p. 329. Cf. MONTESQUIEU, Charles de. op. cit., I, livro XI, cap. VI, p. 327 e ss.
} 
particulares; e o poder executivo dispõe sobre as relações com outras nações, previne as invasões e zela pela segurança interna ${ }^{67}$.

Quando o poder legislativo e o executivo estão reunidos na mesma pessoa, “(...) não existe liberdade porque se pode temer que o mesmo monarca ou o mesmo senado crie leis tirânicas para executá-las tiranicamente" ${ }^{68}$. Não há também liberdade, "se o poder de julgar não estiver separado do poder legislativo e do executivo". Se estivesse unido ao legislativo, o juiz converter-se-ia em legislador, instaurando-se o arbítrio; e se vinculado ao poder executivo, "o juiz poderia ter a força de um opressor" ${ }^{\prime 69}$. Montesquieu afastou, portanto, qualquer possibilidade de preservação da liberdade política "se o mesmo homem, ou o mesmo corpo de principais, ou dos nobres, ou do povo exercessem os três poderes: o de fazer as leis, o de executar as resoluções públicas, e o de julgar os crimes ou os litígios dos particulares" $"$.

O poder judiciário deve ser exercido por pessoas do seio do povo, que devem formar um tribunal de caráter provisório. Nas grandes acusações, com base na lei, os criminosos devem escolher seus juízes ou, ao menos, ter a faculdade de recusá-los para a composição de um júri popular não permanente, integrado por cidadãos comuns escolhidos pelo acusado. À mesma condição social devem pertencer aqueles que vão julgar os infratores, com atenção ainda ao instituto do habeas corpus da Lei de 1679 do direito inglês, "que proíbe a detenção ilegal dos cidadãos por ordem do executivo" "71. Dessa forma, não estando ligado a determinado estado ou profissão, o poder de julgar "torna-se, por

\footnotetext{
${ }^{67}$ Em Locke, o poder supremo é o legislativo, que deve conduzir os homens de acordo com a lei da natureza, por meio da criação de normas imparciais e válidas para todos. Para executá-las, ele "terá à sua disposição a força combinada de todos os membros da sociedade - um poder 'executivo', na verdade. Terá um terceiro poder em virtude da condição na qual a comunidade se encontra; um poder de proteção contra inimigos externos e de comunicação com outras comunidades semelhantes e com indivíduos no estado de natureza. Esse é o poder "federativo"' (LASLETT, Peter. op. cit., p. 262-263); cf. também Segundo Tratado, §§ 143148, in Dois tratados sobre o governo, cit., p. 514-517.

${ }^{68}$ MONTESQUIEU, Charles de. op. cit., I, livro XI, cap. VI, p. 328.

${ }^{69}$ Id., loc. cit. Locke não chegou a elevar o judiciário ao patamar de um poder autônomo: à autoridade legislativa incumbe "dispensar justiça e decidir acerca dos direitos dos súditos por intermédio de leis promulgadas e fixas, e de juízes conhecidos e autorizados” (Segundo Tratado, § 136, in Dois tratados sobre o governo, cit., p. 507).

${ }^{70}$ Id. Ibid., p. 328. Diversamente de Montesquieu, não é possível afirmar que a preocupação central de Locke fosse a distribuição do poder político, como forma de assegurar a existência de um Estado livre. Em sua obra, "não há nenhuma teoria da importância ou da necessidade da permanência perpétua desses poderes em mãos separadas para preservar a liberdade, garantir direitos ou manter a constituição sadia, em harmonia e concórdia" (LASLETT, Peter. op. cit., p. 276).

${ }^{71}$ VERNIÈRE, Paul. op. cit., p. 386.
} 
assim dizer, invisível e nulo. Não se tem constantemente juízes diante dos olhos; e teme-se a magistratura, e não os magistrados"

No campo da persecução criminal, Montesquieu atentou a muitas garantias que se sedimentaram no decorrer do constitucionalismo moderno. A par de um judiciário imparcial e independente formado por colegiados de magistrados, ele defendeu o princípio da reserva legal para a definição dos delitos e aplicação das penas; a matriz da inafastabilidade do controle jurisdicional, com a proibição dos juízos ou tribunais de exceção; o devido processo legal, com o repúdio a penas cruéis ou desproporcionais e também exaltando a extinção das acusações privadas ${ }^{73}$.

Ao identificar a monarquia com um governo moderado, diante da execução das leis atribuída ao príncipe, o autor relevou a presença de um oficial em cada tribunal para perseguir, em nome do soberano, as condutas infracionais, afastando os cidadãos de tal prática; é "a parte pública que por eles deve velar para que, assim, fiquem tranquilos"74. Foi apontada a figura do procurador do rei, em que repousa a origem do Ministério Público, cujos padrões institucionais foram estabelecidos em definitivo somente no período que se seguiu à Revolução Francesa.

Por sua vez, ao contrário do disposto em relação ao judiciário, o exercício dos poderes legislativo e executivo deve ocorrer de forma permanente, pois eles representam a vontade geral do Estado. Como em um Estado livre é o povo que governa a si mesmo, seria recomendável que ele detivesse integralmente o poder legislativo. No entanto, considerando as inconveniências da proposta, Montesquieu admitiu a necessidade de seu exercício por um corpo de representantes, sem mandato imperativo, eleito pelo sufrágio universal. Todos os cidadãos devem ter direito à escolha de seus representantes, "exceto aqueles que estão em tal estado de baixeza, que sejam considerados desprovidos de vontade própria"75.

Já as decisões ativas não devem ser tomadas diretamente pelo povo, como em algumas repúblicas da Antiguidade, e, tampouco, pelo poder legislativo. Ao corpo de representantes não deve ser atribuída nenhuma "decisão ativa, coisa que não faria direito,

\footnotetext{
${ }^{72}$ MONTESQUIEU, Charles de. op. cit., I, livro XI, p. 330.

${ }^{73} \mathrm{Cf}$. Id. Ibid., I, livro VI, p. 194 e ss.

${ }^{74}$ Id. Ibid., I, livro VI, cap. VIII, p. 210.

${ }^{75}$ Id. Ibid., livro XI, cap. VI, p. 332. O “estado de baixeza” diz respeito à condição social do indivíduo (cf. DEDIEU, Joseph. op. cit., p. 333 e 386).
} 
mas para fazer leis, ou para ver se foram bem executadas aquelas que fez, coisa que pode muito bem fazer e, até mesmo, só ele pode fazer bem",76.

Montesquieu confiou o poder legislativo não só a representantes do povo, mas a um Senado, uma espécie de Câmara Alta, cujos membros seriam integrantes da nobreza munidos de um poder hereditário ${ }^{77}$. A parte que lhes compete "na legislação deve então ser proporcional às outras vantagens que possuem no Estado, o que acontecerá se formarem um corpo que tenha o direito de limitar as iniciativas do povo, assim como o povo tem o direito de limitar as dele",78.

De forma a possibilitar um equilíbrio entre as duas forças, evitando, por conseguinte, a inviabilidade do funcionamento do legislativo, Montesquieu enfraqueceu o poder do corpo dos nobres, cujas prerrogativas poderiam levá-lo apenas à defesa de seus próprios interesses. Daí por que ao corpo dos nobres foi reservada somente a faculdade de impedir, vale dizer, "o direito de anular uma resolução tomada por outrem; o que era o poder dos tribunos de Roma"79. Dessa maneira, foram conferidas ao poder legislativo a edição de leis e a função de dispor sobre as despesas públicas. O órgão da nobreza ficou, porém, somente autorizado a decretar o impedimento dos atos provenientes da Câmara Baixa ou dos Comuns ${ }^{80}$.

Por reclamar uma ação imediata do governo, inclusive no que concerne à subordinação do exército, o exercício do poder executivo deve incumbir ao monarca. $\mathrm{Na}$ visão de Montesquieu, trata-se de uma atividade que é melhor administrada por um do que por muitos, ao contrário do que acontece em relação ao legislativo.

A divisão dos poderes estatais admite algumas atenuações, visando a um funcionamento equilibrado. O legislativo não pode deixar de se reunir periodicamente, pois o resultado seria ou a anarquia ou um fortalecimento exacerbado do poder real. Entretanto, atividades ininterruptas do legislativo poderiam acarretar a paralisação das funções executivas, o que justificaria a convocação das sessões pelo monarca. Ademais, se ao executivo não fosse dado limitar as iniciativas do legislativo, seria difícil contê-lo, uma vez que poderia "outorgar-se todos os poderes imagináveis", aniquilando os demais ${ }^{81}$. Mas,

\footnotetext{
${ }^{76}$ MONTESQUIEU, Charles de. op. cit., I, livro XI, cap. VI, p. 333.

${ }^{77}$ Cf. DEDIEU, Joseph. op. cit., p. 333-334.

${ }^{78}$ MONTESQUIEU, Charles de. op. cit., I, livro XI, cap. VI, p. 333.

${ }^{79}$ Id. Ibid., p. 334.

${ }^{80}$ VERNIËRE, Paul. op. cit., p. 386.

${ }^{81}$ MONTESQUIEU, Charles de. op. cit., I, livro XI, cap. VI, p. 336.
} 
além de controlar a oportunidade de funcionamento do legislativo, a ingerência do monarca restringe-se ao poder de veto. De resto, ele não deve dispor da iniciativa para a apresentação de projetos de lei, não deve se manifestar sobre questões envolvendo a arrecadação dos recursos públicos e também não deve participar das sessões ou dos debates ocorridos no parlamento ${ }^{82}$.

Em contrapartida, não há necessidade de controle pelo legislativo das ações governamentais já circunscritas aos lindes legais. "Porém, se num Estado livre o poder legislativo não deve ter o direito de frear o executivo, tem ele o direito e deve ter a faculdade de examinar de que maneira as leis que criou foram executadas" ${ }^{„ 83}$. Com efeito, o poder legislativo não está autorizado a influir diretamente na execução de suas leis pelo monarca, não obstante os ministros possam ser responsabilizados e punidos por condutas relacionadas à má execução de uma lei.

De outro turno, a despeito do poder geral de julgar recair sobre um órgão totalmente dissociado do legislativo, tal regra comporta três exceções, em função dos interesses daqueles que serão levados a julgamento. Os nobres não devem ser submetidos a tribunais ordinários, pois não poderiam deixar de desfrutar o "privilégio que possui o menor dos cidadãos num Estado livre, que é o de ser julgado por seus pares" $"$. O julgamento deve, então, ser atribuído ao corpo do legislativo integrado pela nobreza. Além disso, nos casos de violação por cidadãos comuns aos direitos do povo nos negócios públicos, como o legislativo representa a parte diretamente interessada, ele deve figurar como o órgão acusador; ou seja, o corpo do legislativo que representa o povo realiza a acusação perante o corpo da nobreza que aprecia a causa. O mesmo órgão da nobreza deve pronunciar-se sobre os casos de extremo rigor da legislação, uma vez que aos juízes não caberia moderar a força de uma lei ${ }^{85}$.

O sistema de controle recíproco entre os três poderes do Estado obriga-os a seguir de comum acordo. O resultado é um notável equilíbrio na constituição fundamental do ente político. Os três poderes "deveriam formar um repouso, uma inação. Mas, como pelo

\footnotetext{
${ }^{82}$ Considerando a reprodução idealizada do funcionamento do sistema de governo inglês, como críticas à obra de Montesquieu, foram apontadas as limitações impostas ao poder executivo; restrições que colocariam aquele órgão em uma evidente situação de dependência em relação ao poder legislativo (cf. DEDIEU, Joseph. op. cit., p. 339-340).

${ }^{83}$ MONTESQUIEU, Charles de. op. cit., I, livro XI, cap. VI, p. 336.

${ }^{84}$ Id. Ibid., p. 337.

${ }^{85}$ Id. Ibid., p. 337-338.
} 
movimento necessário das coisas, eles são obrigados a agir", serão compelidos a proceder em concerto ${ }^{86}$.

Considera-se que Montesquieu elaborou grande parte do Livro XI de L'esprit des lois depois de uma viagem à Inglaterra, aproximadamente em 1733, "sob a impressão imediata da vida política inglesa. Descrição abstrata e alusiva, aliás, pois as instituições britânicas não são nem mesmo citadas: é o retrato de uma constituição ideal fundada na separação dos poderes, única garantia da liberdade" ${ }^{\Perp 87}$. Mais do que a constituição inglesa puramente idealizada, o governo moderado da república romana também foi indicado como a verdadeira fonte de inspiração da proposta de Montesquieu ${ }^{88}$.

De todo modo, o sistema de distribuição dos poderes do Estado é o grande legado do autor, principalmente com a ideia de corpos intermediários elevada a um componente fundamental. O equilibro projetado por Montesquieu "não nasce de uma pulverização, mas de uma tensão; a harmonia nasce de um conflito superado, pois a vida impõe movimento", emergindo, enfim, um acordo mútuo entre forças rivais ${ }^{89}$.

\subsection{A independência dos Estados Unidos da América: o marco do constitucionalismo moderno na origem do Attorney General}

Em 1776, o movimento de independência das colônias britânicas da América do Norte representou um momento histórico determinante para o desenvolvimento da democracia moderna, “combinando, sob o regime constitucional, a representação popular

\footnotetext{
${ }^{86}$ MONTESQUIEU, Charles de. op. cit., p. 339.

${ }^{87}$ VERNIÈRE, Paul. op. cit., p. 385. Cf. também LOEWENSTEIN, Karl. Teoria de la Constitucion. 2. ed. Barcelona: Ariel, 1976. p. 60.

${ }^{88} \mathrm{Em}$ Roma, foram combinadas numa constituição de natureza mista as três espécies tradicionais de governo: a monarquia, a aristocracia e a democracia. No curso do processo legislativo ordinário, representando o poder monárquico, os cônsules detinham a iniciativa de apresentação dos projetos de lei. Em seguida, competia ao senado, formado por componentes da aristocracia, aprová-los, para posterior votação pelo povo reunido nos comícios (cf. COMPARATO, Fábio Konder. A garantia institucional contra o abuso de poder, cit., p. 46). Cf. ainda LOEWENSTEIN, Karl. The governance of Rome. Netherlands: Martinus Nijhoff, The Hague, 1973. p. 72-73 e 108 e ss. Considerando e modelo da república romana, Cícero assim se manifestou: "Com efeito, prefiro, no Estado, um poder eminente e real, que dê algo à influência dos grandes e algo também à vontade da multidão. É essa uma constituição que apresenta, antes de mais nada, um grande caráter de igualdade, necessário aos povos livres e, bem assim, condições de estabilidade e firmeza. Os primeiros elementos, de que falei antes, alteram-se facilmente e caem no exagero do extremo oposto. Assim, ao rei sucede o tirano; aos aristocratas, a oligarquia facciosa; ao povo, a turba anárquica, substituindo-se desse modo umas perturbações a outras. Ao contrário, nessa combinação de um governo em que se amalgamam os outros três, não acontece facilmente semelhante coisa sem que os chefes do Estado se deixem arrastar pelo vício; porque não pode haver pretexto de revolução num Estado que, conforme cada um com os seus direitos, não vê sob seus pés aberto o abismo" (CÍCERO, Marco Túlio. op. cit., p. 40).

${ }^{89}$ VERNIÈRE, Paul. op. cit., p. 395.
} 
com a limitação de poderes governamentais" $" 90$. Premida por um forte espírito mercantil, a sociedade americana mostrou-se sempre avessa ao sentimento de honra, ao apego a privilégios e a distinções pessoais que, como demonstrou Montesquieu, dominavam o espírito da aristocracia europeia desde a Idade Média. O princípio da igualdade de condição jurídica foi o elemento central naquela sociedade que, desde o início do século XVII, "constituiu-se como um grupo organizado de cidadãos livres, iguais perante a lei, e cuja diferenciação interna só podia existir em função da riqueza material"91.

Assim, as sucessivas decisões do governo inglês, visando a restringir as relações comerciais entre os colonos americanos e majorar a carga fiscal, tornaram irreversível o desfecho do movimento revolucionário que culminou com a Declaração de Independência dos representantes dos Estados Unidos da América, reunidos em 4 de julho de 1776. Temse o primeiro documento a atestar "os princípios democráticos, na história política moderna" 92 , afirmando-se o princípio da soberania popular, nos moldes projetados no século anterior por John Locke, sob a visão do funcionamento do sistema constitucional inglês ${ }^{93}$.

No século XVII, valendo-se do fundamento do contrato social, coube a Locke fincar os lastros teóricos do regime político de representação popular, aliado ao primado da igualdade de todos perante a lei. Subordinados ao consenso popular (government by consent), os governos são basicamente constituídos para a defesa dos direitos naturais do

${ }^{90}$ Cf. COMPARATO, Fábio Konder. A afirmação histórica dos direitos humanos. 2. ed. São Paulo: Saraiva, 2001. p. $95.4^{\mathrm{a}}$ ed.

${ }^{91}$ Id. Ibid., p. 96. Alexis de Tocqueville prognosticou o tempo em que existiriam na América do Norte milhões de homens iguais entre si, pertencendo a uma mesma família com a mesma origem, civilização semelhante, a mesma língua, religião parecida, iguais hábitos e costumes iguais, e, por meio deles, o pensamento circulando sob as mesmas formas e as mesmas cores TOCQUEVILLE, Alexis de. A democracia na América (1835). In: . Igualdade social e liberdade política: uma introdução à obra de Alexis de Tocqueville. Trad. Cícero Araújo. São Paulo: Nerman, 1998. $1^{a}$ parte, cap. II, p. 62.

${ }^{92}$ COMPARATO, Fábio Konder. A afirmação histórica dos direitos humanos, cit., p. 102.

${ }^{93}$ Fomentados em um cenário de enorme intolerância religiosa, conflitos e guerras civis marcaram a Inglaterra do século XVII, sob o império de forte antagonismo entre o parlamento e a coroa controlada pela dinastia Stuart, de religião católica. Durante a Restauração, no período de 1658 a 1688, com a volta dos Stuart ao trono inglês, acirrou-se a irresignação da nobreza e do alto clero com a continuidade da monarquia católica. Em 1688, com apoio de segmentos da burguesia, a chamada Revolução Gloriosa operou uma alteração dinástica no poder central, com a outorga da coroa a Guilherme de Orange e a sua mulher Maria Stuart, filha de Jaime II, que era protestante. A iniciativa partiu de um grupo de representantes dos Whigs e dos Tories, os dois partidos que integravam o parlamento inglês. Como condição de seu acesso ao trono, o Príncipe de Orange acolheu o Bill of Rights; uma declaração de direitos que assegurava a preservação da autonomia das atividades parlamentares. Com a declaração de que cabia ao parlamento a defesa dos súditos perante o poder real, germinava a garantia das liberdades individuais. $\mathrm{O}$ Bill of Rights é a lei fundamental do Reino Unido, que perdura até hoje, tal como foi concebida séculos atrás (COMPARATO, Fábio Konder. A afirmação histórica dos direitos humanos, cit., p. 89 e ss.; cf. também GOUGH, J. W. op. cit., p. 229-230). 
homem. O povo é o real detentor da soberania política, e a instituição do legislativo, o supremo poder estatal, acontece para guiar os homens de acordo com a lei da natureza, por meio da criação de normas imparciais e válidas para todos, inclusive para aqueles a quem compete o exercício das funções governamentais ${ }^{94}$.

O poder do povo é exercício quando da criação do Estado, sendo acatada a supremacia do governo enquanto ele age no cumprimento do dever de proteção dos direitos naturais do homem, isto é, dos "bens que lhe são próprios e conaturais à sua condição humana: a vida, as liberdades e suas posses (life, liberties and estates)" "95. As leis civis não emanam de uma autoridade superior e sim da própria comunidade (Commonwealth). Consequentemente, os homens que irão exercer o poder legislativo devem ser cidadãos comuns, retomando a mesma posição quando deixarem o cargo $^{96}$. $\mathrm{O}$ exercício das funções do governo não é ilimitado, restando ao povo, na condição de verdadeiro detentor da soberania, a possibilidade de "remover ou alterar o legislativo quando julgar que este age contrariamente à confiança nele depositada"97.

Locke enfatizou a relação fiduciária que envolve o exercício do poder político pelos governantes. Utilizou-se, com frequência, do conceito de trust, sinalizando a necessidade de um "entendimento contínuo entre governantes e governados" alicerçado na confiança de que as ações governamentais estarão limitadas à finalidade da constituição do Estado, ou seja, à promoção do bem de toda a comunidade política (Commonwealth) ${ }^{98}$. A doutrina tornou-se o pressuposto do governo representativo que Locke explicitou em todos os seus pontos, inclusive o do domínio dos partidos "jamais cogitado por ele"99.

No constitucionalismo inglês, sempre foram reputadas de maior eficácia para o controle do exercício do poder político as restrições decorrentes das convenções e costumes amealhados pela tradição política e cultural da nação. Na Inglaterra, considerouse que os limites para conter uma decisão governamental arbitrária "tornaram-se tão

\footnotetext{
${ }^{94} \mathrm{Cf}$. Segundo Tratado, $\$ \S 123$ e ss., in Dois tratados sobre o governo, cit., p. 494 e ss.

${ }^{95}$ COMPARATO, Fábio Konder. Ética: direito, moral e religião no mundo moderno, cit., p. 208. É o que Locke denomina property.

${ }^{96}$ Segundo Tratado, $\$ \S 132-133$ e 154, in Dois tratados sobre o governo, cit., p. 500-502 e 522-523.

${ }^{97}$ Segundo Tratado, $§ 149$, in Dois tratados sobre o governo, cit., p. 518. Locke chegou a defender o direito à revolução, atestando que, quando uma longa série de abusos por parte dos governantes apresentar-se intolerável para o povo, "não é estranhar que ele então se levante e trate de depositar o mando em mãos que possam garantir-lhe os fins para os quais o governo foi originalmente constituído" (Segundo Tratado, $\S$ 225, in Dois tratados sobre o governo, cit., p. 583).

${ }^{98}$ Cf. LASLETT, Peter. op. cit., p. 270-273.

${ }^{99}$ Id. Ibid., p. 265.
} 
consolidados pela tradição nacional que nenhuma ameaça contra eles pareceu suficientemente relevante para exigir a adoção de qualquer lei escrita" ${ }^{\prime 100}$.

Todavia, os líderes revolucionários norte-americanos foram além. À diretriz da soberania popular como a única fonte de legitimidade do poder político, acresceram-se uma rígida separação de poderes e a própria constituição escrita, como "garantias positivas de que nenhum dos poderes do governo excederia dos limites que lhe eram determinados ou seria superior a qualquer outro"101. Nesses moldes, o conceito moderno de uma Constituição foi fruto da criação dos norte-americanos que a conceberam como um documento solene constitutivo do "supremo ato da vontade política de um povo", com a finalidade precípua de proteger o indivíduo contra os abusos dos governantes ${ }^{102}$.

Com base na proteção da liberdade individual e da igualdade de condição jurídica entre os cidadãos, uma declaração de direitos já constava da maioria dos textos das Constituições dos Estados ${ }^{103}$. Por essa razão, a Constituição Federal aprovada na Convenção de Filadélfia, em 1787, priorizou a reorganização das instituições políticas, de sorte a conferir a necessária unidade à nova nação. A organização confederal adotada após a proclamação da independência em 1776 apresentava-se incapaz de evitar as rivalidades entre os Estados, principalmente no campo das relações comerciais. A fórmula inovadora para solucionar o problema do enfraquecimento do poder político da União foi o pacto em torno da criação de um governo central que estendesse o raio de sua ação para abranger todos os cidadãos, além da manutenção do relacionamento com as unidades estatais. É que “enquanto em uma confederação o governo central só se relaciona com os Estados, cuja soberania interna permanece intacta, em uma federação esta ação se estende aos

\footnotetext{
${ }^{100}$ MCILWAIN, Charles Howard. Constitucionalism: ancient and modern. Ithaca, New York: Cornell University Press, 1940. p. 17.

${ }^{101}$ GOUGH, J. W. op. cit., p. 238.

${ }^{102}$ COMPARATO, Fábio Konder. A afirmação histórica dos direitos humanos, cit., p. 109.

${ }^{103}$ Cf. a declaração de direitos dos cidadãos da Constituição de Virginia, de 29.6.1776, votada na Convenção de Filadélfia, em 1787, quando da ratificação das Constituições Estaduais (cf. VIRGINIA (USA). The Constitution of Virginia, June 291 (1), 1776. Disponível em: <http://www.nhinet.org/ccs/docs/va1776.htm>. Acesso em: 18 nov. 2008). No plano federal, a declaração de direitos norte-americana constou das dez primeiras emendas à Constituição Federal, decorrentes de uma proposta aditiva aprovada pelas duas Casas do Congresso Nacional, em 25 de setembro de 1789. "Seguindo o modelo do Bill of Rights britânico, os Estados Unidos deram aos chamados direitos humanos a qualidade de direitos fundamentais, isto é, direitos reconhecidos expressamente pelo Estado, elevando-os ao nível constitucional, acima portanto da legislação ordinária" (COMPARATO, Fábio Konder. A afirmação histórica dos direitos humanos, cit., p. 108).
} 
indivíduos, fazendo com que convivam dois entes estatais de estatura diversa, com a órbita de ação dos Estados definida pela Constituição da União"104.

É claro, contudo, que no projeto constitucional norte-americano não foi desprezada a constatação de Montesquieu sobre a tendência do exercício abusivo do poder político. Porém, como foi visto, o autor buscou combinar a separação de poderes com a teoria do governo misto, ou seja, a distribuição das funções de governo a órgãos diferentes, cada qual formado por grupos sociais também diversos: a realeza, a nobreza e o povo.

Ocorre que a separação de poderes pode não coincidir, propriamente, com a existência de um governo misto. Em atenção à tradição inglesa, a hipótese de um governo misto não deixa de ser compatível com a supremacia do legislativo, "sustentado conjuntamente pelo rei e membros da Câmara dos Pares e dos Comuns (...)"105. Nos Estados Unidos da América, a repulsa às divisões estamentais, firmada sob sólidos alicerces de um capitalismo emergente, afastava qualquer possibilidade da constituição de um governo misto, não obstante o fortalecimento da ideia da distribuição do poder político entre órgãos diversos ${ }^{106}$.

Em um dos ensaios da série denominada O Federalista, James Madison enfrentou a questão de como conjugar um governo popular com o problema das facções, que ele definiu como "um número de cidadãos, representando a maioria ou a minoria do conjunto, que se encontram unidos e atuando sob o impulso comum de paixões ou interesses contrários aos dos outros cidadãos ou aos interesses permanentes e comuns da coletividade" ${ }^{, 107}$.

No modelo de representação popular, impera o princípio de respeito à vontade majoritária, do que adviria a ameaça de os interesses de uma facção detentora do poder político sobrepujarem os dos grupos minoritários, principalmente considerando as diferenças de distribuição de riquezas:

\footnotetext{
${ }^{104}$ LIMONGI, Fernando Papaterra. "O Federalista": remédios republicanos para males republicanos. In: WEFFORT, Francisco C. (Org.). Os clássicos da política: Maquiavel, Hobbes, Locke, Montesquieu, Rousseau, “O Federalista”. 13. ed. São Paulo: Ática, 2004. v. 1, p. 248.

${ }^{105}$ GOUGH, J. W. op. cit., p. 226.

${ }^{106}$ Sobre os antagonismos entre as colônias britânicas e o Parlamento inglês no processo revolucionário de independência americana, cf. POCOCK, J. G. A. 1776: a Revolução contra o Parlamento. In:

Linguagens do ideário político. São Paulo: Ed. da Universidade de São Paulo, 2003. p. 277 e ss.

${ }^{107}$ The Union as a Safeguard Against Domestic Faction and Insurrection, in The Federalist Papers, n. 10, Signet Classic, Penguin Group (USA), 2003, p. 72. A série denominada The Federalist consiste nos ensaios de Alexander Hamilton, James Madison e John Jay publicados na imprensa de Nova York em 1788, visando a contribuir para a ratificação pelos Estados da Constituição elaborada pela Convenção de Filadélfia à nação recém-constituída.
} 


\begin{abstract}
"São ouvidas por toda parte dos mais virtuosos e dignos cidadãos, igualmente adeptos à fé pública e privada e à liberdade coletiva e pessoal, reclamações de que os nossos governos são muito instáveis, de que o bem público não é observado em meio aos conflitos entre partidos rivais, e de que, com frequência, são adotadas medidas, não de acordo com os princípios de justiça e os direitos dos partidos minoritários, mas pela força de uma maioria interesseira e autoritária" ${ }^{" 108}$.
\end{abstract}

No entanto, se em função da supremacia da liberdade individual e da "distribuição variada e desigual da propriedade" ${ }^{\text {109 }}$, de um lado, seria impossível eliminar as causas das facções, de outro, tornava-se indispensável o estabelecimento de meios para o controle de seus efeitos. Assim, a solução residiu na instituição de um governo republicano, concebido como aquele em que se aplica o "esquema da representação (...)"110. Na república representativa, o mal da preponderância dos interesses de uma facção poderia ser evitado aumentando a esfera de atuação de um único governo e, por conseguinte, o número de governados, com o poder político atribuído, em contrapartida, a um menor número de cidadãos $^{111}$. A multiplicação das facções impediria o domínio de uma só, com a neutralização recíproca dos interesses rivais. E a tarefa dos governantes eleitos pelo povo seria a coordenação de tais interesses, de modo a obstar a prevalência de qualquer deles e, ao mesmo tempo, manter a esfera da liberdade necessária ao "desenvolvimento dos indivíduos, em especial de suas atividades econômicas"112.

De outro turno, para evitar a concentração do poder político, a Constituição deveria garantir a autonomia de cada um de seus órgãos, descartando-se, conforme foi anotado, a possibilidade de adoção de um governo misto. O fundamento da república representativa norte-americana consistente na igualdade de todos perante a lei afastava a possibilidade de reconhecimento de quaisquer prerrogativas a agrupamentos específicos intercalados entre a sociedade e os seus representantes, eleitos para o governo do Estado. A ideia de corpos

\footnotetext{
${ }^{108}$ MADISON, James. The union as a safeguard against domestic faction and insurrection. The Federalist Papers, New York, n. 10, p. 72, 2003. Alexis de Tocqueville também atentou para o mesmo fato: "Quando um homem ou um partido é vítima de uma injustiça nos Estados Unidos, a quem se pode dirigir? À opinião pública? É ela que forma a maioria. Ao corpo legislativo?... Representa a maioria e a obedece cegamente. Ao poder executivo?... É nomeado pela maioria e a serve como instrumento passivo. À força pública?... A força pública não é outra coisa que a maioria em armas. Ao jurado?... O jurado é a maioria revestida do direito de pronunciar sentença: mesmo os juízes, em certos Estados, são eleitos pela maioria. Por iníqua ou irracional que seja a medida que o atinja, não há outro remédio senão submeter-se a ela" (TOCQUEVILLE, Alexis de. op. cit., $2^{\text {a }}$ parte, cap. VII, p. 53).

${ }^{109}$ MADISON, James. op. cit., p. 73-74.

${ }^{110}$ Id. Ibid., p. 76.

${ }^{111}$ Cf. LIMONGI, Fernando Papaterra. op. cit., p. 254-255.

${ }^{112}$ Id. Ibid., p. 253.
} 
intermediários para a manutenção de um equilíbrio entre as forças políticas comprometeria a condição atribuída ao povo de real detentor do poder soberano, inclusive tendo em conta a necessidade de afirmação do Estado federal, mediante o fortalecimento da União.

A solução bicameral era o padrão dominante na Convenção de Filadélfia de 1787, principalmente quando os debates revelaram que apenas um compromisso entre os pequenos e os grandes Estados podia resolver os conflitos que ameaçavam a dissolução da convenção. Assim, a Câmara dos Representantes extrairia o seu poder do povo da América, enquanto a força do Senado derivaria dos Estados como sociedades políticas em pé de igualdade. A Câmara constituiria o elemento nacional e o Senado, o elemento federal. Não foi projetada uma forma de representação que fizesse distinção entre pessoas, pois a estrutura federal propunha-se a resolver qualquer problema decorrente de uma "multiplicidade de interesses",

Nesse passo, em linhas gerais, os órgãos superiores do executivo, do legislativo e do judiciário deveriam ser integrados por representantes do povo, "sem canais de comunicação uns com os outros". E, para os diferentes órgãos estatais atuarem separadamente, "é evidente que cada órgão deve ter uma autonomia própria; e, consequentemente, deve ser constituído de forma tal que os membros de um tenham a menor ingerência possível na designação dos membros dos outros" $" 114$.

A composição do judiciário poderia, no entanto, representar uma exceção à regra, em virtude das qualificações especiais exigidas de seus integrantes, com a garantia de vitaliciedade aos juízes prestando-se ao enfraquecimento dos laços de dependência da autoridade do outro poder responsável por respectiva nomeação. Em um ensaio de Alexander Hamilton, foi também ressaltada a vulnerabilidade da função do judiciário em relação às dos poderes legislativo e executivo. Este último detém "a espada da comunidade", enquanto o legislativo dispõe do controle sobre as despesas públicas e da atribuição de regular os direitos e os deveres dos cidadãos ${ }^{115}$. Considerando a primazia da proteção à liberdade individual, Hamilton observou que o judiciário, isoladamente, não seria capaz de ameaçá-la. O perigo decorreria da união deste poder com os dois outros, “não obstante uma separação nominal e aparente; (...) e, como nada pode contribuir mais

\footnotetext{
${ }^{113}$ DIPPEL, Horst. História do constitucionalismo moderno: novas perspectivas. Tradução Antonio Manuel Hespanha e Cristina Nogueira da Silva. Lisboa: Fundação Calouste Gulbenkian, 2007. p. 98-99.

${ }^{114}$ MADISON, James. The structure of the government must furnish the proper checks and balances between the different departments. The Federalist Papers, New York, n. 51, p. 318, 2003.

${ }^{115}$ HAMILTON, Alexander. The Judiciary Department. The Federalist Papers, New York, n. 78, p. 464, 2003.
} 
para sua firmeza e independência do que a estabilidade no cargo, esta prerrogativa deve, portanto, ser considerada justamente como um fator indispensável em sua constituição e, em larga medida, como a cidadela da justiça e da segurança pública"116.

Impossível abdicar da independência dos tribunais para restringir a autoridade legislativa, de sorte a obrigá-la a respeitar as exigências constitucionais na edição das leis ${ }^{117}$. Apenas com um judiciário independente as cortes poderiam cumprir o dever de “invalidar os atos contrários ao manifesto sentido da Constituição. Sem isso, todas as

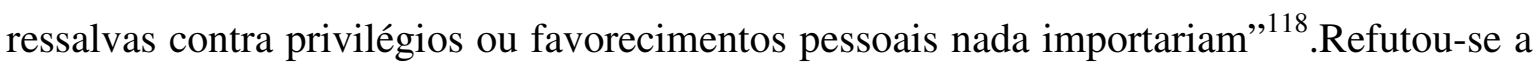
hipótese de tal atuação acarretar qualquer superioridade do judiciário sobre o legislativo. Nenhuma autoridade delegada pode sobrepor-se ao povo; os representantes não estão acima dos representados, e a vontade daqueles não deve, de modo algum, preponderar sobre a de seus constituintes. E, ademais, não seria natural supor que os legisladores fossem os “juízes de seus próprios poderes”. Assim, o judiciário foi projetado para manter a legislatura dentro dos limites assinalados ao exercício de sua autoridade, funcionando como o baluarte da Constituição ${ }^{119}$. Foram essas as condições em que o sistema jurídico norte-americano firmou-se, desde o início, pela supremacia da Constituição sobre as leis; matriz que foi reconhecida pela Suprema Corte no clássico caso Marbury v. Madison, em $1803^{120}$.

Por outro lado, em decorrência da negociação política em torno da implantação do Estado Federal, a Constituição de 1787 conferiu às unidades estatais uma esfera de autonomia para a composição de seus sistemas organizacionais. O regime de descentralização vertical ensejou a existência de órgãos variando em cada Estado e apresentando uma estrutura alheia à que foi estabelecida aos componentes do governo da União.

Também votada na Convenção de Filadélfia de 1787, a Constituição de Virginia, além de conter uma declaração de direitos individuais, enfatizou aos magistrados, entendidos como todos aqueles responsáveis pelo exercício de funções públicas, a natureza de servidores do povo ${ }^{121}$. Do mesmo diploma também constou o princípio da separação

\footnotetext{
${ }^{116}$ HAMILTON, Alexander. op. cit., p. 465.

${ }^{117}$ Hamilton apontou as vedações a projetos de confisco e ao advento de leis ex post facto.

${ }^{118}$ HAMILTON, Alexander. op. cit., p. 465.

${ }^{119}$ Id. Ibid., p. 466.

${ }^{120} \mathrm{Cf}$. COMPARATO, Fábio Konder. A afirmação histórica dos direitos humanos, cit., p. 109-110.

${ }^{121} \mathrm{Cf}$. SACCO, Ricardo Ferreira. Constitucionalismo e Ministério Público: uma visão panorâmica. Belo Horizonte: Mandamentos; FHC/FUMEC, 2008. p. 40 e ss.
} 
dos poderes executivo, legislativo e judiciário, afirmando-se a necessidade da organização de quadros funcionais autônomos, com a vedação ao exercício simultâneo de funções ${ }^{122}$.

Aquela Constituição referiu-se ainda à figura do Attorney General que, no sistema da common law, corresponde ao órgão do Ministério Público de origem francesa ${ }^{123}$. A escolha do agente competia às duas Casas da Assembleia, com a sua nomeação sob a responsabilidade do Governador ${ }^{124}$. Explicitou-lhe o papel de defensor dos interesses da sociedade, mediante a função de promover o processo de impeachment do chefe do executivo, em caso de má administração, corrupção e outras formas de ofensa ao erário. A atribuição foi, concorrentemente, conferida aos cidadãos, com a condenação do Governador podendo gerar o afastamento do cargo e a proibição do exercício de funções públicas $^{125}$.

Datada de 1780, a Constituição de Massachusetts, ainda em vigor, estabeleceu ao Attorney General do Estado, eleito pelo voto popular para um mandato de quatro anos, a atribuição de encaminhar ao legislativo propostas de iniciativa popular referentes a projetos de lei e a emendas ao texto constitucional, após a análise da presença dos

\footnotetext{
122،The legislative, executive, and judiciary department shall be separate and distinct, so that neither exercise the powers properly belonging to the other: nor shall any person exercise the powers of more than one of them, at the same time; except that the Justices of the County (...)" (The Constitution of Virginia, June 291 (1), 1776. Disponível em: <http://www.nhinet.org/ccs/docs/va-1776.htm>). O texto atual do mesmo Estado reproduz a hipótese (cf. Constitution of Virginia, Article III. Division of Powers. Section 1. Departments to be distinct. Virginia General Assembly: legislative information system. VIRGINIA (USA). Constitution of Virginia. Disponível em: <http://legis.state.va.us/laws/search/constitution.htm>. Acesso em: 18 nov. 2008.

${ }^{123}$ A origem do Ministério Público é usualmente identificada com os oficiais que figuravam como procuradores do rei da França, conforme foi destacado por Montesquieu e será visto a seguir.

124، The two Houses of Assembly shall, by joint ballot, appoint Judges of Supreme Court of Appeals, and General Court, Judges in Chancery, Judges of Admiralty, Secretary, and the Attorney-General, to be commissioned by Governor, and continue in office during good behavior" (The Constitution of Virginia, June 291 (1), 1776. Disponível em: <http://www.nhinet.org/ccs/docs/va-1776.htm>). Atualmente, como acontece na maioria dos Estados norte-americanos, o Attorney General de Virginia é eleito pelo povo: "An Attorney General shall be elected by the qualified voters of the Commonwealth at the same time term as the Governor, and the fact of his election shall be ascertained in the same manner, no person shall be eligible for election or appointment to the office of Attorney General unless he is a citizen of United States, has attained the age of thirty years and has the qualifications required for a judge of a court of record. He shall perform such duties and receive such compensation as may be prescribed by law, which compensation shall neither be increased nor diminished during the period for which he shall have been elected. There shall be no limit on the terms of the Attorney General" (Constitution of Virginia, Article V. Executive. Section 15. Attorney General. Virginia General Assembly: legislative information system. VIRGINIA (USA). Constitution of Virginia, cit.

${ }^{125}$ "The Governor, when he is out of office, and others, offending against the State, either by maladministration, corruption, or others means, by which the safety of the State may be endangered, shall be impeachable by the House of Delegates. Such impeachment to be prosecuted by the Attorney-General or such other person or persons, as the House may appoint in the General Court, according to the laws of the land. If found guilty, he or they shall be either forever disabled to hold any office under government, or be removed from such office pro tempore, or subjected to such pains or penalties as the laws shall direct" (The Constitution of Virginia, June 291 (1), 1776. Disponível em: <http://www.nhinet.org/ccs/docs/va1776.htm>). A hipótese remete aos contornos da ação popular de origem romana.
} 
requisitos de admissibilidade das medidas. Essa atuação não deixa de traduzir o papel de um agente intermediário entre o governo e a sociedade para o controle e participação do povo na atividade legislativa ${ }^{126}$.

Contudo, no sistema norte-americano de organização do poder político, o vínculo de subordinação direta à soberania popular afeto ao regime de representação democrática, tradicionalmente, sempre foi considerado o mais expressivo controle sobre a atuação dos dirigentes estatais. Paralelamente a esse aspecto, como foi aventado, procurou-se distribuir a ação governamental em esferas distintas dotadas de um considerável grau de autonomia. E o sistema de descentralização do poder político também se fez presente no plano vertical, com a liberdade das unidades federativas para a sua organização e formas de funcionamento.

Foi o contexto que originou as funções do Attorney General variando conforme o Estado, não obstante a atividade comum de combate ao crime. É importante notar que, em regra, atribuições do Attorney General de defesa em juízo de outras autoridades e organismos governamentais somam-se à proteção de alguns interesses gerais da sociedade e de seus segmentos específicos. Agindo em nome do Estado, os interesses de governantes e de órgãos públicos confundir-se-iam com os da própria coletividade, afastando eventual incompatibilidade no exercício daquelas atribuições, com ressalva obviamente aos casos de cometimento das infrações penais.

No âmbito da União, o Judiciary Act de 1789 dispôs sobre o United State Attorney General para titularizar o Departamento de Justiça, órgão governamental de primeiro escalão vinculado ao Poder Executivo do Estado. Trata-se de um agente diretamente subordinado ao Presidente da República, que é o responsável por sua nomeação para um mandato de quatro anos, com a anuência do Senado Federal. Já na maioria dos Estados, os

\footnotetext{
${ }^{126}$ É a hipótese do initiative petitions (article XLVIII, section 3): "Such petition shall first be signed by ten qualified voters of the commonwealth and shall then be submitted to the attorney general not later than the first Wednesday of the August before the assembling of the general court into which it is to be introduced, and if he shall certify that the measure is in proper form for submission to the people, and that the measure is not, either affirmatively or negatively, substantially the same as any measure which has been qualified for submission or submitted to the people at either of the two preceding biennial elections, and that it contains only subjects not excluded from the popular initiative and which are related or which are mutually dependent, it may then be filed with the secretary of the commonwealth (section 3 superseded by section 1 of amendments, article LXXIV) (MASSACHESETTS (USA). Constitution of the Commonwealth of Massachusetts. Disponível em: <http://www.mass.gov/legis/const.htm>. Acesso em: 18 nov. 2008). Cf. também SACCO, Ricardo Ferreira. op. cit., p. 43.
} 
titulares da função de Attorney General são eleitos pelo povo, também para o exercício de um mandato de quatro anos ${ }^{127}$.

Nos Estados Unidos da América, esses agentes personificam totalmente os órgãos que compõem, não havendo falar em uma estrutura institucional de carreira pública, pautada por critérios de impessoalidade na composição de seus quadros e, tampouco, em garantias constitucionais amparando a atuação dos profissionais admitidos para integrá$\operatorname{los}^{128}$. Movido por vetores políticos ínsitos ao regime de representação democrática, sob o domínio dos partidos e a reboque de interesses econômicos, o Attorney General, sobretudo nos Estados, responde pelos rumos das atividades e do funcionamento de suas agências governamentais, compostas por vários setores especializados formados por profissionais contratados livremente.

\subsubsection{Os principais aspectos da figura do Attorney General}

Desde logo, é importante lembrar que o processo histórico que resultou na declaração de independência das colônias britânicas da América do Norte deu origem a um sistema federativo de Estado, revestido de uma estrutura de descentralização política vertical altamente significativa. O poder da União veio agregar a autonomia das 50 (cinquenta) unidades da federação norte-americana, inclusive no que diz respeito à produção legislativa de diversos ramos jurídicos (direitos civil, penal, administrativo, tributário, trabalhista, etc. $)^{129}$.

Como foi anotado, no campo federal, a autoridade superior responsável pelo Departamento de Justiça ${ }^{130}$ é o United States Attorney General nomeado pelo Presidente da República para um mandato de quatro anos, mediante a anuência do Senado Federal. Àquela autoridade cabe indicar os titulares dos cargos de U.S. Attorney para oficiar perante os tribunais federais distribuídos pelo país. Todos são membros do Departamento de Justiça, também nomeados pelo Presidente da República para um mandato de quatro anos, com a aprovação do Senado. Podem ser demitidos ad nutum e desempenham suas

\footnotetext{
${ }^{127}$ Cf. GUARNIERI, Carlo. Pubblico Ministero e sistema político. Padova: CEDAM, 1984. p. 62 e ss; e AYARRAGARAY, Carlos A. El Ministerio Público: su historia, organizacíon y funcionamiento em la legislacíon comparada y em la República Argentina seguido de las bases para uma próxima organizacíon. Buenos Aires: J. Lajouane, 1928.

${ }^{128}$ Cf. FERRAZ, Antonio Augusto Mello de Camargo. Anotações sobre os Ministérios Públicos Brasileiro e Americano. Justitia, São Paulo, v. 60, n. esp. (60 anos: 1939-1999), p. 1035 e ss., 1999.

${ }^{129}$ GUARNIERI, Carlo. op. cit., p. 62 e ss.

${ }^{130} \mathrm{O}$ órgão corresponde ao Ministério da Justiça brasileiro.
} 
atividades mediante a assistência de advogados livremente contratados, sem a necessidade da adoção de critérios homogêneos para a remuneração de cada qual ${ }^{131}$.

O United State Attorney General é um agente de confiança da Presidência da República e os U.S. Attorneys por ele indicados devem, de idêntico modo, estar afinados com o perfil e compromissos políticos do Chefe do Estado. Costuma-se questionar o real papel do Senado na aprovação dos nomes escolhidos pelo Presidente. Alguns atestam a verificação de uma influência efetiva por parte dos parlamentares, enquanto o entendimento em sentido oposto tende a subestimá-la. É certo, porém, que, com a eleição de um novo Presidente, todos os U.S. Attorneys renunciam ao mandato e abandonam os cargos, ocorrendo a nomeação provisória de um substituto pelo juiz federal da localidade ${ }^{132}$.

No âmbito dos Estados-membros, a atuação é comandada por um Attorney General que responde pela agência estatal (State Attorney General's Office). É menor o vínculo de dependência entre eles e o Governador, pois, na maioria dos Estados, são eleitos pelo povo, também para um mandato de quatro anos ${ }^{133}$. Tal como os agentes federais, os que atuam na esfera estadual desfrutam de plena autonomia à composição de seus organismos, podendo contratar e afastar livremente os profissionais que os integram. Ao contrário do que se vislumbra nos congêneres europeus, não há nenhuma estrutura de carreira pública nas agências dos Attorneys norte-americanos, que funcionam sob o primado da livre iniciativa quanto à formação de sua equipe de trabalho, nos limites dos recursos financeiros disponíveis.

Nos Estados Unidos da América, existe uma outra esfera de organização de procuradores na órbita dos condados que, à semelhança das circunscrições judiciárias existentes no Brasil, são regiões dos Estados, encampando alguns municípios. As funções do Attorney General são desenvolvidas pelos chamados District Attorneys, também eleitos pelo povo para um mandato de quatro anos, com atribuições preponderantes na área criminal $^{134}$.

Os U.S. Attorneys, membros do Departamento de Justiça, procuram fazer valer a legislação federal. Representam os interesses do governo em questões civis e criminais,

\footnotetext{
${ }^{131}$ Cf. FERRAZ, Antonio Augusto Mello de Camargo. op. cit., p. 1035 e ss.

${ }^{132}$ Cf. GUARNIERI, Carlo. op. cit., p. 64 e ss.

${ }^{133}$ AYARRAGARAY, Carlos A. op. cit., p. 89-90.

${ }^{134}$ Cf. FERRAZ, Antonio Augusto Mello de Camargo. op. cit., p. 1036.
} 
patrocinando a defesa em juízo de outros órgãos e agentes governamentais. Desenvolvem ainda atividades extrajudiciais de natureza administrativa, como, por exemplo, a direção ou a supervisão da atuação de outros órgãos públicos, prestando serviços de consultoria jurídica a diversos setores do Executivo, sobretudo ligados à Presidência da República. Inserem-se igualmente na esfera da produção legislativa, respondendo a consultas e enviando sugestões ao parlamento. No que concerne à aplicação da legislação federal, destacam-se a Lei Antitruste e diplomas contra a corrupção oficial, o tráfico de entorpecentes e outras formas de organização criminosa. Na esfera cível, é possível a verificação de iniciativas dirigidas à proteção das liberdades públicas, dos direitos dos consumidores e do meio ambiente.

A atividade de combate ao crime é central em todas as agências norte-americanas, às quais incumbe a promoção da ação penal e o controle das investigações que podem ocorrer em caráter sigiloso. Órgãos de grande destaque na atividade de repressão ao crime, como o Federal Bureau Investigation (FBI), são dirigidos pelo United State Attorney General, titular do Departamento de Justiça.

Naquele país, não impera o princípio da obrigatoriedade na promoção da ação penal, estando plenamente autorizada a formulação de acordos com os réus para a extinção das acusações ou a minoração de penas. Justamente em observância ao princípio da oportunidade, é bem reduzido o controle do judiciário sobre tal atuação. $\mathrm{O}$ respeito à matriz do devido processo legal dá ensejo a intervenções judiciais em benefício dos acusados para coibir práticas abusivas por parte da acusação, não sendo comum, ao revés, nenhuma interferência nas transações celebradas com a defesa ${ }^{135}$.

Por outro lado, conforme foi ressaltado, ofícios federais, sem nenhuma dúvida, representam ramos do Poder Executivo do Estado, com os seus integrantes projetados na seara dos interesses de cunho eleitoral, sob o comando da Presidência da República. Já os titulares dos órgãos estaduais são, em sua maioria, eleitos pelo povo, o que, não obstante atenue os laços de dependência com os governos locais, não há de torná-los de todo indiferentes ao mesmo panorama político. A atribuição primordial das agências norteamericanas reside no combate à criminalidade, de sorte a projetar, sob a égide do regime de representação popular, os seus titulares a uma posição de destaque que lhes permita

${ }^{135}$ Cf. GUARNIERI, Carlo. op. cit., p. 79-81. 
conquistar postos eletivos mais elevados, tanto na esfera federal como no âmbito dos governos estaduais ${ }^{136}$.

Apesar das diferenças no funcionamento das agências estaduais, é possível ainda destacar as atividades de defesa do meio ambiente, dos direitos dos consumidores, idosos e portadores de necessidades especiais, além de atribuições residuais na área criminal, tendo em vista a atuação nos setores dos condados ${ }^{137}$. O Attorney General dos Estados também costuma atuar na proteção dos interesses de outros órgãos e agentes estatais. No entanto, em certas circunstâncias, pode deixar de defender a legitimidade de determinada medida governamental. A hipótese, via de regra, não implica o advento de iniciativas para a apuração de responsabilidades como ocorre no sistema brasileiro, salvo nos casos envolvendo a prática de infrações penais.

A proteção dos interesses gerais da coletividade e de alguns de seus segmentos específicos vai depender das finalidades eleitas pelo organismo estatal, variando conforme as metas prioritárias fixadas no planejamento de sua atuação, incluindo os compromissos de natureza econômica ${ }^{138}$. De toda forma, consoante consagrou a Constituição de Virginia nos idos do século XVIII, o papel de defensor dos interesses do povo é mais perceptível nos titulares das agências estaduais.

Nesse sentido, revela-se a atuação do Attorney General do Estado de Massachusetts, cujo perfil caracterizou-se pela proteção de interesses sociais, com a assunção ao cargo realizada por meio de eleições populares, a partir da $17^{\mathrm{a}}$ emenda ao respectivo diploma constitucional, de $1855^{139}$. Como já disposto, datada de 1780 , a Constituição de Massachusetts assegurou a iniciativa popular para a apresentação de projetos de lei e de emendas ao texto constitucional. O Attorney General ficou responsável pelo encaminhamento das medidas para fins de deliberação do parlamento, após a análise

\footnotetext{
${ }^{136}$ Cf. KERCHE, Fábio. Controle democrático e o sistema judicial: o Ministério Público brasileiro em perspectiva comparada. Associação Brasileira de Ciência Política. Niterói, 2002. Disponível em: <http://www.cienciapolitica.org.br/encontro/instpoll.3.doc>. Acesso em: 24 nov. 2008.

${ }^{137}$ Cf. FERRAZ, Antonio Augusto Mello de Camargo. op. cit., p. 1036.

${ }^{138}$ É o caso das ações promovidas pelo Attorney General em alguns Estados contra as companhias de cigarro em proteção a usuários, enquanto as agências de outros Estados recebiam contribuições dos mesmos setores empresariais (SACCO, Ricardo Ferreira. op. cit., p. 224).

${ }^{139}$ Cf. a exposição de Ricardo Ferreira Sacco baseada em dados colhidos em entrevista realizada, aos 5 de maio de 2005, com Antony J. Melius, Special Assistent to the Attorney General do Estado de Massachusetts (SACCO, Ricardo Ferreira. op. cit., p. 226 e ss.).
} 
da presença dos requisitos de admissibilidade. A par disso, compete-lhe a substituição do governador e do vice-governador, em caso de vacância dos cargos ${ }^{140}$.

Consoante também ocorre com as atribuições dos agentes da União e das demais unidades federativas, os serviços do Attorney General Office de Massachuesetts são prestados de forma descentralizada, com organismos distribuídos pelas regiões do Estado. O principal está sediado em Boston, dispondo de uma equipe técnica e infraestrutura de grande porte, desmembradas em cinco agências especializadas (bureaus): "Executive, Business and Labor Protection, Criminal, Government, e Public Protection"; cada qual se subdivide em algumas unidades, reportando-se todas ao Attorney General ${ }^{141}$. A atuação é coordenada pela agência executiva que trata dos trabalhos junto ao legislativo, das relações com mídia para a divulgação dos serviços prestados, da gestão dos recursos e do planejamento e implantação de suas metas. Perfazendo um total de 450 (quatrocentos e cinquenta) funcionários, as atividades dos demais órgãos são supervisionadas por esse setor.

A figura do Attorney General norte-americano pouca ressonância encontra nos congêneres dos países da Europa continental que, a partir do sistema adotado em Portugal com base no modelo francês, certamente inspiraram os contornos da instituição brasileira, conforme será possível constatar na sequência deste trabalho.

\footnotetext{
${ }^{140}$ SACCO, Ricardo Ferreira. op. cit., p. 43 e ss.; e 225.

${ }^{141}$ Id. Ibid., p. 226. Além de cuidar da repressão aos crimes contra as relações laborais e a ordem econômica, uma outra agência do Attorney General Office de Massachuesetts atua também na tutela de direitos coletivos envolvendo o meio ambiente do trabalho e a fiscalização de vínculos empregatícios. Na área criminal, por meio da unidade respectiva (Criminal Bureau), o Attorney General participa ativamente das investigações dos delitos, contando com oficiais especializados, incluindo um aparato cedido pela polícia civil. A agência dispõe de departamentos específicos destinados à apuração dos crimes contra o patrimônio público, lavagem de dinheiro, tráfico de entorpecentes e fraudes em relações de consumo. Costuma ainda desenvolver projetos envolvendo investigações em larga escala, com apoio de outros Estados e do governo federal. Foram também ressaltados os trabalhos concernentes ao acesso a serviços públicos e à proteção dos direitos civis (direito à privacidade e liberdade de religião), com relevo à defesa do público consumidor, para o que funcionam algumas divisões dirigidas à repressão e prevenção de uma série de práticas abusivas, inclusive por meio da prestação de serviços gratuitos de informação, educação e mediação. Existe ainda um setor especial incumbido de fiscalizar os valores das tarifas dos serviços públicos cf. SACCO, Ricardo Ferreira. op. cit., p. 227-234.
} 


\subsection{A Revolução Francesa e a Declaração dos Direitos do Homem e do Cidadão de 1789: o embrião do Estado-legislador na organização do Parquet}

O movimento revolucionário francês do século XVIII revestiu-se de um caráter totalmente renovador, com vistas a realizar uma inédita ordem sociopolítica. Não se buscou apenas retomar as antigas prerrogativas do povo usurpadas pelo poder real, mas implantar um pioneiro modelo de relações de poder em âmbito universal.

A despeito de afastar qualquer orientação em torno de uma proteção concreta à dignidade humana, o racionalismo abstrato do pensamento informador da iniciativa revolucionária acabou permitindo que um novo ideal de liberdade e igualdade pudesse ser levado "em pouco tempo, a quase todos os quadrantes do mundo"142. De acordo com a declaração de direitos da Revolução Francesa, não importando o lugar em que se encontre no mundo ou a época em que viva, foi atribuído ao homem um valor absoluto, como portador de certos direitos naturais. Assim, ao se pretender avaliar se uma conduta é boa ou má, justa ou injusta, é necessário indagar se ela vai ou não ao encalço do caráter original que os princípios fundamentais outorgam à natureza humana.

Daí a diferença entre a Declaração de Independência dos Estados Unidos da América (1776) e o precedente Bill of Rights inglês (1689), e a Declaração dos Direitos do Homem e do Cidadão da Revolução Francesa (1789). Tanto os ingleses como os norteamericanos tiveram em mira, primordialmente, "a restauração das antigas liberdades e costumes, na linha de sua própria tradição histórica”. Já o escopo dos franceses foi disseminar uma declaração de direitos voltada ao homem em geral, de todos os tempos e lugares, em substituição ao "império da tradição, variável de povo a povo"143, consoante foi preconizado na doutrina de Montesquieu.

Com efeito, Montesquieu pretendeu examinar se as leis estão em consonância com a forma de constituição de um Estado, apreendido a partir do princípio que envolve a sua estrutura e o conserva como tal. Os princípios são responsáveis pelo funcionamento dos entes coletivos, respondendo pela formação e pela manutenção da unidade do conjunto. Tendo em vista uma multiplicidade de fenômenos históricos e elementos empíricos, o Estado é considerado um organismo que persegue determinado objetivo, contando com

\footnotetext{
${ }^{142}$ COMPARATO, Fábio Konder. A afirmação histórica dos direitos humanos, cit., p. 129.

${ }^{143}$ Id. Ibid., p. 129-130. Sobre os antagonismos entre as colônias britânicas e o Parlamento inglês no processo revolucionário de independência americana, cf. POCOCK, J. G. A. 1776: a Revolução contra o Parlamento. In: Linguagens do ideário político. São Paulo: Ed. da Universidade de São Paulo, 2003. p. 277 e ss.
} 
suas leis para guiá-lo ao seu fim. Ao compreender o mundo como um universo variado de coletividades, o propósito de Montesquieu não foi buscar o fundamento absoluto das leis. Para ele, as leis têm sempre um valor relativo, dependendo de sua adequação à forma de constituição de determinado Estado ${ }^{144}$. Inexiste, portanto, qualquer relação com a unidade das leis da natureza, obra de uma razão universal, fundada em princípios válidos para todos os povos.

As matrizes lançadas pela Revolução Francesa e reproduzidas na Declaração dos Direitos do Homem e do Cidadão de 1789 partiram de diverso ponto de vista, tornando-se "uma referência indispensável a todo projeto de constitucionalização dos povos"145. Ao enfoque de Montesquieu em torno das múltiplas diferenças entre as sociedades, com variadas formas de governo, opõem-se "a universalidade, a unidade, a generalidade das máximas do direito"146. Para Montesquieu, "o todo formado pelo espírito da nação era unicamente o objeto das leis; com a Revolução Francesa tornou-se o sujeito da potência legislativa" ${ }^{147}$.

A doutrina de Rousseau do século XVIII incidiu sobre o tema de forma decisiva. Em seu Contrato social, foram agregadas as noções de autoridade, obediência e soberania, objetivando a reconstrução das sociedades, não para restituir aos homens a liberdade natural já perdida, mas para a conquista da liberdade civil. A liberdade é um valor verdadeiramente inalienável, porquanto intrínseco à natureza humana. Entretanto, para Rousseau, a questão fundamental é a "da formação da vontade geral: a única liberdade possível no Estado é que os cidadãos deem leis a si mesmo. A liberdade coincide não com a autodeterminação individual, mas com a autodeterminação coletiva"148. Desse modo, a missão fundamental do Estado consiste em "eliminar totalmente a liberdade do indivíduo isolado e transformá-la em liberdade civil, isto é, na liberdade entendida como perfeita adequação da vontade individual à vontade coletiva (...)"149.

Avulta o princípio da vontade geral, concebido como a única fonte de legitimidade de todo e qualquer governo ${ }^{150}$. Trata-se de um pressuposto ético dirigido à consecução do

\footnotetext{
${ }^{144}$ GROETHYSEN, Bernard. op. cit., p. 351-352.

${ }^{145}$ COMPARATO, Fábio Konder. A afirmação histórica dos direitos humanos, cit., p. 146.

${ }^{146}$ GROETHYSEN, Bernard. op. cit., p. 352.

${ }^{147}$ Id. Ibid., p. 355.

${ }^{148}$ BOBBIO, Norberto. Teoria geral da política: a filosofia política e as lições dos clássicos. Org. Bovero Michelangelo. Trad. Daniela Beccaccia Versiani. Rio de Janeiro: Elsevier, 2000. p. 104.

${ }^{149}$ Id. Ibid., p. 290-291.

${ }^{150} \mathrm{O}$ artigo $6^{\circ}$ da Declaração de 1789 estabeleceu que "a lei é a expressão da vontade geral. Todos os cidadãos têm o direito de concorrer pessoalmente, ou por meio de representantes, à sua formação. Ela deve
} 
bem comum. "No contrato social a vontade individual pode ser boa ou má, mas a vontade geral só pode ser boa. (...) Quando alguém age contra a vontade geral, esse alguém não é moralmente livre, mas escravo de suas paixões e apetites. Ser moralmente livre significa agir de acordo com as leis que o próprio prescreveu, leis que promovem o bem comum definido pela vontade geral" ${ }^{\prime 151}$.

Entretanto, na célebre tríade liberdade, igualdade e fraternidade, a noção de liberdade firmou-se no relacionamento do homem consigo mesmo, sedimentando "o regime da autonomia individual, próprio da civilização burguesa" ${ }^{\prime 52}$. Viu-se a inversão, na era moderna, dos cânones da liberdade fundados na Antiguidade. Para os gregos e romanos, viver em liberdade significava atuar politicamente, mediante a participação direta dos indivíduos nos assuntos da vida pública. Apontando o Estado como a forma mais elevada de uma comunidade, a ideia de Aristóteles é de que só na pólis o homem podia adquirir o status de cidadão entre cidadãos ${ }^{153}$. Nesse sentido, ele lembrou "que aquilo que distingue efetivamente o cidadão dos demais é sua participação no judiciário e na autoridade, isto é, nos cargos públicos e na administração política e legal" ${ }^{\text {"154 }}$. Discorrendo sobre a liberdade dos antigos comparada à dos modernos, Benjamin Constant esclareceu consistir a primeira em exercer coletivamente "várias partes da soberania inteira, em deliberar na praça pública sobre a guerra e a paz, em concluir com os estrangeiros tratados de aliança, em votar as leis, em pronunciar julgamentos, em examinar as contas, os atos, a

ser a mesma para todos, quer proteja, quer puna. Todos os cidadãos, sendo iguais aos seus olhos, são igualmente admissíveis a todas as dignidades, cargos e empregos públicos, segundo sua capacidade e sem outra distinção a não ser a de suas virtudes e seus talentos" (COMPARATO, Fábio Konder. A afirmação histórica dos direitos humanos, cit., p. 154). Sobre a influência do Contrato Social de Rousseau na Declaração de 1789, cf. MURA, Virgilio. Diritti dell'uomo e diritti del cittadino. In: TARANTINO, Antonio (a cura di). Filosofia e politica dei diritti umani nel terzo millennio: atti del V Congresso dei Filosofi Politici Italiani, Lecce, 13-14-15, apr. 2000. Milano: Giuffrè, 2003. p. 23 e ss.

${ }^{151}$ SANTOS, Boaventura de Souza. A crítica da razão indolente: contra o desperdício da experiência. 4. ed. São Paulo: Cortez, 2002. v. 1, p. 130-131; cf. também COMPARATO, Fábio Konder. Ética: direito, moral e religião no mundo moderno, cit., p. 249 e ss. Para Rousseau, a vontade de todos, que identifica o interesse individual e particular de cada um, não se confunde com a vontade geral, que se prende somente ao interesse comum; não representa, portanto, a soma de interesses individuais e "das vontades particulares" (ROUSSEAU, Jean-Jacques. Du contrat social. Paris: Gallimard, 2002. Livro II, Capítulo III, p. 193).

${ }^{152}$ COMPARATO, Fábio Konder. A afirmação histórica dos direitos humanos, cit., p. 143.

${ }^{153}$ Cf. TAYLOR, C. C. W. Politics. In: BARNES, Jonathan (Ed.). The Cambridge companion to Aristotle. New York: Cambridge University Press, 2006. p. 243 e ss. Aristóteles afirmou ser o homem, por natureza, um animal político que "tem o dom da palavra. E (...) o poder da palavra tende a expor o conveniente e o inconveniente, assim como o justo e o injusto. Essa é uma característica do ser humano, o único a ter noção do bem e do mal, da justiça e da injustiça. E é a associação de seres que têm uma opinião comum acerca desses assuntos que faz uma família ou uma cidade" (ARISTÓTELES. Política, cit., Livro I, p. 146). Cf. também COMPARATO, Fábio Konder. Ética: direito, moral e religião no mundo moderno, cit., p. 584 e ss; e ARENDT, Hannah. Entre o passado e o futuro. Trad. Mauro W. Barbosa. 5. ed. São Paulo: Perspectiva, 2005. p. 201 e ss.

${ }^{154}$ ARISTÓTELES. Política, cit., livro III, p. 212. 
gestão dos magistrados, em fazê-los comparecer diante de todo um povo, em acusá-los de delitos, em condená-los ou em absolvê-los (...)"155.

Distanciando-se desses pressupostos, o ponto-chave no projeto de organização política dos revolucionários franceses também foi suprimir as divisões estamentais identificadas diretamente com a tirania monárquica. Por essa razão, como na França todo o poder estava concentrado nas mãos do monarca, foi preciso engendrar um novo centro capaz de levar a cabo os ideais revolucionários. Assim, correspondendo aos anseios da burguesia, em substituição ao rei, a soberania política passou para os representantes da nação reunidos em uma assembleia composta por deputados do chamado Tiers Etat (terceiro estamento), que compreendia os mais diversos grupos sociais, à exceção do clero e da nobreza ${ }^{156}$.

O Tiers Etat foi concebido por Sieyès para o desenvolvimento de sua teoria sobre o poder constituinte da nação, à qual compete criar e organizar o Estado constitucional, em atenção à garantia da ordem econômica para a livre circulação de riquezas. A titularidade da soberania política repousa na nação identificada com os indivíduos que formam a sociedade econômica como um todo unificado por interesses comuns. Muito embora tenha sido atribuído à nação o poder constituinte que irá instituir o Estado constitucional, sua manifestação é realizada por meio de representantes encarregados de exprimir a vontade nacional, consubstanciando-a no texto constitucional extraído de uma assembleia constituinte $^{157}$. Assim o pressuposto da vontade geral de Rousseau foi diretamente identificado com a noção de soberania popular; com o governo do povo como expressão da vontade da maioria dos eleitores, exercida por meio de seus representantes ${ }^{158}$.

Muito embora sob pressupostos divergentes, ao lado da Constituição americana, a Revolução Francesa foi responsável pela instituição da representação política moderna. E a extinção dos corpos intermediários provocou a atomização política na base da sociedade,

\footnotetext{
${ }^{155}$ Da liberdade dos antigos comparada à dos modernos, in Filosofia política, promoção conjunta do curso de pós-graduação em Filosofia da Universidade Federal do Rio Grande do Sul e do Departamento de Filosofia da Universidade de Campinas, n.2, 1985, p. 11.

${ }^{156}$ COMPARATO, Fábio Konder. A afirmação histórica dos direitos humanos, cit., p. 137 e ss.

${ }^{157}$ SIEYĖS, Emmanuel-Joseph. Qu'est-ce que le tiers État? Paris: Au Siège de la Société, 1888. caps. I, p. 28 e ss.; V; p. 64 e ss.; e VI; p. 65-67. O artigo $3^{\text {o }}$ da Declaração dos Direitos do Homem e do Cidadão estabeleceu residir o princípio de toda soberania "essencialmente na Nação. Nenhuma corporação, nenhum indivíduo pode exercer autoridade que dela não emane expressamente" (cf. COMPARATO, Fábio Konder. A afirmação histórica dos direitos humanos, cit., p. 154.).

${ }^{158}$ Cf. DUGUIT, Léon. Fundamentos do direito. Trad. Eduardo Salgueiro. Porto Alegre: Sergio Antonio Fabris, 2005. p. 37-40; e DURKHEIM, Émile. Lições de sociologia. Trad. Monica Stahel. São Paulo: Martins Fontes, 2002. p. 138 e ss.
} 
com a ideia de soberania popular recaindo sobre um conjunto homogêneo e indivisível de indivíduos abstratos, considerados isoladamente. O poder político foi transferido à coletividade, cujos representantes são eleitos pelos votos dos indivíduos que a compõem, "sem divisões internas (...), sempre iguais entre si",159.

O sistema de representação democrática e a primazia da autodeterminação individual convergiram para a potência soberana do Estado-legislador, para o qual foi transferida toda a força da soberania política. E, com a irrupção da ciência positiva no curso do século XIX e os integrantes dos órgãos dos poderes legislativo e executivo figurando como autênticos representantes da vontade popular, abandonou-se a existência de limites substanciais à produção das decisões governamentais. A partir da consolidação dos Estados nacionais, com os princípios da liberdade e igualdade incidindo sobre a singularidade humana, ficou inviável conter o predomínio dos direitos do cidadão sobre os direitos do homem, em que pese o auspício de universalidade da Declaração de 1789.

No decorrer do século XIX, os direitos humanos transmudaram-se em leis nacionais, e a sua fruição, que deveria independer da nacionalidade, foi reservada apenas aos cidadãos de um Estado. Daí a célebre referência de Hannah Arendt ao direito a ter direitos, reportando-se à situação dos apátridas que, com o advento do Estado totalitário no século XX, foram privados da nacionalidade: o mal "que se vem abatendo sobre um número cada vez maior de pessoas não é a perda de direitos específicos, mas a perda de uma comunidade disposta e capaz de garantir quaisquer direitos. O homem pode perder todos os chamados Direitos do Homem sem perder a sua qualidade essencial de homem, sua dignidade humana. Só a perda da própria comunidade é que o expulsa da humanidade" ${ }^{, 160}$.

A verdade é que, à diferença do caso norte-americano, a preocupação maior dos franceses foi a consagração universal de uma declaração de direitos humanos, mais do que dispor sobre formas de organização política capazes de assegurá-los de modo efetivo. Para os franceses pareceu que a existência da lei, com a participação do povo em sua formação,

\footnotetext{
${ }^{159}$ COMPARATO, Fábio Konder. A afirmação histórica dos direitos humanos, cit., p. 141. A Declaração dos Direitos do Homem e do Cidadão de 1789 não esclareceu devidamente se a todos os franceses seria atribuído o exercício dos direitos políticos. No entanto, a Lei de 22.12.1789 reservou o direito de ascender ao corpo do legislativo apenas aos proprietários de terras sobre os quais recaísse uma determinada carga fiscal. O exercício do direito de eleger os governantes também estava condicionado à qualidade de contribuinte de impostos (cf. MURA, Virgilio. op. cit., p. 27).

${ }^{160}$ ARENDT, Hannah. Origens do totalitarismo. Trad. Roberto Raposo. São Paulo: Companhia das Letras, 1999. p. 331; e COMPARATO, Fábio Konder. A afirmação histórica dos direitos humanos, cit., p. 147.
} 
era um requisito suficiente para assegurar a todos os direitos conaturais à pessoa humana. “'Somos livres porque nos damos normas que consideramos afetas aos valores de justiça', parecem sustentar os franceses. 'Somos livres porque nenhuma vontade, nem sequer a dos nossos representantes, colocará em perigo os bens mais sagrados que possuímos em forma de direitos', parecem sustentar os norte-americanos","161.

Os norte-americanos teriam ultrapassado a ideia do povo como guardião de seus direitos para dar atenção à necessidade de limitar o poder do governo, o que significava $o$ poder legislativo e, em última instância, o poder do próprio povo. "Este conceito era - e, em grande medida ainda é - destituído de qualquer fundamento na França, onde a revolução se confrontou com a tarefa de estabelecer uma autoridade legítima” para substituir o poder real ${ }^{162}$. O objetivo das declarações de direitos norte-americanas era, e continua a ser, diferente do da Revolução Francesa. A maioria das declarações de direitos dos Estados Unidos da América confere ao individuo a possibilidade de provocar o controle judicial sempre que sintam que seus direitos estão ameaçados ou foram infringidos. Na França, a declaração de direitos assegurou a própria conduta do Estado de acordo com os princípios democráticos, apesar de limitar bastante a possibilidade de os indivíduos promoverem ações judiciais com base na declaração. Assim, no curso da evolução do reconhecimento dos direitos humanos na França, o debate esteve, muitas vezes, centrado não nos indivíduos e nos seus direitos, mas na teoria do Estado e do seu $\operatorname{poder}^{163}$.

A ideia dos direitos humanos ligada intimamente à Revolução é, para alguns autores, um equívoco, pois teria contribuído essencialmente para entendê-los alheios à relação institucional, deslocando-os para o nível filosófico abstrato das declamações: “os direitos humanos vivem tão alto nas estrelas que ninguém os alcança" "164. O mero reconhecimento dos direitos humanos, sem a ocorrência de relações institucionais capaz de concretizá-los, permite uma ideologia de poder que pratica o princípio da soberania com a aparência de garantia dos direitos humanos.

Todavia, não é possível negar o avanço que a Declaração dos Direitos do Homem e do Cidadão de 1789 representou à época. Juntamente com as declarações de direitos norte-

\footnotetext{
${ }^{161}$ CARBONELL, Miguel. Uma historia de los derechos fundamentales. México: UNAN Editorial Porrúa y CNDH, 2005. p. 99-100.

${ }^{162}$ Cf. DIPPEL, Horst. op. cit., p. 228-229.

${ }^{163} \mathrm{Cf}$. Id., loc. cit.

${ }^{164}$ KRIELE, Martin. Introdução à teoria do Estado: os fundamentos históricos da legitimidade do Estado constitucional democrático. Trad. Urbano Cervelli. Porto Alegre: Sergio Antonio Fabris, 2009. p. 199.
} 
americanas, ela trouxe à tona muitos elementos essenciais ao Estado Democrático de Direito, constituindo um ponto de referência sempre afirmado ao longo do tempo. De qualquer forma, não olvidou a proclamação solene acerca da necessidade da limitação institucional do exercício do poder político: “Toda sociedade, na qual a garantia dos direitos não é assegurada nem a separação dos poderes determinada, não tem constituição" ${ }^{\prime 65}$.

Por outro lado, no contexto da Revolução Francesa não houve espaço para reflexões em torno do aparato organizacional do quadro de oficiais que, até então, vinham desenvolvendo as atividades de proteção dos interesses do monarca e da persecução criminal ante a abolição das acusações privadas. Como foi aventado, não passou despercebido para Montesquieu o fato de se tratarem de procuradores do rei ${ }^{166}$, identificados, sob as luzes do movimento revolucionário, com o sistema de concentração do poder próprio do Antigo Regime.

De certa forma, o ofício do Ministério Público francês não chegou a se desvencilhar de tal perfil, durante toda a evolução institucional consolidada a partir do período imperial, com o movimento de codificação conduzido por Napoleão Bonaparte. Em um quadro burocrático de escalonamento hierárquico inserido no Executivo do Estado, os comissários do rei transformaram-se em agentes subordinados ao Ministro da Justiça, com a precípua incumbência de promover a ação penal, além da representação judicial de outros órgãos governamentais $^{167}$.

\subsubsection{Considerações gerais sobre o Parquet na França}

Como foi ressaltado, de uma maneira geral, é comum relacionar a origem do Ministério Público ao Antigo Regime da França, quando da unificação das funções de advogado e procurador do rei (avocat du roi e procureur du roi $)^{168}$. A figura de procuradores do rei remonta aos oficiais chamados saïon ou graffion existentes nos cantões no século VII. Eles exerciam atividades fiscais e de administração dos bens do coroa, além de outras funções administrativas. As atribuições fiscais revestiam-se de natureza repressiva, inclusive pelo fato de ser a maior parte dos delitos punida por meio da

${ }^{165}$ COMPARATO, Fábio Konder. A afirmação histórica dos direitos humanos, cit., p. 154.

${ }^{166}$ Cf. MONTESQUIEU, Charles de. op. cit., livro VI, cap. VIII, p. 209.

${ }^{167} \mathrm{Cf}$. RASSAT, Michele-Laure. Le ministère public entre son passé et son avenir. Paris: Librairie Générale de Droit et de Jurisprudence, 1967. p. 54-62 e ss.

${ }^{168}$ Cf. 1.1 .3 e 1.3 . 
aplicação de penas pecuniárias ${ }^{169}$. No curso da Idade Média, a defesa dos interesses do rei perante os tribunais competia a advogados comuns que assumiam o perfil de mandatários, com o monarca ocupando uma posição de destaque entre a sua clientela.

Com a formação dos Estados nacionais, houve a absorção do poder jurisdicional pelo monarca. O poder secular afirmou-se sobre a jurisdição da igreja, das corporações e sobre os juízos locais dos senhores feudais. Na medida em que avançava o fortalecimento do poder real, o exercício da jurisdição passou a ser visto como a extensão do poder soberano $^{170}$.

A partir do século XIV, os ramos das atividades de procurador e advogado do rei, embora diversos, acabaram se dirigindo essencialmente à defesa dos interesses do soberano incorporados aos do Estado. Os advogados, pouco a pouco, foram abandonando a sua clientela para a defesa exclusiva dos interesses do monarca. A ordenação de Felipe, o Belo, unificou as funções de advogado do rei, relativas à defesa de seus interesses em juízo, às de procurador do rei, ligadas à administração de seu patrimônio, que se confundia com o do Estado. Além da proteção de outros interesses do monarca, com a extinção das acusações privadas, os procuradores do rei investiram-se no ofício da persecução penal, emergindo a moldura do Ministério Público afirmada em nossos dias ${ }^{171}$.

Como já disposto, no período da Revolução Francesa, houve a extinção dos oficiais do Ministério Público, em virtude de sua correlação com o regime monárquico. Eles eram conhecidos como gens du roi, apesar do reconhecimento pelos cahiers doléances de 1789 de que aqueles oficiais do Antigo Regime, em algumas ocasiões, foram capazes de manter certa independência, deixando de executar ordens por as entenderem contrárias ao bem do reino $^{172}$.

De todo modo, o desenvolvimento das atividades que lhes competiam foi transferido a comissários do soberano encarregados de fiscalizar a aplicação da lei e a execução das decisões judiciais. A Constituição do ano III da Revolução (1795) distinguiu

\footnotetext{
${ }^{169}$ Uma correlação direta entre as funções de procurador do rei e dos saïon ou graffion da Idade Média é questionável, pois, com a extinção do poder real no século $\mathrm{X}$, as atribuições desses oficiais foram transferidas integralmente aos soberanos locais. (cf. RASSAT, Michele-Laure. op. cit., p. 18-19).

${ }^{170}$ SALLES, Carlos Alberto. Entre a razão e a utopia: a formação histórica do Ministério Público. In: VIGLIAR, José Marcelo Menezes; MACEDO JR., Ronaldo Porto (Coords.). Ministério Público II: democracia. São Paulo: Atlas, 1999. p. 17.

${ }^{171}$ Id. Ibid., p. 19. Cf. também CÉDRIC, Trassard. O Ministério Público em França. In: AZEVEDO, Rodrigo Ghiringhelli de; DIAS, João Paulo (Coords.). O papel do Ministério Público: estudo comparado dos países latino-americanos. Coimbra: Almedina, 2008. p. 125-128.

${ }^{172}$ RASSAT, Michele-Laure. op. cit., p. 31. Cf. também SALGADO, J. A. César. O Ministério Público e os atributos de sua dignidade. Justitia, São Paulo, v. 60, n. esp. (60 anos: 1939-1999), p. 879, 1999.
} 
o acusador público dos comissários do rei. O acusador público fícou incumbido de sustentar as práticas delituosas perante os tribunais e, ao contrário dos comissários, não era escolhido pelo monarca, mas em eleições populares, vinculando-se ao parlamento. Em seguida, a Constituição do ano VIII (1799) concentrou o exercício das duas funções nos comissários do rei, definindo a promoção da acusação pública junto aos tribunais por um agente do governo ${ }^{173}$. Germinavam, assim, as atribuições de dominus litis e custos legis nas intervenções processuais do Ministério Público.

Todavia, a consolidação da organização do Parquet deu-se apenas no Império, a partir do movimento de codificação levado a efeito por Napoleão Bonaparte. Na ocasião, foi instituído um sistema de grande hierarquia, com a responsabilidade dos comissários em exercício nos tribunais superiores pela fiscalização dos trabalhos dos que atuavam nos juízos de grau inferior. E, mediante a edição da Lei de 20 de abril de 1810 (Código de Instrução Criminal), foram regulamentadas as funções de representação do executivo junto à autoridade judicial e de promoção da ação penal.

Considerada o embrião do Ministério Público no Estado moderno, sua origem na França é vinculada a períodos de indiscutível concentração do poder político. Sob o comando de Bonaparte, a centralização de poder do Antigo Regime restaurou-se provisoriamente no país, quando o Ministério Público, dispondo de uma estrutura unitária, estabeleceu-se institucionalmente, subordinado ao Ministério da Justiça ${ }^{174}$. Suas atribuições no Estado francês compõem um complexo conjunto de ordenamentos jurídicos, alguns oriundos do período imperial, como a mencionada Lei de 20 de abril de 1810 (Código de Instrução Criminal) ainda em vigor, dificultando uma precisa delimitação de seu perfil institucional ${ }^{175}$.

De um modo geral, trata-se de um organismo encarregado de zelar pela aplicação da lei no que concerne à manutenção da ordem pública. Sob o império do princípio da oportunidade, o Ministério Público intervém no curso de toda a persecução penal, incluindo a fase de execução das penas, além de dirigir e coordenar as atividades da polícia judiciária. Cabe-lhe ainda a proteção de interesses governamentais e de outros órgãos

\footnotetext{
${ }^{173}$ Cf. RASSAT, Michele-Laure. op. cit., p. 32-33. As figuras de comissário do rei e de acusador público foram definidas por um decreto de 1790.

${ }^{174}$ GUARNIERI, Carlo. op. cit., p. 87-88.

${ }^{175} \mathrm{Cf}$. GOYET, Francisque. Le ministère public en matière civile et en matière répressive et l'exercise de l'action publique. 3. ed. Paris: Sirey, 1953. p. 7-8; e RASSAT, Michele-Laure. op. cit., p. 35 e ss.
} 
públicos, a atuação em algumas hipóteses de interesses da sociedade junto à jurisdição civil e a defesa de incapazes ${ }^{176}$.

Conquanto se afigurem dois órgãos distintos, os mesmos requisitos para o exercício da judicatura são reclamados para o desempenho das atividades do Parquet, que é tido, na França, como uma espécie de magistratura (Magistrature du Debout ou Magistrature du Parquet), com a possibilidade da transferência recíproca entre os membros do judiciário e do Ministério Público ${ }^{177}$. Como ocorre com os juízes integrantes da Magistrature du Siège ou Magistrature Assise, os representantes do Ministério Público ingressam na carreira por meio de processos seletivos que, desde 1959, reclamam a conclusão de um curso promovido pela Escola Nacional da Magistratura (Ecole Nationale de la Magistrature), controlada pelo Ministério da Justiça (Garde de Sceaux) ${ }^{178}$.

No ápice do sistema organizacional do Ministério Público francês está o Ministro da Justiça, com poderes de controle sobre toda a instituição, tanto na esfera administrativa como na seara funcional. A supervisão dos trabalhos do Ministério Público pelo Ministro da Justiça pode incidir sobre a própria atuação de seus membros, mediante a expedição de instruções gerais e impessoais de política criminal a todos os magistrados do Ministério Público e também por meio de ordens individuais aos procuradores-gerais, que devem transmiti-las aos procuradores da República que as repassam aos seus substitutos. Nesse caso, os comandos são apensados aos processos respectivos e não podem envolver a

\footnotetext{
${ }^{176}$ Pelo princípio da oportunidade, o Ministério Público pode decidir não iniciar um procedimento investigatório, mesmo diante de fatos que constituam uma infração penal e do conhecimento da autoria. $\mathrm{O}$ arquivamento dos inquéritos é considerado uma decisão administrativa, em que pesem alguns limites à discricionariedade do Ministério Público no desenvolvimento desta atribuição; de um lado, avulta a estrutura hierarquizada do órgão, com a faculdade de que dispõe o Ministro da Justiça para ordenar as acusações; de outro, tem-se a possibilidade de a própria vítima instá-las. Existem também as formas de arquivamento condicional, a mediação para a reparação do dano e o acordo penal em alguns delitos, sob a proposta do Ministério Público antes do início da ação para homologação judicial, condicionada ao reconhecimento da autoria dos crimes. Nos casos de infrações de maior gravidade, o Ministério Público deve, obrigatoriamente, recorrer ao juízo de instrução para aprofundar as investigações. Nessa hipótese, sob controle judicial, a persecução desdobra-se nas etapas de instrução e de julgamento; as cours d'assises julgam os crimes; e o Ministério Público está encarregado das iniciativas correspondentes às duas fases, por via de requerimento e de ação. Nas matérias cíveis, o Ministério Público atua como parte ou fiscal da lei em causas de estado civil (filiação, casamento, etc.), interesses de incapazes e envolvendo interesses econômicos e comerciais de empresas, procurando salvaguardar direitos trabalhistas de índole coletiva. Interessante é a atribuição denominada política da cidade. que consiste na participação do Ministério Público em ações locais (contratos locais de segurança) integradas conjuntamente por outros órgãos públicos e governamentais, além de associações civis, visando a medidas de cunho social, como nas áreas da educação, trabalho, infância e juventude, para a redução dos índices de criminalidade e da violência urbana em regiões mais sensíveis (cf. CÉDRIC, Trassard. op. cit., p. 147-162). Mais especificamente sobre as funções criminais de origem mais remotas, cf. também AYARRAGARAY, Carlos A. op. cit., p. 56-57.

${ }^{177}$ Cf. GUARNIERI, Carlo. op. cit., p. 88-89; e RASSAT, Michele-Laure. op. cit., p. 48.

${ }^{178}$ Cf. GUARNIERI, Carlo. op. cit., p. 88-89.
} 
interrupção de investigações já iniciadas. É possível a solicitação de que se adote perante os tribunais uma determinada posição em temas de interesse do Estado, identificados com a política governamental ${ }^{179}$.

Ante a Suprema Corte da França, o Tribunal de Cassação (Cour de Cassation), oficiam o Procurador-Geral e alguns advogados-gerais. Nos tribunais de segunda instância, as Cortes de Apelação (Cours d'Appel), o Ministério Público se faz representar por procuradores-gerais, advogados-gerais e substitutos. E, nos juízos de primeiro grau, atuam os procuradores da República, sempre sob a supervisão dos agentes em exercício nos tribunais superiores.

Ao contrário dos juízes, os representantes do Parquet não são inamovíveis. A transferência, em tese, pode ocorrer por determinação de seus superiores hierárquicos ou pelo Ministro da Justiça, que é o responsável pela composição dos quadros da carreira, dispondo de certo grau de discricionariedade ${ }^{180}$.

Até a alteração do regime jurídico disciplinar de 1993, o Ministro da Justiça dispunha de plena autoridade sobre os membros do Ministério Público. Atualmente, antes da aplicação de qualquer penalidade, o Ministro deve contar com o parecer do Conselho Superior da Magistratura que pode ser precedido de um inquérito administrativo. Caso ele pretenda impor sanções de maior gravidade, o Conselho deve ser compelido à elaboração de um novo parecer, não obstante não haja nenhuma vinculação ao entendimento emitido pelo órgão colegiado ${ }^{181}$.

Como se vê, trata-se de um quadro burocrático de escalonamento hierárquico inserido no âmbito do Executivo do Estado ${ }^{182}$. A despeito da relação de dependência ao Executivo do Estado, a estrutura hierárquica, que envolve a carreira do Ministério Público, não chega ao ponto de possibilitar a avocação dos processos pelas autoridades

\footnotetext{
${ }^{179}$ Cf. CÉDRIC, Trassard. op. cit., p. 141; e GUARNIERI, Carlo. op. cit., p. 96-97.

${ }^{180}$ Para a nomeação do Procurador-Geral da Corte de Cassação e dos procuradores-gerais junto aos tribunais de recurso não existe a interferência da comissão do Conselho Superior da Magistratura afeta à carreira do Ministério Público. Já as nomeações aos postos de procuradores da República são precedidas de listas tríplices elaboradas por aquela comissão (CÉDRIC, Trassard. op. cit., p. 136-137). Cf. também AYARRAGARAY, Carlos A. op. cit., p. 48-49.

${ }^{181}$ CÉDRIC, Trassard. op. cit., p. 138-139.

${ }^{182}$ Segundo Cédric Trassard, o domínio do Poder Executivo é insignificante na grande maioria dos casos, mesmo porque as orientações gerais do Ministro da Justiça são normalmente observadas. E, não obstante, ao contrário dos juízes, os magistrados do Ministério Público não sejam inamovíveis, as transferências, na prática, não sendo por sanções disciplinares, ocorrem a pedido do interessado (cf. CÉDRIC, Trassard. op. cit., p. 141-143 e 146).
} 
superiores ${ }^{183}$. Um procurador-geral em exercício na respectiva Corte de Apelação não pode avocar nenhum processo de atribuição do ocupante de cargo de inferior hierarquia. Tampouco há de fazê-lo o Procurador-Geral do Tribunal de Cassação em relação aos feitos em trâmite nos tribunais de recurso, ainda que não seja seguida a sua orientação sobre os casos. O poder de substituição dos magistrados do Ministério Público circunscreve-se à organização interna de cada ofício. Por essa razão, em princípio, os membros do Ministério Público poderiam resistir às instruções provenientes de seus superiores na condução de seus casos, deixando de propor uma ação penal, malgrado a existência de uma recomendação em sentido oposto.

Além disso, a doutrina que sustenta a admissibilidade do modelo institucional adotado na França chama atenção à liberdade de opinião do membro do Ministério Público durante a instrução da causa no juízo competente. Na audiência, quando de suas conclusões orais, o magistrado do Parquet pode "dar ouvidos ao que lhe dita a consciência", sendo livre para atuar conforme a sua convicção sobre o caso ${ }^{184}$. No entanto, as possíveis represálias no âmbito administrativo e disciplinar são capazes de inviabilizar o advento de uma atuação independente. $\mathrm{O}$ eventual raio de autonomia funcional não condiz com a hipótese de substituições e de iniciativas disciplinares por parte do Ministro da Justiça, a quem compete, em última instância, o controle sobre todo o aparato institucional, incluindo o sistema de ascensão aos seus patamares mais elevados.

Mesmo pressupondo uma atuação uniforme na seara de repressão à criminalidade, sobretudo em função do princípio da oportunidade na promoção das acusações, questionase a possibilidade de conciliar os papéis de funcionário do Ministro da Justiça e de magistrado especial. Muito embora as funções não sejam executadas simultaneamente pelos representantes do Ministério Público, a conclusão é de que, na maioria das vezes, não é possível alcançar as finalidades a que se voltam de forma satisfatória ${ }^{185}$.

Nessas condições, sob o predomínio dos postulados da harmonia e homogeneidade do período das grandes codificações, o Ministério Público francês consolidou o papel de responsável pelo exercício de uma parcela das funções estatais no âmbito do Poder Executivo do Estado.

\footnotetext{
${ }^{183}$ Cf. GUARNIERI, Carlo. op. cit., p. 97.

184“Si la plume est serve, la parole est libre" (cf. CÉDRIC, Trassard. op. cit., p. 142).

${ }^{185} \mathrm{Cf}$. RASSAT, Michele-Laure. op. cit., p. 250 e ss.
} 


\subsection{Notas sobre o Ministério Público na Itália}

Desdobrando-se do modelo adotado na França, a estrutura orgânica do Ministério Público italiano vincula-se à do Judiciário do Estado ${ }^{186}$. De início, tal como no Estado francês, os órgãos do Ministério Público e do judiciário estavam equiparados, sendo permitida a transferência recíproca entre os seus integrantes, não obstante constituíssem carreiras paralelas. Mas, ao contrário dos magistrados, também na Itália os membros do Ministério Público não eram inamovíveis, com a subordinação direta ao Ministro da Justiça $^{187}$.

$\mathrm{O}$ advento da ditadura fascista acirrou o controle do Executivo tanto sobre o Ministério Público como em relação aos integrantes do Judiciário; desde então, passou a haver uma estreita aproximação entre as duas carreiras. Até o ordenamento judiciário de 1941, o Ministério Público figurava como representante dos interesses do Executivo. Foi esse estatuto que afastou da instituição a realização das tarefas de advocacia dos interesses da administração estatal, afirmando, em contrapartida, a função de zelar pela fiel aplicação da lei. E a Lei 511, de 31 de maio de 1946, limitou o poder do Ministro da Justiça sobre a atuação do Ministério Público, ao restringir a possibilidade de transferência e remoção dos componentes de seu quadro.

Com o estabelecimento do regime republicano após a Segunda Guerra Mundial, a orientação do constituinte de 1947 foi no sentido de afastar qualquer ingerência do Executivo sobre os membros do Ministério Público, que passou a compor, em definitivo, o corpo do Judiciário ${ }^{188}$. Na França, as carreiras dos juízes e do Ministério Público são apenas correlatas, a despeito da possibilidade de transferência do representante de um órgão para o outro. Na Itália, trata-se de um só organismo que representa o judiciário do Estado, dotado de unidade e independência em relação às demais esferas do poder político.

Em vigor a partir de 1948, a Constituição da República consagrou o exercício da administração da justiça em nome do povo, com a submissão dos magistrados apenas à lei. E o Ministério Público foi definido como uma função do quadro da judicatura, permitindo aos seus componentes o exercício da função jurisdicional e das atribuições do Ministério Público, estas últimas destinadas basicamente à persecução criminal. Uma vez que os

\footnotetext{
${ }^{186}$ SACCO, Ricardo Ferreira. op. cit., p. 198 e ss; e KERCHE, Fábio. Controle democrático e o sistema judicial: o Ministério Público brasileiro em perspectiva comparada, cit.

${ }^{187}$ Cf. AYARRAGARAY, Carlos A. op. cit., p. 68.

${ }^{188}$ Cf. GUARNIERI, Carlo. op. cit., p. 21 e ss.
} 
membros do Ministério Público e os juízes pertencem a um só corpo, a passagem de uma a outra função costuma ser autorizada mediante pedido do interessado, podendo ocorrer várias vezes no decurso de sua carreira ${ }^{189}$.

Em 1959, com a criação do Conselho Superior da Magistratura, ficou sedimentada a independência do órgão do judiciário, notadamente em relação ao Executivo, conservando-se ao Ministro da Justiça apenas a faculdade de promover a ação disciplinar contra os magistrados, competência também atribuída ao Procurador-Geral em exercício no Supremo Tribunal Italiano, a denominada Corte de Cassação ${ }^{190}$.

A garantia institucional de inamovibilidade foi conferida a todos os magistrados, ficando a dispensa, suspensão e o remanejamento de pessoal, condicionados ao pedido do interessado ou à decisão motivada daquele Conselho Superior, que é o órgão de superior hierarquia na estrutura organizacional da magistratura ${ }^{191}$. Composto predominantemente por integrantes do Judiciário, o Conselho está encarregado da gestão de seus serviços, respondendo pelos procedimentos relativos a admissões, nomeações, transferências, promoções e faltas funcionais ${ }^{192}$.

A admissão dos membros do Judiciário italiano, incluindo os que deverão exercer as funções do Ministério Público, ocorre mediante concurso público. Durante o estágio probatório é dispensada para os novos magistrados uma formação específica e diferenciada, conforme o exercício das funções do Ministério Público ou jurisdicional do Estado $^{193}$. Já o sistema de ascensão na carreira acontece principalmente por antiguidade, e não se vincula à existência de cargos vagos de grau superior; pressupõe tão somente

\footnotetext{
${ }^{189}$ FABRI, Marco; CAVALLINI, Daniela. O Ministério Público em Itália. In: AZEVEDO, Rodrigo Ghiringhelli de; DIAS, João Paulo (Coords.). O Papel do Ministério Público: estudo comparado dos países latino-americanos, cit., p. 177.

${ }^{190}$ Cf. GUARNIERI, Carlo. op. cit., p. 22-23.

${ }^{191}$ Cf. o que estabelece o artigo 107 da Constituição italiana, com a seguinte redação: "I magistrati sono inamovibili. Non possono essere dispensati o sospesi dal servizio né destinati ad altre sedi o funzioni se non in seguito a decisione del Consiglio superiore della magistratura, adottata o per i motivi e con le garanzie di difesa stabilite dall'ordinamento giudiziario o con il loro consenso. Il Ministro della giustizia ha facoltà di promuovere l'azione disciplinare. I magistrati si distinguono fra loro soltanto per diversità di funzioni. Il pubblico ministero gode delle garanzie stabilite nei suoi riguardi dalle norme sull'ordinamento giudiziario" (cf. Costituzione della Repubblica Italiana. Parte II. Titolo IV. La Magistratura. Sezione I: Ordinamento giurisdizionale. ITÁLIA. Costituzione della Repubblica Italiana. Disponível em: <http://www.edscuola.it/archivio/norme/leggi/costituzione.html>. Acesso em: 24 nov. 2008.

${ }^{192}$ FABRI, Marco; CAVALLINI, Daniela. op. cit., p. 173.

${ }^{193}$ Id. Ibid., p. 187-188.
} 
vantagens econômicas, não implicando necessariamente o desenvolvimento de outras atividades $^{194}$.

A estrutura organizacional do Ministério Público compreende a existência de procuradorias de primeiro e segundo graus. No entanto, entre os integrantes dos correspondentes setores não se verifica nenhuma relação hierárquica ${ }^{195}$. Muito embora integre o Conselho Superior da Magistratura, o Procurador-Geral em exercício junto à Corte de Cassação não responde pela coordenação da instituição, principalmente no que diz respeito às diretrizes políticas incidentes sobre a primordial atividade de combate ao crime.

É preciso considerar que o regime jurídico italiano, inclusive no plano constitucional, submete ao Ministério Público a direção da polícia judiciária; os magistrados que exercem as atividades do Ministério Público controlam plenamente as providências investigatórias ${ }^{196}$. Na área cível, a atuação do Ministério Público acontece na qualidade de parte ou de fiscal da lei, em causas relativas ao estado ou à capacidade de pessoas e nos processos de falência. Pode também intervir em qualquer outro processo na defesa do interesse público. Tal atividade tem escassa relevância no âmbito das funções do Ministério Público, "seguramente mais empenhado nos processos penais”. Segundo alguns autores, como a proteção do interesse público já estaria assegurada pela presença do juiz, a intervenção do Ministério Público no processo civil poderia ser reduzida ou simplesmente eliminada $^{197}$.

Por outro lado, segundo o teor do artigo 107 da Constituição da República, admitese a possibilidade de que a legislação ordinária atenue o vínculo de equiparação entre os membros do Judiciário, tendo em vista aqueles que exercem a atividade jurisdicional e os

\footnotetext{
${ }^{194}$ FABRI, Marco; CAVALLINI, Daniela. op. cit., p. 182-184.

${ }^{195}$ É o que também se infere da norma do artigo 107 da Constituição, ao estabelecer que a distinção entre os magistrados deve ocorrer apenas pela diversidades das funções.

${ }^{196}$ Nesse sentido, é a redação do artigo 109 da Constituição italiana: “L'autorità giudiziaria dispone direttamente della polizia giudiziaria" (cf. Costituzione della Repubblica Italiana. Parte II. Titolo IV. La Magistratura. Sezione I: Ordinamento giurisdizionale. ITÁLIA. Costituzione della Repubblica Italiana, cit. E o Código de Processo Penal de 1988 regulamentou o comando das investigações pelo Ministério Público: Art. 326 I. "Il pubblico ministero e la polizia giudiziaria svolgono, nell'ambito delle rispettive attibuzione, le indagini necessarie per le determinazioni inerenti all'exercizio dell'azione penale". Art. 327 I. "Il pubblico ministero dirige le indagini e dispone direttamente della polizia giudiziaria (...)". Art. 358 I. "Il pubblico ministero compie ogni attività necessaria ai fini indicati nell'art. 326 e svolge altresi accertamenti su fatti e circostanze a favore della persona sottoposta alle indagini” (cf. Códice di Procedura Penale. Parte Seconda. Libro V: Indagini preliminari e udienza preliminari. Titolo I: disposizioni generali art. 326-329; e Titolo V: attività del pubblico ministero art. 358-378. ITÁLIA. Codice di Procedura Penale. Disponível em: <http://www.altalex/com/index.php/?idnot=2011>. Acesso em: 24 nov. 2008.

${ }^{197}$ FABRI, Marco; CAVALLINI, Daniela. op. cit., p. 197-200.
} 
que desenvolvem as funções do Ministério Público ${ }^{198}$. Contudo, não se cogita de afastá-lo da esfera organizacional do Judiciário para reconduzi-lo à condição de um mero ofício do Ministério da Justiça, sob o controle do chefe da pasta. As eventuais distinções legais entre os membros do Judiciário devem se apresentar compatíveis com as garantias asseguradas constitucionalmente aos magistrados em geral, com destaque à posição de independência em relação aos demais organismos do Estado ${ }^{199}$.

A opinião dominante aponta para o vínculo existente entre a garantia de independência do Ministério Público e o princípio da obrigatoriedade da ação penal contemplado no artigo 112 da Constituição, que, por si só, implicaria a necessidade de preservação da independência necessária para a atuação do representante do Ministério Público no cumprimento de sua incumbência constitucional. Tendo em conta a relevância da atribuição de combate ao crime, conjugada à obrigatoriedade do exercício da ação penal, o profícuo desempenho das atividades do Ministério Público não poderia prescindir da manutenção de uma estrutura organizacional alheia a eventuais intervenções governamentais $^{200}$.

Desse modo, a par do conteúdo da norma do referido artigo 107 da Constituição, pela qual se infere a introdução do quadro do Ministério Público no âmbito do Judiciário do Estado, o princípio da obrigatoriedade da ação penal é visto como um elemento essencial à garantia de independência dos procuradores italianos, abarcando, assim, a chamada magistratura requerente que não responde pelo exercício da função jurisdicional do Estado $^{201}$. À mesma conclusão também conduz o teor do artigo 104 da Constituição, ao dispor sobre a composição do Conselho Superior da Magistratura pelo Procurador-Geral em exercício junto à Corte de Cassação ${ }^{202}$.

É de ter realmente evidenciada a independência do Ministério Público em relação ao Executivo, incluindo o que toca à organização burocrática de seus serviços e ofícios. Respeitado o comando constitucional, é nesse contexto que se admite a possibilidade de o legislador ordinário estabelecer garantias distintas aos membros da magistratura

\footnotetext{
${ }^{198}$ Recorde-se a redação de parte do art. 107 da Constituição: “(...) Il pubblico ministero gode delle garanzie stabilite nei suoi riguardi dalle norme sull'ordinamento giudiziario".

${ }^{199}$ Cf. ZANON, Nicolò. Pubblico Ministero e Costituzione. Padova: CEDAM, 1996. p. 5 e ss. Cf. também FABRI, Marco; CAVALLINI, Daniela. op. cit., p.178-179.

${ }^{200}$ Assim dispõe o artigo 112 da Constituição italiana: "Il Pubblico ministero há obbligo di esercitare l'azione penale" (cf. Costituzione della Repubblica Italiana. Parte II. Titolo IV. La Magistratura. Sezione II: norme sulla giurisdizione. ITÁLIA. Costituzione della Repubblica Italiana, cit.

${ }^{201}$ Cf. ZANON, Nicolò. op. cit., p. 9.

${ }^{202}$ Cf. GUARNIERI, Carlo. op. cit., p. 27.
} 
responsáveis pelo exercício das funções do Ministério Público à luz de sua natureza e especificidades $^{203}$.

Por outro lado, a ausência de vínculos hierárquicos entre integrantes de ofícios diversos, aliada à inclusão do organismo no âmbito do judiciário, mantendo-o estranho às conjunturas políticas, põe em xeque a real possibilidade da definição de contornos precisos e uniformes para uma política estatal na área da segurança pública. E a existência de meios eficazes à aferição da responsabilidade no desempenho de suas funções vem sendo muito questionada $^{204}$. Os critérios da atuação do Ministério Público variam de serviço para serviço, inclusive dentro de uma mesma procuradoria, "em flagrante contraste com o princípio da igualdade dos cidadãos perante a lei consagrado na Constituição (artigo

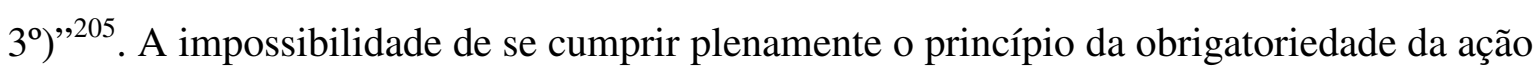
penal permite uma ampla discricionariedade no exercício da função, sem que exista nenhum mecanismo de controle de responsabilidade e de visibilidade das escolhas efetuadas $^{206}$.

Eclodiram, nesse passo, propostas dirigidas à alteração da organização do Ministério Público. Discute-se a criação de uma figura análoga ao Procurador-Geral da República brasileiro, que seria responsável pela atuação do órgão público perante o parlamento. Considerando o corpo de procuradores de superior instância, o agente poderia ser eleito pelo Legislativo para ocupar o vértice do aparato institucional, coordenando as atividades de seus membros. Callamandrei chegou a apresentar uma sugestão nesse sentido, durante os trabalhos da Assembleia Constituinte de 1947. O Procurador-Geral poderia ser nomeado pelo Presidente da República, escolhido em lista tríplice elaborada pela Câmara dos Deputados entre os magistrados integrantes das Cortes de Apelação ou de Cassação, munindo-se de poderes hierárquicos sobre toda a instituição ${ }^{207}$. Também não

\footnotetext{
${ }^{203}$ Cf. ZANON, Nicolò. op. cit., p. 4-5 e 10.

${ }^{204}$ Cf. GUARNIERI, Carlo. op. cit., p. 29 e ss.

${ }^{205}$ FABRI, Marco; CAVALLINI, Daniela. op. cit., p. 180. O Procurador da República responde pelas atividades de sua procuradoria, também composta pelo Procurador-Adjunto e procuradores substitutos. Deliberações do Conselho Superior da Magistratura foram, no entanto, responsáveis pela redução dos poderes diretivos e organizacionais dos titulares das procuradorias, ampliando a autonomia dos procuradores substitutos na condução dos processos, inclusive mediante o reconhecimento do princípio do juiz natural. A redução do âmbito da coordenação hierárquica do Procurador da República acarretou a chamada personalização das funções exercidas por cada magistrado do Ministério Público, provocando reações tendentes a restabelecer certa unidade e coerência na prestação dos serviços, por meio da retomada da atividade diretiva do Procurador da República. Nesse sentido, estão as alterações da Lei 150 de 2005 , cuja aplicação ainda é precária (FABRI, Marco; CAVALLINI, Daniela. op. cit., p. 186 e 214-217).

${ }^{206}$ Id. Ibsi., p. 180.

${ }^{207}$ Cf. GUARNIERI, Carlo. op. cit., p. 33 e ss.; e ZANON, Nicolò. op. cit., p. 173 e ss.
} 
faltam adeptos da completa ruptura dos vínculos entre o Ministério Público e o Judiciário, para a recondução do primeiro à dependência hierárquica do Ministro da Justiça, conforme o modelo prevalente em grande parte dos sistemas políticos da Europa continental ${ }^{208}$.

De todo modo, eventual dificuldade na definição de uma política criminal de proteção à segurança pública não se viu com a conhecida Operação Mãos Limpas do início de 1990, comandada por magistrados do Ministério Público italiano, que desbarataram uma enorme rede de organização criminosa, envolvendo dirigentes econômicos, agentes políticos e servidores públicos em crimes de corrupção, abuso de poder, tráfico de influência, malversação do dinheiro público e lavagem de dinheiro, inclusive para fins de financiamento de campanhas das lideranças dos principais partidos políticos do país. A iniciativa emblemática, que originou uma gama de condenações de políticos e de expressivos representantes de grupos econômicos, constituiu o marco do chamado ativismo judicial, provocando fortes reações dos que foram alvo das investigações. As críticas giraram em torno de uma inaceitável "politização" dos magistrados, contando, em contrapartida, com o pleno apoio da população ${ }^{209}$.

\footnotetext{
${ }^{208}$ Cf. GUARNIERI, Carlo. op. cit., p. 35.

${ }^{209}$ Cf. SACCO, Ricardo Ferreira. op. cit., p. 202 e ss. Junto à Procuradoria-Geral, desde 1992, está em funcionamento a Direção Nacional Anti-Máfia (DNA); um serviço de âmbito nacional, especializado na coordenação dos inquéritos em matéria de crime organizado (FABRI, Marco; CAVALLINI, Daniela. op. cit., p. 201-202).
} 


\section{CAPÍtulo II. O CENÁRIO de CONCENTRAÇÃo DO PODER POLÍTICO NO BRASIL E O PERCURSO HISTÓRICO DO MINISTÉRIO PÚBLICO}

\subsection{A formação do Estado patrimonial no Brasil colônia}

É possível nortear a explicação do desenvolvimento do poder político no Brasil a partir da noção do patrimonialismo, inerente à história portuguesa, como responsável pela consolidação de aspectos centrais na formação de nossa sociedade ${ }^{210}$.

Ao final da Idade Média, Portugal destacou-se por empreendimentos comerciais afirmados por uma notável expansão marítima, que provocou o estabelecimento de colônias na América, Ásia e África. O avanço pioneiro da nação na área mercantil, com a consideração do Estado como patrimônio pessoal do monarca, gerou a hipertrofia do aparato político e administrativo, em muito dificultando uma organização social autônoma para o curso do desenvolvimento econômico, notadamente na esfera da produção industrial.

É o contexto da herança política do patrimonialismo ibérico: na monarquia portuguesa patrimonial, o rei elevava-se sobre todos os súditos como o "titular da riqueza eminente e perpétua, capaz de gerir as maiores propriedades do país, dirigir o comércio, conduzir a economia como se fosse empresa sua". À diferença dos direitos, privilégios e obrigações fixamente determinados do feudalismo, o sistema patrimonial "prende os servidores numa rede patriarcal, na qual eles representam a extensão da casa do soberano",211.

No século XVI, para a execução de suas principais funções — guerra, fazenda e justiça - o soberano dispunha de um extenso complexo de cargos públicos, para cujo

\footnotetext{
${ }^{210}$ Trata-se da abordagem, adotada principalmente por Raymundo Faoro em Os Donos do Poder, de um tipo de sociedade, em atenção aos tipos de dominação examinados por Weber no âmbito da chamada dominação tradicional, cuja forma mais importante consiste no patrimonialismo que, de um modo geral, se identifica com o "regime no qual o governante considera todos os direitos políticos e econômicos como seus direitos pessoais". O governante enxerga a administração como seu instrumento pessoal, e todos os compromissos dos agentes públicos são com a pessoa do governante, com destaque à importância da lealdade e não da imparcialidade, como em uma burocracia (SWERDBERG, Richard. Max Weber e a idéia de solciologia económica. Trad. Dinah Abreu Azevedo. Rio de Janeiro: Ed. UFRJ; São Paulo: Beca Produções Culturais, 2005. p. 123). Cf. WEBER, Max. A política como vocação. In: Ciência e política: duas vocações. Trad. Leônidas Hegenberg e Octany Silveira da Mota. 19. ed. São Paulo: Cultrix, 2000. p. 55-64.

${ }^{211}$ FAORO, Raymundo. Os donos do poder: formação do patronato político brasileiro. 3. ed. São Paulo: Ed. Globo, 2001. p. 38.
} 
provimento priorizava os extraídos do embrião da nobreza, também nutrindo um crescente processo de nobilitação da burguesia mercantil. Era esta alçada ao estamento da aristocracia pela via do "cargo público, instrumento de amálgama e controle das conquistas por parte do soberano" ${ }^{\text {212 }}$. Para o domínio do corpo burocrático, o rei conferia vantagens e títulos da nobreza aos agentes públicos, transformando-os em autoridade pela marca da $\operatorname{aristocracia~}^{213}$.

Assim, seguindo a tradição da metrópole, a organização política e administrativa do Brasil colonial tendia a prestigiar uma sociedade aristocrática, mediante a adesão da burguesia ascendente aos valores e costumes desse estamento social. Eram ignorados na administração colonial os principais traços que informaram o arcabouço organizacional do Estado moderno. Não se vislumbrava a existência de uma separação substancial entre as funções do Estado, também não se verificando esferas diferentes e paralelas "das atividades estatais: geral, provincial, local" ${ }^{214}$.

Aquela organização ressentia-se das características do Estado burocrático weberiano, com vínculos racionais de competência e rigidez nas estruturas hierárquicas, de modo a revestir as relações entre súdito e autoridade dos atributos de objetividade e impessoalidade. É que, no Estado patrimonialista, os benefícios auferidos de funções e empregos públicos estão relacionados "a direitos pessoais do funcionário e não a interesses objetivos, como sucede no verdadeiro Estado burocrático, em que prevalecem a especialização das funções e o esforço para se assegurarem garantias jurídicas dos cidadãos". Os indivíduos que irão exercer funções públicas são escolhidos "de acordo com a confiança pessoal que mereçam os candidatos, e muito menos de acordo com as suas capacidades próprias. Falta a tudo a ordenação impessoal que caracteriza a vida no Estado burocrático" $^{215}$.

De uma maneira geral, é possível afirmar a adoção, no Brasil, do sistema administrativo de Portugal, sem que houvesse um planejamento original, específico para a colônia. As diferenças foram impostas por circunstâncias, tratando-se de ajustamentos

\footnotetext{
${ }^{212}$ FAORO, Raymundo. op. cit., p. 203.

${ }^{213}$ No decorrer do tempo, a venda de empregos passou a elevar à nobreza muitos componentes da burguesia (cf. FAORO, Raymundo. op. cit., p. 202).

${ }^{214}$ PRADO JUNIOR, Caio. Formação do Brasil contemporâneo: Colônia. 23. ed. São Paulo: Brasiliense, 2007. p. 298. Vale acrescer, segundo o mesmo autor, a ausência de uma delimitação entre os assuntos de ordem religiosa regulados pelo código moral e sacramental da Igreja e as matérias concernentes ao Direito, incidentes sobre as relações dos indivíduos na vida social (Id. Ibid., p. 329 e ss.).

${ }^{215}$ HOLANDA, Sérgio Buarque de. Raizes do Brasil. 12. ed. São Paulo: Companhia das Letras, 2004. p. 145146.
} 
regulados "de fato", sem que houvesse uma precisa pré-ordenação normativa. Dessa forma, a administração colonial não conheceu "funções bem discriminadas, competências bem definidas, disposição ordenada, segundo um princípio uniforme de hierarquia e simetria, dos diferentes órgãos administrativos" 216.

A legislação representava um amontoado desconexo de regras e deliberações casuísticas, acrescentando-se umas às outras, sem obedecerem a qualquer plano de conjunto dotado de clareza e uniformidade. Não respeitavam um método lógico nem mesmo as Ordenações do Reino, ou seja, as codificações que constituíam, à época, a base da legislação portuguesa. Nesse panorama, surge o Estado como um ente unitário, abrangendo todos os aspectos da vida social. E a expressão completa do poder estatal recai na figura do rei, com suas delegações de poder decorrendo mais de necessidades práticas dirigidas a uma divisão de funções do que de princípios gerais informadores da constituição e do funcionamento de entidades políticas.

O quadro da administração colonial brasileira, com a inclusão de vários órgãos colegiados, dispersava-se desordenadamente: todos buscavam se dirigir ao rei e "ao seu círculo de dependentes, atropelando os graus intermediários de comando" ${ }^{217}$. Assim, ocorriam disputas de atribuições e resistências de funcionários, com a usurpação de competências funcionais, cuja delimitação, por sua vez, vinha de forma bastante imprecisa nos textos normativos.

A reprodução do modelo do Reino no Brasil, de inegável centralização do poder político, acarretou a concentração de todas as autoridades nas capitais e sedes, deixando o vasto território brasileiro "praticamente desgovernado e a centenas de léguas muitas vezes da autoridade mais próxima” ${ }^{, 18}$. Em muitas ocasiões, assuntos brasileiros de caráter emergencial realmente acabavam ficando sob a responsabilidade de funcionários e agentes locais, colocados entre a metrópole e a colônia. Porém, algum comprometimento da autoridade central não chegava a representar uma autonomia dos entes locais, fundada em

\footnotetext{
${ }^{216}$ Cf. PRADO JUNIOR, Caio. op. cit., p. 300.

${ }^{217}$ FAORO, Raymundo. op. cit., p. 204 e 211-212. No sistema administrativo colonial, órgãos e funções que existiam num lugar, inexistiam em outros, ou apareciam sob forma e designação diferente; quando se constituía um novo órgão ou função, a lei nunca cogitava de entrosá-los harmonicamente, conforme o que já se encontrava estabelecido; regulava "minuciosa e casuisticamente a matéria presente, tendo em vista unicamente as necessidades imediatas" (PRADO JUNIOR, Caio. op. cit., p. 300).

${ }^{218}$ PRADO JUNIOR, Caio. op. cit., p. 302.
} 
critérios de racionalização funcional. Emergiam, ao revés, deliberações arbitrárias, expedidas à margem de qualquer controle e ao arrepio da lei ${ }^{219}$.

Firmou-se o espectro da influência do poder patriarcal na formação da sociedade brasileira. O senhor de terras e escravos representava a autoridade superior, figurando no vértice da hierarquia social, com a expansão de seu poder sendo considerada não só em função das bases econômicas da monocultura agrária, como também da distância entre a terra governada e as instituições do Estado português. Imperava, portanto, o comando senhorial exercido de forma mais direta e imediata, por vezes, mediante o recurso da violência armada ${ }^{220}$.

Era plena e absoluta a relação de dependência entre o senhor de terras e escravos, impossibilitando a constituição de formas de reconhecimento social, independentemente da vontade daquele. De caráter eminentemente pessoal, a tutela do patriarca dependia de suas necessidades e inclinações, determinando a extensão do núcleo familiar, isto é, “como, a quem e em que proporção seria distribuído seu favor e proteção"221.

\footnotetext{
${ }^{219}$ FAORO, Raymundo. op. cit., p. 210. O sistema não decorria de algum espírito superior de ordem e método, mas refletia a atividade de desconfiança generalizada que o governo central assumia em relação a todos seus agentes. "A confiança com outorga de autonomia, contrabalançadas embora por uma responsabilidade efetiva, é coisa que não penetrou nunca nos processos da administração portuguesa" (PRADO JUNIOR, Caio. op. cit., p. 309).

${ }^{220} \mathrm{Em}$ Casa-grande \& senzala, Gilberto Freyre realçou a enorme influência da família patriarcal na organização social e política do Brasil colonial, com destaque ao encontro cultural entre os dois elementos principais do patriarcalismo brasileiro: o português e o escravo negro. Partindo de elementos da escravidão muçulmana, o autor aludiu à existência de uma relação masoquista entre o senhor de terras e os negros para construir a tese da mestiçagem como característica peculiar de nossa formação social. Não obstante a crítica de ter colocado em segundo plano o elemento de opressão e de dominação que orientou aquele processo sincrético, vale conferir o seguinte trecho das primeiras páginas de Casa-grande \& senzala: "O sadismo de senhor e o correspondente masoquismo de escravo, excedendo a esfera da vida sexual e doméstica, têm-se feito sentir através da nossa formação, em campo mais largo: social e político. Cremos surpreendê-los em nossa vida política, onde o mandonismo tem sempre encontrado vítimas em que exercer-se com requintes às vezes sádicos; certas vezes deixando até nostalgias logo transformadas em cultos cívicos, como o do chamado marechal-de-ferro. A nossa tradição revolucionária, liberal, demagógica, é antes aparente e limitada a focos de fácil profilaxia política: no íntimo o que o grosso do que se pode chamar "povo brasileiro' ainda goza é a pressão de um governo másculo e corajosamente autocrático" (FREYRE, Gilberto. Casa-Grande \& Senzala: formação da família brasileira sob o regime da economia patriarcal. 51. ed. rev. São Paulo: Global, 2006. p. 114). Ao comparar os efeitos da escravidão no Brasil com a que se desenvolveu nos Estados Unidos da América, Joaquim Nabuco apontou que, nestes últimos, a constituição social não teria sido afetada como entre nós. Enquanto durou a escravidão nos Estados do Sul da União Americana, os escravos não foram, de modo algum, incorporados à sociedade. A mestiçagem no Brasil gerou cruzamentos sociais entre escravos e livres em uma abrangência ilimitada, atingindo todas as forças sociais e degradando-as igualmente. Foram assim obstruídas as vias de evolução dos segmentos de lavradores, operários, industriais e comerciantes, degenerando a educação e a consciência nacional (cf. NABUCO, Joaquim. O abolicionismo. Brasília: Ed. da UnB, 2003. p. 193-210).

${ }^{221}$ SOUZA, Jessé. A construção social da subcidadania: para uma sociologia política da modernidade periférica. Belo Horizonte: Ed. UFMG, 2003. p. 120. Cf. também a interessante análise de Silvia Maria Jardim Brugger a respeito das relações clientelistas engendradas pelo patriarcalismo brasileiro, com base em dados das relações de compadrio em São João Del Rei, entre 1736 e 1850 (BRUGGER, Silvia Maria
} 
Em linhas gerais, foi esse o cenário que envolveu o surgimento do Ministério Público no Brasil, identificado com o desenvolvimento das magistraturas de procurador da coroa, da fazenda e da justiça preexistentes em Portugal. No curso do desaparecimento do feudalismo, mesclavam-se na metrópole os serviços judicial, administrativo e fiscal, com as funções de procurador da coroa fundadas na representação dos interesses do Estado na pessoa do monarca. Como já se atestou, ele constituía o centro do poder político, decorrendo as atribuições fiscais do procurador da coroa da necessidade de uma orientação específica na condução dos negócios públicos, para que a resolução do rei fosse correspondente "à razão, à justiça e às leis"222.

No século XIV, aos procuradores do rei foram confiadas as funções de promover a repressão aos crimes, além da defesa dos demais interesses da coroa. Criou-se, assim, a magistratura do Ministério Público relativa aos cargos de procurador dos feitos de el-rei e da justiça, de procurador dos feitos da fazenda, de promotores da justiça nos tribunais e nas correições; recebendo estes a incumbência de "representar e promover em nome do rei e da sociedade, mas não julgar, embora fossem todos do corpo da magistratura" ${ }^{223}$.

No Brasil colonial, sob o estrito controle e rigorosa vigilância da metrópole, os governadores das capitanias eram as autoridades superiores, encarnando a pessoa do rei com atribuições de largo alcance, basicamente de natureza militar ${ }^{224}$. Além das capitanias, existiam ainda as unidades municipais, que configuravam o terceiro elo administrativo da colônia, com as vilas administradas por suas câmaras. A importância de uma vila, cuja criação dependia da vontade do soberano, refletia a nomeação pelos governadores do presidente da câmara, residindo na pessoa do juiz de fora. Quando a presença dessa autoridade não se fazia necessária, prevalecia o princípio da eletividade na composição das

Jardim. Escolhas de padrinhos e relações de poder: uma análise do compadrio em São João del Rei (17361850). In: CARVALHO, José Murilo de (Org.). Nação e cidadania no Império: novos horizontes. Rio de Janeiro: Civilização Brasileira, 2007. p. 313-347).

${ }^{222}$ MÁRTENS, João Baptista Ferrão de Carvalho. O Ministério Público e a Procuradoria-Geral da Coroa e da Fazenda: história, natureza e fins. Boletim do Ministério da Justiça, n. 233, p. 8, fev. 1974. Trata-se de relatório do primeiro Procurador-Geral da Coroa e Fazenda de Portugal, publicado originalmente no Diário do Governo, n. 175, de 7 de agosto de 1871.

${ }^{223}$ Id. Ibid., p. 19. Em 1385, o rei D. João I criou em Lisboa a Casa da Suplicação, em substituição à Casa da Justiça localizada em Santarém. E nas Ordenações Manuelinas (1521), sucedidas pelas Ordenações Filipinas (1603), foram compendiadas as funções de promotor de justiça perante a Casa da Suplicação e nos juízos das terras, além das atribuições de procurador dos feitos do rei e da fazenda. Nas terras servia de promotor o escrivão ou o tabelião. (Cf. MÁRTENS, João Baptista Ferrão de Carvalho. op. cit., p. 23; e SALLES, Carlos Alberto. op. cit., p. 20).

${ }^{224}$ As capitanias formavam as nossas maiores unidades administrativas, geridas pelo Conselho Ultramarino, órgão colegiado da metrópole encarregado de cuidar de todos os negócios da colônia. O governador das capitanias era também chamado de vice-rei, capitão-general ou capitão-mor (PRADO JUNIOR, Caio. op. cit., p. 304 e ss.). 
câmaras, que eram constituídas por juízes ordinários, vereadores e um procurador. A escolha de tais agentes sujeitava-se, então, à eleição popular, e suas atribuições estavam prefixadas nas Ordenações do Reino, sem que, no entanto, fosse possível identificar "funções separadas, no tocante à administração, justiça e legislativo (...)"225.

Aos juízes incumbia resolver as controvérsias entre particulares e executar medidas administrativas, procedendo sempre da mesma forma, independentemente da hipótese em questão. Além disso, no regime de administração da colônia, não ocorria o exercício de atribuições em esferas distintas e paralelas: uma geral e outra local. As câmaras acabavam executando tanto medidas de ordem local como funcionando na qualidade de órgãos inferiores da administração das capitanias ${ }^{226}$.

Segundo previam as Ordenações Filipinas, em nome da tradição e dos costumes, e de sorte a garantir um bom governo da terra, apenas os denominados homens bons estavam autorizados a integrar o colégio eleitoral para a composição das câmaras. A par dos nobres de linhagem, a qualidade de homem bom alcançava os senhores de terras, militares e a burocracia civil, englobando progressivamente representantes da burguesia mercantil. A intenção era inserir os proprietários fixados na terra nos "Livros da Nobreza", envolvendoos no quadro político da corte.

Em pouco tempo, as câmaras revelaram-se apenas um braço do poder central, comprometendo qualquer autonomia dos entes locais. Não desmente o fato a nomeação da figura do juiz de fora em algumas vilas para a chefia dos órgãos colegiados, subordinando a autoridade dos juízes ordinários eleitos pelo povo, cuja aceitação, aliás, devia sempre ser confirmada por autoridades do sistema judiciário da metrópole. Os juízes ordinários também podiam ser afastados de suas atividades pelos governadores das capitanias, que costumavam, com frequência, impor às câmaras a realização de determinadas providências e obras locais ${ }^{227}$.

\footnotetext{
${ }^{225}$ FAORO, Raymundo. op. cit., p. 213.

${ }^{226}$ Cabia às câmaras a realização de providências do governo geral, pois o contato direto que mantinham com a população permitia às autoridades mais distantes executarem por meio delas as suas decisões. Além disso, em relação a todos os atos das câmaras existia um recurso para alguma autoridade superior (cf. PRADO JUNIOR, Caio. op. cit., p. 313-314 e 318).

${ }^{227}$ FAORO, Raymundo. op. cit., p. 214. O governador acabava interferindo em muitos negócios das câmaras. Havia cargos cujo provimento era incumbência desses órgãos, mas que, não obstante, os governadores das capitanias costumavam prover. Casos também se verificaram, como se deu em São Paulo em 1799, em que o governador prorrogou o mandato dos juízes ordinários além do prazo para o qual foram eleitos (cf. PRADO JUNIOR, Caio. op. cit., p. 317-318).
} 
Nomeado pelo soberano, o ouvidor era a autoridade superior do sistema judiciário no período colonial, com poderes para decidir os casos criminais, quando não alcançavam integrantes do clero e da nobreza, e não eram da alçada de autoridades inferiores. Os julgamentos dos recursos de suas decisões competiam ao corregedor da corte, com a intervenção do governador em muitas hipóteses devido à confusão entre funções judiciais e administrativas.

Mais tarde, as capitanias dividiram-se em comarcas, e cada qual passou a contar com um ouvidor, que acumulava as funções de corregedor. Nas comarcas de maior importância, como foi o caso da Bahia e do Rio de Janeiro, sedes do governo central, havia um ouvidor para atuar na área cível e outro na esfera criminal. Ambos compunham as Relações daqueles municípios, que eram tribunais criados pela coroa no Brasil para a revisão das decisões de grau inferior. Com jurisdição sobre as capitanias, aqueles colegiados funcionavam sob a presidência do governador, contando com vários outros membros e dispondo de atribuições judiciárias e administrativas ${ }^{228}$. De acordo com as Ordenações Filipinas, o ofício de promotor de justiça verificou-se pela primeira vez no Brasil colonial, com a criação do Tribunal da Relação da Bahia, em 1609. Juntamente com o procurador dos feitos da coroa e da fazenda, o promotor integrava o tribunal constituído por dez desembargadores ${ }^{229}$.

Nessas condições, o sistema orgânico do Brasil colonial subsistiu agregado à centralização da coroa, com a prevalência de uma camada social no arcabouço do governo contribuindo para a preservação da unidade da nação. Neutralizando anseios autonomistas, funcionários e agentes do rei configuravam o móvel integrador, dentro de uma vasta e intrincada rede de funções e cargos públicos, refletindo um círculo de privilégios e honras que lhes conferia "mando, autoridade e fidalguia"230.

\footnotetext{
${ }^{228}$ PRADO JUNIOR, Caio. op. cit., p. 319-320. Cf. também LEAL, Victor Nunes. Coronelismo, enxada e voto: o município e o regime representativo no Brasil. 3. ed. Rio de Janeiro: Nova Fronteira, 1997. p. 215. Vale anotar que a existência de uma série de recursos conduzia, muitas vezes, os julgamentos dos casos "até Lisboa, na Casa de Suplicação, no Desembargo do Paço e na Mesa de Consciência e Ordens. Ai de quem caísse nas mãos dessa justiça tarda, incompetente, cruel, amparada nas duras leis do tempo" (FAORO, Raymundo. op. cit., p. 217).

${ }^{229}$ SALLES, Carlos Alberto. op. cit., p. 21; e LYRA, Roberto. Theoria e pratica da promotoria pública. Rio de Janeiro: Jacintho, 1937. p. 14.

${ }^{230}$ FAORO, Raymundo. op. cit., p. 202.
} 


\subsection{O poder imperial}

Além de explicar o prolongamento do regime monárquico por mais de cinquenta anos, a vinda da família real para o Brasil (1809-1821) também contribuiu para impedir o fracionamento territorial em meio aos conflitos que se sucederam no período de nossa independência ${ }^{231}$.

Na primeira metade de 1822, o Brasil já dispunha de um governo com sede no Rio de Janeiro e um quadro de ministros próprio, caminhando no sentido de promover relações internacionais independentes de Portugal. Em junho do mesmo ano, a convocação da Assembleia Geral Constituinte acresceu-se de um cenário claramente separatista ${ }^{232}$.

Após a independência, com o reconhecimento da nova nação pelas grandes potências, foi necessário organizá-la. De caráter unitário e centralizador, a Constituição outorgada de 1824 resultou de um documento elaborado pelo Conselho de Estado instituído por D. Pedro I, após a dissolução da Assembleia Geral Constituinte. Trata-se de seu primeiro ato de arbítrio, "a afastá-lo do povo", como uma reação autoritária a certo ânimo liberal que impregnava os deputados constituintes eleitos livremente para redigir o primeiro diploma constitucional brasileiro ${ }^{233}$.

A Constituição de 1824 estabeleceu para o Império os três poderes tradicionais: executivo, legislativo bicameral, com Câmara e Senado, e judiciário. Todavia, por herança do absolutismo, implantou-se também o poder moderador, que fora idealizado por constitucionalistas para conter os avanços radicais da Revolução Francesa ${ }^{234}$. Estruturalmente contrário ao pensamento da filosofia liberal dos movimentos revolucionários do século precedente e, à evidência, ao sistema de distribuição dos poderes estatais preconizado por Montesquieu, o exercício do poder moderador era privativo do

\footnotetext{
${ }^{231}$ No início do século XIX, o regente D. João e o governo do Império deslocaram-se para o Brasil, quando Napoleão decidiu pela invasão de Portugal, em virtude de sua resistência ao bloqueio do continente europeu para isolar os britânicos. Em 1815, o Brasil recebeu o título de Reino Unido ao de Portugal e Algarve e, em 1818 , o regente passa a ser D. João VI, com a morte de sua mãe, a rainha D. Maria I. Muito embora a fase final do processo de nossa emancipação tenha sido conduzida, de forma preponderante, pelo príncipe D. Pedro I e grupos políticos das províncias do Rio de Janeiro, São Paulo e Minas Gerais, contrariando a tese de que a independência revestiu-se de um caráter de mera doação da liberdade, não é possível desprezar a luta do povo durante toda a trajetória, contrária às pretensões francesas, inglesas e holandesas. As conjurações mineira, carioca e pernambucana também são exemplos no mesmo sentido (Cf. IGLÉSIAS, Francisco. Momentos democráticos na trajetória brasileira. In: JAGUARIBE, Hélio et al. Brasil, sociedade democrática. Rio de Janeiro: José Olympio, 1985. p. 133-136. (Coleção Documentos Brasileiros)).

${ }^{232}$ BONAVIDES, Paulo; ANDRADE, Paes de. História constitucional do Brasil. 5. ed. Brasília: OAB Ed., 2004. p. 99.

${ }^{233}$ IGLÉSIAS, Francisco. op. cit., p. 136.

${ }^{234}$ Id. Ibid., p. 137.
} 
monarca, que possuía, como principal atribuição, a livre nomeação dos ministros, independentemente da aquiescência do legislativo. Dessa forma, afastando-se do modelo parlamentar inglês, o executivo confundia-se com o poder moderador, com os ministros atuando como meros delegados do rei.

Com a titularidade privativa do poder moderador, considerado como a chave da organização política brasileira, o Imperador exonerava-se de qualquer responsabilidade. A Constituição atribuiu-lhe, além da livre nomeação dos ministros, a nomeação de senadores, a convocação da assembleia geral extraordinária nos intervalos das sessões legislativas, a aprovação e a suspensão interina das resoluções dos conselhos provinciais, a prorrogação e o adiamento da assembleia geral, a dissolução da Câmara dos Deputados, a suspensão dos magistrados em determinados casos e a concessão de perdão ou anistia para as penas ${ }^{235}$.

A Constituição de 1824 regulou também os direitos políticos, autorizando uma parcela da população adulta masculina a participar da formação do governo. A eleição era realizada em dois turnos. Inicialmente, escolhiam-se os eleitores, os quais, por sua vez, elegiam os deputados para um mandato de quatros anos, e senadores vitalícios eleitos em listas tríplices para a escolha pelo Imperador. Nem todos eram elegíveis ou votantes. Para votar e ser votado era preciso que o cidadão contasse com um mínimo de renda. Os chefes das províncias, que eram de indicação do governo central, exerciam o controle na escolha dos votantes. Assim, as eleições acabavam sob o domínio dos ministros nomeados pelo Imperador, que não se via diante de uma maioria oposicionista no parlamento ${ }^{236}$.

A natureza restritiva da elegibilidade para o Senado do Império caracterizava-se ainda pelo requisito relativo à capacidade e às virtudes do candidato ao posto. Inspirava a hipótese "o compromisso da filosofia burguesa com os interesses remanescentes das classes feudais", em atenção aos de uma sociedade agrária e patriarcal. Selava-se, portanto, o pacto de segmentos liberais com os conservadores "do altar e do trono, afeiçoados à tradição colonial" 237 . O direito à propriedade foi plenamente assegurado na Constituição de 1824, que, juntamente com a proclamação da liberdade e da segurança individual "como a

\footnotetext{
${ }^{235}$ Cf. BONAVIDES, Paulo; ANDRADE, Paes de. op. cit., p. 106-107. Ainda, sobre as relações entre o parlamento e o poder moderador durante o Segundo Reinado, cf. FAORO, Raymundo. op. cit., p. 405 e ss.

${ }^{236}$ IGLÉSIAS, Francisco. op. cit., p. 138; e CARVALHO, José Murilo de. Cidadania no Brasil: um longo caminho. 5. ed. Rio de Janeiro: Civilização Brasileira, 2004. p. 30 e ss.

${ }^{237}$ BONAVIDES, Paulo; ANDRADE, Paes de. op. cit., p. 108.
} 
base da inviolabilidade dos direitos civis e políticos dos cidadãos", revelou-se "um sólido esteio dos grandes interesses do patriciado rural" ${ }^{, 238}$.

Por outro lado, principiando-se com a dissolução da Assembleia Constituinte para a outorga da Constituição Imperial, o dissenso do Primeiro Reinado com a nação brasileira resultou do ânimo absolutista de D. Pedro I na condução do governo, à revelia das aspirações liberais constantes do texto constitucional. Seu desprestígio acentuou-se com o desgaste causado pela guerra no Sul por causa da Cisplatina. Choques entre brasileiros e portugueses eram constantes no período, culminando com a abdicação, em 7 de abril de 1831, e a transferência do trono brasileiro ao príncipe D. Pedro de Alcântara, com cinco anos de idade. A regência foi, então, inicialmente trina, sob a designação do parlamento, e depois una, com escolha da chefia pelo voto popular ${ }^{239}$.

À época, sucederam-se muitas perturbações nas províncias, afirmando-se os anseios federalistas voltados à concessão de maior autonomia às unidades nacionais. Algumas reivindicações foram satisfeitas mediante a edição do Ato Adicional de 1834, quando, por um acordo entre a Câmara e o Senado, formalizou-se a reforma constitucional. Foram criadas assembleias legislativas nas províncias, inserindo-se ainda a escolha pelo voto popular de um só regente para um mandato de quatro anos. Não houve, porém, nenhuma alteração no funcionamento do poder moderador e, contrapondo-se a qualquer ideal de descentralização política, os presidentes das províncias continuaram de livre nomeação pelo soberano $^{240}$.

O Código de Processo Criminal do Império (1832) previu a escolha de autoridades judiciais a partir de listas tríplices elaboradas pelas câmaras dos municípios. A escolha do promotor de justiça respeitou o mesmo critério, competindo a nomeação do oficial na corte ao governador, para um mandato de três anos, e ao presidente nas províncias ${ }^{241}$. Da regulamentação de suas funções também se encarregou aquela lei, que, além das disposições relativas à promoção da ação penal, execução das sentenças e dos mandados judiciais, conferiu ao promotor de justiça a incumbência de "dar parte às autoridades competentes das negligências, omissões e prevaricações dos empregados na administração

\footnotetext{
${ }^{238}$ BONAVIDES, Paulo; ANDRADE, Paes de. op. cit., p. 108-109. Cf. também IGLÉSIAS, Francisco. op. cit., p. 138.

${ }^{239}$ Cf. Id. Ibid., p. 111 e 119; e Id. Ibid., p. 139-140.

${ }^{240}$ Cf. Id. Ibid., p. 123-125; e Id. Ibid., p. 142.

${ }^{241}$ SALLES, Carlos Alberto. op. cit., p. 21.
} 
da justiça" ${ }^{242}$. O Código instituiu ainda o habeas corpus e o júri, valorizando, assim, um esquema de significativa participação popular ${ }^{243}$.

De outro turno, movimentos revolucionários abalaram a regência una de Diogo Antônio Feijó, eleito pelo voto popular em $1835^{244}$. A unidade nacional impunha a restauração da ordem pública e, por conseguinte, a reforma da legislação de caráter liberal, então em vigor. Daí a edição, em 12 de maio de 1840, da Lei de Interpretação do texto constitucional, no intuito de introduzir uma substancial limitação às inovações constitucionais advindas com o Ato Adicional de 1834. Além de diminuir, pela via interpretativa, os poderes do presidente das províncias, o diploma restringiu os poderes das câmaras, ampliando a competência do poder legislativo geral. A Lei de Interpretação e a maioridade do Imperador pautaram-se pela manutenção da integridade nacional, com o sacrifício de "muitas crenças que estavam no coração dos liberais e também com o desaparecimento de grande parte das esperanças descentralizadoras e federativas, removidas agora da concretização institucional" ${ }^{, 245}$.

Contando com pouco mais de 14 (quatorze) anos de idade, D.Pedro II assumiu o governo central em 23 de julho de 1840, dando início ao Segundo Reinado, que perdurou por quase meio século, com a alternância de liberais e conservadores no poder, levada a efeito pelo Imperador por meio do comando do poder moderador. Certo equilíbrio entre as duas forças políticas foi fruto da intenção imperial de corrigir as distorções do sistema eleitoral. Como se viu, segundo previa a Constituição de 1824, para a composição dos postos de senadores, deputados gerais ou provinciais, inicialmente havia a escolha dos eleitores pelos votantes. Os presidentes das províncias eram, contudo, nomeados pelo Imperador, o que, considerando a vastidão do território brasileiro, a falta de policiamento e a precariedade da legislação, determinava a preponderância das forças locais no controle das eleições. Os votantes indesejáveis eram sempre afastados, "sob qualquer pretexto ou nenhum"246.

\footnotetext{
${ }^{242}$ SALLES, Carlos Alberto. op. cit., p. 22.

${ }^{243}$ IGLÉSIAS, Francisco. op. cit., p. 147.

${ }^{244}$ Vale destacar os episódios da cabanada no Pará (1835-40), com o assassinato do presidente da província e a recusa de presidentes nomeados pelo Rio de Janeiro, sede do governo central; a sabinada na Bahia, dirigida pelo médico Francisco Sabino, com a pretensão de criar a República Baiense; e a importante revolução farroupilha no Rio Grande do Sul, com as fases da República Rio Grandense, a República Juliana, a presidência e o comando de Caxias, até a pacificação em 1845 (IGLÉSIAS, Francisco. op. cit., p. 143-144).

${ }^{245}$ BONAVIDES, Paulo; ANDRADE, Paes de. op. cit., p. 129.

${ }^{246}$ IGLÉSIAS, Francisco. op. cit., p. 149.
} 
Cumpre lembrar que, com base no trabalho escravo, o domínio da economia recaía na figura do grande latifundiário, que controlava o jogo político valendo-se de seus agentes, garantindo o voto nas eleições. E os magistrados estavam a serviço desse quadro, apresentando a

perfeita combinação de elementos intelectuais, ideológicos e práticos favoráveis ao estatismo. $\mathrm{Na}$ verdade, foram os mais completos construtores de Estado no Império, especialmente os da geração coimbrã. Além das características da educação (...), eles tinham a experiência da aplicação cotidiana da lei e sua carreira lhes fornecia elementos adicionais de treinamento para o exercício do poder público ${ }^{247}$.

O problema não era propriamente de ordem legal, pois, a despeito das garantias que viesse a desfrutar, o integrante da organização judiciária, incluindo a figura do promotor de justiça, apresentava-se "solícito com o poder, ambicioso de honrarias ou vantagens (...)"248. De todo modo, os magistrados eram sempre considerados agentes a serviço do soberano imperial. Nessa linha, versando sobre a reforma do Código de Processo Criminal do Império (1832), a Lei 261, de 3.12.1841, "dispensou a indicação tríplice das câmaras para a nomeação dos juízes municipais", que passaram a ser nomeados pelo Ministro da Justiça. Foram ainda confiadas funções de natureza judiciária a autoridades policiais, conferindo ao chefe de polícia poderes de intervenção na justiça. A legislação não foi "um simples código processual ou de organização judiciária e policial; foi, acima de tudo, um instrumento político, um poderoso aparelho de dominação, capaz de dar ao governo vitórias eleitorais esmagadoras, estivesse no poder o partido conservador ou o liberal" ${ }^{249}$.

Quanto aos promotores públicos, aquele diploma (Lei de 3.12.1841) atribuiu diretamente a sua nomeação ao Imperador ou aos presidentes das províncias. A alteração não deixou de representar um considerável retrocesso na formulação do sistema orgânico do Ministério Público, ao retirar a legitimidade emprestada pela proposta da Câmara

\footnotetext{
${ }^{247}$ CARVALHO, José Murilo de. A construção da ordem: a elite política imperial. Teatro de sombras: a política imperial. Rio de Janeiro: Civilização Brasileira, 2003. p. 99. O autor aponta que, no período compreendido entre 1882 e 1889, "em torno de $50 \%$ dos magistrados e advogados tinham ligação direta ou indireta com a propriedade rural e uma porcentagem muito menor a tinha com o comércio (Id. Ibid., p. 112). Ainda como reflexo do processo de degeneração social provocado pela escravidão no Brasil, Joaquim Nabuco destacou o acesso ao emprego público como o abrigo dos integrantes de "antigas famílias fidalgas. Profissões chamadas independentes, como a advocacia, guardavam estreitos pontos de contanto com o funcionalismo" (NABUCO, Joaquim. op. cit., p. 201-202).

${ }^{248}$ LEAL, Victor Nunes. op. cit., p. 224.

${ }^{249}$ Id. Ibid., p. 223; e IGLÉSIAS, Francisco. op. cit., p. 146-147.
} 
Municipal para colocar "a nomeação e a demissão do Promotor Público sob o exclusivo alvitre dos chefes do Poder Executivo"250.

De outra parte, mediante a colaboração de Rui Barbosa, então deputado pelo Partido Liberal, a instituição de eleições diretas para os órgãos do legislativo veio com a edição da chamada Lei Saraiva (1881), sem a devida reforma constitucional. Não obstante tenha aprimorado o sistema de votação e apuração, inclusive com o estabelecimento do título eleitoral, a lei manteve a exigência de renda mínima para a condição de votante e para o exercício dos cargos, também afastando os analfabetos do processo eleitoral. Como se vê, o sistema alijou da política grande parcela da população, apenas apresentando resultados positivos no início de sua vigência. Retomou-se, nas experiências subsequentes, a usual "manipulação dos agentes desvirtuadores da verdade nas urnas. A fórmula ideal tropeçava sempre com a realidade nacional" 251 .

É verdade que, a partir de meados do Segundo Reinado, o país conheceu uma relativa modernização, com investimentos no setor industrial provocados pela disponibilidade financeira resultante da supressão do tráfico de escravos. Mas a lavoura cafeeira ainda ocupava papel de destaque no cenário econômico. Em 13 de maio de 1888, sucedeu-se a abolição do regime escravocrata, como resultado de um momento de considerável consciência nacional e participação popular. As condições agrárias subsistiram, porém, inalteradas, provocando a vinda para as cidades da população negra, que, sem nenhum preparo para as atividades urbanas, se tornou a base do proletariado no Brasil $^{252}$.

De um modo geral, a realidade política do século XIX procurou impregnar-se do modelo democrático do liberalismo clássico, com a ideia de bem comum definida sob

\footnotetext{
${ }^{250}$ SALLES, Carlos Alberto. op. cit., p. 22. A Lei de 3.12.1841 também estabeleceu a necessidade de que, em cada comarca, as atividades do juiz fossem acompanhadas por, pelo menos, um promotor de justiça, cuja remuneração compunha-se de um valor fixo e de quantias variando conforme cada uma de suas principais atividades (cf. LYRA, Roberto. op. cit., p. 15-16).

${ }^{251}$ IGLÉSIAS, Francisco. op. cit., p. 149. Sempre colocando a questão como um dos efeitos da escravidão no Brasil, Joaquim Nabuco assim se manifestou: “(...) ficou provado que nem mesmo é preciso a candidatura official para eleger camaras governistas. A machina eleitoral é automática, e por mais que mudem a lei, o resultado há de ser o mesmo. (...) Olhando em torno de si, o Imperador não encontra uma só individualidade que limite a sua, uma vontade individual ou collectiva, a que elle se deva sujeitar: n'esse sentido elle é absoluto como o Czar e o Sultão, ainda que se veja no centro de um governo moderno e provido de todos os orgãos superiores (...)" (NABUCO, Joaquim. op. cit., p. 211).

${ }^{252}$ Desde a independência iniciou-se a pressão da Inglaterra pelo fim da escravidão no Brasil. Sucederam-se a Lei Euzébio de Queirós, determinando o fim do tráfico de escravos; a Lei do Ventre Livre (1871) e dos Sexagenários. No curso de todo o processo, merece relevo a ação do negro, com destaque à do Quilombo de Palmares, que durou quase todo século e foi exemplo para dezenas de outros levantes e organizações em vários pontos do território nacional (IGLÉSIAS, Francisco. op. cit., p. 152-153).
} 
moldes utilitários como a soma dos interesses individuais. A proteção da ação privada para a produção de riquezas consagrou-se o supremo objetivo do Estado. Entretanto, o complexo unitário da política brasileira, com o reconhecimento de direitos apenas aos chamados homens bons, certamente não era compatível com o advento do projeto capitalista, que demandava a emancipação da sociedade para livrá-la de expectativas em torno da tutela estatal. Muito embora crescessem as reivindicações para a consolidação do formalismo do Estado liberal, inclusive ante a existência de uma classe média, os princípios hauridos nos movimentos revolucionários do final do século XVIII contrapunham-se aos aspectos patrimonialistas oriundos de nossa herança colonial, refletindo no despreparo e no "atraso político, econômico e social da jovem nacionalidade ${ }^{, 253}$.

\subsection{As oligarquias na República Velha}

A combinação de alguns fatores tornou irreversível a desintegração do Império, com a intervenção militar de 15 de novembro de 1889 instituindo no país a forma republicana de governo e o modelo federativo de organização do Estado, para o efeito de sua descentralização vertical.

Desde logo, cumpre assinalar a crise do trabalho escravo, provocando a adesão à causa republicana por proprietários rurais que sofreram prejuízos com a abolição, sem qualquer indenização pelos prejuízos suportados. A perda pelo trono do apoio da Igreja e dos militares também contribuiu para a mudança do sistema de governo no Brasil. Depois da Guerra do Paraguai, parte considerável do Exército perdera a confiança no poder civil da monarquia, com a influência da doutrina positivista sobre os jovens oficiais. $O$ positivismo conferia às instituições um suposto teor de racionalidade, incompatível com o aparato imperial caracterizado por uma centralização excessiva para as dimensões territoriais do país. Novas exigências administrativas suscitavam a realização de projetos de descentralização ligados à proposta federativa, emergindo a alteração da forma de governo por simples golpe de Estado, que teve o militar como o seu principal agente ${ }^{254}$.

\footnotetext{
${ }^{253}$ BONAVIDES, Paulo; ANDRADE, Paes de. op. cit., p. 103.

${ }^{254}$ Cf. IGLÉSIAS, Francisco. op. cit., p. 156; e BONAVIDES, Paulo; ANDRADE, Paes de. op. cit., p. 216217. ${ }^{254} \mathrm{~A}$ versão positivista da República trazia um arsenal teórico de muita utilidade no Brasil. A monarquia devia ser superada pela fase positivista, "cuja melhor encarnação era a república". A separação entre Igreja e Estado era também uma proposta interessante a grupos de professores, estudantes e, principalmente, militares. "Igualmente, a ideia de ditadura republicana, o apelo a um Executivo forte e
} 
Com a proclamação da República, o Marechal Deodoro da Fonseca assumiu o exercício do poder estatal, expedindo, de pronto, o decreto, de 15.11.1889, que determinou a regência da nação pelo Governo Provisório da República enquanto não fossem realizadas as eleições do Congresso Nacional e das legislaturas de cada um dos Estados, pelos meios regulares $^{255}$. As antigas províncias converteram-se em partes integrantes de uma comunhão federativa dotadas de certo raio de autonomia política. Suas assembleias foram extintas, e os governadores, nomeados pelo Governo Provisório, muniram-se, provisoriamente, de funções legislativas e executivas. Instituiu-se o sistema federativo de Estado, sem, no entanto, comprometer o sentido unitário oriundo do Império ${ }^{256}$.

O federalismo brasileiro foi implantado no caminho oposto ao que se seguiu nos Estados Unidos da América. Enquanto nesta República as treze colônias abrem mão de parte de sua autonomia "para o estabelecimento de uma força aglutinadora central, no Brasil são unidades regidas pelo centro que conquistam relativa liberdade" ${ }^{, 257}$. O modelo federativo brasileiro teve, de fato, um sentido distinto daquele havido nos Estados Unidos. Lá, como vimos, a revolução viera antes, "estava na nova sociedade igualitária formada pelos colonos". A preocupação com a organização do poder era antes consequência da quase ausência de hierarquias sociais. No Brasil, não houve revolução prévia. "Apesar da abolição da escravidão, a sociedade caracterizava-se por desigualdades profundas e pela concentração do poder político. Nessas circunstâncias, o liberalismo adquiria um caráter de consagração da desigualdade, de sanção da lei do mais forte" 258 .

Não há dúvidas quanto à dificuldade de implantação de uma "república à antiga" ou de uma república moderna no Brasil. O apego a valores comunitários caía no vazio dentro de uma tradição cultural, de todo enraizada, que reforçava o patriarcalismo vigente. A proposta de transformar o Estado em promotor do bem comum acabava acentuando a ideia de paternalismo governamental, inexistindo as bases para a consolidação de um sentimento de identidade coletiva. Dessa forma, a dificuldade com os dois modelos de liberdade, a dos

intervencionista servia bem a seus interesses. Progresso e ditadura, o progresso pela ditadura, pela ação do Estado, eis aí um ideal de despotismo ilustrado que tinha longas raízes na tradição luso-brasileira desde os tempos pombalinos do século XVIII" (CARVALHO, José Murilo de. A formação das almas: o imaginário da República no Brasil. São Paulo: Companhia das Letras, 2005. p. 25).

${ }^{255}$ A República foi instituída pelo Decreto n. 1, de 15.11.1889, baixado pelo Marechal Deodoro da Fonseca, e o Governo Provisório subsistiu no poder até 24.2.1891.

${ }^{256} \mathrm{O}$ Decreto responsável pela instituição da República consagrou a previsão do exercício do poder constituinte pelas unidades estaduais da federação (art. $3^{\circ}$ do Decreto 1/1889), concedendo às antigas províncias a possibilidade de criação de suas próprias constituições (cf. SACCO, Ricardo Ferreira. op. cit., p. 64-65). E o Rio de Janeiro constituiu-se em sede do governo federal.

${ }^{257}$ IGLÉSIAS, Francisco. op. cit., p. 157.

${ }^{258}$ CARVALHO, José Murilo de. A formação das almas: o imaginário da República no Brasil, cit., p. 25. 
antigos e a dos modernos, estava na ausência de um elemento que, conforme enfatizou Montesquieu, "era na realidade parte importante, ou mesmo uma premissa, para o funcionamento deles". Para que a república antiga funcionasse, para que os cidadãos aceitassem a liberdade pública em troca da liberdade individual, para que a república moderna funcionasse, para que os cidadãos renunciassem, em grande parte, à influência sobre os negócios públicos em favor da liberdade individual - para isso, era necessária "a existência anterior do sentimento de comunidade, de identidade coletiva, que antigamente podia ser o de pertencer a uma cidade e que modernamente é o de pertencer a uma nação" 259. O sentido de identidade, cimento comum aos dois modelos, constituía elemento essencial para a fundação e a organização de uma comunidade política.

O Governo Provisório regulamentou a eleição das duas casas do parlamento nacional para o exercício do poder constituinte, findo o qual o Congresso seria investido no exercício da função legislativa ordinária. A primeira constituinte republicana instalou-se, assim, em 15.11.1890, composta de 205 (duzentos e cinco) deputados e 63 (sessenta e três) senadores, os quais se dividiram em unitaristas e federalistas; os primeiros, inclinados a conferir mais poderes à União; os segundos, a transferir para os Estados o máximo possível de autonomia. Entre as reivindicações que orientavam a proposta republicana, estavam a realização do princípio federativo, a supressão da vitaliciedade no Senado para mandatos eletivos e temporários; o ensino livre e, principalmente, a extinção do poder moderador ${ }^{260}$.

A Constituição de 1891 buscou neutralizar o poder pessoal dos governantes, além de distanciar o Estado da sociedade, segundo clássico axioma do liberalismo. Em oposição à Constituição Imperial, o novo diploma republicano aboliu os foros de nobreza, as ordens honoríficas e suas prerrogativas; o Poder Moderador, o Senado vitalício e a união entre Estado e Igreja, com a instituição do casamento civil e do ensino laico nos estabelecimentos públicos, além da secularização dos cemitérios. Extinguiu-se também a pena de morte, com a manutenção do instrumento do habeas corpus. Muitos direitos e garantias já constantes da Constituição de 1824 foram incorporados ao texto constitucional da República, como a isonomia, a livre manifestação do pensamento, a liberdade de

\footnotetext{
${ }^{259}$ CARVALHO, José Murilo de. A formação das almas: o imaginário da República no Brasil, cit., p. 30-32.

${ }^{260}$ Cf. BONAVIDES, Paulo; ANDRADE, Paes de. op. cit., p. 215 e 222-234. O Governo Provisório encarregou uma comissão formada por cinco juristas da tarefa de elaborar o projeto de constituição. O projeto foi da lavra de Rui Barbosa, Ministro da Justiça e vice-chefe do governo provisório, que integrou aquela comissão (cf. SACCO, Ricardo Ferreira. op. cit., p. 64-65). A comissão parlamentar designada para a avaliação do projeto enviado ao Congresso pelo governo provisório pouco veio a alterá-lo, ocorrendo a promulgação do novo texto em 24.2.1891.
} 
associação, o direito de reunião, a instituição do júri, a inviolabilidade de domicílio e o direito de propriedade, com a ressalva apenas para os casos de desapropriação por necessidade ou utilidade pública, mediante prévia indenização. Interessa ressaltar a existência de dispositivo estabelecendo que a declaração dos direitos fundamentais da pessoa humana não excluía outras garantias e direitos não enumerados, mas resultantes da forma de governo e de seus respectivos princípios. Pedra angular do Estado de Direito, a essência desse preceito acabou sendo reproduzida em todas as Constituições republicanas, conferindo uma importante latitude para o exercício jurisdicional de proteção dos direitos fundamentais $^{261}$.

Entretanto, uma coisa "foi a ordem constitucional formalmente estabelecida (...) e outra coisa muito diferente, a realidade e a organização social da nação republicana, proveniente da crise do cativeiro e da derrubada das instituições imperiais" ${ }^{262}$. No campo governamental, as instituições republicanas mostravam-se impotentes para suplantar a tradição e os costumes, vindo a padecer dos vícios do passado. O poder moderador encontrou o seu sucedâneo no instituto da intervenção federal, que se transformou em mecanismo de arbítrio do chefe do Executivo, sufocando inteiramente as autonomias estaduais. Às forças armadas foi atribuída a proteção contra o inimigo externo e a defesa das instituições da República.

O presidencialismo no Brasil alimentou a expansão desenfreada da autoridade do Presidente da República, convertendo-o no centro de "todos os poderes, de todas as decisões, de todos os movimentos da máquina de governo”, malgrado a consagração do princípio da separação de poderes no diploma constitucional ${ }^{263}$. Assim, a força de um só poder aglutinou as oligarquias estaduais ao redor do chefe do Executivo, onde gravitavam todos os interesses, com o sério comprometimento dos alicerces de legitimidade republicana e federativa das instituições constitucionais ${ }^{264}$.

\footnotetext{
${ }^{261}$ BONAVIDES, Paulo; ANDRADE, Paes de. op. cit., p. 259.

${ }^{262}$ Id. Ibid., p. 259. A ausência de participação popular na proclamação da República mostrou-se condizente com a ineficácia da Constituição republicana. A organização política nela moldada para o Brasil, uma vez dissociada de sua realidade social, remanesceu no campo teórico (cf. SACCO, Ricardo Ferreira. op. cit., p. 66-67).

${ }^{263} \mathrm{O}$ art. 15 da Constituição de 1891 consagrou o princípio da tripartição dos poderes estatais: "são órgãos da soberania nacional o Poder Legislativo, o Executivo e o Judiciário, harmônicos e independentes entre si" (cf. SACCO, Ricardo Ferreira. op. cit., p. 65).

${ }^{264}$ BONAVIDES, Paulo; ANDRADE, Paes de. op. cit., p. 258-260. Em 1926, sucedeu-se uma revisão constitucional munida de nítido caráter centralizador, restringindo a autonomia dos Estados, que passaram a sofrer rigoroso controle político por parte da União.
} 
Houve a extensão do direito de votar, alcançando os cidadãos alfabetizados, maiores de 21 (vinte e um) anos, muito embora o sufrágio manipulado não escondesse a inautencidade da participação dos cidadãos nos atos de escolha de seus representantes. As organizações partidárias da Primeira República eram frágeis e inconsistentes, prestando-se à manutenção dos privilégios da sociedade patriarcal.

A partir dos primeiros governos civis, o modelo denominado coronelismo passou a dominar a política nacional ${ }^{265}$. Nos moldes da autoridade dos barões feudais da Idade Média, os proprietários de terra detinham o comando político local, reconhecendo a chefia do Estado: os presidentes eleitos, que, em compensação, sacramentavam o poder local, “compondo-se com os chefes regionais". Só se faziam nomeações de funcionários polícia, justiça, educação, saúde - depois de ouvidos os coronéis. Havia, assim, "uma cadeia perfeita de respeitos mútuos e de exercício da força por parte dos coronéis, incontrastáveis em seus núcleos" ${ }^{266}$. Os coronéis, em sua maioria proprietários da sociedade rural, controlavam o poder político da localidade, respondendo pela indicação das autoridades públicas. O coronelismo representava a aliança daqueles com os governadores, e destes com o Presidente da República.

Nas fazendas, imperava a lei do coronel, criada por ele, executada por ele. Seus trabalhadores não eram cidadãos do Estado brasileiro, eram súditos dele. Quando o Estado se aproximava, ele o fazia dentro do acordo coronelista, pelo qual o coronel dava seu apoio político ao governador em troca da indicação de autoridades, como o delegado de polícia, o juiz, o coletor de impostos, o agente do correio, a professora primária. Graças ao controle desses cargos, o coronel podia premiar os aliados, controlar sua mão de obra e fugir dos impostos. Fruto dessa situação eram as figuras do "juiz nosso" e do "delegado nosso", expressões de uma justiça e de uma polícia postas a serviço do setor privado $^{267}$.

\footnotetext{
${ }^{265}$ Quando promulgada a Constituição de 1891, o Marechal Deodoro da Fonseca, então chefe do governo provisório, foi eleito pela Assembleia Constituinte à presidência da República. Com a renúncia de Deodoro, o Vice-Presidente, Floriano Peixoto, assumiu o governo figurando, juntamente com Rui Barbosa, como expressão suprema da República Velha. Prudente de Moraes foi, em seguida, o primeiro presidente civil eleito pelo voto direto, dando início à série de governos em que se alternaram no poder, principalmente, paulistas e mineiros ligados à grande propriedade produtora de café (cf. IGLÉSIAS, Francisco. op. cit., p. 160).

${ }^{266}$ IGLÉSIAS, Francisco. op. cit., p. 161; e BONAVIDES, Paulo; ANDRADE, Paes de. op. cit., p. 263.

${ }^{267}$ CARVALHO, José Murilo de. Cidadania no Brasil: um longo caminho, cit., p. 56. Com a continuidade dos vínculos oriundos no período imperial, os coronéis "são os verdadeiros chefes, colocando todas as autoridades sob sua dependência. O coronel domina tudo, é opressor, mas também amigo, espolia o trabalho dos dependentes, mas também dá alguma proteção, é agente protetor de todas as graças. Opressor, mas padrinho, compadre, autoridade reconhecida. Só é lei o que ele estabelece, seja a pessoa nomeada ou a instituição que vem de fora. É o real assegurador da ordem" (IGLÉSIAS, Francisco. op. cit., p. 161).
} 
As garantias institucionais da vitaliciedade e da irredutibilidade de vencimentos foram conferidas aos membros do Poder Judiciário pela Constituição de 1891. O cenário era, todavia, francamente antagônico à incorporação por seus destinatários do real sentido das prerrogativas, de modo a alijá-las da ideia de qualquer vantagem de cunho pessoal. Houve também, em mero plano formal, pequena referência à independência do Ministério Público, que foi considerado, por decreto do governo provisório, uma instituição necessária em toda organização democrática, com representação nas duas esferas da Justiça Federal. Além da figura do Procurador-Geral da República, previu-se a existência de um Procurador em cada Estado da Federação brasileira. A todos restou assinalada a tarefa de promover a ação pública e de zelar pela fiel execução das leis e demais atos normativos (decretos e regulamentos) ${ }^{268}$. Imediatamente após a vigência da Constituição Federal, foi regulamentado o exercício do Judiciário, com a criação do Supremo Tribunal Federal. Os magistrados ficaram responsáveis pela posse dos membros do Ministério Público. Ao presidente do Supremo Tribunal Federal cabia dar posse ao Procurador-Geral da República, aos juízes das seções estaduais, e a todos os agentes do Ministério Público para atuarem junto a eles. A hipótese chega a sugerir certo vínculo de subordinação aos juízes, os quais, no entanto, não escapavam da sujeição ao aparato geral de concentração de poder e das relações patrimonialistas que dominavam a organização política do Estado.

No mesmo passo caminhava o sistema de representação democrática, com o recurso a técnicas de manipulação do eleitor e do voto figurando, naturalmente, como condição para assegurar a hegemonia política de grupos específicos.

Firmaram-se duas convicções novas, mas gerais: $1^{\circ}$ ) os que não tiravam proveito pessoal nas eleições tanto quanto os que tiravam, e estes com maior razão, passaram a ver no voto um instrumento para alcançar e para manter o poder; $2^{\circ}$ ) a liberdade de escolha era imputada aos chefes locais ou regionais, ou por estes defendida coativamente, o que restringia, na prática, o princípio democrático de que todos os indivíduos possuem igual valor político ${ }^{269}$.

\footnotetext{
${ }^{268}$ A referência constou da exposição de motivos do Decreto 848, de 11.11.1890, baixado no curso do governo provisório pelo Marechal Deodoro da Fonseca. O mesmo regulamento instituiu a Justiça Federal. No mesmo sentido, houve alusão ao Ministério Público no Decreto 1.030, de 14.11.1890, mediante o qual o Presidente Campos Sales (1898) pretendeu posteriormente organizar o órgão judiciário do Distrito Federal (cf. SACCO, Ricardo Ferreira. op. cit., p. 67-68). A regulamentação da Justiça Federal constou do Decreto n. 1, de 26.2.1891. Esse ato normativo foi expedido pelo Marechal Deodoro da Fonseca - agora na condição de presidente do país -, dois dias depois da promulgação da Constituição republicana de 24.2.1891 (cf. SACCO, Ricardo Ferreira. op. cit., p.68-69).

${ }^{269}$ FERNANDES, Florestan. Existe uma crise na democracia no Brasil? In: Mudanças sociais no Brasil. 3. ed. Rio de Janeiro: Difel, 1979. p. 100. Nas palavras de Raymundo Faoro: “o coronel não manda porque tem riqueza, mas manda porque se lhe reconhece esse poder, num pacto não escrito. Ele recebe recebe ou conquista - uma fluida delegação, de origem central no Império, de fonte estadual na República,
} 
O comando dos coronéis desequilibrava a balança do pacto federativo, com os Estados mais fortes concentrando o poder de pressão sobre o governo central. O quadro político não era diverso daquele do Império. Porém, durante a monarquia, o unitarismo derivava da Constituição: "o poder central não era o braço do privilégio de dois grandes Estados, como os da aliança Minas-São Paulo, a aliança 'café com leite', que se sucedeu na República" ${ }^{, 270}$. Com efeito, o sistema político fundado no coronelismo destacou-se pela conhecida política dos governadores de São Paulo e Minas Gerais. Por meio de alianças com coronéis, os governadores travavam relações com o Presidente da República que, quase sempre, era proveniente de um dos dois Estados. A prática da chamada política dos governadores sacrificou, em demasia, o regime republicano e a organização federativa brasileira. Teve vida longa, configurando-se a partir da presidência de Campos Sales, em 1898. Pelo esquema engendrado, os governadores daqueles dois Estados apoiavam os seus presidentes da República, que se alternavam no poder central. Garantiam-lhes os votos dos representantes no Senado e na Câmara dos Deputados, enquanto os presidentes, em contrapartida, apoiavam os governadores, assegurando-lhes a sobrevivência mediante nomeações de funcionários federais para o exercício das atividades públicas nos $\operatorname{Estados}^{271}$.

Era indiscutível a hegemonia da oligarquia cafeeira, não obstante a crescente desvalorização do café no mercado internacional. A queda do preço do produto tornava necessária a proteção estatal, com iniciativas econômicas que geravam inflação e desvalorização da moeda. Todos acabam suportando as perdas pelos insucessos econômicos na exportação do produto $^{272}$. As grandes emissões de dinheiro feitas pelo governo para atender às necessidades geradas pela abolição da escravidão acentuaram o quadro de desigualdade em uma sociedade profundamente hierarquizada. O espírito de especulação, de enriquecimento pessoal a todo custo, conferia ao novo regime "uma marca incompatível com a virtude republicana”. Em semelhantes circunstâncias, nem mesmo a definição utilitarista do interesse público como a soma dos interesses individuais era

graças à qual sua autoridade ficará sobranceira ao vizinho, guloso de suas dragonas simbólicas, e das armas mais poderosas que o governador lhe confia. O vínculo que lhe outorga poderes públicos virá, essencialmente, do aliciamento e do preparo das eleições, notando-se que o coronel se avigora com o sistema de ampla eletividade dos cargos, por semântica e vazia que seja essa operação" (FAORO, Raymundo. op. cit., p. 700).

${ }^{270}$ BONAVIDES, Paulo; ANDRADE, Paes de. op. cit., p. 264.

${ }^{271}$ Cf. IGLÉSIAS, Francisco. op. cit., p. 162.

${ }^{272}$ A situação econômica provocou uma sucessão de rebeliões, com o recurso à decretação do estado de sítio, conforme se verificou durante o governo de Artur Bernardes (1922-1926) (cf. BONAVIDES, Paulo; ANDRADE, Paes de. op. cit., p. 262). 
pertinente. "Simplesmente não havia preocupação com o público. Predominava a mentalidade predatória, o espírito do capitalismo sem a ética protestante"273.

No entanto, o país não deixou de experimentar certo impulso industrial, gerando um crescente processo de urbanização, com manifestações culturais efervescentes nas principais metrópoles. A Semana de Arte Moderna, em São Paulo, representou o marco de um movimento que, além de revisar valores consagrados, "lançou diretrizes para o futuro de soberbas concretizações", buscando a valorização de todas as criações nacionais, do presente e do passado $^{274}$. Mas o proletariado urbano ainda não possuía uma organização satisfatória para a defesa de seus interesses. A questão trabalhista apenas emergiu de forma gradual na fase posterior da trajetória brasileira.

\subsection{Os períodos ditatoriais de Vargas}

Nessa etapa do processo político brasileiro, sucederam-se dois períodos ditatoriais, sob a chefia de Getúlio Vargas. O primeiro decorreu, entre outros fatores, do declínio do acordo oligárquico de São Paulo e Minas Gerais que dava suporte à composição do poder central $^{275}$. O movimento de 30 sacramentou o fim a Primeira República, dando início a uma nova fase de desenvolvimento político, econômico e social no país. Quase todas as lideranças políticas reuniam-se em torno da intenção de consagrar "o fim de uma república cujos vícios de representatividade eram explorados como a raiz de todos os problemas do país" ${ }^{276}$. Como resultado da articulação entre os Estados de Minas Gerais, Rio Grande do Sul e Paraíba, a Aliança Liberal surgiu como um movimento de contestação, que defendia a necessidade de reformas em prol do fim da distorção do regime de representação democrática que norteava o exercício do poder político no Estado brasileiro. O debate permeou-se de um cunho acentuadamente ideológico, polarizado entre a esquerda e a direta, sob o influxo da revolução comunista na Rússia e de organizações fascistas, como na Itália de Mussolini. Não houve, porém, grandes alterações na forma dominante dos

\footnotetext{
${ }^{273}$ CARVALHO, José Murilo de. A formação das almas: o imaginário da República no Brasil, cit., p. 29-30.

${ }^{274}$ IGLÉSIAS, Francisco. op. cit., p. 171-172.

${ }^{275} \mathrm{O}$ sistema foi fortemente abalado pela quebra da Bolsa de Nova York em 1929, provocando a queda dos preços do café. O cenário econômico fortaleceu facções oposicionistas formadas por operários e militares a partir da segunda década do século XX. O alvo dos reformistas eram as oligarquias e o federalismo, no intuito do fortalecimento e unidade do poder central.

${ }^{276}$ BONAVIDES, Paulo; ANDRADE, Paes de. op. cit., p. 269.
} 
quadros partidários e militantes, que continuaram "no ramerrão do poder e do uso de seus privilégios" 277 .

A pregação do tenentismo, já emergente na República Velha, também configurou um importante elemento na mudança da vida pública do país. Conhecedores da realidade social e contando com certo preparo técnico-profissional, os jovens oficiais avançaram para influir nas decisões políticas do Estado $^{278}$. Com um apego vigoroso ao nacionalismo político-econômico, aliado ao apoio a reivindicações sociais inerentes a programas da classe média, os tenentes participaram do movimento de 30, destacando-se no cenário político até o início de 1932.

Em 1930, pelas regras convencionais do jogo das forças políticas das duas oligarquias, o candidato natural à presidência da República era o mineiro Antônio Carlos. Mas, Washington Luís, então Presidente paulista, contrariando a tradição entre os dois Estados, impôs Júlio Prestes à sucessão presidencial. Minas Gerais levantou, em contrapartida, o nome de Getúlio Vargas, do Rio Grande do Sul, que sempre discordara do candidato do "oficialismo, em protesto frequente" ${ }^{279}$. Prestes venceu as eleições, mas o assassinato de João Pessoa, candidato à vice-presidência de Vargas, incitou os rebeldes da Aliança Liberal, dando lugar ao protesto armado, com o auxílio do Exército e da polícia de algumas unidades federativas. Após alguns dias de lutas, Washington Luís foi deposto, em 24 de outubro de 1930, sendo Vargas alçado à chefia de mais um Governo Provisório instalado no país.

A chamada Revolução de 30 representou um movimento de cunho liberal apenas superficialmente, atendo-se a mudanças paliativas, sem alcançar o âmago dos vícios que maculavam o sistema político brasileiro. O fracasso do movimento de 30 patenteou a fórmula meramente abstrata do liberalismo no Brasil, com Vargas, na qualidade do candidato contestador e chefe do movimento armado, estreando o projeto social de um governo ditatorial $^{280}$.

\footnotetext{
${ }^{277}$ IGLÉSIAS, Francisco. op. cit., p. 174. Se o papel da Igreja, na década de 20, foi de caráter conservador, na década seguinte avultaram organizações mais radicais, como se dá com a Ação Integralista Brasileira, criada em 1932. Formaram-se, em contrapartida, grupos de debates para a defesa da causa socialista ou comunista, com a criação do Partido Comunista no ano do centenário da Independência.

${ }^{278}$ IGLÉSIAS, Francisco. op. cit., p. 176.

${ }^{279}$ Id. Ibid., p. 168.

${ }^{280}$ BONAVIDES, Paulo; ANDRADE, Paes de. op. cit., p. 270-271. Cf. ainda IGLÉSIAS, Francisco. op. cit., p. 169. O Governo Provisório foi instituído pelo Decreto de 19.398, de 11.11.1930.
} 
A era Vargas inaugurou um diálogo que considerava as estruturas obreiras um novo fator de organização social. Logo nas primeiras semanas, foi criado o Ministério do Trabalho, sinalizando a futura trajetória governamental de apoio aos trabalhadores organizados em sindicatos, na maioria das ocasiões em funcionamento sob a dependência oficial $^{281}$. Assim, com o compromisso histórico entre a nação e o trabalhismo, Vargas procurou explorar os anseios do movimento de 30 em benefício de um projeto de ambições pessoais exacerbadas, em que "desfrutar o poder pelo poder se tornava mais importante do que manter algumas congruências liberais ou a adesão a fórmulas abstratas, de feitio ideológico, numa sociedade e num país carente de sistemas partidários com estruturas exequíveis" 282 .

O Governo Provisório concentrava em sua chefia o exercício das funções do Executivo e do Legislativo do Estado, com a dissolução do Congresso Nacional, das Assembleias Legislativas e de todas as Câmaras Municipais. Atos governamentais foram subtraídos ao controle do Judiciário, com a possibilidade de qualquer alteração constitucional por ato do chefe do Estado ou de seus delegados ${ }^{283}$.

Em 1923, o movimento constitucionalista de São Paulo objetivou reconduzir o processo revolucionário de 30 aos seus propósitos originários. Vargas sempre adiava a convocação da constituinte. São Paulo, então, levantou-se em armas, contando com o apoio de outros Estados. "Era natural que um centro de poder como aquele, de proeminência sempre acatada, tivesse queixas de sua marginalização", com o governo ocupado por autoridades provenientes de outros Estados ${ }^{284}$. De todo modo, a ação dos paulistas foi firmemente repelida pelo governo central, que se empenhou em atribuir ao movimento o caráter de secessão. Com efeito, o poder absoluto desde que se põe em marcha "não trepida em ter recurso a pretextos e acusações que precipitem no descrédito a causa dos que o combatem" 285 . Foi assim que aquela acusação feita aos paulistas conferiu à ditadura de Vargas ampla margem de apoio nacional. A opinião pública foi deliberadamente manipulada, por meio de questionamentos sobre o real objetivo do movimento, que foi apontado como dirigido à reprodução do sistema político oligárquico no poder central, enveredando também para o risco do comprometimento da integridade nacional.

\footnotetext{
${ }^{281}$ IGLÉSIAS, Francisco. op. cit., p. 177.

${ }^{282}$ BONAVIDES, Paulo; ANDRADE, Paes de. op. cit., p. 273.

${ }^{283}$ Id. Ibid., p. 283-284.

${ }^{284}$ IGLÉSIAS, Francisco. op. cit., p. 178.

${ }^{285}$ BONAVIDES, Paulo; ANDRADE, Paes de. op. cit., p. 277.
} 
Entretanto, a rebelião não deixou de representar um fator determinante para a aceleração da instalação da segunda constituinte republicana. $\mathrm{O}$ movimento constitucionalista de 1932 sinalizou a resistência contra a vocação de continuidade da ditadura. A Constituição não poderia mais tardar. Daí por que, em 15 de novembro de 1933, instalou-se a sessão solene da Assembleia Nacional Constituinte, com o colégio formado por 254 (duzentos e cinquenta e quatro) deputados, 40 (quarenta) dos quais foram eleitos pelos sindicatos legalmente reconhecidos e por associações de profissionais liberais e do funcionalismo público ${ }^{286}$. A representação classista no cenário político foi reminiscência viva das ideias do corporativismo em curso na Itália de Mussolini e na Península Ibérica, sob os regimes de Franco e Salazar ${ }^{287}$. A bancada era composta por parlamentares que não derivavam do sufrágio popular, carecendo de legitimidade no exercício dos mandatos.

Por sua vez, a partir da constituinte de 1823, enraizou-se no Brasil a tradição política de conferir ao "colégio da soberania o exercício simultâneo ou sucessivo da função legislativa ordinária, contrariando assim a boa doutrina constitucional, sempre inclinada para a exclusividade da tarefa constituinte (...),288 . Em 16 de julho de 1934 foi promulgada a Constituição Federal de 1934. Vargas foi eleito pelo próprio Congresso, "como se estabelecia para essa primeira eleição; as segundas seriam diretas como na República Velha e mesmo no Império, desde 1881",289.

Todos os avanços no campo dos direitos e garantias individuais da Constituição de 1891 foram preservados no diploma de 1934. O texto, porém, mostrou-se dúbio, ao abranger princípios antagônicos, que marcavam tendências políticas diversas. De um lado, um liberalismo herdeiro das formulações de 1891, que incorporou os direitos civis e as garantias das eleições livres, do sufrágio universal, da livre organização partidária e das autonomias dos poderes e unidades federativas do Estado. A organização do poder político não abdicou os fundamentos liberais da tradição nacional, com a manutenção da divisão tríplice e a vedação à delegação das atribuições dos órgãos respectivos. Por outro lado, a realidade política brasileira não deixou de perpetuar, com a tendência de concentração do poder político no órgão do executivo, caracterizada pelas faculdades de decretação do

\footnotetext{
${ }^{286}$ BONAVIDES, Paulo; ANDRADE, Paes de. op. cit., p. 285. As mulheres votaram pela primeira vez para a composição da Assembleia Constituinte.

${ }^{287}$ Id. Ibid., p. 329. Dos trabalhos da constituinte de 1933 não se afastaram constantes ameaças de intervenção do poder central.

${ }^{288}$ Id. Ibid., p. 297.

${ }^{289}$ IGLÉSIAS, Francisco. op. cit., p. 179.
} 
estado de sítio e pela ampliação de funções para regular os mais variados setores da vida social e a intervenção do Estado na ordem econômica ${ }^{290}$.

Uma legislação trabalhista assegurava a autonomia sindical, a jornada máxima de trabalho de oito horas, o salário mínimo, a previdência social e os dissídios coletivos. Sob a influência das teses sindicalistas e corporativistas, houve a programação do Estado social na Constituição de 1934, com disposições pertinentes à educação, à previdência e à cultura, além da vinculação do direito à propriedade ao atendimento do interesse social ou coletivo. A família foi colocada sob a tutela do Estado, mediante a proteção da maternidade e da infância, havendo ainda a previsão do direito à subsistência, com a atribuição ao poder público do dever de amparar as pessoas em estado de indigência.

Confirmado no poder, Vargas passou a governar sob nova ordem constitucional. E, nela, o Ministério Público ganhou assento, institucionalizando-se como órgão de cooperação nas atividades governamentais. Foi estabelecido que lei federal organizaria o Ministério Público da União, do Distrito Federal e dos Territórios, enquanto o estatuto do Ministério Público dos Estados caberia às leis locais. A escolha do Procurador-Geral da República ficou sob a responsabilidade do Presidente da República, com a aprovação do Senado, entre os cidadãos que preenchessem os mesmos requisitos exigidos para os Ministros do Supremo Tribunal Federal. A chefia do Ministério Público do Distrito Federal e dos Territórios também era de livre nomeação do Presidente da República, entre os juristas de notável saber jurídico e reputação ilibada, maiores de trinta anos, alistados e eleitores. Os seus vencimentos deveriam ser os mesmos dos que fossem satisfeitos aos Desembargadores $^{291}$. Importa ressaltar o estabelecimento da vedação, para os chefes do Ministério Público da União e dos Estados, do exercício de qualquer outra função pública, salvo o magistério e demais exceções constitucionais ${ }^{292}$.

Ao dispor sobre a autonomia legislativa dos Estados, a Constituição condicionou-a à obediência das garantias do Judiciário e do Ministério Público. A independência da

\footnotetext{
${ }^{290}$ BONAVIDES, Paulo; ANDRADE, Paes de. op. cit., p. 325-326. Foi mantido o mandato de quatro anos para o Presidente da República e abolida a figura do Vice-Presidente. A Constituição de 1934 também catalogou os crimes de responsabilidade do Presidente da República, que se configuravam, entre outras hipóteses, nos atentados contra o exercício dos direitos políticos, sociais ou individuais. Houve uma conquista de enorme importância no campo das garantias fundamentais, com a instituição do mandado de segurança para a defesa de direito certo e incontestável, ameaçado ou violado por ato manifestamente ilegal ou inconstitucional de qualquer autoridade.

${ }^{291}$ Cf. SACCO, Ricardo Ferreira. op. cit., p. 72-73. Cf. ainda MAZZILLI, Hugo Nigro. Regime jurídico do Ministério Público. 6. ed. São Paulo: Saraiva, 2007. p. 49; SALLES, Carlos Alberto. op. cit., p. 28-29; e LYRA, Roberto. op. cit., p. 19 e ss.

${ }^{292}$ Cf. SACCO, Ricardo Ferreira. op. cit., p. 74.
} 
instituição teria sido erigida a princípio fundamental, "integrada, praticamente, nas prerrogativas e garantias que a doutrina vinha reivindicando"293. A inamovibilidade recebeu reconhecimento pelos tribunais e, de forma expressa, o diploma constitucional dispôs sobre a nomeação dos membros do Ministério Público Federal por concurso e sobre a garantia de estabilidade no cargo, cuja perda somente poderia ocorrer por sentença judicial ou como desfecho de processo administrativo, assegurada ampla defesa ${ }^{294}$.

O Presidente Vargas chegou a contrariar o entendimento de alguns autores que viam o Ministério Público como uma verdadeira magistratura. Ele sustentou que se tratava de uma função exercida em nome do chefe do governo. Segundo o Presidente, o Ministério Público estava completamente afastado do órgão do judiciário, diante da incompatibilidade entre as duas funções. Foi enfatizada a natureza do Ministério Público como instituição cooperadora da atividade do governo; "e por governo se deve entender (...) o poder executivo". Nesse sentido, os representantes da instituição estatal seriam "expressão da confiança direta do governo"295. A condição de representante dos interesses governamentais chegou a respaldar o entendimento de que ao Ministério Público incumbiria a realização da política governamental de repressão à criminalidade. A polêmica, contudo, foi afastada em face da Constituição de 1934, pois, agindo na esfera da persecução penal, o Ministério Público não estaria atuando em nome do Executivo, "e sim em nome da sociedade, sob orientação da lei”. Mesmo com os chefes do Ministério Público figurando como "delegados da confiança do Presidente da República ou do Estado" ${ }^{296}$, a tese mostrou-se insustentável, uma vez que não havia a intervenção do Procurador-Geral na convicção do promotor de justiça. Já quando o Executivo surgia como cliente do procurador, não seria possível falar em Ministério Público com rigor técnico. De qualquer forma, o panorama político não era favorável à consagração do Ministério Público como órgão imune à intervenção da chefia do Estado.

\footnotetext{
${ }^{293}$ LYRA, Roberto. op. cit., p. 129.

${ }^{294}$ A Constituição de 1934 estabeleceu a Justiça Federal e a Justiça Estadual, além da Justiça Eleitoral como órgão do judiciário. Cuidou da organização do Ministério Público junto à Justiça Eleitoral e também à Justiça Militar (cf. SACCO, Ricardo Ferreira. op. cit., p. 72; e MAZZILLI, Hugo Nigro. op. cit., p. 49). Cf. o destaque de Roberto Lyra aos entendimentos jurisprudenciais reconhecendo a garantia de inamovibilidade para os membros do Ministério Público (LYRA, Roberto. op. cit., p. 35).

${ }^{295}$ LYRA, Roberto. op. cit., p. 25. São as razões do veto parcial do Presidente Vargas ao Decreto n. 5 , de 24. 1.1935, que, ao dispor sobre o provimento dos cargos do Ministério Público Eleitoral, tinha estabelecido a nomeação dos membros do Ministério Público entre nomes constantes de listas tríplices formadas pelos tribunais eleitorais.

${ }^{296}$ Id. Ibid., p. 129-130.
} 
Não obstante a vigência da Constituição de 1934, os conflitos não cessavam, girando em torno de dois movimentos antagônicos: a Aliança Nacional Libertadora, representando a corrente comunista liderada por Luís Carlos Prestes, e a Ação Integralista Brasileira, de cunho fascista, sob o comando de Plínio Salgado. A forte resistência ao comunismo viabilizou a realização do projeto de Vargas, com vistas ao término do regime constitucional. E o período ditatorial do Estado Novo (1937-1945) instaurou-se no Brasil, com o apoio do Exército.

De cunho altamente corporativista, o regime apresentou-se um arremedo de vários outros então verificados. O Brasil continuava "importando fórmulas estrangeiras, sem mais consulta ao nacional. Antes era o federalismo norte-americano, agora o fascismo italiano ou português. Ou polonês" ${ }^{297}$. A Carta de 1937 atribuía amplos poderes ao Presidente da República, entre os quais a expedição de decretos-leis, a suspensão dos direitos e garantias individuais, a decretação de estados de emergência, a possibilidade de indicação de um dos candidatos à presidência da República e também de dissolução da Câmara dos Deputados, caso não fossem aprovadas as medidas da chefia durante o estado de emergência ou de guerra. Durante o estado de emergência, a vigência de partes da Constituição podia ser suspensa pelo Presidente da República, que estava ainda autorizado a determinar detenções arbitrárias, violando frontalmente a liberdade de ir e $\operatorname{vir}^{298}$.

Aquela Carta foi a primeira Constituição brasileira que dispensou totalmente qualquer tipo de iniciativa voltada à participação popular no exercício do poder político, figurando na base do "surgimento de uma burocracia estatal com pretensões legislativas, de um Executivo centralizado e extremamente forte, e de um Legislativo pulverizado e convertido em Conselho Administrativo" ${ }^{, 299}$. Mas o diploma só foi aplicado casuisticamente; o parlamento nunca chegou a ser instalado, pois a posição era

\footnotetext{
${ }^{297}$ IGLÉSIAS, Francisco. op. cit., p. 179. A Carta de 1937 foi denominada a "polaca", em função da influência da Constituição da Polônia, mas é preciso frisar os reflexos do regime fascista de Mussolini vitorioso na Itália em 1922, e do nazismo implantado por Hitler na Alemanha. O golpe de 1937 recebeu do corporativismo português de Salazar a denominação de "Estado Novo" para a concepção do regime (cf. BONAVIDES, Paulo; ANDRADE, Paes de. op. cit., p. 346).

${ }^{298}$ Cf. BONAVIDES, Paulo; ANDRADE, Paes de. op. cit., p. 338. As prerrogativas do chefe do executivo durante o Estado Novo serviram de paradigma para o arcabouço constitucional disposto pelos militares durante o subsequente regime ditatorial, a partir de 1964.

${ }^{299}$ Id. Ibid., p. 339. A função legislativa do Estado estava flagrantemente comprometida pela existência do Conselho Federal, "com dez de seus membros escolhidos pelo Presidente da República e os restantes pelas Assembleias Legislativas dos Estados. Tratava-se de um corpo parlamentar correspondente a um Senado, sem voto popular (...)" (Id. Ibid., p. 351).
} 
francamente contrária à doutrina liberal e ao modelo de representação democrática dela decorrente ${ }^{300}$.

O Executivo personalizado apresentava-se "com o poder e mesmo com o dever de absorver as funções de proposição legislativa - uma resposta à desconfiança do funcionamento dos partidos e do Parlamento -, e com a obrigação política dos que, porque concentram recursos os mais variados, devem distribuí-los generosamente. Aí estão as bases de um contrato político não liberal, fundado em trocas generalizadas e na lógica da outorga, da política como doação (e não como direito)"301.

Como se vê, o princípio de harmonia e independência dos poderes estava apenas formalmente consagrado na Carta Constitucional, sem qualquer correspondência à realidade. Não havia um Judiciário independente que zelasse pela aplicação de inúmeros dispositivos constitucionais; o próprio texto constitucional deixava margem ao arbítrio, em função de ressalvas para limitações à vitaliciedade e a inamovibilidade dos magistrados, evidentemente por parte da chefia do Executivo. Assistiu-se à dissolução da Justiça Eleitoral e à proibição da existência de partidos políticos, que foram "considerados como fontes de perturbação da ordem. (...) A competência dos três órgãos do poder político ficou limitada ao centralismo do executivo e condicionada aos interesses do chefe supremo da administração - o Presidente da República”,302.

Houve, é claro, um enorme retrocesso imposto ao Ministério Público, cuja alusão no texto constitucional deu-se em alguns dispositivos esparsos que mencionavam vagamente a livre escolha e demissão do Procurador-Geral da República pela chefia do Executivo $^{303}$. A hipertrofia do Estado não permitia a criação de um aparato burocrático eficiente. Nesse plano, introduziram-se as codificações dos principais ramos do direito. A partir do advento da República, o Código Civil de 1917 já trouxera ao Ministério Público diversas de suas atribuições tradicionais, como a curadoria de fundações, a defesa de menores e a legitimidade para a propositura da ação de nulidade de casamento. No campo

\footnotetext{
${ }^{300}$ A Carta de 37 chegou a dispor sobre a utilização da técnica plebiscitária para a aprovação de iniciativas de alteração de seu texto, bem como para a sua aprovação. A hipótese não vingou de modo algum, não passando de manobra para facilitar o jogo de poder. Foi uma mera figura retórica, jamais saindo do texto para a realidade de sua aplicação (cf. BONAVIDES, Paulo; ANDRADE, Paes de. op. cit., p. 346-347).

${ }^{301}$ GOMES, Angela de Castro. Autoristarismo e corporativismo no Brasil: intelectuais e construção do mito Vargas. In: PINTO, António Costa; MARTINHO, Francisco Palomanes (Orgs.). O corporativismo em português: estado, política e sociedade no salazarismo e no varguismo. Rio de Janeiro: Civilização Brasileira, 2007. p. 99.

${ }^{302}$ BONAVIDES, Paulo; ANDRADE, Paes de. op. cit., p. 347-351.

${ }^{303}$ Cf. MAZZILLI, Hugo Nigro. op. cit., p. 49; e SALLES, Carlos Alberto. op. cit., p. 28-29.
} 
da persecução penal, impende ressaltar a vigência do Código Penal de 1940 e do Código de Processo Penal de 1941. Em 1939, o Código de Processo Civil estabeleceu a obrigatoriedade da intervenção do Ministério Público em aproximadamente 60 (sessenta) disposições, marcando definitivamente a sua presença no sistema processual civil. $\mathrm{O}$ Ministério Público acabou, assim, adquirindo um status jurídico ligado à prática judiciária muito antes de conquistar um estatuto legal, principalmente no plano constitucional, que lhe conferisse "organicidade e estabilidade institucional" 304.

Não é possível olvidar a edição da Consolidação das Leis do Trabalho em 1943. O apelo ao trabalhador era constante, "incentivando-o com uma legislação previdenciária. $\mathrm{O}$ salário mínimo, férias, aposentadoria, assistência médica, proteção do menor e da mulher”. Mas de uma total submissão dos dirigentes dos sindicatos ao governo emergia uma organização subjugadora do operário, “com pequenas concessões no sentido corporativista" 305 . Vargas introduziu no governo federal a tradição castilhista ou borgista do Rio Grande do Sul, de fundo positivista. Pregava-se a tese de cunho paternalista para a introdução do proletariado na sociedade, consoante sugeria o molde positivista ${ }^{306}$. A base do modelo era a organização do povo em associações profissionais, "que respondiam ao problema da incorporação de novos atores à esfera pública”. Essas associações “precisavam ser estimuladas e reconhecidas pelo Estado, para exercerem funções de canalização dos interesses de um determinado grupo social. A ideia foi transformá-las em instituições de direito público atuando por delegação estatal. Contrapondo-se à pluralidade e à liberdade sindicais, o modelo pressupunha o sindicato único, sujeito ao controle e tutela do Estado, ${ }^{307}$.

Se é certo que Vargas implantou uma modernização no aparelho do Estado (...), é também certo que atribuiu a essa burocracia poderes mais amplos do que o exigido. $\mathrm{Na}$ ausência do Legislativo, a sua função foi transferida à burocracia que a exercia na realidade. "Mais uma vez uma conjugação que nos é familiar: autoritarismo e tecnocracia” ${ }^{, 308}$. Firmou-se, nos órgãos públicos brasileiros, uma estrutura corporativista cujo fortalecimento exacerbado propiciou a sua multiplicação ao longo do tempo. E, sob o

\footnotetext{
${ }^{304}$ SALLES, Carlos Alberto. op. cit., p. 26-27.

${ }^{305}$ IGLÉSIAS, Francisco. op. cit., p. 180.

${ }^{306}$ Id. Ibid., p. 180-181.

${ }^{307}$ GOMES, Angela de Castro. op. cit., p. 93-94.

${ }^{308}$ BONAVIDES, Paulo; ANDRADE, Paes de. op. cit., p. 338.
} 
vetor do papel dirigente e intervencionista do Estado na economia, proliferaram também os órgãos especializados ${ }^{309}$.

A classe média foi um estrato social beneficiado com o crescimento econômico da era Vargas. Mediante a criação do DASP, Departamento Administrativo do Serviço Público, em 1938, o cidadão comum foi beneficiado por intermédio do procedimento dos concursos para a admissão nas carreiras do serviço público e o estabelecimento de normas de promoção. Tornou-se possível, "sem o favor de ninguém, conquistar posições reservadas só aos protegidos". É uma das notas da racionalidade administrativa governamental "digna de realce pela superioridade da burocracia sobre o antigo clientelismo (...)"310. Aquele departamento de formação e controle do serviço público, ao lançar as bases de um sistema de mérito, buscava a atenção da classe política para a importância dos operadores da máquina estatal, que se tornava cada vez mais complexa. “A espécie de nepotismo que prevaleceu nos primeiros trinta anos da República (...) encontrou no Dasp um incansável perseguidor", colocando termo à primeira fase do clientelismo brasileiro, "na versão que conseguira manter-se intangível durante aproximadamente 110 anos",311.

Caracterizou o Estado Novo uma grande ambiguidade. "Altamente repressivo, com um aparato policial nunca visto antes, ao mesmo tempo é modernizador e realiza apreciável trabalho em favor do bem público" ${ }^{312}$. O povo foi, porém, concebido como mero elemento de manobra política, não obstante o olhar aos segmentos menos favorecidos da sociedade. Mas não há falar em democracia, pois o governo usava o povo apenas em benefício próprio. A democracia depende de um Estado Constitucional de Direito, e uma Constituição não sobrevive se não se alimentar da alma popular, para que possa ajustar-se ao longo do tempo às transformações que o mundo impõe. A convulsão social gerada por pressões externas pode impor a necessidade de novos compromissos com a sociedade. Foi exatamente o que ocorreu ante a vitória dos aliados na Segunda Guerra Mundial ${ }^{313}$.

\footnotetext{
${ }^{309}$ IGLÉSIAS, Francisco. op. cit., p. 182. Vale registrar a criação do Conselho Nacional do Petróleo e o de Águas e Energia Elétrica. Por outro lado, a Companhia Siderúrgica Nacional foi criada em 1941 e, no ano seguinte, a do Vale do Rio Doce, para a exportação de minério de ferro.

${ }^{310}$ IGLÉSIAS, Francisco. op. cit., p. 182.

${ }^{311}$ SANTOS, Wanderley Guilherme dos. O ex-Leviatã brasileiro: do voto disperso ao clientelismo concentrado. Rio de Janeiro: Civilização Brasileira, 2006. p. 32.

${ }^{312}$ IGLÉSIAS, Francisco. op. cit., p. 182-183.

${ }^{313}$ BONAVIDES, Paulo; ANDRADE, Paes de. op. cit., p. 350.
} 


\subsection{O efêmero período de um governo democrático}

Às vésperas do término da Segunda Grande Guerra, Vargas baixou a Lei Constitucional, de 28 de fevereiro de 1945, que configurou um ato institucional introduzindo modificações na Carta de 37 para a abertura do sistema autocrático que estava em vigor. O objetivo era a extinção do processo indireto para as eleições da presidência da República e do parlamento para a preservação da Carta de 37 e, se possível, pela via constitucional, a sua manutenção no centro do poder $^{314}$. Contudo, a iniciativa acabou auxiliando o movimento oposicionista voltado à queda do Estado Novo, o que se concretizou em 29 de outubro de 1945, com a deposição do Presidente Vargas e a transferência do governo a José Linhares, Presidente do Supremo Tribunal Federal, de acordo com a tese de que o poder, nessas ocasiões, devia passar ao Judiciário ${ }^{315}$.

A partir de então, a estrutura partidária formou-se, de um lado, pelos partidos que apoiaram a situação precedente; o Partido Social Democrático (PSD) e o Partido Trabalhista Brasileiro (PTB); e de outro lado, a oposição ao Estado Novo compôs a União Democrática Nacional (UDN). Em 2 de dezembro de 1945, houve eleições para a Câmara dos Deputados e Senado Federal, que receberam poderes ilimitados para votar a Constituição do Brasil ${ }^{316}$. Tratavam-se das eleições para a Assembleia Nacional Constituinte e também para a presidência da República. Enquanto não fosse promulgado o ordenamento constitucional, caberia ao Presidente eleito o exercício de todos os poderes da legislatura ordinária, além do comando do órgão do executivo. Era a manutenção do país sob o regime dos decretos-leis até a vigência da Constituição Federal, de modo que a constituinte pudesse se dedicar ao exercício exclusivo da atividade respectiva ${ }^{317}$.

Revestindo-se de uma técnica jurídica mais aprimorada, a Constituição de 1946 representou a retomada da doutrina liberal, no intuito de conciliá-la com aspectos do

\footnotetext{
${ }^{314}$ BONAVIDES, Paulo; ANDRADE, Paes de. op. cit., p. 356.

${ }^{315}$ IGLÉSIAS, Francisco. op. cit., p. 183. O Estado continuava, no entanto, sob a égide da Carta de 37 , alterada pela Lei Constitucional de 28.2.1945, ou seja, por um processo de reforma constitucional sem nenhuma legitimidade. No exercício do Governo Provisório, sob a vigência da referida lei constitucional, José Linhares, entre outros atos normativos, expediu o que extinguia o Tribunal de Segurança Nacional, símbolo da justiça de exceção para a repressão das liberdades públicas e o que revogava a faculdade do Presidente da República de submeter à reapreciação do parlamento uma lei declarada inconstitucional (BONAVIDES, Paulo; ANDRADE, Paes de. op. cit., p. 357-358).

${ }^{316}$ Pela Lei Constitucional de 28.2.1945, o Conselho Federal da Carta de 37 converteu-se em Senado Federal, o qual, depois da promulgação do ordenamento constitucional, passaria a funcionar, juntamente com a Câmara dos Deputados, de conformidade com um sistema bicameral. Havia ainda o Partido Social Progressista (PSP) conduzido por Ademar de Barros e o Partido Comunista, por Luís Carlos Prestes.

${ }^{317}$ BONAVIDES, Paulo; ANDRADE, Paes de. op. cit., p. 358. Ao contrário do que ocorrera em 1934, ao complementar a tarefa de elaboração da Constituição Federal, a constituinte dissolveu-se para a composição do parlamento.
} 
Estado Social de Direito ${ }^{318}$. Foi uma tentativa de equilibrar as forças progressistas e conservadoras do cenário político do momento, revelando-se tal diretriz nos capítulos referentes à declaração de direitos e à ordem econômica. Assim, o constituinte subordinou a ordem econômica ao atendimento da justiça social, assegurando a todos o direito ao trabalho para uma existência digna, além de reproduzir os direitos da mesma natureza constantes do diploma de 1934. Foi proclamado o princípio de intervenção do Estado no domínio econômico, sob o limite de respeito aos direitos fundamentais, com a propriedade condicionada ao desenvolvimento do bem-estar social ${ }^{319}$.

A Constituição de 1946 expandiu o sistema da democracia representativa. O voto foi estendido a todos os cidadãos com mais de 18 anos, incluindo homens e mulheres. A proibição restringia-se ao voto do analfabeto e dos soldados das forças armadas ${ }^{320}$. Houve a criação do Tribunal Superior Eleitoral, sediado na Capital Federal, e dos Tribunais Regionais, nas capitais dos Estados. Competiam à Justiça Eleitoral as decisões relativas à organização dos partidos políticos, alistamento, votação e reconhecimento dos eleitos. E, em matéria de direitos políticos, o respeito aos direitos fundamentais também vinculou a formação dos partidos ${ }^{321}$. Nesse passo, foi extinta a representação profissional da Constituição de 1934, emergindo o povo como fonte exclusiva da soberania da nação. Reconduziu-se o Senado à composição do Legislativo, com a garantia da inafastabilidade do controle jurisdicional e a inserção da Justiça do Trabalho na esfera do Judiciário ${ }^{322}$.

Além do sistema representativo do clássico modelo liberal, o constituinte procurou restaurar o federalismo, que tinha sido aniquilado no curso do Estado Novo pelas

\footnotetext{
${ }^{318}$ Diversamente do que ocorreu nas constituintes de 1890-1891 e 1933-1934, a Constituição de 1946 não foi precedida de nenhum projeto do órgão do executivo. Sua fonte de inspiração foi a Constituição de 1934, que muitos constituintes desejaram ver restaurada no curso do período de transição entre a queda do Estado Novo e o restabelecimento da nova ordem constitucional (cf. BONAVIDES, Paulo; ANDRADE, Paes de. op. cit., p. 427).

${ }^{319}$ Foram reconhecidos os direitos à previdência social, à greve, à estabilidade na relação de emprego, à indenização em caso de demissão, além da liberdade sindical e de associação profissional. O direito à educação devia inspirar-se no ideal de liberdade e de solidariedade, com a obrigatoriedade do ensino primário e da gratuidade na rede oficial. $\mathrm{O}$ amparo à cultura foi afirmado como um dever do Estado, e ficou assegurado o direito de participação dos empregados nos lucros da empresa, na forma da lei. A natureza de normas programáticas foi atribuída à grande parte dos direitos humanos de cunho social. A compreensão dos princípios constitucionais cingia-se ao aspecto programático, remanescendo significativo o "fosso entre o formalismo da Constituição e concretude da realidade" (Id. Ibid., p. 420 e 425).

${ }^{320}$ A limitação era importante porque, em 1950, os analfabetos correspondiam a $57 \%$ (cinquenta e sete por cento) da população. Os principais prejudicados eram os trabalhadores rurais, uma vez que o analfabetismo concentrava-se na zona rural (cf. CARVALHO, José Murilo de. Cidadania no Brasil: um longo caminho, cit., p. 145).

${ }^{321}$ BONAVIDES, Paulo; ANDRADE, Paes de. op. cit., p. 420-421.

${ }^{322}$ Id. Ibid., p. 418, 424-425. Na Constituição de 1934, o Senado Federal não estava inserido no capítulo destinado ao Poder Legislativo, constando do capítulo sobre a "coordenação de poderes"; sua função era auxiliar a Câmara dos Deputados na elaboração de leis que versassem apenas sobre determinadas matérias.
} 
constantes intervenções nos governos estaduais. Por outro lado, tal como no plano federal, a autonomia dos Estados também estava enfraquecida em escala horizontal, ante a hegemonia incontrastável do órgão do executivo qualificando a via autoritária da organização. Pretendeu-se, assim, consolidar a ideia de distribuição do poder político, de maneira a restituir ao Legislativo e ao Judiciário as prerrogativas de independência. Mas o princípio reduziu-se a uma rígida separação de funções, incompatível com proposições mais atualizadas de controle recíproco.

É exatamente esse o contexto em que o Ministério Público foi introduzido na Constituição de 1946. A instituição foi elevada a um título próprio, sem uma vinculação formal a nenhum outro órgão do Estado $^{323}$. Ganhou o reconhecimento das garantias da inamovibilidade e estabilidade, acolhendo-se a nomeação do Procurador-Geral da República pelo Presidente, entre as pessoas que preenchessem os mesmos requisitos para os Ministros do Supremo Tribunal Federal, mediante a aprovação do Senado. Foram também fixadas regras de admissão nas carreiras por concurso público, com o estabelecimento do princípio de promoção de entrância para entrância. E assim figurava o Ministério Público com o expresso reconhecimento de que se tratava de representante da União $^{324}$.

De qualquer forma, não havia, mais uma vez, consonância do texto constitucional com a realidade do país. Os efeitos produzidos pelos governos sucessivos de Vargas faziam-se presentes, e as lideranças políticas, em vez de trilharem a via das decisões democráticas, preferiram a do populismo, com a manutenção de uma consciência autoritária e paternalista nos intercâmbios políticos respaldando a estrutura partidária do Estado $^{325}$. O mito era o de que as conquistas almejadas pelo povo representavam apenas uma concessão do poder central. O corporativismo alastrou-se por todos os níveis da sociedade, acabando por penetrar as camadas da burocracia, com suas decisões assumindo progressivamente um caráter espesso e incontrolável. O Executivo mantinha os ares imperiais, obstruindo a ação dos órgãos do legislativo e do judiciário ${ }^{326}$.

A possibilidade do controle judicial sobre o processo eleitoral reduziu as fraudes, mas não as eliminou. A fraude era facilitada pela inexistência de cédula oficial para votar.

\footnotetext{
${ }^{323}$ Cf. MAZZILLI, Hugo Nigro. op. cit., p. 49-50; e SALLES, Carlos Alberto. op. cit., p. 29. A organização do Ministério Público estava inserida nos arts. 125 a 128 da CF de 1946.

${ }^{324}$ Era essa a previsão do art. 126 da CF de 1946.

${ }^{325}$ Registre-se a manutenção da legislação sindical do Estado Novo, de inspiração fascista (cf. IGLÉSIAS, Francisco. op. cit., p. 184).

${ }^{326}$ BONAVIDES, Paulo; ANDRADE, Paes de. op. cit., p. 415-416.
} 
Os próprios candidatos distribuíam as cédulas, o que permitia sua troca e anulação "por cabos eleitorais. Coronéis conservavam várias práticas antigas de compra de votos e coerção dos eleitores" ${ }^{, 327}$. Os cabos eleitorais conduziam os eleitores para a sede do município e os mantinham em "currais", sob constante vigilância até o momento do voto. Os cabos também entregavam aos eleitores envelopes fechados com as cédulas dos candidatos. O pagamento pelos votos era realizado em dinheiro, bens ou favores ${ }^{328}$.

Nas regiões urbanizadas, o eleitor não era tão vulnerável a formas de aliciamento e coerção, não obstante estivesse sujeito a apelos populistas que não deixavam de exigir certo convencimento e relações de reciprocidade, como ocorrera com Vargas, por força da edição da legislação trabalhista. Em meio a todos esses fatores, a partir de 1945, a participação popular no processo político cresceu de forma significativa, considerando a organização dos partidos, sindicatos, ligas camponesas e outras associações ${ }^{329}$.

Nas eleições para a Assembleia Nacional Constituinte, a escolha do Presidente da República recaiu no General Eurico Gaspar Dutra, Ex-Ministro da Guerra do Estado Novo, cujo exercício do mandato compreendeu o período de 31 de janeiro de 1946 a 31 de janeiro de 1951. O seu governo teve caráter conciliador, revelando-se convencional nas grandes linhas. No campo da economia, a poupança gerada em função da Segunda Grande Guerra esvaiu-se rapidamente, sem que houvesse nenhum proveito para os cofres públicos ${ }^{330}$.

A campanha sucessória para a presidência da República foi conduzida com tranquilidade, e Vargas foi eleito pelo PTB, voltando novamente ao poder — dessa vez, pelo voto direto. Porém, foi rapidamente acusado por seus opositores de fomentar atividades populistas, por meio das organizações de trabalhadores tuteladas pelo Ministério do Trabalho. Engendrou-se, então, outro movimento para a sua deposição, com significativa participação da UDN, do empresariado e de representantes do capital financeiro. A crise exigia a renúncia à presidência da República, culminando, no entanto, com o suicídio de Vargas em 1954, e a assunção do Vice-Presidente Café Filho à chefia do Executivo.

Nas eleições subsequentes, ao derrotar Juarez Távora, candidato da UDN, sagrou-se vencedor o governador de Minas Gerais Juscelino Kubitschek, lançado pelo PSD. O seu

\footnotetext{
${ }^{327}$ Cf. CARVALHO, José Murilo de. Cidadania no Brasil: um longo caminho, cit., 146-147.

${ }^{328}$ Id. Ibid., p. 147.

${ }^{329}$ Id. Ibid., p. 146.

${ }^{330}$ IGLÉSIAS, Francisco. Momentos democráticos na trajetória brasileira, cit., p. 183.
} 
governo foi um período em que a democracia preponderou na história brasileira ${ }^{331}$. O Presidente da República dispunha de habilidade política para a conciliação de interesses conflitantes, além de ter conquistado o apoio popular. Sob o emblema desenvolvimentista, Kubitschek trouxe para a República um plano de metas, com vistas ao crescimento econômico, valendo-se da expansão industrial, "não só de bens de consumo, como de bens de produção" 332 . O planejamento apresentou resultados satisfatórios em setores importantes, como energia, transportes e indústrias, atingindo o ápice com a criação de Brasília, inaugurada em 21 de abril de 1960. Malgrado o grande impacto, a iniciativa gerou desequilíbrio nas contas públicas, com inflação e endividamento ${ }^{333}$.

O candidato oficial à sucessão de Kubitschek era o General Lott. O apoio da UDN recaiu no candidato da oposição, o Ex-Governador de São Paulo, Jânio Quadros, que acabou vencendo a disputa eleitoral. O Vice-Presidente foi João Goulart, da chapa oficial que disputara a reeleição. Em razão de uma legislação eleitoral defeituosa, "o "país ficou na situação de ter um presidente e um vice-presidente eleitos por forças políticas antagônicas" 334 . Kubitschek, no entanto, não interferiu no processo de escolha, passando a faixa presidencial ao seu sucessor em 25 de janeiro de $1961^{335}$.

O governo de Jânio durou apenas alguns meses, representando uma enorme decepção na vida pública brasileira. Jânio fez política contraditória, procedendo de modo convencional no plano interno, de acordo com a expectativa do Fundo Monetário

\footnotetext{
${ }^{331}$ A vitória de Kubitschek chegou a ser contestada, na tentativa de impedir a posse. Café Filho estava em licença para tratamento de saúde e o exercício da presidência estava a cargo de Carlos Luz, presidente da Câmara dos Deputados. O golpe foi evitado por iniciativa do General Henrique Lott, então Ministro da Guerra, com a presidência da República passando a Nereu Ramos, presidente do Senado, que se firmou no poder, impedindo a reassunção de Café Filho, para a posse do presidente eleito (cf. IGLÉSIAS, Francisco. op. cit., p. 188).

${ }^{332}$ IGLÉSIAS, Francisco. op. cit., p. 190. Kubitschek, em 1959, criou a SUDENE (Superintendência do Desenvolvimento do Nordeste), sob a direção inicial de Celso Furtado. A meta de corrigir desequilíbrios regionais definiu a matriz para a intervenção estatal. Para fins de diminuir as disparidades regionais e de obter maior racionalidade na alocação de recursos da economia, foram criadas a SUDENE e, posteriormente, todas as superintendências regionais. "O futuro mostraria que este segmento do Estado sucumbiria à política de distribuição de espólios, perdendo racionalidade econômica e adquirindo valor no mercado de políticas distributivas, isto é, aquelas que clássica e criticamente são denominadas políticas clientelísticas" (SANTOS, Wanderley Guilherme dos. op. cit., p. 43-44).

${ }^{333}$ IGLÉSIAS, Francisco. op. cit., p. 191. O governo de Kubitschek investiu consideravelmente no setor siderúrgico e hidroelétrico, revelando, ainda que timidamente, uma crescente ação supervisora, administrativa e regulatória do Estado, de larga abrangência (cf. SANTOS, Wanderley Guilherme dos. op. cit., p. 34-37).

${ }^{334}$ CARVALHO, José Murilo de. Cidadania no Brasil: um longo caminho, cit., p. 134.

${ }^{335}$ Kubitschek não apoiou Lott na campanha, e o PTB e o PSD também não tiveram grande empenho na disputa eleitoral. A UDN, por sua vez, não lançou candidato próprio, preferindo aderir a Jânio, que se elegeu por pequenos partidos - o Partido Democrata Cristão, o Partido Socialista, o Partido Trabalhista Nacional, o Partidos Libertador e uma ala dissidente do Partido Republicano. Muitas figuras da linha conservadora preferiram Jânio, sem muita convicção (cf. IGLÉSIAS, Francisco. op. cit., p. 194-195).
} 
Internacional, enquanto adotou uma política externa aberta, de cunho revisionista, voltada a uma aproximação com os Estados socialistas. De resto, comportou-se como um político municipal, sem nenhum planejamento econômico ou administrativo. Limitava-se a perseguir o funcionalismo público, preconizando a necessidade de contenção de despesas, além de entregar-se à devassa da gestão do governo anterior, "com comissões de inquérito quase sempre presidida por militares" ${ }^{336}$.

Em 25 de agosto de 1961, Jânio encaminhou à Câmara dos Deputados o seu pedido de renúncia ${ }^{337}$. A situação era complexa, pois o Vice-Presidente, João Goulart, não tinha a simpatia dos militares e de outros segmentos mais conservadores. Acirrou-se o embate entre organizações e movimentos de conteúdo ideológicos opostos ${ }^{338}$. Já em ascensão no curso do Estado Novo, o sentimento nacionalista expandiu-se, respaldando a defesa de doutrinas de esquerda. Mas o corporativismo que envolvera a formação de entidades sindicais não deu ensejo ao crescimento de movimentos sociais independentes. As diversas facções agruparam-se em dois grandes blocos, quase anulando a estrutura partidária. Havia, de um lado, a Frente Parlamentar Nacionalista; e, de outro, a Ação Democrática Parlamentar; a primeira, com o predomínio da esquerda, defendia a modernização do país e a intensa participação popular, enquanto a Ação Democrática Parlamentar pregava a preservação da ordem, da livre iniciativa e da colaboração do capital estrangeiro ${ }^{339}$.

Os Ministros militares realmente declararam não aceitar a posse do VicePresidente, instalando-se uma crise política no país ${ }^{340}$. Goulart estava em visita à China, mas, quando retornou ao país, partes ponderáveis dos partidos tradicionais, novos partidos, sindicatos e associações de todo tipo eram favoráveis ao encaminhamento pela legalidade. A opção foi o recurso à antiga fórmula política, com a instituição do regime

\footnotetext{
${ }^{336}$ IGLÉSIAS, Francisco. op. cit., p. 194-195.

${ }^{337}$ As razões da renúncia nunca foram esclarecidas devidamente. Cogitou-se de uma estratégia de Jânio Quadros para conseguir poderes especiais do Congresso Nacional para governar discricionariamente. A estratégia contaria com o veto dos militares ao nome de Goulart, fazendo com que a renúncia não fosse aceita e o presidente obtivesse do Congresso os poderes extraordinários que desejava (cf. CARVALHO, José Murilo de. Cidadania no Brasil: um longo caminho, cit., p. 135).

${ }^{338}$ Id. Ibid., p. 136-137.

${ }^{339}$ IGLÉSIAS, Francisco. op. cit., p. 194-198. Juntamente com a Ação Democrática Parlamentar, que reunia deputados conservadores de várias partidos, havia o Instituto de Pesquisas e Estudos Sociais (IPES), financiado por empresários nacionais e estrangeiros; o Instituto Brasileiro de Ação Democrática, que apoiava financeiramente políticos da oposição e organizações sindicais e estudantis contrárias ao governo; associações de proprietários rurais; parte da hierarquia da Igreja. Com a Frente Parlamentar Nacionalista estavam as organizações nacionais unificadas de trabalhadores, não permitidas pela legislação trabalhista, como o Comando Geral dos Trabalhadores (CGT) e o Pacto de Unidade e Ação (PUA), além da União Nacional dos Estudantes (UNE) (cf. CARVALHO, José Murilo de. Cidadania no Brasil: um longo caminho, cit., p. 136-137).

${ }^{340}$ Id. Ibid., p. 135.
} 
parlamentarista e o governo recaindo nas mãos do gabinete aprovado pelo Congresso Nacional. Análogo ao método que se adotou no Brasil Imperial, o sistema teve em mira acalmar os ânimos, sem o apoio real de quem cabia efetivamente realizá-lo ${ }^{341}$.

Em 6 de janeiro de 1963, a instituição do regime parlamentarista de governo foi submetida à consulta popular, mediante plebiscito aprovado pelo Congresso Nacional. $\mathrm{O}$ parlamentarismo foi rejeitado por esmagadora maioria. O sistema nada dizia ao povo; sequer os ministros que chefiaram o gabinete, depois da renúncia do Presidente Jânio Quadros, chegaram a aprová-lo. Goulart adquiria, portanto, os poderes governamentais do presidencialismo, com a revogação, em 23 de janeiro de 1963, da emenda à Constituição que instituíra o parlamentarismo ${ }^{342}$.

Nesse período, o agravamento da crise financeira abalou significativamente a imagem do Presidente da República. Muitas greves se sucederam, num clima de desconfiança generalizada. Incapaz de determinar um curso próprio de ação, "o presidente achava-se imprensado entre os conspiradores de direita, que o queriam derrubar, e os setores radicais da esquerda, que o empurravam em direção de medidas cada vez mais ousadas",343. De todo modo, o clima era de intensa mobilização popular, incluindo toda sociedade, com o povo participando do processo político. Por um curto espaço de tempo, a atividade pública deixava de ser privilégio do governo ou dos partidos políticos para ser exercida por associações de diferentes segmentos sociais. "Todos falam, dispõem, dão testemunho, reivindicam". Faltava, porém, o suporte institucional para uma democracia de $\operatorname{massas}^{344}$.

O golpe de Estado amadurecera em maior velocidade, com generais e patentes menores, governadores e parlamentares conspirando para executá-lo. A gota de água foi a revolução dos marinheiros, no dia 26 de março de 1964, em uma comemoração do segundo

\footnotetext{
${ }^{341}$ IGLÉSIAS, Francisco. op. cit., p. 197-198; e CARVALHO, José Murilo de. Cidadania no Brasil: um longo caminho, cit., p. 135-136. Até o golpe de 64 sucederam-se três gabinetes, no período de dezembro de 1961 a janeiro de 1963; o primeiro coube a Tancredo Neves do PSD.

${ }^{342}$ IGLÉSIAS, Francisco. op. cit., p. 199.

${ }^{343}$ CARVALHO, José Murilo de. Cidadania no Brasil: um longo caminho, cit., p. 141.

${ }^{344}$ IGLÉSIAS, Francisco. op. cit., p. 201. Pesquisas realizadas, em 1964, pelo Instituto Brasileiro de Opinião Pública e Estatística (IBOPE), em oito capitais do país, revelaram que 64\% (sessenta e quatro por cento) da população tinha preferência partidária, aderindo ao sistema de representação democrática. O PTB saía à frente com $29 \%$ (vinte e nove por cento) do eleitorado, seguido da UDN com 14\% (quatorze por cento) e do PSD com 7\% (sete por cento). Outra revelação diz respeito à orientação ideológica dos eleitores às vésperas do golpe. O candidato preferido para as eleições de 1965, que não se realizaram, era Kubitschek; e, confirmando a tendência moderada do eleitorado, 45\% (quarenta e cinco por cento) dos eleitores manifestaram preferência pelo centro como a linha política mais indicada para o governo (cf. CARVALHO, José Murilo de. Cidadania no Brasil: um longo caminho, cit., p. 150).
} 
aniversário da Associação dos Marinheiros e Fuzileiros Navais. O grupo da Marinha encarregado de deter os rebeldes acabou aderindo ao movimento, com a liberação dos oficiais detidos por determinação do Ministro da Marinha. Rompera-se o princípio da hierarquia nas fileiras militares, antecipando a intervenção. No dia 31 de março, as tropas de Minas Gerais “desceram sobre o Rio de Janeiro", contando com o apoio de São Paulo e também do Rio de Janeiro. Goulart desaconselhou qualquer resistência, seguindo para o Rio Grande do Sul e "de lá para o exílio". Não houve nenhuma guerra civil, para a satisfação dos anseios políticos dos “conservadores ou reacionários, dos grandes empresários nacionais e estrangeiros, de parte da Igreja; de todos, enfim, que sempre viveram assustados "com o fantasma do comunismo", 345 . Com o golpe de 31 de março de 1964, a efêmera democracia brasileira foi drasticamente interrompida, mediante nova intervenção militar responsável pela consolidação de mais de vinte anos do último regime ditatorial no país. Começava a era dos militares, com indicações pouco alentadoras. Mas "tudo seria bem pior do que o entrevisto em abril de 1964",346.

\subsection{O autoritarismo pós-64}

O militar sempre teve um papel de relevo na trajetória nacional ${ }^{347}$. O seu ápice foi em 1964, "quando o conservadorismo apela para o soldado, instigando-o à participação", sob o impulso da defesa da ordem estabelecida. O setor tradicional mais conservador "teve a organização que faltou ao governo",348. O Presidente da República foi deposto e instalouse no poder uma direção eminentemente militar, que procurou legitimar-se com atos institucionais, intitulando-se revolucionária. A UDN, que surgira contra o Estado Novo, acabou se comprometendo com o outro regime de arbítrio, mais cruel e obscurantista do que o primeiro; o PSD e o PTB uniram-se aos outros partidos, entre os quais se incluíam adeptos e inimigos da nova ordem. E, de um modo geral, inicialmente a sociedade aprovou o golpe $\mathrm{g}^{349}$.

\footnotetext{
${ }^{345}$ IGLÉSIAS, Francisco. op. cit., p. 202-203.

${ }^{346}$ Id. Ibid., p. 203.

${ }^{347}$ Depois da Guerra do Paraguai, vale recordar que a figura do soldado passou a ocupar o cenário nacional. No ano do centenário da Independência surgiu, no Exército, um segmento mais politizado identificado na figura do tenente que participou do movimento de 30, do golpe de 37 que instituiu o Estado Novo, de sua deposição de 1945, fazendo-se presente nos sucessivos governos. Foi crescente a intervenção do militar na vida pública, com um papel sempre desestabilizador, "por sua interferência com o peso das armas e sentido da casta". (Id. Ibid., p. 205).

${ }^{348}$ Id., loc. cit.

${ }^{349}$ Id. Ibid., p. 205-206.
} 
O Ato Institucional n. 1, de 9 de abril de 1964, estabeleceu a necessidade de eleição de um novo Presidente da República pelo Congresso Nacional, e Castelo Branco assumiu o poder. Foi o primeiro da série de generais presidentes. O parlamento foi mantido, mas muitos parlamentares tiveram seus mandatos cassados. Foram também afastados de suas funções dezenas de oficiais das Forças Armadas, além de membros do Judiciário. Durante o longo período de ditadura militar, o Judiciário mostrou-se inoperante, com aposentadorias e cassações dos direitos políticos de alguns Ministros do Supremo Tribunal Federal. A maioria daqueles que permaneceu em atividade corroborou o arbítrio. Era o governo dos atos institucionais, todos sumários, sem motivação e estranhos a qualquer possibilidade de controle judicial; a obediência era imposta independentemente de respaldo constitucional. O Legislativo tornou-se um "arremedo de representação popular, um subalterno cumpridor de ordens emanadas do sistema, à exceção de poucas figuras que se mantiveram na oposição ${ }^{350}$.

Por intermédio do Ato Institucional n. 2, de 1965, responsável pela abolição das eleições diretas para a Presidência da República e pela implantação do sistema de dois partidos políticos, houve também a reforma do Judiciário, com o aumento do número de juízes nos tribunais superiores, a fim de que os partidários do governo pudessem ser indicados ao preenchimento dos cargos. Foi recriada a Justiça Federal de primeiro grau para o julgamento das causas de interesse da União, com a alteração da competência dos órgãos do Judiciário dos Estados. E o provimento dos novos cargos de juiz federal cabia apenas ao Presidente da República ${ }^{351}$.

Os partidos apenas homologavam a vontade do presidente ou do grupo militar composto por sujeitos indeterminados. "Raramente era sabido quem de fato mandava", com uma proliferação de atos normativos resultantes de "vontades ou arbítrios episódicos"352. A multiplicação de órgãos públicos sempre foi "útil para a constante transferência do poder, pois, quanto mais tempo um regime totalitário permanece no poder, maior é a possibilidade de empregos que dependem exclusivamente do movimento. A regra é a de que "quanto mais visível é uma agência governamental, menos poder ela

\footnotetext{
${ }^{350} \mathrm{O}$ Congresso costumava admitir a aprovação de projetos de lei por decurso de prazo (cf. IGLÉSIAS, Francisco. op. cit., p. 206).

${ }^{351}$ ARANTES, Rogério Bastos. Ministério Público e política no Brasil. São Paulo: EDUC: Ed. Sumaré; Fapesp, 2002. p. 40.

${ }^{352}$ IGLÉSIAS, Francisco. op. cit., p. 207.
} 
detém; e, quanto menos se sabe da existência de uma instituição, mais poderosa ela é. (...) $\mathrm{O}$ verdadeiro poder começa onde o segredo começa"353.

O presidente Castelo Branco cogitou de organizar a nação para entregá-la a um governo civil. Não foi possível, uma vez que, para a maior parte das forças armadas, o trabalho de saneamento da pátria não estava concluído ${ }^{354}$. O segundo Presidente, Costa e Silva, governou de março de 1967 a agosto de 1969. No período de abril de 1964 a dezembro de 1966, foi registrada a edição de quatro atos institucionais e quinze emendas constitucionais, entre as quais, as que determinaram reformas no Legislativo e no Judiciário, notadamente para o fortalecimento do Executivo do Estado. Havia a chamada cláusula excludente, que afastava do exame do Judiciário determinados atos do governo revolucionário.

A necessidade de institucionalização do golpe acarretou a manutenção do Congresso e a edição de uma nova Constituição ${ }^{355}$. Por meio do Ato Institucional n. 4 , de 1966, o Congresso Nacional, que tinha sido fechado, fora convocado para aprovar uma nova Constituição ao país, como uma das últimas realizações de Castelo Branco na presidência da República. O Legislativo acumulou, então, as atribuições de legislador ordinário e de redator da Constituição. Era a utilização de um inexistente Poder Constituinte Congressual, aproveitando-se da mutilação do Legislativo provocada pelas cassações de parlamentares ${ }^{356}$.

Em 1967, outra Constituição foi votada pelo Congresso Nacional. É evidente que a Constituição tornou-se ineficaz por força dos atos institucionais. Ainda assim, a previsão dos direitos e garantias individuais servia para a aparência de um ambiente democrático. É o governo com a plena supremacia do Executivo, com a limitação da autonomia dos Estados, a modificação do sistema tributário e a criação de novos instrumentos de legislatura, como os decretos-leis e as leis delegadas. Foi instituída a eleição indireta para o Presidente e o Vice-Presidente da República, estendendo-se a competência legislativa para o chefe do Executivo, com a implantação de normas sobre a inegibilidade, a suspensão de direitos políticos e sobre restrições à liberdade individual ${ }^{357}$.

\footnotetext{
${ }^{353}$ ARENDT, Hannah. Origens do totalitarismo, cit., p. 453.

${ }^{354}$ IGLÉSIAS, Francisco. op. cit., p. 207.

${ }^{354}$ Id. Ibid., p. 207.

${ }^{355}$ BONAVIDES, Paulo; ANDRADE, Paes de. op. cit., p. 433.

${ }^{356}$ Id. Ibid., p. 436.

${ }^{357}$ Id. Ibid., p. 446.
} 
Muito embora tenha consagrado formalmente um sistema de direitos e garantias individuais, na prática, a Carta contrapunha-se à respectiva eficácia, reservando para a lei ordinária a disposição do conteúdo referente ao exercício daqueles direitos. Além disso, foi implantada a figura do "abuso de direitos individuais", com a função do Procurador-Geral de República de promover a representação perante o Supremo Tribunal Federal contra aqueles que viessem exercer de forma abusiva alguns dos direitos fundamentais de liberdade, como o direito à livre manifestação do pensamento ou o direito de reunião ou associação $^{358}$. A Emenda Constitucional n. 16, de 1965, introduziu a representação contra a inconstitucionalidade de leis ou atos normativos, conferindo, exclusivamente, ao Procurador-Geral da República a atribuição para a sua propositura perante o Supremo Tribunal Federal. A ideia era o controle da administração pública dos Estados, com a transformação do Procurador-Geral em um fiscal da atuação das unidades federativas estaduais para salvaguardar os interesses da União ${ }^{359}$

A situação realmente agravou-se depois da edição do Ato Institucional n. 5, de 13 de dezembro de 1968 (AI-5), com o fechamento do Congresso Nacional e a supressão radical dos direitos civis. Costa e Silva assinou o AI-5, contribuindo para potencializar o estado de exceção. $\mathrm{O}$ ato representou um sério agravamento do regime ditatorial. No período de cinco anos, as cassações alcançaram aproximadamente 5.000 (cinco) mil pessoas. A medida estabeleceu a faculdade de intervenção do governo central em estados e municípios, "detalhando as consequências imputáveis aos que tivessem seus direitos políticos cassados, suspendendo a garantia de habeas corpus e concedendo total arbítrio ao Presidente da República no que se refere à decretação do estado de sítio"360.

Depois do AI-5, veio a outorga da Constituição de 1969, que, na verdade, consistiu numa emenda constitucional, acentuando a preocupação do governo de camuflar um governo democrático perante o cenário internacional. É o que se infere dos preceitos que garantiam o direito de greve ou pluripartidarismo, ou mesmo do capítulo referente aos direitos e garantias individuais ${ }^{361}$. O movimento de 64 procurava encontrar num texto constitucional uma forma de institucionalização do exercício do poder político.

\footnotetext{
${ }^{358}$ ARANTES, Rogério Bastos. op. cit., p. 41.

${ }^{359}$ Id. Ibid., p. 41.

${ }^{360}$ BONAVIDES, Paulo; ANDRADE, Paes de. op. cit., p. 434. O AI-5 foi editado quando Costa e Silva estava afastado por doença e não foi substituído pelo Vice-Presidente, Pedro Aleixo, que discordara da medida. Assim, assumiu o poder uma Junta Militar constituída pelos Ministros das pastas militares que subscreveram o AI-5.

${ }^{361}$ Id. Ibid., p. 435.
} 
O Ministério Público representava assim "o braço institucional do regime autoritário. Como órgão vinculado e dependente do Executivo, ele desempenhou um importante papel para a institucionalização do regime militar, considerando a estratégia dos governantes de forjar um Estado de Direito ${ }^{362}$. Instados por pressões internas e da comunidade internacional, os militares brasileiros realizaram uma série de reformas institucionais, de modo a garantir um domínio estável do poder político. A preocupação do governo com a legalidade formal acabou realçando o papel do Ministério Público como o órgão do executivo encarregado “de impor o respeito à lei e à Constituição"363.

Atuando nesse contexto como agente do Estado, o Ministério Público, que na Carta de 1967 integrava o Judiciário, passou a compor a organização do Executivo quando da Emenda n. 1 de 1969. E a escolha do Procurador-Geral da República competia, evidentemente, ao Presidente da República, com a exclusão de qualquer participação do Senado Federal ${ }^{364}$. Entre outras funções, foi atribuída ao Procurador-Geral a incumbência de requerer a suspensão do exercício do mandato parlamentar até a decisão final do Supremo Tribunal Federal nos processo relativos aos crimes contra a Segurança Nacional $^{365}$.

A administração valeu-se do modelo tecnocrático de modernidade, em continuidade ao que prevalecera anteriormente ${ }^{366}$. Daí a amplitude de funções e subfunções do Estado nacional, com a militarização dos serviços públicos. Uma filosofia agressiva de defesa da ordem confunde o que é jurídico e político com aspectos do policial-militar; contexto em que a autocracia burguesa sobrepõe o seu ideal de Estado, em conexão histórica com o fascismo e o nazismo. O Estado acaba não tendo por função essencial proteger a articulação política de classes desiguais. A sua função consiste basicamente em suprimir qualquer necessidade de articulação política espontânea nas relações entre as classes, tornado-a desnecessária, já que ele próprio prescreve a ordem interna que deve prevalecer e tem de ser respeitada ${ }^{367}$.

O general Emílio Garrastazu Médici exerceu o poder político no período de 31.10.1969 a 15.3.1974, ocasião em que foram introduzidos na constituição todos os atos

\footnotetext{
${ }^{362}$ ARANTES, Rogério Bastos. op. cit., p. 39.

${ }^{363}$ Id. Ibid., p. 40.

${ }^{364} \mathrm{~A}$ alteração constava do art. 95 da Emenda 1/1969 (cf. Id. Ibid., p. 42).

${ }^{365}$ Id. Ibid., p. 42.

${ }^{366}$ IGLÉSIAS, Francisco. op. cit., p. 208.

${ }^{367}$ FERNANDES, Florestan. A revolução burguesa no Brasil: ensaio de interpretação sociológica. 5. ed. São Paulo: Globo, 2006. p. 400.
} 
institucionais. O presidente adotou um estilo populista, com a crescente estatização da economia e uma política repressiva de enorme brutalidade. No auge da política repressiva, “as prisões contínuas levaram ao desaparecimento de centenas de pessoas" 368 . Houve não só a morte e o extermínio de pessoas, mas também a tortura, sempre com o culto do sigilo em nome da segurança pública.

Ernesto Geisel sucedeu Médici, governando o país de 15.3.1974 a 15.3.1979. Foi buscada uma reforma do Judiciário, com a aprovação do Congresso Nacional. Mas, diante de sua rejeição pelo parlamento, houve a imposição da iniciativa pelo próprio governo, por meio de uma emenda constitucional. Dessa forma, o Presidente da República "reformou o judiciário para impor-lhe com mais segurança os atos do Executivo" ${ }^{369}$. Com o Congresso fechado, a Emenda Constitucional n. 7, de 14 de abril de 1977, estendeu ao ProcuradorGeral da República a representação perante o Supremo Tribunal Federal, para fins de interpretação de lei ou ato normativo federal ou estadual. O objetivo era definir o sentido das disposições jurídicas para evitar decisões judiciais contrárias aos interesses governamentais. No mesmo passo, foi introduzida a competência do Procurador-Geral de avocar as causas que estivessem sendo processadas perante qualquer juízo ou tribunal do país, de modo a transferir o julgamento ao Supremo Tribunal Federal, "quando houvesse perigo de grave lesão à ordem, à saúde, à segurança ou às finanças públicas”370.

Por outro lado, caiu por terra qualquer expectativa de estabilidade econômica, acentuando-se os níveis de inflação em patamares surpreendentes, com uma dívida externa de difícil pagamento. Na gestão administrativa, houve algumas realizações de relevo, mediante a expansão dos serviços de comunicações para alcançar todo o território nacional. Foram realizadas obras públicas de grande porte, como a estrada Transamazônica, a barragem de Itaipu e a usina nuclear de Angra dos Reis, consumindo grandes somas de recursos públicos. As denúncias de corrupção e de desvios de verbas eram sempre ignoradas, revelando um total desprezo pela população ${ }^{371}$.

\footnotetext{
${ }^{368}$ IGLÉSIAS, Francisco. op. cit., p. 212.

${ }^{369}$ Id. Ibid., p. 213.

${ }^{370}$ ARANTES, Rogério Bastos. op. cit., p. 42. Houve ainda a reforma da legislação eleitoral e a desfiguração do Senado, com a criação da figura do senador biônico (cf. IGLÉSIAS, Francisco. op. cit., p. 213).

${ }^{371}$ IGLÉSIAS, Francisco. op. cit., p. 209. Após a etapa de desenvolvimento do governo de Juscelino Kubitschek, o crescimento econômico caiu de forma bastante acentuada. A partir de 1968, época de total recrudescimento do regime ditatorial, a faixa de crescimento voltou a subir, ultrapassando o período de Kubitschek e mantendo-se em torno de $10 \%$ (dez por cento) até 1976. Foi quando se falou no "milagre econômico". Porém, com a paulatina desmistificação do "milagre econômico", depois de 1976, o apoio da classe média ao regime militar começou a decair, com reflexos sobre os votos angariados pela oposição nos parlamentos e, em seguida, nos governos estaduais.
} 
Geisel colocou o Legislativo em recesso quando foi recusada a sua proposta de reforma do Judiciário, impondo à sociedade o seu sucessor, o General João Batista Figueiredo, de uma maneira bastante agressiva. De qualquer forma, teve que conduzir o país à democracia, pois o regime não mais se sustentava diante de progressivas manifestações populares oposicionistas, agravadas pela crise financeira, com recordes de inflação e índices de desemprego ${ }^{372}$. Deu-se início, assim, à chamada fase de abertura democrática.

Por outro lado, a partir da vigência do Código de Processo Civil de 1973, vai se afirmando a imagem do Ministério Público como guardião dos interesses da sociedade. Foi durante a ditadura militar que, por força da incumbência de defesa do interesse público, o Ministério Público passou a atuar num raio que extrapolava a proteção de interesses das pessoas jurídicas de direito público, incluindo o Estado ${ }^{373}$. Ampliou-se a noção de interesse público, competindo à própria instituição a interpretação de sua existência ou não nos casos concretos ${ }^{374}$. A hipótese teria contribuído para alimentar o discurso pela independência funcional. É que, como o interesse público pode colidir com os interesses secundários do Estado, o Ministério Público deveria contar com uma autonomia suficiente para agir ${ }^{375}$.

\subsection{A fase de transição e a Constituinte de 1988}

Geisel abriu espaço para a propaganda eleitoral da oposição e, em 1978, o Congresso votou o fim do AI-5, com o restabelecimento do habeas corpus e a atenuação da Lei de Segurança Nacional. No mesmo ano, findou-se o sistema do bipartidarismo, havendo a criação de novos partidos políticos ${ }^{376}$. Em 1982, foram realizadas eleições diretas para governadores e, não obstante mantidas as eleições indiretas, os militares concordaram com a escolha de um civil para a Presidência da República em $1985^{377}$.

A Emenda Constitucional n. 7 de 1977, baixada pelo Presidente Geisel durante o fechamento do Congresso Nacional, estabeleceu a necessidade de lei complementar, de

\footnotetext{
${ }^{372}$ IGLÉSIAS, Francisco. op. cit., p. 213-214.

${ }^{373}$ Alude-se à atribuição do Ministério Público de intervenção nas causas em face da presença do interesse público evidenciado pela natureza da lide ou pela qualidade da parte (art. 82, III, do CPC).

${ }^{374}$ ARANTES, Rogério Bastos. op. cit., p. 34-35.

${ }^{375}$ Id. Ibid., p. 37.

${ }^{376}$ Durante a ditadura, vigorou o sistema de bipartidarismo, com a Aliança Renovadora Nacional (ARENA) e o Movimento Democrático Brasileiro (MDB).

${ }^{377}$ Cf. CARVALHO, José Murilo de. Cidadania no Brasil: um longo caminho, cit., p. 173 e ss.
} 
iniciativa do Presidente da República, para instituir normas gerais sobre a organização do Ministério Público dos Estados. O objetivo "era buscar um perfil nacional da instituição, que reduzisse suas discrepâncias regionais"378. Foi editada, assim, no início do governo de João Batista Figueiredo, a primeira lei orgânica nacional do Ministério Público (Lei Complementar 40, de 14. 12.1981), que, procurando uniformizar alguns princípios de organização e competência, acabou principiando a construção da unidade nacional do Ministério Público ${ }^{379}$.

O diploma consagrou ao Ministério Público o caráter de instituição permanente e essencial à função jurisdicional do Estado, responsável pela defesa da ordem jurídica e dos interesses indisponíveis da sociedade. Também foram antecipadas algumas garantias institucionais confirmadas, posteriormente, na Constituição de 1988. Além dos princípios da unidade e indivisibilidade, a autonomia funcional constou daquela lei, com a inamovibilidade e a irredutibilidade de vencimentos aliando-se a outras vantagens e benefícios relacionados ao serviço público em geral.

O processo de incorporação de prerrogativas foi um aspecto relevante na reconstrução institucional, revelando-se constante, progressivo e linear, desde a edição da Lei Complementar 40/81 até as leis orgânicas de 1993, posteriores ao ordenamento constitucional $^{380}$. A partir dessa lei complementar, o Procurador-Geral de Justiça passou a ser escolhido entre os integrantes das carreiras estaduais. Até então, o chefe da instituição era de livre escolha do governador, normalmente recaindo em pessoas estranhas ao quadro das carreiras. A Lei Orgânica do Ministério Público do Estado de São Paulo (Lei Complementar Estadual 304, de 28.12.1982) previa que a escolha do governador deveria advir de um dos nomes indicados em lista tríplice, cuja elaboração competia ao órgão especial do Colégio de Procuradores de Justiça, composto por membros do Ministério Público que oficiam junto aos tribunais ${ }^{381}$.

\footnotetext{
${ }^{378}$ MAZZILLI, Hugo Nigro. op. cit., p. 51.

${ }^{379}$ ARANTES, Rogério Bastos. op. cit., p. 44 e ss.

${ }^{380}$ Id. Ibid., p. 47-48. A LOMPU (Lei Complementar 75/93) é a lei orgânica do Ministério Público da União, dispondo sobre a organização, as atribuições e o estatuto do Ministério Público da União; e a LONMP é a Lei Nacional do Ministério Público (Lei 8.625/93), dispondo sobre normas gerais para a organização do Ministério Público dos Estados. No Estado de São Paulo, a LOEMP rege a organização de seu Ministério Público (Lei Complementar Estadual 734/93).

${ }^{381}$ Iniciou-se, na instituição paulista, um movimento em prol da ampliação do colégio eleitoral para que a escolha dos integrantes da lista tríplice passasse a ser feita por todos os Procuradores de Justiça, e não apenas pelos membros do órgão especial do Colégio de Procuradores. A reivindicação foi alcançada com a Emenda à Constituição Paulista n. 56 de 1986. Anote-se que, sancionada a Lei Complementar 40/81, a Emenda Constitucional 33, de 30.6.1982, promulgada pela Assembleia Legislativa do Estado de São Paulo,
} 
Ainda em 1981, a Lei 6.938, de 2 de setembro, que instituiu a Política Nacional do Meio Ambiente, atribuiu ao Ministério Público, privativamente, a função de promover a ação de responsabilidade civil e criminal por dano ambiental. O diploma é considerado o primeiro a reconhecer a categoria de direitos ou interesses transindividuais no sistema jurídico brasileiro. Note-se que a Lei Complementar 40/81 já definia, como uma das funções institucionais do Ministério Público, "promover ação civil pública, nos termos da lei”382. No Estado de São Paulo, a atribuição do Ministério Público nessa área foi ampliada por sua Lei Orgânica (Lei Complementar 304/82) para alcançar, além da proteção do meio ambiente, os interesses do consumidor, e o patrimônio cultural e natural do Estado ${ }^{383}$.

Durante o período de transição democrática, a preocupação doutrinária com a criação de um sistema processual para a defesa dos direitos ou interesses transindividuais passou a dominar alguns círculos de notáveis processualistas brasileiros. E o Ministério Público colocava-se como o agente concebido para a função, em virtude das atribuições já conquistadas em precedentes legislações. Mas a sua semelhança com a figura do juiz sugeria certa neutralidade e distanciamento incompatíveis com o dinamismo que a defesa dos novos direitos realmente demandava. Outro ponto desfavorável era a ligação da instituição com o Executivo, desqualificando-a para defesa de direitos ou interesses que, muitas vezes, eram lesionados por agentes deste órgão estatal ${ }^{384}$.

Assim, a possibilidade de conferir ao Ministério Público a legitimidade ativa para a ação civil pública dividia as opiniões. A ideia era centrá-la nos corpos intermediários, para prestigiar o acesso à justiça por meio da sociedade civil organizada. Graças, porém, à ação eficiente do lobby do Ministério Público do Estado de São Paulo junto ao Congresso Nacional e ao Ministério da Justiça, o projeto aprovado originou a Lei da Ação Civil Pública, de 27.07.1985, fortalecendo a posição do Ministério Público em detrimento do papel das associações civis ${ }^{385}$. A exigência de um prazo mínimo de constituição das

conferiu ao Ministério Público a autonomia administrativa e financeira, dispondo de dotação orçamentária própria. A emenda também atribuiu ao Colégio de Procuradores de Justiça a competência para destituir o Procurador-Geral em caso de abuso de poder. Cf. MAZZILLI, Hugo Nigro. op. cit., p. 54-55.

${ }^{382}$ É a redação do art. $3^{\circ}$, III, da Lei Complementar 40/81.

${ }^{383}$ ARANTES, Rogério Bastos. op. cit., p. 52-53. Nesse período, no Ministério Público de São Paulo, foram criadas as primeiras Promotorias de Justiça especializadas para a proteção dos direitos difusos. Havia um dispositivo na Lei Orgânica prevendo a existência de um Promotor de Justiça em cada comarca para atuação na área, sob a designação do Procurador-Geral de Justiça.

${ }^{384}$ É a opinião do processualista italiano, Mauro Cappelletti, que influenciou o desenvolvimento doutrinário brasileiro a respeito do tema (cf. CAPPELLETTI, Mauro; GARTH, Bryan. Acesso à justiça. Trad. Ellen Gracie Northfleet. Porto Alegre: Sergio Antonio Fabris, 1988. p. 51-52).

${ }^{385}$ Em 1982, em nome da Associação Paulista dos Magistrados, formou-se uma comissão de juristas encarregada da elaboração de anteprojeto de lei relativo à defesa dos interesses transindividuais. O projeto 
entidades para a utilização do mecanismo, conjugada à disposição do inquérito civil apenas em prol do Ministério Público, acabou desestimulando a participação dos corpos intermediários na defesa dos direitos de titularidade coletiva. O caminho mais natural era o recurso à ação do Ministério Público, que, por muitos anos, monopolizou o patrocínio das causas de tal natureza. Fortaleceu-se a relação tutelar entre uma forte instituição e uma sociedade incapaz de zelar por seus próprios interesses. Realmente, causa e efeito interagem de modo significativo: "uma sociedade civil incapaz requer um Ministério Público forte e um Ministério Público deve ser forte porque a sociedade civil é incapaz"386.

Por outro lado, com o agravamento da situação econômica e dos escândalos de corrupção, o governo militar veio a se ressentir de sustentação no Congresso Nacional ${ }^{387}$. O MDB (Movimento Democrático Brasileiro) encabeçava a coligação partidária para encontrar uma solução capaz de superar o impasse gerado pela ordem estabelecida e reconduzir o país à democracia. Nesse passo, a partir de 1984, intensificou-se uma forte mobilização da sociedade em torno da abertura democrática, com o movimento por eleições diretas, de enorme repercussão política e participação popular. O objetivo da campanha das "Diretas Já" era compelir o Congresso a aprovar uma emenda constitucional destinada a possibilitar a eleição direta do próximo Presidente da República. O projeto fracassou, mas o candidato lançado pela oposição, Tancredo Neves, então Governador de Minas Gerais, sagrou-se vencedor nas eleições realizadas pelo colégio eleitoral. Foi o primeiro civil eleito para a presidência depois de 1960, morrendo subitamente pouco antes de sua posse. $\mathrm{O}$ exercício do mandato coube, então, ao candidato à Vice-Presidência, José Sarney, indicado pelo PFL (Partido da Frente Liberal). Porém, o clima de otimismo não abandonou o ambiente da Nova República, que seguia premida pelo entusiasmo das manifestações cívicas em favor das eleições diretas. Sucederam-se assim as eleições de 1986, para formar a quarta Assembleia Nacional Constituinte da República.

À época da Constituinte de 1988, nas carreiras do Ministério Público, expandiramse os debates em torno do rumo da instituição a partir da redemocratização do país.

desse grupo, formado por Ada Pellegrini Grinover, Candido Rangel Dinamarco, Kazuo Watanabe e Waldemar Mariz de Oliveira Júnior, foi encaminhado ao Congresso Nacional no início de 1984. Outro projeto, porém, foi lançado por membros do Ministério Público do Estado de São Paulo, o qual foi encaminhado pela CONAMP (Confederação Nacional do Ministério Público) para o Congresso Nacional também em 1984. Após um período de intenso debate no parlamento, os pontos relevantes em benefício do fortalecimento da atuação do Ministério Público acabaram sendo acatados, com a promulgação da Lei da Ação Civil Pública (cf. ARANTES, Rogério Bastos. op. cit., p. 57-60).

${ }^{386}$ ARANTES, Rogério Bastos. op. cit., p. 75.

${ }^{387}$ IGLÉSIAS, Francisco. op. cit., p. 214. 
Contando com grande mobilização de seus agentes, principalmente do Estado de São Paulo, o resultado foi o encaminhamento de um documento versando sobre uma redefinição radical da organização do Ministério Público, com vistas à inclusão no novo texto constitucional. O projeto ficou conhecido como Carta de Curitiba, porquanto ter sido aprovado no Primeiro Encontro de Procuradores-Gerais de Justiça e Presidentes de Associações do Ministério Público, realizado em junho de 1986, na Capital do Estado do Paraná.

No curso dos trabalhos da Assembleia Constituinte, a CONAMP encaminhou ao Congresso aquela proposição, que teve origem, principalmente, em cinco fontes: a) o aparato jurídico preexistente (a Carta de 1969 e a Lei Orgânica 40/81); b) as teses aprovadas no VI Congresso Nacional do Ministério Público de 1985; c) uma pesquisa formulada pela CONAMP contando com um questionário respondido por 977 (novecentos e setenta e sete) membros do Ministério Público; d) o anteprojeto apresentado pelo então Procurador-Geral da República, Sepúlveda Pertence, à Comissão de Estudos Constitucionais, conhecida como Comissão Afonso Arinos; e) uma consolidação provisória elaborada pela própria CONAMP para aquele encontro de $\mathrm{Curitiba}^{388}$.

Um ponto-chave para a organização constitucional do Ministério Público era a sua chefia. A pesquisa realizada pela CONAMP em 1985 revelara que 62\% (sessenta e dois por cento) dos entrevistados preferiam que o Procurador-Geral fosse eleito apenas por seus pares; $22 \%$ (vinte e dois por cento) dos entrevistados aceitavam a nomeação pelo chefe do Executivo; e apenas 1,5\% (um e meio por cento) concordavam com a livre escolha da chefia do Executivo ${ }^{389}$. No entanto, a histórica hegemonia desse órgão não poderia deixar de frear o ímpeto de independência do Ministério Público, restando atribuída ao governador a escolha do Procurador-Geral de Justiça, entre os nomes indicados em lista tríplice formada pelos membros das carreiras estaduais. Para a cargo de Procurador-Geral da República, a própria Carta de Curitiba, não só mantinha intacta a escolha do nome pelo Presidente da República, como possibilitava que ela recaísse em figuras estranhas aos quadros funcionais do Ministério Público. A Constituinte corrigiu apenas a última

\footnotetext{
${ }^{388}$ MAZZILLI, Hugo Nigro. op. cit., p. 86. Cf. também ARANTES, Rogério Bastos. op. cit., p. 77-78.

${ }^{389}$ ARANTES, Rogério Bastos. op. cit., p. 81. A pesquisa da CONAMP também revelara que $76 \%$ dos membros do Ministério Público entrevistados consideravam que o Ministério Público deveria figurar na Constituição em um título alheio aos da organização do Executivo, Legislativo e Judiciário; 10\% queriam vê-lo no capítulo do Executivo; 8,7\% no capítulo do Judiciário, e apenas 0,5\% no capítulo do Legislativo.
} 
distorção para impor a condição de membro da classe à assunção da chefia do Ministério Público da União ${ }^{390}$.

Também foi objeto de discussão o sistema de incompatibilidades para os membros da instituição. Segundo a pesquisa da CONAMP, os agentes entrevistados não atribuíam grande importância à questão das vedações. O exercício da advocacia foi condenado por $40 \%$ (quarenta por cento) dos entrevistados como a atividade mais incompatível com as funções do Ministério Público. Logo em seguida, vinha o exercício de atividade políticopartidária, por $24 \%$ (vinte e quatro por cento) dos entrevistados, mas apenas $2 \%$ (dois por cento) consideravam a inviabilidade do exercício de algum cargo no Executivo do Estado $^{391}$.

“A Constituição confirmou a proibição à advocacia, à atividade político-partidária (...) e ao exercício, ainda que em disponibilidade, de qualquer outra função pública, exceto uma de magistério" ${ }^{, 392}$. Ficaram também vedadas a prestação de serviços de consultoria e a representação judicial de entidades públicas, com a confirmação do princípio já consagrado na Lei Complementar 40/81 do exercício das funções institucionais apenas por integrantes das carreiras $^{393}$. Mas o tratamento casuístico conferido às vedações refletiu-se no direito de opção pela permanência no regime anterior ao diploma constitucional, para os integrantes das carreiras que nelas tivessem ingressado antes de 1988. O precedente sistema da Lei Complementar 40/81 e da Carta de 1969 só impedia a participação em sociedade comercial e o exercício da advocacia. "Paradoxalmente, ingressar ou não na nova ordem constitucional - no que diz respeito aos impedimentos - tornou-se uma questão de escolha

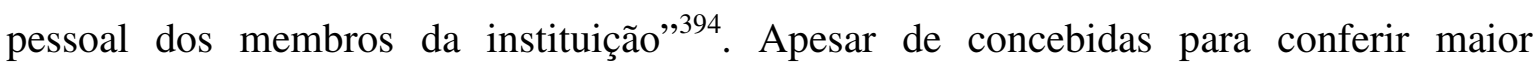
independência no desenvolvimento das funções institucionais, as vedações foram deixadas ao alvedrio da vontade pessoal dos interessados.

\footnotetext{
${ }^{390}$ Sepúlveda Pertence, então Procurador-Geral da República, teria influenciado a proposta sobre a forma de escolha do Procurador-Geral da República que acabou constando da Carta de Curitiba. (ARANTES, Rogério Bastos. op. cit., p. 81).

${ }^{391}$ Id. Ibid., p. 82-83.

${ }^{392}$ Id. Ibid., p. 83.

${ }^{393} \mathrm{O}$ regime de vedações constou do art. 128 , $\S 5^{\circ}$, II, $a$ a $f$, da $\mathrm{CF}$ de 1988 . A norma do $\S 2^{\circ}$, do art. 129 , trouxe a prescrição do exercício das funções do Ministério Público apenas por integrantes da carreira, enquanto a proibição de representação judicial e de consultoria jurídica das entidades públicas veio explicitada no art. 129, IX.

${ }^{394}$ ARANTES, Rogério Bastos. op. cit., p. 83. A possibilidade de opção pelo regime anterior para os membros do Ministério Público admitidos antes da promulgação da Constituição foi introduzida no art. 29, $\S 3^{\circ}$, do Ato das Disposições Constitucionais Transitórias (ADCT).
} 
Com a Lei da Ação Civil Pública, abriram-se as portas para a ampliação das atribuições conquistadas posteriormente na Constituinte de 1988. A introdução do ombudsman na Lei Fundamental foi afastada por influência do Ministério Público, que insistiu em incorporar a correspondente função, inserindo-a no sistema da justiça brasileira $^{395}$. Sem prejuízo do monopólio da propositura da ação penal, a utilização do instrumento da ação civil pública foi elevada ao plano constitucional para a defesa de qualquer direito ou interesse transindividual, com a expressa menção à proteção do meio ambiente e do patrimônio público e social. Também não foi afastada da instituição a ação de inconstitucionalidade de leis ou atos normativos, somente sem o êxito de mantê-la sob o seu exclusivo monopólio ${ }^{396}$.

Os esforços do Ministério Público junto à Constituinte tiveram também um papel decisivo para a introdução de suas garantias no texto constitucional. Não faltou a autonomia funcional, administrativa e financeira, com a inclusão da inamovibilidade, vitaliciedade, irredutibilidade de subsídios e, em especial destaque, a independência funcional ${ }^{397}$. Todas as garantias eram apontadas como essenciais ao desenvolvimento do rol das tarefas atribuídas à instituição. Não abandonando a posição de neutralidade exigida dos integrantes do Judiciário, a estratégia política adotada pelo Ministério Público foi a de ir se distanciando, ao máximo, da ideia de proteção do interesse público vinculado ao interesse do Estado.

De forma bastante ambígua, muito embora procurasse apresentar-se como uma instituição concebida para a defesa dos interesses gerais da sociedade, a prática corporativa era bem diferente. O Ministério Público continuava à sombra do Executivo, com o afastamento de vários de seus integrantes para o exercício de cargos e funções de primeiro

\footnotetext{
${ }^{395}$ ARANTES, Rogério Bastos. op. cit., p. 87-88.

${ }^{396}$ A intenção dos membros do Ministério Público era manter o monopólio da instituição sobre a representação de inconstitucionalidade perante a Suprema Corte. O Procurador-Geral funcionaria como um agente intermediário, decidindo sobre o encaminhamento da representação formulada pelos sujeitos que sagraram colegitimados para o ajuizamento da ação. O legislador constituinte, no entanto, optou por incluir o Procurador-Geral num rol de nove titulares para ação, contrariando, nessa área, a proposta da instituição. Porém, antes da ruptura da exclusividade do Ministério Público para a iniciativa, no período compreendido entre 1985-1988, houve o crescimento do número de representações por inconstitucionalidade. A maioria das hipóteses incidia sobre leis estaduais contestadas em face da Constituição Federal. O fato se explica pela evolução do federalismo brasileiro, ao longo da transição do regime autoritário para a democracia. A redemocratização política brasileira começou no plano estadual, com as eleições em 1982. A partir de então, aumentou o grau de autonomia das unidades federativas estaduais, com o enfraquecimento do governo federal. É possível supor, então, que o crescimento do número de representações por inconstitucionalidade durante o período de 1985-1988 resultou da tentativa de controlar a produção normativa estadual para mantê-la em consonância com os interesses da União. Cf. ARANTES, Rogério Bastos. Ministério Público e política no Brasil, cit., p. 91-92 e 94.

${ }^{397}$ As garantias institucionais constaram dos arts. $127, \S \S 1^{\circ}$ a $6^{\circ}$; e $128, \S 5^{\circ}, \mathrm{I}, a, b$ e $c$, da CF de 1988.
} 
escalão junto aos governos estaduais e também junto ao governo federal, em relação ao qual a vinculação do Ministério Público mostrou-se, sem dúvida, intransponível durante o regime ditatorial. Os membros do Ministério Público afastados das carreiras representariam importante instrumento da política institucional, de cunho altamente corporativista, para a efetivação do projeto de garantias e "vantagens (...), inclusive de ordem econômico-financeira relacionadas ao sistema remuneratório e orçamentário"398

A Constituinte trabalhou mais de um ano para a promulgação da Constituição em outubro de 1988, com a preocupação central de garantir os direitos fundamentais da pessoa humana. Houve a ampliação da universalidade do voto, tornando-o facultativo para os analfabetos, além da possibilidade de exercício desse direito pelos jovens a partir de 16 (dezesseis) anos de idade. Restrições à formação e ao funcionamento dos partidos políticos também foram eliminadas. E a extinção da exigência de fidelidade partidária propiciou a constante troca de partidos por senadores, deputados, vereadores, governadores e prefeitos. Do excesso de restrição durante o governo militar "passou-se a grande liberalidade". Subsistiu a distorção regional na representação parlamentar, com o princípio de "uma pessoa, um voto" amplamente violado pela legislação brasileira. O desequilíbrio do sistema de representação democrática foi reforçado pelo fato de todos os Estados elegerem o mesmo número de senadores, acentuando a sobrerrepresentação das unidades federativas do Norte. Centro-Oeste e Nordeste ${ }^{399}$.

Ao lado dos direitos civis e políticos, o reconhecimento dos direitos sociais dotouse de considerável abrangência, não obstante a persistência de "grandes desigualdades sociais que caracterizam o país desde a independência, para não mencionar o período colonial ${ }^{400}$. De natureza racial e regional, não foi afastada da sociedade brasileira a desigualdade que concentra nas mãos de poucos a riqueza nacional, provocando "níveis dolorosos de pobreza e miséria" ${ }^{, 401}$. De todo modo, após 1985, recuperaram-se os tradicionais direitos civis, como a liberdade de expressão, imprensa e de associação. $\mathrm{O}$ racismo foi previsto, na Constituição, como crime inafiançável e imprescritível, e a tortura

\footnotetext{
${ }^{398}$ MACEDO JÚNIOR, Ronaldo Porto. Ministério Público brasileiro: um novo ator político: o Ministério Público e as organizações não governamentais sem fins lucrativos: estratégias para o futuro. In: VIGLIAR, José Marcelo Menezes; MACEDO JR., Ronaldo Porto (Coords.). Ministério Público II: democracia, cit., p. 111.

${ }^{399}$ CARVALHO, José Murilo de. Cidadania no Brasil: um longo caminho, cit., p. 201-202.

${ }^{400}$ Id. Ibid., p. 207. O sistema de proteção dos direitos humanos constou do Título II da Constituição, com a especificação dos direitos econômicos, sociais e culturais nos subsequentes Títulos VII e VIII.

${ }^{401}$ Id. Ibid., p. 208.
} 
como crime inafiançável e não anistiável ${ }^{402}$. Próprio das chamadas sociedades de massa, assegurou-se a proteção do consumidor também na condição de um direito fundamental, e a fundamentalidade do direito à propriedade ficou condicionada ao atendimento da função social $^{403}$.

Na esteira da criação da Lei da Ação Civil Pública, o legislador constituinte prescreveu uma série de garantias fundamentais destinadas à proteção dos direitos decorrentes da dignidade da pessoa humana, ampliando a esfera de incidência de alguns institutos processuais preexistentes. É o caso do mandado de segurança alçado para a proteção de direito líquido e certo, não amparado por habeas corpus ou habeas data, contra ilegalidade ou abuso de poder de autoridade ou agente de pessoa jurídica no exercício de atribuições do poder público ${ }^{404}$. Em inovadora iniciativa, o constituinte autorizou a propositura do mandado de segurança coletivo por partido político e também por organizações sindicais, entidades de classe ou associações, em defesa dos interesses de seus membros ou associados ${ }^{405}$. O âmbito da ação popular constitucional também foi ampliado para a defesa por qualquer cidadão da moralidade administrativa e do meio ambiente, além do patrimônio público, histórico e cultural ${ }^{406}$. Para atribuir maior eficácia aos direitos fundamentais da pessoa humana, o constituinte inseriu no conjunto das garantias de acesso à justiça o mandado de injunção, por meio do qual passou a ser possível recorrer ao Judiciário para exigir o cumprimento de dispositivos constitucionais ainda não regulamentados ${ }^{407}$. Por fim, a par do habeas corpus e do mandado de segurança, o habeas data, amparando os direitos fundamentais à intimidade e à informação, também foi contemplado para assegurar o acesso e o conhecimento de informações relativas à pessoa do impetrante, constantes de registros ou bancos de dados de entidades

\footnotetext{
${ }^{402}$ CARVALHO, José Murilo de. Cidadania no Brasil: um longo caminho, cit., p. 209.

${ }^{403}$ Esses direitos fundamentais foram explicitados nas normas dos incs. III, IV, XVII, XXII, XXIII e XXXII, XLII e XLIII, do amplo catálogo do art. $5^{\circ}$ da CF de 1988.

${ }^{404}$ A garantia foi introduzida no art. $5^{\circ}$, LXIX, da CF de 1988. O mandado de segurança foi incorporado ao cenário constitucional quando da vigência da Constituição de 1934. A Carta de 1937 suprimiu de seu texto a inscrição do instituto, que foi novamente elevado à condição de garantia fundamental com a promulgação da Constituição de 1946 (art. 141, § 24\%) e assim mantido nas que se sucederam (art. $150, \S 21^{\circ}$, da CF de 1967, e art. 153, § $21^{\circ}$, da Emenda Constitucional n. 1 de 1969).

${ }^{405}$ É a hipótese que vingou na norma do art. $5^{\circ}$, LXX, $a$ e $b$, da CF de 1988.

${ }^{406} \mathrm{O}$ instituto da ação foi positivado no art. 5, LXXIII, da CF de 1988.

${ }^{407}$ CARVALHO, José Murilo de. Cidadania no Brasil: um longo caminho, cit., p. 209. A hipótese originou a norma do art. $5^{\circ}$, LXXI, da CF, com a seguinte redação: “conceder-se-á mandado de injunção sempre que a falta de norma regulamentadora torne inviável o exercício dos direitos e liberdades constitucionais e das prerrogativas inerentes à nacionalidade, à soberania e à cidadania”. Vale também a ressaltar a introdução dos princípios da inafastabilidade do controle jurisdicional e do devido processo legal (art. $5^{\circ}$, XXXV e LIV, da CF).
} 
governamentais ou de caráter público, com a possibilidade de retificação desses dados quando incorretos ${ }^{408}$.

Na linha de ampliar o acesso à justiça, o constituinte previu a necessidade de criação dos Juizados Especiais Cíveis e Criminais, visando a uma célere prestação jurisdicional em causas cíveis de pequena complexidade e em infrações penais de menor potencial ofensivo $^{409}$. Contudo, o acesso à justiça permaneceu limitado a uma pequena parcela da população, em que pese o conjunto de garantias fundamentais e a abrangência das funções conferidas ao Ministério Público. O retardamento na implantação dos quadros da defensoria Pública tornou-os insuficientes ao atendimento da demanda, com a progressiva sobrecarga de processos em todos os setores do Judiciário, incluindo os dos juizados especiais a partir de sua regulamentação em $1995^{410}$.

O arranjo institucional em torno da segurança pública não se apresentou satisfatório, com o agravamento da inadequação dos órgãos encarregados do cumprimento de sua função constitucional. O constituinte retirou do Exército o controle das polícias militares para transferi-lo aos governadores dos Estados ${ }^{411}$. Compondo organizações autônomas, as polícias civil e militar não se revelaram capazes de garantir a segurança dos cidadãos. E não foge à regra o Ministério Público na qualidade de responsável pela promoção da ação penal. Nos grandes centros urbanos, proliferaram as atividades de grupos empresariais na área da segurança privada, para atender as crescentes necessidades da classe alta. Já as favelas ficaram à mercê de milícias e quadrilhas organizadas encarregadas de manter a ordem. Não obstante os avanços com a Constituição de 1988, não foi eliminado o sentimento popular de que a justiça só funciona para as classes sociais mais favorecidas, "ou antes, de que ela não funciona, pois os ricos não são punidos e os pobres não são protegidos" $"$. A efetiva fruição do vasto conjunto de direitos e garantias

\footnotetext{
${ }^{408} \mathrm{O}$ clássico instrumento do habeas corpus foi plenamente restituído ao rol das garantias fundamentais (art. $5^{\circ}$, LXVIII, da CF de 1988), e o habeas data também veio a constar de seu art. $5^{\circ}$, LXXII, $a$ e $b$.

${ }^{409} \mathrm{O}$ art. 98, I, da CF de 1988 versou sobre a hipótese. Sobre a importância da instituição de procedimentos especiais para pequenas causas, cf. ainda CAPPELLETTI, Mauro; GARTH, Bryan. op. cit., p. 90 e ss.

${ }^{410} \mathrm{~A}$ prestação de assistência judiciária às pessoas carentes de recursos foi também elevada à condição de dever fundamental do Estado (art. 5 , LXXIV, da CF de 1988).

${ }^{411}$ Cf. CARVALHO, José Murilo de. Cidadania no Brasil: um longo caminho, cit., p. 212-213.

${ }^{412}$ Id. Ibid., p. 215. Acentuou-se o envolvimento de policiais em redes de organização criminosa e casos de violência ficaram célebres no país, com repercussão constrangedora no exterior. Em 1992, a polícia militar paulista invadiu a Casa de Detenção matando 111 pessoas para interromper um conflito. No mesmo ano, houve o massacre de Vigário Geral, no Rio de Janeiro, quando policiais assassinaram cruelmente 21 pessoas. Em 1996, em frente à Igreja da Candelária, também no Rio de Janeiro, sete crianças que dormiam na rua foram fuziladas por policiais militares. "No mesmo ano, em Eldorado do Carajás, policiais militares do Pará atiraram contra trabalhadores sem-terra, matando 19 deles.” (Id. Ibid., p. 213-214).
} 
fundamentais da chamada Constituição Cidadã ficou reservada às conhecidas oligarquias, ou seja, aos doutores privilegiados "que estão acima da lei, que sempre conseguem defender seus interesses pelo poder do dinheiro e do prestígio social (...)”. São “empresários, banqueiros, grandes proprietários rurais e urbanos, políticos, profissionais liberais e altos funcionários" que chegaram a dispensar os vínculos importantes nos negócios, no governo e no próprio arcabouço institucional do Judiciário ${ }^{413}$.

${ }^{413}$ CARVALHO, José Murilo de. Cidadania no Brasil: um longo caminho, cit., p. 215. 


\section{CAPÍTULO III. A CONSTITUIÇÃO FEDERAL DE 1998 NA DEFESA DOS DIREITOS FUNDAMENTAIS: O PAPEL DAS GARANTIAS INSTITUCIONAIS}

\subsection{A supremacia da vontade estatal na noção de direitos subjetivos}

Durante todo o século XIX e até meados do século XX, o sistema de direitos humanos ficou, de forma prevalente, vinculado ao reconhecimento de direitos subjetivos, sob a égide do princípio da liberdade individual consolidado a partir dos movimentos revolucionários do século XVIII, sobretudo da Revolução Francesa ${ }^{414}$. O caráter relacional da matriz da liberdade foi decisivo para a definição do conceito de direito subjetivo como “o relacionamento de um sujeito dotado de um poder (faculdade) sobre um objeto (res, persona), que tem garantidas suas pretensões em face dos demais sujeitos (erga omnes), aos quais cabe um dever geral de omissão" ${ }^{415}$.

Os limites ao exercício da liberdade individual são impostos pela lei, para que a liberdade de alguém não acabe interferindo na esfera da liberdade dos outros cidadãos. Revela-se o duplo sentido de liberdade: a resistência ao impedimento causado pela liberdade do outro, e a autonomia, diante da possibilidade de se também impor restrições. Em uma zona intermediária indefinida repousa a liberdade como um centro de relações entre sujeitos individuais. Aí está a estrutura do direito subjetivo que, sob o aspecto positivo, estabelece a alguém o poder de dispor sobre algo (res) ou de exigir de alguém uma conduta (persona); sob o aspecto negativo, confere ao respectivo titular a capacidade de exclusão de todos os demais ${ }^{416}$.

No mesmo diapasão, segue-se a teoria do status de Jellinek, segundo a qual o Estado aparece como a encarnação do poder soberano a partir de uma concepção dualista, na tentativa de estabelecer um conceito social e um conceito jurídico de Estado. O primeiro pressupõe as relações de dominação, fundadas em uma unidade de associação de indivíduos assentados em determinado território. Já o conceito jurídico "tem por

\footnotetext{
${ }^{414}$ COMPARATO, Fábio Konder. A garantia institucional contra o abuso de poder, cit., p. 47.

${ }^{415}$ FERRAZ JUNIOR, Tercio Sampaio. Estudos de filosofia do direito: reflexões sobre o poder, a liberdade, a justiça e o direito. 2. ed. São Paulo: Atlas, 2003. p. 105.

${ }^{416}$ Id., loc. cit.
} 
pressuposto a possibilidade de autolimitação jurídica do Estado, ou seja, o Estado, ao submeter-se voluntariamente ao direito que cria, tornar-se sujeito de direitos e deveres" ${ }^{\star 17}$.

Introduzida no campo meramente formal, a teoria do status de Jellinek traduz alguns tipos de relação entre os indivíduos e o Estado para o estabelecimento dos contornos dos direitos subjetivos públicos. Considerando o status passivo do sujeito, a relação é de submissão à vontade estatal; sempre que não houver uma proibição e nem a imposição de uma obrigação pelo Estado, está autorizado o livre exercício da ação individual. O chamado status negativo é a contrapartida, ou seja, a posição de liberdade jurídica implicando, de uma maneira geral, um direito de defesa contra as intromissões indevidas do poder público na esfera da liberdade individual. O status também pode ocorrer de forma positiva, exprimindo a capacidade dos cidadãos de exigirem algumas prestações do Estado, surgindo, finalmente, o status ativo que envolve o direito a uma participação na formação da vontade do Estado, como o direito ao sufrágio ${ }^{418}$. Jellinek, assim como Kelsen, reduziu a essência do direito à determinação de direitos subjetivos fundados na autonomia individual, ou seja, na manifestação da vontade consciente de sujeitos determinados; e as regras jurídicas definidoras desses direitos foram consideradas a expressão da vontade soberana do Estado ${ }^{419}$.

A escola positivista criada no século XIX visou a dissociar o direito de qualquer elemento da ética e das formas de organização política ${ }^{420}$. À ciência do direito cabe apenas explicar o que o direito é, e não o que ele deve ser. Juízos de valores ou elementos empíricos escapam ao âmbito de uma teoria pura do direito. Contrapondo-se à doutrina

${ }^{417}$ BERCOVICI, Gilberto. Soberania e Constituição: para uma crítica do constitucionalismo. São Paulo: Quartier Latin, 2008. p. 255.

${ }^{418}$ Cf. ALEXY, Robert. Teoría de los derechos fundamentales. Trad. Ernesto Garzón Valdés. Madrid: Centro de Estudios Políticos y Constitucionales, 2002. p. 247-261; cf. também o prólogo de Fernando de los Rios, in JELLINEK, Georg. Teoría general del Estado. trad. Fernando de los Rios. México: FCE, 2000. p. 41-47; e FERRAZ JUNIOR, Tercio Sampaio. op. cit., p. 109-112.

${ }^{419}$ Cf. MACEDO JÚNIOR, Ronaldo Porto. Carl Schmitt e a fundamentação do direito. São Paulo: Max Limonad, 2001. p. 83-84. No mesmo século XIX, o subjetivismo jurídico encontrou na escola do direito objetivo de Léon Duguit significativa oposição. Para o autor, o fundamento do direito é a expressão objetiva da solidariedade social, isto é, dos laços que reúnem os homens para a vida em sociedade. A regra de conduta impõe-se aos indivíduos pela "própria força das coisas"; ela só existe porque os homens vivem em sociedade; e do direito objetivo fundado na solidariedade social nascem os direitos subjetivos. É que, sendo todo "indivíduo, com efeito, obrigado pelo direito objetivo a cooperar na solidariedade social, resulta disso, necessariamente, que ele tem o direito de praticar todos aqueles atos pelos quais coopera na solidariedade social e de impedir que, seja quem for, obste a realização do papel social que lhe incumbe" (DUGUIT, Léon. Fundamentos do direito, cit., p. 23 e 25). A doutrina de Duguit é teleológica; o Estado legitima-se por seus fins. $\mathrm{O}$ autor rejeitou a ideia de soberania "como um direito subjetivo do Estado de se determinar pela própria vontade". "O Estado não é soberano, mas garantidor de interdependência e solidariedades sociais", por meio da prestação de serviços públicos (BERCOVICI, Gilberto. op. cit., p. 270271).

${ }^{420}$ Cf. COMPARATO, Fábio Konder. Ética: direito, moral e religião no mundo moderno, cit., p. 350 e ss. 
jusnaturalista, Kelsen afastou qualquer elemento histórico, fático, valorativo ou social da estrutura do direito. O direito prescinde do fato de ser bom ou mau, justo ou injusto; o reconhecimento de sua validade não está condicionado a nenhum critério de justiça, mas somente à existência de um sistema hierárquico de regras expedidas pela autoridade competente. Trata-se de um sistema escalonado de normas em que as inferiores retiram a sua validade das superiores, até alcançar o pressuposto lógico-transcendental de validade de todo o ordenamento (a norma fundamental). A legitimidade de qualquer sistema jurídico passou a ser aferida tão somente com base nesse critério de regularidade formal ${ }^{421}$.

Além disso, Kelsen acolheu o direito em função de sua força coativa. O direito vigente em uma sociedade está representado por normas que se fazem valer por meio da força. A sanção é o elemento essencial de uma norma jurídica; uma regra só é jurídica porque se estabelece por meio de uma sanção. Assim, com apoio no modelo weberiano de monopólio da força legítima, Kelsen apontou o Estado como "uma ordem de coação. Com efeito, o elemento político específico desta organização consiste na coação exercida de indivíduo a indivíduo e regulada por essa ordem, nos atos de coação que essa ordem estatui" $^{, 422}$.

A partir do positivismo jurídico, preponderou a concepção formal de uma Constituição, passando-se a aceitar "a existência e validade de Constituições com qualquer conteúdo. (...) O objeto próprio de uma Constituição deixou de ser a proteção dos cidadãos contra o abuso de poder, reduzindo-se à regulação do funcionamento dos órgãos estatais ${ }^{423}$. Nesse sentido, Jellinek relegou a hipótese de garantias institucionais a algumas medidas destinadas à proteção do direito positivo. O princípio da separação de poderes foi justificado por repousar a organização do Estado moderno "na existência de competências diferentes relativamente independentes entre si”, ${ }^{24}$. Não se considerou a existência de uma relação com o princípio da liberdade individual para a defesa dos cidadãos contra o abuso do poder governamental, mas unicamente uma relativa segurança na manutenção das instituições de direito público ${ }^{425}$.

\footnotetext{
${ }^{421}$ COMPARATO, Fábio Konder. Ética: direito, moral e religião no mundo moderno, cit., p. 362.

${ }^{422}$ KELSEN, Hans. Teoria pura do direito. Trad. João Batista Machado. 3. ed. São Paulo: Martins Fontes, 1991. p. 302; cf. também COMPARATO, Fábio Konder. Ética: direito, moral e religião no mundo moderno, cit., p. 359.

${ }^{423}$ COMPARATO, Fábio Konder. Ética: direito, moral e religião no mundo moderno, cit., p. 362-363.

${ }^{424}$ JELLINEK, Georg. op. cit., p. 678.

${ }^{425}$ Id. Ibid., p. 679.
} 


\subsubsection{O decisionismo de Carl Schmitt na definição de direitos fundamentais e o conceito de garantias institucionais}

Durante a vigência da Constituição de Weimar, a doutrina constitucional das garantias institucionais ganhou contornos mais precisos, com destaque a Carl Schmitt, jurista alemão, apontado como o primeiro que procurou sistematizar o tema ${ }^{426}$. Em sua Teoria da Constituição, ele apresentou o Estado como o status da unidade política de um povo, emanado da decisão de um poder soberano e estabelecido por sua vontade, com força e autoridade ${ }^{427}$. Com realce ao conceito de político incorporado ao de Estado, para Schmitt, "a essência da política é pura decisão e não racionalidade, vontade e não legalidade" ${ }^{428}$. Em sentido absoluto e material, uma Constituição corresponde à ordenação concreta da unidade política de um povo em que consiste o Estado. O Estado é a própria Constituição, como uma realidade existencial presente; um status total de unidade e ordenação. Ainda em sentido absoluto, a Constituição foi também identificada com a forma de governo, como um devir constante sempre em movimento, sob a orientação de um princípio ativo capaz de integrar todos os interesses contrapostos.

Por último, uma Constituição pode também significar a lei fundamental, isto é, um sistema de normas supremas e últimas. O Estado aqui é tratado idealmente, como um dever-ser, uma unidade de normas jurídicas que regulam a sua vida e o seu funcionamento. No entanto, contrapondo-se ao normativismo de Kelsen, Schmitt não admitiu qualquer relação entre a decisão soberana que estabelece o Estado e um sistema de normas constitucionais. A unidade do Reich alemão não se vincula à validade ou à vigência de prescrições constitucionais; repousa na existência do povo alemão que, por sua vontade, fundou a unidade estatal; e é desta mesma decisão soberana que resultou a validade do

\footnotetext{
${ }^{426}$ SCHMITT, Carl. Teoría de la Constitución. Trad. Francisco Ayala. Madrid: Alianza Editorial, 2003. p. 326-335; e BONAVIDES, Paulo. Curso de direito constitucional. 11. ed. São Paulo: Malheiros Ed., 2001. p. 494-495. Menos de um ano após a derrota do Império Alemão na Primeira Guerra Mundial, com a proclamação da República em um panorama de enorme fragmentação política e instabilidade econômica, a Constituição de Weimar foi votada em 6 de fevereiro de 1919. A primeira parte de seu texto disciplinou a organização do Estado, com o estabelecimento de limitações ao exercício do poder governamental. Sua segunda parte, em consonância com a Constituição Mexicana de 1917, estruturou um Estado Democrático Social, cujo modelo serviu a vários países da Europa continental depois da Segunda Grande Guerra. Além dos direitos fundamentais de natureza individual, foram acrescidos os direitos sociais, exigindo do Estado uma atuação orientada para garantir aos cidadãos as condições materiais necessárias a uma existência digna, à luz de uma política adequada de investimentos públicos e distribuição de bens (cf. COMPARATO, Fábio Konder. A garantia institucional contra o abuso de poder, cit., p. 47-48; e A afirmação histórica dos direitos humanos, cit., p. 190).

${ }^{427}$ SCHMITT, Carl. op. cit., p. 29-30 e 205-215.

${ }^{428}$ Cf. MACEDO JÚNIOR, Ronaldo Porto. Carl Schmitt e a fundamentação do direito, cit., p. 77. Cf. ainda G BERCOVICI, Gilberto. Constituição e estado de exceção permanente. Rio de Janeiro: Azougue Editorial, 2004. p. 65 e ss.
} 
texto constitucional. Dessa forma, aparece a Constituição jurídica derivada de uma unidade política concreta. Num plano normativo secundário em relação à constituição positiva concebida como decisão fundamental da unidade política, encontram-se as "leis constitucionais, enquanto realização normativa desta decisão"429.

Por outro lado, a unidade política a que corresponde o Estado baseia-se em dois princípios responsáveis por sua formação. O primeiro é o princípio da identidade de um povo, que aparece quando ele adquire aptidão para distinguir entre "o amigo e o inimigo", em virtude de uma consciência política própria. A origem do Estado repousa na decisão soberana que discrimina quem é amigo e inimigo. A função desta decisão "é a de agrupar o povo em torno de um determinado conteúdo e defendê-lo daqueles que não formam tal identidade ${ }^{, 430}$. O segundo é o princípio da representação, por meio do qual aquela unidade política que é o Estado se faz representar por um corpo governamental. Desprovido de qualquer caráter normativo ou procedimental, o princípio da representação funda-se na ideia da existência real e concreta de um povo; uma unidade política completa e acabada que se faz representar "como um todo" $"$. Com plena independência para agir, o representante não se reduz a um mandato, não se identificando diretamente com um agente ou órgão estatal. O que, então, define uma democracia seria o grau de intensidade dessa representação, uma vez que a unidade política do povo não pode sempre se fazer presente para a tomada de decisões políticas. Dessa forma, quanto mais se concretize o princípio da identidade na condução do governo, menor a distância entre governantes e governados e,

\footnotetext{
${ }^{429}$ SOLON, Ari Marcelo. Teoria da soberania como problema da norma jurídica e da decisão. Porto Alegre: Sergio Antonio Fabris, 1997. p. 92. Conforme o autor observou, a Constituição como decisão política fundamental é intangível, somente podendo ser suprimida, fora de todas as competências legais pelos atos políticos do poder soberano. Cf. ainda SCHMITT, Carl. op. cit., p. 33-35. A concepção de Schmitt em torno da constituição do poder político do Estado remete aos fundamentos do pacto fundamental de Hobbes, em que nenhum soberano recebe o poder a partir dos termos de um pacto. Pactos não passam de "palavras ao vento", não tendo nenhuma força "para obrigar, reprimir, constranger ou proteger ninguém, a não ser a que advém da espada pública; ou seja, das mãos desatadas daquele homem, ou assembleia de homens, que detém a soberania, e cujas ações são garantidas por todos e exercidas por meio da força de todos, nele reunidos" (HOBBES, Thomas. op. cit., Part. II, chap. XVIII, p. 231). Cf. ainda sobre os pontos afins entre o pensamento de Hobbes e a doutrina de Schmitt, BERCOVICI, Gilberto. Constituição e estado de exceção permanente, cit., p. 73-75. Por outro lado, Massimo Severo Giannini apontou a influência da filosofia hegeliana na doutrina alemã de direito público. Cf. GIANNINI, Massimo Severo. Lo stato monoclasse: la riflessione della scienza. In: L'amministrazione pubblica dello stato contemporaneo. Padova: CEDAM, 1998. p. 53.

${ }^{430}$ MACEDO JÚNIOR, Ronaldo Porto. Carl Schmitt e a fundamentação do direito, cit., p. 76. Não há nenhum critério para a discriminação do amigo e inimigo. Por isso, a identidade pode resultar de critérios culturais, raciais, geográficos ou de qualquer outra espécie.

${ }^{431}$ SCHMITT, Carl. op. cit., p. 211-213.
} 
por conseguinte, maior a democracia. Ao revés, quanto mais se realize o princípio da representação, menos democrático o governo se apresenta ${ }^{432}$.

Uma declaração de direitos fundamentais constante da Constituição de um Estado significa tê-los como pressupostos de sua formação, integração e unidade política. Mas, sob a perspectiva do liberalismo clássico, Schmitt inseriu na categoria de direitos fundamentais apenas os direitos de liberdade do homem no estado natural, considerado isoladamente. São direitos pré-estatais de toda e qualquer pessoa, independentemente de sua nacionalidade. O conteúdo de tais direitos não é estabelecido em lei; eles não resultam de nenhuma previsão normativa e, tampouco, podem consubstanciar algum bem jurídico $^{433}$.

O reconhecimento pelo Estado dos direitos fundamentais da pessoa humana deve-se ao princípio de distribuição próprio do Estado liberal burguês, ou seja, da existência de uma esfera de liberdade individual, em princípio inviolável e ilimitada, a qual se contrapõe à faculdade do Estado de restringi-la. Essa faculdade é limitada em princípio, mensurável e condicionada a uma regulamentação legal. Daí serem absolutos os direitos fundamentais autênticos, como a liberdade de religião, a inviolabilidade de domicílio e de correspondência, e a liberdade de expressão. São direitos superiores e anteriores ao Estado que se colocam frente a ele. Desses atributos não decorre, todavia, a impossibilidade de uma intervenção estatal. A inserção do Estado na esfera da liberdade individual do ser humano pode ocorrer com base em preceitos genéricos, abstratos e previamente estabelecidos. Com isso, estaria satisfeita a ideia central do princípio de distribuição de um Estado liberal de Direito.

É bem verdade que conceitos legais indeterminados podem sugerir a possibilidade de uma interferência estatal ilimitada naquele núcleo, supostamente intangível, da liberdade dos indivíduos. Schmitt afastou a hipótese, argumentando que, na prática, sempre ocorreria uma delimitação da faculdade de agir do Estado. Porém, diante do risco de rompimento do sustentáculo de unidade política, sobre o qual repousa o Estado, justificarse-iam intervenções de maior amplitude, com suporte no texto constitucional. É caso do estado de exceção, autorizando a suspensão provisória da vigência dos direitos fundamentais $^{434}$. Figurando como um instrumento de excessiva concentração de poder nas

\footnotetext{
${ }^{432}$ SCHMITT, Carl. op. cit., p. 214.

${ }^{433}$ Id. Ibid., p. 167 e ss.

${ }^{434}$ Id. Ibid., p. 180.
} 
mãos do Presidente da República, o artigo 48 da Constituição de Weimar a ele conferia competência para decretar medidas de natureza legislativa, exatamente no caso de perturbação da segurança coletiva e da ordem pública. O instrumento serviria para recuperar o comando político ao Estado, "como poder superior à sociedade, contrapondose ao pluralismo previsto na Constituição de Weimar". Schmitt defendeu a sua utilização "frente às necessidades concretas de um Estado economicamente oprimido"435.

De todo modo, refletindo os atributos conaturais à pessoa humana, os direitos fundamentais não poderiam ser suprimidos nem por leis ordinárias, nem por via de reforma constitucional, ressalvada a hipótese de um novo ato do poder constituinte do povo. Mas a referência é somente aos direitos individuais relacionados ao homem livre no estado natural. Todos os demais existem no interior do Estado, não desfrutando, de modo algum, da mesma natureza ${ }^{436}$.

Não se confundindo com os direitos fundamentais, Schmitt admitiu a possibilidade de que fosse assegurada, por meio de uma regulamentação constitucional, uma proteção especial para certas instituições, no intuito de impedir iniciativas do legislativo tendentes a suprimi-las ou afetá-las em sua essência: a garantia institucional é limitada.

Existe só no interior do Estado e não se baseia na ideia de uma esfera de liberdade em princípio ilimitada; antes, toca a uma instituição juridicamente reconhecida que, como tal, é sempre algo circunscrito e delimitado a serviço de certas tarefas e de certo fim, ainda que as tarefas não estejam especificadas em particular e seja admissível alguma "universalidade do círculo de atuação",437.

Como status da unidade política de um povo, o Estado moderno é uma unidade fechada que torna relativas todas as posições ocupadas em seu interior por qualquer organização social ou política. As formas de organização do Estado e os institutos da vida

\footnotetext{
${ }^{435}$ BERCOVICI, Gilberto. Soberania e Constituição: para uma crítica do constitucionalismo, cit., p. 314-315. Schmitt justificou a hipótese em função da necessidade de intervenção na ordem econômica, o que seria inviável diante de um parlamento em acelerado processo de desintegração, como era o caso do Reichstag no curso do pós-guerra; dissensos pluralistas seriam responsáveis por uma significativa fragmentação partidária. Para Schmitt, a competência atribuída pela Constituição ao Presidente da República permitiria considerá-lo o protetor de todo o ordenamento constitucional (SCHMITT, Carl. La defensa de la Constitución. Trad. Manuel Sanches Sarto. 2. ed. Madrid: Tecnos, 1998. p. 210-211).

${ }^{436}$ De idêntico modo, os direitos políticos não se relacionam com o homem livre no estado natural; são exercidos no interior do Estado e por ele assegurados, na medida em que dizem respeito à participação dos cidadãos na vida coletiva. Como os direitos políticos, os direitos sociais não são ilimitados em princípio, condicionando-se à existência de uma organização política para a sua garantia. Todos escapam, pois, ao âmbito dos direitos fundamentais Cf. SCHMITT, Carl. op. cit., p. 170-174.

${ }^{437}$ SCHMITT, Carl. op. cit., p. 175.
} 
social, como a universidade, a família, a igreja e as associações, podem receber uma proteção constitucional capaz de produzir diversos efeitos, inclusive a titularidade de direitos subjetivos. Mas não correspondem a direitos fundamentais, pois não pressupõem uma esfera de liberdade, em princípio ilimitada frente ao Estado, e a simultânea faculdade deste, em princípio limitada, de restringi-la.

Assim, à exceção dos concernentes a essa esfera de liberdade individual, Schmitt enfatizou que todos os outros direitos são passíveis de sofrerem plena restrição pelo Estado, incluindo as garantias institucionais, mesmo que direta ou indiretamente elas se voltem a assegurar o exercício dos direitos fundamentais de liberdade. Para ilustrar a diferença, o autor destacou as liberdades de expressão e de associação asseguradas pela Constituição de Weimar aos servidores públicos. Neste caso, teria havido uma confusão entre os direitos fundamentais da pessoa humana e as garantias institucionais. A qualidade de servidor público traduz um status especial; uma posição específica do indivíduo no aparato burocrático do Estado, com suas obrigações funcionais aliadas a outros deveres relativos ao serviço público. O status especial de servidor público é diverso da condição do ser humano em geral. E a liberdade individual ilimitada, sob a ótica de um direito fundamental, se aplicada de maneira consequente, poderia suprimir a própria natureza do conceito de serviço público. Assim, Schmitt atestou ser o status especial de servidor público totalmente determinante na hipótese. Os deveres concernentes a tal condição deveriam preponderar sobre as garantias de liberdade de associação e de expressão. $\mathrm{O}$ direito fundamental de expressão e associação do homem em geral não se confundiria com a garantia dessas mesmas liberdades ao servidor público, identificado com a instituição estatal a que pertence. A primeira hipótese configuraria um autêntico direito fundamental, enquanto a outra equivaleria a determinadas prescrições inseridas na lei constitucional, consubstanciando apenas uma garantia institucional ${ }^{438}$.

A doutrina de Carl Schmitt sobre garantias institucionais é de crucial importância para a compreensão, a contrário senso, de seu papel no contexto das organizações políticas. Os direitos fundamentais seriam apenas os que representam uma esfera da liberdade individual do ser humano, considerado isoladamente. É pressuposta a verificação de um

\footnotetext{
${ }^{438}$ SCHMITT, Carl. op. cit., p. 184-185. No mesmo sentido, para Schmitt, os princípios da inafastabilidade do controle jurisdicional, com a proibição dos tribunais de exceção, e da irretroatividade da lei penal também representam garantias institucionais. $\mathrm{O}$ fato de contarem com uma proteção constitucional contra supressões legislativas se justifica por razões históricas, em função de algumas experiências vivenciadas pela humanidade. Porém, Schmitt não reconheceu a existência de qualquer relação com os direitos fundamentais de liberdade.
} 
núcleo intangível que possibilite o exercício daqueles direitos, uma vez que a faculdade do Estado de estabelecer restrições seria limitada. Não há, no entanto, como inferir os reais limites para a ocorrência de ingerências do poder público. As garantias existem no Estado, que, como o supremo status da unidade política de um povo, constitui um fim em si mesmo, de caráter absoluto. Ora, na medida em que se supõe uma ameaça à preservação de tal status, o suposto raio de intangibilidade dos direitos fundamentais de liberdade pode ser reduzido em qualquer proporção. A configuração do âmbito da possibilidade da ação dos indivíduos acaba remanescendo o alvedrio da vontade estatal. A liberdade "não oferece nenhum padrão ou medida daquilo que o indivíduo está legitimado a opor em face do Estado. A opacidade do conceito mostra um vazio substantivo, (...), pois fica sem explicação o que o indivíduo, faticamente, pode ou não fazer" ${ }^{\text {,439 }}$.

Dessa forma, é possível perceber que, quanto mais se atenuem os vínculos estabelecidos entre os direitos fundamentais da pessoa humana e as garantias que informam a estrutura organizacional e o funcionamento do Estado, maior é o risco da opacidade e ineficácia daqueles. Quanto maior a distância entre a Constituição de um Estado, incorporando-o substancialmente como uma unidade existencial concreta, e um sistema formal de normas jurídicas, maior é a ameaça de abuso no exercício do poder político. Em outras palavras; sob qualquer justificativa versando sobre a necessidade da preservação da unidade política essencial ao Estado, dá-se lugar ao arbítrio.

\subsection{Os reflexos da Declaração Universal dos Direitos Humanos no constitucionalismo contemporâneo: o princípio da dignidade da pessoa humana}

Como se viu, seguindo a tradição do constitucionalismo inglês, para os norteamericanos a função de uma Constituição era consagrar formalmente o ato por meio do qual o povo, o real detentor da soberania, transferia o exercício do poder político aos governantes, para a realização dos direitos naturais do homem. A criação do Estado ocorreria para guiar os indivíduos a uma atuação em conformidade com a lei da natureza, para a preservação dos direitos inalienáveis inerentes à condição humana (direito à vida,

\footnotetext{
${ }^{439}$ FERRAZ JUNIOR, Tercio Sampaio. op. cit., p. 110. O autor apontou que, ao contrário da tradição francesa, na tradição germânica, a atuação da administração pública era exercida com ampla discricionariedade, isto é, se inexistiam limites específicos previstos em lei, era possível fazer tudo o que fosse considerado necessário para a "prossecução do bem público". Na administração francesa, a lei foi concebida como uma condição ao exercício do poder da administração; advém da lei a margem de discricionariedade para a atuação administrativa; daí o desenvolvimento da doutrina do "abuso de poder para os casos em que daquela margem de apreciação o administrador se excedesse” (Id. Ibid., p. 111).
} 
liberdade e propriedade). Por esse motivo, os governantes não poderiam atuar em dissonância da confiança neles depositada pelo povo ${ }^{440}$.

Nesse contexto, a Constituição representa o instrumento concebido para frear eventuais abusos governamentais, mediante um sistema de organização políticadestinado a assegurar o livre exercício dos direitos civis. Assim, o constitucionalismo norte-americano fundou-se no princípio da soberania popular, em direta correlação à defesa dos direitos individuais de liberdade. Cabe à Constituição delimitar as esferas de competências dos órgãos estatais, dentro daquele marco democrático sob as vestes da igualdade formal. Dotada de superioridade jurídica em relação às demais normas, a tarefa da Constituição é garantir o exercício limitado do poder político, em especial do legislativo, para cujas decisões a preservação da liberdade individual mostrou-se uma barreira instransponível. Por sua vez, garantir a Constituição compete ao Judiciário; a neutralidade legitima-o a efetuar a fiscalização dos limites impostos à atuação governamental ${ }^{441}$.

Por outro lado, conforme também foi assinalado, na concepção oriunda da Revolução Francesa, a diluição da ideia de soberania do povo em soberania nacional acabou comprometendo a força normativa da Constituição para condicionar, substancialmente, o comportamento dos poderes constituídos, sobretudo dos órgãos do legislativo e do executivo ${ }^{442}$. Com a adoção do modelo de representação democrática, os direitos humanos foram considerados um produto da atividade do Estado-legislador, que também passou a figurar como sujeito de direitos, ontologicamente distintos dos direitos dos cidadãos. E as decisões governamentais, emanadas dos representantes da vontade popular, foram se manifestando de forma ilimitada. Assim, ao longo de todo século XIX até meados do século $\mathrm{XX}$, na medida em que os paradigmas do direito natural foram sendo substituídos pelos dogmas do positivismo jurídico, os direitos humanos emergiram como uma concessão do Estado, única fonte do direito, surgindo apenas como um reflexo do próprio ordenamento jurídico ${ }^{443}$.

\footnotetext{
${ }^{440}$ Como já disposto, a ideia advém do Segundo tratado sobre o governo de Locke. Cf. 1.2. Cf. ainda ZAGREBELSKY, Gustavo. El derecho dúctil: ley, derechos, justicia. Trad. Marina Gascón. 8. ed. Madrid: Trotta, 2008. p. 54 e ss.

${ }^{44}$ Cf. PRIETO SANCHÍS, Luis. Neoconstitucionalismo y ponderacíon judicial. In: CARBONELL, Miguel (Ed.). Neoconstitucionalismo(s). 2. ed. Madrid: Trotta, 2005. p. 125 e ss.

${ }^{442}$ Id. Ibid., p. 126; cf. também ZAGREBELSKY, Gustavo. op. cit., p. 55.

${ }^{443}$ Cf. PEREZ LUÑO, Antonio Enrique. Derechos humanos, Estado de derecho y Constitución. 6. ed. Madrid: Tecnos, 1999. p. 242.
} 
No sistema proposto por Kelsen, a tarefa de uma Constituição foi reduzida ao estabelecimento de normas procedimentais e de competência, versando somente sobre critérios formais a orientarem as atividades do Estado, notadamente no que concerne à produção legislativa. Não seriam admitidas ingerências do Judiciário que escapassem ao âmbito do controle da estrita legalidade formal. E a apreciação de violações de tal natureza só poderia competir a um órgão superior instituído para o exercício da jurisdição concentrada $^{444}$. A função do Estado de Direito alicerçou-se na manutenção da segurança jurídica, como a obediência a um conjunto de normas estabelecidas pelos órgãos estatais dentro da esfera de suas competências e de acordo com procedimentos previamente estatuídos. Daí por que regras de qualquer conteúdo seriam válidas para imperar ${ }^{445}$. A disposição de garantias, vinculadas ao funcionamento de qualquer instituição pública ou privada, remanescia ao livre talante do Estado; e razões dele próprio, sobretudo se viessem justificadas em prol de sua unidade e identidade, poderiam ensejar a supressão daquelas.

Sob a égide da Constituição de Weimar, da irrupção do movimento nazista na Alemanha adveio o Estado totalitário, que, em um panorama de plena hegemonia e centralização de poder político, provocou o extermínio de sessenta milhões de pessoas e o surgimento de quatro milhões de refugiados, ao final da Segunda Grande Guerra (1939$1945)^{446}$. Foi essa a realidade no mundo ocidental que, ao final do conflito bélico, fez incorporar à consciência da humanidade a necessidade de retomar o estabelecimento de um parâmetro ético universal de convivência entre os indivíduos, para inseri-lo tanto na esfera das organizações políticas dos Estados, como no âmbito de suas relações internacionais.

A alusão é ao princípio da dignidade da pessoa humana, assim proclamado na Declaração Universal dos Direitos Humanos de 1948: “Todos os seres humanos nascem livres e iguais, em dignidade e direitos". Retomando o espírito de Montesquieu como o vetor responsável pela formação e pelo funcionamento das coletividades, tem-se o móvel que há de todos conduzir para a realização dos direitos que dele defluem. O princípio

\footnotetext{
${ }^{444}$ Cf. PRIETO SANCHÍS, Luis. Neoconstitucionalismo y ponderacíon judicial, cit., p. 127-129.

${ }^{445} \mathrm{Cf}$. Fábio Konder Comparato atribuiu ao positivismo jurídico a "incapacidade (ou formal recusa) em encontrar um fundamento ou razão justificativa para o Direito, sem cair em mera tautologia. $\mathrm{O}$ fundamento ou princípio de algo existe sempre fora dele, como sua causa transcendente, não podendo, pois nunca, sob o aspecto lógico e ontológico, ser confundido com um de seus elementos componentes" (COMPARATO, Fábio Konder. Fundamento dos direitos humanos: a noção jurídica de fundamento e sua importância em matéria de direitos humanos. Revista Consulex, ano 4, n. 48, p. 54, dez. 2000).

${ }^{446} \mathrm{O}$ agravamento da crise econômica e a instabilidade política provocada por uma extrema fragmentação partidária contribuíram para a transformação do Estado alemão no fúnebre cenário das atrocidades nazistas (cf. COMPARATO, Fábio Konder. A afirmação histórica dos direitos humanos, cit., p. 209; e Id. Ética: direito, moral e religião no mundo moderno, cit., p. 364 e ss.).
} 
concebe o homem como espécie e cada homem em sua individualidade, insubstituível; não há equivalente; não pode ser trocado por coisa alguma.

Mais ainda: o homem é não só o único ser capaz de orientar suas ações em função de finalidades racionalmente percebidas e livremente desejadas, como é, sobretudo, o único ser cuja existência, em si mesma, constitui um valor absoluto, isto é, um fim em si e nunca um meio para a consecução de outros fins ${ }^{447}$.

Não há dúvida de que a proteção à dignidade da pessoa humana representa o fundamento axiológico da gama de princípios e direitos fundamentais, positivada nos grandes textos normativos, posteriores à Segunda Guerra Mundial. Daí o dever de que toda e qualquer organização política ou social tenha em conta cada um dos indivíduos que a integram. Nenhuma entidade supraindividual, como o Estado, pode dispor do princípio da inviolabilidade da pessoa humana. Não é aceitável, de modo algum, que "certos indivíduos sejam usados em benefício exclusivo de outros" ${ }^{\wedge 48}$. Nesse passo, como desdobramentos da proteção à dignidade humana, os princípios centrais de cunho axiológico de todo sistema de direitos humanos são a liberdade, a igualdade e a solidariedade universal ${ }^{449}$.

Íntima se apresenta a relação entre as liberdades individuais e as liberdades públicas. É sempre tênue o exercício das liberdades privadas, sem a garantia do direito de participação na vida pública. Conforme ensinaram os antigos, a participação dos cidadãos nos assuntos de interesse comum é da essência de uma sociedade livre, que, do mesmo modo, não pode prosperar em organizações políticas em que não se assegura o exercício

\footnotetext{
${ }^{447}$ COMPARATO, Fábio Konder. Fundamento dos direitos humanos: a noção jurídica de fundamento e sua importância em matéria de direitos humanos, cit., p. 60. A matriz do homem como um fim em si mesmo representa o postulado de Kant (Cf. KANT, Immanuel. Fundamentação da metafísica dos costumes. Trad. Paulo Quintela. Lisboa: Ed. 70; LDA, 2004. p. 76-77). Fábio Konder Comparato apontou os atributos do ser humano sobre os quais repousa a dignidade que lhe é intrínseca; são eles: a liberdade, no sentido da autonomia de que dispõem os indivíduos para uma atuação de acordo com sua vontade, ditando regras próprias de comportamento; a autoconsciência, no sentido da capacidade do homem para identificar-se como um ser que existe no mundo, no tempo e no espaço; a sociabilidade, no sentido da vida em sociedade como condição imprescindível ao desenvolvimento e aprimoramento das especificidades humanas; a historicidade, no sentido da contínua e permanente transformação da natureza humana pelas experiências vivenciadas no curso da história; e a unicidade existencial que torna cada ser humano absolutamente insubstituível (Id. Ibid., p. 58-59).

${ }^{448}$ SANTIAGO NINO, Carlos. Derecho, moral y política. II. Fundamentos del liberalismo político. Derechos humanos y democracia deliberativa. Buenos Aires: Gedisa, 2007. p. 21.

${ }^{449}$ COMPARATO, Fábio Konder. A afirmação histórica dos direitos humanos, cit., p. 62 e ss. O fundamento de proteção à dignidade da pessoa humana foi introduzido não só na Constituição do Brasil em 1988, como também nas Constituições de Portugal, da Espanha, da República Italiana e da República Federal Alemã (cf. COMPARATO, Fábio Konder. Fundamento dos direitos humanos: a noção jurídica de fundamento e sua importância em matéria de direitos humanos, cit., p. 55).
} 
das liberdades individuais ${ }^{450}$. É preciso acatar que as duas "dimensões da liberdade são complementares e interdependentes". Sem as liberdades individuais, a liberdade política "não passa de engodo demagógico de Estados autoritários ou totalitários. E o reconhecimento das liberdades individuais, sem efetiva participação política do povo no governo, mal esconde a dominação oligárquica dos mais ricos" ${ }^{\text {451 }}$. O liberalismo convive com indivíduos livres, "mas solitários, livres para agir, mas não tendo voz ativa no cenário em que atuam, nem a mais vaga ideia do propósito a cujo serviço pode ser colocada sua liberdade" $" 452$

A igualdade entre todos os indivíduos veda aos sistemas normativos contemplar privilégios ou discriminações injustificadas a pessoas ou a grupos de pessoas. Mediante disposições genéricas e abstratas, a lei deve colher a todos igualmente. Mas a questão também aponta para a necessidade de ações concretas dirigidas à eliminação dos quadros de marginalização dos seres humanos, como forma de garantir que todos possam ser efetivamente amparados de idêntico modo pela lei.

Ao vincular a noção de equidade à de justiça corretiva, Aristóteles bem expôs a origem do problema, qual seja: "o fato de o equitativo ser justo, porém não o legalmente justo, e sim uma correção da justiça legal”. Isto ocorre porque, embora toda lei seja universal, não é possível fazer uma afirmação universal que seja correta em relação a determinados casos particulares. Dessa forma, quando a lei estabelece uma lei geral e nos vemos diante de um caso que não é abarcado por tal regra, é correto corrigir a omissão, tendo em vista que "legislador falhou e errou por excesso de simplicidade". Dizemos, então, "o que o próprio legislador teria dito se estivesse presente, e que teria incluído na lei se tivesse previsto o caso em pauta"453.

No plano da ideia da vontade estatal como criadora do direito positivo, Jhering procurou explicá-lo tendo em conta a relação com os fins sociais a que se destina. Nesse contexto, ao dispor sobre a igualdade, assim se manifestou:

Se o fardo que a sociedade põe sobre os ombros de seus membros é dividido desigualmente, sofre não só aquele que foi sobrecarregado, como também a sociedade toda, pois que o centro de gravidade é removido, o equilíbrio é perturbado, e o corolário natural disso é a luta

\footnotetext{
${ }^{450}$ Como foi visto, Benjamin Constant divisou as duas concepções de liberdade sedimentadas a partir da Revolução Francesa. Cf. 1.3.

${ }^{451}$ COMPARATO, Fábio Konder. A afirmação histórica dos direitos humanos, cit., p. 227.

${ }^{452}$ BAUMAN, Zigmunt. Em busca da política. Tradução de Marcus Penchel. Rio de Janeiro: Jorge Zahar, 2000. p. 169.

${ }^{453}$ Cf. ARISTÓTELES. Ética a Nicômaco, cit., p. 125.
} 
social com a finalidade de gerar o equilíbrio, luta que, em dadas circunstâncias, constitui ameaça altamente perigosa e abalo da ordem social existente $e^{454}$.

Por essa razão, aos direitos civis e políticos, sedimentados com fulcro no jusnaturalismo dos séculos XVII e XVIII, foram acrescidos os direitos sociais, econômicos e culturais, como reação à legalidade formal que, na esteira da igualdade de todos perante a lei, a sociedade liberal atribuíra à humanidade. Os direitos sociais, econômicos e culturais (direito à assistência social, saúde, educação, trabalho, etc.) representam a consolidação de novas exigências que, ao contrário de imporem ao Estado uma abstenção, dele reclamam uma atuação positiva em prol do bem-estar da coletividade ${ }^{455}$.

No entanto, o princípio da solidariedade é a amálgama dos vetores da liberdade e igualdade, reunindo-os em torno do bem comum. Isso porque, sob a perspectiva da igualdade e da liberdade, "cada qual reivindica o que lhe é próprio. No plano da solidariedade, todos são convocados a defender o que lhes é comum; (...) cada qual zela pelo bem de todos e a sociedade pelo bem de cada um de seus membros" ${ }^{\text {"456. }}$.

Sob os presentes paradigmas, a Declaração Universal de 1948 deu início ao processo de internacionalização dos direitos humanos, demarcando a visão contemporânea, que passou a concebê-los como uma unidade interdependente e indivisível. Dessa forma, adotando-se o critério metodológico que classifica os direitos humanos em gerações, compreende-se que "uma geração de direitos não substituiu a outra, mas com ela interage". Afasta-se assim “a equivocada ideia de sucessão 'geracional' de direitos, na medida em que se acolhe a ideia de expansão, cumulação e fortalecimento dos direitos humanos, todos essencialmente complementares e em constante dinâmica de interação" ${ }^{\text {457. }}$.

Na qualidade de fonte dos direitos humanos de toda e qualquer natureza, o princípio de proteção à dignidade da pessoa humana vem servindo de respaldo a novas reivindicações jurídicas que "têm como titular não o indivíduo na sua singularidade, mas

\footnotetext{
${ }^{454}$ Cf. JHERING, Rudolf von. A finalidade do direito. Trad. Heder K. Hoffmann. Campinas: Bookseller, 2002. t. 1, p. 249.

${ }^{455} \mathrm{~A}$ Revolução Industrial acarretou a enorme pauperização das massas proletárias e a organização da classe trabalhadora. Porém, a despeito da tímida proclamação de alguns na Constituição Francesa de 1848, os direitos sociais, econômicos e culturais afirmaram-se apenas no século XX, a partir da vigência da Constituição Mexicana de 1917 e da Constituição de Weimar de 1919 (cf. COMPARATO, Fábio Konder. A afirmação histórica dos direitos humanos, cit., p. 163-168).

${ }^{456}$ COMPARATO, Fábio Konder. Ética: direito, moral e religião no mundo moderno, cit., p. 577.

${ }^{457}$ PIOVESAN, Flavia. Direitos humanos e o direito constitucional internacional. 5. ed. São Paulo: Max Limonad, 2002. p. 149-150.
} 
sim grupos humanos como a família, o povo, a nação, coletividades regionais ou étnicas e a própria humanidade" ${ }^{458}$. O valor absoluto é sempre reconhecido em benefício da pessoa que, como um fim em si mesmo, representa o fundamento primeiro e último dos princípios que envolvem a natureza humana, concebida tanto em sua singularidade, como na vida em comum $^{459}$. No entanto, por ser a natureza humana variável no curso da história, não há como negar que o exercício dos direitos humanos pode restar limitado diante de muitas circunstâncias que implicam situações de direitos contrastantes da mesma índole. É o que, aliás, condiz com as características de complementaridade, irrevocabilidade e interdependência que os reveste.

Por fim, assentado como o primordial valor intrínseco à pessoa, o princípio de proteção da dignidade humana tende a subverter as próprias ideias de soberania e de cidadania para dissociá-la do Estado, e, ao ensejo da solidariedade universal, centrá-la no gênero humano ${ }^{460}$. Contudo, não se pode olvidar que o sistema internacional de proteção aos direitos humanos é conduzido pelas relações entre os Estados. Os organismos supranacionais dependem das iniciativas dos Estados-membros para um profícuo funcionamento. $\mathrm{E}$ os direitos humanos declarados no plano das relações internacionais têm como destinatários os mesmos Estados, aos quais compete tutelá-los e sobre os quais recai a responsabilidade nos casos de violação. Assim, o longo caminho à transformação de todos os indivíduos em cidadãos do mundo, inevitavelmente, compreende a superação das dificuldades de, antes, torná-los autênticos cidadãos ${ }^{461}$.

\subsubsection{A redefinição do Estado de Direito}

A aceleração do processo de reconhecimento universal dos direitos humanos revivificou o tema dos direitos fundamentais, ou seja, dos “direitos humanos reconhecidos como tal pelas autoridades, às quais se atribui o poder político de editar normas, tanto no

\footnotetext{
${ }^{458}$ LAFER, Celso. A reconstrução dos direitos humanos: um diálogo com o pensamento de Hannah Arendt. São Paulo: Companhia das Letras, 2001. p. 131.

${ }^{459}$ Princípio, para Kant, corresponde ao imperativo da moralidade: a lei prática incondicional que ordena o comportamento humano, independentemente de qualquer intenção ou fim a atingir. $\mathrm{O}$ "imperativo é categórico. Não se relaciona com a matéria da acção e com o que dela deve resultar, mas com a forma e o princípio de que ela mesma deriva; e o essencialmente bom na acção reside na disposição (Gesinnung), seja qual for o resultado" (Fundamentação da metafísica dos costumes, cit., p. 52).

${ }^{460}$ Nesse sentido, FERRAJOLI, Luigi. Más allá de la soberania y la cidadania: um constitucionalismo global. In: CARBONELL, Miguel (Comp.). Teoria de la Constitución: ensayos escogidos. 4. ed. México: Editorial Porrúa y Universidad Autónoma de Mexico, 2008. p. 397-409.

${ }^{461}$ Cf. MURA, Virgilio. Diritti dell'uomo e diritti del cittadino, cit., p. 41-43.
} 
interior do Estado, quanto no plano internacional; os direitos humanos positivados nas Constituições, nas leis, nos tratados internacionais" ${ }^{462}$.

Instando a convergência dos critérios de legitimidade e de legalidade, a Constituição Federal de 1988 respeitou a tendência do constitucionalismo contemporâneo, com a consagração de um extenso rol de princípios de justiça e de direitos fundamentais da pessoa humana, na esteira do processo de seu reconhecimento e afirmação no curso da história. Em harmonia com a Declaração Universal de 1948 e com os principais pactos internacionais que a sucederam, o ideal de proteção à dignidade da pessoa humana inseriuse no centro de uma fundamentação material do Estado de Direito de nossa Constituição ${ }^{463}$.

Esse valor figurou como fundamento do Estado, cujos objetivos são os de construir uma sociedade livre, justa e solidária; garantir o desenvolvimento nacional; erradicar a pobreza e a marginalização; reduzir as desigualdades sociais e regionais; e promover o bem de todos, sem preconceitos de origem, raça, sexo, cor, idade ou quaisquer outras formas de discriminação ${ }^{464}$. Foram estatuídos os clássicos direitos à vida, liberdade e propriedade, bem como os direitos políticos, sociais, econômicos e culturais, com a inclusão também daqueles decorrentes das novas reivindicações do gênero humano, como o direito ao meio ambiente ecologicamente equilibrado e à sadia qualidade de vida ${ }^{465}$.

Com efeito, a introdução de princípios de justiça nos textos constitucionais produziu uma redefinição do papel do Estado de Direito. Vale dizer; é impossível subtrair à Constituição a função de estabelecer como, quando e por quem o poder deve ser exercido no seio de qualquer organização política. Mas, além de disporem sobre a sua organização formal, os documentos constitucionais passaram a gerar uma série de direitos e obrigações imediatamente exigíveis do Estado. A Constituição mantém a determinação sobre "quem deve mandar, como deve mandar e até onde pode mandar", mas também impõe o objeto do

\footnotetext{
${ }^{462}$ COMPARATO, Fábio Konder. A afirmação histórica dos direitos humanos, cit., p. 56.

${ }^{463}$ Cf. PEREZ LUÑO, Antonio Enrique. op. cit., p. 241. Cf. o art. 1 ${ }^{\circ}$, III, da CF. A alusão é ao Pacto Internacional sobre Direitos Civis e Políticos e ao Pacto Internacional sobre Direitos Econômicos, Sociais e Culturais, ambos de 1966.

${ }^{464}$ Cf. o art. $1^{\circ}$, III, $c / c$ o art. $3^{\circ}$, I a IV, da CF.

${ }^{465} \mathrm{O}$ Título II da CF de 1988 foi dedicado à consagração de um vasto conjunto de direitos e garantias resultante do princípio de proteção da dignidade da pessoa humana. Cf. as normas dos arts. $5^{\circ}$ a 17 da $\mathrm{CF}$. Além de um conjunto de garantias incluindo vários mecanismos processuais para a defesa de direitos fundamentais, o catálogo do art. $5^{\circ}$ trouxe basicamente os tradicionais direitos de liberdade. A Constituição destinou também um capítulo próprio (art. $6^{\circ}$ ) para os direitos sociais, econômicos e culturais (direito à saúde, à educação, ao trabalho, à moradia, etc.), inserindo, mais adiante, um título específico sobre a ordem social (Título VIII). Em seguida, foram contemplados os direitos sociais decorrentes da relação de trabalho e, nos capítulos subsequentes, os direitos de nacionalidade e os direitos políticos, abrangendo a estrutura partidária concernente ao regime de representação democrática. Cf. as prescrições dos arts. $7^{\circ}$ a 11 do Capítulo II, do Título II, bem como as de seus Capítulos III a V, da CF. Cf. ainda 3.8.
} 
comando estatal ${ }^{466}$. Conservou-se a herança dos próceres da independência dos Estados Unidos da América, para quem a Constituição foi concebida como o resultado da expressão definitiva da soberania popular para restringir o poder governamental e, por conseguinte, assegurar a liberdade individual dos cidadãos. Porém, a ideia de permanente exercício da soberania pelo povo também se fez presente para provocar a manifestação do Estado na realização dos valores destinados à proteção da dignidade da pessoa humana. Sob o enfoque da supremacia dos princípios fundamentais, o constitucionalismo contemporâneo vem avançando para a realização de um amplo projeto político dirigido à transformação da sociedade. A ordem constitucional pretende, pois, instar a ação do Estado, pormenorizando os elementos das decisões políticas capazes de efetivar as metas estabelecidas aos programas governamentais ${ }^{467}$.

O princípio da supremacia da Constituição reclama de todas as ações dos órgãos estatais o fiel respeito ao comando constitucional, repudiando tanto as atuações positivas, como as omissões que lhe sejam contrárias. E, aqui, é preciso sempre ter em mente que o objetivo básico de uma Constituição é assegurar "a vigência e a eficácia dos direitos fundamentais da pessoa humana. A organização constitucional do Estado e dos Poderes não tem valor em si, mas só o tem na medida em que são preordenados para fazer valer aquele objetivo constitucional" ${ }^{\text {468 }}$.

Munido de forte carga axiológica, o conjunto de direitos fundamentais deve ser incorporado concretamente às ações do Estado. As cláusulas dispõem de força vinculante em relação à atuação dos seus agentes, com o aparato constitucional não mais se restringindo ao estabelecimento de simples molduras de relações entre órgãos públicos, para assumir a função de uma ordenação efetiva da realidade sociopolítica. As atividades dos órgãos estatais estão vinculadas àqueles postulados fundamentais que representam uma pauta para a "realidade vital", um programa de integração política e social gerado pelas experiências do passado, determinante para o presente e para as projeções futuras da sociedade. Configuram, pois, as normas básicas "que marcam uma direção e as decisões de valor para o processo político e para a comunidade (...)"469.

\footnotetext{
${ }^{466}$ Cf. PRIETO SANCHÍS, Luis. Neoconstitucionalismo y ponderacíon judicial, cit., p. 126.

${ }^{467}$ De um modo geral, trata-se de acepção do denominado neoconstitucionalismo, que procurou incorporar um tipo de Estado de Direito como modelo institucional de uma nova fórmula de organização política (cf. Id. Ibid., p. 123).

${ }^{468}$ SILVA, José Afonso da. Comentário contextual à Constituição. São Paulo: Malheiros Ed., 2005. p. 538.

${ }^{469} \mathrm{Cf}$. Klaus Stern dispondo sobre as características da ordem constitucional que devem orientar o processo de interpretação de suas normas (STERN, Klaus. Derecho del Estado e la Republica Federal Alemana.
} 
É nesse contexto que os princípios de organização política e os direitos fundamentais se convertem num todo indivisível, condicionando-se mutuamente, sempre à mercê da unidade do conjunto no qual se inserem em permanente conexão ${ }^{470}$. Mas, ao lado do princípio da unidade, a efetividade também constitui um postulado de interpretação constitucional aplicável às normas de princípios organizacionais e de direitos fundamentais que compõem a estrutura básica do Estado Constitucional de Direito. Os critérios de interpretação constitucional devem sempre "maximizar" a eficácia daqueles preceitos, em atenção ao seu conteúdo e à importância de que dispõem para a determinação da atividade estatal, sempre sem perder de vista a realidade política subjacente ${ }^{471}$.

É indispensável colher uma coexistência harmônica entre normas de princípios fundamentais no âmbito do atual Estado de Direito, reconhecendo-as com máximo grau de hierarquia, máxima força normativa e elevada importância de conteúdo. As relações de tensão devem ser ordenadas com correção, isto é, mediante a identificação do peso específico de preceitos eventualmente contrastantes para limitar as esferas de incidência de eventuais conflitos. Para a efetividade das normas de princípios, que costumam contar com um conteúdo axiológico e, por conseguinte, um campo de abrangência indeterminado, é preciso equilibrar, compatibilizar as discrepâncias que possam surgir em sua aplicação. No âmbito da hermenêutica, não há como afastar o caráter valorativo para a identificação das reais exigências que sustentam os direitos fundamentais de proteção à dignidade da pessoa

Trad. Javier Perez Royo y Pedro Cruz Villalón. Madrid: Centro de Estudios Constitucionales, 1987. p. 286 e ss.). A obediência ao conjunto de direitos fundamentais da pessoa humana deve ser o principal alvo de atenção dos órgãos estatais, levando a atuação do judiciário a se estender sobre toda a produção legislativa, fato que passou a representar o "marco dos direitos fundamentais". Os juízes acabaram, assim, assumindo a responsabilidade de considerá-los necessariamente em suas decisões, como irradiações valorativas obrigatórias sobre todo o ordenamento jurídico (ALEXY, Robert. Los derechos fundamentales en el Estado constitucional democrático. In: CARBONELL, Miguel (Ed.). Neoconstitucionalismo(s), cit., p. 34). As controvérsias de índole constitucional sobre a aplicabilidade das normas de direitos fundamentais não mais representam questões circunscritas somente à relação entre a Corte Constitucional e o Poder Legislativo, passando a abranger também as atividades dos juízes ordinários, como parâmetros indispensáveis em suas decisões.

${ }^{470}$ Cf. PEREZ LUÑO, Antonio Enrique. op. cit., p. 276; e STERN, Klaus. op. cit., p. 237-238 e 291-293. Em estrita atenção ao caráter político da Constituição, Ruddolf Smend desenvolve a sua teoria de integração dos bens, exigências e valores nela insculpidos, com a renúncia a aspectos formais que obscurecem a essência material de tal objeto, isto é, a vida concreta do Estado e da comunidade (cf. SMEND, Rudolf. Costituzione e diritto costituzionale. Trad. F. Fiore e J. Luther. Milano: Giuffrè, 1988. p. 216 e ss.; e STERN, Klaus. op. cit., p. 284-285).

${ }^{471}$ Cf. PEREZ LUÑO, Antonio Enrique. op. cit., p. 278; e STERN, Klaus. op. cit., p. 287-288. Cf. também a observação de Konrad Hesse quanto à atualização normativa permanente dos preceitos constitucionais. Como as possibilidades históricas dessa atualização estão em constante transformação, devem ser priorizados, na solução dos problemas jurídico-constitucionais, os pontos de vista que proporcionem às normas constitucionais uma "força de efeito ótima" (HESSE, Konrad. Elementos de direito constitucional da República Federal da Alemanha. Trad. Luís Afonso Heck. 20. ed. Porto Alegre: Sergio Antonio Fabris, 1998. p. 68). 
humana. É necessária, no entanto, uma investigação conceitual para estabelecer o conteúdo e o alcance das disposições normativas, com base, no entanto, em "argumentos sérios e razoáveis" para justificá-los, de sorte a impedir a superveniência de uma fundamentação pautada por critérios subjetivos de moralidade ${ }^{472}$.

Justamente ao dispor sobre a estrutura normativa dos direitos fundamentais, Robert Alexy ressaltou que, por se tratarem normalmente de princípios, os preceitos dispõem de larga esfera de abrangência e elevado grau de indeterminação. Os princípios são mandatos de otimização caracterizados pela possibilidade de serem cumpridos em diferentes graus, com a medida de seu cumprimento dependendo das possibilidades reais e jurídicas. Diversamente dos princípios, as regras contêm o seu âmbito de incidência predeterminado; são ou não cumpridas; se uma regra é válida, é possível, com exatidão, a realização da exigência nela contida. Dessa maneira, buscando satisfazer as exigências mínimas de uma fundamentação racional para solucionar hipóteses de colisão entre preceitos de direitos fundamentais de estrutura principiológica, o autor propõe um modelo interpretativo de ponderação entre os bens contrastantes, à luz das circunstâncias do caso concreto ${ }^{473}$.

Há sempre que recorrer à unidade da Constituição, perseguindo uma harmonia entre o que é "(aparentemente) contraditório"474; disciplinas de princípios constitucionais usualmente exigem uma concordância prática, pois "nenhum bem jurídico deve ser considerado de grau superior em detrimento de outro valor" igualmente amparado pela Constituição, a menos que ela própria determine a distinção ${ }^{475}$. Daí a obrigatoriedade de opção pelo intérprete da solução que proteja da melhor maneira possível os direitos fundamentais, implicando "conceber o processo hermenêutico constitucional como uma tarefa tendente a maximizar e otimizar a força expansiva e a eficácia dos direitos fundamentais em seu conjunto" ${ }^{, 476}$.

\footnotetext{
${ }^{472}$ Nesse sentido, cf. CRUZ, Luis M. Estúdios sobre el neoconstitucionalismo. Mexico: Porrúa; Instituto Mexicano de Derecho Procesal Constitucional, 2006. p. 55.

${ }^{473}$ Cf. ALEXY, Robert. Teoría de los derechos fundamentales, cit., p. 86 e ss. Cf. ainda, sobre a diferença entre regras e princípios para fins de interpretação constitucional, DWORKIN, Ronald. Taking rights seriously. Cambridge: Harvard University Press, 1977. p. 22 e ss.

${ }^{474}$ STERN, Klaus. op. cit., p. 292-293.

${ }^{475}$ Id. Ibid., p. 293-294. O princípio da concordância prática no âmbito de uma ponderação de bens ou de valores é referido por Konrad Hesse também como uma técnica de interpretação constitucional (HESSE, Konrad. op. cit., p. 66-67).

${ }^{476}$ PEREZ LUÑO, Antonio Enrique. op. cit., p. 315-316. Klaus Stern critica a utilização da máxima "in dúbio pro libertate" como objetivo político e método de interpretação constitucional, caso se pretenda levar em conta apenas o aspecto de proteção dos tradicionais direitos de liberdade (STERN, Klaus. op. cit., p. 295).
} 
É o que impõe o reconhecimento do potencial de eficácia diferenciado atribuído pelo constituinte de 1988 às normas de direitos fundamentais, no claro intuito de revigorá$\operatorname{las}^{477}$. Tal vetor não deixa de encontrar total ressonância nas características de complementaridade, irrevocabilidade e interdependência de qualquer regime jurídico de proteção de direitos humanos. Pelo princípio da vedação do retrocesso, é obrigação do intérprete a realização dos efeitos pretendidos pelo princípio da dignidade da pessoa humana, mediante uma progressiva e permanente efetivação dos valores incorporados em todas as disposições que lhe são correspondentes ${ }^{478}$.

Nessa mesma linha, repousa o conteúdo materialmente aberto atribuído pela Constituição de 1988 aos direitos fundamentais, estabelecendo a necessidade do reconhecimento de direitos nela contidos implicitamente, em decorrência do regime e dos princípios por adotados. Daí também se extrai a extensão da rigidez formal de proteção conferida pelo constituinte ao sistema de direitos fundamentais, para fins do mais elevado grau máximo de intagibilidade ${ }^{479}$. Cumprindo o alerta de a vedação amparar não só a hipótese de iniciativas voltadas à supressão das disposições constantes do sistema, mas também as tendentes a desfigurá-las, é preciso frisar inexistência de qualquer distinção hierárquica entre as modalidades de direitos fundamentais, eis que todos representam desdobramentos de um bem mais elevado, qual seja: a dignidade da pessoa humana como o mais alto valor incorporado à Constituição e, assim, consolidado como a fórmula universal do novo Estado de Direito ${ }^{480}$.

\footnotetext{
${ }^{477} \mathrm{O}$ art. $5^{\circ}, \S 1^{\circ}$, da CF, estabeleceu serem os direitos e garantias fundamentais imediatamente aplicáveis.

${ }^{478}$ Como consequência da eficácia atribuída aos princípios fundamentais, por meio do postulado da vedação do retrocesso, é possível a invalidade pelo Judiciário da revogação de normas jurídicas tendentes a ampliar ou a concretizar os efeitos daqueles. Não se cuida da possibilidade de substituição de uma forma de atingir um objetivo constitucional por outra que se entenda também apropriada. A questão é do esvaziamento do comando constitucional, então concretizado, pela produção normativa, sem que haja substituição por outra capaz de concretizá-lo de modo equivalente (cf. BARROSO, Luís Roberto. Interpretação e a aplicação da Constituição. 6. ed. São Paulo: Saraiva, 2004. p. 379-380).

${ }^{479} \mathrm{O}$ art. $5^{\circ}, \S 2^{\circ}$, da CF, dispõe que o conjunto de direitos e garantias fundamentais do respectivo catálogo da Constituição "não excluem outros decorrentes do regime e dos princípios por ela adotados, ou dos tratados internacionais em que a República Federativa do Brasil seja parte". O princípio de defesa à dignidade da pessoa humana também representa o ponto de referência para a solução de eventuais conflitos entre o direito interno e o Direito Internacional: "No plano de proteção dos direitos humanos interagem o Direito Internacional e o Direito interno movidos pelas mesmas necessidades de proteção, prevalecendo as normas que melhor protejam o ser humano, tendo em vista que a primazia é da pessoa humana. Os direitos internacionais constantes dos tratados de direitos humanos apenas vêm a aprimorar e fortalecer, nunca a restringir ou debilitar o grau de proteção dos direitos consagrados no plano normativo constitucional" (PIOVESAN, Flavia. op. cit., p. 115-116). Cf. ainda o art. 60, § $4^{\circ}$, IV, da CF.

${ }^{480}$ BONAVIDES, Paulo. op. cit., p. 595.
} 


\subsection{O Estado Democrático de Direito na Constituição de 1988: uma república democrática}

No contexto do princípio da dignidade da pessoa como o centro axiológico da concepção do Estado Democrático de Direito, inserem-se os princípios fundamentais do Título I da Constituição de 1988, ou seja, as disposições relativas ao sistema de governo, à forma de Estado, aos objetivos da República e às matrizes que devem orientá-la em suas relações internacionais. O Estado federal brasileiro é uma república democrática, com o exercício do poder político pautado pelo princípio fundamental do controle recíproco entre os órgãos estatais ${ }^{481}$.

No entanto, sobreleva-se sempre o dever do Estado de compelir progressivamente os indivíduos a uma existência moral. A justificação do Estado reside em princípios de natureza ética que legitimam a existência e o exercício do poder político. O Estado há de contar com a organização necessária para assegurar a realização dos princípios morais que representam o fundamento do direito positivo, condicionando as decisões consistentes em determiná-lo. A organização moral da sociedade é a principal tarefa do Estado, que não pode ser reduzido a um mero espectador da vida social, e tampouco ao protagonista da condução de uma engrenagem econômica. Acima das aspirações nacionais existem outras, "menos efêmeras e mais elevadas, porque não se atêm às condições especiais em que se encontram um grupo político determinado (...)" ${ }^{, 42}$. São fins humanos que se sobrepõem a particularidades e tendem à universalidade. Mas, para que as sociedades incorporem a consciência moral necessária à realização desse ideal, é necessário que cada Estado priorize a convocação de seus membros para uma vida moral cada vez mais elevada, de modo que os seus deveres cívicos coincidam com os deveres gerais da humanidade ${ }^{483}$.

\footnotetext{
${ }^{481}$ Cf. os arts. $1^{\circ}$, caput, e III, $\S$ único; e $2^{\circ}, c / c$ os art. $3^{\circ}$, I a IV, da CF. Segundo Luís Roberto Barroso, o princípio da dignidade da pessoa humana tornou-se "o centro axiológico da concepção de Estado Democrático de Direito e de uma ordem mundial idealmente pautada pelos direitos fundamentais" (BARROSO, Luís Roberto. op. cit., p. 374-375). No mesmo sentido é a posição de Luis Prieto Sanchis. Cf. PRIETO SANCHÍS, Luis. El constitucionalismo de los derechos. In: CARBONELL, Miguel (Ed.). Teoría del neoconstitucionalismo: o ensayos escogidos. Madrid: Editorial Trotta; Instituto de Investigaciones Jurídicas - UNAM, 2007. p. 216).

${ }^{482}$ DURKHEIM, Émile. Lições de sociología, cit., p. 100-101.

${ }^{483}$ Id. Ibid., p. 104. Hermann Heller também alertou para a importância de se atribuir ao Estado um fundamento moral. Valendo-se de sua estrutura organizacional, o Estado declara e executa o direito positivo, com base em princípios morais. Ao se afirmar, portanto, que "o Estado só pode ser consagrado por sua especificidade de organização em prol da segurança jurídica, quer dizer que só é possível justificar o Estado enquanto ele serve à aplicação e à execução dos princípios morais do direito" (HELLER, Hermann. Teoría del Estado. Trad. Luis Tóbio. 2. ed. México: Fondo de Cultura Económica, 1998. p. 282285).
} 
Nesse sentido, Cícero definiu a república como a coisa do povo, "considerando tal, não todos os homens de qualquer modo congregados, mas a reunião que tem seu fundamento no consentimento jurídico e na utilidade comum". A primeira causa dessa agregação é "um certo instinto de sociabilidade em todos inato; a espécie humana não nasceu para o isolamento (...), mas com uma disposição que, mesmo na abundância de todos os bens, a leva a procurar o apoio comum"484. Em uma república, a virtude, que mantém os vínculos sociais entre os homens, consiste "em evitar que um indivíduo cause dano a outro (...) e, seguidamente, em garantir que se utilize os bens comuns em proveito da comunidade (...) ${ }^{m 485}$. No mesmo passo, Montesquieu indicou a característica central das repúblicas democráticas; vale lembrar: a prioridade do zelo pelo bem comum que, na comunhão de um espírito virtuoso, leva os indivíduos a se considerarem em pé de igualdade no seio de uma organização política ${ }^{486}$.

Sob a perspectiva de uma república democrática, cabe frisar o nexo incindível entre a democracia e o respeito aos direitos humanos. Não há falar em democracia sem o respeito aos direitos humanos, cuja realização, em contrapartida, só é possível em um regime político democrático. Somente a democracia admite a extensão universal dos direitos políticos, na qualidade de pré-requisito para a produção de todo e qualquer direito ínsito à dignidade da pessoa humana. Trata-se, ademais, de uma condição indispensável ao controle pelos cidadãos das decisões políticas, de maneira que correspondam aos reais interesses da sociedade, tendo em mira o pressuposto republicano de defesa do bem comum $^{487}$. A república é uma instituição que encara a liberdade não apenas como uma reação ao abuso do poder político do Estado, mas como um poder capacitante dos cidadãos; "como liberdade de participar; uma instituição que tenta, sempre de forma inclusiva, (...) obter um equilíbrio entre a liberdade individual contra a interferência e o direito do cidadão intervir". É a amalgama que une os indivíduos em uma comunidade política $^{488}$

A ideia de moralidade política sinaliza a necessidade de atenção aos primados da liberdade, igualdade e solidariedade, consolidados na história da humanidade como os valores centrais do sistema de direitos humanos, a partir dos movimentos revolucionários

\footnotetext{
${ }^{484}$ CÍCERO, Marco Túlio. Da República, cit., Livro Primeiro, XXV, p. 27.

${ }^{485}$ Id. Dos deveres (De officiis). Trad. Carlos Humberto Gomes. Lisboa: Ed. 70 LDA, 2000. p. 22.

${ }^{486}$ Cf.1.1.2.

${ }^{487}$ Cf. MURA, Virgilio. op. cit., p. 37-38.

${ }^{488}$ BAUMAN, Zigmunt. op. cit., p. 168-169.
} 
do século XVIII ${ }^{489}$. É o que vai determinar a noção de participação moral no processo político, transformando os indivíduos em sujeitos morais da coletividade para torná-los corresponsáveis pelas decisões governamentais destinadas à realização dos direitos fundamentais.

Segundo os cânones da liberdade dos antigos, o direito à autodeterminação coletiva pressupõe, sobretudo, que os membros de uma comunidade política possam considerar como suas as medidas que dela sobrevenham, ainda que não tenha havido uma participação ou interferência direta nos correspondentes processos decisórios. A condição de sujeitos morais de uma coletividade implica não só o direito à participação nas decisões comuns, mas também a existência de um interesse direto nas mesmas decisões. Os indivíduos devem ter também a oportunidade de alterá-las, mediante vias de controle da ação dos governantes; é o "povo que governa os governantes"

Além disso, o espírito republicano de apego ao que é de todos faz com que as consequências de uma decisão política na vida de um cidadão devam ser levadas em conta na mesma proporção das repercussões provocadas na vida de seus pares, sinalizando a ilegitimidade de medidas governamentais em que são desprezadas as necessidades de uma minoria em prol da vontade da maioria dos cidadãos ${ }^{491}$. Em muitas circunstâncias, os indivíduos podem assumir a condição de sujeitos morais de uma comunidade política, quando as decisões de interesse coletivo são afastadas da arena do "peso dos números" e da balança da política partidária, e transferidas a órgãos estatais cuja estrutura e funcionamento estejam imunes a essas pressões e radicados com maior isenção nas necessidades e nos interesses da coletividade ${ }^{492}$.

Assim, a atuação independente do Judiciário, com o regime de seleção de seus componentes orientado pela garantia de acesso aos cargos públicos em igualdade de condições, faz parte de um regime democrático de governo capaz de assegurar "a

\footnotetext{
${ }^{489}$ DWORKIN, Ronald. Freedom's law. Cambridge: Harvard University Press, 1997. p. 19.

${ }^{490}$ Id. Ibid., p. 28-29. Dworkin citou como exemplo as decisões de perseguição aos judeus no curso do nazismo. Os judeus alemães, muito embora tenham participado das eleições que conduziram Adolf Hitler à Chancelaria, não tiveram, à evidência, nenhuma participação moral no holocausto; não poderiam, assim, ser considerados membros morais da comunidade política por ele responsável (Id. Ibid., p. 23). Para estabelecer a diferença entre a concepção pessoal de moralidade e a que se insere no âmbito da moralidade pública, Alexy acentuou a diferença entre a resposta às perguntas "Como quero viver?" e "Como queremos viver?". A resposta à primeira questão contém a representação do que é bom na vida de cada um. Já a resposta à segunda questão põe em relevo uma representação comum sobre as condições justas de cooperação em um mundo marcado pelo pluralismo (ALEXY, Robert. Los derechos fundamentales en el Estado constitucional democrático, cit., p. 40).

${ }^{491}$ Id. Ibid., p. 22 e ss.

${ }^{492}$ Cf. DWORKIN, Ronald. op. cit., p. 30 e s.
} 
preservação do sistema de checks and balances, em face do crescimento dos poderes políticos, e também controles adequados perante os outros centros de poder (não governativos ou quase governativos)", controles típicos das nossas sociedades contemporâneas $^{493}$. Dessa forma, o desenvolvimento de centros legítimos de exercício do poder político, com o fortalecimento de instrumentos que ampliem o acesso à justiça, estreitando os canais de comunicação entre o Judiciário e a sociedade civil, sempre será um elemento de vital importância no âmbito de um Estado Democrático de Direito. Com isso, aumentam as perspectivas de uma efetiva participação da sociedade nas decisões estatais envolvendo assuntos de interesse comum ou de interesses dos grupos de pessoas que se ressintam de elos de representatividade junto aos órgãos governamentais ${ }^{494}$.

Não se negue a existência das redes de relações de poder que vêm sendo mantidas entre diversos setores públicos e organizações sociais e econômicas, encerrando-se novos centros de autoridade política, sem um preciso respaldo em instituições jurídicas ${ }^{495}$. Tal situação tende a afastar a possibilidade de análise do poder político do Estado sob uma perspectiva institucional. A Constituição não poderia efetivar um estatuto de exercício do poder político apenas estaria sujeito a práticas políticas de caráter contingencial, resultantes de processos consensuais entre agentes políticos e atores sociais ${ }^{496}$. Debilitando a atuação das instituições do Estado, a hipótese não chega a possibilitar uma real política de consensos, cingindo-se a relações sub-reptícias entre agentes políticos e detentores do poder econômico que apenas se sustentam entre as partes envolvidas. O intercâmbio não representa nenhuma garantia de realização dos direitos fundamentais, não contribuindo

${ }^{493}$ Cf. CAPPELLETTI, Mauro. Juízes legisladores? Trad. Carlos Alberto Alvaro de Oliveira. Porto Alegre: Sergio Antonio Fabris, 1999. p. 107. A natureza da função judicial é diversa das que caracterizam os outros poderes tradicionais do Estado, não interferindo, de modo algum, no raio da autonomia necessária ao respectivo desenvolvimento por seus órgãos. O juiz só se manifesta se é devidamente instado no âmbito do devido processo legal, sob o manto do contraditório e da ampla defesa. São princípios que também garantem a legitimidade do exercício da função jurisdicional, conjugados à ampliação do acesso à justiça derivada da implantação de novos institutos voltados à garantia do rol de direitos fundamentais estatuído nas atuais Constituições. Com a nota da efetividade do processo, a Constituição também consagrou os princípios do devido processo legal e o da inafastabilidade do controle jurisdicional (art. $5^{\circ}$, XXXV, LIV e LV, da CF).

${ }^{494}$ Id. Ibid., p. 99 e ss.

${ }^{495}$ Cf. GARCÍA-PELAYO, Manuel. Las transformaciones del Estado contemporâneo. 2. ed. Madrid: Alianza Editorial, 1996. p. 132 e ss). É o contexto em que se inserem as alianças entre partidos políticos e agentes estatais com organizações e grupos sociais detentores de grande poder econômico, influência política e acesso a informações, resultando em medidas governamentais totalmente alheias à concepção majoritária, base da democracia. São cada vez mais frequentes os casos em que elas não refletem nem a vontade, nem as preferências e, tampouco, os interesses da maioria dos cidadãos (cf. CAPPELLETTI, Mauro. op. cit., p. 94-96).

${ }^{496}$ Cf. VALADÉS, Diogo. Constitución y control político. In: CARBONELL, Miguel (Comp.). Teoria de la Constitución: ensayos escogidos. 4. ed. México: Editorial Porrúa y Universidad Autónoma de Mexico, 2008. p. 354 e ss. 
para a limitação ou o controle do exercício do poder político; ao contrário, procura-se forjar ocorrência de restrições nas ações do Estado, justamente com o fim de não efetivá$\operatorname{las}^{497}$.

Por outro lado, a relevância da atuação institucionalizada dos corpos intermediários constitui outra nota distintiva de um regime democrático de governo ${ }^{498}$. Quando a ação governamental é subtraída ao olhar do povo, os motivos que a determinaram permanecem ignorados pela sociedade, encerrando-se no interior dos órgãos estatais. É indispensável a existência de estreitos vínculos de comunicação entre o povo e o governo, para a extensão da consciência do Estado sobre o maior número de aspectos da vida social, e também da consciência da coletividade sobre o funcionamento dos órgãos governamentais, possibilitando o controle adequado de suas ações. Porém, o papel do Estado não é, de modo algum, ecoar a vontade dos cidadãos, mas se sobrepor a elas, como um foco de novas representações sobre as quais devem incidir as deliberações governamentais, de sorte que a sociedade possa se conduzir da melhor forma possível ${ }^{499}$. É, então, de enorme relevo a intermediação de forças políticas que se coloquem entre o governo e o povo para estreitar os canais de comunicação entre eles e, ao mesmo tempo, manter certa independência do Estado para a gestão dos negócios públicos. Trata-se da importância dos quadros secundários de profissionais que conservam a autonomia do governo, propiciando a adequação de suas decisões às reais expectativas da sociedade, e que, ao mesmo tempo, fornecem o equilíbrio necessário entre as forças políticas para impedir a ocorrência de abuso de poder ${ }^{500}$.

\footnotetext{
${ }^{497}$ VALADÉS, Diogo. op. cit., p. 354-355. No campo da ciência política, retomando a perspectiva institucional de investigações, cf. SKOCPOL, Theda. Bringing the State back in: strategies of analysis in current research: ntroduction. In: EVANS, Peter B. RUESCHEMEYER, Dietrich; SKOCPOL, Theda (Eds.). Bringing the State back in. Cambridge: Cambridge University Press. 1998. p. 3-37; e THELEN, Kathleen; STEINNO, Sven. Historical institutionalism in comparative politcs. In: _______ (Eds.). Structurin politcs historical institutionalism in comparative politcs. Cambridge: Cambridge University Press, 1992. Reprinted 1998. p. 1-32.

${ }^{498}$ DURKHEIM, Émile. Lições de sociología, cit., p. 118 e ss. Segundo Durkheim, o Estado representa um organismo especial encarregado de incorporar certas representações coletivas da sociedade. As representações coletivas são estados de consciência que diferem das consciências individuais, revestindo-se de uma realidade própria. Elas manifestam o modo pelo qual um grupo social encara a si mesmo; correspondem a um tipo de pensamento difuso na sociedade, refletindo os sentimentos, as aspirações e crenças elaboradas pelo corpo social e nele disseminados. Ao Estado cumpre arquitetar as representações coletivas que valem para a coletividade, organizando-as adequadamente (op. cit., p. 70-71 e 110-114).

${ }^{499}$ Id. Ibid., p. 128 e ss.

${ }^{500}$ Id. ibid., p. 133 e ss. Como instrumento da democrática participativa, vale registrar a atuação dos conselhos formados por agentes estatais e integrantes da sociedade civil organizada para influir nas deliberações de políticas públicas.
} 
No século XIX, o institucionalista Maurice Hauriou apontou o Estado como uma instituição corporativa $^{501}$. O Estado seria a encarnação da ideia de uma obra que se realiza e subsiste juridicamente em um meio social. Para a realização de tal ideia, é preciso a organização de um poder; por outro lado, deve haver manifestações de consenso pelos membros do grupo social, dirigidas por órgãos daquele poder e regulamentadas por procedimentos. Com isso, o poder organizado e as manifestações de consenso da sociedade interiorizam-se em torno da ideia central da obra a que corresponde o Estado. Remetendo à concepção dos antigos, a liberdade política está condicionada à participação dos cidadãos nas decisões governamentais, revelando aquelas manifestações de consenso dos membros da sociedade acerca das providências adotadas pelos órgãos estatais. É o que enseja a personificação do Estado, transformando-o em uma pessoa moral, sem perder a individualidade objetiva: "a personalidade moral sobrepõe-se à individualidade objetiva do corpo estatal, mas esta não desaparece" ${ }^{, 502}$.

Nesse contexto, Hauriou não viu razão alguma para que a vida política restasse vinculada apenas a uma organização de três membros ${ }^{503}$. É perfeitamente natural que um sistema de distribuição de poderes vá experimentando alterações ao longo do tempo, com o surgimento de outros instrumentos para a condução da ideia diretriz da obra que constitui o Estado, sempre mediante a participação ativa dos cidadãos na vida púbica. O elemento essencial do princípio de separação dos poderes seria justamente um funcionamento em concerto, por meio de uma colaboração recíproca entre os órgãos estatais. De uma concepção dinâmica e flexível do postulado de Montesquieu, resulta um sistema de organização política de equilíbrio e inter-relação entre as forças que o compõem, produzindo uma vida permanente e contínua para o governo e a garantia da liberdade dos cidadãos $^{504}$. Assim, Hauriou destacou a crescente utilização de mecanismos da democracia

\footnotetext{
${ }^{501}$ Refutando as ponderações de Durkheim em torno da redução do direito a elementos objetivos, no intuito de transpor a dicotomia entre o subjetivismo e o objetivismo jurídico, Hauriou apontou, em sua teoria da instituição, "todo elemento da sociedade cuja duração não depende da vontade subjetiva de sujeitos determinados". Ele definiu uma instituição como "uma ideia objetiva transformada em obra social por um fundador; ideia que recruta adesões no meio social e submete ao seu serviço vontades subjetivas indefinidamente renovadas". Cf. HAURIOU, Maurice. Principios de derecho público y constitucional. Trad. Carlos Ruiz del Castilho. Granada: Editorial Comares, 2003. p. 90-91; e La teoria de la institucion y de la fundacion. Trad. Arturo Enrique Sampay. Buenos Aires: Abeledo-Perrot, 1968. Cf. ainda MACEDO JÚNIOR, Ronaldo Porto. Carl Schmitt e a fundamentação do direito, cit., p. 81 e ss.

${ }^{502}$ HAURIOU, Maurice. La teoria de la institucion y de la fundacion, cit., p. 57. "O Estado, para Hauriou, é a mais eminente das instituições da ordem social, que busca constituir o governo central de uma nação e desenvolver o interesse público, consistindo em uma superestrutura política fundada no consentimento" (BERCOVICI, Gilberto. Soberania e Constituição: para uma crítica do constitucionalismo, cit., p. 271).

${ }^{503}$ HAURIOU, Maurice. Principios de derecho público y constitucional, cit., p. 417, p. 420-421.

${ }^{504}$ Cf. Id. Ibid., p. 417.
} 
participativa, como o referendum popular, por meio do qual o povo exerce o controle sobre o exercício da função legislativa, e os conselhos deliberativos, cuja atuação incide sobre as decisões do Executivo. Pode haver sucessivas intervenções de diferentes órgãos estatais para a superveniência de uma decisão política. É a hipótese da edição de uma lei, em que a iniciativa do projeto provém do executivo para a subsequente votação pelo legislativo; se aprovado, o texto legal é levado a referendum popular, retornando, por último, ao órgão do executivo para se transformar em uma decisão executória ${ }^{505}$.

Na esfera de um regime político democrático, também para Heller, o povo deve exercer, de forma eficaz, uma parcela do poder político, o que se traduz no controle da atuação dos agentes estatais. Para a garantia dos direitos fundamentais, a realidade do aparato estatal deve reproduzir uma organização voltada à imposição de limites ao exercício do poder político por parte do povo, mediante preceitos constitucionais. É a maneira de assegurar a consecução da liberdade, ou seja, "o poder social e político" recaindo sobre os destinatários das funções do Estado ${ }^{506}$.

Como se vê, é de crucial importância o constante fortalecimento de todas as instituições, instrumentos e processos democráticos no interior dos Estados, eis ser a democracia o único sistema político cujo bom funcionamento depende não só do comportamento dos governantes como da atitude e da conduta dos governados, segundo a virtude cívica já retratada. Somente nos Estados democráticos poderão advir medidas eficazes para a plena realização dos direitos humanos ${ }^{507}$. A democracia é um sistema aberto, sempre incompleto, que corresponde a um devir constante. Como foi revelado, pressupõe a implantação de canais permanentes de comunicação entre governantes e governados, reverenciando ainda a existência de instrumentos de controle do poder político que garantam a participação direta da população e de vários organismos estatais nos processos decisórios versando sobre matérias de interesse geral da coletividade. A ênfase é na impossibilidade de abrir mão de uma estrutura e funcionamento orgânicos compatíveis com a efetividade dos direitos fundamentais de proteção à dignidade humana, constituindo o princípio da representação popular somente um dos núcleos essenciais de um regime democrático de governo. Mas o atual Estado Democrático de Direito reclama a existência

\footnotetext{
${ }^{505}$ HAURIOU, Maurice. Principios de derecho público y constitucional, cit., p. 424.

${ }^{506}$ Cf. HELLER, Hermann. op. cit., p. 315.

${ }^{507}$ Cf. MURA, Virgilio. op. cit., p. 37-38. O artigo 21 da Declaração Universal de 1948 dispõe o seguinte:

"Cada um tem o direito de participar do governo de seu próprio país, seja diretamente, seja através de representantes eleitos livremente (Id. Ibid., p. 37).
} 
de outros, na esfera de um sistema eficiente de controle recíproco entre os órgãos estatais que tenha na diretriz de realização integral da dignidade humana o principal elemento de sua agenda política.

\subsubsection{As garantias institucionais no Estado Democrático de Direito: o princípio do controle recíproco entre os órgãos estatais}

Sob a ótica do liberalismo clássico, as garantias constitucionais surgiram como instrumentos relacionados à defesa dos direitos fundamentais dos indivíduos contra o abuso do poder governamental. A necessidade da preservação de uma esfera da liberdade individual contra ingerências do Estado alçou à condição de garantias constitucionais alguns institutos jurídicos para a realização dessa finalidade ${ }^{508}$. Encontraram, então, presença nas Constituições modernas, de um lado, as declarações de direitos do homem concebido isoladamente; de outro, preceitos de organização, com as atividades estatais distribuídas entre ramos diversos. Nessa linha, sucederam-se alguns desdobramentos, como o princípio da reserva legal para restrições pelo Estado aos direitos fundamentais; a necessidade de fixação legal das competências para o exercício de funções públicas, de sorte a possibilitar uma atuação previamente calculável; e um judiciário independente, tanto para a apreciação dos conflitos criminais e de direito privado, como para o controle da legalidade dos atos da administração pública ${ }^{509}$.

Como foi anotado, com o desenvolvimento da doutrina publicista alemã a partir da República de Weimar, a concepção de garantias constitucionais teve alargado o seu raio de abrangência, passando a contar com a modalidade autônoma que Carl Schmitt denominou garantias institucionais. Constituem "formas de organização do Estado ou institutos da vida social, cuja função é assegurar o respeito aos direitos subjetivos fundamentais,

\footnotetext{
${ }^{508}$ BONAVIDES, Paulo. op. cit., p. 494-497.

${ }^{509}$ A Constituição Federal de 1988 manteve as garantias fundamentais do liberalismo clássico. Foi contemplado em seu catalogo o cerne da liberdade individual (art. 5, II): "ninguém será obrigado a fazer ou deixar de fazer alguma coisa senão em virtude de lei". Por outro lado, ao se referir ao surgimento do direito administrativo, Massimo Severo Giannini destacou a distinção entre a tradição do sistema inglês e norte-americano e o que se adotou nos Estados da Europa continental para o estabelecimento de limites à atuação da administração pública na esfera dos direitos individuais dos cidadãos. No sistema de common law, a autorização para ingerências administrativas na esfera da liberdade individual ocorria em função de princípios constitucionais bem consolidados. Nos Estados da Europa continental, em que o reconhecimento da validade de princípios constitucionais sempre foi mais escasso, a dimensão da atuação regulamentar se tornou bem mais significativa, com reflexos no desenvolvimento de institutos para a incidência de respectivo controle jurisdicional, como as hipóteses de abuso e desvio de poder (cf. GIANNINI, Massimo Severo. Lo stato monoclasse: la riflessione della scienza, cit., p. 50-51).
} 
declarados na Constituição" ${ }^{, 510}$. Podem se revelar em normas que estabelecem a organização e o modo de atuação do poder estatal ou em preceitos de alguns institutos da vida social, como o sistema público de ensino, a família ou a seguridade social ${ }^{511}$.

Todavia, ao contrário do que Schmitt sustentou, as garantias institucionais estão inteiramente ligadas ao conjunto de direitos fundamentais contemplados no ordenamento constitucional. Sob aquele primeiro aspecto, configuram uma proteção qualificada a determinadas formas de organização do Estado, de modo a tornar intangível a essência do instituto, materialmente considerada. Caracterizam, portanto, uma proteção qualificada à espécie, "fazendo parte das disposições insuprimíveis não só pela lei, mas até mesmo pela via do processo de emenda à Constituição" ${ }^{" 512}$. Se reveladas como formas de organização e de funcionamento dos órgãos estatais, aquelas garantias obrigam aos poderes públicos o respeito inarredável à natureza central do instituto, notadamente apreendida no âmbito do conjunto dos direitos fundamentais que representam as bases primordiais do Estado Democrático de Direito. A estreita conexão entre o princípio da dignidade da pessoa humana e as garantias institucionais condiciona a organização e o funcionamento dos órgãos estatais aos contornos por elas explicitados. O escopo é preservar a identidade, os traços essenciais de determinado instituto da vida pública, para o desenvolvimento da função de assegurar o respeito aos direitos fundamentais da pessoa humana.

A preocupação da doutrina constitucional consolidada a partir dos movimentos revolucionários do século XVIII foi a de identificar um modelo mais adequado de Constituição. Desde o século XX, a expectativa gira em torno da efetividade do sistema constitucional. Se as questões de outrora versavam a respeito da organização do poder político do Estado, as de hoje centram-se em tornar eficazes os meios de limitar o seu exercício $^{513}$. Os avanços na contenção das violações dos direitos humanos positivados nos ordenamentos constitucionais dependem, em larga medida, da efetividade dos sistemas de controle do exercício do poder político neles contemplados. Para a consolidação da

\footnotetext{
${ }^{510}$ COMPARATO, Fábio Konder. A garantia institucional contra o abuso de poder, cit., p. 48.

${ }^{511}$ Id. Ibid., p. 48-49. Klaus Stern destacou a diferença: Institut garantien, se garantem institutos jurídicos de natureza privada; e Institutionellen garantien, se garantem instituições jurídicas de direito público. (cf. STERN, Klaus. op. cit., p. 275 e ss.). Como formas de atuação do Estado, destacam-se, na CF de 1988, as garantias institucionais do art. 37, caput, com a seguinte redação: "a administração pública direta e indireta de qualquer dos Poderes da União, dos Estados, do Distrito Federal e dos Municípios obedecerá aos princípios da legalidade, impessoalidade, moralidade, publicidade e eficiência (...)". Cf. ainda os $\S \S 1^{\circ}$ a $8^{\circ}$, do art. 226, da CF, que protegem a família como base da sociedade brasileira.

${ }^{512}$ COMPARATO, Fábio Konder. A garantia institucional contra o abuso de poder, cit., p. 49. Cf. também BONAVIDES, Paulo. Curso de direito constitucional, cit., p. 495 e ss.

${ }^{513}$ Cf. VALADÉS, Diogo. op. cit., p. 346 e ss.
} 
democracia, é preciso reconhecer o relevo de uma Constituição normativa, cuja rigidez e eficácia permitam um elevado grau de certeza na atuação dos órgãos estatais, principalmente no que diz respeito aos modos de tutela dos direitos fundamentais. Daí decorre a importância dos instrumentos de controle do exercício do poder político do Estado; sem mecanismos de controle "aplicáveis e aplicados", é impossível a efetividade do sistema constitucional de proteção dos direitos humanos e, por conseguinte, da própria democracia. Os primados da supremacia e da efetividade da Constituição caem por terra sem o funcionamento de instituições capazes de realizar os valores políticos democráticos que orientam a força normativa do ordenamento constitucional ${ }^{514}$.

Assim, considerando a proteção dos direitos humanos indissociável de um regime político democrático, não há como afastar a necessidade do funcionamento de um sistema de controle recíproco entre os órgãos estatais ${ }^{515}$. Tal sistema reveste-se de inegável natureza procedimental. Porém, como elemento essencial à proteção do conjunto de direitos fundamentais, não é possível refugir ao caráter substantivo. O conteúdo material da Constituição ultrapassa a mera regulamentação formal das relações entre os órgãos responsáveis pelo exercício do poder político, com vistas à inclusão no universo jurídico de fatores políticos e sociais que envolvem o conteúdo do ordenamento constitucional, conferindo sentido às suas prescrições ${ }^{516}$. A primazia é, no entanto, a atenção ao conteúdo axiológico do princípio da dignidade da pessoa humana, na qualidade do principal do Estado Democrático de Direito.

Nesse sentido, paralelamente ao plano da descentralização vertical e à hipótese do controle interno pertinente a uma mesma esfera organizacional do Estado, a garantia que há muito prepondera para a limitação do exercício do poder político é, sem nenhuma dúvida, o princípio que foi projetado por Montesquieu de modo a assegurar a preservação da liberdade humana. A organização jurídico-estatal com divisão de poderes é o que vai criar os pressupostos para que o poder político "possa ter obrigações jurídicas perante os cidadãos" ${ }^{517}$. Assim, um regime democrático fundado na proteção dos direitos humanos

\footnotetext{
${ }^{514}$ VALADÉS, Diogo. op. cit., p. 353.

${ }^{515} \mathrm{O}$ princípio do controle recíproco entre os órgãos estatais, não obstante positivado segundo a clássica divisão tríplice, está assegurado na norma do art. $2^{\circ}$ da $\mathrm{CF}$, entre os postulados fundamentais de constituição do Estado.

${ }^{516}$ Cf. VALADÉS, Diogo. op. cit., p. 356-358.

${ }^{517}$ KRIELE, Martin. Introdução à teoria do Estado: os fundamentos históricos da legitimidade do Estado constitucional democrático, cit., p. 295.
} 
obriga a distribuição do poder estatal, de modo a vinculá-lo juridicamente a esse objetivo e, via de consequência, coibir os eventuais abusos em seu exercício ${ }^{518}$.

Para Karl Loewenstein, o Estado é concebido como a forma preponderante de organização coletiva, na qual o exercício do poder político aparece como o efetivo controle efetuado por autoridades encarregadas de desempenhar determinadas funções no interesse da sociedade $^{519}$. O autor substituiu a clássica divisão de Montesquieu por outras três esferas concernentes à dinâmica de exercício do poder político no âmbito do Estado Democrático de Direito. A primeira delas consiste na determinação das decisões políticas fundamentais representando os fatores decisivos para a vida de uma comunidade ${ }^{520}$. Os órgãos do executivo e do legislativo normalmente participam dessas deliberações, cujo processo também não deve dispensar a participação do eleitorado ${ }^{521}$.

O segundo aspecto da tripartição proposta por Loewenstein é o da execução das decisões políticas fundamentais, podendo alcançar muitas áreas das atividades do Estado. As leis representam o primordial instrumento para a execução de anteriores decisões políticas; e a administração constitui o meio de execução que costuma se manifestar com bastante expressão no dia a dia da vida pública. A sociedade estatal do século XX caracterizou-se pela transformação do "Estado legislativo" no "Estado administrativo", com crescentes intervenções para regular as relações sociais, notadamente as de natureza econômica. Todavia, a função de execução das decisões políticas fundamentais também abrange a atuação do Judiciário na solução dos conflitos de interesses. Assim, como atributo essencial do Estado Democrático de Direito, a função de execução das decisões políticas fundamentais também deve contar com a participação de mais de um órgão estatal $^{522}$.

À evidência, não há como afastar de tal contexto o exercício de funções levadas a efeito à consecução dos bens e valores que informam o princípio da dignidade da pessoa

\footnotetext{
${ }^{518}$ Cf. VALADÉS, Diogo. op. cit., p. 364. Lembre-se que, no Estado Democrático de Direito, "não há soberano, ou seja, ninguém que possua a soberania, portanto, o poder ilimitado, incondicional, indiviso de transpor e criar o Direito"; o poder estatal está divido em órgãos e cada órgão tem somente o poder jurídico que lhe foi conferido pela ordem constitucional” (KRIELE, Martin. op. cit., p. 171).

${ }^{519}$ LOEWENSTEIN, Karl. Teoria de la Constitucion, cit., p. 26 e ss.

${ }^{520}$ Id. Ibid., p. 64. O autor exemplificou a hipótese discriminando várias matérias de índole constitucional, como as relativas à ordem econômica, ao sistema educacional, à política fiscal e às relações internacionais.

${ }^{521}$ Muito embora tenha admitido que nem todas as emendas constitucionais contenham decisões políticas de caráter fundamental, tal como Hauriou, Loewenstein aludiu à exigência de que as reformas de iniciativa do Executivo sejam confirmadas por meio de referendo popular, após a sua aprovação pelo Legislativo do Estado. Cf. LOEWENSTEIN, Karl. Teoria de la Constitucion, cit., p. 65. Cf. 3.3 sobre a exposição sobre a doutrina de Hauriou.

${ }^{522}$ Id. Ibid., p. 66-68.
} 
humana. Por estarem atreladas à consecução da decisão política fundamental de constituição da sociedade, funções que tais devem estar distribuídas a órgãos diferentes ${ }^{523}$. É o que caracteriza um dos pontos do terceiro aspecto do desenvolvimento da atuação de controle social do Estado, segundo a doutrina de Loewenstein ${ }^{524}$. A vertente diz respeito à existência de um sistema de controle político, com o princípio fundamental do controle recíproco entre os órgãos estatais imperando na conformação e no funcionamento das instituições do Estado Democrático de Direito. Um regime de controle do poder político impõe a determinação e a execução das decisões políticas fundamentais, como resultados de processos que contem com a participação de mais de um órgão do Estado. O entendimento é o de que o "ato político só será eficaz quando diversos detentores do poder estatal participam e cooperam em sua realização" ${ }^{, 525}$. Outro traço que se colhe do mesmo princípio é a necessidade do exercício autônomo e independente, por determinadas instituições, de funções de controle sobre a atuação de outros órgãos. Esse aspecto volta-se a impedir a existência de um determinado ato, englobando também hipóteses relativas à apuração de responsabilidades, quando um órgão deve prestar contas a outro sobre o fiel cumprimento da função que lhe foi cometida ${ }^{526}$.

Nessas condições, estando atualmente inserido no campo da proteção da dignidade da pessoa humana, o princípio de controle recíproco incide sobre todo o aparato institucional do Estado, que se ampara nos valores que dão sentido à sua existência e determinam o seu telos $^{527}$. Reclamando uma apreensão material à luz da forma de governo, o vetor implica a realização apropriada das funções do Estado, "dos órgãos aos quais é confiado o exercício destas funções, assim como das forças reais que se personificam nesses órgãos ${ }^{528}$ ". É inafastável que a estrutura básica de cada órgão esteja vinculada à função que lhe foi destinada; um órgão não deve desenvolver atividades estranhas à sua configuração central, o que "exclui a participação dos membros de um deles nas funções

\footnotetext{
${ }^{523}$ Vale frisar ter a Constituição contemplado o princípio da dignidade da pessoa humana como um dos fundamentos do Estado, não havendo, assim, nenhuma dúvida sobre a natureza de uma decisão política fundamental. Cf. o art. $1^{\circ}$, III, da CF.

${ }^{524}$ LOEWENSTEIN, Karl. Teoria de la Constitucion, cit., p. 68-72.

${ }^{525}$ Id. Ibid., p. 70. Recorde-se a noção de equilíbrio arquitetada por Montesquieu: a distribuição do poder político do Estado resulta sempre de uma tensão, ou seja, de um acordo mútuo entre forças contrastantes. Cf. 1.1 .2 e 1.1.3.

${ }^{526}$ Karl Loewenstein também apontou como detentores do poder político, além das autoridades do aparato oficial do Estado, os próprios destinatários do respectivo exercício, participando por meio do sistema de representação democrática ou de mecanismos da democracia participativa nas atividades dos órgãos estatais (cf. Id. Ibid., p. 36).

${ }^{527}$ Cf. Id. Ibid., p. 30-31.

${ }^{528}$ HESSE, Konrad. op. cit., p. 369.
} 
de outro (...), quando tais atividades não forem compatíveis entre si”. O objetivo é tornar eficazes os mecanismos de controle em suas relações de reciprocidade ${ }^{529}$.

A hipótese envolve ainda um sistema de incompatibilidades, ainda que não haja vedações expressas. É que, independentemente da existência de qualquer regulamentação, princípios orgânicos de natureza fundamental são de imediata aplicação por todos os poderes públicos e, à evidência, pelos órgãos aos quais se dirigem, dotando-se de plena eficácia para reger a sua formação e o seu funcionamento ${ }^{530}$. As bases organizacionais do Estado Democrático de Direito são totalmente vinculantes, tanto no que concerne à formação de seus órgãos, como em relação ao funcionamento de cada qual. "O efeito mais imediato e indiscutível do ato constitucional é o de edificar de maneira imediata e efetiva um sistema de poderes capazes de funcionar e de atuar, e que em conjunto correspondam à estrutura básica do Estado, ${ }^{, 531}$.

Sob essa ótica, o alcance do princípio do controle recíproco entre os órgãos estatais dota-se, na atualidade, de uma flexibilidade bem acentuada, perpassando todo o ordenamento constitucional; a divisão de órgãos e funções; as formas de cooperação que os une em torno de fins comuns; e os limites para mantê-los em equilíbrio. A aferição da esfera de abrangência da matriz está condicionada à forma de governo do Estado, de maneira a identificar o centro mais vulnerável de concentração do poder político para a implantação de um aparato organizacional tendente a obstá-la. É preciso produzir "efeitos concretos na realidade da vida estatal constitucionalmente ordenada", mediante o estabelecimento de responsabilidades aos agentes públicos e políticos, além da estabilidade gerada pelo funcionamento de órgãos revestidos de estruturas e formas de funcionamento diversas ${ }^{532}$. Afigura-se, pois, o principal fundamento orgânico do Estado Democrático de Direito, como parte integrante de todo e qualquer sistema democrático de governo e, por conseguinte, matriz indispensável para a plena realização dos direitos fundamentais da pessoa humana.

\footnotetext{
${ }^{529}$ LOEWENSTEIN, Karl. Teoria de la Constitucion, cit., p. 373.

${ }^{530}$ GARCÍA DE ENTERRÍA, Eduardo. La Constitucíon como norma y el Tribunal Constitucional. 4. ed. Madrid: Civitas, 2006, p. 86-87.

${ }^{531}$ Id. Ibid., p. 85.

${ }^{532}$ HESSE, Konrad. op. cit., p. 377. No mesmo sentido, Klaus Stern estabeleceu que na atualidade o sistema de divisão e limitação dos poderes do Estado tem se desenvolvido sob vários pontos de vista, ultrapassando a divisão tradicional entre as funções legislativa, executiva e judiciária para, por exemplo, a configuração de órgãos coletivos de deliberação política (STERN, Klaus. op. cit., p. 236-237). Sobre o relevo do conteúdo material atribuído às hipóteses de garantias institucionais, cf. CERVATI, Angelo Antonio. Le garanzie costituzionali nel pensiero di Costantino Mortati. In: GALIZIA, M.; GROSSI, P. (a cura di). Per la storia del pensiero giuridico moderno: il pensiero giuridico di Costantino Mortati. Milano: Giuffrè, 1990. v. 33, p. 428 e ss.
} 
Dessa forma, pelas considerações tecidas sobre os órgãos dos Estados Unidos da América, da França e da Itália, responsáveis pela execução de funções análogas às do Ministério Público brasileiro, já é possível antever as diferenças entre as respectivas estruturas e formas de funcionamento ${ }^{533}$. Realmente, não é de cogitar da existência de um modelo uníssono. E o grau de incidência do princípio do controle recíproco entre os órgãos estatais depende da aferição da natureza, dimensão e finalidades das funções dos entes públicos, para a avaliação do real papel de cada um na esfera da organização política dos Estados. Porém, em sendo estabelecida a ordenação constitucional, é imperiosa a sua afirmação concreta, sobretudo se tal ordenação reflete um projeto institucional destinado à proteção dos direitos fundamentais da pessoa humana e, assim, satisfazer a exigência primordial de uma república democrática.

${ }^{533}$ Cf. 1.2.1, 1.3.1 e 1.4. 


\section{CAPÍtulo IV. O MiNistério PÚBlico NA CONSTITUIÇÃo FEDERAL DE 1988 COMO UM RAMO DO PODER POLÍTICO DO ESTADO}

\subsection{A natureza das funções institucionais}

Com foi visto, a origem e a evolução do Ministério Público ligaram-se, historicamente, "ao monopólio do uso da violência pelo Estado" "534, exigindo que um de seus órgãos se especializasse na função da persecução penal, de forma a garantir a ordem pública necessária à proteção da ação individual para o livre desenvolvimento das relações econômicas fundadas no exercício do direito à propriedade. "A tarefa de punir é exclusivamente do Estado e o Ministério Público é o órgão estatal que detém a responsabilidade exclusiva da acusação no processo criminal",535.

No desenvolvimento dessa função, extrai-se o postulado de defesa do interesse público como a faculdade de impor restrições aos direitos individuais dos cidadãos, para o efeito de salvaguardar a segurança, a salubridade e a moralidade públicas contra os ataques capazes de lesioná-las. A intervenção do Estado deveria ser apenas negativa: estabelecer proibições e restrições, sem ingressar na seara de obrigações positivas para os cidadãos ou para ele próprio ${ }^{536}$. Do mesmo modo, a posição do individuo frente ao Estado era de cunho negativo, ou seja, apenas no sentido de frear a atividade do poder público que extrapolasse os limites do necessário à proteção da ordem pública reclamada para o exercício da liberdade individual vinculado, basicamente, à aquisição da propriedade.

É essa a concepção que traduz a primeira etapa da afirmação histórica dos direitos humanos que, com a passagem do Estado absolutista para o Estado de Direito, deu origem aos chamados direitos de liberdade que impõem uma abstenção do Estado ao regular exercício por seus titulares. Transitando pela preocupação do individualismo "em estabelecer limites do todo em relação ao indivíduo",537, o interesse público aparece como uma categoria contraposta à do interesse privado ou individual; surge como o interesse do

\footnotetext{
${ }^{534}$ Alude-se à conhecida concepção weberiana definindo o Estado, com destaque ao meio específico que lhe é peculiar (cf. WEBER, Max. A política como vocação, cit., p. 55 e ss.).

${ }^{535}$ ARANTES, Rogério Bastos. Ministério Público e política no Brasil, cit., p. 25-26.

${ }^{536}$ GORDILLO, Agustín. Tratado de derecho administrativo: la defensa del usuario y del administrado. 5. ed. Belo Horizonte: Del Rey; San Paoblo: Fundacíon de Derecho Administrativo. 2003. t. 2, V-6 e V-7.

${ }^{537}$ LAFER, Celso. A reconstrução dos direitos humanos: um diálogo com o pensamento de Hannah Arendt, cit., p. 122. Cf. 1.3.
} 
conjunto social identificado com o Estado, que emergia como um todo homogêneo incorporando uma sociedade estática. À época dos prenúncios da modernidade, "ninguém punha em dúvida que o objetivo primordial do Estado era a segurança, entendida como a conservação da ordem natural das coisas"

No Estado de Direito estruturado sob o princípio liberal, a função de tutelar as autonomias privadas tem caráter de exceção. É reconhecida a existência de direitos da pessoa humana que são anteriores ao Estado, cuja função seria somente assegurar o livre exercício pelos integrantes do corpo social. Daí por que a noção jurídica de incapacidade sob as bases do liberalismo clássico deve sempre respeitar o princípio da limitação do poder político.

Entretanto, com a consolidação dos Estados modernos, no curso do século XIX até meados do século XX, sedimentou-se a proeminência do Estado-legislador, que, na esteira da doutrina positivista, deixou de admitir, efetivamente, a existência de direitos naturais à condição humana. O reconhecimento de qualquer direito passou a representar uma concessão do Estado ao indivíduo, mediante os procedimentos formalmente previstos para a produção legislativa ${ }^{539}$.

No Brasil, a clara supremacia da vontade estatal permeou-se pelo paternalismo do tipo tradicional orientando a formação de uma sociedade "em que o Estado é considerado como uma família in grande - ou paterna, ou patriarcal, ou patronal (...) - e o poder do soberano é assimilado ao do pai ou do patriarca ou do patrão". Nesse modelo de organização política, avultando a figura do "soberano-pai ou do soberano-patrão", a família é elevada ao grupo monocrático, "no qual o sumo poder está concentrado nas mãos de um único e os súditos são, no sentido jurídico da palavra, 'incapazes' - ou temporariamente até a maioridade, como é o caso dos filhos, ou perenemente como é o caso dos escravos" $" 540$.

Moldou-se, assim, no âmbito da estrutura organizacional do Estado, a função do Ministério Público: na área criminal, dirigida à proteção da ordem pública, mediante a

\footnotetext{
${ }^{538}$ COMPARATO, Fábio Konder. Um quadro institucional para o desenvolvimento democrático. In: JAGUARIBE, Hélio et. al. Brasil: sociedade democrática. Rio de Janeiro: José Olympio, 1985. p. 402-402. (Coleção Documentos Brasileiros). Recorde-se ainda a concepção de leis reproduzida por Montesquieu como "relações necessárias derivadas da natureza das coisas" (cf. Cap. I, 1.1.1, p. 13 e ss.).

${ }^{539}$ Cf. 3.1.

${ }^{540}$ BOBBIO, Norberto. Governo dos homens ou governo das leis? In: O futuro da democracia. Trad. Marco Aurélio Nogueira. 9. ed. São Paulo: Paz e Terra, 2004. p. 176. Cf. ainda ARANTES, Rogério Bastos. op. cit., p. 27. Cf. o Cap. II, notadamente 2.1 a 2.4.
} 
promoção da ação penal; e na área cível, voltada a suplantar os vícios da capacidade de manifestação da vontade de sujeitos de direito envolvidos em controvérsias judiciais. A atuação do Ministério Público na área cível firmou-se na ideia da indisponibilidade de certos direitos a partir da incapacidade de seu exercício por seus titulares. A ação do órgão estatal visava à supressão dos vícios de capacidade para a manifestação da vontade dos sujeitos de direitos.

Considerando que o sistema jurídico liberal tem como premissa que todo indivíduo tem capacidade de decidir autonomamente sobre seus interesses, naquelas situações nas quais essa premissa notoriamente não ocorre (como no caso dos incapazes, de disposição de última vontade, de ausentes, etc.), surge a necessidade da atuação ministerial para reconduzir a relação jurídica à situação de normalidade ${ }^{541}$.

Sob a égide do valor da liberdade individual, o conceito de direito subjetivo nasceu, historicamente, aliado à proteção de determinado tipo de interesses, sempre subjacentes à propriedade. É preciso recordar ter sido o caráter relacional do valor da liberdade, sedimentado no liminar do Estado moderno, responsável pela concepção do direito subjetivo firmada no curso de todo século XIX até meados do século XX, a partir do predomínio da doutrina positivista ${ }^{542}$. E a ideia de indisponibilidade de direitos ou interesses sempre esteve atrelada à noção tradicional de direito subjetivo fundada no "poder de vontade concebido pelo direito objetivo" para a realização autônoma de um interesse juridicamente protegido. É o conceito conferido por Michoud, ao conjugar a noção de Windscheid, que reduzia a hipótese de direito subjetivo ao poder da vontade individual, com a de Jhering, que enfatizou a natureza de "um interesse juridicamente protegido" 543 . A vontade seria necessária, não para o exercício do direito, mas para a sua proteção; "a lei não protege a vontade, mas o interesse que tal vontade representa" "544. As características da hipótese de direito subjetivo são, por conseguinte, a individualidade e a exclusividade. $\mathrm{O}$ interesse amparado por um direito subjetivo é próprio a cada titular, individualmente considerado; é um interesse "exclusivo e excludente", cuja pretensão é uti

\footnotetext{
${ }^{541}$ SALLES, Carlos Alberto. op. cit., p. 39. Recorde-se que a primeira lei orgânica do Ministério Público dos Estados (Lei Complementar 40/81) incumbiu-o da defesa da ordem pública e dos interesses indisponíveis da sociedade, como instituição permanente e essencial à função jurisdicional do Estado. Cf. 3.7.

${ }^{542}$ Cf. 3.1. Cf. KAUFMANN, Arthur. Filosofia do direito. 2. ed. Trad. António Ulisses Côrtes. Lisboa: Fundação Calouste Gulbenkian, 2007. p. 154 e ss.

${ }^{543} \mathrm{Id}$., loc. cit. O direito objetivo é referido como conjunto de normas jurídicas que regulam a vida humana em uma determinada comunidade.

${ }^{544}$ GORDILLO, Agustín. op. cit., t. 2, III-2.
} 
singuli para uma ou mais pessoas ${ }^{545}$. No entanto, vinculando-o aos interesses encampados pelo ordenamento jurídico, o significado atribuído por Jhering à hipótese de direito subjetivo acabou vingando ao longo do tempo, e hoje tal concepção não deixa de estar relacionada ao meio que se confere para a proteção de um interesse juridicamente tutelado $^{546}$. A hipótese não é, contudo, um postulado de defesa de interesses determinados a priori. Trata-se de uma categoria conceitual meramente formal e abstrata, a despeito dos efetivos interesses que estejam por ela amparados nos ordenamentos jurídicos pátrios ${ }^{547}$.

Levando em consideração a evolução do sistema constitucional de proteção dos direitos humanos, na medida em que se alterou a concepção do valor da liberdade, desvinculando-a da amálgama inicial da propriedade, a categoria conceitual de direito subjetivo passou a absorver outros tipos de interesses consubstanciados em bens e valores inerentes à proteção da dignidade da pessoa humana. Foi anotado que, na sequência da Declaração Universal dos Direitos Humanos de 1948, com o processo de internacionalização dos direitos humanos, o seu conjunto passou a se caracterizar pela ideia de expansão, cumulação e de um progressivo fortalecimento, principalmente no plano de proteção nos Estados constitucionais. Tendo como fonte o princípio de proteção da dignidade humana, o conjunto de direitos e garantias fundamentais vem absorvendo novas reivindicações jurídicas que extrapolam a ideia do indivíduo concebido na sua singularidade para atingir grupos específicos de pessoas, coletividades regionais ou étnicas, e até a própria coletividade ${ }^{548}$. Essas reivindicações traduzem uma série de interesses que acabaram sendo inseridos na categoria conceitual de direito subjetivo, para fins de

\footnotetext{
${ }^{545}$ GORDILLO, Agustín. op. cit., t. 2, III-9 e III-15. Note-se que o conceito tradicional de sujeito de direito vincula-se à possibilidade de ser titular de direitos e deveres. Nesse sentido são também as considerações de Gordillo: "A todo direito corresponde o dever de alguém; todo direito exige que haja um titular e um obrigado; todo dever jurídico reclama igualmente a existência de um obrigado e de um beneficiário. Do ponto de vista do objeto ou conteúdo, o dever jurídico pode consistir em uma obrigação de dar, fazer, não fazer. Em todos os casos, o dever é uma atividade exigível sob a perspectiva daquele que está obrigado a prestá-la, apresentando-se em correlação com o direito subjetivo de alguém consistente na possibilidade de exigir a realização daquela atividade" (Id. Ibid., t. 2, III-1). Cf. ainda KAUFMANN, Arthur. op. cit., p. 155157.

${ }^{546}$ GORDILLO, Agustín. op. cit., t. 2, III-2. Fábio Konder Comparato apontou a "confusão entre o direito subjetivo propriamente dito, que é a pertinência de um bem da vida a alguém, e a chamada pretensão (Anspruch, na terminologia alemã), que é o modo, judicial, ou extrajudicial, reconhecido pelo ordenamento jurídico, para garantir o respeito ao direito subjetivo. A ausência, ou o não exercício, da pretensão não significa, de modo algum, que não haja direito subjetivo. Desde sempre, por exemplo, no direito privado, tem-se admitido que a inexigibilidade judicial das obrigações por efeito da prescrição (inércia do credor em pedir o pagamento durante um prazo fixado em lei) não suprime o direito subjetivo que lhe serve de fundamento. Se o devedor pagar espontaneamente uma obrigação prescrita, não terá ação para reclamar de volta o que pagou, pois a prescrição não eliminou a relação de crédito - débito" (COMPARATO, Fábio Konder. A afirmação histórica dos direitos humanos, cit., p. 58-59).

${ }^{547}$ Cf. GORDILLO, Agustín. op. cit., t. 2, III-13.

${ }^{548}$ Cf. 3.2
} 
reconhecimento da pretensão a que correspondem, sobretudo à luz dos novos instrumentos projetados para a tutela judicial de direito ou interesses de incidência coletiva ${ }^{549}$.

Todavia, malgrado a natureza das funções do Ministério Público, diretamente identificada com a defesa da ordem jurídica, do regime democrático e dos interesses sociais e individuais indisponíveis ${ }^{550}$, ainda hoje a sua atuação na área cível vem respaldada na necessidade de suprimir as deficiências na autonomia da vontade individual; isto é, sob a ótica do conceito meramente formal de direito subjetivo fundado no poder de vontade concebido pelo direito objetivo para a realização autônoma de um interesse protegido no ordenamento jurídico em vigor, independentemente da identificação da natureza do bem jurídico em questão. Mesmo agindo na tutela coletiva de direitos fundamentais, a premissa da hipossuficiência dos correspondentes titulares ainda se mostra presente para lastrear a função do Ministério Público, que busca "elevar ao máximo a razão existente entre a importância pública do bem subjetivo lesado (que deve ser a mais alta possível) e a capacidade da vítima ou da sociedade de defendê-lo em benefício de todos (que deve ser a mais baixa possível)" ${ }^{\text {551 }}$. É o que permeia a noção de indisponibilidade relativa de um interesse público, nomeadamente nas causas concernentes ao estado de pessoas, pátrio-poder, tutela, curatela, interdição, declaração de ausência e disposição de última vontade. "A indisponibilidade relativa é atribuída a situações incidentes sobre um bem de que não pode dispor determinada pessoa", como no caso de venda de um imóvel pertencente a incapaz ${ }^{552}$.

Por outro lado, sob o pressuposto da existência de um interesse geral da coletividade abstratamente considerada como um todo intangível, o parâmetro de defesa do interesse público também serve de paradigma para o desenvolvimento de grande parte das funções do Ministério Público, como no caso da promoção privativa da ação penal pública.

\footnotetext{
${ }^{549}$ Segundo entendimentos adotados pela Corte Constitucional alemã, Robert Alexy destacou a pluralidade de formas e conteúdos de normas de organização e procedimento no âmbito do conjunto de direitos fundamentais, correspondendo a uma pluralidade de posições jurídicas capazes de traduzir o reconhecimento de direitos subjetivos a organização e procedimentos (cf. ALEXY, Robert. Teoría de los derechos fundamentales, cit., p. 454 e ss.).

${ }^{550} \mathrm{Cf}$. a redação do art. 127, caput, da CF: “O Ministério Público é instituição permanente, essencial à função jurisdicional do Estado, incumbindo-lhe a defesa da ordem jurídica, do regime democrático e dos interesses sociais e individuais indisponíveis".

${ }^{551}$ ARANTES, Rogério Bastos. op. cit., p. 101-102.

${ }^{552}$ MAZZILLI, Hugo Nigro. op. cit., p. 296-297. Cf. o art. 82, I a III, do CPC. Conforme anotou Rogério Bastos Arantes, a introdução da defesa do interesse público no Código de Processo Civil de 1973 foi o ponto de inflexão cujo percurso "vai da indisponibilidade e incapacidade individuais às coletivas ou sociais, como requisitos de legitimação da presença do Ministério Público na esfera cível” (ARANTES, Rogério Bastos. op. cit., p. 31-38).
} 
Daí por que, não raro, uma abordagem aleatória em torno da existência ou não de interesses indisponíveis, ou de um interesse público, como algo que existe por si mesmo, é utilizada para embasar, genericamente, as diversas hipóteses de atuação do Ministério Público, inclusive para justificar a desnecessidade de sua ação ${ }^{553}$.

Não é possível, contudo, supor a existência de interesse público desvinculado dos interesses de cada um dos membros da sociedade. O interesse do todo, "do conjunto social, nada mais é que a dimensão pública dos interesses individuais, ou seja, dos interesses de cada indivíduo enquanto partícipe da Sociedade (identificada juridicamente no Estado)". O interesse público surge como um interesse pessoal dos membros da sociedade, enquanto "partícipes de uma coletividade maior na qual estão inseridos, tal como nela estiveram os que os precederam e nela estarão os que virão a sucedê-los nas suas gerações futuras" 554 . O interesse público não consiste em algo inerme e estático, pois não se concebe nenhum equilíbrio social sem movimento. O interesse público correlato à ideia de bem comum sempre contém uma força social refletindo uma tensão entre comportamentos humanos. Coibir violações ao interesse público e promovê-lo mediante ações positivas são duas "faces de uma mesma moeda", que devem ser agregadas para o bem-estar de uma comunidade política ${ }^{555}$.

Nos termos do presente significado atribuído ao interesse público, é possível afirmar que a atual destinação do Ministério Público representa a essência do princípio republicano, por se voltar primordialmente à realização do bem comum. A defesa da ordem jurídica, do regime democrático e dos interesses sociais e individuais indisponíveis envolve, de forma imediata, uma postura ativa em torno da valorização do que é de todos e também de cada um; do apego à coisa pública indissociável da elevação moral e da sedimentação do espírito cívico que o processo de reconhecimento universal dos direitos

\footnotetext{
${ }^{553}$ Sobre o conceito jurídico de interesse público, cf. MELLO, Celso Antonio Bandeira de. Curso de direito administrativo. 18. ed. São Paulo: Malheiros Ed., 2005. p. 50 e ss. O art. 26, VIII, da Lei 8.625/95 (Lei Orgânica Nacional do Ministério Público, que dispõe sobre normas gerais para a organização do Ministério Público dos Estados), estabelece que, no exercício de suas funções, o Ministério Público poderá "manifestar-se em qualquer fase dos processos, acolhendo solicitação do juiz, da parte ou por sua iniciativa, quando entender existente interesse em causa que justifique a intervenção". No mesmo sentido, no âmbito das atribuições do Ministério Público do Trabalho, o art. 83, II, da Lei Complementar 75/93 (Lei Orgânica do Ministério Público da União), confere a ele a competência junto aos órgãos da Justiça do Trabalho de "manifestar-se em qualquer fase do processo trabalhista, acolhendo solicitação do juiz ou por sua iniciativa, quando entender existente interesse público que justifique a intervenção".

${ }^{554}$ MELLO, Celso Antonio Bandeira de. op. cit., p. 52.

${ }^{555}$ GORDILLO, Agustín. op. cit., t. 2, V-10 e V-11.
} 
humanos outorgou à humanidade ${ }^{556}$. Ao consagrar a natureza das funções institucionais do Ministério Público como instituição permanente e essencial à função jurisdicional do Estado, não houve nenhuma referência à hipótese de defesa dos direitos subjetivos individuais indisponíveis no texto constitucional. E o mesmo diploma vedou expressamente a representação judicial e a consultoria jurídica de entidades públicas, apenas autorizando o exercício, pelo Ministério Público, de atividades compatíveis com suas finalidades institucionais ${ }^{557}$. Aí estão os pressupostos de delimitação do interesse público para legitimar a ação do Ministério Público, em benefício de pessoas singularmente consideradas, de grupos de pessoas passíveis de determinação, de grupos de pessoas insuscetíveis de determinação ou até mesmo de toda coletividade ${ }^{558}$. O interesse público que deve lastrear a ação do Ministério Público pode realmente estar ligado a qualquer um desses sujeitos, mas o que importa é, acima de tudo, a identificação de correspondente bem jurídico no âmbito do sistema de proteção dos direitos humanos contemplado na Constituição de 1988.

Não se imagina a intervenção do Ministério Público em toda causa envolvendo, ainda que de forma direta e imediata, uma violação a direitos ou garantias fundamentais da pessoa humana $^{559}$. Além da atuação privativa na promoção da ação penal pública, é preciso admitir que, muito embora possa estar identificado no catálogo de direitos fundamentais, o interesse público para justificar a atuação do Ministério Público em hipóteses de defesa de interesses individuais depende do alcance social que a causa venha a conter ${ }^{560}$. Algumas vezes, essa repercussão social encontra direta ressonância no regime jurídico de proteção especial conferido a determinadas pessoas. No entanto, a intervenção do Ministério Público em favor de determinados segmentos de pessoas sujeitos a um regime jurídico de proteção especial, como é caso dos idosos, índios, crianças e adolescentes ou portadores de

\footnotetext{
${ }^{556} \mathrm{Cf}$. 3.2 e 3.3. Cf. a esse respeito as considerações de Gustavo Zagrebelsky sobre a natureza republicana da função que caracteriza a justiça constitucional (ZAGREBELSKY, Gustavo. Jueces constitucionales. In: CARBONELL, Miguel (Ed.). Teoría del neoconstitucionalismo: o ensayos escogidos, cit., p. 100-102).

${ }^{557}$ Cf. o art. 127, caput, c/c o art. 129, IX, da CF. Além da defesa de interesses governamentais do Estado, a assistência judiciária aos necessitados e a substituição processual do réu revel citado fictamente são funções que, à evidência, não mais condizem com o que, na atualidade, representa a natureza das funções do Ministério Público. Essas funções, aliás, estão afetas às atribuições constitucionais de outros entes considerados essenciais ao exercício da função jurisdicional do Estado. Cf. os arts. 131 a 134, da CF.

${ }^{558}$ Cf. MAZZILLI, Hugo Nigro. Regime jurídico do Ministério Público, cit., p. 294-295.

${ }^{559} \mathrm{O}$ Ministério Público do Trabalho, por exemplo, não intervém na maioria dos processos trabalhistas em curso junto aos órgãos da Justiça do Trabalho, não obstante os conflitos envolvendo os direitos fundamentais de cunho social prescritos no ordenamento constitucional. Cf. 4.1.1, com as considerações sobre as atribuições do Ministério Público do Trabalho e as normas dos arts. 6 a 10, da CF.

${ }^{560}$ Cf. ARANTES, Rogério Bastos. op. cit., p. 108-113.
} 
deficiência $^{561}$, não deve partir do critério de hipossuficiência de sujeitos de direitos. Deve, ao contrário, ter em mira o primado da igualdade, que, no sentido material, impõe um tratamento jurídico condizente às diversidades humanas, para que as peculiaridades de certos grupos sociais possam ser observadas, com a mitigação de suas vulnerabilidades ou de eventuais efeitos de quadros discriminatórios; e isso em prol da construção de uma sociedade livre, justa e solidária; e na busca do bem comum, sem preconceitos de origem, sexo, cor, idade e quaisquer outras formas de discriminação ${ }^{562}$. É o caso da ação do Ministério Público em todas as causas da Justiça Especializada da Infância e da Juventude, que nada tem a ver com a supressão do poder da vontade de incapazes para atos da vida civil. Legitima-se o ofício do Ministério Público em função da doutrina de proteção integral proclamada pela Constituição Federal, para amparar a criança e o adolescente em caráter de absoluta prioridade. Trata-se de um segmento social caracterizado por seres humanos ainda em desenvolvimento, reclamando, por conseguinte, um tratamento jurídico compatível com o atributo especial que os torna em situação de maior vulnerabilidade ${ }^{563}$.

Sob o prisma processual, é preciso ressaltar que o Ministério Público sempre age na qualidade de parte, independentemente da posição que esteja ocupando no processo A tradicional figura de fiscal da lei não há mais como prevalecer diante dos anos de vigência do modelo institucional da Constituição de 1988. Assim, partindo da premissa de que é ele sempre parte no processo, no sentido de estar vinculado à defesa de interesses predeterminados, cai por terra a usual distinção entre a figura de órgão agente e órgão interveniente, apenas tendo em consideração a iniciativa na propositura da ação ${ }^{564}$.

Mas é preciso acolher que, no âmbito do sistema de proteção dos direitos e garantias fundamentais, a aferição da repercussão social, para instar a atuação do Ministério Público, muitas vezes se extrai da incidência coletiva da lesão, atual ou

\footnotetext{
${ }^{561} \mathrm{O}$ art. 129, V, da CF, estabelece, como uma das funções institucionais do Ministério Público, a defesa judicial dos direitos e interesses das populações indígenas, que receberam tratamento específico nas disposições dos arts. 2312 232, também da CF. A Lei 7.853/89 institui a tutela dos interesses das pessoas portadoras de deficiência, definindo a atuação do Ministério Público. Cf. ainda os arts. $7^{\circ}$, XXXI; 37, VIII, $227, \S 2^{\circ}$, e 244 , todos da CF. Ainda no comando constitucional (art. 230, $\S \S 1^{\circ}$ e $2^{\circ}$, da CF), a Lei 10.741/03 corresponde ao Estatuto do Idoso.

${ }^{562} \mathrm{Cf}$ o o art. $3^{\circ}$, I e IV, da CF, dispondo sobre os objetivos fundamentais do Estado. Cf. 3.2 sobre o conteúdo do princípio da igualdade aplicável às chamadas ações afirmativas.

${ }^{563} \mathrm{Na}$ esteira dos preceitos do art. 227 da CF, o Estatuto da Criança e do Adolescente (Lei 8.069/90) regulamentou o regime de proteção especial instituído pelo ordenamento constitucional à criança e ao adolescente. Cf. ainda as normas do art. 201 d (Lei 8.069/90), que estabelecem as hipóteses de intervenção do Ministério Público.

${ }^{564}$ Cf. MAZZILLI, Hugo Nigro. op. cit., p. 293. Ainda que uma ação civil pública tenha sido ajuizada por terceiro igualmente legitimado, o Ministério Público nela deverá intervir na qualidade de parte, como se sua tivesse sido a iniciativa processual.
} 
iminente. Hipóteses dessa ordem normalmente envolvem os direitos ou interesses titularizados por uma pluralidade de pessoas e até mesmo o interesse público, entendido como a dimensão dos interesses dos indivíduos enquanto partícipes de uma comunidade política. Sobretudo levando em conta a posição de destaque do Ministério Público no sistema da ação civil pública, não há como deixar de priorizar o atendimento de suas obrigações inseridas nesse contexto ${ }^{565}$.

A atenção é à nota da efetividade do processo, que, apreendida mediante a conjugação do princípio do devido processo legal à matriz da inafastabilidade do controle jurisdicional, representa, sem nenhuma dúvida, a principal garantia do sistema processual brasileiro $^{566}$. Não há como negar a responsabilidade do Ministério Público pela realização da efetividade do processo que integra o rol das garantias fundamentais cujo zelo lhe compete. E, tendo em vista o liame de proporcionalidade entre meios e fins, as atividades processuais hão de ser otimizadas, com o seu aproveitamento da melhor maneira possível, de sorte a provocar, in concreto, a atuação do direito, com o mínimo dispêndio de tempo e energias. A ideia de flexibilidade racional das fórmulas procedimentais, voltada à utilidade prática do processo, impõe a impossibilidade de um "dispêndio exagerado em relação aos bens que estão em disputa. Mesmo quando não se trata de bens materiais deve haver uma necessária proporção entre meios e fins, para o equilíbrio do binômio custo-benefício". É o que recomenda o princípio da economia, que "preconiza o máximo resultado na atuação do direito com o mínimo emprego possível de atividades processuais" ${ }^{\circledR 57}$. A delonga de uma solução judicial dos conflitos "aumenta os custos para as partes, pressionando

\footnotetext{
${ }^{565} \mathrm{~A}$ ação civil pública foi elevada ao plano constitucional como meio expressamente destinado ao exercício de uma das funções institucionais do Ministério Público relativa à proteção do patrimônio público e social, do meio ambiente e de outros interesses difusos e coletivos (art. 129, III, da CF). No plano infraconstitucional, a ação civil pública funda-se, basicamente, na Lei da Ação Civil Pública (Lei 7.347, de 24.7.1985) - LACP - e no Código de Defesa do Consumidor (Lei 8.078, de 11.9.1990) - CDC-, que classificou as modalidades de direitos ou interesses de incidência coletiva passíveis de serem garantidos mediante a utilização daquele instrumento (cf. o art. 81, § único, do CDC). É preciso anotar que nem todos os casos inseridos no sistema processual da ação civil pública envolvem direitos ou interesses que dispõem do atributo de proteção da dignidade da pessoa humana. O mecanismo da ação civil pública, sob a inspiração do sistema da class action norte-americana, envolve a proteção dos chamados direitos ou interesses individuais homogêneos, tradicionalmente tutelados uti singuli, decorrendo o tratamento judicial coletivo de sua origem comum. A atuação do Ministério Público, na tutela dos interesses ou direitos individuais homogêneos, é admitida à vista da relevância social do objeto da lide. O parâmetro que se deve preconizar é a natureza do bem jurídico correspondente ao objeto da lide, à luz do sistema de proteção dos direitos e garantias fundamentais. Cf. GRINOVER, Ada Pellegrini et al. Código Brasileiro de Defesa do Consumidor: comentado pelos autores do anteprojeto. 8. ed. Rio de Jeneiro: Forense Universitária, 2006. p. 870-872.

${ }^{566}$ Cf. o art. $5^{\circ}$, XXXV, LIV e LV, da CF.

${ }^{567}$ GRINOVER, Ada Pellegrini; CINTRA, Antonio Carlos de Araújo; DINAMARCO, Candido R. Teoria geral do processo. 11. ed. rev. e atual. São Paulo: Malheiros Ed. 1995. p. 73.
} 
economicamente os mais fracos a abandonarem as causas (...)". Foi o que levou a Convenção Europeia para a Proteção dos Direitos Humanos e Liberdades Fundamentais a "reconhecer explicitamente que a Justiça que não cumpre as suas funções dentro de um ‘prazo razoável' é, para muitas pessoas, uma Justiça inacessível”,568.

Desse modo, não é mais viável justificar a atuação do Ministério Público como custos legis, limitada apenas ao oferecimento de pareceres em grau recurso nas causas em que haja obrigatoriedade de sua intervenção. Sob as vestes do contraditório, ao agente em exercício junto ao juízo a quo, sempre é assegurada a regular oportunidade de se pronunciar no processo, seja mediante a utilização de meio recursal pertinente ao reexame da decisão prolatada, seja por meio de sua manifestação ou da apresentação de resposta ao recurso interposto pela parte contrária. Tem-se, portanto, exaurida a intervenção do Ministério Público nessa etapa; o plus consistente na apresentação dos pareceres pelos membros da instituição que oficiam perante os tribunais representa um excesso de tempo e energia absolutamente desnecessário e, por conseguinte, em vulneração à cláusula fundamental da efetividade do processo, com potencial robustecido pela garantia a todos, no âmbito judicial e administrativo, de razoável duração do processo e do acesso aos meios capazes de assegurar a celeridade de sua tramitação ${ }^{569}$.

Por último, é necessário lembrar que a realização do princípio republicano pelo Ministério Público no exercício de suas funções institucionais implica a defesa do regime democrático. Já se frisou a estreita conexão entre uma democracia e a proteção dos direito humanos no plano das organizações políticas estatais. Na defesa do regime democrático, cabe ao Ministério Público zelar pela legitimidade dos instrumentos de participação popular nos processos de formação da vontade estatal, do que depende a sua real correspondência à concretização dos valores traduzidos no conjunto de direitos e garantias fundamentais de proteção à dignidade humana. Nessa qualidade, são de fundamental importância as funções eleitorais do Ministério Público, dedicadas ao controle da legitimidade dos mecanismos de exercício do sufrágio popular; seja na eleição pelo povo de seus representantes; seja na escolha entre duas ou mais opções colocadas em plebiscito ou referendo ${ }^{570}$. É preciso que o Ministério Público intervenha "nas hipóteses de perda ou

${ }^{568}$ CAPPELLETTI, Mauro; GARTH, Bryan. op. cit., p. 20-21.

${ }^{569} \mathrm{Cf}$. o art. $5^{\circ}$, LXXVIII, da CF. O dispositivo foi introduzido no texto constitucional pela Emenda 45, de 8.12.2004, que pretendeu arquitetar um novo quadro institucional para o sistema da justiça brasileira.

${ }^{570}$ Cf. MARUM, Jorge Alberto de Oliveira. Ministério Público Eleitoral. In: VIGLIAR, José Marcelo Menezes; MACEDO JR., Ronaldo Porto (Coords.). Ministério Público II: democracia, cit., p. 152. Para concretizar o mandamento de defesa do regime democrático, caberia a iniciativa de propor mandado de 
suspensão de direitos políticos, e no zelo ao livre funcionamento dos partidos políticos"571. Todo o processo eleitoral deve ser objeto de ampla físcalização pelos agentes da instituição, "passando pelo registro das candidaturas, pela campanha eleitoral, pelo exercício do sufrágio e pela apuração até achegar à proclamação dos vencedores e

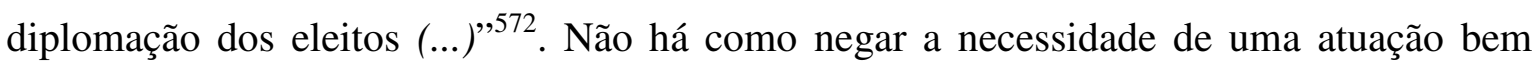
mais significativa do Ministério Público para coibir as nocivas práticas em detrimento do regime de representação democrática, como os gravíssimos abusos do poder econômico, inscrições fraudulentas de candidaturas, propagandas eleitorais enganosas e apresentação de contas fictícias de campanhas ${ }^{573}$.

Nesse sentido, o Ministério Público foi instituído pela constituinte de 1988 para a proteção de bens e valores inerentes ao conjunto de direitos e garantias fundamentais da pessoa humana que caracterizam, em nossos tempos, todo e qualquer sistema político estruturado e em funcionamento no comando dos princípios democrático e republicano. Em outras palavras; caracterizam o Estado Democrático de Direito ${ }^{574}$.

\subsubsection{A repressão à criminalidade no Estado Democrático de Direito}

De início, impende recordar a frutífera proposta de Montesquieu voltada à organização política do Estado moderno, que, centrando-se na preservação da liberdade humana, contou com duas balizas centrais: uma, da liberdade em relação à constituição fundada na distribuição do poder político entre ramos diversos; e a outra, da liberdade em relação aos cidadãos, com a lei figurando como restrição ao exercício da liberdade individual $^{575}$.

\footnotetext{
injunção quando, por exemplo, a falta de regulamentação da participação popular nas decisões políticas, "quer pelo plebiscito, quer pelo referendo, quer pela iniciativa do processo legislativo", tornar inviável o exercício das prerrogativas da soberania popular. O mandado de injunção é a garantia fundamental voltada a possibilitar a fruição regular dos direitos e liberdades constitucionais das prerrogativas inerentes à cidadania, à soberania e à nacionalidade ante a falta de norma reguladora (art. $5^{\circ}, \mathrm{LXXI}$, da CF).

${ }^{571}$ MAZZILLI, Hugo Nigro. op. cit., p. 113. O autor também atentou à possibilidade do ajuizamento de mandado de injunção para suprir a inadmissível falha da ausência de lei complementar dispondo sobre casos de inelegibilidade, "a fim de proteger a probidade administrativa, moralidade para o exercício do mandato, considerada a vida pregressa do candidato, e a normalidade das eleições contra a influência do poder econômico ou o abuso do exercício de função, cargo ou emprego na administração direta ou indireta" (art. 14, § $9^{\circ}$, da CF).

${ }^{572}$ MARUM, Jorge Alberto de Oliveira. op. cit., p. 156.

${ }^{573}$ Id. Ibid., p. 157.

${ }^{574}$ Cf. 3.3.

${ }^{575} \mathrm{Cf}$. 1.1.3. A doutrina de Montesquieu foi bastante significativa no campo do reconhecimento de garantias fundamentais em matéria penal (a imparcialidade do judiciário, a reserva legal para a definição dos delitos e das penas, extinção das acusações privadas, etc.).
} 
Assim, conforme também foi abordado, rompendo definitivamente com a era do Absolutismo, o molde da nova estrutura política do Estado liberal, identificado nos documentos que emanaram dos movimentos revolucionários do século XVIII, foi a construção do esquema de limitação do poder político, "a ele opondo a garantia do indivíduo, como sujeito de direito. Ao mesmo passo, na ordem econômica, a liberdade de comércio e de iniciativa" fortaleceu a burguesia e antecipou a presença da empresa, como célula da sociedade capitalista ${ }^{576}$.

Os princípios da liberdade e igualdade revestiam a natureza dos direitos e das garantias fundamentais da pessoa humana no constitucionalismo nascente, com as relações sociais concebidas em torno do individualismo, tanto no plano jurídico, quanto no econômico. "Ao despotismo se opõem a força da liberdade e a segurança individual, na mística inviolabilidade da lei todo-poderosa" ${ }^{, 577}$. O Estado assumiu a posição de simples árbitro, apenas um fator de equilíbrio para assegurar a liberdade de agir dos cidadãos dentro dos limites fixados pela lei, de maneira a conter os eventuais abusos do individualismo. E a igualdade colocava todos no mesmo plano, para o livre exercício da autonomia da vontade e da capacidade de contratar.

Foi esse o sentido da liberdade dos tempos modernos que, segundo a fórmula do $\operatorname{artigo} 4^{\circ}$ da Declaração dos Direitos do Homem e do Cidadão de $1789^{578}$, orientou a noção do chamado poder de polícia do Estado, concebendo-o a partir da função de evitar a perturbação da ordem para assegurar o livre exercício da liberdade individual.

A humanização do direito penal foi uma das bandeiras do pensamento ilustrado. $\mathrm{O}$ artigo $7^{\circ}$ daquela Declaração incorporou a ideia principal de secularização, isto é, da emancipação do direito penal, desatrelando-o de aspectos teológicos e da tradicional equação entre pena e castigo. Era preciso, por um lado, haver a descrição taxativa das condutas delituosas e, por outro, moderar a cominação das penas. A liberdade dos indivíduos devia estar protegida pela lei, com a punição dos agentes que ultrapassassem os

\footnotetext{
${ }^{576}$ TÁCITO, Caio. Poder de polícia e polícia do poder. In: Temas de direito público (estudos e pareceres. Renovar, 1997. v. 1, p. 546.

${ }^{577}$ Id. Ibid., p. 547.

${ }^{578}$ Nesse sentido é o conteúdo do art. $4^{\circ}$ da Declaração dos Direitos do Homem e do Cidadão de 1789: "A liberdade consiste em poder fazer tudo o que não prejudique a outrem; em consequência, o exercício dos direitos naturais de cada homem só tem por limites os que assegurem aos demais membros da sociedade a fruição desses mesmos direitos. Tais limites só podem ser determinados pela lei" (COMPARATO, Fábio Konder. A afirmação histórica dos direitos humanos, cit., p. 154).
} 
seus contornos na execução de prisões e na formulação das acusações, não obstante a necessidade de respeito às intervenções legítimas ${ }^{579}$.

A Declaração dos Direitos do Homem e do Cidadão reafirmou o princípio da legalidade em matéria penal, com ênfase à anterioridade legal e ao caráter não retributivo das penas. A matriz da presunção de inocência também foi consagrada, acrescida da repressão legal para os abusos praticados em detenções acautelatórias ${ }^{580}$.

É importante observar a menção feita à força pública pelo mesmo documento da Revolução Francesa. Reproduzindo o modelo contratualista de constituição do Estado e da sociedade civil, "a força seria a substituição que a sociedade constituída pelo contrato social propõe como alternativa à força privada que reina no estado de natureza" ${ }^{„ 581}$.

Sob essa ótica, "logo internacionalizada no movimento racionalista do século XIX", a persecução penal pelo Estado, no curso da evolução da disciplina do chamado poder de polícia, não deixou de reproduzir uma "linha ascensional" de intervenção do poder público $^{582}$.

Atualmente, diante da complexidade das sociedades estatais contemporâneas, a proeminência do poder econômico, mesmo propugnando um retorno à privatização, fez

${ }^{579}$ Cf. CARBONELL, Miguel. op. cit., p. 127-129. Segundo o art. $7^{\circ}$ da Declaração dos Direitos do Homem e do Cidadão de 1789: "Ninguém pode ser acusado, detido ou preso, senão nos casos determinados pela lei e de acordo com as formas por ela prescritas. Os que solicitam, expedem, executam ou fazem executar ordens arbitrárias devem ser punidos; mas todo cidadão convocado ou detido em virtude da lei deve obedecer incontinenti; ele se torna culpado em caso de resistência” (COMPARATO, Fábio Konder. $A$ afirmação histórica dos direitos humanos, cit., p. 154).

${ }^{580}$ É a redação do art. $8^{\circ}$ da Declaração dos Direitos do Homem e do Cidadão de 1789: "A lei só pode estabelecer penas estrita e evidentemente necessárias, e ninguém pode ser punido senão em virtude de uma lei estabelecida e promulgada anteriormente ao delito, e legalmente aplicada" (COMPARATO, Fábio Konder. A afirmação histórica dos direitos humanos, cit., p. 154). O art. 15 da Constituição Francesa de 1793 afirmou a necessidade de previsão de sanções proporcionais ao delito e úteis para a sociedade. $\mathrm{O}$ mesmo ordenamento, em seu art. 14, consagrou o princípio da não retroatividade da lei penal, que o pensamento moderno excetuou apenas para beneficiar o acusado (cf. CARBONELL, Miguel. Uma historia de los derechos fundamentales, cit., p. 130). O art. $9^{\circ}$ da Declaração dos Direitos do Homem e do Cidadão de 1789 estabeleceu que: "como todo homem deve ser presumido inocente até que tenha sido declarado culpado, se se julgar indispensável detê-lo, todo rigor desnecessário para que seja efetuada a sua detenção deve ser severamente reprimido pela lei” (COMPARATO, Fábio Konder. A afirmação histórica dos direitos humanos, cit., p. 154).

${ }^{581}$ CARBONELL, Miguel. op. cit., p. 135. Segundo o art. 12 da Declaração dos Direitos do Homem e do Cidadão de 1789: "A garantia dos direitos do homem e do cidadão carece de uma força pública; esta força é portanto instituída em proveito de todos, e não para a utilidade particular daqueles a quem é confiada" (COMPARATO, Fábio Konder. A afirmação histórica dos direitos humanos, cit., p. 154). Não é possível dissociar-se do pacto fundamental de Hobbes, responsável pela constituição do poder soberano que irá privar os homens do estado de natureza para a instituição do Estado. É o poder coercitivo "que advém da espada pública; ou seja, das mãos desatadas daquele homem ou assembleia de homens que detêm a soberania, e cujas ações são garantidas por todos e exercitadas por meio de todos, nele reunidos" (Leviathan, cit., part. II, chap. XVIII, p. 231).

${ }^{582}$ TÁCITO, Caio. Poder de polícia e seus limites. In: Temas de direito público (estudos e pareceres, cit., v.1, p. 522. 
multiplicar os bens jurídicos sujeitos à proteção do Estado, por meio de sua ação repressiva. A preponderância do interesse geral da sociedade e da ordem pública costuma justificar uma crescente atuação repressiva do Estado na esfera dos direitos fundamentais dos indivíduos, por vezes sem uma precisa caracterização do modo pela qual ela deve ocorrer, dos fundamentos jurídicos a que corresponde ou dos órgãos por ela responsáveis $^{583}$.

$\mathrm{Na}$ esteira dos traços que diferenciaram o reconhecimento dos direitos humanos a partir do movimento de independência dos Estados Unidos da América e da Revolução Francesa, é preciso lembrar que a manifestação do legislador, nos países da Europa continental, foi adquirindo, ao longo do tempo, uma considerável amplitude para autorizar uma atuação estatal restritiva ao exercício dos direitos individuais. Sem o abandono do conteúdo de defesa da ordem pública para a ação preventiva ou repressiva do Estado, as doutrinas francesa e italiana ampliaram largamente os poderes gerais de polícia, mediante a ação legislativa repercutindo na órbita de atuação do órgão do executivo ${ }^{584}$. Nos Estados Unidos da América, com a preocupação pelas garantias dos direitos naturais da pessoa humana de maior alcance, o police power foi submetido ao controle judicial pela Suprema Corte para, com fulcro no aspecto substantivo do devido processo legal, a apreciação da constitucionalidade de iniciativas dos Estados-membros na edição de leis restritivas a direitos cujo exercício seria insuscetível de uma excessiva interferência governamental ${ }^{585}$.

De todo modo, considerando o fundamento de proteção da dignidade da pessoa humana como alicerce da organização política dos Estados contemporâneos, não é possível sobrelevar a supremacia da vontade soberana do Estado na análise do sistema jurídico de combate à criminalidade. $\mathrm{O}$ foco sempre há de residir no conjunto de direitos e garantias

${ }^{583}$ GORDILLO, Agustín. op. cit., t. 2, V-7 a V-10.

${ }^{584}$ TÁCITO, Caio. Poder de polícia e polícia do poder, cit., p. 525. Cf. 1.3.

${ }^{585} \mathrm{Cf}$. 1.2. Fundado em leis estaduais, em um primeiro momento, o police power subordinava os direitos individuais à regra do bem comum, conduzindo, em sua expressão externa, "ao abandono da filosofia individualista do laissez faire e à aproximação do coletivismo". Com o desenvolvimento da Revolução Industrial, a partir de 1877, a jurisprudência da Suprema Corte cedeu à pressão dos interesses econômicos para retomar o papel de neutralidade do Estado, com o judiciário assumindo grande importância no cenário político. "Due process e state power tornaram-se, assim, expressões antinômicas, como símbolos da oposição da iniciativa privada e do interesse público." A crise econômica de 1929 revivificou a ação intervencionista do Estado, transpondo-a ao nível federal. Firmou-se um novo police power que serviu de lastro no âmbito federal à reforma do New Deal, concebido em termos de uma rigorosa regulamentação da iniciativa privada. A Suprema Corte acabou sujeitando-se ao fortalecimento do Poder Executivo, com a função do due process of law restringindo-se ao respeito de cláusulas processuais, sobretudo em matéria penal. Os procedimentos da administração pública não são estranhos à doutrina norte-americana, seja pela disposição de regulamentar (rule-making power), como de ordenar ou de executar (directing ou summary power) (TÁCITO, Caio. Poder de polícia e seus limites, cit., p. 527-530). Cf. também BARROSO, Luís Roberto. op. cit., p. 219 e ss. 
fundamentais que representam a base do sistema democrático de governo, com especial atenção ao cânone da liberdade. Do ponto de vista axiológico, indissociável do atual papel do Estado Democrático de Direito, não é viável considerar a evolução da atividade de preservação da segurança pública, "sem dar um passo decisivo na história da luta das liberdades públicas e dos direitos humanos em geral" $" 586$.

A essência da previsão de crimes pelo Estado, mediante a atuação de seu órgão legislativo, é "garantir as condições vitais da sociedade" hipóteses de violação a direitos e garantias fundamentais derivados do primado de proteção à dignidade da pessoa humana. Onde bastam os demais meios para a proteção dos bens materiais e imateriais inerentes aos valores da liberdade, igualdade e solidariedade do Estado Democrático de Direito, não se faz necessária a manifestação do poder de controle social no campo do direito penal.

Muito embora a dimensão dos comportamentos ofensivos àqueles bens e valores fundamentais seja mutável no curso da história, o conceito de crime "é o mesmo em toda parte"; representa "uma agressão às condições vitais da sociedade, expressa em forma de direito", pela convicção de que sua defesa só será possível mediante a disposição de uma rigorosa restrição pelo Estado à esfera da liberdade e da propriedade dos eventuais transgressores. Quanto mais valioso um bem, maior deverá ser a sua proteção jurídica ${ }^{588}$. Mesmo quando o titular do direito violado é o próprio Estado ou a coletividade, o exercício do ius puniendi não representa jamais uma relação entre súdito e soberano; é meramente instrumental, como garantia do dever imposto pelo ordenamento jurídico de respeito aos direitos de cada uma das pessoas que formam o corpo social, inclusive dele próprio ou do Estado, que surge como pessoa jurídica que "existe e convive no universo jurídico em concorrência com todos os demais sujeitos de direito" "589.

São essas as premissas indispensáveis para a análise da função de combate ao crime reservada ao Ministério Público pela Constituição Federal, ao alçá-lo à condição de órgão do Estado incumbido de promover, privativamente, a ação penal pública, tendo em vista

\footnotetext{
${ }^{586}$ GORDILLO, Agustín. op. cit., t. 2, V-3 e V-5. O autor preconizou a abolição da expressão "poder de polícia" do vocabulário jurídico da atualidade, mediante a reformulação do conteúdo da matéria sob as luzes do processo de internacionalização dos direitos humanos.

${ }^{587}$ JHERING, Rudolf von. op. cit., t. 1, p. 321.

${ }^{588}$ Id. Ibid., p. 324-325.

${ }^{589}$ MELLO, Celso Antonio Bandeira de. op. cit., p. 57.
} 
um extenso rol de garantias institucionais sobre formas de organização e de atuação estatal, sedimentadas no plano da persecução criminal ${ }^{590}$.

Daí a dimensão do papel do Ministério Público como inteiramente responsável pelo exercício do ius puniendi. É ele o responsável pela palavra final do Estado a respeito de medida tradicionalmente vinculada a princípios que deram origem a todo e qualquer regime jurídico de proteção dos direitos humanos ao longo da História. A função de promover a ação penal pública é privativa do Ministério Público; e, diversamente dos sistemas adotados na França e nos Estados Unidos da América, no Brasil incide sobre a sua iniciativa o princípio da obrigatoriedade, na qualidade de um dever irrecusável diante de violações à legislação criminal ${ }^{591}$.

Sob o império da obrigatoriedade, a preponderância do papel do Ministério Público na atividade de combate ao crime, como titular privativo da ação penal, depreendese pela promoção do arquivamento de inquérito policial ou de procedimento investigatório perante o órgão do judiciário. É certo que, no catálogo específico dos direitos e garantias fundamentais, a Constituição Federal assegurou a possibilidade de propositura de ação privada nos casos de ação pública, como forma de controle diante de omissão injustificada

\footnotetext{
${ }^{590} \mathrm{Cf}$. o art. 129 , I, da CF, que estabelece a promoção privativa da ação penal pública como a primeira função institucional do Ministério Público. Já no âmbito do conjunto de direitos e garantias fundamentais do art. $5^{\circ}$ da CF, vale o destaque aos seguintes preceitos: o inc. XXXVII, proibindo juízo ou tribunal de exceção; o inc. XXXVIII, reconhecendo a instituição do júri, com as garantias da plenitude da defesa, sigilo das votações e soberania dos veredictos; o inc. XXXIX, vedando o reconhecimento de crime sem lei anterior que o defina, nem pena sem prévia determinação legal; o inc. XL, vedando a retroatividade da lei penal, salvo em benefício do réu; o inc. XLV, proibindo que qualquer pena passe da pessoa do condenado, salvo no caso de reparação civil pelos danos provocados pela conduta ilícita; o inc. XLVI, estabelecendo a necessidade de individualização da pena; o inc. XLVII, proibindo a pena de morte, de caráter perpétuo, de trabalhos forçados, de banimento e cruéis; o inc. XLVII, dispondo sobre a necessidade de cumprimento da pena em estabelecimentos distintos, de acordo com a natureza do delito, a idade, e o sexo do apenado; o inc. XLIX, impondo aos presos o respeito à integridade física e moral; o inc. L, garantindo para as presidiárias as condições para que possam permanecer com seus filhos durante o período de amamentação; o inc. LI, vedando a extradição dos brasileiros, salvo o naturalizado, em caso de crime comum, praticado antes da naturalização, ou de comprovado envolvimento em tráfico ilícito de entorpecentes e drogas afins, na forma da lei; o inc. LII, vedando a extradição de estrangeiro por crime político ou de opinião; o inc. LIII, impondo que qualquer pessoa seja processada e sentenciada apenas pela autoridade competente; o inc. LVII, estabelecendo a presunção de inocência até o trânsito em julgado de sentença penal condenatória; o inc. LVIII, vedando, salvo nas hipóteses previstas em lei, a identificação criminal de pessoa civilmente identificada; e o inc. LXXV, impondo ao Estado a obrigação de indenizar o condenado por erro judiciário, assim como o que ficar preso além do tempo fixado na sentença. Não é possível olvidar o célebre instituo do habeas corpus cuja concessão se impõe "sempre que alguém sofrer ou se achar ameaçado de sofrer viol6encia ou coação em sua liberdade de locomoção, por ilegalidade ou abuso de poder" (art. $5^{\circ}$, LXVIII, da CF).

${ }^{591}$ A Constituição mitigou o alcance do princípio da obrigatoriedade da ação penal, ao dispor sobre os Juizados Especiais Criminais para fins de conciliação nos casos de infração de menor potencial ofensivo, permitindo a transação nas hipóteses autorizadas por lei (cf. o art. 98, I, da CF; e Lei 9.099/95).
} 
do Ministério Público ${ }^{592}$. Todavia, o entendimento dominante é o de que a promoção do arquivamento de inquérito policial, de um modo geral, não configura uma situação de inércia para justificar a ação penal privada substitutiva. A omissão injustificada do Ministério Público pode, por sua vez, verificar-se em face da ausência de iniciativa durante a persecução penal, do arquivamento de representação sem controle judicial, e até mesmo por força da requisição de diligências desnecessárias à propositura da ação ${ }^{593}$.

O controle judicial incidente sobre pedidos de arquivamento de inquéritos consiste apenas em provocar a decisão definitiva do Procurador-Geral, cuja nomeação compete ao chefe do Executivo e cuja destituição depende da deliberação de órgãos do legislativo, sujeitando-o, assim, “a notáveis influências político-partidárias",594. E, pela prática de infrações penais, cabe exatamente ao Procurador-Geral decidir sobre a propositura de ação contra as mais altas autoridades públicas dos demais órgãos do Estado, incluindo, é claro, o Executivo $^{595}$.

\subsubsection{Os atos investigatórios}

No plano da proteção do direito fundamental à segurança, o cumprimento do dever do Estado de preservação da ordem e da incolumidade das pessoas e do patrimônio é atribuição dos órgãos policiais, dentro das competências definidas no texto constitucional $^{596}$. A apuração das infrações penais incumbe à polícia judiciária do Estado,

\footnotetext{
${ }^{592}$ Cf. o art. $5^{\circ}$, LIX, da CF: "será admitida ação privada nos crimes de ação pública, se esta não for intentada no prazo legal".

${ }^{593}$ Cf. MAZZILLI, Hugo Nigro. op. cit., p. 303, nota 820. Uma vez determinado o arquivamento do inquérito pelo juiz competente, a ação penal não poderá ser intentada sem a existência de novas provas (cf. os arts. 28 e 18 do CPP; e a Súmula 524 do STF). À luz do art. 16 do CPP, a jurisprudência já considerou admissível o indeferimento pelo juiz das diligências requeridas pelo Ministério Público em autos de inquérito policial, quando prescindíveis ao oferecimento de denúncia (RT 455/402). Foi também admitida, diante do pedido de arquivamento de inquérito, a determinação judicial de diligências para a supressão de falhas ou omissões, antes do envio dos autos ao Procurador-Geral (RT 518/383, 445/440).

${ }^{594}$ MAZZILLI, Hugo Nigro. op. cit., p. 304 . Cf. o art. 128 , $\S \S 1^{\circ}$ a $4^{\circ}$, da CF, e o art. 28 do CP.

${ }^{595}$ Cf. os arts. 102, I, $b$ e $c$, e 105, I, $a$, da CF; e os arts. 46, § único, III, 48, II, da Lei Complementar 75/93. Cf. ainda o art. 29, V e VII, da Lei 8.625/93; o art. 116, I e XII, da Lei Complementar Estadual 734/93; e o art. 74, I e II, da Constituição do Estado de São Paulo. A Lei Complementar 75/93 é a Lei Orgânica do Ministério Público da União (LOMPU); a Lei 8.625/93 é a Lei Orgânica Nacional do Ministério Público que estabelece normas gerais para a organização do Ministério Público dos Estados (LONMP); e a Lei Complementar Estadual 734/93 é a Lei Orgânica do Ministério Público do Estado de São Paulo (LOEMP). Nos casos de competência originária do Procurador-Geral, a decisão de arquivamento de inquérito policial é submetida ao exame meramente formal dos tribunais competentes (cf. as Leis 8.658/93 e 8.038/90). E, no que diz respeito à instância recursal administrativa, o art. 12, XI, da Lei 8.625/93 remete a hipótese à regulamentação pelas leis orgânicas dos Estados para a revisão da medida pelo Colégio de Procuradores de Justiça, mediante requerimento de legítimo interessado (art. 117 da Lei Complementar Estadual 734/93).

${ }^{596} \mathrm{O}$ art. $5^{\circ}$, caput, da $\mathrm{CF}$, garante, a todos os brasileiros e aos estrangeiros residentes no país, a inviolabilidade do "direito (...) à segurança (...)". Cf. ainda o art. 144, I a V, §§ $1^{\circ}$ a $9^{\circ}$, da CF, dispondo
} 
correspondendo a dever de ofício nos delitos de ação penal pública que impõe as providências pertinentes ao deslinde do fato ilícito, pela instauração de inquérito policial $^{597}$.

A fase investigatória prévia à acusação é de competência da polícia judiciária, sob o controle do Ministério Público. Cabe-lhe, não só requisitar a instauração de inquéritos policiais, como acompanhar e determinar as provas que devem ser produzidas. Muito embora com iniciativas instrutórias mais reduzidas, o juiz não deixa de exercer um papel de controle sobre a atuação dos outros órgãos estatais, ao supervisionar o andamento dos inquéritos, além de proferir decisões cautelares relativas "à liberdade pessoal (prisão cautelar) ou a medidas restritivas de direitos (busca e apreensão, sequestro, arresto, interceptações telefônicas etc.), ou ainda à produção antecipada de provas",598.

É possível afirmar que, rotineiramente, em procedimentos de investigação criminal, existe a participação de mais de um órgão para a decisão final do Ministério Público sobre a propositura da ação penal. Verifica-se o desenvolvimento de uma função do Estado, em que órgãos de mais de uma esfera da organização política são compelidos a cooperar para o advento da decisão acusatória; cada um, é claro, há de agir no âmbito de suas atribuições legais e constitucionais, para a produção de um resultado legítimo e eficaz ${ }^{599}$.

sobre a organização das polícias, para fins de assegurar a segurança pública concebida como "dever do Estado, direito e responsabilidade de todos, devendo ser exercida para a preservação da ordem e da incolumidade das pessoas e do patrimônio (...)" (art. 144, caput, da CF).

${ }^{597}$ Cf. a redação do art. $4^{\circ}$ do CPP: "A polícia judiciária será exercida pelas autoridades policiais no território de suas respectivas circunscrições e terá por fim a apuração das infrações penais e de sua autoria”. O $\S$ único, ainda do art. $4^{\circ}$, estabelece que tal competência não "excluíra a de autoridades administrativas, a quem por lei seja cometida a mesma função". Cf. também os arts. $5^{\circ}, 6^{\circ}$, I a IX; e $7^{\circ}$, do Código Penal.

${ }^{598}$ GRINOVER, Ada Pellegrini. A legislação brasileira em face do crime organizado. In: ___ _. A marcha do processo. Rio de Janeiro: Forense, 2000. p. 88. No comando de garantias fundamentais dos primórdios do Estado de Direito, ao órgão do judiciário cabe decretar a prisão de qualquer pessoa, mediante ordem escrita e devidamente fundamentada, salvo em situações de flagrante delito (art. o art. $5^{\circ}$, LXI, da CF). Tem-se ainda que a prisão de qualquer pessoa e o local onde se encontre deve ser imediatamente comunicada ao juiz competente (art. $5^{\circ}$, LXII, da CF), a quem cabe determinar o pronto relaxamento das detenções ilegais (art. $5^{\circ}, \mathrm{LXV}$, da $\mathrm{CF}$ ) e conceder a liberdade provisória aos que a ela fazem jus (art. $5^{\circ}$, LXVI, da CF).

${ }^{599}$ A respeito das formas de controle do poder político estatal, cf. 3.3.1. O usual é que, findo o prazo legal previsto à conclusão do inquérito e não havendo hipótese de prisão, a autoridade policial solicite ao juiz competente a devolução dos autos para ulteriores diligências, caso a prática delituosa ainda não tenha sido elucidada (art. 10, $\S 3^{\circ}$, do CPP). É o procedimento corriqueiro que passa a envolver o controle judicial e, principalmente, do Ministério Público, como titular privativo da ação penal, sobre as atividades policiais na apuração dos delitos. E à autoridade policial impõe-se a realização de todas as diligências requisitadas tanto pelo juiz como pelo órgão do Ministério Público (art. 13, II, do CPP), o qual pode ainda, mesmo depois de serem concluídas as investigações pela autoridade policial, requisitar a produção de outros elementos probatórios, imprescindíveis ao esclarecimento do fato (art. 16 do CPP). A respeito das formas de controle do poder político estatal, cf. 3.3.1. 
Entretanto, o inquérito policial não é indispensável para a propositura da ação penal pública. Já no plano constitucional, o legislador conferiu ao Ministério Público alguns instrumentos destinados à colheita de provas para o desenvolvimento de suas funções institucionais, sempre na esteira das garantias fundamentais de proteção da pessoa humana, com realce às do devido processo legal e da inafastabilidade do controle jurisidicional ${ }^{600}$. São disposições que autorizam a expedição de notificações nos procedimentos de sua competência, além da requisição de informações e de documentos para instruí-los, bem como da "instauração de inquérito policial, indicados os fundamentos jurídicos de suas manifestações processuais" ${ }^{\prime 601}$.

Em primeiro lugar, nos procedimentos administrativos presididos pelo Ministério Público, é possível notificar qualquer pessoa para a produção de depoimentos ou para a prestação de esclarecimentos sobre o objeto da investigação ${ }^{602}$. Tendo em vista a garantia fundamental do devido processo legal, a expedição de notificações pelo Ministério Público exige a existência de um processo administrativo em curso, com a exposição, ainda que de forma sucinta, dos motivos que determinaram a designação da audiência ${ }^{603}$.

Hipóteses de requisição também foram introduzidas para a instrução daqueles procedimentos. As requisições são de natureza coercitiva, revestem-se de autoexecutoriedade e dispõem de força vinculante em relação aos seus destinatários. É o que acontece com a requisição de documentos, informações e exames periciais que se pode

\footnotetext{
${ }^{600}$ São garantias fundamentais que traduzem a nota do princípio da efetividade do processo: "a lei não excluirá da apreciação do Poder Judiciário lesão ou ameaça a direito" (art. $5^{\circ}, \mathrm{XXXV}$, da CF) e "ninguém será privado da liberdade ou de seus bens sem o devido processo legal" (art. $5^{\circ}$, LIV, da CF). Cf. ainda o art. 12 do CPP, bem como a Lei dos Juizados Especiais Criminais, que também permite a propositura da ação penal, sem o inquérito (art. 77, § $1^{\circ}$, da Lei 9.099/99). O Ministério Público normalmente tem acesso, por diversos meios, a elementos probatórios que justifiquem a propositura da ação penal, como nas hipóteses de informação direta da vítima e de provas extraídas de processos judiciais ou administrativos em que esteja oficiando. É o exemplo de provas oriundas de procedimentos do Tribunal de Contas ou produzidas em sede de inquérito civil (cf. o art. $8^{\circ}, \S 1^{\circ}$, da Lei 7.347/85).

${ }^{601}$ Cf. o art. 129, VIII, da CF. Equivocadamente, a Constituição inseriu as hipóteses do art. 129, incs. VI e VIII, como funções institucionais do Ministério Público, quando, na verdade, representam instrumentos necessários ao desenvolvimento de atividades previstas no mesmo dispositivo. O art. 26, IV, da Lei 8.625/93, diz competir ao Ministério Público "requisitar diligências investigatórias e a instauração de inquérito policial e de inquérito policial militar, observado o disposto, no art. 129, inciso VIII, da Constituição, podendo acompanhá-los". A Lei Complementar 75/93 dispôs incumbir ao "Ministério Público da União, sempre que necessário ao exercício de suas funções institucionais: (...) II - requisitar diligências investigatórias e a instauração de inquérito policial e de inquérito policial militar, podendo acompanhá-los e produzir provas; III - requisitar à autoridade competente a instauração de procedimentos administrativos, ressalvados os de natureza disciplinar, podendo acompanhá-los e produzir provas" (art. $7^{\circ}$, II e III).

${ }^{602} \mathrm{~A}$ ausência injustificada ao ato pode ensejar a designação de nova data para a oitiva do faltoso, com a sua condução coercitiva mediante o auxílio de força policial (art. 26, I, alínea $a$, Lei 8.625/93; e o art. $8^{\circ}$, I, VII e IX, da Lei Complementar 75/93).

${ }^{603} \mathrm{Cf}$. o art. 129 , VIII, e $\S 4^{\circ}, c / c$ os arts. 93 , X, e $5^{\circ}$, LIV, da CF.
} 
dirigir a qualquer órgão público ou privado, pessoas físicas ou jurídicas e autoridades ou agentes da União, Estados, Distrito Federal e Municípios, incluindo os da administração indireta ou fundacional. Ao Ministério Público também foi conferida a possibilidade de requisitar de outros órgãos a realização de exames, perícias, a prestação de serviços temporários de servidores e a disposição de meios necessários à realização de atividades específicas $^{604}$.

Como se vê, é difícil afastar dos membros da instituição a possibilidade de, diretamente, realizar providências investigatórias voltadas ao exercício da promoção da ação penal, principalmente diante da crescente gravidade do crime organizado no Brasil, "no que diz respeito ao narcotráfico, à indústria do sequestro", à exploração de crianças e de adolescentes, "e aos denominados 'crimes de colarinho branco', com amplas conexões internacionais envolvendo sérios prejuízos à ordem econômica pela 'lavagem de dinheiro" $", 605$.

\footnotetext{
${ }^{604}$ Segundo a Lei $8.625 / 93$, para a instrução de seus procedimentos administrativos o Ministério Público poderá "requisitar informações, exames periciais e documentos de autoridades federais, estaduais e municipais, bem como dos órgãos e entidades da administração direta, indireta ou fundacional, de qualquer dos Poderes da União, dos Estados, do Distrito Federal e dos Municípios"; poderá ainda requisitar "informações e documentos a entidades privadas, para instruir procedimentos ou processos em que (...)" os seus membros estejam oficiando (art. 26, I, b; e II). Para o exercício de suas atribuições, a Lei Complementar 75/93 estabeleceu, nos procedimentos administrativos instaurados pelo Ministério Público, a possibilidade de: "II - requisitar informações, exames, perícias e documentos de autoridades da Administração direta ou indireta; III - requisitar da Administração Pública serviços temporários de seus servidores e meios materiais necessários para a realização de atividades específicas; IV - requisitar informações e documentos a entidades privadas; $\mathrm{V}$ - realizar inspeções e diligências investigatórias; VI - ter livre acesso a qualquer local público ou privado, respeitadas as normas constitucionais pertinentes à inviolabilidade do domić́lio; VIII - ter acesso incondicional a qualquer banco de dados de caráter público ou relativo a serviço de relevância público; IX - requisitar o auxílio de força policial" (art. $8^{\circ}$, II a VI, e VIII e IX). E "a falta injustificada e o retardamento indevido do cumprimento das requisições do Ministério Público implicarão a responsabilidade de quem lhe der causa" (art. $8^{\circ}, \S 3^{\circ}$ da Lei Complementar 75/93). Sobre iniciativas análogas no âmbito das atribuições de proteção da criança e do adolescente, cf. também as disposições do art. 201, II, VI, $a, b$ e $c$, VII, XI e XII, do Estatuto da Criança e do Adolescente ECA (Lei 8.069/90). Tanto a elaboração da prova em outras esferas públicas, para posterior encaminhamento ao Ministério Público, como a colaboração de servidores ou profissionais, em caráter temporário, para que os elementos sejam produzidos nas instâncias da própria instituição, podem ser objeto de determinação por parte do Ministério Público Cf. o art. 26, I, $b$; da LONMP (Lei 8.625/93); o art. $8^{\circ}$, III, da LOMPU (Lei Complementar 75/93).

${ }^{605}$ GRINOVER, Ada Pellegrini. A legislação brasileira em face do crime organizado, cit., p. 89. A Constituição Federal alçou à condição de garantias fundamentais da pessoa humana a punição de determinados comportamentos delituosos (art. $5^{\circ}$, XLII, XLIII e XLIV). Vale o destaque aos seguintes diplomas: A Lei 7.716/89, com alterações introduzidas pela Lei 9.459/97, definindo, no comando constitucional, os crimes de preconceito racial como de natureza imprescritível e inafiançável, sujeitos à pena de reclusão. A Lei dos Crimes Hediondos (Lei 8.072/90, com alterações introduzidas pelas Leis 8.930/94, 9.695/98 e 11.464/07) que determina para alguns crimes, como o tráfico ilícito de entorpecentes e a extorsão qualificada pela morte e mediante sequestro, a insuscetibilidade de anistia, graça, indulto e fiança, impondo o inicial cumprimento da pena em regime fechado. A legislação amplia o prazo da prisão temporária para investigações e introduz o instituto da delação premiada, com a possibilidade de redução da pena para o participante que denunciar à autoridade a organização criminosa. A delação premiada também foi prevista para os crimes contra o sistema financeiro (Leis 9.080/95 e 7.492/86). A Lei 9.455/97 tipificou
} 
Por outro lado, não pode ser incondicional a possibilidade de o Ministério Público exercer atividades investigatórias de apuração dos delitos, independentemente da instauração ou da existência de inquérito policial. A medida não pode ocorrer "em quaisquer circunstâncias, para quaisquer fins e por quaisquer formas"606. Alguns limites realmente não podem ser desprezados. Considerando uma determinada investigação levada a efeito pela polícia judiciária, o Ministério Público pode produzir, diretamente, elementos probatórios no respectivo inquérito policial. O pressuposto, nessa hipótese, é o de que a fase investigatória prévia à acusação não deixará de contar com o controle de mais de um órgão estatal, ou seja, a iniciativa do Ministério Público justificar-se-ia em nome da celeridade do esclarecimento do fato delituoso, em atuação integrada com o órgão policial e sob o crivo da autoridade judicial competente nos autos do inquérito.

Já uma investigação autônoma pelo Ministério Público deverá obedecer a determinados requisitos no âmbito da matriz do devido processo legal, considerando, desde logo, a presença de motivos aptos a justificar a adoção da medida; consistem em situações fáticas que podem autorizar ou até exigir na forma da lei a prática de atos investigatórios em procedimentos próprios e regularmente instaurados; são pressupostos fáticos cuja ocorrência pode "deflagrar in concreto a competência que o agente dispõe em abstrato"607; são razões objetivas capazes de ensejar a iniciativa isolada do Ministério Público, porquanto amparada nas regras de suas atribuições funcionais, na finalidade de atingir um estágio mais próximo possível de certeza na formação do juízo acusatório.

\footnotetext{
as modalidades de tortura, com a criação de causas de aumento de pena e a imposição de restrições de natureza processual. Não é tão rigorosa quanto a Lei dos Crimes Hediondos por permitir o indulto e por ter sido o primeiro diploma que acolheu a progressão do regime de cumprimento da pena em conduta equiparada aos crimes hediondos. A Lei 9.034/95, alterada pela Leis 9.303/96 e 10.217/01, dispõe sobre meios para a prevenção e repressão de ações praticadas por organizações criminosas. A delação premiada foi igualmente disciplinada, assim como a insuscetibilidade de liberdade provisória e de fiança aos agentes que tenham tido intensa participação na organização criminosa. A Lei 9.613/98, com alterações introduzidas pelas Leis 10.467/02 e 10.701/03, dispondo sobre hipóteses de lavagem de dinheiro, também prevê a delação premiada para o colaborador e introduz a inversão do ônus da prova para a liberação de bens, direitos e valores apreendidos ou sequestrados, cabendo ao acusado comprovar a licitude de sua origem. Contemplou a mesma lei o retardamento da execução da ordem de prisão em benefício das investigações e criou o COAF - "Conselho de Controle de Atividades Financeiras, nomeado pelo Ministério da Fazenda, também incumbido do processo administrativo investigatório, podendo proceder a requisições de informações". (GRINOVER, Ada Pellegrini. A legislação brasileira em face do crime organizado, cit., p. 91-92).

${ }^{606}$ MELLO, Celso Antonio Bandeira de. op. cit., p. 85.

${ }^{607}$ Id. Ibid., p. 86.
} 
É claro que existe um campo induvidoso de situações que não apenas possibilitam como exigem a atuação investigatória do Ministério Público ${ }^{608}$. Mas haverá uma variedade de situações indeterminadas que pode, em tese, legitimar a ação do Ministério Público. Nos casos de omissão normativa em explicitar os motivos capazes de determinar a instauração de procedimento administrativo autônomo na área criminal, a constatação da legitimidade das condutas investigatórias dependerá da avaliação da adequação, do compasso entre a "situação tomada como base para a prática do ato e a finalidade que a lei atribui à competência exercitada" pelo órgão do Ministério Público ${ }^{609}$; finalidade que constitui a produção de elementos que lhe permitam alcançar aquele estágio mais próximo de certeza na formação da opinio delictis à propositura da ação penal.

Os chamados poderes investigatórios do Ministério Público são meramente instrumentais. São meios de que necessita dispor para o exercício de suas funções institucionais, não se confundindo, de modo algum, com a ideia de “'de 'domínio', de 'propriedade' ou de 'autonomia da vontade",610. A utilização dos mecanismos deve, portanto, corresponder à satisfação de dever prioritário no comando das garantias fundamentais de previsão constitucional e em respeito à competência da polícia judiciária do Estado estabelecida no mesmo plano ${ }^{611}$.

\footnotetext{
${ }^{608} \mathrm{E}$ a hipótese da presença de indícios revelando a participação de policiais em eventos de organização criminosa (cf. MAZZILLI, Hugo Nigro. op. cit., p. 309-310).

${ }^{609}$ MELLO, Celso Antonio Bandeira de. Discricionariedade e controle jurisdicional. 2. ed. São Paulo: Malheiros Ed., 1996. p. 94-95.

${ }^{610}$ Id. Ibid., p. 101.

${ }^{611}$ A resolução do CNMP (Conselho Nacional do Ministério Público), 13, de 2.10.2006, regulamentou a instauração do procedimento investigatório criminal no âmbito das atribuições do Ministério Público. Autorizou-o a lançar mão do instrumento para apurar a ocorrência de infrações penais de natureza pública, sem prejuízo da possibilidade de formalização da investigação por outros órgãos legitimados da administração pública (art. $1^{\circ}, \S$ único). Em julgamento de habeas corpus, o Min. Rel. Celso de Mello assim se posicionou sobre a matéria: “(...) A cláusula de exclusividade inscrita no art. 144, § $1^{\circ}$, inciso IV, da Constituição da República - que não inibe a atividade de investigação criminal do Ministério Público - tem por única finalidade conferir à Polícia Federal, dentre os diversos organismos policiais que compõem o aparato repressivo da União Federal (polícia federal, polícia rodoviária federal e polícia ferroviária federal), primazia investigatória na apuração dos crimes previstos no próprio texto da Lei fundamental ou, ainda, em tratados ou convenções internacionais. - Incumbe, à Polícia Civil dos Estados-membros e do Distrito Federal, ressalvada a competência da União Federal e excetuada a apuração dos crimes militares, a função de proceder à investigação dos ilícitos penais (crimes de contravenções), sem prejuízo do poder investigatório de que dispõe, como atividade subsidiária, o Ministério Público. - Função de polícia judiciária e função de investigação penal: uma distinção conceitual relevante, que também justifica o reconhecimento, ao Ministério Público, do poder investigatório em matéria penal (...)" (STF, 2a Turma, HC 94173/BA, Rel. Min. Celso de Mello, j. 27.10.2009, DJU 27.11.2009). No mesmo sentido: “(...) A denúncia pode ser fundamentada em peças de informação obtidas pelo órgão do MPF sem a necessidade do prévio inquérito policial (...). Não há óbice a que o Ministério Público requisite esclarecimentos ou diligencie diretamente a obtenção da prova de modo a formar seu convencimento a respeito de determinado fato, aperfeiçoando a persecução penal, mormente em casos graves como o presente, que envolvem altas somas em dinheiro (...)" (STF, $2^{\mathrm{a}}$ Turma, RE 535478/SC, Rel. Min. Ellen Gracie, j. 28.10.2008, DJU 21.11.2008).
} 
Daí por que, sob o critério da razoabilidade, ora concebido como desdobramento do devido processo legal, a condução pelo Ministério Público de procedimentos administrativos dirigidos à apuração de crimes deve ocorrer por força de circunstâncias concretas que se apresentem adequadas para justificar a conduta "em vista da finalidade que esta se propõe a prover"612 . Para que não reste dúvida sobre a legitimidade da atuação do Ministério Público, sempre com base no princípio do devido processo legal, é necessária a motivação do ato de instauração do procedimento investigatório autônomo. Ou seja, deverá haver a exteriorização das razões que demandaram a eclosão do ato, para que se confira a adequação da decisão às exigências impostas no caso concreto ao esclarecimento do fato delituoso, o que representa a finalidade específica que incumbe ao Ministério Público alcançar no cumprimento do dever institucional de responder pela titularidade privativa da ação penal pública.

O princípio da motivação é uma garantia de controle político. A limitação da ação estatal envolve a coordenação de sua atividade, não só no sentido de que seja conhecida, mas no sentido de se saber se o que é feito é aquilo que deve ser feito ${ }^{613}$. Assim, apenas se forem explicitadas as razões das iniciativas investigatórias do Ministério Público, será possível o controle da legalidade e legitimidade dos atos; ou seja, será possível constatar se foi obedecido o limite imposto à atuação estatal para a preservação da liberdade individual. A motivação serve para verificar se o ato correspondeu a uma aplicação válida da norma jurídica e se foi "apreciado de maneira correta no contexto fático que autorizava a sua aplicação" $" 614$. A proeminência dos direitos fundamentais implica um dever concreto de justificar as decisões estatais destinadas a limitá-los, principalmente para fins de garantia do controle jurisdicional ${ }^{615}$.

O devido processo legal sempre impõe a atenção à ampla defesa e ao princípio da publicidade, traduzindo a lisura e a transparência no exercício das atividades do Ministério

\footnotetext{
${ }^{612}$ MELLO, Celso Antonio Bandeira de. Discricionariedade e controle jurisdicional, cit., p. 95. Recorde-se que o princípio da razoabilidade tem sua origem ligada ao desenvolvimento do princípio do devido processo legal no plano do direito constitucional norte-americano. O tema foi aprofundado "à luz dos métodos de argumentação e exposição sistemática que caracterizam o modo de entender e praticar o direito nos países de tradição jurídica romano-germânica" (BARROSO, Luís Roberto. op. cit., p. 224).

${ }^{613}$ GOMES FILHO, Antonio Magalhães. A motivação das decisões penais. São Paulo: Ed. Revista dos Tribunais, 2001. p. 90-91. CANOTILHO, J. J. Gomes. Direito constitucional e teoria da Constituição. 7. ed. Coimbra : Almedina, 2003. p. 551 e ss.

${ }^{614}$ GOMES FILHO, Antonio Magalhães. op. cit., p. 93.

${ }^{615}$ Id. Ibid., p. 93-94. Cf. o art. 5º XXXV e LXI; e o art. 93, IX, da CF. Segundo dispõe a Resolução 13/06 CNMP, o procedimento investigatório será instaurado por portaria fundamentada que deverá conter a indicação dos fatos a serem investigados e, "sempre que possível, o nome e a qualificação do autor da representação e a determinação das diligências iniciais" (art. $4^{\circ}$, caput).
} 
Público. É evidente que medidas urgentes destinadas à colheita de provas devem ser tomadas de imediato, de modo a viabilizar a elucidação da conduta ilícita e, por vezes, a identificação de seus autores. No entanto, ainda que a ciência dos interessados deva, em muitos casos, ser diferida, é inconcebível o ocultamento de atos de investigação criminal aos sujeitos que sejam diretamente por eles afetados. A publicidade não pode ser alijada daqueles que figurem como objeto das investigações do Ministério Público e, tampouco, dos advogados que, no exercício regular de sua atividade profissional, os representem ${ }^{616}$.

A questão das requisições sobre informações sigilosas no âmbito da persecução penal merece, com efeito, uma especial atenção, eis envolver o confronto específico com direitos e garantias fundamentais identificados como valores essenciais de todo e qualquer sistema de direitos humanos, para a preservação de uma esfera intangível da liberdade individual. O princípio fundamental é aquele que assegura a inviolabilidade da intimidade, da vida privada, da honra e da imagem das pessoas, do qual decorre a inviolabilidade de domicílio e do sigilo da correspondência e das comunicações telegráficas, de dados e de

\footnotetext{
${ }^{616}$ Cf. os arts. $5^{\circ}$, XIII, e 133, da CF. O mesmo art. $5^{\circ}$, LX, da CF, estabelece que restrições legais à publicidade de atos processuais são admissíveis para a defesa da intimidade ou de interesse social. A ressalva que autoriza o sigilo para a proteção de interesse social não pode, no entanto, alcançar as pessoas diretamente afetadas pelos atos de investigação praticados pelo Ministério Público. A proteção de interesse social no combate à criminalidade não pode, em princípio, servir para justificar o pleno comprometimento do corolário da ampla defesa da garantia fundamental do devido processo legal (art. $5^{\circ}$, LIV e LV, da CF). $\mathrm{O}$ respeito à publicidade nos atos e peças do procedimento investigatório criminal também constou da Resolução 13/06 CNMP (art. 13, § único), que ressalvou a possibilidade de decretação de sigilo, por "decisão fundamentada, quando a elucidação do fato ou interesse público exigir; garantida ao investigado a obtenção, por cópia autenticada, de depoimento que tenha prestado e dos atos de que tenha, pessoalmente, participado" (art. 14). O autor do fato investigado deverá ser "notificado a apresentar, querendo, as informações que considerar adequadas, facultado o acompanhamento por advogado" (art. $7^{\circ}$ da Resolução 13/06 CNMP). No mesmo sentido, pronunciou-se o STF: “O Ministério Público, sem prejuízo da ação fiscalizadora intra-orgânica e daquela desempenhada pelo Conselho Nacional do Ministério Público, está permanentemente sujeito ao controle jurisdicional dos atos que pratique no âmbito das investigações penais que promova 'ex propria auctoritae', não podendo, dentre outras limitações da ordem jurídica, desrespeitar o direito do investigado ao silêncio ('nemo tenetur se detegere'), nem lhe ordenar a condição coercitiva, nem constrangê-lo a produzir prova contra si próprio, nem lhe recusar o conhecimento das razões motivadoras do procedimento investigatório, nem submetê-lo a medidas sujeitas à reserva constitucional de jurisdição, nem impedi-lo de fazer-se acompanhar de Advogado, nem impor, a este, indevidas restrições ao regular desempenho de suas prerrogativas profissionais (...). O procedimento investigatório instaurado pelo Ministério Público deverá conter todas as peças, termos de declarações ou depoimentos, laudos periciais e demais subsídios probatórios coligidos no curso da investigação, não podendo, o 'Parquet', sonegar, selecionar ou deixar de juntar, aos autos, quaisquer desses elementos de informação, cujo conteúdo, por referir-se ao objeto da apuração penal, deve ser tornado acessível tanto à pessoa sob investigação quanto ao seu Advogado. O regime de sigilo, sempre excepcional, eventualmente prevalecente no contexto de investigação penal promovida pelo Ministério Público, não se revelará oponível ao investigado e ao Advogado por este constituído, que terão direito de acesso - considerado o princípio da comunhão de provas - a todos os elementos de informação que já tenham sido formalmente incorporados aos autos do

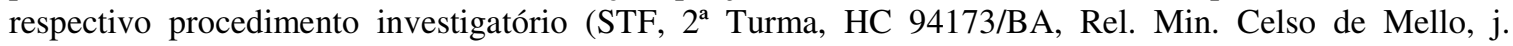
27.10.2009, DJU 27.11.2009).
} 
comunicações telefônicas. A restrição ao exercício de direito fundamental corresponde a constrangimento excepcional indissociável do controle judicial ${ }^{617}$.

A atividade de investigação de delitos pelo Ministério Público deve suceder-se sob os limites expostos, que se traduzem "em uma exigência ética a ser respeitada, em um instrumento de garantia para o indivíduo". A defesa da ordem pública reproduzida na busca da verdade real, como diretriz dominante no processo penal, não pode ocorrer no sentido de obtenção de uma "verdade absoluta" ou "ontológica", em detrimento de garantias fundamentais de proteção à dignidade da pessoa humana. A idoneidade dos meios utilizados pelo Ministério Público para produção de provas constitui pressuposto “de

${ }^{617} \mathrm{Cf}$. o art. $5^{\circ}, \mathrm{X}$ e XI, da CF. O inc. XII também do art. $5^{\circ}$ protege a inviolabilidade do sigilo "da correspondência e das comunicações telegráficas, de dados e das comunicações telefônicas, salvo, no último caso, por ordem judicial, nas hipóteses e na forma que a lei estabelecer para fins de investigação criminal e instrução processual penal". Note-se a impropriedade do dispositivo que só autoriza a quebra do sigilo das comunicações telefônicas mediante determinação judicial, conferindo caráter absoluto à preservação do sigilo das correspondências, comunicações telegráficas e de dados. A hipótese ofende a isonomia, por sacrificar, de forma desproporcional, a completa fruição da garantia do sigilo em relação a formas de comunicação análogas à da comunicação telefônica. Não se verifica, prima facie, nenhuma razão plausível para o tratamento discriminatório proveniente da disposição constitucional. Ademais, ressente-se de razoabilidade o alcance da exceção constitucional ao sigilo apenas no que diz respeito à prova colhida para o processo penal. Mas, segundo esclareceu Ada Pellegrini Grinover, a Assembleia Nacional Constituinte aprovou texto diverso "do que veio afinal a ser promulgado". A redação aprovada no plenário, em segundo turno, foi a seguinte: "É inviolável o sigilo da correspondência e das comunicações de dados, telegráficas e telefônicas, salvo por ordem judicial, nas hipóteses e na forma que a lei estabelecer, para fins de investigação criminal e instrução processual". "Foi a Comissão de Redação que, exorbitando de seus poderes, acrescentou ao texto as palavras 'comunicações', 'no último caso' e 'penal', limitando consideravelmente o alcance da norma constitucional legitimamente aprovada em plenário." Daí a inconstitucionalidade da redação restritiva do inc. XII, do art. $5^{\circ}$ da CF, por vício de competência e afronta ao processo legislativo. No entanto, a Lei 9.296/96, que rege o regime das interceptações telefônicas, atendendo a literalidade da redação do art. $5^{\circ}$, XII, da CF, só permite a interceptação de comunicações telefônicas e em sistemas de informática e telemática por ordem motivada da autoridade judicial, em casos de crimes punidos com a pena de reclusão (cf. GRINOVER, Ada Pellegrini. O regime brasileiro das interceptações telefônicas. In: ___ A marcha do processo, cit., p. 101-102). Cf. também o art. 5, XXXV, da CF: "a lei não excluirá da apreciação do Poder Judiciário lesão ou ameaça a direito"; e o art. 5, LIV, também da CF: "ninguém será privado da liberdade ou de seus bens sem o devido processo legal". A hipótese de flagrante delito consiste na ressalva à dependência de prévia autorização judicial para as buscas domiciliares (art. $5^{\circ}, \mathrm{XI}$, da CF). A situação não se modifica nos casos de acesso do Ministério Público a dados, documentos e informações que digam respeito à divulgação de fatos cujo sigilo seja inerente ao exercício de determinadas profissões, como acontece com médicos ou advogados (art. $5^{\circ}$, XIII, da CF). O sigilo da fonte inerente ao exercício da profissão jornalística não é inviolável. Contudo, em suas atividades de investigação, deve ser resguardado pelo Ministério Público, sob pena de apuração da responsabilidade civil e criminal, por força do uso indevido das informações. Cf. o art. $5^{\circ}$, XIV, da CF; o $\S 2^{\circ}$, do art. 26, da Lei 8.625/93; e o $\S 1^{\circ}$, do art. $8^{\circ}$, da Lei Complementar 75/93. O $\S 2^{\circ}$, do mesmo art. $8^{\circ}$, da Lei Complementar 75/93 proíbe a qualquer autoridade opor ao Ministério Público, sob qualquer pretexto, a "exceção de sigilo, sem prejuízo da subsistência do caráter sigiloso da informação, do registro, do dado ou do documento que lhe seja fornecido". No mesmo sentido, é a redação do art. $6^{\circ}, \S 1^{\circ}$, da Resolução 13/06 CNMP. 
tutela da esfera pessoal de liberdade: seu valor é um valor de garantia” para a conquista de "uma verdade processualmente válida" 618.

\subsubsection{2. $O$ controle externo da atividade policial}

O respeito a garantias fundamentais do Estado Democrático de Direito não implica nenhum menosprezo à iminência das atividades estatais de repressão à criminalidade, a qual, adotando um funcionamento em rede com a participação de organizações de grande porte, vem assumindo, na atualidade, notáveis proporções. Daí a crescente necessidade de uma reestruturação dos órgãos da polícia judiciária e do Ministério Público, mediante setores e equipes especializadas no combate ao crime organizado, para uma atuação integrada. Entretanto, ressalvadas algumas iniciativas quanto à formação de grupos de atuação especial, o funcionamento dos quadros do Ministério Público, com a independência funcional amparando as atividades de seus membros, dificulta o planejamento e a implantação de uma política institucional de atuação coesa na área criminal $^{619}$.

Muito embora tenham sido estruturados em organizações políticas constituídas em sentido divergente, ao contrário do Ministério Público brasileiro, os seus congêneres da França e dos Estados Unidos da América contam com o princípio da oportunidade da ação penal, para propiciar o estabelecimento de uma política mais eficaz de combate ao crime. Nos órgãos e nas agências dos dois países, prepondera uma estrutura hierárquica, facilitando a eleição de projetos prioritários no exercício dessa função estatal. O modelo francês, estruturado em carreira pública sob o controle do Ministro da Justiça, não deixa de ser alvo de algumas críticas justamente pela falta da independência necessária no exercício

\footnotetext{
${ }^{618}$ GRINOVER, Ada Pellegrini. As provas ilícitas na Constituição. In: ___ _ o processo em evolução. Rio de Janeiro: Forense Universitária. 1996. p. 46-47. A Constituição considerou ainda "inadmissíveis, no processo, as provas obtidas por meios ilícitos" (art. $5^{\circ}, \mathrm{LVI}$, da CF).

${ }^{619}$ No Ministério Público do Estado de São Paulo, está em funcionamento o GAECO - Grupo de Atuação Especial de Combate ao Crime Organizado - para agir na identificação, prevenção, repressão das atividades de organizações criminosas, em todo o Estado, valendo-se da fixação de metas gerais e regionais extraídas do Plano Geral de Atuação do Ministério Público e da designação de núcleos de atuação regionalizada, por meio de atos específicos da Procuradoria-Geral de Justiça. A atuação do GAECO deve ser realizada, de forma prioritária, na fase de investigação e oferecimento da denúncia, cabendo ao Promotor de Justiça natural oficiar na ação penal, desde então. A designação dos Promotores de Justiça com atuação criminal para agirem junto ao GAECO está condicionada à prévia indicação dos agentes pelos órgãos de execução abrangidos por sua atuação. Cf. o Ato Normativo 549, de 27.08.2008, editado pela Procuradoria-Geral de Justiça, nos termos da deliberação aprovada, por maioria absoluta, pelo Órgão Especial do Colégio de Procuradores de Justiça.
} 
de mister, que deveria remanescer alheio a interferências governamentais ${ }^{620}$. Com a organização do Ministério Público dispondo de algumas características similares às da instituição brasileira e também sob o predomínio da obrigatoriedade da ação penal, na Itália, chegou-se a questionar a impropriedade do sistema de inclusão do Ministério Público no órgão do judiciário e da ausência de vínculos hierárquicos entre integrantes de cada ofício para a implementação de uma diretriz uniforme de repressão à criminalidade, não obstante os resultados da chamada operação "mãos limpas"621.

A histórica concentração do poder político brasileiro na chefia do Executivo e os traços patrimonialistas que, a todo tempo, estiveram presentes em seu funcionamento, longe estão de recomendar a adoção do princípio da oportunidade da ação penal ${ }^{622}$. Os habituais excessos do poder central provocam um processo de corrupção endêmico em nosso regime político, aumentando o risco da impunidade de governantes eventualmente envolvidos em práticas ilícitas. De todo modo, nos três congêneres do Ministério Público brasileiro, tanto os órgãos estatais da França e da Itália como as agências governamentais dos Estados Unidos da América podem comandar as atividades policiais no curso da persecução penal, o que, na realidade, não acontece no Brasil.

Um sistema de controle recíproco do exercício do poder político do Estado Democrático, como já se atestou, pressupõe a obrigação de um órgão de prestar contas a outro sobre o fiel cumprimento da função em que foi investido. Nessa hipótese, os meios de controle são autônomos e devem estar reservados a órgãos diferentes para utilização de forma independente ${ }^{623}$. É o caso do controle externo da atividade policial, que foi, constitucionalmente, atribuído ao Ministério Público brasileiro, como titular privativo da ação penal. A atribuição deve estar regulamentada na lei complementar de organização de cada uma de suas carreiras, representando uma ação de vigilância e de verificação "teleologicamente dirigida à melhor coleta dos elementos" para a decisão do Ministério Público a respeito da propositura da ação penal. É, "sob o aspecto da atividade policial, vista como fornecedora de elementos para a formação da opinio delicts do órgão do Ministério Público, que se destina a imposição de um sistema de controle ministerial"624 ${ }^{\text {. E }}$

\footnotetext{
${ }^{620} \mathrm{Cf} .1 .2 .1$ e 1.3 .1 .

${ }^{621}$ Cf. 1.4 .

${ }^{622}$ Cf. o Cap. II.

${ }^{623}$ Cf. 3.3.1.

${ }^{624}$ MAZZILLI, Hugo Nigro. op. cit., p. 333. Cf. ainda o art. 129, VII, da CF, dispondo sobre o controle externo da atividade policial como um das funções institucionais do Ministério Público. Em atenção ao sistema de proteção dos direitos e garantias fundamentais da pessoa humana, a Lei Orgânica do Ministério
} 
a dificuldade da instituição em exercê-lo, incluindo o efetivo acompanhamento das medidas adotadas em sede dos inquéritos policiais, representa um obstáculo ao enfrentamento das atuais exigências na preservação da segurança pública ${ }^{625}$.

O controle externo da atividade policial não corresponde a nenhuma forma de vigilância de natureza disciplinar, que constitui um autocontrole dentro do próprio órgão do Executivo do Estado. É uma decorrência da organização hierárquica do quadro administrativo e se efetiva "pela imposição de penas chamadas disciplinares (...), aplicadas aos funcionários que faltem a deveres do cargo"626. O poder disciplinar é um instrumento de controle interno à disposição das instâncias superiores de um mesmo quadro público para a preservação do ordenamento jurídico contra as faltas funcionais de seus servidores. Pela característica de intimidação de suas sanções, "se previne a infração às regras do serviço e pela sua aplicação se reprime a violação delas" ${ }^{\text {627 }}$. A hipótese não deve mesclarse a relações de um sistema de controle externo entre órgãos estatais. Assim, é forçoso admitir a incompatibilidade de membros do Ministério Público figurando em instâncias de

Público da União estabeleceu os objetivos do controle externo da atividade policial; quais sejam: a) o respeito aos fundamentos do Estado Democrático de Direito, aos objetivos fundamentais da República Federativa do Brasil, aos princípios informadores das relações internacionais, bem como aos direitos assegurados na Constituição; b) a preservação da ordem pública, da incolumidade das pessoas e do patrimônio público; c) a preservação e a correção da ilegalidade ou de abuso de poder; d) a indisponibilidade da persecução penal; e) a competência dos órgãos incumbidos da segurança pública (art. $3^{\circ}$ da Lei Complementar 75/93). Ainda segundo a Lei Complementar 75/93, o exercício pelo Ministério Público de controle externo da atividade policial deve ser realizado por meio de medidas judiciais e extrajudiciais, com a possibilidade do "livre ingresso em estabelecimentos policiais ou prisionais"; do "acesso a quaisquer documentos relativos à atividade-fim policial"; de representação "à autoridade competente pela adoção de providências para sanar a omissão indevida, ou para prevenir ou corrigir ilegalidade ou abuso de poder"; de "requisitar à autoridade competente a instauração de inquérito policial sobre a omissão ou fato ilícito ocorrido no exercício da atividade policial"; e de "promover a ação penal por abuso de poder" (art. $9^{\circ}$, caput, e I a V). As disposições da Lei 8.625/93 que tratavam do controle externo da atividade policial foram objeto de veto (art. 25, X e XI). Porém, o referido art. 80 do mesmo diploma (Lei 8.625/93) autorizou a aplicação subsidiária das disposições da Lei Complementar 75/93 aos Ministérios Públicos dos Estados.

${ }^{625}$ No Ministério Público de São Paulo, o controle externo da atividade policial restringe-se ao comparecimento de seus membros ao distrito policial, após comunicação prévia ao delegado titular. Inexiste nenhum dado concreto para pautar a visita. Depois de um exame meramente formal do livro de ocorrências, uma ata é lavrada para o registro da fiscalização Cf. DIAS JÚNIOR, Paulo Roberto. Um novo modelo de gestão: reflexos na atuação do Ministério Público. In: CONGRESSO NACIONAL DO MINISTÉRIO PÚBLICO. MINISTÉRIO PÚBLICO E JUSTIÇA SOCIAL, p. 16, 6-9 nov. 2005. Anais... Belo Horizonte: CONANP - Associação Nacional dos Membros do Ministério Público; Associação Mineira do Ministério Público - AMMP, 2005. p. 720. No Ministério Público da Bahia, além de diligências decorrentes de denúncias encaminhadas por supostas vítimas ao Promotor de Justiça, existem as visitas rotineiras feitas, de surpresa, às delegacias e aos estabelecimentos prisionais para a apuração de eventuais irregularidades. Cf. SANCHES FILHO, Alvino Oliveira. Ministério Público e controle externo da polícia na Bahia. In: SADEK, Maria Tereza (Org.). Justiça e cidadania no Brasil. São Paulo: Ed. Sumaré, 2000. p. 200-201.

${ }^{626}$ FAGUNDES, M. Seabra. O controle dos atos administrativos pelo Poder Judiciário. 7. ed. Rio de Janeiro: Forense, 2005. p. 127, nota 127.

${ }^{627}$ Id., loc. cit. 
chefia de pastas da polícia judiciária, como autoridades de superior hierarquia do respectivo aparato organizacional do Executivo, cuja atividade deve ser objeto de controle externo pela instituição estatal ${ }^{628}$.

Considerando que o Ministério Público brasileiro não pode dispor do exercício da ação penal, o seu papel central na incumbência de repressão à criminalidade implica uma participação ativa na colheita dos elementos necessários à formação da opinio delictis, mediante o controle da atuação da polícia judiciária na fase prévia ao oferecimento da acusação. O controle externo da atividade policial serve, inclusive, para sustentar as medidas investigatórias do Ministério Público, sob o argumento de que não seria compatível com o alcance de suas finalidades institucionais se ele "só pudesse obter acesso aos elementos preparatórios à promoção da ação penal pública, para a qual é o único titular constitucional, sob dependência de inquérito policial conduzido por instituição subordinada aos governantes" $" 629$. Entretanto, tendo em conta as atribuições do Procurador-Geral no exercício da persecução penal e a forma de sua investidura nos cargos de chefia do Ministério Público, não é possível concluir pela ausência de vínculos de sujeição aos mesmos governantes. Alia-se à hipótese a mencionada assunção por membros do Ministério Público a cargos de confiança dos órgãos da polícia judiciária do Estado ${ }^{630}$.

O sistema só vem a acentuar a tradicional concentração do poder político na chefia do Executivo, não chegando a contribuir para uma atuação conjunta entre os agentes do Ministério Público e os policiais, para fins do desenvolvimento eficaz da atividade de controle externo. São ambiguidades que acabam comprometendo as atividades investigatórias essenciais à função institucional de combate à criminalidade, sobretudo em confronto com as atuais proporções de redes de organização criminosa envolvendo a

\footnotetext{
${ }^{628} \mathrm{O}$ art. $7^{\circ}$, III, da Lei Complementar 75/93 excluiu, corretamente, a possibilidade de requisição pelo Ministério Público de procedimentos administrativos disciplinares na esfera de competência de outros órgãos do Estado. Não é dado ao Ministério Público ordenar a instauração de procedimento administrativo disciplinar envolvendo agentes ou servidores de outros órgãos estatais. Diante do conhecimento de fato que configure falta funcional por eles cometida, além das medidas relativas a suas funções institucionais, o que compete ao membro do Ministério Público é informar a ocorrência à autoridade competente para as providências cabíveis, para fins de controle interno pelo próprio órgão público. Portanto, tão logo o membro do Ministério Público, com atribuições de controle externo sobre a atividade policial, tenha conhecimento da configuração de falta disciplinar deverá comunicá-la ao superior hierárquico do agente transgressor para a apuração da hipótese em sede própria. Em caso de inércia ou omissão por parte da autoridade competente, sem nenhuma dúvida, caberá ao Ministério Público a apuração de responsabilidades no âmbito específico de suas atribuições institucionais concernentes à persecução penal.

${ }^{629}$ MAZZILLI, Hugo Nigro. op. cit., p. 310. Cf. também SANCHES FILHO, Alvino Oliveira, op. cit., p. 202203.

${ }^{630}$ Recorde-se competir ao Procurador-Geral a posição definitiva quanto à rejeição pelo órgão do judiciário da promoção de arquivamento de inquérito policial (art. 28 do CPP). Cf. ainda o art. 128 , $\S 1^{\circ}$ e $3^{\circ}$, da $\mathrm{CF}$, dispondo sobre a nomeação do Procurador-Geral pelo chefe do Executivo.
} 
participação de agentes públicos, atores políticos e representantes de grandes grupos econômicos. São ambiguidades que, acima de tudo, subvertem as bases de organização e funcionamento do Estado Democrático de Direito, para levar a cabo a consecução de seus objetivos fundamentais no comando do princípio de controle do poder político de idêntica índole ${ }^{631}$.

\subsubsection{As características centrais do controle de constitucionalidade: uma breve apresentação de alguns mecanismos}

Convém inicialmente enfatizar que "a missão mais importante da jurisdição constitucional consiste na defesa dos valores que a Constituição incorpora, sobretudo o valor da dignidade da pessoa humana, que atrai todos os direitos fundamentais do homem" ${ }^{, 632}$. Trata-se, como se viu, de princípio que se irradia por todo o ordenamento jurídico, devendo pautar "a atuação de todos os órgãos de poder, inclusive a do Judiciário, na determinação do sentido das normas"633. Isso significa que a defesa daquele valor "se superpõe a todas as demais considerações”, impondo a interpretação expansiva de todos os pressupostos do controle da constitucionalidade dos atos do poder público, na qualidade de expressivo meio de defesa da Constituição. "A justiça constitucional, para alcançar esse desideratum, tem-se baseado nos princípios da jurisprudência dos valores"634.

Sob o aspecto material, é importante o reconhecimento do atributo da eficácia incidente sobre os princípios fundamentais, por expressarem as principais decisões políticas de constituição do Estado, de que resulta a configuração básica de sua organização do poder político. Mas o grau de eficácia a ser admitido aos princípios fundamentais depende da identificação dos efeitos pretendidos por suas disposições, considerando os comportamentos capazes de realizar as finalidades nelas contempladas ou

\footnotetext{
${ }^{631}$ Sobre as dificuldades de relacionamento entre membros do Ministério Público e delegados de polícia geradas pela atribuição de controle externo da atividade policial, cf. SANCHES FILHO, Alvino Oliveira, p. cit., p. 203-205. Quando da organização dos Estados Unidos da América, vale recordar a preocupação de James Madison com o problema das facções, quando grupos de pessoas atuam sob o impulso comum de paixões ou interesses circunscritos às suas facções, distanciando-se dos que são compartilhados pela coletividade. A hipótese é agravada em face do corporativismo que reveste órgãos públicos no Brasil, cujos interesses tendentes a sustentá-los acabam perdendo de vista os fins a que se destinam. Cf. 1.2, 2.4 e 3.3.1. Cf. ainda os arts. $2^{\circ}$ e $3^{\circ}$, I a IV, da CF.

${ }^{632}$ SILVA, José Afonso da. Comentário contextual à Constituição, cit., p. 546.

${ }^{633}$ BARROSO, Luís Roberto. op. cit., p. 374-375. No mesmo sentido é a posição de Luis Prieto Sanchis (cf. El constitucionalismo de los derechos, cit., p. 216). Cf. ainda o 3.2.1.

${ }^{634}$ SILVA, José Afonso da. op. cit., p. 546.
} 
de preservar os bens jurídicos que pretendam tutelar ${ }^{635}$. A análise de uma regra jurídica frente a um princípio fundamental demanda reconhecê-lo em sua estrutura aberta, com um grau de abrangência indeterminado a priori. Já se anotou que os princípios universais de proteção da dignidade humana pressupõem uma pluralidade de "mundos constitucionais", sem que venham especificadas as possíveis colisões, nem as condições de precedência de uns sobre outros e tampouco as condutas respectivas de cunho obrigatório.

A produção legislativa está, portanto, aberta a uma série de possibilidades para a realização daqueles princípios fundamentais, procurando conciliar razões que justifiquem cada um, quando se apresentem potencialmente contraditórias, "para alcançar um ponto ótimo de recíproca satisfação ou, ao menos, para evitar o aniquilamento de qualquer delas" "636 . É o sentido do chamado juízo de ponderação, a serviço da interpretação de cláusulas materiais da Constituição, notadamente no âmbito do conjunto de direitos fundamentais. Tal modelo de interpretação confere um nível de objetividade em sede do controle judicial de constitucionalidade de leis e atos normativos, não restringindo o raio de ação do legislador, senão nas hipóteses em que a sua iniciativa não corresponder à mínima exigência de "racionalidade ou de vedação a arbitrariedades"637.

A ideia de um regime democrático de governo não pode conviver com atos de violação aos direitos humanos, ainda que sob o primado da soberania popular. Quando a vontade do povo, manifestada por meio de seus representantes ou até diretamente, não encontrar ressonância no dever maior de respeito à dignidade da pessoa humana, é imperioso o exercício da função republicana pelo Estado, para fins de tutela do bem comum. É a atividade que incumbe à justiça constitucional do Estado Democrático de Direito $^{638}$.

O Brasil não aderiu à proposta de criação de uma Corte Constitucional, ao contrário do sistema concentrado que foi adotado em vários Estados europeus para o exame do controle de constitucionalidade dos atos normativos. A criação daquele órgão correspondia a um anseio generalizado da comunidade jurídica, sobretudo tendo em vista a experiência

\footnotetext{
${ }^{635}$ BARROSO, Luís Roberto. op. cit., p. 380.

${ }^{636}$ PRIETO SANCHÍS, Luis. El constitucionalismo de los derechos, cit., p. 220-221.

${ }^{637}$ Id. Ibid., p. 222. A ponderação resulta num modelo argumentativo de hierarquia móvel e axiológica, na medida em que concede um maior peso a uma dessas razões, à luz de circunstâncias concorrentes.

${ }^{638}$ Segundo Gustavo Zagrebelsky, é o aspecto republicano que caracteriza a justiça constitucional. A atividade legislativa é função daquilo sobre o que se vota, enquanto "a justiça constitucional é função daquilo sobre o que não se vota, porque é res publica” (ZAGREBELSKY, Gustavo. Jueces constitucionales, cit., p. 101-102).
} 
bem-sucedida "em diversos países que, tal como o Brasil, emergiam de ciclos ditatoriais". No entanto, "pressões corporativas e posições, mais ligadas à conservação de poderes que ao aperfeiçoamento institucional, conduziram à rejeição da inovação",639.

Dessa forma, a justiça constitucional brasileira evoluiu para a adoção de um sistema misto de controle da constitucionalidade das leis e atos normativos, acolhendo os métodos difuso e concentrado. O primeiro insere-se na competência do Supremo Tribunal Federal para o julgamento de recurso extraordinário interposto nas causas decididas em única ou última instância, quando a decisão recorrida declarar a inconstitucionalidade de tratado ou lei federal, ou quando considerar a validade de lei ou de ato de governo local contestado em face da Constituição ${ }^{640}$. Já o método de controle concentrado admite a competência do Supremo Tribunal Federal para a apreciação de duas modalidades de comportamentos contrastantes com a ordem constitucional: a) a inconstitucionalidade por ação; b) a inconstitucionalidade por omissão ${ }^{641}$.

A Constituição enumerou as pessoas e os entes legitimados à propositura da ação direta de inconstitucionalidade, entre os quais se inclui o Procurador-Geral da República $^{642}$. Em se tratando da constitucionalidade de leis ou atos normativos estaduais ou municipais, questionada em face da Constituição Estadual, a função também foi atribuída ao Procurador-Geral do Ministério Público dos Estados ${ }^{643}$. O legislador constituinte preferiu, no entanto, romper o monopólio do Ministério Público para a propositura da ação direta de inconstitucionalidade.

Uma última observação é necessária: a Constituição acrescentou permissivo para a propositura de ação declaratória de lei ou ato normativo federal, com a manutenção do

\footnotetext{
${ }^{639}$ BARROSO, Luís Roberto. O direito constitucional e a efetividade de suas normas: limites e possibilidades da Constituição brasileira. 5. ed. Rio de Janeiro: Renovar, 2001. p. 176. A teoria do judicial review emanou do julgamento do famoso caso Malbury versus Madison. Cf. 1.2. Na França, não houve a implantação de um sistema de controle judicial sobre a constitucionalidade dos atos do legislativo. Ao judiciário francês cabe solucionar os conflitos entre particulares e as questões penais, não havendo falar na invalidação dos atos do parlamento. O controle da legalidade dos atos da administração é de competência do Conselho Constitucional. Cf. BARROSO, Luís Roberto. O direito constitucional e a efetividade de suas normas: limites e possibilidades da Constituição brasileira, cit., p. 170, e nota 100. O autor destacou o papel desenvolvido pela Corte Costituzionale italiana que, interpretando a legislação remanescente do fascismo, muito contribuiu à redemocratização do país. Na Espanha, logo após o regime franquista, o Tribunal de Garantias Constitucionais figurou como um importante instrumento de estabilização democrática. Cf. BARROSO, Luís Roberto. O direito constitucional e a efetividade de suas normas: limites e possibilidades da Constituição brasileira, cit., p. 177.

${ }^{640} \mathrm{Cf}$. o art. 102, III, da CF.

${ }^{641} \mathrm{Cf}$. os arts. 102 , I, a; e $103, \S 2^{\circ}$, da CF.

${ }^{642} \mathrm{Cf}$. o art. 103, IV, da CF.

${ }^{643}$ Cf. o art. 29, I, da Lei 8.625/93, dispondo sobre a atribuição do Procurador-Geral de Justiça.
} 
Procurador-Geral da República figurando entre as autoridades legitimadas a lançar mão da medida ${ }^{644}$. Esta tende a servir de "um meio paralisante de debates em torno de questões jurídicas fundamentais de interesse coletivo" ${ }^{\natural 45}$. O alvo parece ser realmente o de sustar os efeitos de decisões de inconstitucionalidade prolatadas em ações em curso, contrárias à posição governamental. Outra hipótese levaria a questionar a existência de interesse no ajuizamento da ação, eis que, em virtude do princípio da presunção de constitucionalidade de leis ou atos normativos, a cada órgão estatal, cabe a interpretação e a aplicação do ordenamento constitucional no âmbito de sua competência. "O princípio funciona como um fator de autolimitação da atuação judicial" ${ }^{\text {646 }}$, de maneira que um ato normativo somente pode ser declarado inconstitucional quando houver razões fundadas sugerindo a mácula. Subsiste, pois, a situação de interesse governamental na supressão da eficácia de decisões de outros processos. É inquestionável, nesse caso, o vício de inconstitucionalidade a eivar o instituto. Verifica-se a inversão do papel do controle judicial na seara da atividade legislativa, além da afronta ao princípio do devido processo legal por subtrair às partes daqueles processos a garantia de acesso à justiça gerando inaceitável ofensa aos corolários do contraditório e da ampla defesa ${ }^{647}$. Cai por terra a titularidade do Ministério Público para a ação por aproximá-lo da atividade de representação judicial de entidades públicas, colidindo frontalmente com suas funções e finalidades institucionais ${ }^{648}$.

\subsubsection{A inconstitucionalidade por ação}

A inconstitucionalidade comissiva resulta da produção de atos legislativos ou administrativos em afronta aos princípios e regras constitucionais. Pode ocorrer sob o aspecto formal, ou seja, na hipótese de dissonância da produção do ato normativo das formalidades procedimentais exigidas; e também sob o prisma material, quando o conteúdo do ato normativo contrariar o de algum preceito do ordenamento constitucional.

Dessa forma, a Constituição Federal reconheceu a competência do Supremo Tribunal Federal para "processar e julgar, originariamente, a ação direta de inconstitucionalidade de lei ou ato normativo federal ou estadual" ${ }^{\text {649 }}$. A ação tem por

\footnotetext{
${ }^{644}$ Cf. os arts. 102, I, $a$, e 103 , VI, da CF.

${ }^{645}$ Cf. SILVA, José Afonso da. op. cit., p. 539.

${ }^{646}$ Cf. BARROSO, Luís Roberto. Interpretação e a aplicação da Constituição, cit., p. 371.

${ }^{647}$ Cf. os arts. $2^{\circ}, 5^{\circ}$, XXXV, LIV e LV, $c / c$ o art. 60 , $§ 4^{\circ}$, III e IV, da CF.

${ }^{648} \mathrm{Cf}$. os arts. 127 , caput, e $129, \mathrm{IX}, \mathrm{da} \mathrm{CF}$.

${ }^{649}$ Cf. o art. 102, I, $a$, da CF.
} 
objeto o controle de lei ou de ato normativo federal ou estadual em face da Constituição Federal, não havendo falar no correspondente controle direto de constitucionalidade de lei ou ato normativo municipal, o que só é viável frente à Constituição do Estado a que pertence o Município $^{650}$.

O controle direto é realizado por meio de ação genérica e abstrata, cuja finalidade é afastar o ato eivado de vício de inconstitucionalidade do ordenamento jurídico. O objeto da ação consiste no ataque à lei em tese, incluindo as emendas constitucionais produzidas em desrespeito às formalidades do processo de sua formação, com a inobservância às vedações quanto aos momentos de sua elaboração e quanto ao núcleo insuscetível de modificação pelo processo de emendas ${ }^{651}$. Tratados ou convenções internacionais, desde que incorporados ao direito interno, colocam-se no mesmo plano das leis ordinárias, submetendo-se, por conseguinte, ao respectivo controle por via da ação direta de inconstitucionalidade. $\mathrm{E}$ as decisões prolatadas nessa sede têm efeito erga omnes, a todos vinculando, inclusive os órgãos judiciários e da administração direta e indireta das unidades federativas do Estado ${ }^{652}$.

A natureza normativa de lei ou de atos administrativos do poder público consiste num comando geral, abstrato e impessoal, destinado a incidir para o futuro em reiteradas aplicações, de modo a alcançar um número indeterminado e indeterminável de destinatários. Atos normativos federais ou estaduais, passíveis de submissão ao controle direto de inconstitucionalidade, devem se manifestar para uma "universalidade de destinatários ou para uma universalidade de ações" ${ }^{653}$. É necessário ressaltar que os regulamentos no direito brasileiro estão estritamente vinculados às disposições legais. Não podem inovar a ordem jurídica, diversamente do que ocorre com as leis. Assim, caso um regulamento venha a inovar a ordem jurídica nada obsta a sua sujeição ao controle direto

\footnotetext{
${ }^{650} \mathrm{Cf}$. o art. $125, \S 2^{\circ}$, da CF.

${ }^{651} \mathrm{Cf}$. o art. $60, \S \S 1^{\mathrm{o}}, 2^{\mathrm{o}}, 3^{\mathrm{o}}$ e $4^{\mathrm{o}}$, I a IV, e $\S 5^{\circ}$, da CF.

${ }^{652}$ Cf. o art. 102, $\S 2^{\circ}$, da CF. Cf. SILVA, José Afonso da. op. cit., p. 547. Uma vez amparadas pela coisa julgada material, as decisões são oponíveis também ao próprio Supremo Tribunal Federal. Seus efeitos, porém, não atingem outros atos normativos, de cunho administrativo, de idêntico teor, que devem ser objeto de outra ação direta de inconstitucionalidade. É possível a concessão da medida cautelar para a suspensão da eficácia do ato impugnado, com os efeitos da medida acautelatória também a todos oponíveis, mas a partir de sua prolação, não alcançando, portanto, situações pretéritas (ex nunc). O Procurador-Geral da República tem legitimidade para propor pedido de natureza cautelar nas ações diretas de inconstitucionalidade, cujo julgamento também compete, originariamente, ao Supremo Tribunal Federal. Cf. 46, § único, I, da Lei Complementar 75/93.

${ }^{653}$ SILVA, José Afonso da. op. cit., p. 544.
} 
de inconstitucionalidade, pois "naquilo em que (...) extravasou os limites da lei, ele é diretamente inconstitucional (...)"654.

\subsubsection{A inconstitucionalidade por omissão}

Comportamentos ofensivos à ordem constitucional também podem ocorrer através de um non facere, ou seja, quando decorre de uma inércia ou de uma omissão dos órgãos estatais. Normalmente o legislador tem a faculdade de decidir discricionariamente sobre a edição ou não de uma norma. Sua inércia, de um modo geral, não tem o condão de caracterizar um comportamento inconstitucional. Todavia, quando a Constituição impõe ao órgão do legislativo o dever de regulamentar a atuação de determinado preceito constitucional, a abstenção será ilegítima, configurando a hipótese de inconstitucionalidade por omissão. Nesse caso, ao Judiciário cabe apenas o reconhecimento do estado de inércia, com a ciência do legislador para que supra a sua inatividade. A mera ciência não cria nenhum vínculo jurídico. Muito embora possa ter um efeito moral e político, a eventual recalcitrância do órgão legislativo sem qualquer sanção não impede que se perpetue a inobservância do comando constitucional ${ }^{655}$.

\footnotetext{
${ }^{654}$ SILVA, José Afonso da. op. cit., 544. Para fins de controle concentrado de constitucionalidade, o ato normativo é, especificamente, ato administrativo emanado de qualquer dos órgãos estatais. A lei, além de conter um comando genérico, abstrato e impessoal, é ato proveniente do órgão do legislativo segundo um procedimento qualificado voltado à sua edição. Existem leis, no entanto, que dispõem apenas dos atributos formais, pois, na verdade, por produzirem efeitos concretos equiparam-se a verdadeiros atos normativos, no sentido material. Por sua vez, existem atos administrativos que, muito embora não ostentem a qualidade de leis no sentido formal, assim possam ser substancialmente considerados. É o caso das leis delegadas e medidas provisórias previstas no texto da Constituição Federal. Cf. as normas dos arts. 62 e 68, da CF. O Supremo Tribunal Federal afastou a possibilidade de controle por via direta de inconstitucionalidade de leis ou atos normativos de efeitos concretos. Cf. STF, ADIn 842-DF, rel. Min. Celso de Mello, RTJ 147/545. José Afonso da Silva criticou o entendimento restritivo adotado pelo Supremo Tribunal Federal, argumentando que a eficácia da lei não se confunde com o simples ato administrativo. $\mathrm{O}$ efeito da lei, ainda que concreto, não é administrativo, já que não pode ser desfeito por outro ato administrativo. A lei de efeito concreto tem, portanto, o condão de inovar a ordem jurídica. Cf. SILVA, José Afonso da. op. cit., p. 541542. Atos normativos que produzam efeitos concretos são passíveis de ataque em outra sede constitucional, normalmente o mandado de segurança (art. $5^{\circ}$, LXIX e LXX, $a$ e $b$, da CF), com os efeitos da decisão incidindo apenas sobre os sujeitos da relação jurídica processual. Cf. ainda os arts. 49, V, e 84, IV, da CF.

${ }^{655}$ BARROSO, Luís Roberto. O direito constitucional e a efetividade de suas normas: limites e possibilidades da Constituição brasileira, cit., p. 164. Cf. o art. 103, § 2º da CF: "Declarada a inconstitucionalidade por omissão de medida para tornar efetiva norma constitucional, será dada ciência ao Poder competente para a adoção das providências necessárias e, em se tratando de órgão administrativo, para fazê-lo em trinta dias". $\mathrm{O}$ constituinte conferiu à matéria o mesmo tratamento da Constituição portuguesa de 1976. Em seu anteprojeto constitucional de 1986, Fábio Konder Comprato incluiu o art. 251, com o seguinte conteúdo: "Se as leis complementares, necessárias à aplicação dos dispositivos desta Constituição, não forem editadas dentro de três anos de sua promulgação, o Ministério Público ou qualquer interessado poderá pedir ao Poder Judiciário a aplicação direta desses dispositivos constitucionais aos casos concretos". (COMPARATO, Fábio Konder. Muda Brasil: uma Constituição para o desenvolvimento democrático. 4. ed. São Paulo: Brasiliense, 1987. p. 150).
} 
Outra solução conferida pelo constituinte para a hipótese de omissão legislativa consiste na garantia fundamental do mandado de injunção: "Conceder-se-á mandado de injunção sempre que a falta de norma regulamentadora torne inviável o exercício dos direitos e liberdades constitucionais e das prerrogativas inerentes à nacionalidade, à soberania e à cidadania" ${ }^{656}$. O mandado de injunção tem, como um de seus pressupostos, a inviabilidade do exercício de um direito ou liberdade constitucional, ou de uma prerrogativa intrínseca à nacionalidade, soberania e cidadania. Pressupõe que a impossibilidade de fruição dos direitos resulte da ausência de normas regulamentares. $\mathrm{O}$ mandado de injunção não se presta a instar o órgão competente à produção da norma faltante. Não se confunde com a ação direta de inconstitucionalidade por omissão, em razão do que o Judiciário deverá suprir a inércia do Legislativo ou do Executivo para, nos limites da controvérsia, criar o preceito inexistente, de maneira a possibilitar o exercício do direito por seu titular.

Por meio do mandado de injunção,

\begin{abstract}
"se pode pleitear e, eventualmente, conseguir que o Poder Judiciário, pelo seu órgão competente, primeiro formule a regra, que complemente, que supra aquela lacuna do ordenamento; e, em seguida, sem solução de continuidade, esse mesmo órgão aplique a norma ao caso concreto do impetrante, isto é, profira uma decisão capaz de tutelar, em concreto, aquele direito, aquela liberdade constitucional ou aquela prerrogativa inerente à cidadania, à nacionalidade ou à soberania, mediante, por ex., uma ordem de fazer ou não fazer, conforme o caso, dirigida à pessoa física ou jurídica, de direito privado ou de direito público, que estivesse resistindo ao exercício do direito, da liberdade, da prerrogativa, diante da falta de norma regulamentadora"657.
\end{abstract}

${ }^{656}$ Cf. o art. $5^{\circ}$, inc. LXXI, da CF. Pode ser atribuída ao direito pátrio a criação do instituto (cf. BARROSO, Luís Roberto. $O$ direito constitucional e a efetividade de suas normas: limites e possibilidades da Constituição brasileira, cit., p. 248; e BONAVIDES, Paulo. Curso de direito constitucional, cit., p. 505).

${ }^{657}$ BARBOSA MOREIRA, José Carlos. Mandado de injunção. Revista de Processo, São Paulo, n. 56, p. 115, out./dez. 1989. Em detrimento das reais potencialidades do instituto, o Supremo Tribunal Federal, sob inflexível interpretação do princípio da separação dos poderes, vinha limitando a aplicação da garantia fundamental, somente para o efeito de cientificar o órgão responsável pela omissão sobre o seu estado de mora. "O novo 'writ' constitucional, consagrado pelo art. 5', LXXI, da Carta Federal, não se destina a constituir direito novo, nem a ensejar ao Poder Judiciário o anômalo desempenho de funções normativas que lhe são constitucionalmente estranhas. O mandado de injunção não é o sucedâneo constitucional das funções político-jurídicas atribuídas aos órgãos estatais inadimplentes. A própria excepcionalidade desse novo instrumento jurídico impõe ao Judiciário o dever de estrita observância do princípio constitucional da divisão funcional do Poder. Reconhecido o estado de mora inconstitucional do Congresso Nacional, único destinatário do comando para satisfazer, no caso, a prestação legislativa reclamada, e considerando que, embora previamente cientificado do Mandado de Injunção n. 283, rel. Min. Sepúlveda Pertence, absteve-se de adimplir a obrigação que lhe foi constitucionalmente imposta, torna-se prescindível nova comunicação à instituição parlamentar, assegurando-se aos impetrantes, desde logo, a possibilidade de ajuizarem, imediatamente, nos termos do direito comum ordinário, a ação de reparação de natureza econômica instituída em seu favor pelo preceito transitório" (STF, MI 284-3/DF, j. 22.11.1991, Rel. Min. Marco Aurélio, DJU 26.6.1992). Como se vê, evoluindo, paulatinamente, em prol da ampliação do cabimento do 
De outra parte, retoma-se o ponto de serem, via de regra, autoaplicáveis disciplinas atributivas de todo e qualquer direito fundamental da pessoa humana, competindo aos órgãos estatais a criação das condições necessárias para a real produção de seus efeitos. Por essa razão, a recusa da autoridade competente em admitir a hipótese pode também ensejar a propositura de ações de outra natureza, como o mandado de segurança, mediante o reconhecimento incidental da inconstitucionalidade por omissão ${ }^{658}$. O cabimento do mandado de injunção há de implicar necessariamente, considerando as circunstâncias de cada caso concreto, a impossibilidade de fruição do direito, em razão da falta de norma regulamentadora, a despeito de sua natureza ${ }^{659}$. E o sujeito ativo do mandado de injunção é o titular do direito cujo exercício se apresentar inviável em virtude da ausência de norma regulamentadora. Note-se que, sendo difusos ou coletivos os direitos ou interesses objeto de tutela, poderá o Ministério Público promover o mandado de injunção. Nada impede, porém, o reconhecimento da legitimidade de terceiros nos mesmos casos ${ }^{660}$.

mandado de injunção, em recente pronunciamento, a Corte Constitucional posicionou-se no sentido de reconhecer a possibilidade de fruição do direito de greve pelos servidores públicos (art. 37, inc. VII, da CF), mediante a aplicação analógica da Lei Federal 7.783/89 (Lei de Greve para trabalhadores da iniciativa privada). Os pronunciamentos sobre o exercício do direito de greve por servidores públicos ocorreram no MI 670-9 e no MI 712-8 impetrados, respectivamente, pelo Sindicato dos Servidores Policiais Civis do Estado do Espírito Santo e pelo Sindicato dos Trabalhadores do Poder Judiciário do Pará; o estado de mora do Congresso Federal quanto à regulamentação do correspondente dispositivo constitucional (art. 37, VII, da CF) já havia sido reconhecido no MI 20/Distrito Federal, em julgamento de 19.5.2004.

${ }^{658} \mathrm{Cf}$. o art. $5^{\circ}$, LXIX e LXX, $a$ e $b$, da CF. "Não cabe mandado de injunção para reclamar a regulamentação de dispositivo constitucional dotado de eficácia imediata (...)" (STF, MI 59-0/DF, Rel. Min. Octavio Gallotti, j. 31.10.1996, DJU 21.2.1997). Cf. ainda o art. $5^{\circ}, \S 1^{\circ}$, da CF.

${ }^{659}$ Leis complementares ou ordinárias, bem como os regulamentos de todas as espécies.

${ }^{660}$ Nesse sentido, cf. BARROSO, Luís Roberto. O direito constitucional e a efetividade de suas normas: limites e possibilidades da Constituição brasileira, cit., p. 256. Cf. ainda os arts. 127, caput, e 129, II, III e IX, da CF; o art. 6º VIII, da Lei Complementar 75/93; e os arts. 80 da Lei 8.625/93 e 116, da Lei Complementar Estadual 734/93. O Estatuto da Criança e do Adolescente permite a propositura pelo Ministério Público de mandado de injunção na defesa dos interesses sociais e individuais indisponíveis da criança e do adolescente (art. 201, IX, da Lei 8.069/90). Essa legitimação do Ministério Público não impede a de terceiros. Cf. o art. 129, § $1^{\circ}$, da CF. O Supremo Tribunal Federal aceitou, por aplicação analógica do artigo $5^{\circ}$, inciso LXX, da Constituição, a propositura de mandado de injunção coletivo por entidades associativas e sindicatos, como substitutos processuais de seus membros: "Mandado de injunção coletivo: admissibilidade, por aplicação analógica do art. 5, LXX, da Constituição; legitimidade, no caso, de entidade sindical de pequenas e médias empresas, as quais, notoriamente dependentes do crédito bancário, têm interesse comum na eficácia do art. 192, § $3^{\circ}$, da Constituição, que fixou limites aos juros reais" (STF, MI 361-1/RJ, Rel. Min. Sepúlveda Pertence, j. 8.4.1994, DJU 17.6.1994). "O STF firmou-se no sentido de admitir a utilização, pelos organismos sindicais e pelas entidades de classe, do mandado de injunção coletivo, com a finalidade de viabilizar, em favor dos membros ou associados dessas instituições, o exercício de direitos assegurados pela CF" (STF, MI 472-2, Rel. Min. Celso de Mello, j. 16.11.1994, DJU 22.11.1994); e "Entidades sindicais dispõem de legitimidade ativa para a impetração do mandado de injunção coletivo, que constitui instrumento de atuação processual destinado a viabilizar, em favor dos integrantes da categoria que essas instituições representam, o exercício de liberdades, prerrogativas e direitos assegurados pelo ordenamento constitucional” (STF, Pleno, MI 472-DF, Rel. Min. Celso de Mello, j. 6.9.1995, v.u., DJU 2.3.2001). 


\subsubsection{A arguição de descumprimento de preceito fundamental}

O controle da inconstitucionalidade de leis ou atos normativos, por via de ação direta, envolve o descumprimento de qualquer princípio ou regra constitucional. Todavia, enquanto essa forma de controle representa uma violação a todo tipo de disposição constitucional, a arguição de descumprimento de preceito fundamental envolve somente aqueles que constituem "a essência do conjunto normativo constitucional" 661 . São preceitos que conferem identidade à Constituição, por incorporarem valores que informam a estrutura básica do Estado; e, consequentemente, devem também orientar a organização e o funcionamento de todos os seus órgãos, além de vincularem o desenvolvimento do ordenamento jurídico.

A lei de regência da espécie só admite o descumprimento de preceito fundamental por atos do poder público, podendo dispor de natureza normativa ou não ${ }^{662}$. Assim, se um ato de efeito concreto, mesmo proveniente do órgão do legislativo, estiver em ofensa a um preceito fundamental, é cabível o seu ataque pela via em questão perante a Suprema Corte. E o Ministério Público Federal dispõe de correspondente atribuição, por intermédio de iniciativa do Procurador-Geral de República ${ }^{663}$.

O diploma que regulamentou a medida trouxe, porém, uma restrição que padece de evidente vício de ilegitimidade. É que foi conferido ao instrumento o caráter de subsidiariedade, ao estatuir que "não será admitida arguição de descumprimento de preceito fundamental quando houver qualquer outro meio eficaz de sanar a lesividade" ${ }^{\text {,64 }}$. Não é aceitável a consagração de um mecanismo apenas subsidiário para missão de tamanha relevância, qual seja: a proteção dos princípios fundamentais do Estado Democrático de Direito. Trata-se inegavelmente de uma garantia implicitamente introduzida no catálogo de direitos e garantias fundamentais, por força do conteúdo materialmente aberto que lhe foi atribuído pelo legislador constituinte. $\mathrm{O}$ instrumento caracteriza-se, portanto, por um potencial de eficácia diferenciado, descabendo supor a sua aplicação subsidiária disciplinada por legislação infraconstitucional ${ }^{665}$.

\footnotetext{
${ }^{661}$ Cf. SILVA, José Afonso da. op. cit., p. 554. Cf.o art. 102, § 1º da CF: “a arguição de descumprimento de preceito fundamental, decorrente desta Constituição, será apreciada pelo Supremo Tribunal Federal, na forma da lei".

${ }^{662}$ Cf. o art. $1^{\circ}$ da Lei 9.882, de 3.12.1999.

${ }^{663} \mathrm{Cf}$. o art. 46, § único III, da Lei Complementar 75/93.

${ }^{664} \mathrm{Cf}$. o $§ 1^{\circ}$, do art. $4^{\circ}$, da Lei 9.882/99.

${ }^{665} \mathrm{Cf}$. o art. $5^{\circ}$, $\S \S 1^{\circ}$ e $2^{\circ}$, da CF.
} 


\subsubsection{A representação interventiva}

Um elemento essencial de garantia na Constituição é a estrutura federal do Estado. Com vistas à descentralização vertical, trata-se de uma divisão de poderes que também tem por objeto o controle de forças, que não só se manifesta no campo político, "como também na conservação da ordem constitucional (...)”, com a função de unir as partes mutuamente dependentes sob uma ordem constitucional comum $^{666}$. O Estado federal assenta no princípio da autonomia dos entes que o compõem, o que implica a posse de competências exclusivas e a existência de um governo próprio. A capacidade de agir dentro um círculo preestabelecido é reconhecida pela Constituição aos Estados, aos Municípios e ao Distrito Federal $^{667}$.

Na condição de providência que atinge diretamente o princípio federativo, de inegável índole fundamental, a intervenção é um ato político de natureza excepcional, só podendo ocorrer nos casos taxativamente prescritos no texto constitucional, como exceção ao princípio da não intervenção. Mas, justamente para realizar o equilíbrio federativo quando ele é afetado, a Constituição impõe o sacrifício daquela autonomia das unidades federativas, afastando provisoriamente a sua capacidade de agir. Além disso, os pressupostos de intervenção da União nos Estados e no Distrito Federal constituem situações que colocam em risco a segurança ou a ordem constitucional ${ }^{668}$.

Para a garantia da Constituição, está assegurada ainda a possibilidade de intervenção para prover a execução de lei federal, ordem ou decisão judicial, bem como para a observância dos seguintes princípios:

a) forma republicana, sistema representativo e regime democrático; b) direitos da pessoa humana; c) autonomia municipal; d) prestação de contas da Administração Pública, direta e indireta; e) aplicação do mínimo exigido da receita resultante de impostos estaduais, compreendida a proveniente de transferências, na manutenção e desenvolvimento do ensino e nas ações e serviços de saúde ${ }^{669}$.

\footnotetext{
${ }^{666}$ STERN, Klaus. op. cit., p. 374-375.

${ }^{667}$ Cf. SILVA, José Afonso da. op. cit., p. 324. Cf. os arts. 25, 29, 30 e 32, da CF.

${ }^{668}$ Cf. SILVA, José Afonso da. op. cit., p. 324. Cf. também o art. $1^{\circ}$, caput, da CF. Segundo estabelece o art. 34 da Constituição, "a União não intervirá nos Estados nem no Distrito Federal, exceto para: I - manter a integridade nacional; II - repelir invasão estrangeira ou de uma unidade da Federação em outra; III - pôr termo a grave comprometimento da ordem pública; IV - garantir o livre exercício de qualquer dos Poderes nas unidades da Federação; V- reorganizar as finanças da unidade da Federação que: a) suspender o pagamento de dívida fundada por mais de dois anos consecutivos, salvo por motivo de força maior; b) deixar de entregar aos Municípios receitas tributárias fixadas nesta Constituição, dentro dos prazos estabelecidos em lei (...)".

${ }^{669}$ Cf. o art. 34, VI e VII, da CF.
} 
No caso de recusa à execução de lei federal, foi atribuída ao Procurador-Geral da República a função de representar o Supremo Tribunal Federal para assegurar a executoriedade do diploma. À mesma autoridade compete propor perante aquele tribunal a ação direta de inconstitucionalidade interventiva nas hipóteses de violação a princípios fundamentais do Estado Democrático de Direito ${ }^{670}$.

As hipóteses de intervenção dos Estados em seus Municípios também estão disciplinadas na Constituição Federal ${ }^{671}$. De idêntico modo, o princípio é o da não intervenção, de sorte que a medida só poderá ocorrer nas situações excepcionais previstas no ordenamento constitucional. Ao Procurador-Geral de Justiça incumbe promover a representação junto aos Tribunais de Justiças, para fins de deferimento da ação interventiva municipal. A representação do chefe do Ministério Público constitui a peça inicial da ação direta de inconstitucionalidade interventiva, nos casos de inobservância de princípios assegurados na Constituição Estadual ou para prover a execução de lei ${ }^{672}$. E a titularidade para a intervenção decorrente do descumprimento de ordem ou decisão judicial depende evidentemente da condição do Ministério Público de interessado no processo. É preciso observar também que, nos casos de intervenção por iniciativa da instituição, a Constituição não exige a apreciação do órgão do legislativo, com o decreto de intervenção restringindose à suspensão do ato impugnado, "se essa medida bastar ao restabelecimento da normalidade" 673 .

\subsubsection{A afirmação de legítimo defensor dos interesses do povo e a ação civil pública}

Diversamente dos congêneres norte-americano, italiano e francês, bem como dos da maioria dos Estados latino-americanos, a partir da segunda metade do século passado, o Ministério Público brasileiro acabou adquirindo uma série de atribuições envolvendo a proteção de direitos ou interesses considerados em sua dimensão coletiva, como os

\footnotetext{
${ }^{670}$ Dispõe o art. 36, da CF, que "a intervenção dependerá: (...) III - de provimento, pelo Supremo Tribunal Federal, de representação do Procurador-Geral da República, na hipótese do art. 34, VII, e no caso de recusa à execução de lei federal".

${ }^{671}$ Segundo o art. 35, da CF, “o Estado não intervirá em seus Municípios, nem a União nos Municípios localizados em Território Federal, exceto quando: I - deixar de ser paga, sem motivo de força maior, por dois anos consecutivos a dívida fundada; II - não forem prestadas contas devidas, na forma da lei; III - não tiver sido aplicado o mínimo exigido da receita municipal na manutenção e desenvolvimento do ensino e nas ações e serviços públicos de saúde; IV - o Tribunal de Justiça der provimento a representação para assegurar a observância de princípios indicados na Constituição Estadual, ou para prover a execução de lei, de ordem ou decisão judicial".

${ }^{672} \mathrm{Cf}$. o art. 29, II, da Lei 8.625/93, tratando da atribuição do Procurador-Geral de Justiça.

${ }^{673}$ Cf. o art. 36, $\S 3^{\circ}$, da CF. Cf. MAZZILLI, Hugo Nigro. op. cit., p. 322.
} 
concernentes ao meio ambiente, ao consumidor, aos idosos, às pessoas portadoras de deficiência, às crianças e ao adolescente; ao patrimônio público e social; enfim, relacionados a uma gama de bens materiais ou imateriais absorvidos pela categoria de interesses difusos ou coletivos ${ }^{674}$.

Na conformidade com os cânones em que se funda a República Federativa do Brasil, uma atuação diretamente concebida sob as vestes do conteúdo normativo do artigo 127, caput, da Constituição representa, com toda certeza, a afirmação do papel do Ministério Público de legítimo defensor e promotor dos direitos e garantias que consubstanciam os valores essenciais a uma vida digna em sociedade. Estão inseridas nesse campo as atividades de defesa do efetivo respeito dos poderes públicos e dos serviços de relevância pública aos direitos fundamentais da pessoa humana, conjugadas à função de proteção do patrimônio público e social, do meio ambiente e de outros interesses difusos e coletivos ${ }^{675}$. Agindo na tutela de interesses transindividuais, dotados de evidente natureza social e, não raro, com inevitáveis repercussões na direção governamental, é possível afirmar que o Ministério Público brasileiro afigura-se, hoje, uma importante ferramenta na implementação dos direitos sociais, econômicos e culturais, cuja natureza "envolve diretamente a definição de políticas públicas" no âmbito do sistema constitucional de proteção dos direitos humanos ${ }^{676}$.

Por meio da edição da Lei 6.938, de 31 de agosto de 1981 (Lei da Política Nacional do Meio Ambiente), pela primeira vez no Brasil, em relação à tutela ambiental, mencionou-se a proteção de direitos ou interesses transindividuais. A proclamação dessa modalidade de direitos ou interesses, típica das sociedades de massa e, por isso, comuns a um conjunto de pessoas, impunha realmente a criação de novas técnicas de garantia. É que

\footnotetext{
${ }^{674}$ MACEDO JÚNIOR, Ronaldo Porto. Ministério Público brasileiro: um novo ator político: o Ministério Público e as organizações não governamentais sem fins lucrativos: estratégias para o futuro, cit., p. 106 e ss. No sistema da common law dos Estados Unidos da América, não obstante os procuradores-gerais das unidades federativas tenham assumido um papel mais importante na proteção dos interesses difusos, é preciso lembrar a condição de agente político inserido no sistema de representação democrática. "Essa condição se, de um lado, pode inspirá-lo, pode, também, inibi-lo a adotar a posição independente de um 'advogado do povo' contra componentes poderosos do establishment ou contra o próprio Estado" (CAPPELLETTI, Mauro; GARTH, Bryan. op. cit., p. 52).

${ }^{675} \mathrm{Cf}$., novamente, o conteúdo das disposições dos Títulos I e II, da CF, em imediata consonância com a natureza das funções institucionais atribuídas ao Ministério Público. Cf. ainda o art. 129, II e III, das CF.

${ }^{676}$ MACEDO JÚNIOR, Ronaldo Porto. O quarto poder e o terceiro setor: o Ministério Público e as organizações não governamentais sem fins lucrativos: estratégias para o futuro. In: VIGLIAR, José Marcelo Menezes; MACEDO JR., Ronaldo Porto (Coords.). Ministério Público II: democracia, cit., p. 254256. As atividades que foram consolidadas na tutela de direitos ou interesses de natureza transindividuais aumentaram consideravelmente o relevo da vocação do Ministério Público de órgão agente, afastando-o da figura tradicional de fiscal da lei. Cf. 4.1.
} 
as ofensas a direitos ou interesses transindividuais costumam afetar concomitantemente várias pessoas e, em diversas ocasiões, categorias específicas de pessoas, chegando até mesmo a atingir todos os integrantes de uma comunidade política. Dessa forma, no campo do direito processual, a ideia foi a da criação de mecanismos de tutela diferenciados voltados à solução molecular dos chamados conflitos de massa, de maneira a ser a lide resolvida de uma só vez, com a incidência dos efeitos da decisão sobre todos os titulares dos direitos violados.

A Lei 7.347 de 24 de julho de 1985 (Lei da Ação Civil Pública) sistematizou o processo coletivo no país, criando o instrumento básico de defesa em juízo daqueles direitos para a proteção do meio ambiente, do consumidor; e dos bens de valor artístico, estético, histórico, turístico e paisagístico, mediante criativa e inédita adaptação de institutos processuais, sobretudo no que diz respeito à legitimidade ativa e alcance da coisa julgada $^{677}$. Em seguida, a Constituição de 1988 elevou ao nível constitucional a proteção "do patrimônio público e social, do meio ambiente e de outros interesses difusos e coletivos", por intermédio da promoção do inquérito civil e da ação civil pública pelo Ministério Público ${ }^{678}$. E, em 11 de setembro de 1990, o sistema da ação civil pública recebeu uma importantíssima complementação, com o advento do Código de Defesa do Consumidor - CDC (Lei 8.078/90). O diploma, além de aumentar a esfera de abrangência do instituto para a defesa de todos os direitos ou interesses transindividuais, logrou apontálos e defini-los.

Na lição de José Carlos Barbosa Moreira: o CDC estabeleceu distinção suficientemente nítida entre a classe dos interesses 'difusos', pertinentes a séries de pessoas indeterminadas e unidas por meras circunstâncias de fato, como a de frequentarem a mesma praia ou usarem o mesmo produto medicinal, e a dos interesses 'coletivos', peculiares a grupos menos fluidos, formados por pessoas que se vinculam entre si ou com outrem 'por uma relação jurídica base' 679 .

\footnotetext{
${ }^{677}$ Cf. o art. $1^{\circ}$, I, II e III, da Lei $7.347 / 85$.

${ }^{678} \mathrm{Cf}$. o art. 129, III, da CF. Tem-se também a representação judicial e extrajudicial das entidades associativas para a defesa de seus membros (art. $5^{\circ}, \mathrm{XXI}$, da CF); a atribuição dos sindicatos à proteção dos direitos individuais e coletivos da categoria profissional (art. $8^{\circ}$, III, da CF); e a legitimidade dos índios e de suas comunidades à proteção de seus direitos e interesses (art. 232 da CF).

679، Assim, por exemplo, qualifica-se como difuso o interesse em evitar a poluição das águas oceânicas, ou em fazer proibir a comercialização da droga que se revelou prejudicial à saúde; qualifica-se, em vez disso, como coletivo o interesse dos contribuintes de determinado tributo na modificação do procedimento de cobrança observado pelo fisco e havido como desnecessário e ilegalmente gravoso, ou o dos estudantes de uma universidade em que as aulas lhes sejam ministradas com regularidade em ambiente sadio e
} 
Além disso, sob a inspiração do sistema da class action norte americana, o CDC criou também a categoria dos chamados direitos ou interesses individuais homogêneos, tradicionalmente tutelados a título pessoal, decorrendo o tratamento judicial coletivo de sua

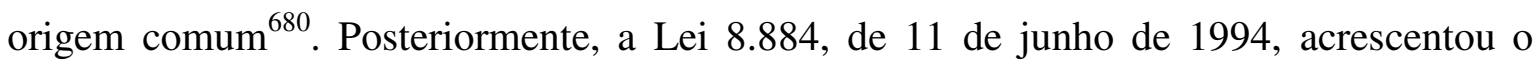
inciso $\mathrm{V}$ ao artigo $1^{\circ}$, da Lei 7.347/85, para a proteção da ordem econômica e da economia popular, enquanto o Estatuto da Cidade (Lei 10.257, de 10 de julho de 2.001) introduziu, no mesmo artigo $1^{\circ}$ da Lei $7.347 / 85$, o inciso VI para a defesa da ordem urbanística. O Estatuto da Criança e do Adolescente (Lei 8.069, de 13 de julho de 1990) não deixou de reconhecer a dimensão coletiva dos direitos ou interesses das crianças e adolescentes, o que também foi disciplinado em prol das pessoas portadoras de deficiência, mediante especial tratamento jurídico (Lei 7.853, de 24 de outubro de 1989) ${ }^{681}$.

A legitimidade ativa à propositura da ação civil pública revestiu-se de certa amplitude, acabando o legislador por estendê-la, concorrentemente, ao Ministério Público, à Defensoria Pública, à União, Estados, Municípios e Distrito Federal; às entidades e órgãos da administração pública, direta ou indireta, ainda que sem personalidade jurídica; e às associações legalmente constituídas há pelo menos um ano que incluam entre os seus

apropriado" (BARBOSA MOREIRA, José Carlos. Os deveres para com a comunidade. In: Temas de direito processual: sexta série. São Paulo: Saraiva, 1997. p. 311). Cf. o art. 81, § único, I e II, da Lei 8.078/90. Cf. ainda o art. 110 da Lei 8.078/90 e o art. $1^{\circ}$, IV, da Lei 7.347/85.

${ }^{680} \mathrm{Cf}$. o art. 81, § único, III, da Lei 8.078/90.

${ }^{681}$ Segundo a Constituição Federal: "a ordem econômica, fundada na valorização do trabalho humano e na livre iniciativa, tem por fim assegurar, a todos, existência digna, conforme ditames da justiça social", observados, entre outros, os seguintes princípios: a função social da propriedade, a livre concorrência, a defesa do consumidor; a defesa do meio ambiente, a redução das desigualdades regionais e sociais, e a busca do pleno emprego. Cf. o art. 170, II, III, IV, V, VI, VII e VIII, da CF. A Lei 8.884/94 instituiu um regime de prevenção e repressão contra a ordem econômica, autorizando o Ministério Público a ingressar em juízo para a defesa de interesses individuais ou individuais homogêneos, mediante a interrupção de práticas ofensivas à ordem econômica, com o pagamento de indenização por perdas e danos. Por sua vez, como um dos principais desdobramentos do princípio fundamental da função social da propriedade (art. $5^{\circ}$ XII e XIII, da CF), o Estatuto da Cidade foi editado para regulamentar o direito fundamental do art. 182, da CF: “A política de desenvolvimento urbano, executada pelo Poder Público municipal, conforme diretrizes fixadas em lei, tem por objetivo ordenar o pleno desenvolvimento das funções sociais da cidade e garantir o bem-estar de seus habitantes". No mesmo sentido, a Lei 8.974/95, que instituiu normas relativas à Biossegurança no Brasil, atribuiu "aos Ministérios Públicos da União e dos Estados a tarefa de propor ação de responsabilidade civil e criminal por danos causados ao homem, aos animais, às plantas e ao meio ambiente, decorrentes do uso indevido das técnicas de engenharia genética e da liberação no meio ambiente de organismos geneticamente modificáveis" (cf. ARANTES, Rogério Bastos. Ministério Público e política no Brasil, cit., p. 105). Cf. o art. 225, $\S 1^{\circ}$, II, da CF, que atribui ao poder público, para efetivar o direito de todos ao meio ecologicamente equilibrado, o dever de "preservar a diversidade e a integridade do patrimônio genético do País e fiscalizar as entidades dedicadas à pesquisa e manipulação de material genético”. Cf. ARANTES, Rogério Bastos. op. cit., p. 99-105. Cf. ainda os arts. 210 e ss., do Estatuto da Criança e do Adolescente ECA (Lei 8.069/90). 
fins institucionais a defesa dos direitos ou interesses tutelados ${ }^{682}$. Na esteira do ordenamento constitucional, importa anotar que aquelas legislações, ao acolherem a dimensão coletiva dos direitos sobre os quais versaram, colocaram em relevo a intervenção do Ministério Público para a tutela respectiva. E os estatutos organizacionais da instituição adotaram a mesma linha, acentuando o potencial dos instrumentos de investigação que lhe foram conferidos pela Constituição Federal, com especial destaque à promoção do inquérito civil ${ }^{683}$.

Trata-se de um poderoso instrumento, que permite reunir muitos elementos probatórios antes do ajuizamento da ação, tornando, em muitas ocasiões, incontroversos os fatos no curso da lide. Realmente, a possibilidade de utilização do inquérito civil apenas pelo Ministério Público acabou colocando-o numa posição privilegiada em relação aos outros entes legitimados para fazer uso da ação civil pública. Com isso, reduziu-se, em um primeiro momento, a intervenção das entidades civis, que adotaram a estratégia de apenas representar ao Ministério Público para que partisse dele a iniciativa de instauração do inquérito civil para a colheita das informações. Porém, na medida em que, ao longo do tempo, arrefece a fragilidade da democracia brasileira, com a emancipação da sociedade civil organizada, afirmou-se a convicção em torno da plena possibilidade de uma utilização eficaz do mecanismo da ação civil pública também por outros entes legitimados ${ }^{684}$. Se a ideia é de o Ministério Público figurar como um órgão intermediário entre o povo e os agentes do chamado "governo da maioria", para aquele equilíbrio de forças políticas extraído da doutrina de Montesquieu, o espaço aberto, no campo de utilização da ação civil pública, é à atuação conjunta do Ministério Público e das associações também legitimadas, incluindo a possibilidade do litisconsórcio entre os órgãos do Ministério Público da União, do Distrito Federal e dos Estados ${ }^{685}$.

\footnotetext{
${ }^{682} \mathrm{Cf}$. o art. $1^{\text {o }}$, I a V, $a$ e $b$, da Lei 7.347/85. Cf. também o art. 82, I a IV, do CDC (Lei 8.078/90). Quanto às iniciativas do Ministério Público para as ações civis, recorde-se que a sua legitimidade não impede a de terceiros nas mesmas hipóteses (art. 129, $\S 1^{\circ}$, da CF).

${ }^{683}$ A promoção do inquérito civil pelo Ministério Público, com a possibilidade de expedição de notificações e de requisição de informações e documentos, ganhou assento constitucional. Cf. o art. 129, III e VI, da CF. Cf. os arts. $8^{\circ}, \S \S 1^{\circ}$ e $2^{\circ}$; e $9^{\circ}, \S \S 1^{\circ}$ a $4^{\circ}$, da Lei $7.347 / 85$. E a LOMPU e a LONMP esmiuçaram instrumentos de investigação de largo alcance nos procedimentos administrativos de competência do Ministério Público, incluindo o inquérito civil. Cf. os arts. $6^{\circ}$, I a III; e $7^{\circ}$, I a IX, e $\S \S 1^{\circ}$ a $5^{\circ}$, da Lei Complementar 75/93; e os arts. 25, IV, e 26, I, $a$ a $c$, II, V, $\S \S 1^{\circ}, 2^{\circ}$ e $3^{\circ}$ da Lei 8.625/93.

${ }^{684}$ Recentemente, a Defensoria Pública foi incluída no rol dos órgãos legitimados para a ação, Cf. o art. $5^{\circ}$, II, da Lei 7.347/85. Cf. ainda os arts, $5^{\circ}$, LXXIV, e 134, da CF.

${ }^{685} \mathrm{Cf}$. o art. $5^{\circ} \S \S 2^{\circ}$ e $5^{\circ}$, da Lei 7.347/85. O Ministério Público, ainda que não ajuíze a ação, deve intervir obrigatoriamente nos processos; e, em caso de desistência ou abandono da ação por associação legitimada, o Ministério Público ou outro legitimado poderá assumir a legitimidade ativa. Cf. o art. $5^{\circ}, \S \S 1^{\circ}$ e $3^{\circ}$, da Lei 7.347/85. É preciso dissipar, como previram os próceres da constituição dos Estados Unidos da
} 
A democratização do Estado elevou o processo à condição de garantia constitucional. A democratização da sociedade levou-o, porém, a ultrapassar os limites da tutela dos direitos individuais para não só proteger o indivíduo e as coletividades do agir contra legem do Estado e dos particulares, mas também "atribuir a ambos o poder de provocar o agir do Estado e dos particulares no sentido de se efetivarem os objetivos politicamente definidos pela comunidade" ${ }^{686}$. É nesse plano que repousa a configuração política dos direitos ou interesses próprios de uma sociedade de massa.

Deles emergiram novas formas de gestão da coisa pública, em que se afirmaram os grupos intermediários. (...) Trata-se de uma nova forma de limitação ao poder do Estado, em que o conceito unitário de soberania, entendida como soberania absoluta do povo, delegada ao Estado, é limitado pela soberania social atribuída aos grupos naturais e históricos que compõem a nação ${ }^{687}$.

Assim, o processo está a serviço da "participação na formulação do direito pelos corpos intermediários e de provocação da atuação dos agentes públicos e privados no tocante aos interesses coletivos ou transindividuais por cuja satisfação forem responsáveis" ${ }^{688}$. Despindo-se de sua tradicional roupagem individualista, avultou um modelo social capaz de suplantar esquemas abstratos para a adoção de fórmulas mais concretas: "Do plano estático ao plano dinâmico, o processo transformou-se de individual em coletivo, ora inspirando-se no sistema das class actions da common law, ora estruturando novas técnicas, mais aderentes à realidade social e política subjacente" ${ }^{689}$.

A atual expressão moderna do devido processo legal revela-se na defesa de direitos ou interesses transindividuais, com a modificação do próprio papel do magistrado, como responsável por decisões envolvendo conflitos de massa, de índole política. É o "motivo pelo qual todas as leis processuais têm investido o julgador de maiores poderes de

América, a possibilidade de que os interesses específicos de cada facção, movida por paixões e objetivos comuns de fortalecimento institucional, sobrepujem as finalidades de interesse público na esfera do aproveitamento de um meio genuinamente concebido para alcançá-las. Cf. 1.2.

${ }^{686}$ PASSOS, Joaquim José Calmon de. Democracia, participação e processo. In: GRINOVER, Ada Pellegrini et al. (coords.). Participação e processo. São Paulo: Ed. Revista dos Tribunais, 1988. p. 95.

${ }^{687}$ GRINOVER, Ada Pellegrini. Significado social, político e jurídico da tutela dos interesses difusos. In: . A marcha do processo, cit., p. 18.

${ }^{68}$ PASSOS, Joaquim José Calmon de. op. cit., p. 94-96.

${ }^{689}$ GRINOVER, Ada Pellegrini. Significado social, político e jurídico da tutela dos interesses difusos, cit., p. 18. 
impulso" ${ }^{690}$. Daí a possibilidade de o sistema da ação civil pública abranger "todas as espécies de ações capazes de propiciar sua adequada e efetiva tutela"691. Houve, assim, a introdução de inédito regime de proteção às obrigações específicas, estendido posteriormente ao processo comum, procurando o legislador deixar "claro que, na obtenção da tutela específica da obrigação de fazer ou não fazer, o que importa, mais do que a conduta do devedor, é o resultado prático protegido pelo Direito"692. A ação civil pública é, pois, um gênero, que é formado pela Constituição e, "do ponto de vista infraconstitucional, pelo Código de Defesa do Consumidor - na parte processual - e pela Lei da Ação Civil Pública. Essa é a base genérica”. Os dois textos legais interagem, complementando-se reciprocamente e constituindo o marco candente do processo coletivo brasileiro $^{693}$.

\subsubsection{A essência do controle da legitimidade na gestão do patrimônio público}

A garantia da ação popular conferida ao cidadão encontra-se situada no campo dos direitos políticos contemplados na Constituição de 1988, a qual, por diversos meios, assegurou a participação do povo no processo político do Estado. Trata-se de uma garantia fundamental que confere a qualquer cidadão legitimidade para o exercício de um controle político da função executiva do Estado, como expressão direta da soberania popular e, principalmente, do princípio republicano de preponderância do bem comum sobre todo e qualquer interesse particular $^{694}$.

${ }^{690}$ GRINOVER, Ada Pellegrini. A ação popular portuguesa: uma análise comparativa. In: . A marcha do processo, cit., p. 57. Os princípios do devido processo legal e da inafastabilidade do controle jurisdicional compõem o núcleo central da efetividade do processo. Cf. o art. $5^{\circ}, \mathrm{XXXV}, \mathrm{LIV}$ e LV, da CF. ${ }^{691}$ Cf. o art. 83 da Lei 8.078/90.

${ }^{692}$ WATANABE, Kazuo et al. Código Brasileiro de Defesa do Consumidor: comentado pelos autores do anteprojeto. 7. ed. Rio de Janeiro: Forense Universitária, 2001. p. 842. Cf. o art. 84 da Lei 8.078/90; e o art. 461 do CPC.

${ }^{693}$ NERY JUNIOR, Nelson. Defesa do patrimônio público em juízo - o sistema do processo coletivo e o interesse público. In: SUNDFELD, Carlos Ari; BUENO, Cássio Scarpinella (Coords.). Direito processual público: a Fazenda Pública em juízo. São Paulo: Malheiros Ed., 2000. p. 255. Cf. os arts. 90 e 117 da Lei 8.078/90; e o art. 21 da Lei 7.347/85.

${ }^{694}$ Com origem no direito romano, a ação popular remete à função do pretor da república romana, cujo ofício tornou-se uma considerável contribuição à civilização da humanidade. Cf. LOEWENSTEIN, Karl. The governance of Rome, cit., p. 60-61. No cenário constitucional brasileiro, aparece a ação popular na Carta de 1934, submergindo, porém, logo em seguida, no curso do período ditatorial do Estado Novo. Ressurgiu na Constituição de 1946, para albergar também a proteção ao patrimônio de autarquias e sociedades de economia mista de todas as entidades federativas do Estado; e assim foi mantida na Constituição Federal de 1967 e na Emenda Constitucional 1/69. Cf. os arts. 113 da CF de 1934, 141, § 38, da CF de 1946, e o art. 153, § 31, da EC 1/69. É a redação do art. $5^{\circ}$, inc. LXXIII, da CF: "Qualquer cidadão é parte legítima para propor ação popular que vise anular ato lesivo ao patrimônio público ou de entidade de que o Estado participe, à moralidade administrativa, ao meio ambiente e ao patrimônio histórico e cultural (...)”. 
No entanto, a garantia da ação popular constitucional é também uma ação coletiva, pois a atividade jurisdicional é instada pelo autor para a tutela, não de seu interesse pessoal, mas de interesse de todos os integrantes de sua comunidade política. É válido afirmar que "talvez a primeira manifestação normativa brasileira no sentido de conceber tutela jurisdicional para os direitos difusos, como concebidos modernamente pela doutrina, tenha sido a criação da ação popular constitucional (...)"695.

A atuação do Ministério Público também se dirige ao mesmo tipo de controle, mediante a utilização do sistema da ação civil pública, cuja esfera de abrangência é bem mais significativa. Sempre à luz do compromisso com o bem comum, além da proteção do meio ambiente e do patrimônio histórico e cultural, a intervenção do Ministério Público é no sentido de zelar pela integridade do patrimônio brasileiro, com realce ao princípio da moralidade na gestão da coisa pública. A afronta a qualquer bem material ou imaterial concernente ao patrimônio público representa uma enorme lesão para toda coletividade, por ter sido privada de ver respeitada a ordem jurídica no trato de seus prioritários interesses $^{696}$.

Em aplicação dos princípios fundamentais que regem a atuação administrativa do Estado, a Constituição cominou drásticas penalidades para os responsáveis por atos de improbidade administrativa ${ }^{697}$. Em vigor desde 02 de junho de 1992, a Lei de Improbidade Administrativa (Lei 8.4292/92) sedimentou o papel do Ministério Público no sistema de controle do poder político do Estado, cometendo-lhe a função de físcalizar o comportamento dos governantes no trato da coisa pública, considerando basicamente o arcabouço de garantias institucionais, cuja obediência é inarredável na gestão dos negócios

\footnotetext{
${ }^{695}$ NERY JÚNIOR, Nelson. Princípios do proceso civil na Constituição Federal. 4. ed. São Paulo: Ed. Revista dos Tribunais, 1997. p. 112. No mesmo sentido, cf. BARBOSA MOREIRA, José Carlos. A ação popular do direito brasileiro como instrumento de tutela jurisdicional dos chamados "interesses difusos", In: _. Temas de direito processual: primeira série. São Paulo: Saraiva, 1977. p. 110-123. Ressalte-se que a Lei 7.347/85 invocou expressamente a ação popular no caput de seu art. $1^{\circ}$, enfatizando a natureza da espécie.

${ }^{696}$ Cf. o art. 129 , III, da CF. Cf. também o art. $1^{\circ}$ da Lei 7.347/85. A LONMP atribuiu ao Ministério Público a promoção de inquérito civil e ação civil pública "para anulação ou declaração de nulidade de atos lesivos ao patrimônio público ou à moralidade administrativa do Estado ou de Município, de suas administrações indiretas ou fundacionais ou de entidade privadas de que participem" (art. 25, IV, b, da Lei 8.625/93). Cf. 3.3 e 3.3 .1 .

${ }^{697} \mathrm{Cf}$. o art. $37, \S 4^{\mathrm{o}}$, da $\mathrm{CF}$ : "os atos de improbidade administrativa importarão a suspensão dos direitos políticos, a perda de função pública, a indisponibilidade de bens e o ressarcimento ao erário, na forma e gradação previstas em lei, sem prejuízo da ação penal cabível".
} 
públicos. Impõe-se à administração pública estatal a obediência "aos princípios da legalidade, impessoalidade, moralidade, publicidade e eficiência (...)"698.

A perspectiva é a inversão do nefasto quadro brasileiro de impunidade que reproduz incessantemente a isenção de qualquer responsabilidade política ou jurídica dos responsáveis por comportamentos atentatórios aos princípios da probidade e da moralidade na gestão do patrimônio a todos comum. Mais uma vez, é imperiosa a lembrança da Antiguidade sobre os valores que devem sustentar qualquer comunidade política. A honestidade é um bem valioso para a realização da virtude, o espírito cívico de uma república, correspondendo à disposição moral de todos de jamais sobrelevar os interesses pessoais aos do Estado ${ }^{699}$. Ninguém pode desejar aumentar o seu patrimônio à custa da desvantagem alheia. A utilidade de algo deve estar indissociável da retidão comportamental. Para Cícero, o sistema do direito das nações e as leis dos povos asseguram a presença da república nas cidades; "é precisamente neste aspecto que reside a finalidade das leis", de modo a assegurar que aquilo que é útil para alguém também o seja para o benefício de todos, sob pena de dissolução dos laços sociais que unem os homens em uma comunidade política. O espírito da cidade exige a solidariedade entre os cidadãos "para com a causa do bem comum”, sem o que o espírito de justiça será consequentemente aniquilado $^{700}$. É a virtude que deve revestir o espírito de um governante, nada existindo de mais admirável "quando o que manda não é escravo de paixão alguma e dá exemplo de

\footnotetext{
${ }^{698}$ Registre-se ainda a explicitação também das garantias da finalidade, razoabilidade e motivação e interesse público pela Constituição paulista (art. 11). Também segundo a Lei de Improbidade Administrativa, os "agentes públicos de qualquer nível ou hierarquia são obrigados a velar pela estrita observância dos princípios da legalidade, impessoalidade, moralidade e publicidade no tratamento dos assuntos que lhes são afetos" (art. $4^{\circ}$ da Lei 8.492/92). A lei conceituou as condutas ofensivas à administração direta ou indireta de qualquer dos poderes da União, dos Estados, do Distrito Federal e dos Municípios, bem como de empresa incorporada ao patrimônio público ou de entidade para cuja criação ou custeio o erário haja concorrido ou concorra com mais de $50 \%$ (cinquenta por cento) do patrimônio ou da receita anual. Atos praticados contra o patrimônio de entidade que recebe subvenções ou benefícios fiscais também estão sujeitos ao alcance da legislação, reputando-se agente público, para as suas finalidades, todo aquele que exerce mandato, emprego ou função nas entidades mencionadas, ainda que transitoriamente ou sem remuneração, por eleição, nomeação, designação, contratação ou qualquer outra forma de investidura ou vínculo. As disposições do diploma atingem ainda aquele que, mesmo não sendo agente público, induza ou concorra para a prática do ato de improbidade ou dele se beneficie sob qualquer forma, ainda que indiretamente (arts. $1^{\circ}, \S$ único, $2^{\circ}$ e $3^{\circ}$, da Lei 8.492/92). Foram tipificadas as modalidades de atos de improbidade que importem enriquecimento ilícito, que causem prejuízo ao erário e que atentem contra os princípios da administração pública, com o estabelecimento de respectivas medidas sancionatórias, incluindo desde o ressarcimento do dano até a perda de função pública e a suspensão dos direitos políticos (arts. $9^{\circ}$ a 12, da Lei 8.492/92).

${ }^{699}$ Lembrem-se as considerações de Montesquieu sobre o espírito cívico, que movimenta as forças sociais e políticas de uma república democracia. Cf. 1.1.2.

${ }^{700}$ Cf. CÍCERO, Marco Túlio. Dos deveres (De officiis), cit., p. 121-124.
} 
tudo o que ensina e preconiza, não impondo ao vulgo leis que é o primeiro a não respeitar $(\ldots)^{,, 701}$.

\subsubsection{Considerações gerais sobre o controle das políticas públicas}

Entre os direitos de solidariedade garantidos nas modernas constituições "estão os direitos ao trabalho, à saúde, à segurança material e à educação. Tornou-se lugar-comum observar que a atuação positiva do Estado é necessária para assegurar o gozo de todos esses direitos sociais básicos". E, como se viu, o direito de acesso à justiça recebeu especial atenção para "armar os indivíduos de novos direitos substantivos em sua qualidade de consumidores, locatários, empregados e, mesmo, cidadãos"702.

De início, cabe frisar que, mesmo em face de uma interpretação literal, a exigência de autoaplicabilidade dos direitos e garantias fundamentais tem incidência sobre todos os direitos inerentes ao princípio da dignidade da pessoa humana. Incluem-se, por conseguinte, em seu espectro, não só os direitos do catálogo constitucional específico, como também aqueles que, em razão do conteúdo materialmente aberto que lhe foi atribuído, advêm de tratados internacionais, estão situados em outras partes do texto constitucional e até mesmo fora dele $\mathrm{e}^{703}$.

Nesse passo, o legislador constituinte estabeleceu serem os direitos e garantias fundamentais imediatamente aplicáveis. O destaque é à orientação no sentido de se tratar de um mandado de otimização, estabelecendo aos órgãos estatais a tarefa de reconhecerem a maior eficácia possível aos direitos fundamentais, com a presunção de aplicabilidade imediata de toda e qualquer disciplina que os contemple. As exceções para "serem legítimas, dependem de convincente justificação à luz do caso concreto, no âmbito de uma exegese calcada em cada norma de direito fundamental e sempre afinada com os postulados de uma interpretação tópico-sistemática (...),704.

A autoaplicabilidade das normas prescritivas de direitos fundamentais não costuma ser questionada diante dos clássicos direitos, em que a fruição por seus titulares reclama apenas uma abstenção do poder público ou dos particulares. Outra, contudo, é a situação

\footnotetext{
${ }^{701}$ CÍCERO, Marco Túlio. Da República, cit., p. 31.

${ }^{702}$ CAPPELLETTI, Mauro; GARTH, Bryan. op. cit., p. 11-12.

${ }^{703}$ A alusão é ao catalogo do art. $5^{\circ}$, do Capítulo I, do Título II da CF. Cf. o art. $5^{\circ}, \S 2^{\circ}$, que estabelece o conteúdo materialmente aberto aos direitos e garantias fundamentais.

${ }^{704}$ SARLET, Ingo Wolfgang. A eficácia dos direitos fundamentais. 3. ed. Porto Alegre: Livr. do Advogado, 2003. p. 259. Cf. o art. $5^{\circ}, \S 1^{\circ}$, da CF. Cf. ainda o 3.2.1.
} 
quando se depara com os direitos sociais, econômicos e culturais, de natureza prestacional, muito embora, em várias hipóteses, estejam “veiculados em dispositivos que apresentam a mesma estrutura lógico-normativa das demais regras definidoras de direitos, comportando aplicação direta e imediata" 705 .

Ao longo do tempo, os preceitos consagradores de direitos sociais da pessoa humana foram relegados à condição de meras normas de cunho programático, nas quais o constituinte limitou-se a traçar os princípios para serem cumpridos pelos órgãos legislativos, executivos, jurisdicionais e administrativos, como programas de suas atividades, visando à realização dos fins sociais do Estado. Mesmo assim, por estarem revestidas de juridicidade e do efeito derrogatório dos atos que lhes sejam contrários, as “"normas programáticas’ vinculam também os tribunais, pois os juízes têm acesso à constituição, com o consequente dever de aplicar as normas em referência (por mais geral e indeterminado que seja o seu conteúdo) (...) $)^{\text {706 }}$.

Entretanto, em que pese o dever dos poderes estatais de criarem todas as condições necessárias à efetividade dos direitos e garantias fundamentais, sem exceção alguma, o argumento de entraves relacionados à ausência ou indisponibilidade de recursos financeiros (limite da reserva do possível), à inviabilidade de implementação pelos tribunais de programas socioeconômicos, bem como à ocorrência de colisão com outros direitos fundamentais, é utilizado para justificar a impossibilidade de um controle judicial sobre o tema. A questão da eficácia dos direitos sociais, econômicos e culturais situa-se no plano da realização de políticas públicas. Não se trata de um comportamento passível de análise isoladamente, mas de atividades resultantes de um conjunto de vários atos que as compõem. O direito dos indivíduos a prestações de bem-estar social apareceria num

\footnotetext{
${ }^{705}$ BARROSO, Luís Roberto. O direito constitucional e a efetividade de suas normas: limites e possibilidades da Constituição brasileira, cit., p. 148.

${ }^{706}$ CANOTILHO, J. J. Gomes. op. cit., p. 1.180. Ao defender a possibilidade de se invocar uma norma constitucional programática para impor ao poder público a oferta de determinada prestação, Luís Roberto Barroso, nos termos do disposto no artigo 215 da Constituição Federal, apresentou a seguinte situação: "um grupo teatral idôneo deseja encenar uma peça de indiscutível valor artístico. Todas as casas de espetáculos existentes na cidade estão ocupadas com a exibição de outras obras, à exceção de um teatro pertencente à municipalidade, que está ocioso. Nada há de estranhável em admitir-se o cabimento de uma ação contra a entidade estatal para ensejar a utilização daquele bem público" (cf. BARROSO, Luís Roberto. $O$ direito constitucional e a efetividade de suas normas: limites e possibilidades da Constituição brasileira, cit., p. 158).
} 
segundo momento, como reflexo da realização de políticas públicas nos diferentes setores sociais enunciados no texto constitucional ${ }^{707}$.

De todo modo, é necessário admitir que o mencionado obstáculo referente à ocorrência de colisão com outros direitos fundamentais reflete as tensões entre valores e bens tutelados, em idêntico grau de supremacia, pelo ordenamento constitucional, reclamando uma solução aderente às condições sociopolíticas da atualidade. Daí a utilidade da aplicação do modelo ponderativo já referido, de ressonância doutrinária, proposto por Robert Alexy, a partir da distinção entre regras e princípios para aprofundá-la no tratamento dos direitos fundamentais ${ }^{708}$. O modelo de Alexy corresponde à máxima da proporcionalidade, cujo processo hermenêutico deve percorrer as seguintes etapas na análise da legitimidade das medidas governamentais: a) a avaliação da adequação da medida questionada com o fim de interesse público adstrito a um dos princípios constitucionais; b) a atenção ao requisito da necessidade, que impõe a avaliação acerca da inexistência de meio menos gravoso ao outro princípio fundamental capaz de satisfazer aquele objetivo de interesse público; c) o exame da proporcionalidade em sentido estrito, ou seja, quando, depois de se chegar à conclusão pela presença dos pressupostos da adequação e necessidade, avulta o cotejo do resultado obtido in concreto com a restrição imposta ao princípio contrastado. É necessário avaliar "se o que se perde com a medida é de maior relevo daquilo que se ganha" ${ }^{\text {709 }}$. No processo de concretização das disposições fundamentais, graças ao princípio da proporcionalidade são levados em conta todos os enunciados constitucionais relevantes para a decisão do caso concreto, em consideração à atuação do órgão do legislativo ou do executivo cuja intervenção no âmbito de incidência de determinado princípio fundamental esteja sendo questionada ${ }^{710}$.

\footnotetext{
${ }^{707}$ COMPARATO, Fábio Konder. O Ministerio Público na defesa dos direitos econômicos, sociais e culturais. In: GRAU, Eros Roberto; CUNHA, Sérgio Sérvulo da (Orgs). Estudos de direito constitucional em homenagem a José Afonso da Silva. São Paulo: Malheiros Ed., 2003. p. 249 e ss. Cf. o art. $6^{\circ}$ da CF, com a seguinte redação: "são direitos sociais a educação, a saúde, o trabalho, a moradia, o lazer, a segurança, a previdência social, a proteção à maternidade e à infância, a assistência aos desamparados (...)”. O rol é meramente exemplificativo, com as suas hipóteses explicitadas mais adiante nos Títulos VII e VIII, da Lei Fundamental.

${ }^{708}$ Cf. ALEXY, Robert. Teoría de los derechos fundamentales, cit., p. 86 e ss. Cf. 3.2 .1

${ }^{709}$ Cf. BARROSO, Luís Roberto. Interpretação e a aplicação da Constituição, cit., p. 372-373; e BERNAL PULIDO, Carlos. El principio de proporcionalidad y los derechos fundamentales. 3. ed. Madrid: Centro de Estudios Políticos y Constitucionales, 2007. p. 692 e ss. Cf. 4.2.1, a respeito da matriz da razoabilidade no plano do aspecto substantivo do devido processo legal do sistema da common law,

${ }^{710}$ BERNAL PULIDO, Carlos. op. cit., p. 555-556. Nesse sentido: “(...) Não obstante a formulação e a execução de políticas públicas dependam de opções cargo daqueles que, por delegação popular, receberam investidura em mandato eletivo, cumpre reconhecer que não se revela absoluta, nesse domínio, a liberdade de conformação do legislador, nem a atuação do Poder Executivo. É que, se tais Poderes do Estado, agirem
} 
Essa técnica de interpretação constitucional possibilita o reconhecimento da eficácia dos direitos sociais, econômicos e culturais, de natureza prestacional, concebidos em sua dimensão coletiva para tratamento em sede da ação civil pública. Tendo em mira as peculiaridades de cada caso concreto, não se há de negar o direito a bens essenciais a uma existência digna, à luz de uma repercussão de pouca significância no âmbito de outros princípios constitucionais. A bem da verdade, o raio de atuação dos órgãos do legislativo e do executivo para o cumprimento de seus deveres fundamentais nunca foi comprometido por um desmedido controle judicial. O desequilibro sempre se manifestou pela hegemonia do Executivo, cujos excessos devem ser contrabalanceados em um sistema eficaz de controle do poder político do Estado.

Sob diversa ótica, é necessário frisar o fato de toda e qualquer atuação administrativa vincular-se às garantias institucionais de natureza principiológica estabelecidas na Constituição Federal ${ }^{711}$. O exercício da função administrativa consiste no dever de implementar, no interesse de outrem (a coletividade), os objetivos fundamentais do Estado, sempre seguindo o que determina a ordem jurídica em vigor. Na esfera da discricionariedade conferida pela lei, os comportamentos administrativos comissivos ou omissivos não podem conter discriminações injustificadas e nem consubstanciar medidas que não "guardem relação ou proporção com os fins objetivados pelo legislador". Mesclando-se ao princípio da proporcionalidade de inspiração europeia, a matriz da razoabilidade "aumenta a tarefa do Poder Judiciário, que tem que apreciar o conteúdo axiológico das normas constitucionais e legais e invalidar os atos administrativos que estejam em desconformidade com o mesmo" ${ }^{, 712}$.

de modo irrazoável ou procederem com clara intenção de neutralizar, comprometendo-a, a eficácia dos
direitos sociais, econômicos e culturais, afetando, como decorrência causal de uma injustificável inércia
estatal ou de um abusivo comportamento governamental, aquele núcleo intangível consubstanciador de um
conjunto irredutível de condições mínimas necessárias a uma existência digna e essenciais à própria
subsistência do indivíduo, aí, então, justificar-se-á, como precedentemente já enfatizado - e até mesmo por
razões fundadas em um imperativo ético-jurídico -, a possibilidade de intervenção do Poder Judiciário, em
ordem a viabilizar, a todos, o acesso aos bens cuja fruição lhes haja sido injustificadamente recusada pelo
Estado (...)." (ADPF 45/DF Argüição de Descumprimento de Preceito Fundamental, Rel. Min. Celso de
Mello, j. 29.04.2004, DJU 05.05.2004).
${ }^{11}$ São as mencionadas garantias do art. 37, caput, da CF.
${ }^{12}$ DI PIETRO, Maria Sylvia. Discricionariedade administrativa na Constituição de 1988. 2. ed. São Paulo:
Atllas, 2001. p. $233-234$. Nesse sentido: "Na atualidade, a Administração pública está submetida ao
império da lei, inclusive quanto à conveniência e oportunidade do ato administrativo. Comprovado
tecnicamente ser imprescindível, para o meio ambiente, a realização de obras de recuperação do solo, tem o
Ministério Público legitimidade para exigi-la. O Poder Judiciário não mais se limita a examinar aspectos
extrínsecos da administração, pois pode analisar, ainda, as razões de conveniência e oportunidade, uma vez
que essas razões devem observar critérios de moralidade e razoabilidade" (STJ, RESP 42570/GO, Rel. Min.
Eliana Calmon, j. 11.11 .2003 , DJU 22.3.2004). "A atuação da Administração Pública deve seguir os 
É preciso ressaltar que as máculas de inconstitucionalidade que podem inquinar as atuações do poder público no campo dos direitos sociais, econômicos e culturais podem se revelar tanto de forma comissiva, em virtude da eleição de meios inidôneos à persecução dos fins colimados, como por franca omissão, ante a indevida abstenção em disponibilizar prestações que estariam ao alcance dos mesmos desideratos. No que concerne a muitas atividades do órgão do executivo, as obrigações impostas pela Constituição Federal para a realização dos direitos fundamentais de natureza prestacional são suscetíveis de controle pelo Ministério Público, por meio da utilização do instituto da ação civil pública.

A atividade do Ministério Público de zelar pelo efetivo respeito dos poderes públicos e dos serviços de relevância pública aos direitos fundamentais da pessoa humana abriu um grande espaço para uma atuação institucional capaz de responder aos problemas sociais emergentes, tendo em vista as crônicas deficiências do acerto democrático entre os órgãos estatais. No Brasil, a função de defensor do povo foi incorporada às atividades do Ministério Público, com a possibilidade de canalização das demandas ao controle jurisdicional Nessa área de atuação, é possível a expedição de recomendações objetivando a melhoria dos serviços públicos e o "respeito aos interesses, direitos e bens cuja defesa lhe cabe promover, fixando prazo razoável para a adoção das providências cabíveis" "713. Mas, se não houver o devido atendimento, o membro do Ministério Público deverá prosseguir com os seus trabalhos, adotando a medida judicial pertinente ao caso. Note-se que a função original de ombudsman ou defensor do povo é a de fiscalizar os atos dos poderes públicos, zelando pelo respeito aos direitos humanos, com competência para receber reclamações “do cidadão e dar publicidade a elas, provocando os órgãos responsáveis a encaminhar a solução para os problemas apontados"714. Não ocorre nenhuma atuação junto ao órgão jurisdicional; as defensorias do povo ou ouvidorias "não estão habilitadas a buscar remédio judicial para as lesões de direitos (...) $)^{, 715}$.

parâmetros da razoabilidade e da proporcionalidade, que censuram o ato administrativo que não guarde uma proporção adequada entre os meios que emprega e o fim que a lei almeja alcançar. A razoabilidade encontra ressonância na ajustabilidade da providência administrativa consoante o consenso social acerca do que é usual e sensato (...)” (STJ, RESP 443310/RS, Min. Luiz Fox, j. 21.10.2003, DJU 3.11.2003).

${ }^{713}$ Cf. o art. $6^{\circ}, \mathrm{XX}$, da Lei Complementar 75/93. Cf. SALLES, Carlos Alberto. op. cit., p. 33. Cf. o art. 129, II, da CF.

${ }^{714}$ ARANTES, Rogério Bastos. op. cit., p. 87. A instituição do ombudsman, de origem escandinava, disseminou-se em vários países da Europa nos anos 70, como meio de fiscalização da administração pública, e pela América Latina, entre os anos 80 e 90, nos países que transitaram para a democracia. Cf. também CAPPELLETTI, Mauro; GARTH, Bryan. op. cit., p. 127 e ss.

${ }^{715}$ ARANTES, Rogério Bastos. op. cit., p. 87. 
Os obstáculos burocráticos e processuais envolvendo a lentidão do andamento das ações ajuizadas não deixam dúvidas sobre a conveniência de soluções consensuais na fase pré-processual do inquérito civil, por intermédio da celebração de compromissos de ajustamento de conduta para antecipar a solução dos litígios, sem o recurso ao judiciário ${ }^{716}$. Cumpre, no entanto, ressaltar que tais acordos têm eficácia de título executivo extrajudicial, tornando viável a propositura da ação de execução, em caso de descumprimento da avença, de modo a provocar, coercitivamente, a satisfação das obrigações ajustadas e a aplicação das sanções previstas ${ }^{717}$. Por essa razão, no campo do controle das políticas públicas, o presente deslinde consensual nem sempre é acatado pelas autoridades responsáveis. Para a configuração dessa função do Ministério Público, importa observar não lhe competir o planejamento de políticas públicas, agindo em parceria com o órgão do executivo, em sede de inquéritos civis ou de procedimentos administrativos análogos. Via de regra, não cabe ao Ministério Público participar das opções adotadas pelos governantes, não obstante deva apoiá-las institucionalmente, quando traduzirem iniciativas satisfatórias à efetividade dos direitos em questão. Em outras palavras; sua função é basicamente de controle; na ausência ou deficiência de um planejamento adequado, cumpre-lhe instar as autoridades responsáveis para o cumprimento de seus deveres fundamentais, inclusive por intermédio da fiscalização dos investimentos públicos e da execução de programas já concluídos ${ }^{718}$. Mas o raio de ação dos agentes que representam a "vontade majoritária" há de ser preservado justamente para que a função de controle possa ser exercida pelo Ministério Público de forma independente, sem o risco de eventual vinculação com interesses ligados à estrutura político-partidária do regime político de representação democrática.

\subsubsection{Notas sobre as políticas de ação afirmativa}

Em atenção ao princípio da igualdade essencial de todo ser humano, "o pecado capital contra a dignidade humana consiste, justamente, em considerar e tratar o outro - um indivíduo, uma classe social, um povo - como um ser inferior, sob pretexto da diferença de

\footnotetext{
${ }^{716}$ ARANTES, Rogério Bastos. op. cit., p. 89.

${ }^{717} \mathrm{Cf}$. os arts. $5^{\circ}, \S 6^{\circ}$, da ILei 7.347/85; e 113 do CDC (Lei 8.078/90). Cf. ainda o art. 585, II e VII, do CPC.

${ }^{718} \mathrm{Sem}$ prejuízo da possibilidade do reconhecimento de eficácia às normas atributivas de direitos sociais, econômicos e culturais, Fábio Konder Comparato chamou a atenção para a importância da fiscalização do Ministério Público sobre o modo pelo qual o Poder Executivo realiza a sua tarefa constitucional de elaboração de execução dos orçamentos. Cf. COMPARATO, Fábio Konder. O Ministerio Público na defesa dos direitos econômicos, sociais e culturais, cit., p. 258-259. Cf. também os arts. 165, 198, §§ $2^{\circ}$ e $3^{\circ}$; e 212 , da CF.
} 
etnia, gênero, costumes ou fortuna patrimonial" ${ }^{719}$. A diversidade humana representa fonte de valores positivos e, como tal, deve sempre ser respeitada.

A igualdade de todos perante a lei é princípio regente dos ordenamentos jurídicos da atualidade, tanto no plano internacional, como no das organizações políticas estatais. $\mathrm{Na}$ esteira do princípio da dignidade da pessoa humana, o fundamento central das ações afirmativas é a consideração do postulado da igualdade, tomado em seu aspecto material na qualidade de ponto nuclear do regime democrático insculpido à República Federativa do Brasil. A Constituição contemplou os aspectos formal e material da igualdade, com este último sentido apreendido da conjugação aos objetivos fundamentais do Estado, principalmente o de "promover o bem de todos, sem preconceitos de origem, raça, sexo, cor, idade e quaisquer outras formas de discriminação" $" 720$. Somente por meio de condutas ativas é possível a construção da sociedade brasileira, segundo os paradigmas que foram traçados na Constituição. Se a igualdade implicasse apenas "a vedação de tratamentos discriminatórios, o princípio seria absolutamente insuficiente para possibilitar a realização dos objetivos fundamentais da República constitucionalmente definidos"721.

A questão aponta a outorga de um tratamento jurídico diferenciado a determinados segmentos de pessoas, em atenção a peculiaridades que as tornam socialmente vulneráveis $^{722}$. Também sugere a necessidade de eliminação dos quadros de marginalização de seres humanos, como forma de assegurar que todos possam ser efetivamente amparados de idêntico modo pela lei. Para a consolidação do processo de igualdade entre os homens, sobreleva-se a importância da adoção de providências capazes de, concretamente, alçar ao seio da coletividade grupos de indivíduos socialmente vulneráveis. Ações afirmativas são, portanto, medidas de cunho especial realizadas voluntária ou compulsoriamente em uma determinada esfera organizacional, visando a superar os efeitos de desvantagens experimentadas por determinados segmentos sociais. $\mathrm{O}$ alvo das chamadas ações afirmativas pode ser os que estão sujeitos a um padrão de

\footnotetext{
${ }^{719}$ COMPARATO, Fábio Konder. A afirmação histórica dos direitos humanos, cit., p. 226.

${ }^{720} \mathrm{Cf}$. os arts. $1^{\circ}$, II e III, e $3^{\circ}$, I, III e IV, da CF. O art. $5^{\circ}$, caput, da CF, dispõe sobre a igualdade de todos perante a lei e sobre a garantia do direito à igualdade para todos os brasileiros e estrangeiros residentes no país.

${ }^{721}$ ROCHA, Carmem Lúcia Antunes. Ação afirmativa: conteúdo democrático do princípio da igualdade jurídica. Revista Trimestral de Direito Público, São Paulo, n. 15, p. 92, 1996.

${ }^{722} \mathrm{O}$ art. 227 da CF, regulamentado pelo Estatuto da Criança e do Adolescente (Lei 8.069/90), confere à criança e ao adolescente um regime jurídico de proteção integral, ao dispor sobre o tratamento prioritário a ser dispensado pelo Estado, pela família e pela sociedade a esse segmento de pessoas ainda em desenvolvimento. Na mesma linha, destacam-se a chamada Lei Maria da Penha (Lei 11.340/06), voltada à proteção da mulher, e a Lei 7.853/89, que instituiu regime de proteção especial às pessoas portadoras de deficiência.
} 
inferioridade, inclusive por força de iníquos processos discriminatórios, que os distanciou das condições de equidade em relação a aspectos fundamentais da cidadania, como o acesso à educação, à moradia, a postos de trabalho, entre outras prestações indissociáveis de uma existência digna. Na condição de providências que se impõem para diluir os efeitos permanentes, por vezes, históricos, dos quadros de marginalização social, as ações afirmativas destinam-se, basicamente, à realização do princípio fundamental da igualdade, sempre em consideração à pluralidade e diversidade humana ${ }^{723}$. Nesse contexto deve ser introduzida a função constitucional do Ministério Público de defesa judicial dos direitos e interesses das populações indígenas. Sob os mesmos pressupostos, a atuação institucional deve se estender a outros grupos vulneráveis de pessoas, como é, sem nenhuma dívida, o caso dos negros que ainda hoje suportam os nefastos efeitos do processo de escravidão do Brasil $^{724}$.

\subsection{A organização do Ministério Público}

Diversamente dos congêneres europeus e norte-americano, o tratamento dispensado à estrutura orgânica do Ministério Público brasileiro, agregando-se à considerável ampliação de suas funções institucionais, também permite constatar a posição em que foi inserido no âmbito da organização política do Estado ${ }^{725}$. É o que revelam, entre outros, os seguintes fatores: a independência conferida à atuação de seus membros, com as garantias de vitaliciedade, inamovibilidade e irredutibilidade de subsídio, e um sistema de vedações, também intimamente relacionado ao princípio da independência funcional ${ }^{726}$; a autonomia funcional, administrativa e financeira, assentada na possibilidade de prover diretamente os seus cargos, no permissivo para a iniciativa de leis sobre o seu aparato orgânico, incluindo

\footnotetext{
${ }^{723}$ A esse respeito, cf. 3.2.

${ }^{724}$ Cf. o art. 129, V, da CF. Na qualidade de típica ação afirmativa, a Constituição dedicou o Cap. VIII do Título VIII aos direitos dos índios. O art. 232 da CF estabelece serem os índios, suas comunidades e organizações "partes legítimas para ingressar em juízo em defesa de seus direitos e interesses, intervindo o Ministério Público em todos os atos do processo". A atribuição de zelar pelos direitos ou interesses das populações indígenas é do Ministério Público da União, notadamente dos órgãos do Ministério Público Federal e do Ministério Público do Trabalho. Cf. o art. 5º II, e os arts. 37, II, e 83, V, da Lei Complementar 75/93. Sobre os reflexos da escravidão na formação da sociedade brasileira, cf. 2.1 e 2.2.

${ }^{725}$ Cf. 1.2.1, 1.3.1 e 1.4, com a síntese da organização e o funcionamento do sistema do Attorney General dos Estados Unidos da América, do Parquet francês e do Ministério Público italiano. O constituinte de 1988 afastou a instituição dos capítulos do Legislativo, do Executivo e do Judiciário para introduzi-lo, ao lado da Advocacia Geral da União (seção II) e da Defensoria Pública (seção III), na primeira seção do Capítulo IV (Das funções essenciais à justiça) do Título IV (Da Organização dos Poderes). Cf. ARANTES, Rogério Bastos. Ministério Público e política no Brasil, op. cit., p. 79; e MAZZILLI, Hugo Nigro. op. cit., p. 102 e ss. Cf. ainda 3.7.

${ }^{726} \mathrm{Cf}$. os arts. $127, \S 1^{\mathrm{o}}$; e $128, \S 5^{\mathrm{o}}$, I, $a, b$, e $c$, e II, $a$ a $f$, da CF.
} 
as de criação de seus cargos, e na possibilidade de formulação de sua proposta orçamentária $^{727}$; a vedação à delegação legislativa em matéria relativa à sua organização e, finalmente, a condição de crime de responsabilidade do Presidente da República atribuída aos atos que atentem contra o livre exercício da instituição estatal ${ }^{728}$.

Estruturado em carreiras públicas, o ingresso no Ministério Público ocorre mediante concurso de provas e títulos; procedimento que também é adotado para fins de progressão aos graus mais elevados daquelas ${ }^{729}$. Em correlação à forma federativa do Estado, a Constituição previu a existência do Ministério Público da União, com desdobramentos resultantes da organização do Judiciário da União, e dos Ministérios Públicos dos Estados. Além destes últimos funcionando nas unidades federativas estatais, o Ministério Público Federal, o Ministério Público do Trabalho, o Ministério Público Militar e o Ministério Público do Distrito Federal e Territórios são carreiras do Ministério Público da União ${ }^{730}$.

A Constituição também estabeleceu que leis complementares da União e dos Estados estipulassem a organização, as atribuições e o estatuto de cada Ministério Público. No âmbito do Ministério Público da União, está em vigor a LOMPU (Lei Complementar 75, de 20 de maio de 1995), que é a Lei Orgânica do Ministério Público da União, dispondo sobre a organização, as atribuições e o estatuto de cada uma de suas carreiras. A LONMP (Lei Federal 8.625, de 12 de fevereiro de 1993) é a Lei Orgânica Nacional do Ministério Público, dispondo sobre normas gerais para a organização do Ministério Público dos Estados. No Estado de São Paulo, a LOEMP (Lei Complementar Estadual 734, de 26 de novembro de 1993) é a Lei Orgânica de seu Ministério Público. Segundo a Constituição, a lei de organização do Ministério Público da União seria de iniciativa privativa do chefe do Executivo. A iniciativa, porém, é concorrente, uma vez que a mesma Lei Fundamental "a tornou facultada ao respectivo chefe do parquet"731. A hipótese

\footnotetext{
${ }^{727} \mathrm{Cf}$. os arts. $127, \S \S 2^{\mathrm{o}}$ a $6^{\mathrm{o}}$; e $128, \S 5^{\mathrm{o}}$, da $\mathrm{CF}$.

${ }^{728} \mathrm{Cf}$. os arts. $68, \S 1^{\circ}$, I; e 85 , II, da CF.

${ }^{729} \mathrm{Cf}$. o art. $129, \S \S 3^{\mathrm{o}}$ e $4^{\mathrm{o}}, c / c$ o art. 93 , I a III, da CF.

${ }^{730}$ Cf. o art. 128, I, $a$ a $d$, e II, da CF. Não existem mais Territórios no Brasil, porque os dois únicos que existiam foram transformados em Estados.

${ }^{731}$ MAZZILLI, Hugo Nigro. op. cit., p. 497. Cf. a redação do $§ 5^{\circ}$, do art. 128, da CF: "Leis complementares da União e dos Estados, cuja iniciativa é facultada aos respectivos Procuradores-Gerais, estabelecerão a organização, as atribuições e o estatuto de cada Ministério Público (...)". Cf. ainda o art. 61, § $1^{\circ}$, II, d, da CF.
} 
estende-se à iniciativa dos governadores para edição dos estatutos estaduais do Ministério Público, também facultada, concorrentemente, aos Procuradores-Gerais de Justiça ${ }^{732}$.

Todas as funções das carreiras do Ministério Público têm a natureza e os traços comuns dispostos na Constituição. As disposições gerais da LOMPU, estabelecendo as principais funções e instrumentos de atuação do Ministério Público da União, podem orientar as atividades dos Ministérios Públicos Estaduais. A LOMPU é de aplicação subsidiária para o Ministério Público dos Estados. "Dessa forma, a legislação que instrumentaliza o Ministério Público da União também há de servir de guia na atuação dos Ministérios Públicos dos Estados"733.

\subsubsection{O Ministério Público da União}

Conforme ficou assinalado, a estrutura e a forma de funcionamento do Ministério Público da União encontram previsão em sua lei orgânica, a LOMPU (Lei Complementar 75/93). O diploma principiou pormenorizando a destinação constitucional da instituição concernente à defesa da ordem jurídica, do regime democrático e dos interesses sociais e individuais indisponíveis, tendo em consideração ainda os seguintes fundamentos: a soberania e a representatividade popular; os direitos políticos; os objetivos fundamentais da República; a indissolubilidade da União; a independência e a harmonia dos poderes da União; a autonomia dos Estados, do Distrito Federal e dos Municípios; as vedações impostas à União, aos Estados, ao Distrito Federal e aos Municípios; e, por fim, a legalidade, a impessoalidade, a moralidade e a publicidade relativas à administração pública direta, indireta ou fundacional de qualquer dos poderes da União ${ }^{734}$.

Em seguida, a LOMPU destacou alguns princípios constitucionais por cuja observância compete ao Ministério zelar; quais sejam: os relativos ao sistema tributário, às

\footnotetext{
${ }^{732}$ Reconhecendo clara deficiência na sistematização da matéria, Hugo Nigro Mazzilli atentou à possibilidade de existirem duas leis federais: uma que estabelece a organização do Ministério Público da União, de iniciativa do Presidente da República, também facultada, concorrentemente, ao Procurador-Geral da República (art. $61, \S 1^{\circ}$, II, $d$, primeira parte; $c / c$ o $\S 5^{\circ}$, do art. 128, da CF); e outra fixando normas gerais da organização do Ministério Público dos Estados, esta sim, a única de iniciativa privativa do Presidente da República. Cf. MAZZILLI, Hugo Nigro. Regime jurídico do Ministério Público, cit., p. 195-196.

${ }^{733}$ MAZZILLI, Hugo Nigro. op. cit., p. 498. Nesse sentido, cf. o art. 80 da Lei 8.625/93. Cf. o art. 127, caput, e o art. 129, I a IX, e $\S \S 1^{\circ}$ e $2^{\circ}$, da CF. Vale também anotar que, quando a lei menciona o Ministério Público, normalmente se refere a qualquer deles. É o que acontece com o CPP, CPC ou a Lei da Ação Civil Pública. A Constituição deixou claro que outras atribuições podem ser cometidas ao Ministério Público, desde que compatíveis com suas finalidades institucionais (art. 129, IX, da CF).

${ }^{734}$ Cf. o art. 127 , caput, da CF; e o art. $1^{\circ}$ da Lei Complementar $75 / 93$, além das normas do art. $5^{\circ}$, I, do mesmo diploma (Lei Complementar 75/93).
} 
finanças públicas, à atividade econômica, ao sistema financeiro nacional, à política urbana, agrícola, fundiária e de reforma agrária; à seguridade social, à educação, à cultura e ao desporto, à ciência e à tecnologia, à comunicação social e ao meio ambiente; e à segurança pública. O diploma legal também repisou as atribuições conferidas pela Constituição Federal, reportando-se à defesa do patrimônio nacional, do patrimônio público e social, do patrimônio cultural brasileiro, do meio ambiente e dos direitos e interesses coletivos, especialmente das comunidades indígenas, da família, da criança, do adolescente e do idoso $^{735}$. E, finalmente, houve a especificação da relevante tarefa de zelar pelo efetivo respeito dos poderes públicos e dos serviços de relevância pública aos direitos assegurados na Constituição, com o destaque aos serviços de comunicação social, da saúde e da educação, bem como à vinculação aos princípios da legalidade, da impessoalidade, da moralidade e da publicidade ${ }^{736}$.

A LOMPU, corretamente, procurou identificar o rol das funções do Ministério Público com a sua natureza constitucional de defesa da ordem jurídica, do regime democrático e dos direitos sociais e individuais indisponíveis. É que, na verdade, parte das funções dispostas na Constituição constitui instrumentos de atuação do Ministério Público, na qualidade de meios processuais e extraprocessuais à realização das incumbências, antes explicitadas $^{737}$. Entre esses mecanismos, a LOMPU relacionou a ação direta de inconstitucionalidade e a ação direta de inconstitucionalidade por omissão, a arguição de descumprimento de preceito fundamental, o mandado de injunção, o mandado de segurança, o habeas corpus, a representação para a intervenção federal nos Estados e no Distrito Federal, e a promoção privativa da ação penal pública e da ação civil pública. Foi mencionada ainda a possibilidade de o Ministério Público representar o órgão judicial competente para a quebra de sigilo da correspondência e das comunicações telegráficas, de dados e das comunicações telefônicas, para fins de investigação criminal ou instrução processual penal, disciplinando-se também o acesso a outras informações sigilosas no âmbito de providências investigatórias de largo alcance, como a realização de notificações e requisições, além da instauração de inquéritos civis e procedimentos administrativos

\footnotetext{
${ }^{735}$ Cf. o art. $5^{\circ}$, II e III, da Lei Complementar 75/93. Cf. também o art. 129, III e V, da CF.

${ }^{736} \mathrm{Cf}$. o art. 129, II, da CF; e os preceitos do art. $5^{\circ}$, IV e V, $a$ e $b$, da Lei Complementar 75/93.

${ }^{737}$ Nesse sentido, MAZZILLI, Hugo Nigro. op. cit., p. 501. Cf. os arts. $6^{\circ}$ a $8^{\circ}$, da Lei Complementar 75/93.
} 
análogos. E o controle externo da atividade policial não deixou de ser devidamente regulamentado ${ }^{738}$.

Por outro lado, o Ministério Público da União é chefiado pelo Procurador-Geral da República, cuja nomeação compete ao "Presidente da República, dentre os integrantes da carreira, maiores de trinta e cinco anos, após a aprovação de seu nome pela maioria absoluta do Senado Federal, para mandato de dois anos, permitida a recondução". A aprovação do nome do Procurador-Geral pelo Senado é realizada por voto secreto, após arguição pública $^{739}$. E, muito embora deva sempre ser precedida de nova aprovação pelo Senado, a Constituição não restringiu o número de reconduções ao cargo. Já a destituição do Procurador-Geral deve ocorrer por iniciativa do Presidente da República, precedida de autorização da maioria absoluta do Senado Federal ${ }^{740}$.

$\mathrm{Na}$ direção de todas as carreiras que formam o Ministério Público da União (Ministério Público Federal, Ministério Público do Trabalho, Ministério Público Militar e Ministério Público do Distrito Federal e Territórios), entre outras funções, cabe ao Procurador-Geral da República representar a instituição; apresentar projetos de lei sobre o Ministério Público da União e sua proposta orçamentária; expedir atos de provimento dos cargos das carreiras; dar posse ao Procurador-Geral de Justiça do Distrito Federal e Territórios; nomear e dar posse ao Vice-Procurador-Geral da República, ao ProcuradorGeral do Trabalho e ao Procurador-Geral da Justiça Militar; decidir conflitos de atribuição entre os integrantes das diferentes carreiras do Ministério Público da União; e expedir

\footnotetext{
${ }^{738}$ Cf. o art. $6^{\circ}$, XVIII, $a$, da Lei Complementar 75/93; e o art. $5^{\circ}$, XII, da CF; o art. 129, III, VI e VIII, da CF; e os arts. $7^{\circ}$ e $8^{\circ}$, da Lei Complementar 75/93; o art. 129, VII, da CF; e, sobre o controle externo, os preceitos dos arts. $3^{\circ}, 9^{\circ}$ e 10 , da Lei Complementar 75/93. Lembre-se que o diploma também atentou à expedição de recomendações pelo Ministério Público, visando à melhoria dos serviços públicos e de relevância pública. Cf. o art. $6^{\circ}, \mathrm{XX}$, da Lei Complementar 75/93.

${ }^{739} \mathrm{Cf}$. o art. $128, \S 1^{\circ}$, da CF; e o art. 25, caput, da Lei Complementar 75/93. Cf. ainda o art. 52, III, e, da CF. Pelo texto constitucional, seria viável cogitar de que o Procurador-Geral da República pudesse advir de qualquer uma das carreiras do Ministério Público da União. Acontece que ele é também o chefe do Ministério Público Federal, o que, à evidência, acaba provocando a sua nomeação apenas entre os integrantes dessa carreira. Cf. a redação do $\S 1^{\circ}$, do art. 128, da CF: “O Ministério Público da União tem por chefe o Procurador-Geral da República, nomeado pelo Presidente da República dentre os integrantes da carreira, maiores de trinta e cinco anos (...)". Cf. o art. 45 da Lei Complementar 75/93, estabelecendo a figura do Procurador-Geral da República também na chefia do Ministério Público Federal.

${ }^{740}$ Cf. o art. $128, \S 2^{\circ}$, da CF; e o art. 25 , $\S$ único, da Lei Complementar 75/93. O Vice-Procurador-Geral da República é agente de confiança do Procurador-Geral, que deverá designá-lo entre os integrantes da carreira, maiores de trinta e cinco anos. Nos casos de impedimento do Procurador-Geral, incumbe ao ViceProcurador substituí-lo provisoriamente. Já, em caso de vacância, o exercício do cargo é transferido ao Vice-Presidente do Conselho Superior do Ministério Público Federal, até o seu provimento definitivo. Cf. o art. 27 da Lei Complementar 75/93.
} 
regulamentos no âmbito do Ministério Público da União, ressalvadas as competências estabelecidas para os outros órgãos ${ }^{741}$.

A Constituição apontou o Procurador-Geral da República como o chefe do Ministério Público da União, que, como se viu, compreende o Ministério Público Federal, o Ministério Público do Trabalho, o Ministério da Justiça Militar e o Ministério Público do Distrito Federal e Territórios. Ocorre que a própria Constituição, padecendo de certa imprecisão técnica, estabeleceu, para o Ministério Público do Distrito Federal, a figura do Procurador-Geral de Justiça, cuja nomeação compete ao Presidente da República, entre os integrantes de lista tríplice elaborada pelo Colégio de Procuradores e Promotores de Justiça, para um mandato de dois anos, permitida apenas uma recondução, precedida de nova lista tríplice ${ }^{742}$. A LOMPU procurou contornar a imprecisão constitucional estabelecendo a chefia das demais carreiras do Ministério Público da União, tendo em vista certa autonomia que logrou reconhecer ${ }^{743}$. Instituiu, assim, para o Ministério Público do Trabalho e para o Ministério Público Militar, um Procurador-Geral, com mais de trinta e cinco anos de idade e de cinco anos de carreira, nomeado pelo Procurador-Geral da República entre os integrantes de "lista tríplice escolhida mediante voto plurinominal, facultativo e secreto, pelo Colégio de Procuradores, para mandato de dois anos, permitida uma recondução, observado o mesmo processo"744. Ao contrário do que se verifica em relação ao Procurador-Geral de Justiça do Distrito Federal e Territórios, cuja nomeação compete ao Presidente da República, os Procuradores-Gerais do Ministério Público do Trabalho e do Ministério Público Militar serão nomeados pelo Procurador-Geral da República $^{745}$.

\footnotetext{
${ }^{741}$ Cf. o art. 26, II, III, IV, VII e XIII, da Lei Complementar 75/93. No ápice da estrutura organizacional do Ministério Público da União, existe ainda o Conselho de Assessoramento Superior, que está encarregado de opinar sobre matérias de interesse geral da instituição, incluindo a sua proposta orçamentária, e as propostas sobre as alterações de sua lei orgânica e sobre a fixação dos valores remuneratórios de suas carreiras. O Conselho de Assessoramento também poderá propor aos Conselhos Superiores das carreiras do Ministério Público da União medidas para uniformizar os atos decorrentes de correspondente poder normativo. A composição do colegiado recai nas pessoas do Procurador-Geral da República, que deverá presidi-lo, além do Vice-Procurador-Geral e dos Procuradores-Gerais de cada uma das carreiras. Cf. os arts. 28, 30 e 31, da Lei Complementar 75/93.

${ }^{742}$ Cf., novamente, o art. 128, I, $a$ a $d$, e $\S \S 1^{\circ}$ e $3^{\circ}$, da CF. Cf. ainda o art. 156 , $\S 1^{\circ}$, da Lei Complementar $75 / 93$.

${ }^{743} \mathrm{O}$ art. 32 da Lei Complementar 75/93 prescreveu serem as carreiras dos diferentes ramos do Ministério Público da União "independentes entre si, tendo cada uma delas organização própria (...)".

${ }^{744}$ Cf. os arts. 88, caput, e 121, caput, da Lei Complementar 75/93.

${ }^{745}$ Segundo Hugo Nigro Mazzilli, "todas as instituições compreendidas pelo Ministério Público da União deveriam ter um único procurador-geral, à exceção do Ministério Público do Distrito Federal e Territórios, que, por disposição expressa no texto constitucional, terá chefia própria" (MAZZILLI, Hugo Nigro. op. cit., p. 174). Já para José Afonso da Silva, o Ministério Público do Distrito Federal não estaria em situação
} 
A destituição do Procurador-Geral da República há de ocorrer por iniciativa do Presidente da República, precedida de autorização da maioria absoluta do Senado Federal, em votação secreta. E a do Procurador-Geral de Justiça do Distrito Federal pode também se dar por decisão da maioria absoluta do Senado, mediante representação do Presidente da República. Quanto aos Procuradores-Gerais do Ministério Público do Trabalho e do Ministério Público Militar, a destituição deve ser proposta para o Procurador-Geral da República pelo respectivo Conselho Superior, mediante deliberação obtida com base em voto secreto de dois terços dos seus integrantes ${ }^{746}$.

A primeira carreira do Ministério Público da União constitui o Ministério Público Federal, a quem incumbe exercer suas funções nas causas de competência do Supremo Tribunal Federal, do Superior Tribunal de Justiça, dos Tribunais Regionais Federais e dos Juízes Federais, além dos Tribunais e Juízes Eleitorais. Deve também atuar nas causas de competência de quaisquer juízes e tribunais, para defesa de direitos e interesses dos índios e das populações indígenas; do meio ambiente e dos bens e direitos de valor artístico, estético, histórico, turístico e paisagístico que integrem o patrimônio nacional. $\mathrm{O}$ Ministério Público Federal pode ainda interpor recurso extraordinário das decisões da Justiça dos Estados nas representações de inconstitucionalidade ${ }^{747}$.

A carreira do Ministério Público Federal é constituída dos cargos de SubprocuradorGeral da República, Procurador Regional da República e Procurador da República. Os Procuradores da República oficiam junto aos Juízos Federais e junto aos Tribunais Regionais Eleitorais, onde não estiver sediada a Procuradoria Regional da República. Os Procuradores Regionais da República oficiam junto aos Tribunais Regionais Federais, enquanto a atuação dos Subprocuradores-Gerais da República verifica-se junto ao Tribunal Superior Eleitoral, ao Supremo Tribunal Federal e ao Superior Tribunal de Justiça; nestes últimos, os Subprocuradores-Gerais agem por delegação do Procurador Geral de República $^{748}$.

idêntica à dos Ministérios Públicos dos Estados, integrando, por conseguinte, o Ministério Público da União e não havendo falar em chefia própria. Cf. SILVA, José Afonso da. op. cit., p. 598. Quanto à forma de investidura do Procurador-Geral do Distrito Federal, cf. o art. 128, $\S 3^{\circ}$, da CF; e o art. 156, caput, da Lei Complementar 75/93.

${ }^{746} \mathrm{Cf}$. o art. $128, \S 2^{\circ}$, da CF; e o art. 25 , $\S$ único, da Lei Complementar 75/93. Cf. o art. $128, \S 4^{\circ}$, da CF; e o art. 156, § $2^{\circ}$, da Lei Complementar 75/93. Cf., por último, os arts. 88, § único; 98, III, 121, § único; e 131, III, todos da Lei Complementar 75/93.

${ }^{747} \mathrm{Cf}$. o art. 37, I e II, e §, único, da Lei Complementar 75/93.

${ }^{748} \mathrm{Cf}$. os arts. 44 , § único; 66, § $1^{\circ}$, e 70, da Lei Complementar 75/93. A atuação dos Procuradores da República, Procuradores Regionais da República e dos Subprocuradores-Gerais da República para o ofício 
No que diz respeito ao desenvolvimento de atividades-fins ${ }^{749}$ do Ministério Público Federal, incumbe ao Procurador-Geral da República o exercício das funções junto ao Supremo Tribunal Federal, "manifestando-se previamente em todos os processos de sua competência" ${ }^{, 750}$. Perante a mesma Corte, o Procurador-Geral da República ajuizará ação direta de inconstitucionalidade e a representação para a intervenção federal nos Estados e no Distrito Federal. Por sua vez, perante o Superior Tribunal de Justiça, o ProcuradorGeral deve propor a representação para intervenção federal nos Estados e no Distrito Federal, nos casos de recusa à execução de lei federal, e a ação penal nos casos de competência originária. Essas funções poderão ser delegadas aos Subprocuradores-Gerais da República ${ }^{751}$.

$\mathrm{Na}$ esfera orgânica do Ministério Público Federal insere-se ainda a figura do Procurador Federal dos Direitos do Cidadão, designado, entre os Subprocuradores-Gerais da República, mediante prévia aprovação do Conselho Superior. As funções do ofício serão exercidas pelo prazo de dois anos, permitida uma recondução, precedida de nova decisão do Conselho. Àquele agente compete garantir o respeito aos direitos fundamentais da pessoa humana pelos poderes públicos federais, pelos órgãos da administração federal direta ou indireta, pelos concessionários e permissionários de serviço público federal e por entidades que exerçam outra função delegada da União ${ }^{752}$.

Segundo foi aventado, responde pela direção da administração superior ${ }^{753}$ do Ministério Público Federal o próprio Procurador-Geral da República, cujas atribuições incluem, entre outras, a designação de membros da instituição para cargos e funções, como a chefia da Procuradoria Regional da República e a da Procuradoria Federal dos Direitos do Cidadão. Também é ele o responsável pela nomeação do Corregedor-Geral, entre os

junto a órgãos jurisdicionais diversos dos previstos para as respectivas categorias dependerá de autorização do Conselho Superior do Ministério Público Federal. Cf. os arts. 66, § 2º 68 , § único; e 70, § único, da Lei Complementar 75/93.

${ }^{749}$ A referência a atividades-fins do Ministério Público diz respeito a funções desenvolvidas como órgão de execução; como é o caso das funções discriminadas no art. 129, I, II, III, IV e V, da CF.

${ }^{750}$ Cf. o art. 46, caput, da Lei Complementar 75/93.

${ }^{751}$ Cf. as hipóteses do art. 34, VII, da CF; e o art. 46, § único, da Lei Complementar 75/93. Em seguida, cf. os arts. 34, VI, e 105, I, $a$, da CF; e o art. 48, I e II, da Lei Complementar 75/93. Sobre a delegação das funções aos Subprocuradores-Gerais, cf. os arts. 47, e 48, § único, da Lei Complementar 75/93.

${ }^{752}$ Cf. os arts. 39 e 40, da Lei Complementar 75/93. Em cada Estado e no Distrito Federal será designado pelo Procurador-Geral da República órgão do Ministério Público Federal para exercer as funções do ofício de Procurador Regional dos Direitos dos Cidadãos, mediante instruções do Procurador Federal, respeitado o princípio da independência funcional. Cf. o art. 41, § único, e 49, III, da Lei Complementar 75/93.

${ }^{753} \mathrm{~A}$ referência à administração superior do Ministério Público relaciona-se aos órgãos responsáveis pelas decisões políticas institucionais atinentes a todas as questões envolvendo a organização e o funcionamento do Ministério Público. 
nomes de lista tríplice formada pelo Conselho Superior, além de se encarregar da elaboração da proposta orçamentária, da decisão dos conflitos de atribuição entre órgãos do Ministério Público Federal, em grau de recurso; da autorização para o afastamento de membros da instituição, depois de ouvido o Conselho Superior; e da decisão de processo administrativo disciplinar ${ }^{754}$.

Ao Colégio de Procuradores da República, que é integrado por todos os membros da carreira em atividade, entre outras funções, cabe a elaboração das listas para a composição de tribunais superiores e a eleição de alguns dos membros do Conselho Superior $^{755}$.

O Conselho Superior do Ministério Público Federal é responsável pelo exercício do poder normativo no âmbito da instituição, com a aprovação das regras sobre o concurso de ingresso na carreira, sobre designações e sobre os critérios de promoção por merecimento. Ao mesmo órgão também compete, entre outras decisões, a aprovação do agente indicado pelo Procurador-Geral para o exercício das funções de Procurador Federal dos Direitos do Cidadão; a aprovação do Procurador Regional Eleitoral; a elaboração de listas tríplices para o cargo de Corregedor-Geral e para a promoção de membros do Ministério Público pelo critério de merecimento. A autorização das designações excepcionais de membros do Ministério Público, efetuadas pelo Procurador-Geral, além da decisão sobre a remoção e a disponibilidade dos integrantes da carreira, também compete ao Conselho Superior, que deve ainda designar Subprocurador-Geral da República para "conhecer inquérito, peças de informações ou representação sobre crime comum atribuível ao Procurador-Geral da República e, sendo o caso, promover a ação penal"756.

O presidente e membro nato do Conselho Superior é o Procurador-Geral da República. O Vice-Procurador também o compõe na qualidade de membro nato. Além disso, para um mandato de quatro anos, permitida uma reeleição, integram o Conselho quatro Subprocuradores-Gerais da República, eleitos por todos os membros do Colégio de

\footnotetext{
${ }^{754}$ As atribuições do Procurador-Geral da República na gestão do Ministério Público Federal estão previstas nas normas do art. 49, I a XXIII, da Lei Complementar 75/93. Em seus impedimentos (férias, licenças, etc.), ele será substituído pelo Vice-Procurador-Geral; e, na vacância do cargo, o Vice-Presidente do Conselho Superior exercerá a Procuradoria-Geral da República, até o provimento definitivo do cargo. Cf. os arts. 27, 52; e 54, § $2^{\circ}$, da Lei Complementar 75/93. Cf. também MAZZILLI, Hugo Nigro. op. cit., p. 510 .

${ }^{755}$ Cf. os arts. 52 e 53, I a III, da Lei Complementar 75/93.

${ }^{756}$ Cf. o inc. X, do art. 57, da Lei Complementar 75/93. Todas as atribuições do Conselho Superior do Ministério Público Federal estão definidas no art. 57, I a XXV, da mesma Lei Complementar 75/93.
} 
Procuradores, e quatro Subprocuradores-Gerais da República, eleitos apenas por seus pares $^{757}$.

As funções de Vice-Procurador-Geral da República, de Procurador Federal dos Direitos do Cidadão e de Corregedor-Geral somente podem ser exercidas por Subprocuradores-Gerais da República, que constituem o último grau da carreira do Ministério Público Federal. Já o cargo de Procurador-Geral da República pode ser preenchido por qualquer integrante da carreira, incluindo os titulares do cargo inicial de Procurador da República ${ }^{758}$.

A estrutura orgânica do Ministério do Trabalho é análoga à do Ministério Público Federal, incumbindo-lhe agir junto aos órgãos da Justiça competente em matérias envolvendo relações de emprego e a proteção dos direitos fundamentais dos trabalhadores, incluindo a sua tutela coletiva. Os membros do Ministério Público do Trabalho podem se manifestar "em qualquer fase do processo trabalhista, acolhendo solicitação do juiz ou por sua iniciativa, quando entender existente interesse público que justifique a intervenção"; e, além disso, devem "intervir obrigatoriamente em todos os feitos nos segundo e terceiro graus de jurisdição da Justiça do Trabalho, quando a parte for pessoa jurídica de Direito Público, Estado estrangeiro ou organismo internacional" ${ }^{, 759}$.

Tal como no Ministério Público Federal, o cargo inicial da carreira é o de Procurador do Trabalho, e o de último nível é o de Subprocurador-Geral do Trabalho. Os Subprocuradores-Gerais são designados para oficiar junto ao Tribunal Superior do Trabalho; os Procuradores Regionais do Trabalho, que ocupam o nível intermediário da carreira, exercem as suas funções junto aos Tribunais Regionais do Trabalho; enquanto os

\footnotetext{
${ }^{757}$ Cf. o art. 54, I, II e III, da Lei Complementar 75/93. Cf. ainda o $§ 2^{\circ}$, do art. 54, da Lei Complementar $75 / 93$.

${ }^{758}$ Cf. os arts. 25, caput, 40, caput, 44, § único, 64, caput, da Lei Complementar 75/93.

${ }^{759}$ Cf. o art. 83, II e XIII, da Lei Complementar 75/93. Cabem ainda aos membros do Ministério Público do Trabalho as seguintes funções: "promover a ação civil pública no âmbito da Justiça do Trabalho, para defesa de interesses coletivos, quando desrespeitados os direitos sociais constitucionalmente garantidos"; "propor ações cabíveis para a declaração de nulidade de cláusula de contrato, acordo ou convenção coletiva que violem as liberdades individuais ou coletivas ou os direitos indisponíveis dos trabalhadores"; "propor as ações necessárias à defesa dos direitos e interesses dos menores, incapazes e índios, decorrentes das relações de trabalho; instaurar instância em caso de greve, quando a defesa da ordem jurídica ou o interesse público assim o exigir"; "promover ou participar da instrução e conciliação em dissídios decorrentes da paralisação de serviços de qualquer natureza, oficiando obrigatoriamente nos processos, manifestando sua concordância ou discordância, em eventuais acordos firmados, antes da homologação, resguardado o direito de recorrer em caso de violação à lei e à Constituição Federal”; "promover mandado de injunção, quando a competência for da Justiça do Trabalho"; e "atuar como árbitro, se assim for solicitado pelas partes, nos dissídios de competência da Justiça do Trabalho” (art. 83, IIII, IV, V, VIII, IX, X e XI, da Lei Complementar 75/93).
} 
Procuradores do Trabalho atuam junto aos Juízes de primeiro grau, embora possa também agir junto aos Tribunais Regionais ${ }^{760}$.

No que toca ao funcionamento orgânico do Ministério Público do Trabalho, as atribuições administrativas do Colégio de Procuradores, que é composto por todos os membros da carreira, são praticamente idênticas às do mesmo quadro do Ministério Federal, assim como também o são as atividades de direção da carreira do ProcuradorGeral do Trabalho e do Conselho Superior, cuja composição em nada difere da que é

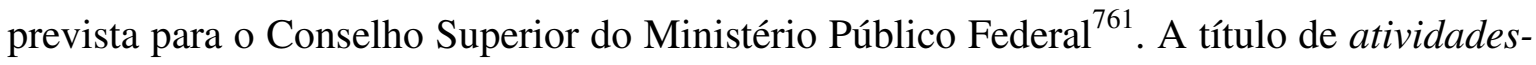
fins, ao Procurador-Geral do Trabalho compete o exercício das funções atribuídas ao Ministério Público do Trabalho junto ao Plenário do Tribunal Superior do Trabalho, propondo as ações cabíveis e manifestando-se nos processos de sua competência ${ }^{762}$.

Outra carreira do Ministério Público da União é o Ministério Público Militar, ao qual compete promover a ação penal pública militar em caráter privativo; promover a declaração de indignidade ou de incompatibilidade para o oficialato, e manifestar-se em qualquer fase do processo, acolhendo a solicitação do juiz ou por sua iniciativa, quando entender existente interesse público que justifique a intervenção. A carreira do Ministério Público Militar também se verifica em três níveis: o cargo inicial é o de Promotor de Justiça Militar; o de grau intermediário é o de Procurador de Justiça Militar; e o da última etapa da carreira é o de Subprocurador-Geral de Justiça Militar. Os Procuradores e os Promotores de Justiça do Ministério Público Militar serão designados para o ofício junto às Auditorias Militares, enquanto os Subprocuradores-Gerais devem agir junto ao Tribunal Superior Militar ${ }^{763}$.

Ao Procurador-Geral da Justiça Militar compete exercer as funções do Ministério Público junto ao Superior Tribunal Militar. E, quanto às atribuições de chefia do órgão, a esfera de sua competência identifica-se com as do Procurador-Geral da República, na condição de chefe do Ministério Público Federal, e com as do Procurador-Geral do

\footnotetext{
${ }^{760}$ Cf. o art. 86, caput, e $\S$ único, da Lei Complementar 75/93. Cf. ainda os arts. 107, § único, 110, caput, 112, caput, e $\S$ único, da Lei Complementar 75/93.

${ }^{761}$ Cf. as normas 91, 93, 94, 95 e 98, da Lei Complementar 75/93. Em seus impedimentos, o ProcuradorGeral do Trabalho também será substituído pelo Vice-Procurador-Geral e, na vacância do cargo, o exercício competirá ao Vice-Presidente do Conselho Superior, até o seu provimento definitivo. O ViceProcurador-Geral do Trabalho será designado pelo Procurador-Geral, entre os Subprocuradores-Gerais. Cf. o art. 89 da Lei Complementar 75/93.

${ }^{762}$ Cf. o art. 90 da Lei Complementar 75/93.

${ }^{763}$ Cf. o art. 116, I a III; o art. 119, caput, e $\S$ único; e os arts. 140, 143 e 145, da Lei Complementar 75/93.
} 
Trabalho $^{764}$. Em linha análoga à da gestão dos mesmos órgãos da administração superior do Ministério Público Federal e do Ministério Público do Trabalho, seguem as funções conferidas ao Conselho Superior do Ministério Público Militar e ao Colégio de Procuradores, que também é integrado por todos os membros da carreira em atividade ${ }^{765}$. É diversa apenas a forma de composição do Conselho Superior, integrando-o o ProcuradorGeral, o Vice-Procurador-Geral e todos os Subprocuradores-Gerais da Justiça Militar ${ }^{766}$.

O Ministério Público do Distrito Federal é a última carreira do Ministério Público da União, cuja organização, segundo o ordenamento constitucional, deveria constar da lei que dispusesse as regras gerais do Ministério Público dos Estados. A LONMP, no entanto, silenciou a respeito da matéria, que acabou sendo prevista, corretamente, na LOMPU, considerando a carreira como um dos desdobramentos do Ministério Público da União ${ }^{767}$.

A carreira do Ministério Público do Distrito Federal e Territórios é formada pelos cargos de Procurador de Justiça, Promotor de Justiça e de Promotor de Justiça Adjunto. O cargo inicial é o de Promotor de Justiça Adjunto e o de último nível é o de Procurador de Justiça. Os Promotores de Justiça e os Promotores de Justiça Adjuntos são designados para atuar junto aos órgãos jurisdicionais de primeiro grau. Já os Procuradores de Justiça devem oficiar nos tribunais superiores ${ }^{768}$. O Ministério Público do Distrito Federal também está encarregado de zelar pelo respeito dos demais órgãos públicos aos direitos constitucionais do cidadão. A designação do Procurador Distrital dos Direitos dos Cidadãos compete ao Procurador-Geral de Justiça, entre os integrantes do quadro de Procuradores de Justiça, mediante prévia aprovação do Conselho Superior, para o exercício das funções pelo prazo de dois anos, permitida recondução, desde que precedida de nova decisão do Conselho ${ }^{769}$.

A investidura do Procurador-Geral de Justiça na chefia da instituição ocorre de forma semelhante à dos chefes do Ministério Público dos Estados. Desde que não tenham sofrido, nos últimos quatro anos, nenhuma condenação definitiva nem estejam respondendo a

\footnotetext{
${ }^{764}$ Cf. os arts. 123 e 124, I a XXII, da Lei Complementar 75/93. Cf. também o art. 122 da LOMPU, que trata da substituição do Procurador-Geral pelo Vice-Procurador-Geral da Justiça Militar, nos casos de impedimentos, e do exercício do cargo, em caso de vacância, pelo Vice-Presidente do Conselho Superior, até o seu provimento definitivo.

${ }^{765} \mathrm{Cf}$. os arts. 126, 127, e 131, I a XXII, da Lei Complementar 75/93.

${ }^{766} \mathrm{Cf}$. o art. 128, I e II, da Lei Complementar 75/93.

${ }^{767}$ Cf. 61, § $1^{\circ}$, II, $d$, da CF. A LONMP é a Lei Federal 8.625/93 que dispões sobre normas gerais para a organização do Ministério Público dos Estados. A LOMPU é a Lei Complementar 75/93 que representa o estatuto do Ministério Público da União. Cf. ainda o art. 128, § $5^{\circ}$, da CF.

${ }^{768}$ Cf. os arts. 154, § único; 175, 178 e 179, da Lei Complementar 75/93. A LOMPU também relacionou algumas incumbências do Ministério Público do Distrito Federal e Territórios com a disposição dos instrumentos para a sua realização. Cf. o art. 150, I a VII, da Lei Complementar 75/93.

${ }^{769}$ Cf.o art. 151, I a IV; e 152, caput, $\S \S 1^{\circ}$ e $2^{\circ}$, da Lei Complementar 75/93.
} 
processo criminal ou administrativo, todos os membros do Ministério Público do Distrito Federal e Territórios podem concorrer à formação da lista tríplice para a nomeação ao cargo de Procurador-Geral pelo Presidente da República, por se tratar de carreira inserida no âmbito do Ministério Público da União. Do mesmo modo, a destituição do ProcuradorGeral, antes do término do mandato, deve ocorrer por deliberação do Senado Federal, mediante a representação do Presidente da República ${ }^{770}$.

Também na condição de órgãos da administração superior do Ministério Público do Distrito Federal, as atividades da Procuradoria-Geral de Justiça, do Conselho Superior e do Colégio de Procuradores e de Promotores de Justiça são análogas às funções desenvolvidas por esses órgãos na esfera organizacional das outras carreiras do Ministério Público da União. Note-se que o Colégio de Procuradores e de Promotores de Justiça é integrado por todos os membros em atividade daquele Ministério Público ${ }^{771}$. O Conselho Superior é composto pelo Procurador-Geral de Justiça; pelo Vice-Procurador-Geral; por quatro Procuradores de Justiça, eleitos para mandato de dois anos pelo Colégio de Procuradores e de Promotores de Justiça; e por quatro Procuradores de Justiça, eleitos também para mandato de dois anos, mas somente pelos integrantes do quadro de Procuradores ${ }^{772}$.

Todas as carreiras do Ministério Público da União contam com uma Corregedoria, que é o órgão da administração superior incumbido de fiscalizar as atividades funcionais e a conduta dos membros da instituição. Os Corregedores-Gerais serão nomeados pelo Procurador-Geral, entre os integrantes do último nível das carreiras constantes de lista tríplice elaborada pelo Conselho Superior ${ }^{773}$. Do mesmo modo, todas as carreiras dispõem ainda das Câmaras de Coordenação e Revisão, com atribuições dirigidas à coordenação e à

\footnotetext{
${ }^{770} \mathrm{Cf}$. o art. $128, \S 3^{\circ}$, da CF; e o art. 156 , caput, e $\S 1^{\circ}$, da Lei Complementar 75/93. O $\S 4^{\circ}$, do art. 128, da $\mathrm{CF}$, estabelece que os "Procuradores-Gerais nos Estados e no Distrito Federal e Territórios poderão ser destituídos por deliberação da maioria absoluta do Poder Legislativo, na forma da lei complementar respectiva”. Assim, quanto à destituição do Procurador-Geral de Justiça do Distrito Federal, a LOMPU condicionou a deliberação do Senado à prévia representação do Presidente da República (art. 156, § 2º da Lei Complementar 75/93). Compete ao Procurador-Geral de Justiça a designação do Vice-ProcuradorGeral, entre os Procuradores de Justiça, para substituí-lo em seus impedimentos; e, na vacância do cargo, ele será exercido pelo Vice-Presidente do Conselho Superior, até o seu provimento definitivo. Cf. o art. 157 da Lei Complementar 75/93.

${ }^{771}$ A LOMPU enumerou o rol de funções do Procurador-Geral de Justiça na chefia da instituição. Cf. o art. 159, I a XXIII, da Lei Complementar 75/93. Enunciou também as funções do Conselho Superior e do Colégio de Procuradores e Promotores de Justiça. Cf. os arts. 166, I a XXIII; e 162, I a V, da Lei Complementar 75/93. Sobre a composição do Colégio, cf. o art. 161 da Lei Complementar 75/93.

${ }^{772}$ Cf. o art. 163, I a III, da Lei Complementar 75/93. O Procurador-Geral e o seu Vice compõem o Conselho na condição de membros natos.

${ }^{773}$ Cf. os arts. 63 a 65; 104 a 106; 137 a 139; e 172 a 174, da Lei Complementar 75/93. Apenas poderão integrar a lista os agentes do último nível das carreiras, ou seja, os Subprocuradores-Gerais do Ministério Público Federal, do Ministério Público do Trabalho e do Ministério Público Militar; e os Procuradores de Justiça do Ministério Público do Distrito Federal.
} 
integração das atividades de seus membros, respeitada a independência funcional. As Câmaras foram constituídas, entre outros fins, para o encaminhamento de informações técnico-jurídicas aos agentes do Ministério Público e para a solução dos conflitos de atribuição. Todas elas são compostas por três agentes: um indicado pelo Procurador-Geral e os outros dois pelo Conselho Superior, para o exercício das funções por um período de dois anos, preferencialmente, entre os integrantes dos quadros do último grau das carreiras (Subprocuradores-Gerais e Procuradores de Justiça do Ministério Público do Distrito Federal e Territórios) ${ }^{774}$. Não é possível deixar de lembrar a função de execução de todos os Conselhos Superiores do Ministério Público consistente na revisão do ato de arquivamento do inquérito civil ${ }^{775}$. E, finalmente, tem-se que as estruturas básicas de lotação e de administração das carreiras do Ministério Público da União são organizadas por disposições regulamentares expedidas por seus Conselhos Superiores ${ }^{776}$.

\subsubsection{O Ministério Público dos Estados}

Para o Ministério Público dos Estados, a LONMP (Lei 8.625/93) contemplou normas gerais de organização. Além das funções previstas nas Constituições Federal e Estadual, nos estatutos estaduais e em outras legislações, a LONMP atribuiu ao Ministério Público, entre outras atividades, a ação de inconstitucionalidade de leis ou atos normativos estaduais ou municipais em face da Constituição Estadual; a promoção privativa da ação penal pública; a representação de inconstitucionalidade para efeito de intervenção do Estado nos Municípios; e a promoção do inquérito civil e da ação civil pública para a proteção, prevenção e reparação dos danos causados ao meio ambiente, ao consumidor, aos bens de valor artístico, estético, histórico, turístico e paisagístico, bem como a outros interesses difusos, coletivos ou individuais homogêneos. O sistema processual da ação civil pública também está a serviço da anulação ou declaração de nulidade de atos lesivos ao patrimônio público ou à moralidade administrativa do Estado ou de Município, de suas administrações indiretas ou fundacionais e de entidades privadas de que participem ${ }^{777}$. Em

\footnotetext{
${ }^{774}$ Cf. os arts. 58 a 62; 99 a 103; 132 a 136; e 167 a 171, da Lei Complementar 75/93. As Câmaras de Coordenação e Revisão do Ministério Público Federal e do Ministério Público do Distrito Federal e Territórios devem estar organizadas por função ou por matéria, por meio de ato normativo aprovado pelo Conselho Superior.

${ }^{775}$ Cf. o art. $9^{\circ}, \S 3^{\circ}$, da Lei 7.347/85 (Lei da Ação Civil Pública).

${ }^{776}$ Cf. os arts. 82, 115, 148 e 181, da Lei Complementar 75/93; e os seus arts. 57, I, 98, I, e 131, I, retratando o poder normativo dos Conselhos Superiores.

${ }^{777}$ Cf. o art. 25, I a IV, $a$ e $b$, da Lei 8.625/93. Para Hugo Nigro Mazzilli, a edição de normas gerais sobre a organização dos Ministérios Públicos dos Estados estaria reservada à lei complementar; a única, aliás, de
} 
seguida, depois de relacionar outros instrumentos à disposição do Ministério Público, a LONMP não deixou de estatuir a tarefa de proteção aos direitos assegurados nas Constituições Federal e Estadual, garantindo-lhes o respeito pelos poderes estaduais ou municipais, pelos órgãos da administração pública estadual ou municipal, direta ou indireta, pelos concessionários e permissionários de serviço público estadual ou municipal, e por entidades que exerçam outra função delegada do Estado ou do Município ou executem serviço de relevância pública ${ }^{778}$.

Junto ao primeiro grau da jurisdição estadual, as funções do Ministério Público são exercidas por Promotores de Justiça, que não podem oficiar nos tribunais senão para impetrarem o habeas corpus e o mandado de segurança, além dos casos de correição parcial. Já os Procuradores de Justiça formam o quadro de último nível das carreiras, cabendo-lhes o exercício das atribuições junto aos tribunais, desde que não cometidas ao Procurador-Geral de Justiça, "e inclusive por delegação deste"779. A carreira do Ministério Público do Estado de São Paulo compreende três entrâncias (inicial, intermediária e final) e duas instâncias (primeira e segunda); e "a promoção será sempre voluntária e far-se-á, alternadamente, por antiguidade e merecimento, do cargo da investidura inicial à entrância inicial, de uma para outra entrância e, da entrância mais elevada, para o cargo de Procurador de Justiça",780.

Quanto à sua chefia, os Ministérios Públicos dos Estados “formarão lista tríplice dentre os integrantes da carreira, na forma da lei respectiva, para a escolha de seu Procurador-Geral, que será nomeado pelo Chefe do Poder Executivo, para mandato de dois anos, permitida uma recondução",781. E a eleição da lista tríplice será realizada mediante voto plurinominal de todos os integrantes da carreira ${ }^{782}$. Na instituição paulista, a escolha por toda a classe para a formação da lista tríplice só está autorizada entre os Procuradores

competência realmente privativa do Presidente da República (art. $61, \S 1^{\circ}, \mathrm{II}, d$, da CF). Daí por que só teriam eficácia os dispositivos da Lei 8.625/93 que não invadissem matérias organizacionais das legislações complementares das instituições estaduais, além de não contrariarem as respectivas Constituições. Assim, segundo o autor, a eficácia da Lei 8.625/93 somente deve ser reconhecida em relação às disposições sobre as atribuições do Ministério Público; matéria passível de ser objeto de lei ordinária federal. Cf. MAZZILLI, Hugo Nigro. op. cit., p. 368.

${ }^{778}$ Cf. os arts. 26, I a V, e 27, I a IV, da Lei 8.625/93. Para o Ministério Público do Estado de São Paulo, a LOEMP (Lei Complementar Estadual 734/93) estabeleceu, de forma minuciosa, as funções e os instrumentos à disposição do Ministério Público. Cf. os arts. 103 e 104, da Lei Complementar Estadual $734 / 93$.

${ }^{779}$ Cf. o art. 31 da Lei 8.625/93. Cf. ainda o art. 32, I, da Lei 8625/93.

${ }^{780}$ Cf.o art. 133 da Lei Complementar 734/93.

${ }^{781} \mathrm{Cf}$. o art. $128, \S 3^{\circ}$, da CF.

${ }^{782} \mathrm{Cf}$. o art. $9^{\circ}, \S 1^{\circ}$, da Lei $8.625 / 93$. 
de Justiça. Por sua vez, a destituição do Procurador-Geral de Justiça depende de deliberação da maioria absoluta do Poder Legislativo Estadual ${ }^{783}$.

A LONMP encarregou o Procurador-Geral de Justiça de exercer as atribuições decorrentes da autonomia administrativa, funcional e financeira da instituição, além de enunciar um rol de hipóteses que autorizam o remanejamento de membros do Ministério Público para o exercício de diversas funções, por meio de designações daquela chefia ${ }^{784}$. No que concerne ao desenvolvimento de atividades-fins do Ministério Público, compete ao Procurador-Geral de Justiça o controle judicial sobre a inconstitucionalidade de leis ou atos normativos estaduais ou municipais em face da Constituição Estadual; a ação penal nos casos de competência originária; e as atribuições relativas à instauração de inquérito civil e à propositura de ação civil pública, quando a autoridade reclamada for o Governador, o Presidente da Assembleia Legislativa ou os Presidentes de Tribunais ${ }^{785}$.

Composto por todos os Procuradores de Justiça, o Colégio de Procuradores de Justiça é também um órgão da administração superior do Ministério Público dos Estados. Nas carreiras com um número superior a vinte e cinco Procuradores de Justiça, poderá ser constituído um Órgão Especial, com o mínimo de onze e o máximo de vinte e cinco membros, "para o exercício das atribuições delegadas da competência do Colégio, provendo-se a metade das vagas por antiguidade e a outra metade por eleição de todos os integrantes da segunda instância" 786 .

\footnotetext{
${ }^{783}$ Cf. o art. 10 da Lei Complementar Estadual 734/93. Sobre a destituição do Procurador-Geral de Justiça, cf. o $128, \S 4^{\circ}$, da CF. A Lei 8.625/93 exigiu a iniciativa do Colégio de Procuradores de Justiça para a deliberação pela Assembleia Legislativa sobre a destituição do Procurador-Geral de Justiça. Cf. o art. $9^{\circ}$, § $2^{\circ}$, da Lei 8.625/93. A hipótese padece de clara mácula de inconstitucionalidade, por contrariar o sistema estatuído na Constituição Federal. Do mesmo vício padece a LOEMP, que, não obstante não tenha estabelecido a iniciativa do Colégio de Procuradores, também condicionou a destituição do chefe do Ministério Público à deliberação de um terço dos membros do legislativo estadual (art. 14 da Lei Complementar Estadual 734/93). A LONMP estabeleceu ainda que "caso o Chefe do Poder Executivo não efetive a nomeação do Procurador-Geral de Justiça nos quinze dias que se seguirem ao recebimento da lista tríplice, será investido automaticamente no cargo o membro do Ministério Público mais votado, para exercício do mandado" (art. $9^{\circ}, \S 4^{\circ}$, da Lei 8.625/93).

${ }^{784}$ Cf. as normas do art. 10 da Lei 8.625/93. Compete também ao Procurador-Geral a propositura de ação civil para a perda do cargo pelo membro do Ministério Público em exercício sob a égide da garantia da vitaliciedade. Cf. o art. $128,5^{\circ}$, I, $a$, da CF; e o art. 38 , $\S \S 1^{\circ}$ e $2^{\circ}$, da Lei 8.625/93. Segundo a LONMP, cabe ainda ao Procurador-Geral de Justiça a decisão sobre processo disciplinar contra membro do Ministério Público. Cf. o art. 10, XI, da Lei 8.625/93. No Ministério Público do Estado de São Paulo, é o próprio Corregedor que instaura o processo, preside o seu curso e aplica as respectivas sanções. O procedimento ofende a garantia fundamental do devido processo legal. Cf. o art. $5^{\circ}$, LIV e LV, da CF. Sobre o tema, cf. MAZZILLI, Hugo Nigro. op. cit., p. 383.

${ }^{785}$ Cf. o art. 29, I a VIII, da Lei 8.625/93.

${ }^{786}$ MAZZILLI, Hugo Nigro. op. cit., p. 383. O autor sustentou a possibilidade de aplicação do art. 93, XI, da $\mathrm{CF}$, para a composição do órgão especial do Colégio de Procuradores de Justiça, em virtude do disposto no $\S 4^{\circ}$, do art. 129. No entanto, a Lei 8.625/93 autoriza a instalação de Órgão Especial, quando os colegiados
} 
O Colégio de Procuradores de Justiça deve opinar, por solicitação do ProcuradorGeral ou de quarta parte dos seus integrantes, sobre qualquer matéria relativa aos interesses gerais da instituição. Além disso, cabe-lhe deliberar a respeito de algumas decisões provenientes de outros órgãos da administração superior, como nos recursos contra decisões de não vitaliciamento, disponibilidade e remoção compulsória de membro do Ministério Público e contra decisões de procedimentos disciplinares. Compete ainda ao Colégio a aprovação da proposta orçamentária anual do Ministério Público e propor ao Procurador-Geral a criação de cargos, alterações da lei orgânica, além de providências relacionadas ao desempenho das funções institucionais ${ }^{787}$.

Finalmente, o Conselho Superior também compõe a administração superior do Ministério Público dos Estados. Sua principal atuação consiste na indicação do membro do Ministério Público mais antigo para remoção ou promoção por antiguidade, e na elaboração das listas tríplices dos candidatos ao provimento de cargos nos concursos internos de promoção ou remoção pelo critério de merecimento. Além disso, compete ao Conselho decidir sobre o vitaliciamento, a disponibilidade e a remoção compulsória de agentes da instituição ${ }^{788}$. No exercício de atividades-fins, o Conselho Superior é responsável pela revisão dos atos de arquivamento de inquérito civil ${ }^{789}$.

A LONMP reservou à lei orgânica do Ministério Público de cada Estado a competência para dispor sobre a composição, posse e duração do mandato dos integrantes do Conselho Superior. Apenas exigiu, para fins de elegibilidade, a condição de se tratar de Procuradores de Justiça em atividade ${ }^{790}$. No Ministério Público do Estado de São Paulo, além do Procurador-Geral e do Corregedor-Geral, na qualidade de membros natos, o Conselho Superior é composto de mais nove Procuradores de Justiça; três deles devem ser

\footnotetext{
contarem com mais de 40 (quarenta) integrantes. Cf. o art. 13, § único, da Lei 8.625/93. Para o Ministério Público do Estado de São Paulo, a LOEMP estabeleceu serem as atribuições do Colégio de Procuradores exercidas por um Órgão Especial composto por 42 (quarenta e dois) Procuradores. Integram o órgão o Procurador-Geral de Justiça, o Corregedor-Geral, 20 (vinte) Procuradores de Justiça mais antigos na classe, como membros natos, e outros 20 (vinte) Procuradores de Justiça, eleitos apenas por seus pares, para um mandato de 2 (dois) anos. Cf. o art. 23, caput, da Lei Complementar Estadual 734/93.

${ }^{787} \mathrm{Cf}$. as disposições do art. 12 da Lei 8.625/93. Incumbe ao Colégio decidir sobre a destituição do Corregedor-Geral, em casos de abuso de poder ou grave omissão nos deveres do cargo, por representação do Procurador-Geral ou da maioria dos seus integrantes, bem como sobre a propositura pelo ProcuradorGeral da ação de decretação de perda do cargo de membro do Ministério Público. Cf. o art. 12, VI e X, da Lei 8.625/93. Sobre o procedimento relativo à ação de perda do cargo, cf., mais uma vez, o art. $38, \S \S 1^{\circ} \mathrm{e}$ $2^{\circ}$, da Lei 8.625/93.

${ }^{788}$ Cf. o art. 15 , II, IV, VII e VIII, da Lei $8.625 / 93$.

${ }^{789}$ Cf. o art. 30 da Lei 8.625/93; e o art. $9^{\circ}$, $\$ \S 1^{\circ}$ a $4^{\text {o }}$, da Lei da Ação Civil Pública (Lei 7.347, de 24.7.1985).

${ }^{790}$ Cf. o art. 14 , I e II, da Lei 8.625/93. O Procurador-Geral e o Corregedor-Geral do Ministério Público integram o Conselho Superior como membros natos.
} 
extraídos do Órgão Especial do Colégio de Procuradores, eleitos apenas por seus pares; e os outros seis são eleitos pelos demais integrantes da carreira, para um mandato de dois anos, vedada a recondução consecutiva ${ }^{791}$.

Por fim, o Corregedor-Geral do Ministério Público dos Estados é eleito por todos os integrantes do Colégio de Procuradores e deve ostentar idêntica condição funcional. Investe-se no cargo por um período de dois anos, permitida uma recondução, para responder pelos trabalhos de orientação e fiscalização das atividades funcionais e da conduta dos membros da instituição ${ }^{792}$.

\subsubsection{O Ministério Público Eleitoral}

É incontestável a importância das funções eleitorais do Ministério Público, de modo a interferir, decisivamente, no processo eleitoral, fiscalizando-o devidamente sob a égide dos princípios fundamentais do Estado Democrático de Direito. Entretanto, o Ministério Público Eleitoral não recebeu nenhum tratamento constitucional, à diferença do Ministério Público do Trabalho e do Ministério Público Militar. Ao tratar dos órgãos do Ministério Público da União, a Constituição "silenciou sobre o Ministério Público Eleitoral, deixando de lhe conferir status constitucional como seria esperado, tendo em vista o espírito democrático que a inspirou (...)",793. Não houve, tampouco, a introdução, de forma explícita, da função eleitoral no rol das atividades consagradas à instituição no ordenamento constitucional ${ }^{794}$.

As atribuições eleitorais do Ministério Público foram conferidas ao Ministério Público Federal, ao qual compete exercer as funções da instituição junto à Justiça Eleitoral, atuando em todas as fases do processo respectivo. Cabe-lhe propor as ações para declarar ou decretar a nulidade de negócios jurídicos ou atos da administração pública, infringentes a "vedações legais destinadas a proteger a normalidade e a legitimidade das eleições, contra a influência do poder econômico ou o abuso do poder político ou administrativo"

\footnotetext{
${ }^{791}$ Cf. o art. 26 da Lei Complementar Estadual 734/93. Nas eleições, o voto é obrigatório, secreto e plurinominal.

${ }^{792}$ Cf. os arts 16 a 18 , da Lei 8.625/93.

${ }^{793}$ MARUM, Jorge Alberto de Oliveira. op. cit., p. 159.

${ }^{794}$ Cf. os arts. 128 I, $a$ a $d$, e II; e 129 , I a IX, todos da CF.

${ }^{795} \mathrm{Cf}$. o $§$ único, do art. 72, da Lei Complementar 75/93. Cf. o caput, do mesmo art. 72, da Lei Complementar $75 / 93$.
} 
O Procurador-Geral Eleitoral é o Procurador-Geral da República, que exerce as funções do Ministério Público junto ao Tribunal Superior Eleitoral, podendo designar outros membros do Ministério Público para atuarem perante aquela Corte ${ }^{796}$. Nas causas de competência dos Tribunais Regionais Eleitorais, devem atuar os Procuradores Regionais Eleitorais, designados pelo Procurador-Geral entre os Procuradores Regionais da República, ou, onde não houver, entre os Procuradores da República vitalícios, para um mandato de dois anos. Sob a coordenação do Procurador Regional Eleitoral, outros membros do Ministério Público podem ser designados pelo Procurador-Geral, para o exercício das funções institucionais junto aos Tribunais Regionais ${ }^{797}$.

As funções eleitorais perante o juízo de primeiro grau são exercidas pelo Promotor Eleitoral, que deve ser um membro do Ministério Público dos Estados. Trata-se de uma função essencialmente federal, cujo exercício pelo Ministério Público dos Estados ocorre por delegação ${ }^{798}$. A LOMPU estabeleceu, assim, que o Promotor Eleitoral deve ser o membro do Ministério Público local que esteja oficiando junto ao juízo encarregado do serviço eleitoral de cada zona ${ }^{799}$. Porém, conforme disposição da LONMP, para o exercício das funções junto à Justiça Eleitoral, os membros do Ministério Público dos Estados podem ser designados pelo respectivo Procurador-Geral de Justiça, por solicitação do Procurador-Geral da República ${ }^{800}$. No Estado de São Paulo e em outros Estados, costuma vigorar um sistema de rodízio anual para a designação dos Promotores de Justiça ${ }^{801}$.

\subsection{Os princípios da unidade, indivisibilidade e independência funcional}

Em primeiro lugar, convém lembrar o significado atribuído pela doutrina alemã à hipótese de garantias institucionais, consideradas como uma proteção qualificada para

\footnotetext{
${ }^{796}$ Cf. o art. 74, § único, da Lei Complementar 75/93. Também segundo a LOMPU, o Procurador-Geral designará, entre os Subprocuradores-Gerais da República, o Vice-Procurador-Geral Eleitoral para substituílo em seus impedimentos e responder pelo exercício do cargo em cargo de vacância, até o provimento definitivo do cargo. Cf. o art. 73, § único, da Lei Complementar 75/93. Recorde-se que o Procurador-Geral da República, além de chefe do Ministério Público da União, é também o chefe do Ministério Público Federal. Sobre a organização da Justiça Eleitoral, cf, as normas dos arts. 118 a 121, da CF.

${ }^{797}$ Cf. os arts. 76, caput, e 77, § único, da Lei Complementar 75/93.

${ }^{798}$ MARUM, Jorge Alberto de Oliveira. op. cit., p. 160.

${ }^{799}$ Cf. o art. 79 da Lei Complementar 75/93. A filiação a partido político impede o exercício de funções eleitorais do Ministério Público por um período de até dois anos do seu cancelamento. Cf. o art. 80 da Lei Complementar 75/93.

${ }^{800} \mathrm{Cf}$. o art. 73 da Lei $8.265 / 93$.

${ }^{801} \mathrm{O}$ regime não permite um maior aprofundamento no tratamento do tema e na condução dos processos, ante a troca dos agentes responsáveis após um ano de exercício da função. Nesse sentido, cf. MARUM, Jorge Alberto de Oliveira. op. cit., p. 162.
} 
certas instituições, no intuito de ampará-las naquilo que constitui a sua essência. Não obstante tenham sido inicialmente desvinculadas de qualquer conexão com os direitos fundamentais da pessoa humana, a ideia é, hoje, a de uma proteção especial a determinadas instituições da vida pública ou privada, a serviço da realização das finalidades ou tarefas a que foram constituídas no âmbito do Estado Democrático de Direito, que encontra no princípio da dignidade da pessoa humana o seu principal fundamento ${ }^{802}$. Nesse sentido, traduzindo aquela proteção especial à esfera nuclear das funções do Ministério Público, considerando-as imbuídas pela defesa da ordem jurídica, do regime democrático e dos interesses sociais e individuais indisponíveis, o constituinte estabeleceu serem os seus princípios institucionais "a unidade, a indivisibilidade e a independência funcional" 803.

Estando diretamente conectados, o princípio da unidade significa que os membros do Ministério Público integram um só órgão, enquanto a indivisibilidade implica a possibilidade de substituição de uns pelos outros, segundo a forma estabelecida em lei ${ }^{804}$. Dentro de uma estrutura orgânica multifacetada, o ordenamento constitucional procurou conferir alguma consistência aos princípios da unidade e indivisibilidade, ao tratar os ramos do Ministério Público Nacional "como se constituíssem uma instituição única”, buscando dispor que a instituição abrange todos os Ministérios Públicos que veio a indicar $^{805}$. Mas "não é fácil construir uma unidade e indivisibilidade de instituições que se inserem no contexto da organização federativa, de si diversificante" ${ }^{806}$. A incidência dos princípios da unidade e indivisibilidade limitar-se-ia a cada uma das carreiras dos Estados, além daquelas que configuram o Ministério Público da União. Seria, dessa forma, "irreal falar numa verdadeira unidade no Ministério Público" ${ }^{807}$.

Tem-se ainda que, ao contrário do princípio hierárquico orientando o funcionamento do Parquet francês, o exercício das funções do Ministério Público

\footnotetext{
${ }^{802}$ Cf. 3.1.1 e 3.3.1.

${ }^{803} \mathrm{Cf}$. o art. 127 , caput, e $\S 1^{\mathrm{o}}$, da CF.

${ }^{804}$ MAZZILLI, Hugo Nigro. op. cit., p. 116.

${ }^{805}$ SILVA, José Afonso da. Comentário contextual à Constituição, cit., p. 595.

${ }^{806}$ Id., loc. cit.

${ }^{807}$ MAZZILLI, Hugo Nigro. op. cit., p. 116. Segundo observou Maria Tereza Sadek, "no que se refere ao Ministério Público dos estados, não se pode falar de um único modelo no qual estejam contidas todas as instituições estaduais. As variações regionais e estaduais são, como observamos notáveis. O modelo comporta desde um Ministério Público mais voltado para a persecução penal até um Ministério Público que se define, sobretudo, como agente possuidor de responsabilidade social. No primeiro caso, tem-se um Ministério Público mais afeito às suas atribuições tradicionais, enquanto no limite oposto encontra-se um Ministério Público que busca expandir ao máximo as possibilidades contempladas nas legislações" (SADEK, Maria Tereza. Cidadania e Ministério Público. In: SADEK, Maria Tereza (Org.). Justiça e cidadania no Brasil, cit., p. 17-18).
} 
brasileiro ocorre sob o manto da garantia institucional de independência, significando que, no exercício de sua atividade-fim, o membro do Ministério Público não está "sujeito a determinações superiores, e só deve observância à Constituição e às leis. Ninguém tem o poder legítimo de lhe dizer 'faça isso', ou 'faça aquilo', 'faça assim' ou 'faça de outro modo'. E, se o disserem, ele não está obrigado a atender" ${ }^{\prime 808}$. Para permanecer imune a todo tipo de pressão ou influências, o agente da instituição desfruta de independência funcional, subordinando-se somente à lei e à própria consciência, segundo o entendimento dominante a respeito do tema. Sob essa definição, a independência funcional residiu, a partir da vigência da Constituição de 1988, no principal fundamento para a transformação do Ministério Público numa espécie de agente político, "livre de constrangimentos significativos, exceto os colocados por sua própria consciência” ${ }^{\text {"89 }}$. É de cogitar de certo paradoxo criado pelo constituinte de 1988, ao instituir a figura de um agente "com independência típica dos órgãos judiciais inertes e neutros, porém destinado à ação política de defesa dos interesses da sociedade, num quadro em que a lei, como o céu, é o limite" ${ }^{\text {}}{ }^{10}$.

Entretanto, mesmo considerando a possibilidade de unidade e indivisibilidade do Ministério Público apenas em relação a cada uma de suas carreiras, é difícil supor a inocorrência de qualquer dissonância entre aqueles dois princípios e o postulado da independência funcional. Quando um agente deles substitui o outro, não haveria falar em nenhuma cindibilidade na atuação institucional, malgrado a impossibilidade de se reclamar qualquer vinculação entre as opiniões de ambos. Ainda assim, a unidade, a indivisibilidade e a independência funcional caminhariam lado a lado; seriam muitos "falando em um só nome, mas de forma plural, pois que o regime democrático, cuja defesa é dever da instituição, pressupõe e fundamenta-se no pluralismo de ideias" ${ }^{\text {(111. }}$. Mas a unidade e a indivisibilidade consubstanciam a ideia da ação de um só órgão, uma única instituição, não sendo possível dissociá-la do agente que a faz agir; i.e., todos os membros do Ministério Público formariam, juntos, um só todo. Assim, aquele pluralismo de ideias não poderia implicar a inexistência de um grau de coesão na prática das atividades-fins do Ministério Público, principalmente considerando as que se destinam ao controle das decisões adotadas

\footnotetext{
${ }^{808}$ SILVA, José Afonso da. Comentário contextual à Constituição, cit., p. 596. A composição e a forma de funcionamento dos órgãos do Ministério Público brasileiro têm pontos afins às dos ofícios do Ministério Público italiano que, como se viu, integra a esfera do órgão do judiciário estatal. Cf. 1.4.

${ }^{809}$ ARANTES, Rogério Bastos. Ministério Público e política no Brasil, cit., p. 80.

${ }^{810}$ Id., loc. cit.

${ }^{811}$ FRISCHEISEN, Luiza Cristina Fonseca. Princípio do promotor natural. In: VIGLIAR, José Marcelo Menezes; MACEDO JR., Ronaldo Porto (Coords.). Ministério Público II: democracia, cit., p. 145-156.
} 
por outros órgãos estatais de largo alcance social, inseridas no conjunto de direitos e garantias fundamentais de proteção da dignidade humana.

É bem verdade que uma homogeneidade na linha de atuação institucional seria mais condizente com o predomínio do princípio hierárquico, com ordens emanadas de autoridades superiores sobre quando, como e onde deve concentrar-se o desenvolvimento das funções do Ministério Público. O postulado de independência impede a imposição de qualquer procedimento funcional aos seus membros, ressalvadas as exceções legais ${ }^{812}$. Por outro lado, na chamada atividade-meio, envolvendo as decisões de cunho organizacional e de funcionamento de seus quadros, o predomínio do princípio hierárquico é bem acentuado, o que, no entanto, em nada favorece a configuração objetiva dos princípios da unidade e indivisibilidade, comprometendo, em contrapartida, a garantia institucional de independência no desenvolvimento de funções voltadas à proteção do conjunto de direitos fundamentais da pessoa humana ${ }^{813}$.

\subsubsection{Os corolários da inamovibilidade e do princípio do promotor natural}

Desdobram-se do princípio da independência funcional as garantias da inamovibilidade e do promotor natural, que também são reconhecidas em prol do desenvolvimento das funções do Ministério Público ${ }^{814}$. Os princípios impõem o exercício de suas atividades-fins por agentes previamente investidos em atribuições legais, com a vedação de seu afastamento por simples ato de vontade das autoridades da administração superior da instituição. Membros do Ministério Público não podem ser afastados de seus cargos "com as correspondentes funções a eles agregadas. Isso significa que a lei deve discriminar previamente as atribuições do órgão ministerial”, não se aceitando designações casuísticas a pretexto da unidade e chefia da instituição ${ }^{815}$. As garantias da inamovibilidade

\footnotetext{
${ }^{812}$ A título de elucidação, não podem provir dos superiores hierárquicos da instituição as determinações voltadas à interposição ou não de um recurso em determinado caso concreto; o oferecimento ou não de denúncia ou quanto a pedido de condenação ou de absolvição de alguém em respectivo processo criminal. As hipóteses de rejeição pelo Procurador-Geral da promoção de arquivamentos de inquéritos policiais ou inquéritos civis configuram exceção à regra. Cf. o art. 28 do CPP, e o art. $9^{\circ}$ da Lei 7.347/85. Por outro lado, podem sobrevir de várias esferas da instituição recomendações, sem caráter vinculativo. Cf. os arts. 10, XII, 15, X; 17, IV; e 20, da Lei 8.625/93.

${ }^{813}$ Cf. o art. 43, XIV, da Lei 8.625/93, que estabelece, como um dos deveres institucionais, o acolhimento das decisões provenientes da administração superior do Ministério Público.

${ }^{814} \mathrm{~A}$ Constituição assegurou expressamente à instituição a garantia da "inamovibilidade, salvo por motivo de interesse público, mediante decisão do órgão competente do Ministério Público, pelo voto da maioria absoluta de seus membros, assegurada ampla defesa" (art. 128, § 5 , I, $b$, da CF).

${ }^{815}$ MAZZILLI, Hugo Nigro. op. cit., p. 203.
} 
e do promotor natural mesclam-se para alcançar, não só o titular do cargo, mas também as respectivas funções, sem o que seria possível admitir-se a manutenção do agente em determinado cargo, suprimindo-lhe, porém, as suas atividades. Os princípios materializamse nas regras de atribuição dos vários quadros funcionais do Ministério Público estabelecidas "nas leis orgânicas que estipulam a ocupação dos cargos e funções, vedada a interferência dos Procuradores-Gerais na designação de membros do Parquet, salvo nos limites daquelas leis orgânicas" ${ }^{\$ 16}$. Nesse sentido, o princípio do promotor natural é

uma garantia de ordem pública destinada tanto a proteger o membro do Ministério Público, na medida em que lhe assegura o exercício pleno e independente de seu ofício, quanto tutelar a própria coletividade, a quem se reconhece o direito de ver atuando em quaisquer causas, apenas o promotor cuja intervenção se justifique a partir de critérios abstratos e predeterminados, estabelecidos em $1 \mathrm{ei}^{817}$.

Arquitetada em função dos crimes de ação pública, a matriz do promotor natural é inerente ao princípio do devido processo legal: além do direito a julgamentos por um órgão imparcial e independente, não é possível negar aos supostos infratores o direito de defesa a acusações provenientes de outro órgão estatal que também disponha dos mesmos $\operatorname{atributos}^{818}$.

O Estado de Direito transfere à lei a prévia disposição "sobre qual órgão do Ministério Público deve oficiar num caso para impedir escolhas casuísticas, quer por favoritismo, quer por perseguição" ${ }^{, 819}$. É preciso frisar que, estando atrelada ao princípio do promotor natural, a garantia de inamovibilidade não implica apenas a impossibilidade do

\footnotetext{
${ }^{816}$ FRISCHEISEN, Luiza Cristina Fonseca. op. cit., p. 142. Aliado à garantia da inamovibilidade, o princípio do promotor natural identifica-se com o modelo burocrático do arcabouço estatal weberiano, em termos da existência de competências funcionais fixas, carreira baseada em antiguidade, qualificação profissional assegurada mediante processos de seleção dos agentes públicos, e com a sua separação dos meios administrativos, sem a apropriação do cargo. Nas palavras de Weber: "O Estado moderno é um agrupamento de dominação que apresenta caráter institucional e que procurou (com êxito) monopolizar, nos limites de um território, a violência física legítima como instrumento de domínio e que, tendo esse objetivo, reuniu nas mãos dos dirigentes os meios materiais de gestão. Equivale isso a dizer que o Estado moderno expropriou todos os funcionários que, segundo o princípio dos 'Estados' dispunham outrora, por direito próprio, de meios de gestão, substituindo-se a tais funcionários, inclusive no topo da hierarquia". $\mathrm{O}$ exercício da autoridade se impõe em razão da 'legalidade', em razão da crença da validade de um estatuto legal e de uma "competência positiva, fundada em regras racionalmente estabelecidas ou, em outros termos, a autoridade fundada na obediência, que reconhece obrigações conformes ao estatuto estabelecido. Tal o poder, como o exerce o 'servidor do Estado' em nossos dias e como o exercem todos os detentores do poder que dele se aproximam sob esse aspecto" (WEBER, Max. A política como vocação, cit., p. 57-58 e $62)$.

${ }^{817}$ É o trecho do pronunciamento do Min. Celso de Mello no julgamento do HC 67.759-RJ (cf. MAZZILLI, Hugo Nigro. op. cit., p. 122, nota 123).

${ }^{818}$ Id. Ibid., p. 205. Cf. as garantias fundamentais do art. $5^{\circ}$, XXXV, LIII e LIV, da CF.

${ }^{819}$ Id. Ibid., p. 123-124; e FRISCHEISEN, Luiza Cristina Fonseca. op. cit., p. 142-143.
} 
afastamento de membro do Ministério Público de um cargo, mas se destina a proteger, substancialmente, o exercício das funções a ele afetas. Cabe supor a necessidade de disposições legais definindo precisamente a "distribuição de atribuições entre os membros do Ministério Público", para que o princípio da inamovibilidade, conjugado ao do promotor natural, pudesse ser assegurado em sua plenitude. É que, vale lembrar mais uma vez: "não basta que não se remova o agente do cargo; é necessário que lhe seja assegurado o exercício das funções do cargo" $" 820$.

É necessário também repisar o atributo de garantias institucionais de toda sociedade e de cada um de seus membros, no sentido de que a intervenção do Ministério Público ocorra mediante critérios legais predeterminados. A inamovibilidade e o princípio do promotor natural constituem decorrência da independência funcional, correspondendo ao dever do membro do Ministério Público de agir nos lindes de suas atribuições normativas, de forma a assegurar a impessoalidade da ação institucional ${ }^{821}$. Os princípios da inamovibilidade e do promotor natural não seriam, portanto, compatíveis com a discriminação genérica de atribuições a Procuradorias ou a Promotorias de Justiça para serem distribuídas livremente por seus integrantes. Tampouco poderia haver a criação e o provimento de cargos sem funções fixas, possibilitando, para a direção do Ministério Público, a designação dos titulares para quaisquer setores de execução, mediante uma casuística interferência no exercício de atividades específicas, sobretudo nas relacionadas a questões de maior expressão social, política ou econômica.

Todavia, consoante ressalvou o próprio texto constitucional, o princípio da inamovibilidade não é absoluto. Por motivo de interesse público, é possível a remoção do titular de um cargo, mediante a decisão do órgão colegiado competente, "pelo voto da maioria absoluta de seus membros, assegurada a ampla defesa" ${ }^{„ 822}$. Além dessa hipótese, existem outras possibilidades de resultar da chefia da instituição a designação de agentes

\footnotetext{
${ }^{820}$ MAZZILLI, Hugo Nigro. op. cit., p. 389.

${ }^{821}$ Ao Conselho Nacional do Ministério Público compete zelar pela observância das garantias institucionais do art. 37, caput, da CF, entre as quais se inclui o princípio da impessoalidade na atuação administrativa estatal. Cf. o art. 130-A, § $2^{\circ}$, II, da CF.

${ }^{822} \mathrm{Cf}$. o art. $128, \S 5^{\circ}, \mathrm{I}, b$, da CF. No mesmo sentido, é a previsão do art. 95 , II, da CF, alcançando os membros do judiciário. Conforme disciplinou a LOEMP, no Ministério Público do Estado de São Paulo, a remoção compulsória está autorizada, por razão de interesse público, sob a representação do ProcuradorGeral de Justiça ou do Corregedor dirigida ao Conselho Superior, ou por determinação de ofício deste último colegiado. Cf. os arts. 36, IX, e 138, da Lei Complementar Estadual 734/93. Ainda no âmbito da LOEMP, foi também autorizado o afastamento cautelar do membro do Ministério Público durante o processo judicial voltado à perda do cargo. Cf. art. 158, § único, da Lei Complementar Estadual 734/93. Nesses casos, caberá a designação de outro membro do Ministério Público para a substituição. Cf. o art. 10, IX, da Lei 8.625/93, e o art. 225 da Lei Complementar Estadual 734/93.
} 
para o exercício das funções institucionais em determinados casos concretos ou em determinadas áreas de atuação. O Procurador-Geral de Justiça pode designar um membro específico da instituição para o acompanhamento de inquérito policial ou de diligência investigatória, desde que o agente disponha de atribuições "para, em tese, oficiar no feito" ${ }^{\text {, }}$. Havendo o consentimento do titular do cargo, o Procurador-Geral pode também designar outro membro do Ministério Público para agir em determinado feito, de atribuição daquele ${ }^{824}$. É possível ainda o afastamento compulsório, específico em relação a um determinado caso concreto, com a designação de agente para exercer as funções processuais afetas a outro integrante da instituição, mediante decisão do Procurador-Geral de Justiça, submetida à prévia apreciação do Conselho Superior ${ }^{825}$. A presente hipótese não se confunde com o afastamento voluntário, nem com a remoção compulsória de previsão constitucional, mediante a qual se altera a própria lotação do membro do Ministério Público, afastando-o de todas as atribuições do cargo anterior ${ }^{826}$. O afastamento voluntário corresponde à designação pelo Procurador-Geral de membro do Ministério Público para funcionar em feito determinado, mediante a concordância do agente que teria atribuições legais para atuar no caso. A pretexto de auxílio ao titular do cargo, a lei permite ao chefe da instituição afastá-lo de um caso concreto, desde que haja a sua concordância ${ }^{827}$. Recorde-se que as garantias institucionais da inamovibilidade e do promotor natural não incidem na esfera da livre disponibilidade de nenhum membro do Ministério Público; estão a serviço do desenvolvimento da função para a qual o órgão estatal foi legitimamente constituído, independentemente da vontade de seus integrantes.

No âmbito do Ministério Público da União, na qualidade de chefe do Ministério Público Federal, o Procurador-Geral da República é responsável pelas designações de membros da instituição: a) para o cargo de Procurador Federal dos Direitos do Cidadão e os das respectivas Procuradorias nos Estados e no Distrito Federal; b) para funcionarem perante juízos diversos dos que compõem os órgãos da Justiça Federal; c) para o

\footnotetext{
${ }^{823}$ Cf. o art. 10 , IX, e, da Lei 8.625/93.

${ }^{824}$ Cf. o art. 24 da Lei 8.625/93.

${ }^{825} \mathrm{Cf}$. o art. 10 , IX, $g$, da Lei 8.625/93.

${ }^{826}$ A remoção compulsória de membros do Ministério Público dos Estados é uma das atribuições do Conselho Superior. Cf. o art. $128, \S 5^{\circ}$, I, $b$, da CF; e o art. 15, VIII, da Lei 8.625/93.

${ }^{827}$ Cf. o art. 24 da Lei 8.62593.
} 
acompanhamento de "procedimentos e inquéritos policiais instaurados em áreas estranhas à sua competência específica, desde que relacionados a fatos de interesse da instituição",828.

No que diz respeito ao exercício das funções eleitorais do Ministério Público Federal, é o Procurador-Geral da República responsável pela designação, por necessidade de serviço, de membros do Ministério Público para o ofício junto ao Tribunal Superior Eleitoral. Incumbe também ao Procurador-Geral designar o Procurador Regional Eleitoral em cada Estado e no Distrito Federal, podendo ainda designar outros membros do Ministério Público Federal para o ofício junto aos Tribunais Regionais Eleitorais, sob a coordenação do Procurador Regional ${ }^{829}$. As atividades eleitorais do Ministério Público perante a primeira instância da jurisdição são exercidas, por delegação do Ministério Público Federal, pelo Promotor de Justiça Eleitoral, que é um membro do Ministério Público dos Estados. A LOMPU apontou o Promotor Eleitoral como o agente incumbido de oficiar junto ao juízo responsável pelo serviço eleitoral de cada zona. A LONMP, porém, estipulou que, por solicitação do Procurador-Geral da República, os membros do Ministério Público dos Estados são designados pelo respectivo Procurador-Geral de Justiça para o exercício das funções eleitorais ${ }^{830}$.

Por sua vez, as atribuições dos cargos do Ministério Público são normalmente estipuladas por decisão de sua administração superior. As legislações orgânicas introduziram na esfera da competência dos órgãos respectivos a determinação do sistema de fixação dos serviços. Dir-se-ia que, para tanto, apenas dois critérios poderiam ser admitidos: " $a$ ) ou a lei comete diretamente ao titular de um cargo as funções da instituição;

\footnotetext{
${ }^{828}$ Cf. o art. 49, III, da Lei Complementar 75/93. No exercício de suas atividades de chefia da instituição, incumbe também ao Procurador-Geral de Justiça do Ministério Público do Distrito Federal a designação do Procurador Distrital dos Direitos do Cidadão. Cf. 159, III, da Lei Complementar 75/93. Cf. o art. 37, I; e o art. 49, XV, $d$, da Lei Complementar 75/93, tratando da hipótese do item b. Por último, sobre a atribuição do item c, cf. o art. 49, XV, e, da Lei Complementar 75/93. A mesma atribuição também foi conferida ao Procurador-Geral de Justiça do Distrito Federal. Cf. o art. 159, XIII, $d$, da Lei Complementar 75/93. O Conselho Superior do Ministério Público Federal deve aprovar o nome do Procurador Federal dos Direitos do Cidadão e também a designação, em caráter excepcional, de membros do Ministério Público Federal para o exercício de atribuições processuais perante juízos, tribunais ou ofícios diferentes dos estabelecidos para cada categoria. Sobre a atribuição do Conselho de aprovação do Procurador Federal dos Direitos do Cidadão, cf. o art. 57, II, da Lei Complementar 75/93. É idêntica a atribuição do Conselho do Ministério Público do Distrito Federal. Cf. o art. 166, II, Lei Complementar 75/93. Quanto à atribuição do Conselho de aprovação das designações do Procurador-Geral para casos concretos, cf. o art. 57, XIII, da Lei Complementar 75/93. A mesma atribuição está prevista para os Conselhos Superiores do Ministério Público do Trabalho, do Ministério Público Militar e do Ministério Público do Distrito Federal. Cf. os arts. 98, XI, 131, XI; e 166, XIV, da Lei Complementar 75/93.

${ }^{829}$ Cf. os arts. 73 a 77, § único, da Lei Complementar 75/93.

${ }^{830}$ Segundo a LONMP, apenas se não ocorrer designação exclusivamente para os serviços eleitorais, o Promotor será o membro do Ministério Público local que oficie perante o juízo responsável por aqueles serviços. Cf. o art. 73, $\S 1^{\circ}$, da Lei 8.625/93. Cf. o art. 10, IX, $h$, da Lei 8.625/93, dispondo sobre a atribuição do Procurador-Geral de Justiça para a designação do Promotor Eleitoral.
} 
b) ou a lei fixa critérios que devam ser prévia e impessoalmente observados para a distribuição de serviços, e estes critérios assumem validade por período determinado" ${ }^{\text {831 }}$. $\mathrm{O}$ modelo adotado na LOMPU para as carreiras do Ministério Público da União aproxima-se desta última hipótese, ao estabelecer a necessidade de designações com validade bienal, segundo prescrições previamente estabelecidas. O sistema seria mais adequado para dinamizar a realização das tarefas institucionais, com a alteração das atribuições dos quadros do Ministério Público, mediante critérios normativos previamente estabelecidos e em períodos predeterminados ${ }^{832}$. Assim, observados os critérios legais e as disposições normativas fixadas pelos órgãos do Conselho Superior, aos Procuradores-Gerais do Ministério Público da União incumbe a designação dos ofícios dos membros das carreiras, bem como alterar parcialmente a lista bienal de designações, atendendo às necessidades dos serviços. E as Câmaras de Coordenação e Revisão resolvem sobre a distribuição especial de inquéritos, feitos e procedimentos, quando a matéria assim exigir ${ }^{833}$.

Mediante proposta do Procurador-Geral de Justiça, no plano do Ministério Público dos Estados, a tarefa de fixar as atribuições das Promotorias e das Procuradorias é do Colégio de Procuradores de Justiça, formado por integrantes da instituição em exercício junto aos tribunais. Os serviços das Procuradorias de Justiça também são definidos pelo Colégio de Procuradores, visando “à distribuição equitativa dos processos por sorteio, observadas as regras da proporcionalidade, especialmente a alternância fixada em função

\footnotetext{
${ }^{831}$ MAZZILLI, Hugo Nigro. op. cit., p. 389. Na primeira hipótese, inserem-se as promotorias de comarcas de um só cargo, a cujo titular compete desenvolver todas as atribuições do Ministério Público, ou algumas promotorias especializadas implantadas para lidarem com matérias específicas, com as atribuições de seu cargos fixadas em lei.

${ }^{832}$ Hugo Nigro Mazzilli acentuou a semelhança do sistema do Poder Judiciário da Alemanha, em que se verifica uma divisão de funções anual, antes do início do ano do judiciário. Cf. MAZZILLI, Hugo Nigro. op. cit., p. 207-208. A LOMPU conceituou a designação como o ato que discrimina as funções que sejam compatíveis com as previstas na legislação, "para cada classe das diferentes carreiras" (art. 214 da Lei Complementar 75/93). "A designação para o exercício de funções diferentes das previstas para cada classe, nas respectivas carreiras, somente será admitida por interesse do serviço, exigidas a anuência do designado e a autorização do Conselho Superior" (art. 214, § único, da Lei Complementar 75/93). Além da obediência aos critérios legais, as designações serão realizadas mediante a fixação de regras pelo Conselho Superior para o exercício de função definida pela legislação e para o exercício de função nos ofícios definidos em lei (art. 215, I e II, da Lei Complementar 75/93). Salvo quando houver outro critério previsto na LOMPU, as designações "serão feitas por lista, no último mês do ano, para vigorar por um biênio, facultada a renovação" (art. 216 da Lei Complementar 75/93).

${ }^{833}$ Cf. o art. 49, VI, e XII, b, da Lei Complementar 75/93. No mesmo sentido, são as atribuições legais do Procurador-Geral do Trabalho, do Procurador-Geral da Justiça Militar e do Procurador-Geral de Justiça do Distrito Federal (cf. os arts. 91, V, e XI, $b ; 124$, V, e X, $b$; e 159, X, $b$, da Lei Complementar 75/93). Sobre a atribuição das Câmaras de Coordenação e Revisão, cf. os arts. 62, VI; 103, IV; 136, V; e 171, VI, da Lei Complementar 75/93. Ao Conselho Superior de todos os órgãos do Ministério Público da União cabe o exercício do poder normativo para dispor sobre as designações para os diferentes ofícios do Ministério Público e os critérios para a distribuição dos feitos. Cf. os arts. 57, I, $c$ e $d$; 98, I, $c$ e $d$; 131, I, $c$ e $d$; e 166, I, $c$ e $d$, da Lei Complementar 75/93.
} 
da natureza, volume e espécie dos feitos”. A prescrição, entretanto, pode deixar de ser aplicada, caso haja uma divisão interna dos serviços, conforme critérios próprios ${ }^{834}$. No Ministério Público do Estado de São Paulo, a LOEMP estabelece que, excetuadas as funções privativas do Procurador-Geral, toda a atuação do Ministério Público nos tribunais é de atribuição dos Procuradores de Justiça. E os princípios do promotor natural e da inamovibilidade não costumam alcançar a atuação de tais agentes, não se cogitando de “cargos com atribuições previamente determinadas, inalteráveis ao arbítrio do ProcuradorGeral ou de outros órgãos da administração do Ministério Público (...), no caso o próprio Colégio de Procuradores de Justiça (...) ${ }^{\Perp 835}$.

Não é difícil concluir pela fragilidade dos pressupostos da inamovibilidade e do promotor natural relativos ao provimento de cargos, com funções previamente regulamentadas, às quais se vinculariam os respectivos titulares. Dentro desses limites, nem sempre precisos e bastante vulneráveis a deliberações casuísticas ou aleatórias pelos órgãos da administração superior, são fixadas as esferas de ação dos membros do Ministério Público. Seria preciso suprimir da esfera de competência dos órgãos da administração superior do Ministério Público todos os mecanismos capazes de propiciar uma escolha aleatória de seus membros para determinados casos concretos ou para oficiarem em determinadas áreas de atuação.

De outro turno, objetivando o atendimento aos princípios da unidade e da indivisibilidade do Ministério Público, não se admite a intervenção de mais de um de seus órgãos no mesmo processo ou procedimento. O objetivo é evitar a situação de mais de um agente atuando na mesma causa de forma desnecessária, muitas vezes prejudicando o andamento do processo. A opinião dominante é a de que o órgão do Ministério Público que oficiar no processo pela primeira vez deve continuar atuando nos autos, também no intuito de impedir o advento de posicionamentos conflitantes capazes de gerar o desprestígio das

\footnotetext{
${ }^{834}$ Cf. o art. 21 , caput e $\S$ único, da Lei 8.625/93. O $\S 3^{\circ}$, do art. 23 , da Lei $8.625 / 93$, estabelece que a exclusão, inclusão ou outra modificação nas atribuições das Promotorias de Justiça ou de seus cargos serão efetuadas mediante proposta do Procurador-Geral de Justiça aprovada por maioria absoluta do Colégio de Procuradores.

${ }^{835}$ Cf. MAZZILLI, Hugo Nigro. op. cit., p. 400-402. Conforme foi observado, as funções dos Procuradores de Justiça restringem-se, basicamente, à oferta de pareceres, agindo como fiscais da lei na fase recursal dos feitos em que haja a obrigatoriedade de intervenção do Ministério Público. Já o preenchimento de funções de confiança é objeto de livre escolha da chefia da instituição. No Ministério Público do Estado de São Paulo, algumas funções do quadro administrativo da Procuradoria-Geral, de cunho técnico, administrativo, contábil e de recursos humanos, são exercidas por Promotores ou Procuradores de Justiça. Cf. os arts. 19, III, $b$; e 20, § único; e 75, da Lei Complementar Estadual 734/93.
} 
atividades institucionais ${ }^{836}$. Dessa forma, para a solução de conflitos de atribuição entre membros do Ministério Público dos Estados, a LONMP fixou a competência do Procurador-Geral de Justiça para designar aquele que deve oficiar na causa ${ }^{837}$. Na chefia do Ministério Público da União, ao Procurador-Geral da República cabe dirimir os conflitos de atribuição entre os integrantes de suas diferentes carreiras. Já às respectivas Câmaras de Coordenação e Revisão cabe a decisão sobre os conflitos entre os membros do Ministério Público Federal, do Ministério Público do Trabalho, do Ministério Público Militar e do Ministério Público do Distrito Federal ${ }^{838}$.

Considerando a larga esfera de abrangência de causas afetas ao conjunto de direitos fundamentais, sobretudo se concebidos em sua dimensão coletiva, não raro um mesmo caso concreto pode reclamar a aplicação de regimes jurídicos diversos, reproduzidos nas atribuições de mais de um quadro funcional do Ministério Público ou até mesmo de quadros pertencentes a órgãos diversos, repercutindo inclusive nos âmbito da competência dos órgãos jurisdicionais. No campo do controle das políticas públicas, dedicado à efetividade dos direitos fundamentais de cunho social, econômico e cultural, é perfeitamente possível a ocorrência, em determinadas causas, da hipótese de conflitos entre direitos de proteção à dignidade da pessoa humana, insculpidos em normas de natureza principiológica de alcance indeterminado, situadas em idêntico patamar de supremacia, formal e substancialmente, no ordenamento constitucional. Refletindo nas atribuições normativas de mais de um órgão do Ministério Público, aqueles direitos devem receber a devida atenção no desenvolvimento das atividades voltadas à sua tutela. A intervenção nas causas de apenas um membro do Ministério Público, somente à luz do regime jurídico concernente às atribuições de seu cargo ou setor, pode prejudicar uma efetiva graduação da esfera de proteção a ser dispensada aos bens jurídicos contrapostos no caso concreto ${ }^{839}$. Fatos ilícitos envolvendo redes de organização criminosa, com a participação de agentes públicos, podem exigir do Ministério Público uma atuação fundada na aplicação da Lei de

\footnotetext{
${ }^{836}$ Cf. MAZZILLI, Hugo Nigro. op. cit., p. 416-413. Dispondo sobre as atribuições concorrentes e os conflitos de atribuição no Ministério Público do Estado de São Paulo, cf. o art. 114 da Lei Complementar Estadual 734/93.

${ }^{837}$ Cf. o art. 10, X, da Lei 8.625/93.

${ }^{838}$ Cf. o art. 26, VII, da Lei Complementar 75/93. Sobre a atribuição das Câmaras, cf. ainda os arts 62, VII, 103, VI, 36, VI; e 171, VIII, da Lei Complementar 75/93.

${ }^{839} \mathrm{~A}$ respeito da colisão entre direitos e garantias fundamentais, cf. 3.2.1. Na área cível, houve o caso pioneiro da atuação conjunta do Ministério Público Federal e do Ministério Público do Estado de São Paulo perante a Justiça Federal, gerando a proibição de comercialização do leite contaminado pelo acidente radioativo de Chernobyl. Cf. MAZZILLI, Hugo Nigro. op. cit., p. 509. Cf. o já abordado § 5º do art. $5^{\circ}$, da Lei 7.347/85, que admitiu, para a defesa dos interesses tutelados pela via da ação civil pública, o litisconsórcio facultativo entre os Ministérios Públicos da União, do Distrito Federal e dos Estados.
} 
Improbidade Administrativa e da legislação criminal atinente à matéria, com desdobramentos nas esferas da competência das Justiças Federal e Estadual e das atribuições de órgãos do Ministério Público ${ }^{840}$.

Ao tratar das atribuições concorrentes e dos conflitos de atribuição entre agentes do Ministério Público do Estado de São Paulo, a LOEMP proíbe, desde logo, a atuação simultânea de mais de um de seus órgãos no mesmo processo ou procedimento, a não ser para fins de uma ação conjunta e integrada. Caso exista mais de uma "causa bastante para a intervenção do Ministério Público, nela oficiará o órgão incumbido do zelo do interesse público mais abrangente". Contudo, em se tratando de interesses de abrangência equivalente, oficiará no feito o órgão do Ministério Público investido da atribuição mais especializada; sendo todas as atribuições igualmente especializadas, incumbirá ao órgão que por primeiro oficiar no processo ou procedimento, ou a seu substituto legal, exercer todas as funções de Ministério Público ${ }^{841}$.

Confrontando essas normas com as que dispõem sobre as funções de cargos especializados do Ministério Público do Estado de São Paulo, não é difícil antever a possibilidade de o tratamento de um mesmo caso concreto inserir-se na esfera legal das atribuições de mais de uma Promotoria de Justiça. Sob uma eventual consideração fluida a respeito do interesse público mais abrangente, é possível a alteração indevida do desenvolvimento de muitas atividades dos órgãos de execução pelo Procurador-Geral de Justiça na solução de conflitos de atribuição. Em hipóteses que tais, o comprometimento da garantia de independência do Ministério Público, contando com os tênues alicerces da inamovibilidade e do princípio do promotor natural, está longe de favorecer a unidade e indivisibilidade, com vistas ao atendimento dos amplos objetivos atualmente colocados sob a tutela da instituição ${ }^{842}$.

\footnotetext{
${ }^{840}$ Cf. o art. 109, IV, da CF. Cf. ainda os arts. $6^{\circ}$, V, VII, $b$, XIV, $b$ e $f$, 37, I e 38, I e II; da Lei Complementar 75/93; e os arts. 25, III, IV, b; 26, I, IV; da Lei 8.625/93.

${ }^{841} \mathrm{Cf}$ o art. 114 , caput e $\$ \S 1^{\circ}, 2^{\circ}$ e $3^{\circ}$, da Lei Complementar Estadual 734/93.

${ }^{842}$ Conforme dispõe a LOEMP, no Ministério Público do Estado de São Paulo, para os cargos especializados de Promotor de Justiça, "são atribuídas as funções judiciais e extrajudiciais nas seguintes áreas de atuação: “(...) IV - Promotor de Justiça da Infância e Juventude: proteção integral da criança e do adolescente, bem como as relações jurídicas decorrentes de seu regime jurídico especial, desde que de competência da Justiça da Infância e da Juventude; (...) VI - Promotor de Justiça do Meio Ambiente: defesa dos interesses difusos ou coletivos relacionados com o meio ambiente e outros valores artísticos, históricos, estéticos, turísticos e paisagísticos; VII - Promotor de Justiça do Consumidor: defesa dos interesses difusos ou coletivos relacionados com o consumidor; VIII - Promotor de Justiça de Mandados de Segurança: mandados de segurança, ações populares, habeas data e mandados de injunção ajuizados em primeira instância; IX Promotor de Justiça do Patrimônio Público e Social: defesa da probidade e legalidade administrativas e da proteção do patrimônio público e social; X - Promotor de Justiça de Habitação e Urbanismo: defesa de
} 
A abrangência da competência dos órgãos da administração superior para o remanejamento de agentes e para a fixação das atribuições de cargos e setores da instituição, além de enfraquecer o princípio da independência funcional, não serve para garantir nenhum grau de homogeneidade nos parâmetros informadores da atuação do Ministério Público com base no paradigma de proteção da dignidade da pessoa humana. Diretrizes meramente formais e não finalísticas em torno do significado das garantias da unidade, indivisibilidade e independência funcional refletem o funcionamento de um modelo organizacional que condiz apenas com o padrão de neutralidade e racionalidade que outrora norteava as atividades de repressão ao crime e de mera supressão dos vícios da vontade de sujeitos de direito envolvidos em conflitos de interesses de natureza individual. Não se vê, porém, nenhuma correlação com o atual cenário de conflituosidade resultante do crime organizado e do caráter marcadamente político de uma atuação capaz de afetar significativos interesses de lideranças político-partidárias e de grandes grupos econômicos ${ }^{843}$.

\subsubsection{A construção de objetivos comuns: um desafio institucional do Ministério Público}

Desde a última década do século passado, não vêm faltando várias proposições dirigidas a renovações estruturais no funcionamento do Ministério Público, envolvendo a necessidade de compatibilizar os princípios da unidade e indivisibilidade com a independência funcional no desenvolvimento de suas atividades, para maior atenção ao que constitui a natureza da instituição estatal, ou seja, a defesa do conjunto de direitos fundamentais da pessoa humana à vista dos instrumentos colocados à disposição do Ministério Público ao alcance de tal fim.

Nessa linha, vem sendo preconizado o abandono do pressuposto da equiparação organizacional com o Judiciário, para a relativização da obrigatoriedade da ação do Ministério Público, subvertendo-se o objetivo de "ocupar todos os espaços" de forma

interesses difusos ou coletivos nas relações jurídicas relativas a desmembramento, loteamento e uso do solo para fins urbanos; (...) XIV - Promotor de Justiça de Direitos Humanos: garantia de efetivo respeito dos Poderes Públicos e serviço de relevância pública aos direitos assegurados nas Constituições Federal e Estadual, e, notadamente, a defesa dos interesses individuais homogêneos, coletivos e difusos dos idosos, das pessoas com deficiência, e da saúde pública" (art. 295 da Lei Complementar Estadual 734/93). Cf. o art. 115 da Lei Complementar Estadual 734/93, que atribuiu ao Procurador-Geral de Justiça a competência para dirimir os conflitos de atribuição. Cf. ainda o art. 10, X, da Lei 8.625/93.

${ }^{843}$ Cf. MACEDO JÚNIOR, Ronaldo Porto. O quarto poder e o terceiro setor: o Ministério Público e as organizações não governamentais sem fins lucrativos: estratégias para o futuro, cit., p. 255-256. 
pouco eficiente, com a canalização progressiva das funções de defesa da cidadania, sem abrir mão de outras que se apresentem inconciliáveis ou prejudiciais ao satisfatório desenvolvimento daquelas ${ }^{844}$. Não sendo possível, necessário, e nem mesmo permitido que tudo seja feito, a ideia é priorizar "o que é essencial à natureza e à função da instituição" ${ }^{845}$, mediante a reavaliação dos casos de intervenção do Ministério Público, do papel da segunda instância, da necessidade de abertura de sucessivos concursos públicos à ampliação do número de seus membros, dos critérios de indisponibilidade da ação penal e da ação civil, etc. Há tempo são frequentes as discussões em torno da otimização das funções institucionais, por intermédio da adoção de projetos de atuação e formação de equipes de trabalho, incluindo a implantação de um sistema informacional de dados, além de iniciativas para o estreitamento das relações com diversos setores da sociedade civil $\operatorname{organizada}^{846}$.

O impacto inicialmente gerado pelo desenvolvimento das atribuições do Ministério Público, envolvendo a tutela de direitos ou interesses transindividuais, passou a incitar o planejamento e a implantação de projetos efetivamente hábeis à afirmação do papel de agente político moldado à instituição. O resultado de sua atuação não mais se restringe aos precisos contornos de interesses predeterminados de sujeitos individuais para alcançar os de grupos de pessoas indeterminadas, muitas vezes incorporados aos de todos os membros da coletividade e chegando até mesmo a romper a fronteira da soberania nacional para atingir valores essenciais à própria subsistência do gênero humano, como são as exigências que se põem atualmente na seara da tutela ambiental. Paralelamente a isso, o crescimento das redes de organização criminosa, com a utilização de mecanismos de alta tecnologia informacional, vem exigindo, cada vez mais, dos meios de repressão à criminalidade para mantê-los em parâmetros condizentes com as garantias do Estado Democrático de Direito. E a participação ativa do Ministério Público, principalmente na fase de produção das

\footnotetext{
${ }^{844}$ ARANTES, Rogério Bastos. op. cit., p. 108 e ss.

${ }^{845}$ MACEDO JÚNIOR, Ronaldo Porto. Vinculatividade dos planos de atuação do Ministério Público. In: VIGLIAR, José Marcelo Menezes; MACEDO JR., Ronaldo Porto (Coords.). Ministério Público II: democracia, cit., p. 131.

${ }^{846} \mathrm{O}$ objetivo seria justamente responder às funções derivadas do modelo institucional da Constituição de 1988, que, como se viu, ampliaram-se consideravelmente com diplomas como o Código de Defesa do Consumidor, o Estatuto da Criança e do Adolescente, o Estatuto do Idoso e o Estatuto da Cidade, a partir da edição da Lei da Ação Civil Pública. Oriundos de fontes materiais diversas e tutelando interesses nem sempre conciliáveis in concreto, todas essas legislações destacam-se por impor tratamentos diferenciados em favor de determinados segmentos sociais e por exigirem "iniciativas inéditas por parte do Executivo, em termos de formulação, implementação e execução de políticas públicas” (FARIA, José Eduardo. As transformações do Judiciário em face de suas responsabilidades sociais. In: humanos, direitos sociais e justiça. São Paulo: Malheiros, 2002. p. 62-63). (Org.). Direitos
} 
provas para a formação da opinio delictis, com o efetivo controle da atividade policial, está longe de se ajustar ao funcionamento individualista de quadros estruturados em extensão à organização monocrática do órgão do judiciário ${ }^{847}$.

Um dos critérios para atividades mais coesas é a adoção de planos de atuação em caráter vinculante, conjugados à formação de grupos de atuação especial. E realmente existem disposições legais que autorizam a fórmula. No Estado de São Paulo, a ação do Ministério Público deve levar em conta os objetivos fixados anualmente no Plano Geral de Atuação, "destinados a viabilizar a consecução de metas prioritárias nas diversas áreas de suas atribuições legais" $" 848$. Para fins de execução das diretrizes contidas no plano geral, devem ser elaborados os Programas de Atuação das Promotorias de Justiça, os Programas de Atuação Integrada e os Projetos Especiais, com a possibilidade da implantação de Grupos de Atuação Especial, em caráter transitório. A matéria é objeto de decisão do Procurador-Geral, de acordo com as deliberações dos setores envolvidos ${ }^{849}$.

Em que pese o suporte jurídico, existem posições contrárias à ideia de vinculatividade dos programas de atuação, com base em eventual ofensa ao princípio da independência funcional. Sob a roupagem de um Ministério Público moderno, os instrumentos prestar-se-iam a camuflar uma organização institucional caracterizada pela excessiva concentração de atribuições funcionais e administrativas na figura do Procurador-Geral, de sorte a preservar os interesses das autoridades do órgão do executivo $^{850}$. De fato, a criação dos Grupos de Atuação Especial costuma decorrer de iniciativas da administração superior do Ministério Público, com a indicação dos agentes à

\footnotetext{
${ }^{847}$ Cf. 4.1.1, 4.1.1.1 e 4.1.12.

${ }^{848}$ Cf. o art. 97 da Lei Complementar Estadual 734/93. Segundo a LOEMP, “o Plano geral de Atuação será estabelecido pelo Procurador-Geral de Justiça, com a participação dos Centros de Apoio Operacional, das Procuradorias e Promotorias de Justiça, ouvidos o Órgão Especial do Colégio de Procuradores de Justiça e o Conselho Superior do Ministério Público" (art. 98, caput, da Lei Complementar Estadual 734/93).

${ }^{849}$ Sobre os planos gerais, cf. o art. 98, § único, I, II e III, da Lei Complementar Estadual 734/93. Cf. ainda o art. 47, V, $d$, da Lei Complementar estadual 734/93, sobre a criação dos Grupos de Atuação Especial. Os Programas de Atuação das Promotorias de Justiça devem contar com a especificação das "providências judiciais e extrajudiciais necessárias à sua concretização, a forma de execução dos órgãos do Ministério Público neles envolvidos e os meios e recursos para sua implantação" (art. 100 da Lei Complementar Estadual 734/93). Considerando os planejamentos das Promotorias de Justiça baseados no Plano Geral de Atuação do Ministério Público, nascem os Programas de Atuação Integrada, que devem ser elaborados pelos integrantes das Promotorias envolvidas, sempre que necessário para a consecução daquele Plano Geral de Atuação. Cf. o art. 101 da Lei Complementar Estadual 734/93. Às Promotorias de Justiça compete o encaminhamento à Procuradoria-Geral de sugestões para a elaboração do Plano Geral, bem como a definição, de acordo com ele, dos respectivos Programas de Atuação da Promotoria e dos Programas de Atuação Integrada. E, para a consecução das diretrizes e objetivos definidos nesses programas, às Promotorias incumbe propor ao Procurador-Geral a constituição de Grupos de Atuação Especial, de caráter transitório. Cf. o art. 47, V, $a$ e $b, \S \S 1^{\circ}$ e $2^{\circ}$, da Lei Complementar estadual 734/93.

${ }^{850}$ Cf. MAZZILLI, Hugo Nigro. op. cit., p. 391.
} 
composição das equipes decidida pelo Procurador-Geral, sem a participação dos membros das carreiras; sequer dos que dispõem de atribuições legais para os trabalhos dos grupos. Daí por que, no Ministério Público do Estado de São Paulo, há anos, os planos gerais de atuação são genéricos e em nada observados pelos membros da instituição. Preponderam, com toda certeza, os seguintes aspectos: 1) um número elevado de objetivos; 2) a disposição de metas extremamente vagas; 3) a ausência de identificação dos fatores responsáveis pela eleição das prioridades; 4) a omissão quanto aos meios a serem empregados para a consecução dos objetivos; e 5) ao final do período, a falta de avaliação e de divulgação dos resultados eventualmente obtidos ${ }^{851}$.

De qualquer forma, a matriz da independência funcional, com os desdobramentos da inamovibilidade e do promotor natural, não autoriza, de modo algum, cogitar da existência de qualquer impedimento à realização de planos de atuação do Ministério Público, incluindo a formação de grupos especiais para implementá-los ${ }^{852}$. As ferramentas não destoam do real sentido daqueles primados fundamentais, isto é, o de garantir, em prol da sociedade, uma ordenação impessoal do desenvolvimento das funções institucionais, dentro de limites preestabelecidos com transparência, e pautados por diretrizes objetivas imanentes ao interesse público a ser tutelado ${ }^{853}$. Com isso, evitar-se-ia o descrédito da frequente superveniência de linhas de condutas conflitantes, muitas vezes numa mesma esfera organizacional da instituição. "Como explicar para a sociedade que a linha de atuação do MP é uma na Comarca 'A' e outra na Comarca 'B'? E que na Comarca 'B' a atuação do MP na $1^{\text {a }}$ Vara difere daquela desenvolvida na $2^{\text {a }}$ Vara?",854

Outra reflexão incide sobre a quantidade de membros do Ministério Público atuando num mesmo setor. Propõe-se a redução do número de agentes lotados nos quadros funcionais, sem prejuízo da hipótese de redução desses setores; cada qual deveria contar

\footnotetext{
${ }^{851}$ Cf. DIAS JÚNIOR, Paulo Roberto. Um novo modelo de gestão: reflexos na atuação do Ministério Público, cit., p. 717-718.

${ }^{852}$ Nesse sentido, cf. MACEDO JÚNIOR, Ronaldo Porto. Vinculatividade dos planos de atuação do Ministério Público, cit., p. 130-137; e FRISCHEISEN, Luiza Cristina Fonseca. op. cit., p. 139-149.

${ }^{853}$ É o que se extrai do trecho do voto do Min. Rel. Sepúlveda Pertence no julgamento do HC 70.290-2/RJ, de 30.6.1993: "Nem me parece que o sistema constitucional constitua óbice à continuidade e ao aprofundamento da experiência de grupos especiais de promotores, dedicados a matérias específicas: na medida em que constituídos na forma da lei, o plexo de atribuições de tais equipes, ipso facto, estará subtraído da esfera protegida das atribuições legais ordinárias do agente que tenha a sua demarcação na competência do juízo perante o qual sirva. Estou, data venia, convencido de que a opinião contrária é fruto do mimetismo a que aludi e parte da falsa ideia de que a rotina ronceira do ofício de cada órgão do Ministério Público deve ter atribuições coextensivas ao de um órgão do judiciário. Nada, entretanto, o impõe e as conveniências da administração e dos fins institucionais do Ministério Público frequentemente o desaconselham".

${ }^{854}$ DIAS JÚNIOR, Paulo Roberto. op. cit., p. 719.
} 
com "uma estrutura própria (com funcionários, bacharéis, escreventes e demais auxiliares)" ${ }^{855}$. O membro do Ministério Público seria o agente encarregado de tomar as decisões sobre os rumos das atividades, sem, no entanto, responder por sua execução direta. A hipótese não deixa de lembrar o modelo de organização das agências norteamericanas do Attorney General, que se ressentem da rigidez de carreiras públicas, com os serviços contratados livremente, e, portanto, concebidas de forma totalmente diversa das prestações do arcabouço administrativo dos órgãos públicos brasileiros ${ }^{856}$. Realmente, um dos problemas na ordenação da prestação dos serviços é o de não serem os servidores da instituição diretamente subordinados aos agentes dos quadros funcionais em que estão lotados; são, antes, subordinados aos seus superiores administrativos que aos próprios membros da instituição. Nesse contexto, com setores cada vez mais inchados, a atuação de cada membro do Ministério Público acaba sendo potencialmente diluída, com a dificuldade da identificação de suas funções com os aspectos concretos das exigências hodiernas de proteção do amplíssimo rol dos bens e valores subjacentes à proteção da dignidade da pessoa humana.

No plano de uma "relativização" ou "racionalização" da ação do Ministério Público nos processos judiciais, mediante disposições regulamentares, é conferida uma esfera de discricionariedade para decisões dos agentes sobre a necessidade de sua intervenção nos casos concretos. Faculta-se aos membros do Ministério Público a avaliação, de lege ferenda, da conveniência ou não de seu ofício. A prática coloca em relevo a importância dos planos de atuação institucional, em caráter vinculante, representando, porém, uma séria distorção no cumprimento dos deveres institucionais. A garantia institucional de independência é reduzida à noção de livre arbítrio, levando ao predomínio da autonomia da vontade individual na prestação de serviços públicos ${ }^{857}$.

\footnotetext{
${ }^{855}$ Cf. MAZZILLI, Hugo Nigro. op. cit., p. 392. É a situação do Ministério Público do Estado de São Paulo, notadamente em sua Capital, com Promotorias e Procuradorias constituídas de um vasto número de agentes, com sucessivos concursos de ingresso para ampliar a quantidade dos integrantes da carreira, quando, em contrapartida, não se investe na melhoria do aparato técnico-administrativo. Hugo Nigro Mazzilli não deixou de observar que, para cada novo promotor que ingressasse no Ministério Público de São Paulo, deveria haver a admissão de vários servidores de maior qualificação, gerando inclusive uma economia na aplicação dos recursos orçamentários. São aproximadamente 2.000 (dois mil) membros do Ministério Público em atividade no Estado de São Paulo, com dois ou mais concursos por ano. Cf. Id., loc. cit.

${ }^{856}$ Cf. 1.2.1.

${ }^{857}$ Segundo foi ressaltado, o que costuma ocorrer é que, sob o argumento genérico da presença ou da ausência de interesse público ou de interesses individuais indisponíveis, fica ao alvedrio do membro do Ministério Público decidir sobre a sua intervenção no caso. Ao tratar das funções do Ministério Público do Trabalho, a própria LOMPU facultou aos agentes a intervenção em qualquer fase do processo trabalhista, quando entenderem existente interesse público que justifique a intervenção (art. 83, II, da Lei Complementar 75/93). Cf. 4.1.
} 
$\mathrm{Na}$ estrutura organizacional do Ministério Público, existe uma excessiva concentração de atividades-fins junto aos tribunais superiores nas mãos do ProcuradorGeral, com a possibilidade de delegação a outros membros das carreiras. As funções repercutem diretamente na esfera do controle político da ação do órgão do executivo, cujo chefe responde pela nomeação do Procurador-Geral ${ }^{858}$. Dessa forma, como a usual tarefa dos membros do Ministério Público que oficiam em instâncias superiores remanesce limitada ao oferecimento de pareceres em grau de recurso, "qual verdadeira assessoria jurídica aos tribunais" ${ }^{\prime 859}$, supõe-se a possibilidade de transferir as funções do ProcuradorGeral como órgão de execução para os agentes da instituição em exercício junto aos tribunais, diminuindo, inclusive, o risco da preponderância de interesses colidentes com o espírito republicano que deve informar o exercício daquelas atividades de controle ${ }^{860}$. No âmbito do Ministério Público dos Estados, acolhe-se ainda a possibilidade de transferir para os Procuradores de Justiça a propositura de ações civis públicas no caso de a lesão aos interesses a serem tutelados abranger mais de uma comarca ou até mesmo todo o Estado. As funções de controle pelo efetivo respeito do poder público e dos serviços de relevância pública aos direitos fundamentais que interessem a uma região ou a todo Estado também poderiam ser desenvolvidas com a participação de Procuradores de Justiça e de Procuradores Regionais do Ministério Público Federal ${ }^{861}$.

Quanto ao relevante desenvolvimento das funções eleitorais do Ministério Público, já se anotou que, por delegação do Procurador-Geral da República, o exercício das funções eleitorais perante o juízo de primeiro grau foi atribuído ao membro do Ministério Público

\footnotetext{
${ }^{858} \mathrm{Cf} .128, \S \S 1^{\mathrm{o}}$ e $3^{\mathrm{o}}$, da CF. Sobre as atribuições do Procurador-Geral no exercício das atividades-fins do Ministério Público, cf. 4.2.1 e 4.2.2. Recorde-se que as funções do Procurador-Geral da República, na qualidade de chefe do Ministério Público Federal, podem ser delegadas, mediante designações, a Subprocuradores-Gerais da República. Cf. o art. 47, caput, da Lei Complementar 75/93. No plano do Ministério Público dos Estados, está também autorizada a delegação pelo Procurador-Geral de suas funções a membro do Ministério Público. Cf. o art. 29, IX, Lei 8.625/93, e, no mesmo sentido, o art. 116, XIV, da Lei Complementar Estadual 734/93.

${ }^{859}$ MAZZILLI, Hugo Nigro. op. cit., p. 400. Sobre essa atribuição dos membros do Ministério Público, cf. 4.1 .

${ }^{860}$ Sobre a natureza republicana das funções institucionais do Ministério Público, sobretudo no controle da legitimidade na gestão do patrimônio público, cf. 3.3, 4.1 e 4.1.3.1.

${ }^{861}$ Recorde-se que os Procuradores Regionais e os Procuradores de Justiça são, respectivamente, membros do Ministério Público da União e do Ministério Público dos Estados que oficiam perante tribunais superiores. Cf. o art. 31 da Lei 8.625/93; e os arts. 68110 e 175, da Lei Complementar 75/93. Cf. ainda 4.2.1 e 4.2.2. As matrizes da unidade e da indivisibilidade indicam a existência de um único Ministério Público formado por órgãos e setores cujos integrantes fazem-no agir. Assim, nas hipóteses em que haja interesse da União, a competência será da Justiça Federal, correspondendo à atribuição do Ministério Público respectivo. Contudo, é perfeitamente possível e recomendável o litisconsórcio entre órgãos do Ministério Público e, na hipótese da atuação do Ministério Público do Estado exceder a abrangência de uma só comarca, ela poderia ser cometida aos Procuradores de Justiça. Cf. o art. 109, I, da CF; e o art. 37, I, da Lei Complementar 75/93. Cf. ainda o art. $5^{\circ}, \S 5^{\circ}$, da Lei 7.347/85. Nesse sentido, cf. MAZZILLI, Hugo Nigro. op. cit., p. 403.
} 
dos Estados. O sistema adotado em São Paulo e em outros Estados para as designações do Procurador-Geral é o de um rodízio anual de Promotores, que não permite um maior aprofundamento na matéria e na condução dos casos. O sistema, ademais, ressentir-se-ia de respaldo nas garantias da inamovibilidade e do promotor natural, pois, "ao término do ano de exercício, o Promotor Eleitoral tem sua designação cessada para atuar em feitos em que vinha trabalhando, sem que se tenha promovido, removido ou aposentado". A ideia é, então, a de criação de cargos com atribuições fixas a serem regularmente providos nos concursos de movimentação nas carreiras ${ }^{862}$.

Por sua vez, no planejamento e execução das políticas públicas da área social, é inegável a atual projeção dos grupos da sociedade civil organizada. E, há anos, discute-se o relacionamento entre eles e o Ministério Público, tendo em vista os "compromissos com finalidades públicas e sociais” ${ }^{\sharp 63}$. Tornou-se realidade a privatização de serviços públicos, como nas áreas da saúde, educação e previdência, com parcelas significativas de suas fontes de custeio no erário. Além disso, acentuou-se o papel das organizações não governamentais na defesa dos interesses de determinados segmentos sociais. É o atual relevo do papel dos corpos intermediários, extraído da lição de Montesquieu, como canais de participação democrática e influência na definição das prestações governamentais, por meio de "sua articulação com grupos de pressão e sua proximidade ou origem nos movimentos sociais" ${ }^{\prime 864}$.

Com efeito, na medida em que aumentam as reivindicações em torno da parcela de responsabilidade do Ministério Público por uma atuação promocional, voltada à implementação dos direitos sociais, econômicos e culturais, cresce a necessidade de uma maior aproximação com determinados setores da sociedade civil organizada, visando ao estabelecimento de uma agenda em comum. Somam-se, aliás, experiências nesse sentido, a

\footnotetext{
${ }^{862}$ MARUM, Jorge Alberto de Oliveira. op. cit., p. 162-163. Nas Capitais dos Estados poderia ser criada uma Promotoria de Justiça Eleitoral, com cargos fixos. Nas demais comarcas, as atribuições eleitorais deveriam ser fixadas em cargos específicos. Os membros do Ministério Público que ocupassem esses cargos atuariam automaticamente junto aos juízes eleitorais de determinadas zonas. Dessa forma, estariam solucionados os problemas com o sistema de rodízio anual, mediante designações do Procurador-Geral. Nesse sentido, cf. Id. Ibid., p. 163.

${ }^{863}$ MACEDO JÚNIOR, Ronaldo Porto. O quarto poder e o terceiro setor: o Ministério Público e as organizações não governamentais sem fins lucrativos: estratégias para o futuro, cit., p. 249.

${ }^{864}$ Id. Ibid., p. 253. Cf. o relato da experiência do Ministério Público paraibano no desenvolvimento das funções de defesa da cidadania, com a participação de organismos governamentais e não-governamentais. CAVALCANTI, Rosângela Batista. O Ministério Público na Paraíba. In: SADEK, Maria Tereza (Org.). Justiça e cidadania no Brasil, cit., p. 161 e ss.
} 
despeito das atribuições normativas dos integrantes dos órgãos de execução ${ }^{865}$. Em contrapartida, na medida em que as organizações sociais transformam-se também em prestadoras de serviços públicos, amplia-se a necessidade de um controle maior pelo Ministério Público do desenvolvimento de suas atividades, não apenas em razão da origem pública de parte de seus recursos, como também por força da finalidade social de suas ações $^{866}$.

A implantação, no Ministério Público, de um sistema de informações dotado de maior transparência certamente beneficiaria o contato com diversos setores da sociedade civil organizada. Isso acontece, periodicamente, em audiências públicas, mas ainda de modo incipiente. É que, em geral, não se dispõe de dados para dialogar de forma mais estreita com representantes daqueles setores. Apenas se faz o registro das demandas sociais formuladas nas audiências públicas, sem a preocupação de conhecer as reais circunstâncias que as envolvem e, sobretudo, as suas causas, o que reduz o grau de eficácia da atuação dos agentes da instituição, dificultando ainda a formulação de projetos capazes de aprimorá-1a ${ }^{867}$.

$\mathrm{Na}$ atualidade, a criação de qualquer um dos mencionados projetos de atuação institucional exige um sistema informacional de dados extraídos da realidade, de maneira a propiciar o estabelecimento de metas, prioridades, definição de grupos de trabalho, avaliações de desempenho e resultados, além de facilitar a apuração de responsabilidades. O sistema deve estar apto ao oferecimento de elementos da realidade social, da movimentação judiciária, da estrutura e funcionamento organizacional do próprio Ministério Público, com a inclusão de dados que permitam a avaliação das decisões tomadas pelos órgãos da administração superior e também do desempenho funcional dos membros da instituição. O sistema deve possibilitar uma constante ampliação de sua base de informações e qualquer tipo de cruzamento que se necessite produzir entre elas. $\mathrm{O}$ mínimo de esperar de uma gestão institucional pautada pela transparência é a garantia do

\footnotetext{
${ }^{865}$ Vale destacar a iniciativa de Promotores de Justiça de São Paulo do Tribunal do Júri de Santo Amaro. Visando à redução dos altos índices de homicídios da região, eles intermediaram uma ação conjunta entre lideranças comunitárias, proprietários de estabelecimentos comerciais, entidades não governamentais, líderes religiosos, representantes da polícia militar e representantes do Executivo municipal, voltada a antecipar o horário de encerramento das atividades de bares e restaurantes da localidade. Constatou-se, após um período de tempo, uma considerável redução naqueles índices. Cf. MARTINELLI, Jaqueline Lorenzetti et al. Promotoria comunitária: a experiência do júri de Santo Amaro. In: CONGRESSO DO MINISTÉRIO PÚBLICO DO ESTADO DE SÃO PAULO, 3., 2005, São Paulo. Anais... São Paulo: Páginas \& Letras Ed., 2006. v. 2, p. 989-998.

${ }^{866}$ MACEDO JÚNIOR, Ronaldo Porto. O quarto poder e o terceiro setor: o Ministério Público e as organizações não governamentais sem fins lucrativos: estratégias para o futuro, cit., p. 258-259.

${ }^{867}$ Cf. DIAS JÚNIOR, Paulo Roberto. op. cit., p. 715.
} 
amplo e fácil acesso a eficiente um sistema informacional por toda a classe e também pela sociedade ${ }^{868}$.

${ }^{868} \mathrm{Cf}$. o art. $5^{\circ}$, X e XXXIII, da CF. Decisões da maior importância da administração superior do Ministério Público, como a criação e a extinção de cargos, bem como a alteração de suas atribuições, com frequência são tomadas sem que cheguem ao conhecimento da classe quais foram os elementos e os fundamentos que as embasaram. É inquestionável também a importância de cruzamento de dados em sede de investigações criminais, considerando ainda o desenvolvimento da função de controle externo da atividade policial. Cf. DIAS JÚNIOR, Paulo Roberto. op. cit., p. 711-712. 


\section{CAPÍTULO V. A INDEPENDÊNCIA DO MINISTÉRIO PÚBLICO E A REALIZAÇÃO DOS DIREITOS FUNDAMENTAIS NA PERSPECTIVA DE UM REGIME POLÍTICO DEMOCRÁTICO}

\subsection{A garantia de independência funcional e a gestão democrática da instituição}

Tal como explicitou a Constituição Federal de 1988, as funções institucionais do Ministério Público traduzem a natureza de um dos órgãos responsáveis pelo exercício do poder político do Estado; e isso por ter incorporado uma série de iniciativas de cunho decisório destinadas à proteção do valor da dignidade da pessoa humana, reconhecido naquele diploma como elemento que conforma a estrutura básica do Estado, do qual resultam os seus objetivos primordiais ${ }^{869}$. O caráter de corresponsável pelo exercício do poder político do Estado revela-se, sobretudo, pelas funções que revestem, de modo substancial, condicionamentos de algumas condutas de outros órgãos do Estado, levadas a efeito para a realização de bens materiais e imateriais afetos àquele princípio fundamental. Reforça essa condição do Ministério Público a atividade de controle social sobre a ação dos indivíduos, no sentido de guiá-los à concretização do mesmo valor, incluindo as providências punitivas aos comportamentos que lhe sejam contrários, como é o caso da tradicional intervenção de repressão à criminalidade.

Os princípios institucionais da unidade, indivisibilidade e independência funcional do Ministério Público estão a serviço das tarefas já reproduzidas neste trabalho, circunscrevendo-as de modo integral. Portanto, essas garantias institucionais, além de configurarem o núcleo essencial de uma instituição do Estado concebida à proteção da ordem jurídica, do regime democrático e dos direitos sociais e individuais indisponíveis, buscam ampará-lo, para impedir toda e qualquer iniciativa tendente a suprimi-lo ou afetá$10{ }^{870}$. Ocorre que, conforme foi assentado, fatores da estrutura organizacional e do funcionamento do Ministério Público impedem a concretização dos princípios da unidade, indivisibilidade e independência funcional, contribuindo para dissociá-los dos fins a que,

\footnotetext{
${ }^{869}$ Do princípio da dignidade da pessoa humana certamente emanam os fins de construir uma sociedade livre, justa e solidária; da garantia do desenvolvimento nacional, da erradicação da pobreza e da marginalização, com a redução das desigualdades sociais e regionais; e da promoção do bem de todos, sem preconceitos de origem, raça, sexo, cor, idade e quaisquer outras formas de discriminação. Cf. o art. $1^{\circ}$, III, $c / c$ o art. $3^{\circ}$, I a IV, da CF.

${ }^{870}$ É a noção de Carl Schmitt atribuída à hipótese de garantias institucionais. Cf. 3.1.1.
} 
necessariamente, devem se voltar ${ }^{871}$. A independência funcional não autoriza supor algum critério hierárquico de interferência direta na atuação funcional dos membros do Ministério Público; ninguém pode dar ou receber ordens de como, quando e onde agir. No entanto, em dissonância da unidade e indivisibilidade da instituição, não há uma estrutura organizacional que possibilite a superveniência de decisões coletivas no plano do exercício de suas atividades-fins. E essa característica não deixa de consistir em um grande empecilho para a adoção dos projetos tendentes à construção de objetivos comuns a todos que a integram ${ }^{872}$.

Pelo postulado "da livre convicção", que orienta o desenvolvimento das funções do Ministério Público sob o manto da garantia de independência, seus membros entendem estarem autorizados a atuar, livremente, nos limites de suas atribuições normativas e de acordo com o disposto em lei. A hipótese remete à ideia de "livre arbítrio", com a liberdade não mais vivenciada no agir associativo, mas no querer e no relacionamento consigo mesmo. Segundo observou Hannah Arendt, devido ao desvio filosófico da ação para a força da vontade, "da liberdade como um estado de ser manifesto na ação para o liberum arbitrium, o ideal de liberdade deixou de ser o virtuosismo (...), tornando-se a soberania, o ideal de um livre arbítrio, independente dos outros e eventualmente prevalecendo sobre eles" ${ }^{\text {873 }}$. A noção de detentor de parte de um poder soberano, compreendido como um fim em si mesmo, pode obstar a percepção concreta pelos membros do Ministério Público do real destinatário de sua atuação funcional; a percepção de que a condição de órgão responsável pelo exercício de uma parcela do poder político do Estado resulta das funções que lhe foram cometidas, cujo desenvolvimento deve sempre ocorrer em benefício dos interesses prioritários da sociedade brasileira ${ }^{874}$.

Todavia, atrelando-se à concepção da liberdade individual do homem singular da modernidade, a garantia de independência funcional do Ministério Público no

\footnotetext{
${ }^{871}$ Cf. 4.3, 4.3.1 e 4.3.2.

${ }^{872}$ Cf. COMPARATO, Fábio Konder. A garantia institucional contra o abuso de poder, cit., p. 55. Ao diferenciar a estrutura organizacional do Judiciário e do Ministério Público das que informam os órgãos do executivo e do legislativo, o autor assim dispôs: "Ao contrário do Executivo, que atua unitariamente com base no critério hierárquico, e do Legislativo, que manifesta a sua vontade, a partir de decisões coletivas, nem o Judiciário, nem o Ministério Público estão estruturados globalmente para tomarem decisões coletivas que manifestem uma vontade comum" (COMPARATO, Fábio Konder. A garantia institucional contra o abuso de poder, cit., p. 55). Cf. 4.3.2.

${ }^{873}$ ARENDT, Hannah. Entre o passado e o futuro, cit., p. 211. É a concepção de liberdade da modernidade que orientou a supremacia da vontade estatal na configuração do sistema de direitos humanos, vinculado à noção dos direitos subjetivos. Cf. 3.1.

${ }^{874}$ É o significado extraído da lição de Fábio Konder Comparato à hipótese de função social. Cf. COMPARATO, Fábio Konder. Um quadro institucional para o desenvolvimento democrático, cit., p. 398.
} 
desenvolvimento de suas atividades-fins acaba resultando em uma estrutura organizacional de acentuado isolamento, em que desaparecem os canais de comunicação entre os integrantes das carreiras, sobretudo entre os que estão em exercício em instâncias diversas. E a interação é praticamente inviável entre os componentes de carreiras diferentes, dificultando cogitar de decisões coletivas capazes de expressar uma vontade comum da classe. Esta não se confunde, porém, com a expressão de nenhum poder soberano que se apresente imune a um sentido finalístico apreendido da natureza da instituição estatal.

A expressão de uma vontade comum do Ministério Público envolve o advento de decisões coletivas sobre matérias de interesse comum de cunho organizacional que, lembrando Montesquieu, possam refletir a unidade de um corpo político, considerando a harmonia entre partes diversas em benefício do bem geral a que foi instituído. A partir da definição do objeto de uma organização política, as leis devem servir para orientar as suas ações no sentido de alcançá-lo, fazendo prosperar os interesses comuns. É o espírito que norteou a constituição de um corpo coletivo, o princípio que move todas as forças sociais e políticas em torno de fins comuns ${ }^{875}$.

O objeto do Ministério Público brasileiro consiste na realização do primado republicano do Estado Democrático de Direito que derivou do espírito cívico que movimentou as forças sociais e políticas quando da edição da Lei Fundamental de 1988. O espírito virtuoso que orienta o funcionamento de uma república implica a atenção ao bem comum, com a disposição moral de jamais sobrelevar os interesses pessoais aos do Estado. Hoje, sem nenhuma dúvida, o valor da dignidade da pessoa humana - com os direitos e garantias que lhe são subjacentes - traduz a essência do princípio republicano que deve orientar o funcionamento dos órgãos governamentais de qualquer sociedade estatal ${ }^{876}$. A natureza das funções do Ministério Público reflete a sua razão de existir, impondo-se, portanto, uma organização e um funcionamento compatíveis com as garantias institucionais estabelecidas para consolidá-la. Em outras palavras; de uma efetiva configuração dos princípios da unidade, indivisibilidade e independência funcional depende a realização das incumbências de defesa da ordem jurídica, do regime democrático e dos direitos sociais e individuais indisponíveis; e, via de consequência, das funções correspondentes a este núcleo essencial que constitui a natureza do Ministério Público no Brasil.

\footnotetext{
${ }^{875} \mathrm{Cf}$. 1.1.1.

${ }^{876}$ Cf. 3.3.
} 
Nesse passo, importa ressaltar que uma gestão efetivamente democrática da instituição pode servir ao alcance desse fim. Das considerações a respeito da organização e do funcionamento do Ministério Público foi possível perceber que, de uma maneira geral, resultam dos órgãos de sua administração superior todas as decisões que envolvam, por exemplo, a criação e a extinção dos cargos públicos e dos serviços auxiliares; a fixação dos planos de atuação e das diretrizes para a formação de equipes de trabalho; as designações dos membros da instituição nas várias hipóteses de não incidência da garantia de inamovibilidade; os critérios dos concursos de ingresso e de movimentação nas carreiras; a definição das atribuições dos cargos, a atuação das corregedorias; a aplicação dos recursos orçamentários; e as propostas de alteração das leis orgânicas. Provêm, enfim, dos órgãos da administração superior do Ministério Público, com destaque à Procuradoria-Geral, todas as iniciativas de cunho organizacional que atingem diretamente o desenvolvimento das funções institucionais ${ }^{877}$.

Por essa razão, ora considerando o Ministério Público isoladamente no sistema da organização política brasileira, a perspectiva de sua gestão democrática revela-se sob os seguintes aspectos: em primeiro lugar, o da implantação de meios que assegurem a participação de seus membros em decisões versando sobre organização e o funcionamento da instituição, aliada à necessidade do aprimoramento de seu sistema de representação democrática para os assentos da administração superior; e, em um segundo momento, a questão da legitimidade dos concursos públicos de ingresso e de movimentação nas carreiras.

\subsubsection{A democracia participativa e as decisões políticas institucionais}

Para a formulação de medidas que interfiram no planejamento e na execução das atividades institucionais, o socorro é, inicialmente, ao ideal de democracia insculpido por Rousseau para a refundação das sociedades políticas. A ideia de seu Contrato Social traduz os pressupostos de uma relação associativa tendente a fomentar, e jamais sufocar, a emancipação prometida pela modernidade. A ordenação de um corpo coletivo deve "equilibrar a liberdade e a igualdade, a autonomia e a solidariedade, a razão e a ética, a

${ }^{877}$ Cf. 4.2 a 4.3 .2 . 
autoridade e o consentimento, em nome de uma racionalização plena da vida colectiva e da vida individual" ${ }^{\prime 878}$.

Visando à regeneração moral das sociedades políticas, sob o postulado do contrato social Rousseau defendeu a indissociável conjugação dos valores da igualdade e liberdade para a formação e a subsistência de um ente coletivo, essencialmente democrático, em que as noções de autoridade e soberania estão, de forma indivisível, adstritas à vontade geral, que não representa, entretanto, nenhuma faculdade subjetiva, consistindo, ao revés, num princípio ético objetivo, superior à vontade dos indivíduos, que impõe a supremacia do bem público sobre os interesses particulares ${ }^{879}$.

A conquista da liberdade civil reclama o consenso entre indivíduos que se encontram numa posição de plena igualdade jurídica ${ }^{880}$. A liberdade "é mera decorrência da igualdade de base, estabelecida entre todos os cidadãos, de sorte que, numa sociedade de iguais, seria politicamente impossível que uns oprimissem os outros" ${ }^{„ 881}$. A alienação dos indivíduos a esse corpo moral coletivo não pressupõe a obediência a nenhuma autoridade superior. A liberdade que eles passam a adquirir decorre justamente de sua submissão às leis que prescrevem para a própria obediência. A liberdade resulta, portanto, do livre consentimento às leis, pois as obrigações colocadas aos indivíduos são aquelas que eles mesmos reconheceram como válidas e necessárias. Inexistem elementos coercitivos, pois o que se verifica é a adesão à própria vontade. É esse, em poucas linhas, o sentido de emancipação e de independência capaz de transformar os membros dos entes coletivos em “personalidades autônomas" 882 .

Todavia, o princípio da soberania popular, cuja concepção foi atribuída a Rousseau a partir da Revolução Francesa, não há de ser tomado em sentido absoluto. Acima da supremacia da vontade coletiva imperando nas deliberações da vida pública estará sempre

\footnotetext{
${ }^{878}$ SANTIAGO NINO, Carlos. Derecho, moral y política, cit., p. 131-132. Sobre a influência do pensamento de Rousseau na Revolução Francesa, cf. 1.3.

${ }^{879}$ COMPARATO, Fábio Konder. Ética: direito, moral e religião no mundo moderno, cit., p. 240-251. O autor observou a semelhança com o imperativo categórico de Kant. Também dispondo sobre a influência do pressuposto da vontade geral na doutrina de Kant, cf. ERNST, Cassier. A questão de Jean-Jaques Rousseau. In: SADEK, Maria Tereza; QUIRINO, Célia Galvão (Orgs.). O pensamento político clássico: Maquiavel, Hobbes, Locke, Montesquieu, Rousseau. 2. ed. São Paulo: Martins Fontes, 2003. p. 464. Cf. ainda ROUSSEAU, Jean-Jacques. Du contrat social, cit., livro II, cap. III, p. 193-194.

${ }^{880}$ Cf. ROUSSEAU, Jean-Jacques. op. cit., livro I, cap. IX, p. 187-189.

${ }^{881}$ COMPARATO, Fábio Konder. Ética: direito, moral e religião no mundo moderno, cit., p. 254.

${ }^{882}$ ERNST, Cassier. op. cit., p. 461-462.
} 
"o princípio da moralidade, que é a vontade geral" $" 883$. E as leis seriam expressões desse princípio ético fundamental, ligando-se necessariamente ao bem comum. Daí a legitimidade do povo para editá-las. Cabe a todos os integrantes de uma comunidade política a elaboração de leis que, ao contrário de configurarem uma oposição à liberdade, servem para garanti-la, na medida em que realizam a igualdade entre os homens, instandoos a agir de acordo com os preceitos da razão pública ${ }^{884}$.

No intuito de viabilizar a compatibilidade entre os princípios da unidade, indivisibilidade e independência funcional, mediante o advento de decisões coletivas envolvendo aspectos da estrutura organizacional e do funcionamento do Ministério Público, é possível conceber o funcionamento de um ente coletivo sob os valores da igualdade e liberdade, que foram projetados por Rousseau como fontes de renovação das organizações políticas. Conjugada a outras prerrogativas que lhe são correlatas, a garantia de independência funcional conferida a todos os membros do Ministério Público coloca cada qual em relação a seus pares numa posição de plena igualdade jurídica, no que concerne ao desenvolvimento das funções institucionais. Não existe nenhum vínculo hierárquico na realização das atividades-fins do Ministério Público.

Dessa forma, é de ver os pressupostos de liberdade e igualdade do pacto social de Rousseau permeando a garantia institucional de independência para o abandono do postulado individualista da "livre convicção", no sentido de alcançar uma união de propósitos entre os membros do Ministério Público em torno da construção de objetivos comuns. A liberdade a ser apreendida da independência funcional do Ministério Público deve significar para todos os seus agentes a alienação de si mesmo a um corpo moral coletivo, por força da adesão a obrigações derivadas de anseios comuns; uma adesão que reclama o livre consentimento a deliberações por todos tomadas, porquanto terem sido reconhecidas como necessárias à preservação do ente político. A lembrança de Aristóteles

\footnotetext{
${ }^{883}$ COMPARATO, Fábio Konder. Ética: direito, moral e religião no mundo moderno, cit., p. 253 . Incorrendo em certa contradição, Rousseau acabou admitindo a supremacia absoluta da soberania popular, tergiversando a respeito do paradigma ético da vontade geral. Para Hannah Arendt, o pensador é o mais expressivo representante da soberania derivada diretamente da vontade, com a concepção do poder político "à imagem estrita da força de vontade individual". E justamente essa identificação da liberdade com soberania teria provocado aquela equação filosófica de liberdade com o livre arbítrio. Cf. ARENDT, Hannah. Entre o passado e o futuro, cit., p. 211-212.

${ }^{884}$ Retomando os aspectos da concepção da liberdade dos antigos, Rousseau rechaçou a ideia de representação popular, com críticas ao sistema de governo inglês, que Montesquieu concebeu como modelo ideal de um Estado livre, Cf. COMPARATO, Fábio Konder. Ética: direito, moral e religião no mundo moderno, cit., p. 260-261. Sobre a polêmica em torno da democracia representativa versus democracia direta, com base nas doutrinas de Rousseau e Montesquieu, cf. BENEVIDES, Maria Victoria de Mesquita. A cidadania ativa referendo, plebiscito e iniciativa popular. 3. ed. São Paulo: Ática, p. 49-55.
} 
é também de especial relevo: o conjunto que representa uma coletividade "é sempre mais importante que as partes"; aquela terá sempre prioridade sobre o indivíduo, que, "quando isolado, não é autossuficiente; no entanto, ele o é como parte relacionada ao conjunto. (...) Mas a justiça é o vínculo dos homens nos Estados; porque a administração da justiça, que é a determinação daquilo que é justo, é o princípio da ordem numa sociedade política" ${ }^{\$ 85}$.

Já considerando a natureza das funções do Ministério Público, é possível identificar o princípio ético da vontade geral de Rousseau como móvel informador das deliberações sobre o funcionamento da instituição estatal, de interesse comum a todos os seus membros. Os paradigmas republicanos do Estado Democrático de Direito da Constituição de 1988 representam o princípio da supremacia do bem comum capaz de ensejar a livre adesão de todos a decisões por todos compartilhadas, em igualdade de condições, sobre matérias que a todos atingem, posto que delas depende a realização das garantias consagradas para a subsistência da instituição estatal.

Em atenção aos primados da liberdade, igualdade e solidariedade, consolidados no curso da história como os valores centrais do sistema universal de direitos humanos, a ideia de moralidade política pressupõe que todos os membros do Ministério Público possam se sentir corresponsáveis pelas decisões destinadas à realização das funções primordiais da instituição. Apenas elevando-os à qualidade de sujeitos morais de uma coletividade é possível supor a eficácia de planejamentos de trabalho compatíveis com a natureza daquelas atividades. Para tanto, é preciso transpor interesses corporativistas, para que se coloquem em relevo questões de cooperação de que possa resultar uma linha de atuação coesa, também marcada pelo pluralismo. No comando daqueles três cânones fundamentais, a condição de sujeitos morais atribuída aos membros do Ministério Público não pode prescindir do direito à autodeterminação coletiva, de modo que possam considerar como suas muitas das decisões dos órgãos da administração superior. Por essa razão, impõe-se a existência de meios que assegurem a sua participação ativa em decisões versando sobre questões de interesse comum que apresentem direta correlação à eficácia dos princípios da unidade, indivisibilidade e da independência funcional, e, por conseguinte, sejam dirigidas à proteção do núcleo essencial das funções institucionais ${ }^{886}$.

\footnotetext{
${ }^{885}$ ARISTÓTELES. Política, cit., livro I, p. 146-147.

${ }^{886}$ Recorde-se que o núcleo essencial das funções institucionais identifica-se com a defesa da ordem jurídica, do regime democrático e dos interesses sociais e individuais indisponíveis, sob a égide do sistema de proteção aos direitos humanos positivado na Constituição de 1988. Cf. o art. $1^{\circ}$, III, c/c o art, 127, caput, da CF.
} 
Hauriou concebeu o surgimento de uma instituição "toda vez que uma ideia diretora se impõe objetivamente a um grupo de homens, e as atividades reciprocamente se autolimitam segundo as regras sociais indispensáveis à consecução do fim para cuja função a autoridade do todo se constitui e se exerce" ${ }^{\text {887. }}$. Para a realização da ideia diretora, é preciso que haja a organização de um poder de gestão. Mas, além do elemento objetivo, uma instituição corporativa também exige manifestações de consenso dos membros do grupo dirigidas por órgãos daquele poder e regulamentadas por procedimentos. Para Hauriou, são as manifestações de consenso dos membros do ente coletivo que o transformam em uma pessoa moral, sem perder o aspecto objetivo de sua existência. A participação dos membros do Ministério Público nas decisões concernentes à sua gestão caracteriza aquelas manifestações de consenso centradas na realização da ideia diretora. A liberdade política está condicionada à participação dos integrantes das chamadas instituições-pessoa nas decisões provenientes da autoridade superior. Por essa razão, seguindo o molde da liberdade dos antigos, Hauriou destacou a relevância de instrumentos da democracia participativa ou semi-indireta na eclosão de decisões políticas.

Assim, tendo em mira todos esses pressupostos, é perfeitamente possível a ampliação dos meios de uma participação ativa dos membros do Ministério Público nas decisões envolvendo os interesses gerais da instituição. Trata-se, aliás, de uma das ferramentas indispensáveis para todo e qualquer sistema de controle político genuinamente democrático $^{888}$. Dessa forma, além dos instrumentos de consultas e audiências públicas que vêm sendo utilizados em algumas ocasiões, preconiza-se a possibilidade de adoção de outros mecanismos — análogos à iniciativa popular, ao referendo ou ao plebiscito revestidos de caráter vinculante. As iniciativas das leis orgânicas dos Procuradores-Gerais poderiam, por exemplo, ser objeto de deliberação definitiva por todos os membros das respectivas carreiras do Ministério Público. Daí a possibilidade de advirem decisões políticas institucionais configurando a "manifestação de uma vontade coletiva, contraposta à dos demais órgãos do Estado", na expectativa de um funcionamento efetivamente compatível com o cumprimento do dever de controle das decisões deles emanadas ${ }^{889}$.

\footnotetext{
${ }^{887}$ É a referência de Miguel Reale ao institucionalismo de Hauriou. Cf. REALE, Miguel. Teoria do direito e do Estado. 5. ed. São Paulo: Saraiva, 2000. p. 290) A esse respeito, cf. também 3.3.

${ }^{888}$ Cf. 3.3. e 3.3.1.

${ }^{889} \mathrm{Cf}$. COMPARATO, Fábio Konder. A garantia institucional contra o abuso de poder, cit., p. 55. O modelo de iniciativa popular pode corresponder ao direito dos membros do Ministério Público de provocarem iniciativas de caráter normativo dos órgãos da administração superior, no âmbito de suas competências. Muitas vezes usados como sinônimos, os modelos referentes ao referendo e ao plebiscito geram algumas
} 


\subsubsection{O aprimoramento do sistema de representação democrática}

De início, razão assiste a Norberto Bobbio ao firmar que, atualmente, quando se deseja apontar um indicador do desenvolvimento democrático nas sociedades estatais, este deve ser o número dos locais diferentes dos centros políticos tradicionais nos quais é exercido o direito de voto; ou seja, para um juízo sobre o Estado de democratização num dado país, o critério não deve ser apenas o de "quem" vota, mas o do "onde" se vota, com o "votar" entendido como o ato típico e mais comum do "participar" processo de institucionalização de canais de participação em instâncias diversas da sociedade civil e dos órgãos estatais é um fenômeno que, sob a marca do pluralismo, só tem a contribuir para a ruptura da apatia política e do “'indiferentismo' (qualunquismo) dos que cultivam o seu particular" ${ }^{\prime 291}$, contrastante com a ideia de regime democrático que realmente representa a única solução legítima para a organização do Estado. Contudo, existem, ainda hoje, alguns blocos das sociedades estatais que não foram afetados por aquele processo de democratização, impedindo que se complete a transformação democrática da sociedade. Em outras palavras;

se o avanço da democracia for de agora em diante medido pela conquista dos espaços até então ocupados por centros de poder não democráticos, tantos e tão importantes ainda são estes espaços que a democracia integral (posto que seja meta desejável e possível) ainda está distante e incerta ${ }^{892}$.

É exatamente nesse contexto que se pretende incluir as deficiências do sistema de representação democrática vigente para a composição de alguns órgãos da administração superior do Ministério Público, os quais concentram todas as atribuições para decisões atinentes à estrutura organizacional e ao funcionamento da instituição ${ }^{893}$. Principalmente nas carreiras do Ministério Público dos Estados, o sistema prioriza, de forma desmedida, o

ambiguidades. É possível a distinção pela natureza do tema colocado sob a deliberação do conjunto de participantes e também quanto ao momento da convocação. Segundo o entendimento adotado por Maria Victoria de Mesquita Benevides, o referendo concerne a disposições normativas, com a convocação sempre após da edição dos atos normativos. O plebiscito significa uma deliberação sobre medidas futuras, de um sentido político e organizacional. Cf. BENEVIDES, Maria Victoria de Mesquita. op. cit., p. 39-41. Também no plano do orçamento participativo, é possível sujeitar à deliberação definitiva de todos os membros do Ministério Público dos Estados a aprovação do Colégio de Procuradores sobre a proposta orçamentária anual elaborada pelo Procurador-Geral de Justiça. No âmbito do Ministério Público de São Paulo, cf. o art. 22, VIII, da Lei Complementar 734/93, dispondo sobre a competência do Colégio de Procuradores para a aprovação da proposta orçamentária anual elaborada pelo Procurador-Geral.

${ }^{890}$ BOBBIO, Norberto. Democracia representativa e democracia direta. In: O futuro da democracia.

Trad. Marco Aurélio Nogueira. 9. ed. São Paulo: Paz e Terra, 2004. p. 68.

${ }^{891}$ Id. Ibid., p. 69.

${ }^{892}$ Id. Ibid., p. 70.

${ }^{893}$ Cf. 4.2 a 4.2 .2 . 
direito de integrantes dos quadros de último nível das carreiras de participarem dos processos eleitorais.

A Constituição atribuiu ao Presidente da República a nomeação do chefe do Ministério Público da União - o Procurador-Geral da República -, escolhido entre os integrantes da carreira, "maiores de trinta e cinco anos, após a aprovação de seu nome pela maioria absoluta dos membros do Senado Federal" ${ }^{894}$. Não obstante sem o devido respaldo constitucional, na esteira do regime estabelecido pela legislação infraconstitucional às chefias do Ministério do Trabalho e do Ministério Público Militar, o Colégio de Procuradores da República, composto por todos os membros do Ministério Público Federal, é responsável pela formação de lista tríplice para a escolha do Procurador-Geral da República, entre todos os integrantes da carreira, mediante o voto plurinominal de seus membros ${ }^{895}$.

Por sua vez, o Procurador-Geral de Justiça é o chefe do Ministério Público dos Estados e do Ministério Público do Distrito Federal e Territórios. A sua escolha pelos Governadores resulta da formação de listas tríplices entre os integrantes das carreiras, "na forma da lei respectiva" ${ }^{\text {896 }}$. Quanto à lista tríplice para a nomeação do Procurador-Geral de Justiça do Distrito Federal, a LOMPU garantiu ao Colégio de Procuradores e de Promotores de Justiça, composto por todos os membros da carreira, o direito de formá-la, mediante a eleição entre todos os seus membros com mais de cinco anos de exercício nas funções do Ministério Público ${ }^{897}$. Já nas eleições de formação das listas tríplices para os cargos de Procurador-Geral de Justiça dos Estados, a LONMP chancelou o modelo constitucional, exigindo apenas a escolha entre os integrantes das carreiras, "na forma da lei respectiva", mediante o voto plurinominal de todos os seus membros ${ }^{898}$.

\footnotetext{
${ }^{894}$ Cf. o art. $128, \S 1^{\circ}$, da CF.

${ }^{895}$ Recorde-se que o Procurador-Geral da República é a figura do ápice da estrutura organizacional do Ministério Público da União, que compreende o Ministério Público Federal, o Ministério Público do Trabalho, o Ministério Público Militar e o Ministério Público do Distrito Federal e Territórios. Cf. o art. 128 , I, $a$ a $d$, e $\S 1^{\circ}$, da CF. Ocorre que é ele também o chefe do Ministério Público Federal, provocando a sua escolha entre os integrantes dessa carreira. As demais dispõem de chefias próprias. Cf. o art.128, $\S 3^{\circ}$, da CF; e os arts. 45, 87, 120 e 155, da Lei Complementar 75/93. O art. 88, caput, da Lei Complementar 75/93, dispõe sobre o processo de nomeação do Procurador-Geral do Trabalho pelo Procurador-Geral da República, "dentre os integrantes da Instituição, com mais de trinta e cinco anos de idade e de cinco anos na carreira, integrantes de lista tríplice escolhida mediante voto plurinominal, facultativo e secreto, pelo Colégio de Procuradores, para um mandado de dois anos, permitida uma recondução (...)". No mesmo sentido, cf. o art. 121, caput, da Lei Complementar 75/93, dispondo sobre o processo de nomeação do Procurador-Geral da Justiça Militar.

${ }^{896}$ Cf. o art. $128, \S 3^{\circ}$, da CF.

${ }^{897} \mathrm{Cf}$. o art. 156 , caput, e $\S 1^{\mathrm{o}}$, da Lei Complementar $75 / 93$.

${ }^{898}$ Cf. o art. $9^{\circ}$, caput, e $\S 1^{\circ}$, da Lei $8.625 / 93$.
} 
Os Conselhos Superiores do Ministério Público Federal, do Ministério Público do Trabalho e do Ministério Público do Distrito Federal devem ser compostos por oito integrantes do último nível das carreiras, além dos Procuradores-Gerais e Corregedores figurando na qualidade de membros natos ${ }^{899}$. Desses oito Conselheiros, quatro são eleitos por seus pares, ficando apenas a escolha dos outros quatro reservada para todos integrantes das carreiras $^{900}$. A LONMP também estabeleceu, somente para os integrantes dos Colégios de Procuradores de Justiça, a possibilidade de serem eleitos para a composição do Conselho Superior do Ministério Público dos Estados ${ }^{901}$. Lembre-se que, nas carreiras estaduais em que os Colégios superem um determinado número de membros, suas funções são transferidas para um Órgão Especial, cuja forma de composição deve constar das respectivas leis orgânicas ${ }^{902}$.

Acentuando as restrições do sistema de representação para composição dos órgãos da administração superior das carreiras do Ministério Público, a LOEMP autorizou somente os Procuradores de Justiça a concorrerem nas eleições de formação da lista tríplice para a nomeação do Procurador-Geral de Justiça do Estado de São Paulo ${ }^{903}$. Ressalte-se que a Constituição apenas exigiu a condição de se tratar de integrante das carreiras. Muito embora o preceito careça de eficácia plena, é certamente taxativa a menção a "integrantes da carreira"904, sem nenhuma limitação quanto à instância de atuação funcional dos candidatos. Assim, tendo em vista o postulado de interpretação do ordenamento constitucional que recomenda sempre conferir a maior eficácia possível ao conteúdo de suas normas, incabível se apresenta a limitação contida na legislação paulista, sobretudo se para desfigurar um elemento central do princípio democrático de organização do Estado $^{905}$.

\footnotetext{
${ }^{899}$ Cf. os arts. 54, I a III, 95, I a III; e 163, I a III, da Lei Complementar 75/93. O último nível das carreiras do Ministério Público Federal e do Ministério Público do Trabalho corresponde ao cargo de SubprocuradorGeral; e os Procuradores de Justiça do Distrito Federal formam o espectro do último nível do seu Ministério Público. Cf. os arts. 44, § único; 86, § único; e 154, § único, da Lei Complementar 75/93.

${ }^{900} \mathrm{Cf}$. os arts. 54, II e III; 95, II e III; e 163, II e III, da Lei Complementar 75/93. Não existe eleição para a composição do Conselho Superior do Ministério Público Militar, que é integrado por todos os Subprocuradores-Gerais do último nível da carreira. Cf. o art. 128, II, da Lei Complementar 75/93.

${ }^{901}$ Cf. o art. 14, II, da Lei 8.625/93. Os Procuradores de Justiça são os ocupantes dos cargos de último nível das carreiras que oficiam junto aos tribunais. Cf. o art. 31 da Lei 8.625/93.

${ }^{902}$ Cf. o art. 13, § único, da Lei 8.625/93.

${ }^{903}$ Cf. o art. 10, caput, da Lei Complementar Estadual 734/93.

${ }^{904} \mathrm{Cf}$. o art. $128, \S 3^{\circ}$, da CF.

${ }^{905}$ Cf. ALMEIDA, Fernanda Leão de; MACHADO, Martha de Toledo. A composição dos órgãos superiores do Ministério Público do Estado de São Paulo - na trilha de uma gestão mais democrática. In: CONGRESSO DO MINISTÉRIO PÚBLICO DO ESTADO DE SÃO PAULO, 3., cit., v. 2, p. 670. Tratase de tese aprovada por unanimidade que defendemos no Congresso do Ministério Público do Estado de
} 
A LOEMP também reservou somente para os Procuradores de Justiça o direito de concorrem nas eleições para a composição do Conselho Superior do Ministério Público de São Paulo. Além disso, permitiu para todos integrantes da carreira apenas a escolha de seis, dos nove Conselheiros eleitos pela classe; a escolha dos outros três ficou para o Órgão Especial do Colégio de Procuradores, entre os seus pares ${ }^{906}$. Os Promotores de Justiça não têm nenhuma participação nas eleições para a formação desse Órgão Especial, que é composto por quarenta e dois membros — vinte dos quais são os Procuradores de Justiça mais antigos nas carreiras na qualidade de membros natos, sendo os outros vinte eleitos somente por Procuradores de Justiça ${ }^{907}$.

Ao se projetar um sistema de representação política, existem diretrizes que se mostram incompatíveis de adoção concomitante. Em um regime de delegação, não se verifica a característica de relações fiduciárias. Se alguém representa outrem, na qualidade de delegado, é ele pura e simplesmente "um porta-voz, um núncio de seus representados", com o seu mandato "extremamente limitado e revogável ad nutum" "908. Se, ao contrário, o representante é um fiduciário, "tem o poder de agir com certa liberdade em nome e por conta dos representados, na medida em que, gozando da confiança deles, pode interpretar com discernimento próprio os seus interesses" ${ }^{\text {"909 }}$. É o caso em que inexiste um mandato imperativo, recaindo a hipótese de representação sobre os interesses gerais de todos os membros do grupo. "Se o representante é chamado a representar os interesses gerais do representado não é necessário que pertença à sua categoria profissional”. Quando "o representante é chamado a representar os interesses específicos de uma categoria, normalmente ele pertence à mesma categoria dos representados" ${ }^{910}$. Entretanto, o que caracteriza uma democracia representativa é exatamente a relação fiduciária entre representantes e representados, nos moldes em que foi concebida por John Locke, no

São Paulo (3. : 2005 : São Paulo). No mesmo sentido, cf. ALMEIDA, Fernanda Leão de; MAC DOWELL, Claudia Ferreira; LORZA, Flavio Farinazzo; GODOY, Maria Teresa Penteado de Moraes. A democratização na administração superior. In: CONGRESSO DO MINISTÉRIO PÚBLICO DO ESTADO DE SÃO PAULO, 3., cit., v. 2, p. 787-794. Sobre os princípios de interpretação constitucional informadores dos preceitos de direitos e garantias fundamentais, cf. 3.2.1.

${ }^{906} \mathrm{Cf}$. os arts. 26 a 28 , da Lei Complementar 734/93. O voto é secreto, obrigatório e plurinominal; e o mandato dos eleitos é de dois anos.

${ }^{907} \mathrm{Cf}$. os arts. 23 e 24 da Lei Complementar 734/93. O mandato dos que participam do processo eleitoral é de dois anos; e a votação é secreta, mediante voto plurinominal. O Procurador-Geral e o Corregedor também integram o Órgão Especial do Colégio de Procuradores.

${ }^{908}$ BOBBIO, Norberto. Democracia representativa e democracia direta, cit., p. 58.

${ }^{909}$ Id., loc. cit.

${ }^{910}$ Id. Ibid., p. 58-59. No curso dos períodos do governo de Getúlio Vargas, sob a bandeira da causa trabalhista, recorde-se a introdução do sistema de representação classista no parlamento nacional, favorecendo sobremaneira o domínio do poder político por aquele chefe de Estado. Cf. 3.4. 
século XVII, para a organização das sociedades estatais. Montesquieu não deixou de endossar a proposta de representação popular para a formação do órgão do legislativo em um Estado livre, sem mandato imperativo, eleito pelo sufrágio universal ${ }^{911}$.

No âmbito de suas competências, os integrantes dos órgãos da administração superior do Ministério Público respondem por interesses gerais da instituição; eles agem como fiduciários de todos os seus membros e não como agentes delegados para decisões apenas sobre os assuntos de interesse dos quadros de instância superior. Por conseguinte, não se justifica, de modo algum, privar uma parcela significativa dos membros da classe do direito de participação democrática nos processos eleitorais estabelecidos para composição daqueles órgãos. A situação sugere a "predominância de interesses particulares, de grupo, de categoria, no pior sentido da palavra, corporativos" ${ }^{\text {912 }}$. E Aristóteles já definira os traços de uma comunidade política oligárquica, identificando-os justamente com "o método de escolha dos magistrados". Disse ele: "impor aos cidadãos ricos e somente a eles a obrigação de participar da Assembleia para votar nos magistrados e realizar alguma outra obrigação que recaia sobre um cidadão, isso é oligárquico"913.

Nesse sentido, por envolver práticas decisórias versando sobre interesses gerais do Ministério Público, o sistema eleitoral para a escolha dos integrantes dos órgãos da administração superior de todas as carreiras não poderia prescindir do respeito ao princípio do sufrágio universal, com o alargamento do direito de votar e ser votado a todos os membros das carreiras. O princípio do sufrágio universal atua "como proibição de discriminação", vedando a exclusão injustificada de indivíduos da participação eleitoral. Tem o princípio um "sentido dinâmico para obrigar a extensão do direito de voto, tornando inconstitucionais as restrições desnecessárias e desproporcionais"; e impondo ao legislador a obrigação de assegurar, "na medida do possível, a possibilidade real do exercício do voto"914.

\footnotetext{
${ }^{911}$ Cf. $1.2,1.1 .3$ e 1.2 .

${ }^{912}$ BOBBIO, Norberto. Democracia representativa e democracia direta, cit., p. 62.

${ }^{913}$ ARISTÓTELES. Política, cit., livro II, p. 184.

${ }^{914}$ CANOTILHO, J. J. Gomes. op. cit., p. 302. Todos os membros do Ministério Público do Trabalho, do Ministério Público Militar e do Ministério Público do Distrito Federal devem também participar da formação da lista tríplice para a escolha do Procurador-Geral da República, que, no entanto, deve ser formada apenas por agentes em atividade no Ministério Público Federal. É que aquela autoridade, além de chefiar as carreiras do Ministério Público da União, também responde pela chefia do Ministério Público Federal. De resto, segundo o modelo da LOMPU, nada impede a manutenção das chefias próprias daquelas duas carreiras do Ministério Público da União (cf. as normas dos arts. 87, 88, 120 e 121, da Lei Complementar 75/93).
} 
$\mathrm{Na}$ perspectiva da construção de comunidades inclusivas, o princípio da universalidade do sufrágio apenas comporta limitações fundadas em motivos legítimos, isto é, aqueles que, sob o vetor da razoabilidade, guardem uma estrita correspondência com as necessidades exigidas no desenvolvimento das funções da administração superior do Ministério Público. A produção de normas jurídicas pelo Estado sempre "far-se-á diante de certas circunstâncias; será destinada à realização de determinados fins a serem atingidos pelo emprego de determinados meios". A realização do princípio democrático no plano da organização do Ministério Público está intimamente relacionada “com os valores fundamentais da organização estatal, explícitos ou implícitos, como a ordem, a segurança, a paz, a solidariedade; em última análise, a justiça. A razoabilidade é, precisamente, a

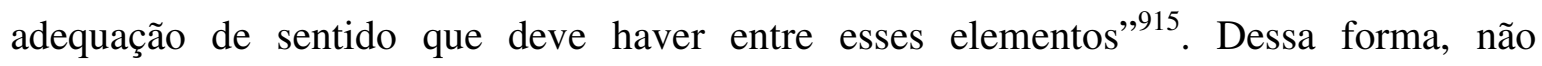
refugindo à razoabilidade as limitações que condicionam a ascensão aos cargos da administração superior da instituição a limites mínimos de idade e de exercício nas carreiras, as demais restrições ao princípio do sufrágio universal refletem uma estrutura oligárquica de representação política sem qualquer ressonância no Estado Democrático de Direito.

Portanto, a despeito da pertinência de uma análise também de outros aspectos do regime de representação democrática do Ministério Público ${ }^{916}$, o enfoque aqui reside apenas na necessidade do aprimoramento desse sistema para garantia do direito de acesso aos órgãos da administração superior com a extensão do direito de votar e ser votado ${ }^{917}$. E isso porque a igualdade é o ethos da democracia dispondo de um papel decisivo num Estado Democrático de Direito. Além da igualdade de todos perante a lei, é preciso acrescer a igualdade política, que, entre outros fatores, compreende o sufrágio universal e o acesso a cargos públicos como elementos voltados a assegurar aquela participação ativa nos assuntos comuns ${ }^{918}$.

\footnotetext{
${ }^{915}$ BARROSO, Luís Roberto. Interpretação e a aplicação da Constituição, cit., p, 226. Cf. também ALMEIDA, Fernanda Leão de; MAC DOWELL, Claudia Ferreira; LORZA, Flavio Farinazzo; GODOY, Maria Teresa Penteado de Moraes. A democratização na administração superior, cit., p. 791.

${ }^{916}$ Por exemplo, as questões do voto secreto ou obrigatório, nominal ou plurinominal.

${ }^{917}$ As atribuições reservadas ao Colégio de Procuradores de Justiça do Ministério Público dos Estados podem ser transferidas do Órgão Especial a um colegiado acessível a todos os integrantes das carreiras em processos eleitorais de que todos participem. Cf. ALMEIDA, Fernanda Leão de; MACHADO, Martha de Toledo. A composição dos órgãos superiores do Ministério Público do Estado de São Paulo - na trilha de uma gestão mais democrática, cit., p. 665-675.

${ }^{918}$ Cf. KAUFMANN, Arthur. op. cit., p. 225-226; e RECASENS SICHES, Luis. Filosofía del derecho. 19. ed. Mexico: Editorial Porrúa, 2008. p. 521.
} 


\subsubsection{A legitimidade dos concursos públicos}

É com o princípio da igualdade que se inaugura a exposição acerca da legitimidade dos concursos de ingresso e de movimentação nas carreiras do Ministério Público. É da essência do Estado Democrático de Direito a garantia de acesso, em igualdade de condições, a "cargos públicos e postos políticos, administrativos, judiciais, etc., de seu país" "19 . O direito dos cidadãos de acesso a cargos e funções públicas não significa concretamente que toda pessoa possa ser designada para qualquer função pública, pois só poderá sê-lo caso satisfaça os requisitos de aptidão para o exercício da atividade estatal. $\mathrm{O}$ que a igualdade obriga é que todos aqueles que reúnam as condições de capacidade reclamadas para o exercício de determinadas funções possam aspirar legitimamente à designação para desempenhá-las; e tal designação sempre deverá recair naqueles que apresentem maior aptidão para o alcance desse fim $^{920}$. Paralelamente aos requisitos de capacidade técnica, há falar também em condições gerais exigíveis para o exercício de toda e qualquer função do Estado, isto é, o pressuposto de idoneidade moral capaz de assegurar o bom trato à coisa pública ${ }^{921}$.

Sob o marco da legalidade, o princípio da igualdade é o fio condutor da garantia de acesso às carreiras do Ministério Público. No entanto, não é demais lembrar que a estrutura organizacional do Estado Democrático de Direito sustenta-se sobre uma ordem de valores materiais formalmente declarados na Constituição, na qualidade de decisões supremas de toda vida coletiva ${ }^{922}$. Por essa razão, no comando do ethos da igualdade formal e material, os concursos de ingresso e movimentação nas carreiras do Ministério Público, na qualidade de típica atuação administrativa do Estado, amparam-se também nas garantias institucionais da publicidade, moralidade, eficiência, motivação, sempre tendo em vista a finalidade de interesse público que se impende alcançar com qualquer prestação de serviços em proveito da coletividade ${ }^{923}$.

\footnotetext{
${ }^{919}$ RECASENS SICHES, Luis. op. cit., p. 595.

${ }^{920}$ Id., loc. cit.

${ }^{921}$ É o que justifica a vedação ao acesso a cargo ou funções públicas para os indivíduos que tenham sofrido condenação criminal pela prática de determinadas infrações. Cf. RECASENS SICHES, Luis. op. cit., p. 595.

${ }^{922}$ Cf. GARCÍA DE ENTERRÍA, Eduardo. La Constitucíon como norma y el Tribunal Constitucional, cit., p. 103-104.

${ }^{923}$ Cf. o art. 37, caput, da CF. O art. 111 da Constituição do Estado de São Paulo impõe à administração pública direta, indireta ou fundacional, de qualquer dos poderes do Estado, a obediência "aos princípios de legalidade, impessoalidade, moralidade, publicidade, razoabilidade, finalidade, motivação e interesse público". A impessoalidade é o conteúdo do vetor da igualdade, constituindo uma diretriz determinante no desenvolvimento de qualquer função estatal. A esse respeito, cf. também 3.3.1, 4.1, 4.1.3.1 e 4.1.3.3.
} 
Dessa maneira, não só as limitações formais, como as que dispõem sobre a competência para a prática do ato, se enquadram no princípio da legalidade. A matriz não mais se circunscreve à feição "própria do positivismo que interessava ao Estado liberal do século XIX”. Em sentido amplo, o princípio da legalidade adquiriu um conteúdo axiológico exigindo a "conformidade da Administração Pública com o Direito, o que inclui, não apenas a lei em sentido formal, mas todos os princípios que são inerentes ao ordenamento jurídico do Estado de Direito Social e Democrático" ${ }^{924}$. A moralidade deve nortear todas as funções do aparato burocrático estatal; e é justamente no campo da chamada discricionariedade que se identifica o seu enorme relevo. A liberdade de opção entre as possíveis alternativas para a atuação do poder público está condicionada à observância dos valores subjacentes à determinada coletividade. As ideias predominantes no meio social sobre a qualidade do comportamento dos agentes públicos ou políticos devem preponderar para a constatação da validade de seus atos, a despeito de estarem expressamente protegidos pelo ordenamento jurídico ${ }^{925}$.

É que as atividades dos agentes estatais devem sempre atender as finalidades extraídas daquela ordem de valores materiais. Quando, para a prática de determinada conduta, a lei confere aos seus responsáveis uma possibilidade de opção, sua atuação estará necessariamente condicionada à obediência dos princípios fundamentais que devem informá-la. $\mathrm{O}$ atendimento à finalidade constante de um preceito legal não deixa de ser também uma imposição para instituições do direito privado. Mas, para os órgãos e agentes estatais, é preciso acrescer uma finalidade legal específica; qual seja: o objetivo universal de promoção do bem comum ${ }^{926}$.

Foi dito que o respeito à igualdade para o provimento de cargos públicos deve ser assegurado pela garantia de acesso a todos que apresentem as condições necessárias ao cumprimento dos deveres inerentes às respectivas funções. Mas a igualdade na proteção da dignidade humana implica também estabelecer as desigualdades jurídicas fundadas nas desigualdades fáticas que se mostrem relevantes para a justiça social. São desigualdades fáticas que devem se reproduzir em determinadas situações jurídicas ${ }^{927}$. E, para a avaliação de que desigualdades devam ser consideradas juridicamente, é necessário dispor do

\footnotetext{
${ }^{924}$ DI PIETRO, Maria Sylvia. Discricionariedade administrativa na Constituição de 1988, cit., p. 137.

${ }^{925}$ Id. Ibid., p. 161 e ss.

${ }^{926}$ Cf. GIANNINI, Massimo Severo. L'interpretazione dell'atto amministrativo e la teoria giurica generale dell'interpretazionezi. In: Scritti. Milano: Giuffrè, 2000. v. 1, p. 237.

${ }^{927}$ RECASENS SICHES, Luis. op. cit., p. 590.
} 
imperativo axiológico de defesa da dignidade da pessoa humana, que, enquanto unidade ética, não pode excluir a diversidade entre os indivíduos, impondo a atenção às diferenças que possuam um valor social ${ }^{928}$.

De indiscutível aplicação aos procedimentos de ingresso em cargos, empregos ou funções públicas, o princípio da igualdade ou impessoalidade veda a interferência de interesses sectários, de "simpatias ou animosidades pessoais", políticas ou ideológicas, na atuação administrativa, coibindo discriminações injustificáveis em afronta ao direito fundamental à igualdade ${ }^{929}$. No entanto, a consolidação do processo de igualdade material sobreleva a importância da adoção de providências capazes de alçar concretamente ao seio da coletividade grupos de indivíduos socialmente vulneráveis ${ }^{930}$. Providências dirigidas a beneficiar o acesso de determinados segmentos sociais a cargos, empregos ou funções públicas devem ser testadas em termos de razoabilidade, devendo ser empreendidas na justa medida das necessidades de proteção in concreto de uma situação de desigualdade material, sem o sacrifício excessivo da eficiência no desenvolvimento do serviço público.

Daí por que, no âmbito do devido processo legal ${ }^{931}$, a fixação dos critérios para o ingresso em cargos ou funções estatais não pode prescindir do postulado da motivação, pois, sobretudo quando os agentes públicos ou políticos dispõem "de certa liberdade (discricionariedade administrativa)" para praticar um ato, não há como saber "se o comportamento que tomou atendeu ou não ao princípio da legalidade, se foi deferente com a finalidade normativa, se obedeceu à razoabilidade e à proporcionalidade, a menos que

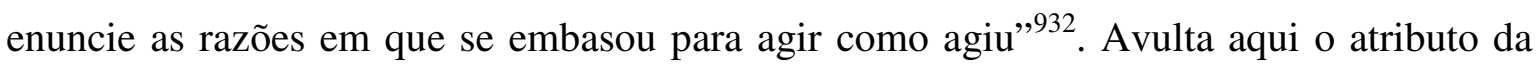
publicidade elevando a transparência na atuação estatal a um componente indispensável na estrutura organizacional do Estado Democrático de Direito ${ }^{933}$.

Ora expostos em apertada síntese, esses princípios constituem requisitos intransponíveis na condução dos concursos instaurados pelo Ministério Público, máxime para a afirmação de sua natureza de uma instituição estatal projetada sob os alicerces republicanos da organização política do Brasil.

\footnotetext{
${ }^{928}$ RECASENS SICHES, Luis. op. cit., p. 590.

${ }^{929}$ Cf. MELLO, Celso Antonio Bandeira de. Curso de direito administrativo, cit., p. 104.

${ }^{930}$ Sobre o fundamento das chamadas ações afirmativas, cf. 4.1.3.3.

${ }^{931}$ Cf. o at. $5^{\circ}$, LIII, XXXV, LIV e LV, da CF.

${ }^{932}$ MELLO, Celso Antonio Bandeira de. Curso de direito administrativo, cit., p. 70 . Sobre o princípio da motivação, cf. ainda 4.1.1.1.

${ }^{933}$ Como garantias fundamentais que se desdobram do princípio da publicidade, cf. o conteúdo do art. $5^{\circ}$, XXXIII, XXXIV, $a$ e $b$; e o LXXII, $a$ e $b$, da CF.
} 


\subsubsection{Os concursos de ingresso}

Assim é que, em benefício de brasileiros natos ou naturalizados, o ingresso nas carreiras do Ministério Público ocorre por meio de concurso público de provas e títulos, com a participação da Ordem dos Advogados em sua realização, a exigência do bacharelado em Direito, a comprovação de, no mínimo, três anos de atividade jurídica, e o respeito, para o fim de nomeações, à ordem de classificação dos candidatos aprovados. Para a comprovação de atividades jurídicas, foram admitidos somente os trabalhos desenvolvidos após a obtenção do grau de bacharel em Direito, incluindo o exercício de cargo, emprego ou função, como o magistério superior, no qual prepondere a interpretação e aplicação de normas jurídicas ${ }^{934}$.

Desde que se apresente pautado por elementos objetivos, o exame psicotécnico é aceitável para as nomeações aos cargos, assim como também vem sendo admitida a possibilidade de uma investigação sigilosa da vida pregressa dos candidatos $^{935}$. À evidência, em razoável detrimento do comando da publicidade na atuação administrativa, o caráter sigiloso daquela investigação tem por finalidade assegurar a eficácia do direito fundamental à intimidade, não podendo, em contrapartida, "ser usado como óbice a que o

${ }^{934} \mathrm{Cf}$. o art. $129, \S 3^{\mathrm{o}}$, da $\mathrm{CF}$. Cf. ainda, disciplinando os concursos de ingresso nas carreiras do Ministério Público, os arts. 186 a 194, da Lei Complementar 75/93; as normas do art. 59 da Lei 8.625/93, e os arts. 122 a 125, da Lei Complementar Estadual 734/93. Quanto à fixação de limites mínimo e máximo de idade para o concurso de ingresso, a jurisprudência só tem admitido requisitos que tais em função da natureza das atribuições do cargo a ser provido (Súmula 638 do STF) (cf. MAZZILLI, Hugo Nigro. op. cit., p. 340-341 e 343). Em contraste com tal entendimento, a LOEMP estabeleceu, como um dos requisitos para o ingresso na carreira do Ministério Público do Estado de São Paulo, a idade inferior a 40 (quarenta) anos, ou a 45 (quarenta e cinco) anos, se o candidato for funcionário público (art. 122, § $3^{\circ}$, V, da Lei Complementar Estadual 734/93). Em atenção a um critério restritivo razoável, a LOMPU vedou a nomeação dos candidatos aprovados no concurso que tenham completado sessenta e cinco anos (art. 191 da Lei Complementar 75/93). A exigência constitucional de reserva de vagas para portadores de deficiência decorre de expressa exigência constitucional (art. 37, VIII, da CF). E a política de ação afirmativa foi implantada no âmbito dos concursos de ingresso na carreira do Ministério Público do Estado de São Paulo (cf. o art. $4^{\circ}, \S \S 1^{\circ}$ a $11^{\circ}$, do Regulamento constante do Ato Normativo 600/2009-PGJ/CPJ, de 30.7.2009). A Resolução 4/2006-CNMP do Conselho Nacional do Ministério Público, dispondo sobre a necessidade de comprovação da exigência do período de três anos de atividade jurídica no ato da inscrição definitiva do concurso por intermédio de documentos e certidões que demonstrem efetivamente o exercício da atividade jurídica no período.

${ }^{935}$ Sobre o exame psicotécnico, cf. o entendimento de que a avaliação do candidato, "com base em critérios subjetivos, sem um grau mínimo de objetividade, ou em critérios não revelados, é ilegítima por não permitir o acesso ao Poder Judiciário para a verificação de eventual lesão de direito individual pelo uso desses critérios (...)" (STF, 1 ${ }^{\mathrm{a}}$ T., RE 243926-CE, Rel. Min. Moreira Alves, j. 16.5.2000, v.u., DJU 10.8.2000). Segundo a LOMPU, a idoneidade moral é um dos requisitos à inscrição nos concursos de ingresso nas carreiras dos ramos do Ministério Publico da União (art. 187 da Lei Complementar 75/93). A LOEMP estabelece, como um dos requisitos para a inserção na carreira do Ministério Público do Estado de São Paulo possuir "boa conduta social e não registrar antecedentes criminais incompatíveis com o exercício da função" (art. 122, § 3º VII, da Lei Complementar 734/93). Já a LONMP, independentemente de outros previstos nas respectivas leis orgânicas, incluiu apenas como requisitos de ingresso na carreira do Ministério Público: Estadual "I - ser brasileiro, II - ter concluído o curso de bacharelado em Direito, III estar quite com o serviço militar, IV - estar em gozo dos direitos políticos” (art. 59, § $3^{\circ}$, da Lei 8.625/93). 
próprio candidato tenha acesso às informações colhidas, e as possa contestar"936. É Incabível privar o candidato de, diretamente ou por intermédio de seu procurador, ter amplo acesso ao conteúdo e às decisões referentes a todos os exames que realizou e às informações e dados produzidos sobre a sua pessoa no curso do procedimento seletivo. $\mathrm{O}$ devido processo legal assim impõe, de sorte a garantir o duplo grau da instância administrativa, uma vez que o reexame retira o arbítrio de quem decide e obriga a fundamentação, "abrindo ensejo à possibilidade de controle, inclusive judicial, sem o qual não existe o chamado Estado de Direito"937.

Restrições indevidas às vias administrativas ofendem, com toda certeza, as garantias da inafastabilidade do controle jurisdicional e do devido processo legal, na medida em que possibilitam o advento de decisões sem a necessária fundamentação, consagrando a deslealdade administrativa consistente na explicitação de motivos desconhecidos pelo interessado apenas quando do controle judicial incidente sobre o ato. A hipótese pode configurar inadmissível obstáculo à sua impugnação judicial ${ }^{938}$.

Os concursos de ingresso nas carreiras do Ministério Público costumam contar, depois da prova oral, com uma entrevista, em caráter reservado, destinada a um contato entre os componentes da banca examinadora e os candidatos, para a avaliação de sua

\footnotetext{
${ }^{936}$ MAZZILLI, Hugo Nigro. Regime jurídico do Ministério Público, cit., p. 461; e RMS 13.327-MG, 5 T., STJ, j. 13.3.2002, rel. Min. Gilson Dipp, DJU 8.4.2002, p. 237.9 (op. cit., p. 461, nota 604). Cf. a redação da norma de direito fundamental do art. $5^{\circ}, \mathrm{X}$, da CF: "são invioláveis a intimidade, a vida privada, a honra e a imagem das pessoas (...)".

${ }^{937}$ FERRAZ, Sergio; DALLARI, Adilson Abreu. Processo administrativo. São Paulo: Malheiros Ed., 2002. p. 89. Cf. as garantias de inafastabilidade do controle jurisdicional e do devido processo (art. $5^{\circ}, \mathrm{XXXV}$, LIV e LV, da CF). O regulamento do concurso de ingresso no Ministério Público do Estado de São Paulo assegura aos candidatos o direito de "recorrer, motivadamente, para a Comissão de Concurso contra o conteúdo e o resultado de quaisquer das provas, no tocante a erro material, ao teor das questões e das respostas e à classificação final" (art. 10, caput, do Ato Normativo 600/2009-PGJ/CPJ). O prazo para o acesso às vias recursais administrativas é de apenas dois dias, contados da publicação do resultado de cada fase do concurso (art. 10, $\S 3^{\circ}$, do Ato 600/2009-PGJ/CPJ). Além disso, o recurso não pode voltar-se, "exclusivamente, à simples revisão ou majoração da nota atribuída" (art. 10, § 4º do Ato 600/2009PGJ/CPJ). O prazo para a interposição de recurso contra os resultados das provas escritas da segunda e da terceira fase do concurso público também é de dois dias; e a impugnação pode versar apenas sobre a nulidade de questões, não se admitindo a "simples revisão da correção das provas escritas" (art. 24 , § $2^{\circ}$, do Ato 600/2009-PGJ/CPJ). O regulamento paulista não é claro quanto ao acesso dos candidatos às avaliações sobre a documentação exigida para a aceitação da inscrição definitiva, sobre o exame psicotécnico e sobre a investigação a respeito de sua vida pregressa (arts. $25, \S \S 1^{\circ}$ a $4^{\circ}$; e $26, \S$ único, 27, e 29 , I a VI, $\S \S 1^{\circ}$ e $2^{\circ}$, do Ato 600/2009-PGJ/CPJ).

${ }^{938}$ É importante a observação de Carlos Ari Sundfeld quanto à dificuldade causada para a impetração de mandado de segurança para impugnar o ato (art. $5^{\circ}$, LXIX, da CF), diante da impossibilidade de réplica ou de produção de provas em função do estreito rito previsto àquela garantia fundamental. Cf. SUNDFELD, Carlos Ari. Motivação dos atos administrativos como garantia dos administrados. Revista de Direito Público, São Paulo, v. 18, n. 75, p. 118-127, jul./set. 1985. Quanto à imposição de as decisões administrativas serem devidamente motivadas e proferidas em sessão pública, cf. também os arts. 93, X, e $129, \S 4^{\circ}$, da CF.
} 
personalidade, cultura, vida social e moral ${ }^{939}$. A medida é de todo desarrazoada, excedendo, em muito, os limites impostos à satisfação do interesse público correspondente ao ingresso nos órgãos estatais de "pessoas de comprovada idoneidade moral" "940. Aliam-se àquela entrevista a investigação da vida pregressa dos candidatos - extensiva ao seu núcleo familiar —, a imposição de apresentação de currículo do interessado — com referências a respeito de seu cônjuge ou companheiro — e a exigência de relações de fontes de referências que devem provir de membros do Ministério Público, do Poder Judiciário, do magistério jurídico superior e da $\operatorname{advocacia}^{941}$.

A discricionariedade para a constatação da idoneidade moral das pessoas que pretendem ingressar nas carreiras do Ministério não justifica a adoção de critérios personalíssimos capazes de ensejar a manipulação da regra jurídica "de maneira a sacar dela efeitos não pretendidos nem assumidos pela lei aplicável" ${ }^{\text {"942 }}$. Em colidência com as garantias institucionais da ação administrativa, notadamente com a matriz da impessoalidade, o conjunto das referidas providências em concursos de ingresso nas carreiras do Ministério Público remonta à origem do funcionalismo patrimonial brasileiro, que, ao longo de nossa história, sempre apresentou traços alheios a um corpo de servidores “puramente dedicados a interesses objetivos e fundados nesses interesses". Ao contrário, é possível acompanhar "o predomínio constante das vontades particulares que encontram seu ambiente próprio em círculos fechados e pouco acessíveis a uma ordenação impessoal"943.

Além dos princípios da finalidade, da razoabilidade e da impessoalidade dos atos administrativos, a entrevista pessoal, em caráter reservado e sigiloso, ofende também os comandos da publicidade, da inafastabilidade do controle jurisdicional e do devido processo legal, considerando os corolários que os envolvem ${ }^{944}$. Nem se diga que o sigilo volta-se à tutela do direito à privacidade dos interessados. É que a obtenção de dados sigilosos sobre a vida pregressa dos candidatos ocorre na fase de investigação social, antes da arguição oral $^{945}$. Em decisão devidamente motivada e mediante a garantia de pleno

\footnotetext{
${ }^{939} \mathrm{Cf}$. os arts. 35 e 36 do Ato 600/2009-PGJ/CPJ, que regulamentou os concursos de ingresso do Ministério Público de São Paulo.

${ }^{940}$ Cf. o art. 187 da LOMPU (Lei Complementar 75/93); e o art. 122, $\S 33^{\circ}$, VII, da LOEMP (Lei Complementar Estadual 734/93).

${ }^{941}$ Cf. os arts. 26, caput; 29, IV e V; e 35 do Ato 600/2009-PGJ/CPJ.

${ }^{942}$ MELLO, Celso Antonio Bandeira de. Curso de direito administrativo, cit., p. 99.

${ }^{943}$ HOLANDA, Sérgio Buarque de. Raízes do Brasil, cit., p. 146.

${ }^{944}$ Cf., mais uma vez, o art. 37, caput, da CF, o art. 111 da Constituição paulista e os os arts. $5^{\circ}$, XXXV, LIV e LV, da CF.

${ }^{945}$ Cf. o art. $9^{\circ}$ do Ato 600/2009-PGJ/CPJ: “Os candidatos habilitados à quarta fase do concurso, cujas inscrições definitivas tenham sido deferidas, serão submetidos a sindicância da vida pregressa, investigação
} 
acesso aos interessados, o conteúdo de tais dados pode embasar o afastamento de pessoas de comprovada inidoneidade à assunção nas carreiras do Ministério Público. De resto, descabe cogitar da pertinência da abordagem de quaisquer elementos da vida íntima dos candidatos por integrantes da banca examinadora, como condição à sua aprovação nos concursos. A entrevista para a avaliação de algum aspecto da personalidade dos participantes, como o de sua formação cultural, deve estar revestida de total publicidade, inclusive para a constatação da adequação do ato à finalidade última de atendimento do interesse público do procedimento seletivo ${ }^{946}$.

A confirmação nas carreiras do Ministério Público dá lugar à vitaliciedade, depois do decurso do estágio probatório de dois anos, com a aceitação dos ingressantes. Mesmo no período anterior à Constituição de 1988, não se aceitava a exoneração ad nutum, sob o mero argumento da não confirmação no estágio probatório. O devido processo legal deve ser observado na esfera administrativa, para o afastamento dos membros do Ministério Público, mesmo daqueles cujo exercício ainda não esteja sob o amparo da garantia institucional de vitaliciedade ${ }^{947}$.

\subsubsection{Os concursos de movimentação nas carreiras}

No que diz respeito à movimentação nas carreiras da instituição, a Constituição estabelece que as promoções dos representantes do Ministério Público, no que couber, devem obedecer às diretrizes concernentes aos juízes. São elas:

promoção de entrância para entrância, alternadamente, por antiguidade e merecimento, atendidas as seguintes normas: a) é obrigatória a promoção do juiz que figure por três vezes consecutivas ou cinco alternadas em lista de merecimento; b) a promoção por merecimento pressupõe dois anos de exercício na respectiva entrância e integrar o juiz a quinta parte da lista de antiguidade desta, salvo se não houver com tais requisitos quem aceite $o$ lugar vago; c) aferição do merecimento conforme o desempenho e pelos critérios objetivos de produtividade e presteza no exercício da jurisdição e pela frequência e aproveitamento em cursos oficiais ou reconhecidos de aperfeiçoamento; d) na apuração da antiguidade, o tribunal somente

social e exame psicotécnico e, na mesma data da realização do exame oral, a entrevista pessoal com a Comissão de Concurso".

${ }^{946}$ Cf. o art. 127, caput, da CF; e as funções institucionais enunciadas no art. 129, I, II, III, IV, V e VII, da CF.

${ }^{947} \mathrm{Cf} .128, \S 5^{\mathrm{o}}$, I, $a$, da CF. O instituto da confirmação na carreira já estava previsto na Lei Complementar 40/81 - a primeira lei orgânica do Ministério Público. Cf. Hugo Nigro Mazzilli. op. cit., p. 461. Sobre a aquisição da vitaliciedade pelos membros do Ministério Público, cf. os arts. 197, 198 e 208, Lei Complementar 75/93; os arts. 60, $\S 1^{\circ}$ e $2^{\circ}$, da Lei 8.625/93; e as normas dos arts. 128 a 131 , da Lei Complementar 734/93. 
poderá recusar o juiz mais antigo pelo voto fundamentado de dois terços de seus membros, conforme procedimento próprio, e assegurada ampla defesa (...); e) não será promovido o juiz que, injustificadamente, retiver autos em seu poder além do prazo legal $(. . .)^{948}$.

Nos procedimentos de provimento derivado dos cargos do Ministério Público, é o Conselho Superior que deve responder pela indicação do candidato mais antigo, quando de se trate de promoção ou remoção por antiguidade, ou de formar a lista tríplice, quando se trate de promoção ou remoção pelo critério de merecimento. Os concursos de promoção e remoção pelo critério de antiguidade não costumam ensejar maiores dificuldades, resultando a automática elevação do candidato mais antigo em grau inferior das carreiras aos seus patamares mais elevados ${ }^{949}$.

É obrigatória também a promoção ou a remoção do membro do Ministério Público que figure por três vezes consecutivas ou cinco alternadas em listas de merecimento ${ }^{950}$. Além disso, priorizando o tempo de serviço, a Constituição impõe, para a promoção ou remoção por merecimento, o exercício na entrância pelo período mínimo de dois anos e a classificação do candidato na primeira quinta parte da lista de antiguidade dos agentes em exercício na entrância, salvo se não houver com tais requisitos quem aceite o lugar vago.

Quando figurarem na lista de merecimento candidatos que apresentem apenas uma dessas

\footnotetext{
${ }^{948}$ Cf. o art. $129, \S 4^{\circ}, c / c$ o art. 93, II, $a$ a $e$, da CF. Sobre as regras de promoção e remoção dos membros do Ministério Público no plano da legislação infraconstitucional, cf. os arts. 199 a 201, da Lei Complementar 75/93; os arts. 61 a 63, Lei 8.625/93 e os arts. 143 a 152, da Lei Complementar Estadual 734/93. A última regra relativa ao atraso na prestação dos serviços é comum tanto para a promoção por antiguidade como pelo critério de merecimento.

${ }^{949}$ Sobre a estrutura organizacional das carreiras do Ministério Público, cf. 4.2, 4.2.1 e 4.2.2. Segundo a LONMP, a lei orgânica regulamentará o regime de remoção ou promoção dos membros do Ministério Público dos Estados, observados os seguintes princípios: "I - promoção voluntária por antiguidade e merecimento, alternadamente, de uma para outra entrância ou categoria e da entrância ou categoria mais elevada para o cargo de Procurador de Justiça (...); II - apurar-se-á a antiguidade na entrância (...)" (art. 61, I e II, da Lei 8.625/93). No âmbito do Ministério Público da União, a LOMPU estabelece que "as promoções far-se-ão, alternadamente, por antiguidade e merecimento" (art. 199 da Lei Complementar 75/93). As vagas a serem providas pelo critério de antiguidade devem obedecer à classificação da lista de antiguidade organizada no primeiro trimestre de cada ano, aprovada pelo Conselho Superior (art. 202, $\S \S 1^{\circ}$ a $4^{\circ}$, da Lei Complementar 75/93).

${ }^{950} \mathrm{Cf}$. o art. 93 , II, $a, c / c$ o art. $129 \S 4^{\circ}$, da CF. As legislações de organização do Ministério Público reproduzem a hipótese constitucional; cf. o art. 200, § $3^{\circ}$, da LOMPU (Lei Complementar 75/95), o art. 61, III, da LONMP (Lei 8.625/93), e os arts. 148, $\S$ único, e 149, $\S 1^{\circ}$ e $2^{\circ}$, da LOEMP (Lei Complementar Estadual 734/93). A promoção obrigatória do candidato que figurar por três vezes consecutivas ou cinco alternadas em lista de merecimento não está condicionada à inscrição do candidato para todos os cargos colocados em concurso. Mas existe, para o Ministério Público de São Paulo, a previsão de interrupção da consecutividade, caso o candidato tenha dado causa a sua não indicação (art. $149, \S 1^{\circ}$, da Lei Complementar Estadual 734/93); e o Conselho Superior paulista, quanto a esse preceptivo legal, adotou o entendimento (Assentos 10/96 e 2/94-CSMP-SP) de que o fato de o interessado não se inscrever para todos os cargos colocados em concurso pelo critério de merecimento é capaz de configurar hipótese de interrupção da consecutividade. Cf. MAZZILLI, Hugo Nigro. op. cit., p. 464.
} 
condições de ordem temporal, a precedência deverá ser reconhecida para aquele que estiver melhor situado na ordem de antiguidade, respeitada a mencionada prioridade constitucional $^{951}$.

Os critérios atinentes ao estágio de dois anos na entrância e à posição do candidato na primeira quinta parte da lista de antiguidade não deixam nenhuma margem de opção ao Conselho Superior, para fins de indicação dos nomes que deverão integrar a lista tríplice dos cargos a serem preenchidos pelo critério de merecimento. Contudo, poderá ocorrer a igualdade de condições dos participantes do concurso quanto ao preenchimento dos requisitos temporais, ocasião em que se entende aceitável a indicação de qualquer deles para compor as listas tríplices de merecimento do Conselho Superior. É o caso em que se depara com a necessidade de aferição do merecimento conforme o desempenho do candidato e pelos critérios objetivos de produtividade e presteza no exercício de suas funções, além da frequência e do aproveitamento em cursos oficiais ou reconhecidos de aperfeiçoamento $^{952}$. Como se vê, utilizando os chamados conceitos indeterminados, a Constituição estipulou alguns contornos para as indicações dos candidatos às listas dos cargos abertos para provimento pelo critério de merecimento nos concursos de progressão e remoção nas carreiras do Ministério Público. Conceitos relativamente análogos chegaram a ser reproduzidos nas leis de organização dos órgãos da instituição estatal ${ }^{953}$.

${ }^{951}$ Cf. o art. 93, II, $b, c / c$ o art. $129 \S 4^{\circ}$, da CF. Note-se que a legislação infraconstitucional exige que o candidato tenha dois anos de estágio na respectiva categoria ou cargo (art. 61, IV, da Lei 8.626/93).

${ }^{952}$ Cf. o art. 93, II, $c$, c/c o art. $129, \S 4^{\circ}$, da CF. O fato de a Constituição ter atribuído, expressamente, o caráter de objetividade apenas aos requisitos de presteza e produtividade não conduz à admissão de nenhuma espécie de subjetivismo na avaliação do desempenho dos candidatos inscritos nos procedimentos seletivos. É claro, por outro lado, que critérios de presteza e produtividade não podem se restringir a dados numéricos referentes aos trabalhos dos candidatos. Hugo Nigro Mazzilli atentou ainda à incompatibilidade da participação do Procurador-Geral na formação "da lista que ele próprio vai receber e entre cujos componentes ele mesmo vai escolher para efetuar o provimento derivado do cargo" Cf. MAZZILLI, Hugo Nigro. op. cit., p. 462, 468-469.

${ }^{953}$ A LONMP (Lei Federal 8.625/93) atribuiu à lei orgânica de cada órgão das unidades estatais a competência para regulamentar o regime de promoção e remoção de seus membros, observados os seguintes preceitos: "I - promoção voluntária, por antiguidade e merecimento, alternadamente, de uma para outra entrância ou categoria e da entrância ou categoria mais elevada para o cargo de Procurador de Justiça (...). II - apurar-se-á (...) o merecimento pela atuação do membro do Ministério Público em toda a carreira, com prevalência de critérios de ordem objetiva, levando-se inclusive em conta sua conduta, operosidade e dedicação no exercício do cargo, presteza e segurança nas suas manifestações processuais, o número de vezes que já tenha participado de listas, bem como a frequência e o aproveitamento em cursos oficiais, ou reconhecidos, de aperfeiçoamento" (art. 61, I e II, da Lei 6.825/93). Segundo as normas da LOEMP (Lei Complementar Estadual 734/93), nos concursos de movimentação na carreira do Ministério Público do Estado de São Paulo, "a lista de merecimento será formada com os nomes dos três candidatos mais votados, desde que obtida a maioria dos votos, procedendo-se, para alcançá-la, a tantas votações quantas necessárias, examinados em primeiro lugar os nomes dos remanescentes de lista anterior" (art. 147, § $1^{\circ}$ ). "Somente poderão ser indicados os candidatos que: a) não tenham sofrido pena disciplinar ou remoção compulsória no período de 1 (um) ano, anterior à elaboração da lista; b) não tenham sido removidos por permuta no 
Diante da imprecisão legislativa, a tendência atual é, portanto, ir ao encontro de diretrizes capazes de afastar completamente a existência de móveis subjetivos norteando o desenvolvimento das funções administrativas do Conselho Superior nas promoções ou remoções por merecimento. $\mathrm{Na}$ ausência de outros critérios objetivos condizentes com os conceitos legais revestidos de certa indeterminação, é a ordem de antiguidade dos candidatos o recurso que se destaca, mesmo para os cargos a serem preenchidos pelo critério de merecimento. A hipótese, porém, não corresponde a nenhum estímulo ao desenvolvimento das funções institucionais, alimentando um ambiente de apatia e isolamento, na medida em que a ascensão aos graus mais elevados das carreiras passa a depender somente do decurso do tempo ${ }^{954}$.

Assim, sem deixar de admitir a existência de uma esfera de discricionariedade para a condução dos procedimentos seletivos pelo Conselho Superior, é imperiosa a atenção às garantias institucionais que devem orientar o comportamento dos órgãos estatais na eclosão de atos administrativos. O provimento derivado de cargos públicos representa típica atividade administrativa e, via de consequência, quando estiver no exercício dessa função, o Ministério Público investe-se no dever de agir em impostergável respeito aos lindes constitucionais que a envolvem ${ }^{955}$.

Consoante já foi ressaltado, a par dos requisitos temporais de aferição inconteste ${ }^{956}$, os chamados conceitos indeterminados constaram de previsões normativas para orientarem

período de 6 (seis) meses anteriores à elaboração da lista; c) tenham completado 2 (dois) anos de exercício no cargo anterior e estejam classificados no primeiro quinto da lista de antiguidade, salvo se não houver com tais requisitos outro candidato ou quando o número limitado de inscritos inviabilizar a formação da lista tríplice e o interesse do serviço exigir o imediato provimento do cargo" (art. 147, § 2ª, a, b e c). Já a LOMPU (Lei Complementar 75/93) prescreveu que "o merecimento, para efeito de promoção, será apurado mediante critérios de ordem objetiva, fixados em regulamento elaborado pelo Conselho Superior do respectivo ramo (...)" (art. 200, caput); a lei reportou-se, de resto, aos requisitos de ordem temporal (exercício de, pelo menos, dois anos na categoria e integrar a primeira quinta parte da lista de antiguidade), salvo se não houver com tais requisitos quem aceite o lugar vago; em caso de recusa, a lei prestigiou o critério de antiguidade, ao estabelecer que a fração deva ser completada mediante a inclusão de outros integrantes da categoria, "na sequência da ordem de antiguidade" (art. 200, § 1', da Lei Complementar 75/93).

${ }^{954}$ MAZZILLI, Hugo Nigro. op. cit., p. 471. Chegou-se a sugerir a substituição de critérios discricionários por pontuações destinadas à classificação dos candidatos, revelando o descontentamento com a falta de transparência do sistema, sobretudo no Ministério Público de São Paulo, cujo quadro quantitativo é, sem dúvida, extremamente denso. C. FABBRINI, Renato Nascimento et al. (Coord.). Proposta de revalorização do critério de merecimento nos concursos de promoção e remoção no Ministério Público. São Paulo: Associação Paulista do Ministério Público, 2000.

${ }^{955}$ Cf. ALMEIDA, Fernanda Leão de; YARD, Anna Trotta. A legitimidade do concurso instaurado pelo critério de merecimento: alguns paradigmas constitucionais. In: CONGRESSO NACIONAL DO MINISTÉRIO PÚBLICO. MINISTÉRIO PÚBLICO E JUSTIÇA SOCIAL, 16., cit., p. 706.

${ }^{956}$ A referência é aos pressupostos de dois anos de exercício na respectiva entrância e de integrar o membro do Ministério Público a quinta parte da lista de antiguidade (art. 93, II, $b$, c/c 129, § 4º da CF). 
o exame do mérito dos candidatos nos procedimentos seletivos internos instaurados pelo critério de merecimento. Dispõem de considerável fluidez as noções de presteza, produtividade ou segurança ligadas ao desempenho dos profissionais no exercício de suas funções. E, mesmo depois da operação hermenêutica de localização de uma zona de certeza positiva, não é possível considerar que expressões legais que designam conceitos indeterminados, "ao serem confrontadas com o caso concreto, ganham, em todo e qualquer caso, densidade suficiente para autorizar a conclusão de que se dissipam por inteiro as dúvidas sobre a aplicabilidade ou não do conceito por elas recoberto" ${ }^{957}$. Há situações em que uma só intelecção da hipótese normativa seria admissível; em outras, porém, mais de um entendimento não poderia ser "objetivamente reputável como incorreto" $" 958$.

É forçoso, portanto, inserir a questão dos conceitos indeterminados no âmbito da discricionariedade administrativa. Se, diante de determinada situação concreta, o agente público, quando da aplicação do conceito legal, mesmo depois de precisá-lo, puder adotar mais de uma solução que dele não destoe, não há como afastar a ideia de discricionariedade. Porém, ainda que nem todos os elementos da atividade da autoridade pública sejam passíveis de pronta identificação em sua lei de regência, não é a livre manifestação de vontade daquela que lhes poderá conferir substância ou direção. O seu ato estará ordenado pela satisfação do interesse público que se depreende, ainda que implicitamente, da própria legislação ${ }^{959}$.

Nessa hipótese, avulta o dever regulamentar que, no interior das possibilidades comportadas pelo enunciado legal, serve para limitar a discricionariedade administrativa, dispondo sobre o modus procedendi nas relações com administrados por ocasião da execução da lei; serve também para caracterizar comportamentos ou situações enunciadas na lei mediante conceitos vagos cuja determinação mais precisa deva ser embasada em elementos configurados a partir de critérios técnicos, para a garantia do princípio da igualdade e da segurança jurídica; e serve, por fim, para "decompor o conteúdo de conceitos sintéticos, mediante simples discriminação integral do neles se contém"960.

\footnotetext{
${ }^{957}$ MELLO, Celso Antonio Bandeira de. Discricionariedade e controle jurisdicional, cit., p. 22.

${ }^{958}$ Id., loc. cit. No mesmo sentido, cf. também SÁNCHEZ MORÓN, Miguel. Discrecionalidad admnistrativa y control judicial. Madrid: Editorial Tecnos, 1994. p. 116-120.

${ }^{959}$ Cf. GIANNINI, Massimo Severo. Il podere discrezionale della pubblica amministrazione concetti e problemi. In: Scritti. Milano: Giuffrè, 2000. v. 1, p. 276-277.

${ }^{960}$ MELLO, Celso Antonio Bandeira de. Curso de direito administrativo, cit., p. 337-338. Agustín Gordillo chamou a atenção também à necessidade de não haver qualquer alteração no espírito da lei. Assim, mesmo que o regulamento não pareça em contradição com o texto da lei, será ilegítimo se contrariar o seu espírito, ou seja, a finalidade que emana do contexto jurídico. Cf. GORDILLO, Agustín. Tratado de derecho
} 
O princípio da legalidade torna o exercício da função regulamentar do Estado meramente executiva, eis encontrar-se integralmente subordinada e dependente da lei; não há falar na fixação de direitos, deveres, restrições ou obrigações que não se encontrem preestabelecidos em lei. Entretanto, o trabalho de realização do direito pelos órgãos estatais obriga, por vezes, a regulamentação de seu funcionamento, de modo a concretizar os elementos estabelecidos na ordem jurídica ${ }^{961}$. O regulamento é justamente o instrumento destinado a restringir a liberdade relativa resultante da generalidade e abstração de termos legais para explicitar a ação administrativa, de maneira a colocar em execução os princípios fundamentais que devem sempre guiá-la. A existência dos regulamentos acontece para que se disponha sobre o modo de agir dos órgãos públicos, "tanto no que concerne aos aspectos procedimentais de seu comportamento, quanto no que respeita aos critérios que devem obedecer em questões de fundo, como condição para cumprir os objetivos da lei" ${ }^{962}$.

Daí a necessidade de que as diretrizes adotadas pelo Conselho Superior disponham de regulamento próprio, específico para cada procedimento ${ }^{963}$. Em sede de concursos públicos voltados ao provimento de cargos do Ministério Público pelo critério de merecimento, a fixação do conteúdo dos respectivos regulamentos dependerá das atribuições inerentes às vagas, que configuram o interesse público in concreto cuja satisfação se requer, sempre em consideração ao princípio fundamental da igualdade. Assim agindo, o Conselho Superior fica vinculado aos padrões de conduta que ele próprio estabeleceu para a condução do procedimento seletivo. A definição do regulamento do concurso deve estar de acordo com as peculiaridades dos cargos a serem preenchidos, mesmo se suas atribuições englobarem várias áreas jurídicas ou ainda não estiverem devidamente fixadas. Desse modo, inclusive fatores que já estejam regulamentados genericamente podem ser perfeitamente utilizados para o regramento da conduta do Conselho Superior no cumprimento das disposições legais em cada concurso público,

administrativo: parte general. 7. ed. Belo Horizonte: Del Rey; San Paoblo: Fundacíon de Derecho Administrativo, t. 1, VII-38.

${ }^{961}$ FAGUNDES, M. Seabra. op. cit., p. 49. Cf. ainda os arts. $5^{\circ}$, II, 37, caput, e 84, IV, da CF.

${ }^{962}$ MELLO, Celso Antonio Bandeira de. Curso de direito administrativo, cit., p. 323.

${ }^{963}$ No que couber, atente-se à possibilidade de utilização, por aplicação analógica, de previsões do regime jurídico de licitações e contratos administrativos (Lei 8.666/93). Como modalidade de licitação, o concurso deve ser precedido de regulamento próprio a ser reproduzido no correspondente ato de convocação dos interessados, com a indicação de suas diretrizes (cf. o art. 52, § $1^{\circ}$, da Lei 8.666/93). Cf. também o art. 37, I e II, da CF que consagrou o princípio da acessibilidade mediante concurso a cargos, funções ou empregos públicos. 
vinculando-se às prescrições previamente eleitas na indicação dos candidatos à composição das listas tríplices para o provimento dos cargos pelo critério de merecimento ${ }^{964}$.

Sob a moldura legal de aferição do mérito dos candidatos, a fim de que se reúnam subsídios para a eclosão de suas indicações em parâmetros objetivos, o edital do concurso deve estabelecer os fatores que prevalecerão para a formação da lista tríplice, com base nas atribuições e características específicas dos cargos públicos. Os candidatos poderão instruir o requerimento de inscrição, segundo os elementos previstos no ato de convocação, sempre à luz da persecução da finalidade de interesse público in concreto, qual seja: um desempenho eficiente das atividades do cargo cujo provimento se almeja alcançar ${ }^{965}$.

Considerando o provimento derivado dos cargos do Ministério Público como um assunto de interesse comum a todos os integrantes das carreiras, a forma de atuação do Conselho Superior pode derivar de deliberação em processo decisório contando com a participação de toda a classe. A hipótese apenas poderia respaldar a sua legitimidade, assegurando a eficácia da medida, e, consequentemente, conferindo maior segurança e agilidade nos procedimentos de movimentação nas carreiras ${ }^{966}$.

\footnotetext{
${ }^{964}$ A resolução 2/2005-CNMP do Conselho Nacional do Ministério Público dispõe genericamente "que: $a$ ) as promoções e remoções por merecimento de membros do Ministério Público da União e dos Estados serão realizadas em sessão pública, em votação nominal, aberta e fundamentada (art. $1^{\circ}$ ); b) o merecimento será aferido conforme o desempenho e por critérios objetivos de produtividade e presteza no exercício das atribuições e pela frequência e aproveitamento em cursos oficiais ou reconhecidos de aperfeiçoamento (art. $2^{\circ}$ ), devendo-se considerar, para tanto, o desempenho, produtividade e presteza nas manifestações processuais; o número de vezes em que já tenha participado de listas; a frequência e o aproveitamento em cursos oficiais ou reconhecidos de aperfeiçoamento, atribuindo-se respectiva gradação, observados, para o efeito de participação nesses cursos, critérios de isonomia e razoabilidade, respeitado sempre o interesse público (art. $3^{\circ}$ ); c) inexistindo especificação de critérios valorativos que permitam diferenciar os membros do Ministério Público inscritos, deverão ser indicados os de maior antiguidade na entrância ou no cargo (art. $4^{\circ}$, parágrafo único)”. Na gestão do Hugo Nigro Mazzilli no Conselho Superior do Ministério Público de São Paulo, foi editado o Ato 5/94-CSMP (Regimento Interno do CSMP-SP, DOE, seç. I, 21.10.94, p. 44-56), com a exposição de 30 (trinta) fatores para orientar a aferição do merecimento dos candidatos; entre os quais estão o exame dos dados constantes do prontuário funcional; o exercício das funções institucionais com esforço e independência; os problemas e dificuldades enfrentados; a conduta do membro do Ministério Público na sua vida pública e particular; a contribuição à organização e melhoria dos serviços judiciários e correlatos da Comarca; o aprimoramento da cultura jurídica, por meio da publicação de livros, teses, estudos, artigos e a obtenção de distinções ou prêmios relacionados com sua atividade funcional; as iniciativas que redundaram em reais benefícios para a comunidade, etc.. Cf. MAZZILLI, Hugo Nigro. op. cit., p. 463.

${ }^{965} \mathrm{~A}$ condução dos concursos internos instaurados pelo critério de merecimento reclama, sem nenhuma dúvida, a pronta implantação de um banco de dados ou de um sistema de informações que se afigure "mecanismo efetivo e confiável de coleta de informações sobre os Promotores que disputam um concurso para promoção/remoção" (DIAS JÚNIOR, Paulo Roberto. op. cit., p. 722).

${ }^{966} \mathrm{O}$ princípio da segurança jurídica corresponde à estabilidade nas relações jurídicas estatais, de natureza administrativa, impedindo a desconstituição injustificada de respectivos atos normativos. Cf. FERRAZ, Sergio; DALLARI, Adilson Abreu. op. cit., p. 73 e ss.
} 
Por outro lado, a ausência de regulamento prévio, específico para o concurso público, não pode amparar o descumprimento de garantias fundamentais em sua realização. As diretrizes jurídicas já existentes devem ser sopesadas pelo Conselho Superior ainda que não haja a regulamentação de cada procedimento seletivo. Nada impede o cotejo do perfil funcional dos candidatos com as peculiaridades e necessidades dos cargos, tendo em conta a aplicação do princípio da razoabilidade, em intrínseca conexão com as demais garantias regentes da atividade administrativa. Principalmente, é de ter em mira o dever de motivar as decisões que dela resultem e de lhes conferir a mais ampla publicidade ${ }^{967}$.

As decisões do Conselho Superior, quando da composição das listas tríplices, devem ser devidamente fundamentadas, com a formal explicitação dos fundamentos fáticos e jurídicos que determinaram o ato de escolha dos participantes do concurso. A essas medidas deve ser conferida a mais ampla divulgação, com a garantia de pleno acesso aos interessados. É que, sem o conhecimento das causas determinantes da decisão administrativa, será impossível aferir a sua efetiva correspondência com os alicerces jurídicos que devem informá-la, a fim de ser resguardada a plena possibilidade de sujeição ao controle judicial ${ }^{968}$.

Por último, encontra ainda previsão legal a hipótese de remoção por permuta, como meio de movimentação nas carreiras do Ministério Público ${ }^{969}$. Mas há razões de interesse público que podem eivá-la de ilegitimidade. Configura claro caso de desvio de finalidade a remoção de membros do Ministério Público por permuta para burlar a ordem de classificação em concursos públicos; elas são feitas entre candidatos que estão, de um lado, bem classificados na lista de antiguidade, e, de outro, mal colocados na mesma lista, sem

\footnotetext{
${ }^{967}$ As sessões de julgamento dos concursos podem ser registradas e transmitidas via internet. Hipóteses de sigilo devem encontrar ressonância no ordenamento constitucional. Cf. $5^{\circ}, \mathrm{X}, \mathrm{da} \mathrm{CF}$. Ínsito ao princípio da publicidade, a Constituição contempla o direito à informação (art. $5^{\circ}$, XXXIII, da CF). Cf. ainda as garantias fundamentais do art. 5\%, XXXIV, e LXXII, da CF. É, portanto, evidente a mácula de inconstitucionalidade do permissivo a que o sigilo, além de decorrente de hipóteses legais, seja resultante de deliberação da maioria dos integrantes do Conselho Superior. Não existe nenhum fundamento a deixar ao livre talante de membros do Ministério Público, cuja finalidade institucional é a proteção da ordem jurídica, o cumprimento de obrigações que lhes foram constitucionalmente prescritas. Cf. o art. $15, \S 1^{\circ}$, da Lei 8.666/93.

${ }^{968}$ Cf. o art. $5^{\circ}$, XXXV, LIV e LV; e o art. $93, \mathrm{X}, c / c$ o art. $129, \S 4^{\mathrm{o}}$, todos da CF. Cf. ALMEIDA, Fernanda Leão de; YARD, Anna Trotta. A legitimidade do concurso instaurado pelo critério de merecimento: alguns paradigmas constitucionais, cit., p. 706-709; e TOURINHO, Rita. O controle jurisdicional da promoção por merecimento do membro do Ministério Público. In: CONGRESSO NACIONAL DO MINISTÉRIO PÚBLICO. MINISTÉRIO PÚBLICO E JUSTIÇA SOCIAL, 16., cit., p. 691- 698.

${ }^{969}$ Cf. o art. 213 da Lei Complementar 75/93; os arts. 64, I, II e III; e 65, da Lei 8.625/93; e o art. 139, $\S 1^{\circ}$ a $3^{\circ}$, da Lei Complementar Estadual 734/93.
} 
nenhuma chance de disputar a indicação num concurso regular com os demais interessados $^{970}$. O comportamento ofende as garantias institucionais da impessoalidade, finalidade e, sobretudo, da moralidade administrativa. Não condiz com a lealdade e boa fé exigidas de representantes do Ministério Público a prática de expediente destinado à manipulação, por via reflexa, da ordem de classificação de candidatos em concursos públicos. É evidente que o fato de não haver nenhuma impugnação incidente sobre a hipótese não possui o condão de ensejar o reconhecimento de sua validade jurídica. Um órgão estatal de destaque no controle da legitimidade da atuação administrativa dos demais não pode jamais incidir em violações análogas as que lhe incumbe coibir ${ }^{971}$.

\subsubsection{O princípio democrático do controle recíproco entre os órgãos estatais e a garantia de independência funcional}

No plano da estrutura básica do Estado Democrático de Direito, concebido para a realização da decisão política fundamental de proteção à dignidade da pessoa humana, é inafastável o funcionamento de um modelo coerente de controle do poder político. Dele dependerá o êxito do funcionamento das instituições estatais encarregadas de concretizar aquela decisão fundamental, assumindo uma dimensão decisiva o reconhecimento do campo de abrangência de todos os elementos que envolvem o correspondente princípio organizacional, de modo a propiciar a efetividade de seus mecanismos. A interação dos diversos aspectos que contribuem para o funcionamento de um sistema de controle político, e de cada uma de suas instituições, é o que realmente possibilita o estabelecimento de limites ao exercício do poder estatal à luz da proteção do conjunto de direitos fundamentais da pessoa humana, impedindo o advento de práticas abusivas ou ineficazes. A total atenção às garantias institucionais incidentes sobre o exercício do poder político pode, inclusive, suplantar a pendência relativa à efetividade dos direitos, econômicos, sociais e culturais, na expectativa de seu fiel atendimento nas organizações contemporâneas do Estado Democrático de Direito. No âmbito de um sistema eficaz de controle, o modo de distribuição e coordenação entre os órgãos que o compõem é o que

\footnotetext{
${ }^{970}$ MAZZILLI, Hugo Nigro. op. cit., p. 464-465.

${ }^{971}$ Cf. 4.1.3.1.
} 
permite identificar a direção política em torno da realização dos objetivos fundamentais do Estado, a reboque dos princípios da supremacia e efetividade da Constituição ${ }^{972}$.

É, portanto, nesse contexto que se insere o princípio estrutural de organização e funcionamento do Estado; qual seja: a matriz do controle recíproco entre os seus órgãos, a qual, por estar diretamente conectada à proteção dos direitos e garantias fundamentais, dispõe de larga abrangência e flexibilidade, iluminando o sentido jurídico-político de toda a ordem constitucional ${ }^{973}$. Vale frisar que o princípio fundamental consagra a necessidade de uma delimitação de competências funcionalmente ordenadas na distribuição das funções estatais, com sua atribuição a diferentes titulares, implicando a separação, funcional, institucional e pessoal, além da existência de relações de interdependência e de um sistema de controle para conter abusos e desvios no desenvolvimento daquelas atividades ${ }^{974}$.

Nesse sentido, para a caracterização de um regime político democrático, a fórmula de descentralização horizontal do poder do Estado projetada por Loewenstein não deixou de contemplar um sistema de controle em funcionamento sob a égide daquele vetor fundamental $^{975}$. A arquitetura do Estado Democrático de Direito deve contar com mecanismos de controle recíproco entre os seus órgãos na esfera das atribuições destinadas à realização dos princípios fundamentais que orientaram a constituição da comunidade política. Considerando o valor da dignidade da pessoa humana como fundamento maior do Estado Democrático de Direito, a necessidade de intervenção de mais de um de órgão estatal para o advento de uma decisão envolvendo a proteção daquele valor fundamental constitui um dos meios de controle do exercício do poder político. Além disso, o sistema de controle também deve compreender a hipótese de um órgão estar autorizado a frustrar a ação de outro, incluindo a apuração de responsabilidades, mediante o estabelecimento do dever de prestação de contas sobre o fiel desenvolvimento das funções que foram

\footnotetext{
${ }^{972}$ VALADÉS, Diogo. Constitución y control político, cit., p. 352 e 360-361. Cf. ZOLO, Danilo. Teoria e crítica do Estado de direito, cit., p. 92-93.

${ }^{973}$ Cf. CANOTILHO, J. J. Gomes. op. cit., p. 1.174.

${ }^{974}$ Id. Ibid., p. 556-558.

${ }^{975}$ Cf. 3.3.1. Recorde-se que, sem abrir mão da premissa de Montesquieu de distribuição do poder político do Estado a diferentes órgãos do Estado, mas procurando apresentar uma proposta alternativa à clássica fórmula tríplice, Loewenstein desdobrou em três vertentes a dinâmica do processo político do Estado Democrático de Direito. A primeira corresponde à determinação das decisões políticas fundamentais, ou seja, dos pressupostos conformadores de uma organização política que, num regime democrático, se caracteriza por sua distribuição entre órgãos diferentes, para uma participação em comunhão. O segundo aspecto refere-se à execução da decisão fundamental; função que, no Estado Democrático de Direito, também deve estar distribuída a órgãos de natureza diversa. Por último, sempre no plano da realização de decisões fundamentais, o autor destacou o funcionamento de um sistema de controle político. Cf. LOEWENSTEIN, Karl. Teoria de la Constitucion, cit., p. 65 e ss. Cf. ainda 1.1.3, sobre a engrenagem arquitetada por Montesquieu.
} 
constitucionalmente distribuídas para a consecução das decisões fundamentais do Estado $^{976}$.

No comando do princípio democrático do controle recíproco entre os órgãos estatais, as instituições da vida pública que integram o sistema de controle do poder político, do ponto de vista estrutural, devem dispor de uma organização adequada para o cumprimento de seus deveres constitucionais, o que obriga, desde logo, que as relações de reciprocidade ocorram entre instituições autônomas e independentes ${ }^{977}$. Desse modo, além da possibilidade do reconhecimento de garantias institucionais complementares para a execução das funções de controle, tem-se ainda a conformação jurídico-constitucional de um regime de vedações ou incompatibilidades "tendente a evitar quaisquer uniões pessoais entre os órgãos de soberania"978; ora apreendidos como instituições responsáveis por funções de controle político no âmbito do Estado Democrático de Direito.

Sob essa ótica, não é difícil identificar o papel do Ministério Público projetado na Constituição Federal, para fins de proteção da dignidade da pessoa humana, de modo a concretizar os objetivos primordiais do Estado. O conjunto das funções cometidas à instituição, à luz da natureza que as reveste, não poderia ensejar conclusão diversa. A função de promover a ação penal pública é privativa do Ministério Público, cabendo-lhe também o controle da legitimidade da gestão do patrimônio público, mediante a aplicação da Lei de Improbidade Administrativa. Existe ainda a função de controle de constitucionalidade das leis e atos normativos e, além disso, a introdução no sistema de justiça da tradicional função de ombudsman, por força da atribuição do Ministério Público de controle das políticas públicas da área social, com a possibilidade de canalização de muitas demandas para a intervenção judicial. Dessa última hipótese podem, inclusive, resultar soluções extrajudiciais de caráter consensual, remetendo à modalidade de controle político em que a ação estatal advém da interferência de mais de um órgão no curso de um processo decisório. São ocasiões em que o Ministério Público coloca-se como um corpo intermediário para a adequação das decisões políticas às reais expectativas da população ${ }^{979}$.

Nas palavras de Fábio Konder Comparato, o equilíbrio constitucional republicano resulta da distinção entre

\footnotetext{
${ }^{976}$ Id. Ibid., p. 70 . Cf. o art. $1^{\text {o }}$, III, da CF, c/c o art. $2^{\text {o }}$ da CF.

${ }^{977}$ Cf. LOEWENSTEIN, Karl. Teoria de la Constitucion, cit., p. 232 e ss.

${ }^{978}$ Cf. CANOTILHO, J. J. Gomes. op. cit., p. 1.174.

${ }^{979} \mathrm{Cf}$. o art. 127 , caput, c/c/ o art. 129 , I, II, III, IV e IX, da CF. Cf. 4.1 a 4.1.3.3. Cf. ainda 3.3, com as considerações de Durkheim sobre o papel dos corpos intermediários para um equilíbrio entre as diversas forças políticas que permeiam a sociedade estatal.
} 
o poder ativo e o poder impediente. (...) O primeiro se distingue pela iniciativa e autoexecutoriedade, enquanto o segundo se resume na prerrogativa do veto ou embargo. (...) A combinação democrática ótima consiste, exatamente, em dosar o poder ativo e o poder impediente entre os órgãos do Estado e mesmo no seio do povo ${ }^{980}$.

Na qualidade de uma instituição permanente e essencial à função jurisdicional do Estado, o Ministério Público detém o chamado poder ativo, para instar, às vezes em caráter de exclusividade, o controle judicial sobre determinados comportamentos sociais, objetivando a tutela de direitos e garantias fundamentais da pessoa humana, incluindo a possibilidade de iniciativas dirigidas à intervenção do Judiciário na conduta de outros órgãos ou agentes do Estado. Assim, diferenciando-o dos congêneres da França, da Itália e Estados Unidos da América, são as funções institucionais do Ministério Público brasileiro, consideradas em seu todo, que obrigam a adoção de uma estrutura organizacional capaz de possibilitar o profícuo funcionamento no âmbito do sistema de controle do poder político do Estado Democrático de Direito da Constituição de $1988^{981}$.

Como se vê, não é possível afastar a garantia de independência funcional conferida à instituição do campo de incidência do princípio democrático do controle recíproco entre órgãos estatais disciplinado na Constituição Federal como um dos principais fundamentos da organização política da República do Brasil. No plano de uma análise sistêmica dos preceitos constitucionais, a garantia de independência do Ministério Público representa clara densificação daquele princípio fundamental de conteúdo mais genérico e incidência de maior amplitude por traduzir uma ideia diretiva básica do estatuto jurídico-político estatal $^{982}$. Dessa forma, com o âmbito de sua atuação concebido para o reconhecimento de uma proteção qualificada à esfera nuclear da instituição, a garantia de independência funcional do Ministério Público preside todo o conjunto de normas afeto à sua organização e funcionamento, sobretudo as que foram diretamente admitidas para intensificá-la ${ }^{983}$. São elas certamente o princípio da autonomia funcional, administrativa e financeira; as garantias da vitaliciedade, da inamovibilidade - conjugada ao princípio do promotor

\footnotetext{
${ }^{980}$ COMPARATO, Fábio Konder. Um quadro institucional para o desenvolvimento democrático, cit., p. 399400. Cf. 1.1.2 e 1.1.3, com a exposição da doutrina de Montesquieu.

${ }^{981}$ Sobre os aspectos centrais dos congêneres do Ministério Público brasileiro, cf. 1.2.1, 1.3.1 e 1.4.

${ }^{982}$ Cf. CANOTILHO, J. J. Gomes. op. cit., p. 1.174-1.1.76.

${ }^{983}$ Sobre a função de caráter material no campo das diretrizes de interpretação constitucional, cf. BARROSO, Luís Roberto. Interpretação e a aplicação da Constituição, cit., p. 376. Cf. 3.2.1 e 4.1, sobre a natureza das funções institucionais. Cf. ainda o art. 127 , caput, $c / c$ os arts. $2^{\circ} ; 127, \S 1^{\circ}$, e $60, \S 4^{\circ}$, III e IV, todos da CF.
} 
natural - , e da irredutibilidade de subsídios e, no mesmo contexto, um regime de incompatibilidades, de previsão expressa ${ }^{984}$.

Todavia, no rumo de sua tradição histórica, o constituinte ateve-se a estabelecer alguns aspectos organizacionais reproduzindo a manutenção dos vínculos do Ministério Público com a chefia dos órgãos do executivo do Estado, o que, com toda certeza, acaba comprometendo a plena afirmação de seu papel no sistema de controle do poder político do Estado Democrático de Direito da Constituição de 1988. Vale observar que o preconizado respeito às garantias institucionais que devem orientar a organização e o funcionamento do Ministério Público não sugere a existência de um órgão isolado, submerso em um universo estanque. A expectativa é justamente de maior liberdade para a sua ação junto às demais esferas da organização política. Cumpre o destaque ao movimento de forças em concerto, que Montesquieu tão bem arquitetou para a preservação da liberdade humana à luz da realidade seu tempo. É o equilíbrio e a harmonia provocados por ações, "tornadas solidárias (...) que se distinguem e se amalgamam, fortalecem-se mutuamente e se aniquilam uma pela outra", mediante um "agenciamento delicado de engrenagens, cuja ação minuciosamente regulada põe em movimento, com um impulso uniforme, toda máquina governamental (...)"985.

\subsubsection{A abrangência do sistema de incompatibilidades e o rompimento dos vínculos com o Executivo do Estado}

A responsabilidade do Ministério Público por atividades de controle do poder político do Estado implica a observância de um sistema de incompatibilidades derivado da aplicação do princípio fundamental do controle recíproco entre os órgãos estatais. No regime de incompatibilidades que a Constituição estabeleceu, de forma taxativa, à instituição, foram introduzidas as vedações de recebimento, a qualquer título e sob qualquer pretexto, de honorários, percentagens ou custas processuais; de auxílios ou contribuições de pessoas físicas e de entidades públicas ou privadas; de participação em sociedade comercial; de exercício da advocacia; de exercício, ainda que em

\footnotetext{
${ }^{984} \mathrm{Cf}$. os arts. $2^{\mathrm{o}}, 127, \S \S 1^{\mathrm{o}}$ a $6^{\mathrm{o}}$; e $128, \S 5^{\mathrm{o}}$, I e II, da CF. Cumpre também registrar a forma de provimento dos cargos e funções do Ministério Público. Cf., então, o art. $129, \S \S 3^{\circ}$ e $4^{\circ}$.

${ }^{985}$ DEDIEU, Joseph. op. cit., p. 336-337.
} 
disponibilidade, de qualquer outra função pública, salvo uma de magistério; e, por fim, a proibição de desenvolvimento de atividade político-partidária ${ }^{986}$.

Em suas relações com o Judiciário, as funções do Ministério Público incorporam-se à categoria de controle político que exige a intervenção de mais de um órgão do Estado para o advento de uma decisão fundamental. Na seara do princípio do controle recíproco entre os órgãos estatais, a superveniência de algumas decisões do Judiciário depende de atos decisórios da instituição para a provocação do exercício da função jurisdicional do Estado. É o que se verifica nas ações diretas de inconstitucionalidade ajuizadas pelo Ministério Público, com base em violações a direitos ou garantias fundamentais, visando a frustrar os efeitos de uma lei. Do mesmo modo, as ações por atos de improbidade administrativa incluem-se nesse campo, ou seja, no de que o desenvolvimento da função judicial de controle de atos dos outros agentes políticos está condicionado a uma prévia decisão do Ministério Público ${ }^{987}$.

A Constituição estabelece, porém, que um quinto dos lugares dos Tribunais Regionais Federais, dos Tribunais dos Estados e do Distrito Federal deve ser composto por membros do Ministério Público, com mais de dez anos de carreira, indicados em lista sêxtupla pelos órgãos de representação das respectivas classes ${ }^{988}$. O chamado quinto constitucional, cujo objetivo seria o de "temperar" os tribunais ${ }^{989}$, traduz em certa medida a intenção já superada de projeção do papel institucional do Ministério Público, por meio da aproximação de suas hipóteses de intervenção com a forma de atuação dos juízes. A ideia era a de se manifestar em quase todos os processos judiciais não na "função de agente, mas na condição de custos legis, ou fiscal da lei, emitindo um parecer que deveria ser marcado pela legalidade e imparcialidade, características distintivas da atividade judicial" ${ }^{, 990}$.

${ }^{986}$ Cf. o art. $128, \S 5^{\circ}$, II, $a$ a $f$, da CF.

${ }^{987}$ Cf. 4.1.1 a 4.1.3.3, com destaque às funções constitucionais do Ministério Público. Regulamentando o art. $37, \S 4^{\circ}$, da CF, a Lei 8.429/92 atribuiu ao Ministério Público e à pessoa jurídica diretamente afetada pelos atos de improbidade administrativa a titularidade da ação civil contra os responsáveis (art. 17).

${ }^{988}$ Cf. o art. 94 da CF. Recorde-se que a LONMP conferiu ao Conselho Superior do Ministério Público dos Estados a atribuição para a elaboração da lista (art. 15, I, da Lei 8.625/93). Na esfera do Ministério Público da União, a atribuição compete ao Colégio de Procuradores da República (art. 53, I e II, da Lei Complementar 75/93) e ao Colégio de Procuradores e de Promotores de Justiça do Ministério Público do Distrito Federal (art. 162, III e V, da Lei Complementar 75/93). Sobre a organização do Ministério Público, cf. 4.2 a 4.2.2.

${ }^{989}$ Cf. MAZZILLI, Hugo Nigro. op. cit., p. 347.

${ }^{990}$ MACEDO JÚNIOR, Ronaldo Porto. Ministério Público brasileiro: um novo ator político: o Ministério Público e as organizações não governamentais sem fins lucrativos: estratégias para o futuro, cit., p. 104. 
Acontece que, hoje, as funções de controle político cometidas ao Ministério Público contrapõem-se frontalmente ao perfil de "órgão imparcial e inerte", convertendo-o em uma "instituição ativa, agente, comprometida direta e exclusivamente com a defesa dos interesses da sociedade" ${ }^{, 991}$. Portanto, na medida em que se intensifica a impropriedade daquele antigo perfil, intensifica-se igualmente a inadequação do chamado quinto constitucional. O objetivo de "temperar" os quadros dos tribunais, ainda que fosse realmente alcançado, não mais se coaduna com as funções institucionais a serem, ativamente, desenvolvidas junto ao Judiciário para a efetividade do conjunto de direitos e garantias fundamentais, sobretudo no âmbito da aplicação do princípio democrático do controle recíproco entre os órgãos estatais.

Também se impõe o reconhecimento da ilegitimidade das previsões relativas aos membros do Ministério Público em exercício nos tribunais de contas ${ }^{992}$. Dotados de autonomia organizacional, os tribunais foram projetados junto aos órgãos do legislativo, para auxiliá-los na tarefa de controle externo das contas da chefia do Executivo, bem como dos demais responsáveis pelo manejo de bens e valores públicos. É, pois, atribuição do Legislativo, com o auxílio dos tribunais de contas, "verificar a legitimidade e a economicidade dos atos contábeis, financeiros, orçamentários, operacionais e patrimoniais da Administração direta e indireta" ${ }^{993}$. A despeito da controvérsia em torno da existência de um Ministério Público autônomo integrando a estrutura própria dos tribunais de $\operatorname{contas}^{994}$, a Constituição estabeleceu a exclusividade do exercício de suas funções para os

${ }^{991}$ FERRAZ, Antonio Augusto Mello de Camargo; DIAS JÚNIOR, Paulo Roberto. Aperfeiçoamento do sistema de investidura do Procurador-Geral de Justiça: pressuposto para a afirmação do Ministério Público como defensor do regime democrático. In: VIGLIAR, José Marcelo Menezes; MACEDO JR., Ronaldo Porto (Coords.). Ministério Público II: democracia, cit., p. 121.

${ }^{992} \mathrm{Cf}$. a redação do art. 130 da CF: "aos membros do Ministério Público junto aos Tribunais de Contas aplicam-se as disposições desta seção pertinentes a direitos, vedações e formas de investidura”.

${ }^{993}$ SILVA, José Afonso da. Comentário contextual à Constituição, cit., p. 464 . Cf. os arts. 70 e ss. da CF. No âmbito federal, essa função fiscalizatória compete ao Congresso Nacional; nas esferas dos Estados e Municípios, respectivamente, às Assembleias Legislativas e às Câmaras dos Vereadores, sempre com o auxílio dos respectivos tribunais de contas. De forma indireta, a Constituição estabeleceu a implantação de tribunais de contas nos Estados e no Distrito Federal. Cf. os arts. 31 e 75 da CF. Em alguns Estados, o controle das contas municipais é feito com o auxílio do próprio tribunal de contas estadual; em outros, foram criados conselhos de contas municipais, como órgãos estaduais para o exame das contas dos respectivos Municípios. Apenas os Municípios de São Paulo e do Rio de Janeiro possuem seus próprios tribunais. De todo modo, aos tribunais de contas estaduais e municipais, bem como aos conselhos de contas municipais, no que couber, estende-se a aplicação das normas de caráter organizacional dos arts. 70 a 74, da CF. Cf. Id. Ibid., p. 471.

${ }^{994}$ Assim foi estatuído na Lei Orgânica do Tribunal de Contas da União, em inadmissível inserção na esfera da competência disciplinada pela Constituição às leis orgânicas do Ministério Público. Cf. o art. 128, § 5º, da CF; e os arts. 80 a 84 da Lei 8.443, de 16.07.1992, dispondo sobre a organização do Tribunal de Contas. Por outro lado, sobre a autonomia organizacional do Tribunal de Contas, cf. o art. 73 da CF. Sobre a questão da existência de um Ministério Público integrando a estrutura organizacional dos tribunais de 
integrantes das carreiras, vedando-lhes, a par disso, o exercício de outra função pública e a prestação de serviços de consultoria, assessoria ou procuradoria jurídica junto a entidade públicas ${ }^{995}$. Na esteira da garantia institucional de independência, tais exigências sinalizam não só a impossibilidade da implantação de um quadro do Ministério Público no âmbito da estrutura organizacional dos tribunais de contas, como também a respectiva composição por membros das carreiras ${ }^{996}$. Não obstante a importância da função dos tribunais no sistema de controle do poder político do Estado, a atuação do Ministério Público de exame da legitimidade da gestão do patrimônio público, por si só, impediria o exercício de atividades junto àqueles tribunais. O Ministério Público conta muitas vezes com os elementos resultantes da atividade fiscalizatória dos tribunais de contas para alicerçar a decisão decorrente dessa atividade institucional. Afigura-se, assim, aquela modalidade de controle em que a decisão de um órgão estatal depende da cooperação de outro, com a aplicação de todas as garantias institucionais para assegurar a idoneidade e a segurança em tal prática ${ }^{997}$.

Por outro lado, é pressuposto lógico do desenvolvimento das funções de controle sobre as atividades do Legislativo que, junto a ele, não haja o exercício de nenhuma atividade por nenhum membro do Ministério Público. Sua participação nos processos eleitorais para mandatos parlamentares é alvo do sistema de incompatibilidades, que, vinculado ao princípio do controle recíproco entre os órgãos estatais, visa a conferir uma proteção orgânica e objetiva às tarefas constitucionalmente atribuídas à instituição. Em face de suas funções eleitorais, já resultaria evidente a incompatibilidade do exercício de atividades político-partidárias por seus agentes, ainda que não houvesse previsão constitucional expressa. A estrutura político-partidária é intrínseca ao regime de representação democrática estabelecido à composição do Legislativo de todas as unidades federativas do Estado e, além disso, as respectivas campanhas eleitorais não prescindem do

contas, cf. MAZZILLI, Hugo Nigro. op. cit., p. 159 e ss; e GOMES, Mauricio Augusto. Ministério Público e Tribunais de Contas na Constituição. Revista dos Tribunais, São Paulo, v. 685, p. 264-267, nov. 1992.

${ }^{995} \mathrm{Cf}$. o art. 128 , II, $d$; e o art. 129 , IX e $\S 2^{\circ}$, da CF.

${ }^{996}$ A Constituição estabeleceu que um terço dos nove Ministros do Tribunal de Contas da União será objeto de escolha do Presidente da República, com "aprovação do Senado Federal, sendo dois alternadamente dentre auditores e membros do Ministério Público junto ao tribunal, indicados em lista tríplice pelo Tribunal, segundo critérios de antiguidade e merecimento" (art. 73, § $2^{\circ}$, I, da CF).

${ }^{997}$ Cf. 4.1.3.1. Acresce ainda destacar a atuação de fiscalização da aplicação dos recursos orçamentários no plano da atuação de controle das políticas públicas. Nesse sentido, cf. COMPARATO, Fábio Konder. O Ministerio Público na defesa dos direitos econômicos, sociais e culturais. In: GRAU, Eros Roberto; CUNHA, Sérgio Sérvulo da (Orgs). Estudos de direito constitucional em homenagem a José Afonso da Silva. São Paulo: Malheiros Ed., 2003. p. 253 e ss. Cf. 4.1.3.2. Anote-se ainda que a indicação dos membros do Ministério Público para formação dos tribunais de contas compete ao chefe do Executivo. Cf. o art. $73, \S 2^{\circ}$, I, da CF. 
recebimento de auxílios ou contribuições de pessoas físicas e entidades privadas, o que também integra o regime de incompatibilidades do Ministério Público ${ }^{998}$.

Entretanto, a manutenção de vínculos com o executivo representa a mais significativa ofensa a esse regime. A concentração abusiva "de poderes, de direito e de fato" na chefia de tal órgão jamais retrocedeu no cenário político brasileiro ${ }^{999}$. E, atualmente, mesmo sob um consolidado regime de representação democrática, o chefe do Executivo continua sendo o grande encarregado tanto da formulação quanto da execução de todos os programas de ação estatal, num quadro permeado por sérios desvios de conduta no trato da coisa pública. Daí por que as funções de controle político exercidas pelo Ministério Público no sentido de obstar os comportamentos lesivos aos direitos e garantias fundamentais costumam incidir, precipuamente, sobre os atos dos órgãos do executivo, considerando a fiscalização das condutas de seus integrantes ${ }^{1000}$.

Ocorre que, fruto de um lobby bastante eficaz durante os trabalhos da Assembleia Nacional Constituinte, visando a "acomodar interesses particulares" 1001 , foi introduzido no Ato das Disposições Constitucionais Transitórias (ADCT) um preceito autorizando os membros do Ministério Público admitidos antes da promulgação da Constituição Federal a optarem "pelo regime anterior, no que diz respeito às garantias e vantagens (...), observando-se quanto às vedações, a situação jurídica da data desta",1002.

A hipótese envolve "a opção pelo exercício de atividades políticas, que a Constituição vedou" ${ }^{\prime 1003}$. E, realmente, as proibições constitucionais incluem o exercício de outra função pública e de atividades político-partidárias, acrescidos da impossibilidade de recebimento de contribuições ou vantagens de qualquer natureza, como também da prestação de consultoria jurídica a entidades públicas ${ }^{1004}$. Porém, com base em entendimento do Supremo Tribunal Federal, privilegiando indevidamente a supremacia da vontade individual no exercício de função pública, membros do Ministério Público que

\footnotetext{
${ }^{998} \mathrm{Cf}$. o art. $128, \S 55^{\circ}$, II, $d$, e $f$, da CF.

${ }^{999}$ COMPARATO, Fábio Konder. A garantia institucional contra o abuso de poder, cit., p. 50. Cf. ainda a exposição do Cap. II.

${ }^{1000}$ É o plano em que se inserem a função de zelar pelo respeito dos poderes públicos e dos serviços de relevância pública aos direitos da cidadania e a proteção do patrimônio público e social, mediante a utilização dos potentes instrumentos do sistema da ação civil pública, sem prejuízo da aplicação da Lei de Improbidade Administrativa no combate à corrupção. Cf. o diagnóstico de Rogério Bastos Arantes, com base em levantamentos sobre a atuação do Ministério Público de São Paulo, Ministério Público e política no Brasil, cit., p. 153 e ss. Cf. ainda o 4.1.3.1 e 4.1.3.2

${ }^{1001}$ MAZZILLI, Hugo Nigro. op. cit., p. 278.

${ }^{1002}$ Cf. o $\S 3^{\circ}$, do art. 29 , da ADCT. Cf. 2.7.

${ }^{1003}$ SILVA, José Afonso da. Comentário contextual à Constituição, cit., p. 912.

${ }^{1004} \mathrm{Cf}$. o art. $128, \S 5^{\circ}$, II, $d, e$, e $f$; e o art. 129, IX, da CF.
} 
ingressaram nas carreiras antes da promulgação do diploma constitucional, delas vêm se afastando para o provimento de cargos administrativos de elevados escalões nos órgãos do executivo das unidades federativas do Estado ${ }^{1005}$.

A situação está criando quadros paralelos nas carreiras do Ministério Público, com “vedações díspares" ${ }^{\text {"1006 }}$, em inadmissível restrição ao alcance do conteúdo material de disposições que amparam a garantia de independência funcional. Reiterada prática apresenta-se flagrantemente incompatível com a natureza das incumbências e finalidades do Ministério Público, apreendido como um órgão uno, indivisível e independente no âmbito do sistema de controle político do Estado Democrático de Direito da Constituição Federal $^{1007}$. É nítida a impossibilidade de se reconhecer a preponderância de norma do ADCT, dirigido à regulamentação de situações excepcionais e provisórias apenas na fase inicial de adaptação da estrutura organizacional do Estado às diretrizes da nova ordenação constitucional. No entanto, ainda que o conteúdo daquele dispositivo do ADCT estivesse introduzido no próprio texto da Constituição, seria viável acolher a não obrigatoriedade de sua aplicação, diante da violação a princípios de incontestável supremacia ${ }^{1008}$.

As autorizações dos afastamentos das carreiras para a composição de cargos de confiança dos órgãos do Executivo do Estado por membros do Ministério Público inibem um aspecto central que deve identificar o exercício do poder estatal por uma instituição; qual seja: a impessoalidade, de modo a desvincular-se, o máximo possível, dos indivíduos de que dela façam parte. É uma das pilastras do Estado Democrático de Direito que o exercício do poder político se verifique de forma impessoal, despersonalizada; é, consequentemente, essencial a sua institucionalização, de maneira a ser identificado com

\footnotetext{
${ }^{1005}$ ADIn n. 2.836-RJ, rel. Min. Eros Roberto Grau, j. STF Pleno de 17.11.05, v.u., DJU 9.12.05. Cf. ainda MAZZILLI, Hugo Nigro. op. cit., p. 270 e ss. Atualmente, as Secretarias Estaduais de Segurança Pública e da Secretaria da Justiça e Defesa da Cidadania são chefiadas por membros do Ministério Público do Estado de São Paulo; Promotor de Justiça da mesma carreira figura como Assessor Especial do Governador; três Procuradores de Justiça são Secretários Adjuntos das Secretarias Municipais de Serviços, de Transportes e de Participação e Parceria; o atual Corregedor-Geral do Município de São Paulo é também Procurador de Justiça de seu Ministério Público; e existem dois Deputados Federais e um Deputado Estadual provenientes da mesma carreira (cf. APMP Notícias e Órgão Informativo da Associação Paulista do Ministério Público, São Paulo, ano 3, n. 16, jun. 2009).

${ }^{1006}$ MAZZILLI, Hugo Nigro. op. cit., p. 278.

${ }^{1007} \mathrm{Cf}$. o art. $2^{\circ} \mathrm{c} / \mathrm{c}$ o art. 127 , caput, e $\S 1^{\mathrm{o}}$, da CF.

${ }^{1008} \mathrm{Cf}$. o art. $2^{\mathrm{o}}$, e os arts. 127 , caput, e $\S 1^{\mathrm{o}}$, c/c o art. $128, \S 5^{\circ}$, II, $a$ a $f$; e 129 , I a IX, da CF. Mais uma vez, a alusão é ao alcance na estrutura e no funcionamento organizacional do Ministério Público do princípio democrático do controle recíproco entre os órgãos estatais de que resultou o regime de incompatibilidades que lhe é intrínseco, notadamente em razão das incumbências atribuídas para a instituição. Sobre a ausência de força vinculante a disposições constitucionais ofensivas a princípios que se inserem na órbita de proteção aos direitos conaturais da pessoa humana (direitos supralegais), cf. BACHOF, Otto. Normas constitucionais inconstitucionais? Trad. José Manuel Cardoso. Coimbra: Almedina, 2008. p. 55 e ss.
} 
uma instituição ou um cargo: várias pessoas ostentam a condição de agente político por terem sido legitimamente investidas em um cargo público para atuarem em nome de uma instituição estatal $^{1009}$.

Para a aferição da esfera de abrangência de um sistema de incompatibilidades inerente ao princípio fundamental do controle recíproco entre os órgãos estatais, o enfoque deve residir no risco de comprometimento na órbita das respectivas intervenções ${ }^{1010}$. Assim, considerando justamente a órbita da atuação do Ministério Público em suas relações de reciprocidade com os órgãos do judiciário, do legislativo e, principalmente, do executivo do Estado no âmbito do sistema de controle político do Estado Democrático de Direito, aliada às taxativas vedações constitucionais, impende realmente afastar os membros da instituição de qualquer um daqueles quadros funcionais.

Cumpre, por último, tratar de dois permissivos contidos na LOMPU sobre os afastamentos das carreiras pelos membros do Ministério Público da União. O primeiro volta-se a assegurar a participação do Ministério Público como instituição observadora "em qualquer órgão da administração pública direta, indireta ou fundacional da União, que tenha atribuições correlatas às funções da instituição". O segundo possibilita a regulamentação da participação do Ministério Público nos órgãos colegiados da União ou do Distrito Federal, constituídos para a defesa de direitos ou interesses relacionados com as funções da instituição ${ }^{1011}$. O primeiro preceito é inócuo, nada justificando a sua aplicação. Não é possível admitir o afastamento de membros do Ministério Público de suas funções para figurarem como meros observadores do funcionamento de outros órgãos. Se existe algum objetivo institucional para tal observação, avulta o desenvolvimento de uma típica atividade-fim, que deverá ser necessariamente reproduzida em atos concretos de execução. Outra é a situação da participação do Ministério Público em colegiados constituídos para o planejamento e implementação das políticas públicas da área social, envolvendo a efetividade dos direitos sociais, econômicos e culturais de proteção à dignidade da pessoa humana. Paralelamente à representação popular, é um dos vetores de convergência democrática a participação "institucionalizada das forças sociais, organizadas em

\footnotetext{
${ }^{1009}$ LOEWENSTEIN, Karl. Teoria de la Constitucion, cit., p. 234. Note-se que o sistema de incompatibilidades previsto ao Ministério Público incorporou a chamada quarentena, com a extensão aos membros do Ministério Público da proibição imposta aos magistrados de exercício da advocacia no juízo ou tribunal do qual se afastou, antes de decorridos três anos do afastamento do cargo por aposentadoria ou exoneração. Cf. o art. 128, § 6 $6^{\circ}$, c/c o art. 95 , $\S$ único, V, da CF.

${ }^{1010}$ Cf. STERN, Klaus. Derecho del Estado e la Republica Federal Alemana, cit., p. 374-375.

${ }^{1011} \mathrm{Cf} . \S \S 1^{\circ}$ e $2^{\circ}$, do art. $6^{\circ}$, da Lei Complementar 75/93. Recorde-se que a LOMPU (Lei Complementar 75/93) tem aplicação subsidiária para o Ministério Público dos Estados (art. 80 da Lei 8.625/93).
} 
associações de interesses" na formação da vontade estatal em questões de política econômica e social ${ }^{1012}$. São grupos de segmentos da sociedade civil organizando as correspondentes demandas perante os órgãos estatais. As entidades colocam-se entre o governo e o povo, estreitando os canais de comunicação entre eles e, por conseguinte, possibilitando uma maior correspondência entre as decisões políticas e as reais expectativas de uma sociedade pluralista ${ }^{1013}$.

O mecanismo de democracia participativa não deixa de encontrar ressonância na função do Ministério Público de zelar pelo respeito dos poderes públicos e dos serviços de relevância pública aos direitos fundamentais, com a instituição funcionando como um corpo intermediário na composição dos interesses em jogo. Porém, é necessário atentar à formação dos conselhos. Não existe nenhuma possibilidade de retroceder a consolidada tendência de privatização da prestação dos serviços sociais, sob o pressuposto da diminuição do papel do Estado. Verifica-se ainda a questão das fontes de custeio de muitas entidades, residindo em contribuições extraídas dos cofres públicos. Não raro, as associações civis que se fazem representar naqueles colegiados são prestadoras de serviços públicos, mantendo vínculos contratuais com o órgão do executivo do Estado. Assim, se, de um lado, a participação do Ministério Público pode fortalecer a órbita de uma de suas intervenções, de outro, pode comprometer a atuação de controle da gestão do patrimônio público e social $^{1014}$.

\subsubsection{A alteração da forma de escolha do Procurador-Geral}

A nomeação do Procurador-Geral de República e do Procurador-Geral de Justiça dos Estados pelos respectivos chefes dos órgãos do Executivo configura uma outra distorção no sistema organizacional do Ministério Público ${ }^{1015}$. É bem verdade que o constituinte de 1988 afastou de tais chefias a possibilidade de livre nomeação da autoridade superior do Ministério Público, que passou a ser, obrigatoriamente, um integrante das carreiras ${ }^{1016}$. Porém, a repercussão das funções institucionais de controle no âmbito das atividades do Executivo já aclarava a necessidade de subtrair à instituição

\footnotetext{
${ }^{1012}$ MACHADO, J. Baptista. Participação e descentralização democratização e neutralidade na Constituição de 76. Coimbra: Almedina, 1982. p. 52.

${ }^{1013} \mathrm{Na}$ esteira da doutrina de Montesquieu, é a observação de Durkheim sobre uma característica de um sistema democrático de governo. Cf. 3.3.

${ }^{1014} \mathrm{Cf}$. o art. 129, II e III, da CF.

${ }^{1015} \mathrm{Cf}$. o art. $128, \S \S 1^{\circ}$ e $3^{\circ}$, da CF.

${ }^{1016}$ MAZZILLI, Hugo Nigro. op. cit., p. 265-267.
} 
qualquer interferência governamental. A prerrogativa de escolha de seus chefes pelas autoridades mais importantes a serem potencialmente objeto da fiscalização do Ministério Público significa o risco de relegar a um plano secundário os interesses sociais que lhe compete proteger para a preponderância de outros, alvejados pelas autoridades superiores do órgão do executivo ${ }^{1017}$. O sistema "traz em si o germe de envolvimentos e compromissos de caráter político-partidário", estabelecendo-se uma situação em que "não é raro que procuradores-gerais, alguns em pleno exercício, acabem gradualmente integrando o governo, até formalizarem sua participação como secretários de Estado"1018.

Em atenção às carreiras estaduais, no curso dos trabalhos da constituinte de 1988, já se defendia a necessidade de escolha do Procurador-Geral apenas por integrantes da própria instituição, na medida em que só assim seria possível atingir a desejada independência funcional, desvinculando a nomeação ou destituição de critérios políticopartidários "que sempre informam as decisões dos governantes e dos parlamentares"1019. Porém, não refoge à realidade o entendimento de que tal proposição poderia engendrar um sistema "excessivamente fechado e apto a facilitar o corporativismo, com todos os seus defeitos"1020. Uma alternativa que chegou a ser aventada foi a eleição por todos os membros das carreiras de um único nome entre os seus integrantes, submetido à ulterior apreciação do Legislativo, que apenas poderia recusá-lo em hipóteses previamente definidas em lei ${ }^{1021}$. A inadequação desse método parece incontestável diante da necessidade do fortalecimento das funções eleitorais desenvolvidas por membros do Ministério Público, que são objeto de designação do Procurador-Geral ${ }^{1022}$. Ademais, sob a eterna influência do Executivo do Estado, o jogo de forças no corpo parlamentar está inteiramente atrelado à estrutura político-partidária do regime de representação democrática, não havendo como afastar o risco de ingerências de tal ordem.

\footnotetext{
${ }^{1017}$ Cf. FERRAZ, Antonio Augusto Mello de Camargo; DIAS JÚNIOR, Paulo Roberto. op. cit., p. 117.

${ }^{1018}$ MAZZILLI, Hugo Nigro. op. cit., p. 266. Muito embora esteja sendo adotada a formação de lista tríplice pelos membros do Ministério Público Federal para a indicação do Procurador-Geral da República, é importante ressaltar a ausência de respaldo constitucional. Conforme observou Maria Tereza Sadek, o "Procurador-Geral da República, cargo máximo do Ministério Público da União, segundo prescreve a Constituição (...), é nomeado pelo Presidente da República, dentre os integrantes da carreira (...). Nas instituições estaduais a influência do poder político é relativamente atenuada. O Procurador-Geral de Justiça - cargo máximo do Ministério Público do estado - é indicado pelo Governador a partir de uma lista tríplice eleita pelos integrantes da instituição" (SADEK, Maria Tereza. Cidadania e Ministério Público, cit., p. 16).

${ }^{1019}$ Id. Ibid., p. 267.

${ }^{1020}$ MAZZILLI, Hugo Nigro. op. cit., p. 267. Sobre a vaga do corporativismo no Brasil durante os governos de Getúlio Vargas, cf. 2.4.

${ }^{1021}$ Cf. FERRAZ, Antonio Augusto Mello de Camargo; DIAS JÚNIOR, Paulo Roberto. op. cit., p. 124.

${ }^{1022}$ Cf. 4.2 .3 e 4.3.2.
} 
O equilíbrio no modelo hermético e corporativista de escolha dos chefes das carreiras apenas por seus membros poderia ser conquistado mediante um alicerce de legitimidade democrática. Juntamente com a alteração dos outros fatores até aqui retratados, as raízes para legitimar a atuação do Ministério Público centrada na defesa do conjunto dos direitos fundamentais da pessoa humana podem ser firmadas na participação popular no desfecho do processo de escolha do Procurador-Geral da República e do Procurador-Geral do Ministério Público dos Estados e do Distrito Federal. Sobretudo levando em conta as premissas de extensão do princípio do sufrágio universal em prol dos integrantes das carreiras, na fase de formação das listas tríplices com os nomes dos candidatos mais votados, bem como o devido respeito ao sistema de incompatibilidades, a subsequente escolha de um dos nomes indicados nas listas tríplices poderia ser transferida da chefia do Executivo para o povo ${ }^{1023}$.

Além disso, a gestão do Procurador-Geral assim legitimado deve limitar-se à alta missão de planejamento e realização das políticas institucionais, não mais se justificando o monopólio de nenhuma das atividades-fins do Ministério Público. A maioria delas, aliás, incide sobre o controle do comportamento de agentes políticos dos outros órgãos estatais. Não há razão para privar os membros da instituição que oficiam junto aos tribunais de realizá-las, inclusive sob a perspectiva da necessária valorização de suas incumbências ${ }^{1024}$.

No âmbito do Estado Democrático de Direito, a responsabilidade política legitimase quando o povo, como um centro de poder independente, pode confirmar ou rechaçar as autoridades superiores de órgãos inseridos no sistema de controle político arquitetado no ordenamento constitucional $^{1025}$. É, mais uma vez, lembrada a noção de liberdade dos antigos:

\footnotetext{
${ }^{1023} \mathrm{O}$ modelo relaciona-se intimamente com a necessidade da ampliação do sufrágio universal no sistema de representação democrática interna corporis. Cf. 5.1.2.

${ }^{1024}$ É preciso afastar a ideia de qualquer hipótese de dispendiosas campanhas eleitorais que costumam orientar o regime de representação democrática; a apresentação dos projetos institucionais pelos três candidatos mais votados pela classe pode perfeitamente contar com o acesso gratuito aos veículos de comunicação. Por sua vez, a transparência na implantação de um completo banco de dados pelo Ministério Público — de fácil acesso por via da rede informacional da internet —, certamente só poderá contribuir para que a população conheça os compromissos dos candidatos atinentes à condução dos assuntos de interesse geral do Ministério Público, que acabam atingindo-a diretamente na condição de destinatária imediata de suas funções institucionais. Sobre a necessidade de transferência aos membros do Ministério Público que oficiam junto aos tribunais das funções do Procurador-Geral como órgão de execução, bem como da implantação de um eficiente banco de dados no Ministério Público, cf. 4.3.2.

${ }^{1025}$ Cf. LOEWENSTEIN, Karl. Teoria de la Constitucion, cit., p. 71 . O projeto de sujeição do candidato mais votado pela classe a referendo popular poderia retardar a investidura ante a eventual rejeição do nome. A assunção automática ao cargo pelo segundo candidato mais votado ressentir-se-ia de qualquer legitimidade, já que não foi escolhido, em caráter preferencial, por pares e, tampouco, aprovado pelo voto popular.
} 


\begin{abstract}
A condição essencial para ter-se uma vida cívica livre e feliz (...) reside na criação de eficazes instituições cívicas; e a condição para que essas se mantenham em boa ordem, por sua vez, está na garantia de conservar-se o poder soberano, em última instância, em mãos do conjunto inteiro dos cidadãos ${ }^{1026}$.
\end{abstract}

Nesses termos, o ponto ora em relevo é apenas o da possibilidade de substituir a palavra final do chefe do Executivo por uma forma de controle popular. É a consideração de uma sociedade estatal formada por cidadãos emancipados responsáveis para decisões sobre a vida da comunidade política a que pertencem. Tal como a democracia plena, o cidadão totalmente emancipado está longe de existir. "Nenhum dos dois é um dado, eles são tarefas para as quais se tem constantemente de trabalhar. Não se pode alcançar o máximo de democracia se não se aspirar em absoluto à democracia" ${ }^{1027}$.

\title{
5.2.3. A autonomia funcional, administrativa e financeira
}

A Constituição também estabeleceu ao Ministério Público a autonomia funcional, administrativa e financeira, do que decorre a possibilidade de propor ao órgão do legislativo "a criação e a extinção de seus cargos e serviços auxiliares, provendo-os por concurso público de provas e de provas e títulos, a política remuneratória e os planos de carreira", cabendo à lei dispor sobre a sua organização e o seu funcionamento ${ }^{1028}$.

A autonomia é a possibilidade "de gerir os próprios assuntos dentro de um círculo prefixado. (...)"1029. Alcança o Ministério Público enquanto instituição, permitindo a delimitação do alcance dos interesses cuja defesa lhe compete, com a disposição dos meios de organização e funcionamento voltados a esse fim. Já a independência funcional atinge o titular de cargo ou função do Ministério Público, ligando-se, de forma mais imediata, "ao exercício das atividades-fins da instituição"1030; "é uma garantia conferida a cada um de seus órgãos, ou a cada um de seus membros, enquanto agentes políticos" para o exercício de suas funções institucionais ${ }^{1031}$. Vale dizer, uma instituição pode dispor de autonomia

\footnotetext{
${ }^{1026}$ SKINNER, Quentin. As fundações do pensamento político moderno, cit., p. 171.

${ }^{1027}$ KAUFMANN, Arthur. op. cit., p. 442.

${ }^{1028}$ Cf. a redação do art. $127, \S 2^{\circ}$, da CF. No mesmo sentido, cf. o art. 92 da Constituição paulista.

${ }^{1029}$ SILVA, José Afonso da. op. cit., p. 595-596. Em seu art. 2º a Lei Complementar 40/81 já havia alçado a autonomia organizacional a um dos princípios institucionais do Ministério Público. Cf. 3.8.

${ }^{1030}$ Id. Ibid., p. 596.

${ }^{1031}$ MAZZILLI, Hugo Nigro. Regime jurídico do Ministério Público, cit., p. 143.
} 
organizacional sem contar com a garantia de independência; mas, esta última, sem dúvida, pressupõe a verificação da primeira.

Dessa forma, ao Ministério Público foi assegurada a independência funcional, na qualidade de uma instituição do Estado Democrático de Direito, cujo funcionamento e organização obrigam-se ao comando de funções destinadas à proteção do princípio da dignidade da pessoa humana. E a autonomia funcional, administrativa e financeira é outro desdobramento da independência funcional do Ministério Público, como pressuposto para o desenvolvimento satisfatório de suas tarefas de controle do poder político do Estado. Daí, com efeito, ter a Constituição elevado o Ministério Público à condição de uma instituição autônoma, permitindo-lhe a autogestão dos próprios assuntos, de modo a efetivar a sua independência ${ }^{1032}$.

Sob os lindes da legalidade e da legitimidade, a autonomia funcional, administrativa e financeira conferida ao Ministério Público pressupõe a esfera de competência necessária para decidir sobre todas as matérias relativas à gestão institucional, sem qualquer interferência de outros órgãos ou agentes políticos do Estado. Está vedada, ao Executivo, a expedição de atos normativos que interfiram na capacidade de autogestão do Ministério Público, a qual deve subordinar-se apenas aos mandamentos legais e constitucionais $^{1033}$.

\footnotetext{
${ }^{1032} \mathrm{O}$ âmbito dessa autonomia infere-se das normas dos $\S \S 2^{\circ}$ a $6^{\circ}$, do art. 127 , da CF.

${ }^{1033}$ MAZZILLI, Hugo Nigro. op. cit., p. 146. No âmbito da organização dos Estados, a LONMP assegurou ao Ministério Público a "autonomia funcional, administrativa e financeira, cabendo-lhe, especialmente: I praticar atos próprios de gestão; II - praticar atos e decidir sobre a situação funcional e administrativa do pessoal, ativo e inativo, da carreira e dos serviços auxiliares, organizados em quadros próprios; III elaborar suas folhas de pagamento e expedir os competentes demonstrativos; IV - adquirir bens e contratar serviços, efetuando a respectiva contabilização; V - propor ao Poder Legislativo a criação e a extinção de seus cargos, bem como a fixação e o reajuste dos vencimentos de seus membros; VI - propor ao Poder Legislativo a criação e a extinção dos cargos de seus serviços auxiliares, bem como a fixação e o reajuste dos vencimentos de seus servidores; VII - prover os cargos iniciais da carreira e dos serviços auxiliares, bem como nos casos de remoção, promoção e demais formas de provimento derivado; VIII - editar atos de aposentadoria, exoneração e outros que importem em vacância de cargos da carreira e dos serviços auxiliares, bem como os de disponibilidade de membros do Ministério Público e de seus servidores; IX organizar suas secretarias e os serviços auxiliares das Procuradorias e Promotorias de Justiça; X - compor os seus órgãos de administração; XI - elaborar seus regimentos internos; XII - exercer outras competências dela decorrentes". Além disso, foi atestado que as "decisões do Ministério Público fundadas em sua autonomia funcional, administrativa e financeira, obedecidas as formalidades legais, têm eficácia plena e executoriedade imediata, ressalvada a competência constitucional do Poder Judiciário e do Tribunal de Contas" (art. $3^{\circ}, \S$ único, da Lei 8.625/93). Para o Ministério Público da União, a LOMPU também garantiu autonomia funcional, administrativa e financeira, cabendo-lhe propor ao Legislativo "a criação e extinção de seus cargos e serviços auxiliares, bem como a fixação dos vencimentos de seus membros e servidores; prover os cargos de suas carreiras e dos serviços auxiliares; organizar os serviços auxiliares"; e "praticar atos próprios de gestão". A elaboração de sua proposta orçamentária compete também ao Ministério da União, respeitados os limites da lei de diretrizes orçamentárias (art. 23, caput, da Lei Complementar 75/93).
} 
A autonomia financeira do Ministério Público integra o contexto de sua autonomia administrativa, sem o que cairia por terra a condição de um órgão independente inserido no sistema de controle do poder político do Estado. Nesse sentido, no que concerne às especificações do plano financeiro, à instituição incumbe elaborar "sua proposta orçamentária dentro dos limites estabelecidos na lei de diretrizes orçamentárias"; e, se a proposta orçamentária for encaminhada em desacordo com tais limites, o Executivo "procederá aos ajustes necessários para fins de consolidação da proposta orçamentária anual". Por último, advém a vedação de "despesas ou a assunção de obrigações que extrapolem os limites estabelecidos na lei de diretrizes orçamentárias, exceto se previamente autorizadas, mediante a abertura de crédito suplementar"1034.

A autonomia financeira do Ministério Público implica a formulação de proposta orçamentária para "prover as atividades e serviços do órgão titular da dotação. Essa autonomia pressupõe a existência de dotações que possam ser livremente administradas, aplicadas e remanejadas pela unidade orçamentária a que foram destinadas" ${ }^{1035}$. Assim, dentro dos limites estabelecidos na lei de diretrizes orçamentárias, o Ministério Público deve elaborar a sua respectiva proposta para ser incorporada ao projeto de lei orçamentária, de iniciativa do Executivo, para a apreciação pelo Legislativo ${ }^{1036}$. Note-se que o Ministério Público não tem iniciativa para a elaboração do projeto de lei orçamentária; deve realizar a proposta de seu orçamento para integrar o projeto de lei orçamentária de iniciativa do órgão do executivo. Este, por sua vez, está autorizado apenas a fazer as alterações que se mostrem necessárias à devida adequação aos limites da lei de diretrizes orçamentárias. Ao Executivo incumbe propor o projeto final de orçamento, estando, porém, constitucionalmente obrigado a respeitar a proposta parcial exclusiva do Ministério Público, "dentro dos limites gerais fixados pela lei de diretrizes orçamentárias, segundo determina a Constituição"1037.

\footnotetext{
${ }^{1034}$ Cf. a redação do art. $127, \S \S 3^{\circ}$ a $6^{\circ}$, da CF. Sobre o assunto, a LONMP contém a seguinte redação: "O Ministério Público elaborará sua proposta orçamentária dentro dos limites estabelecidos na Lei de Diretrizes Orçamentárias, encaminhando-a diretamente ao Governador do Estado, que a submeterá ao Poder Legislativo" (art. $4^{\circ}$ da Lei 8.625/93).

${ }^{1035}$ MAZZILLI, Hugo Nigro. op. cit., p. 147.

${ }^{1036}$ Cf. o art. 84, XXIII; e o art. $127, \S 3^{\circ}$, da CF. Registre-se que as leis que definem o plano plurianual, as diretrizes orçamentárias e os orçamentos anuais são de iniciativa do Executivo estatal. Cf. ainda o art.165, da CF. A autonomia administrativa e financeira do Ministério Público cede espaço ao controle do Tribunal de Contas, do Conselho Nacional do Ministério Público, além do controle jurisdicional em sede própria. E os seus agentes podem ser responsabilizados nas esferas penal, administrativa e política por eventuais abusos na gestão e aplicação dos recursos orçamentários da instituição.

${ }^{1037}$ COMPARATO, Fábio Konder. Autonomia do Ministerio Público: iniciativa do processo legislativo. Justitia, São Paulo, v. 60, n. esp. (60 anos: 1939-1999), p. 1126, 1999. Cf. o § 5º do art. 127, da CF. A
} 
Quanto à autonomia funcional e administrativa do Ministério Público, é necessário observar que a Constituição outorgou-lhe iniciativa concorrente para propor ao Legislativo: a) a criação e a extinção dos seus cargos e serviços auxiliares; b) a política remuneratória e os planos de carreira, sua organização e funcionamento; c) a edição das respectivas leis complementares, com regras sobre a sua organização e atribuições ${ }^{1038}$. A conclusão pela outorga de iniciativa concorrente do Ministério Público decorre de dispositivo constitucional conferindo ao Presidente da República a iniciativa privativa para as leis que disponham, justamente, sobre a organização do Ministério Público da União, bem como sobre normas gerais para a organização do Ministério Público dos Estados. Assim, em se tratando de organização do Ministério Público dos Estados, “observado o princípio da simetria, só se admite a iniciativa do processo legislativo pelo governador ou pelo Procurador-Geral de Justiça" ${ }^{1039}$.

É imperioso subverter, também nesse ponto, a tendência histórica de centralização do poder político do Estado na chefia do Executivo, expurgando a vinculação com o Ministério Público em matéria de iniciativas para as legislações sobre assuntos institucionais que lhe são próprios, ou seja, estão contidos no princípio de sua autonomia organizacional, que decorre imediatamente do "princípio de independência funcional (...) perante o Legislativo, o Executivo e o Judiciário" ${ }^{\text {1040 }}$. No exercício da prerrogativa institucional de independência e, por conseguinte, também de autonomia, o Ministério Público deve dirigir-se diretamente, por meio de seus Procuradores-Gerais, ao Legislativo. Contraria o sistema de controle recíproco entre os órgãos estatais a atribuição de iniciativa concorrente do chefe do Executivo para proposta de leis que disponham sobre a estrutura organizacional e o funcionamento da instituição. Apenas em matéria de composição dos orçamentos anuais é admitida a mediação do Executivo. "Mas, ainda aí, a proposta

\footnotetext{
Emenda Constitucional n. 45 de 2004 introduziu a alteração relativa à possibilidade de ajuste pelo órgão do executivo da proposta do Ministério Público aos limites da lei de diretrizes orçamentárias. Ressalvada essa hipótese, o entendimento dominante é de não ser admitido ao executivo proceder a reduções na proposta apresentada pelo Ministério Público. Em precedentes entendimentos, o Supremo Tribunal Federal já havia firmado a posição no sentido da impossibilidade de alteração unilateral da proposta de orçamento relativa ao judiciário (MS 22.685, medida liminar, rel. Min. Carlos Velloso, DJU de 19.12.1996; MS 23.277, rel. Min. Sepúlveda Pertence, DJU de 26.11.1998; MS 22.230, rel. Min. Carlos Velloso). Segundo Hugo Nigro Mazzilli, "mutatis mutandis, essa lição também se aplica à autonomia financeira do Ministério Público" (MAZZILLI, Hugo Nigro. op. cit., p. 149-150). Note-se ainda a fixação de um limite máximo para gastos com o Ministério Público decorrente da Lei de Responsabilidade Fiscal. Cf. o art. 20 da Lei Complementar 101/2000. Cf. ainda os preceitos do art. 169 da CF.

${ }^{1038}$ MAZZILLI, Hugo Nigro. op. cit., p. 152. Cf. também o art. $127, \S 2^{\circ}$, e $128, \S 5^{\circ}$, da Cf.

${ }^{1039}$ Id. Ibid., p. 153. Cf. o art. $61, \S 1^{\mathrm{o}}$, II, $d$, da CF.

${ }^{1040}$ COMPARATO, Fábio Konder. Autonomia do Ministerio Público: iniciativa do processo legislativo, cit., p. 1.128 .
} 
orçamentária emanada do Ministério Público (...) não pode ser alterada pelo Executivo, ao elaborar o projeto final de orçamento, desde que respeitadas tenham sido as limitações pela lei de diretrizes orçamentárias" ${ }^{\prime 1041}$.

\subsubsection{A questão do controle externo}

Na estrutura organizacional do Estado Democrático de Direito, os mecanismos de controle externo realizam-se por via daquelas relações de reciprocidade que os seus órgãos estabelecem na condição de corresponsáveis pelo exercício do poder político. Como também se atestou, os controles externos ocorrem, basicamente, de duas formas: mediante a necessária intervenção de mais de um órgão no processo relativo à superveniência de uma decisão política; ou mediante a intervenção de um órgão nas atividades de outro, de maneira a frustrar a produção de seus efeitos. As respectivas intervenções dos entes públicos para a efetivação ou para a supressão de uma decisão no marco do processo político caracterizam um sistema de controle recíproco, sempre em consideração à diretriz primordial do Estado Democrático de Direito concebido para a proteção dos direitos fundamentais da pessoa humana ${ }^{1042}$.

Por sua vez, um sistema de controle político deve também incorporar a hipótese de controle interno, que se opera numa mesma esfera organizacional ${ }^{1043}$. Estando necessariamente vinculado a uma só esfera da organização política, um sistema de controle interno exige a existência de uma instituição constituída por uma pluralidade de membros. Nesse caso, determinada função está atribuída a diversos indivíduos que compõem a entidade estatal, entre os quais foi devidamente distribuída para ser desempenhada em comunhão. Para o funcionamento de um sistema de controle interno no âmbito de um mesmo órgão, é necessária a existência de uma instituição organizada coletivamente ${ }^{1044}$.

\footnotetext{
${ }^{1041}$ COMPARATO, Fábio Konder. Autonomia do Ministerio Público: iniciativa do processo legislativo, cit., p. 1.128.

${ }^{1042}$ Recorde-se que o princípio fundamental encontra-se incorporado à norma do art. $2^{\circ}$ da $\mathrm{CF}$.

${ }^{1043}$ LOEWENSTEIN, Karl. Teoria de la Constitucion, cit., p. 232-233. É o caso da aprovação de uma lei pelo parlamento, mediante a participação de suas duas Casas, o qual, por sua vez, afigura-se um órgão uno e independente em relação aos demais no espectro do sistema de controle externo. Outro exemplo, num sistema parlamentarista de governo, é a necessidade de aprovação pelo Conselho de Ministros de uma decisão política do Primeiro Ministro.

${ }^{1044}$ LOEWENSTEIN, Karl. Teoria de la Constitucion, cit., p. 235 e p. 250-251. Por isso, estão necessariamente excluídas da hipótese de controle interno as funções estatais atribuídas a uma só pessoa “que possui o monopólio de seu exercício". Cf. Id. Ibid., p. 235.
} 
No âmbito do Judiciário, a organização colegiada dos tribunais, acrescida do princípio do duplo grau de jurisdição, é uma garantia que corresponde à hipótese de controle interno sobre as atividades-fins dos magistrados ${ }^{1045}$. Já as atividades dos membros do Ministério Público não se sujeitam ao controle interno, ressalvadas raríssimas exceções, como a revisão das promoções de arquivamento do inquérito policial pelo ProcuradorGeral e do inquérito civil pelo Conselho Superior ${ }^{1046}$. Não é de cogitar da possibilidade de uma intervenção direta de autoridades da administração superior no exercício das funções dos membros da instituição. Recorde-se que, diversamente do que ocorre com o Parquet da França, o princípio hierárquico não tem aplicação sobre a atuação funcional do Ministério Público brasileiro, o que, não obstante seja inerente ao princípio da independência funcional, não deixa de colocar em segundo plano as garantias institucionais da unidade e indivisibilidade do Ministério Público. Viu-se, aliás, que o comprometimento da garantia de independência já se faz sentir pela preponderância do princípio hierárquico na gestão institucional, sem em nada contribuir para a realização das duas outras matrizes fundamentais $^{1047}$. Quanto ao controle externo, admitir a interferência direta de outro centro do poder político na execução das atividades-fins do Ministério Público implicaria o sacrifício absoluto de seu real papel no contexto da organização do Estado, em clara infringência ao princípio democrático do controle recíproco entre os seus órgãos.

Nessa linha de raciocínio, não se supõe, de um modo geral, o estabelecimento de meios de controle interno ou externo incidentes sobre a execução das atribuições do Ministério Público, à exceção, respectivamente, da ação correcional, e, é claro, do controle jurisdicional para o qual a grande maioria delas se dirige ${ }^{1048}$. Remanesce, portanto, em relação ao Ministério Público a expectativa de um efetivo controle sobre as chamadas atividades-meio, de caráter organizacional. E foi, justamente, o que procurou introduzir a Emenda Constitucional 45, de 8.12.2004, com a criação do Conselho Nacional do Ministério Público objetivando edificar um novo quadro institucional para o sistema da Justiça brasileira. O órgão, "popularizado como de controle externo", possui três frentes de

\footnotetext{
${ }^{1045}$ Cf. LOEWENSTEIN, Karl. Teoria de la Constitucion, cit., p. 250-251.

${ }^{1046} \mathrm{Cf}$. 4.1.1 e 4.1.3.

${ }^{1047}$ Cf. 4.3. a 4.3.2.

${ }^{1048}$ Cf. 5.2.
} 
atribuições: "a) organização e planejamento das políticas institucionais; b) fiscalização de atos administrativos; c) acompanhamento do cumprimento de medidas disciplinares" 1049 .

Acontece que o equívoco na implantação do Conselho Nacional foi o de se projetar no cenário político como um órgão de controle externo, malgrado as suas funções sinalizem a prevalência de um controle interno e, assim, inserido no espectro da própria organização do Ministério Público. Relações de hierarquia entre instâncias diversas do aparato burocrático de um mesmo órgão estatal são inerentes ao exercício da ação disciplinar. A relação de sujeição entre o "órgão e seu agente justifica o poder sancionador (disciplinar) como decorrência do princípio hierárquico, na medida em que a relação de emprego assentada no regime jurídico peculiar vincula-se à relação de hierarquia" ${ }^{1050}$. E, nas carreiras do Ministério Público, a função disciplinar está legalmente atribuída às Corregedorias $^{1051}$.

Todavia, ao figurar como uma instância correcional de superior hierarquia, a despeito daquela competência correcional, o Conselho Nacional está autorizado a agir para receber e conhecer das reclamações contra os membros do Ministério Público, incluindo os responsáveis pelos serviços auxiliares, “avocar processos em curso, determinar a remoção, a disponibilidade ou a aposentadoria (...) e aplicar outras sanções administrativas, assegurada a ampla defesa”. Além disso, é possível a revisão, de ofício ou mediante provocação, dos processos disciplinares julgados há menos de um ano ${ }^{1052}$. Não há dúvida de que não foram observados aspectos elementares de várias garantias fundamentais; a competência concorrente atribuída ao Conselho Nacional instaura uma duplicidade de

${ }^{1049}$ SADEK, Maria Tereza. Judiciário: mudanças nem sempre à vista Brasil o que resta fazer? Rio de Janeiro: Fundação Konrad Adenauer, set. 2006. p. 140. (Caderno Adenauer VII, n. 3). Cf. as disposições do art. $130-\mathrm{A}, \mathrm{I}$ a VI, $\S \S 1^{\circ}$ e $2^{\circ}$, I a V; $\S 3^{\circ}$, I a III; e $\S \S 4^{\circ}$ e $5^{\circ}$, da CF.

${ }^{1050}$ ALMEIDA JUNIOR, Roberto Luiz Ferreira; MARTINS JUNIOR, Wallace Paiva. O controle externo do Ministério Público e do Poder Judiciário. In: CONGRESSO DO MINISTÉRIO PÚBLICO DO ESTADO DE SÃO PAULO, 3., cit., v. 2, p. 882. Cf. a esse respeito, 4.1.1.2, sobre a função institucional do Ministério Público do controle externo da atividade policial.

${ }^{1051}$ A LOMPU tratou da Corregedoria das carreiras do Ministério Público da União como órgão encarregado de fiscalizar as atividades funcionais e o comportamento dos membros da instituição; cabe-lhe a realização de sindicâncias e correições, a instauração de inquéritos e a proposta ao Conselho Superior de instauração do respectivo processo administrativo, além do acompanhamento do desenvolvimento das atividades daqueles que ainda estão em estágio probatório. Cf. as regras dos arts. 63 a 65; 104 a 106; 137 a 139172 a 174, da Lei Complementar 75/93. A LONMP também dispõe sobre as funções do Corregedor-Geral do Ministério Público dos Estados; entre elas, as de realizar inspeções e correições; propor ao Conselho Superior o não vitaliciamento de membro do Ministério Público; instauração de processos disciplinares com a aplicação das sanções cabíveis. Cf. o art. 17, I, III, e V, da Lei 8.625/93. A LOEMP dedicou um capítulo ao regime disciplinar relativo à fiscalização funcional e à conduta dos membros do Ministério Público de São Paulo (cf. os arts. 227 a 293, da Lei Complementar Estadual 734/93). Além disso, ao contrário dos outros estatutos, a LOEMP tipificou as hipóteses configuradoras de faltas funcionais. Cf. o art. 173, I a VII, c/c o art. 169, da Lei Complementar Estadual 734/93.

${ }^{1052}$ Cf. o art. $130-\mathrm{A}, \S 2^{\circ}$, III e IV, da CF. 
instâncias disciplinares, sugerindo a possibilidade de decisões contraditórias; a avocação de processos em curso, com a transferência das competências decisória e processante, inibe o duplo grau de jurisdição da instância administrativa; a possibilidade de revisão de processos já julgados afronta o princípio da segurança jurídica, além da ofensa à legalidade pela inexistência de lei disciplinadora do processo sancionatório acentuar o nível de infringência ao devido processo legal ${ }^{1053}$.

Entretanto, o que importa ressaltar é que a função disciplinar atribuída ao Conselho Nacional acabou introduzindo-o na estrutura interna da organização do Ministério Público, frustrando maiores expectativas em torno do funcionamento de um órgão de controle externo. Por sua vez, a mesma conclusão também resulta da previsão do controle sobre a gestão funcional, administrativa e financeira do Ministério Público, sob o pressuposto de sua autonomia ${ }^{1054}$. A fiscalização de um órgão sobre as atividades desenvolvidas por outro por força de sua autonomia organizacional não implica, necessariamente, o exercício de uma função afeta a um controle externo. A autonomia pode ser conferida a um órgão público como resultado de simples diretriz de descentralização na esfera de uma mesma estrutura organizacional de determinada instituição do Estado. É o que, aliás, se verifica em relação às diversas entidades autônomas criadas para a prestação de serviços públicos da administração direta e indireta do Executivo ${ }^{1055}$.

Um modelo institucional mais próximo ao de um controle externo sobre o funcionamento do Ministério Público não poderia deixar de apreendê-lo no âmbito de incidência da garantia fundamental do controle recíproco entre os órgãos estatais. Portanto, tendo em conta a inviabilidade de uma interferência direta nas atividades-fins dos membros do Ministério Público, um controle externo sobre as atividades-meio deveria centrar-se nas decisões políticas institucionais, ou seja, nas práticas de gestão do Ministério Público, intimamente relacionadas com os princípios destinados a conformar e a proteger a esfera nuclear da natureza de suas funções institucionais. A premissa é a consideração do Ministério Público à luz das incumbências de defesa da ordem jurídica, do regime democrático e dos interesses sociais e individuais indisponíveis, cujo desenvolvimento deve se pautar, substancialmente, pelos princípios da unidade, da indivisibilidade e da independência funcional. O conjunto das funções institucionais do Ministério Público

\footnotetext{
${ }^{1053}$ Cf. ALMEIDA JUNIOR, Roberto Luiz Ferreira; MARTINS JUNIOR, Wallace Paiva. op. cit., p. 888. Cf. ainda as garantias fundamentais do art. $5^{\circ}$, XXXVII, LIII a LVII; e 37, caput, da CF.

${ }^{1054} \mathrm{Cf}$. os arts.130-A, $\S 2^{\circ}$, I e II/ c/c o art. 37, caput, todos da CF.

${ }^{1055}$ Cf. o art. 175 , \& único, da CF.
} 
traduz a existência de um órgão uno e independente amparado pelo princípio fundamental de controle recíproco entre os órgãos estatais do Estado Democrático de Direito. E a autonomia funcional, administrativa e financeira da instituição é mera decorrência do postulado maior $^{1056}$.

O relevo de uma alteração conceitual é inegável, já que desloca o campo de um controle para as decisões sobre as políticas institucionais do Ministério Público, ou seja, as decisões provenientes da administração superior das carreiras que se relacionem diretamente com os aspectos da organização do Ministério Público, necessários para a sua real configuração como um órgão responsável pela tutela dos valores republicanos na esfera do controle político do Estado Democrático de Direito da Constituição de 1988.

É possível conduzir à apreciação do Conselho Nacional as medidas da administração superior do Ministério Público versando sobre as seguintes questões: propostas de edição ou alteração das leis orgânicas e de criação de cargos; disposições sobre a fixação de atribuições funcionais, critérios normativos e atos de designação dos membros do Ministério Público para cargos e funções; critérios de designações e de disposições sobre o exercício das funções eleitorais; definição das atribuições e de formas de divisão dos trabalhos dos procuradores que oficiam junto aos tribunais; diretrizes para a solução de conflitos de atribuição entre os membros do Ministério Público, incluindo os de carreiras diversas; disposições sobre concursos públicos de ingresso e de movimentação nas carreiras; medidas voltadas à racionalização das atribuições da instituição, à formulação de planos de atuação e à implantação de equipes de trabalho, inclusive para a ação conjunta entre membros de carreiras diversas; critérios para a transferência das funções do Procurador-Geral para os agentes que oficiam junto aos tribunais; critérios para o controle externo da atividade policial; metas para o estabelecimento de uma agenda comum com organizações sociais; diretrizes para a implantação de sistemas informacionais de fácil acesso pela população; e diretrizes para o estabelecimento de cargos e funções de confiança junto aos órgãos da administração superior e para as designações de seus ocupantes $^{1057}$. Atrelando-se aos princípios da unidade, indivisibilidade e independência funcional, com os seus corolários da inamovibilidade e do promotor natural, a essas questões caberia ainda acrescentar algumas das que foram expostas neste capítulo, relacionadas ao regime de incompatibilidades e às alternativas para a gestão democrática

${ }^{1056}$ Cf. o art. $2^{\mathrm{o}}, c / c$ o art. 127, caput e $\S \S 1^{\mathrm{o}}$ a $6^{\mathrm{o}}$, da CF.
${ }^{1057}$ Cf. 4.3 a 4.3 .2$. 
da instituição. Dessa maneira, avultaria um sistema de controle preponderantemente de cunho cooperativo, voltado às políticas de integração e planejamento.

Por outro lado, não é possível olvidar que as medidas administrativas oriundas do Ministério Público constituem res pública, não havendo razão para afastá-las da esfera de um controle externo, independentemente da função de autotutela dos órgãos da administração superior e da possibilidade de sujeição ao devido controle jurisdicional. É perfeitamente admissível o zelo pela observância das garantias fundamentais aplicáveis para a atuação administrativa de quaisquer órgãos do Estado ${ }^{1058}$. Assim, sendo corrigidas, em matéria correcional, as distorções já apontadas e mantendo intacta a competência respectiva dos órgãos das carreiras do Ministério Público, o que o Conselho Nacional deve fazer é examinar se o comportamento adotado pelas Corregedorias deu-se em deferência às circunstâncias do caso concreto e em respeito às matrizes do devido processo legal, além das que norteiam a atividade administrativa do Estado. Nesse sentido, poderão ser sanados eventuais excessos ou omissões. Em outras palavras: o Conselho não deve exercer diretamente nenhuma função correcional, mas apenas controlar o seu exercício pelos órgãos competentes.

A aproximação das funções do Conselho Nacional à hipótese de um controle externo afasta a possibilidade de participação de membros da própria instituição na atuação do órgão encarregado de fiscalizá-la. Já se frisou a importância de um sistema de incompatibilidades para a efetividade do desenvolvimento das funções de controle do poder político do Estado; é intrínseca a proibição de seu exercício por integrantes do órgão sobre o qual deverá incidir a atuação de vigilância e fiscalização. É também aconselhável a exclusão de representantes do Judiciário na composição do Conselho Nacional do Ministério Público. O nível de interação entre as funções dos dois órgãos no âmbito do sistema de controle do poder político não recomenda a ingerência de nenhum deles na esfera organizacional do outro.

Nesse sentido, com a possibilidade de subsistir a representação da Ordem dos Advogados do Brasil, além dos cidadãos indicados pelo Congresso Nacional ${ }^{1059}$, a lembrança, mais uma vez, é à visão de Durkheim sobre os ensinamentos de Montesquieu para realçar a importância da ação dos corpos secundários na intermediação das forças políticas do Estado Democrático de Direito. Assim, em substituição aos membros do

\footnotetext{
${ }^{1058} \mathrm{Cf}$. os arts. 37 , caput, e o art. $130-\mathrm{A}, \S 2^{\mathrm{o}}$, II, da CF
}

${ }^{1059} \mathrm{Cf}$. o art. $130-\mathrm{A}, \mathrm{IV}, \mathrm{V}, \mathrm{VI}, \S 4^{\mathrm{o}}$, da CF. 
Ministério Público e também da Magistratura, a composição dos assentos do Conselho Nacional poderia ser complementada por representantes indicados por organizações não governamentais da sociedade civil, cujos fins associativos apresentem uma estreita consonância com as finalidades institucionais do Ministério Público ${ }^{1060}$. Ainda na senda de uma gestão institucional verdadeiramente democrática, também não há nenhuma razão para retardar a criação das ouvidorias do Ministério Público, segundo expressa previsão constitucional $^{1061}$. A expectativa é a de abertura de canais de comunicação com o Conselho Nacional para que as reivindicações da sociedade sobre a atuação do Ministério Público possam se traduzir numa estrutura organizacional e num funcionamento mais compatíveis com o seu atendimento.

${ }^{1060}$ Cf. 5.2.1, sobre as razões que envolvem uma eventual incompatibilidade à participação dos membros do Ministério Público nos conselhos federais e estaduais. Daí a referência a associações cujas finalidades não possibilitem nenhum tipo de relação de caráter econômico/financeiro com órgãos do Estado.

${ }^{1061}$ Cf. a redação do $\S 5^{\circ}$, do art. 130-A, da CF. 


\section{CONCLUSÃO}

A experiência histórica não deixa dúvidas de que o maior problema em torno dos direitos humanos é o encalço de meios capazes de assegurar a sua efetiva proteção. Por força da consolidação do processo de internacionalização dos direitos humanos a partir da Declaração Universal de 1948, suplantou-se a noção de soberania nacional pelos limites externos impostos aos Estados pela tutela dos direitos ou interesses imanentes ao princípio da dignidade da pessoa humana. Como suprema manifestação da vontade estatal, o poder soberano revelou-se uma categoria dissonante do universo jurídico fundado na proteção incondicional daquele valor maior, tanto no plano internacional, como no do direito interno.

A presente constatação leva a repensar o constitucionalismo contemporâneo em função da necessidade de uma reengenharia institucional apta à garantia dos direitos fundamentais da pessoa humana. É, sem nenhuma dúvida, uma das vias por intermédio da qual há de avançar o regime internacional de proteção dos direitos humanos. Vale dizer: é preciso suprimir as inúmeras deficiências que ainda obstam o exercício, em sua integralidade, da cidadania, para que se rompam as barreiras da nacionalidade, rumo ao reconhecimento da cidadania universal. O único fundamento legítimo de um regime político é realmente a sua Constituição, que deve prover meios hábeis para a garantia dos direitos fundamentais, sempre em consideração ao caráter de unidade, complementaridade e interdependência de que se revestem.

$\mathrm{Na}$ fase do liberalismo clássico, o constitucionalismo pautava-se pelo respeito às chamadas liberdades negativas e aos direitos políticos lastreados no princípio majoritário do regime de representação democrática. A principal função do Estado era garantir a segurança por meio da edição de leis, entendidas como comandos gerais e abstratos, com a consideração da sociedade de forma unitária, como um todo homogêneo, sem distinções ou divisões estamentais. A lei funcionava como o instrumento de estabilidade social compatível com a natureza do Estado liberal, para a satisfação da liberdade individual e da igualdade de condição jurídica entre os integrantes da sociedade. O equilíbrio do constitucionalismo clássico, fundado na distribuição dos poderes estatais, pressupunha, assim, a produção do direito, mediante a edição de leis, como a função básica do Estado. E a democracia reduzia-se, essencialmente, ao primado da soberania popular a ser exercida 
pelo povo por meio de seus representantes, com a legitimidade do sistema atribuída ao curso do processo eleitoral.

Todavia, desde a segunda etapa do processo histórico de reconhecimento dos direitos humanos, ante a superveniência dos direitos sociais, econômicos e culturais, a legitimidade daquela situação foi radicalmente questionada, com a eclosão do Estado intervencionista caracterizado pela incorporação da função legislativa pelos órgãos do Executivo. A lei foi perdendo a posição de superior hierarquia na ordem jurídica estatal, não deixando dúvidas sobre a inadequação do modelo de organização do Estado liberal à realidade das sociedades contemporâneas. Hoje, somam-se às clássicas liberdades negativas um amplo rol de direitos imanentes à proteção da dignidade humana, que, além de ultrapassarem as fronteiras nacionais da cidadania, não mais se firmam nos princípios da igualdade e liberdade da era moderna. Os direitos sociais, econômicos e culturais, acrescidos dos que vêm absorvendo interesses prioritários de toda a humanidade, não se esteiam em uma noção abstrata de proteção da dignidade humana. Geradas por um acelerado processo de desenvolvimento tecnológico, as progressivas exigências de transformação social a cargo do Estado não podem contar apenas com a lei como instrumento capaz de sustentar todos os objetivos de mudança a serem alcançados.

$\mathrm{Na}$ atualidade, para o efeito de proteção dos direitos fundamentais da pessoa humana, a atuação do Estado legitima-se basicamente pela realização de programas de ação de grande amplitude, com a lei figurando apenas como um de seus elementos. Daí a inoperância da tradicional divisão tripartida das funções do Estado, para hodiernamente representar um mecanismo de limitação do exercício do poder político hábil à tutela das liberdades negativas ou à realização dos programas necessários para a eficácia dos direitos sociais, econômicos e culturais, do que, aliás, depende a regular fruição dos direitos civis.

Aliando-se à extensão da atuação dos órgãos governamentais, emerge a tendência de preconizar o afastamento das decisões políticas fundamentais para conduzi-las à esfera de atuação dos chamados poderes invisíveis, desprovida de qualquer responsabilidade jurídica ou política, em razão da ausência de controles precisos e estáveis sobre as suas ações. A realidade não deixa de pôr em questão a capacidade das forças vitais, que comandam esse processo decisório, de gerar o equilíbrio desejado. Lembre-se que a lição de Montesquieu não era, de forma alguma, deixar de reproduzi-las no arcabouço institucional do Estado. 
Não é possível alijar a matriz do Estado de Direito como o projeto jurídico que sempre esteve na base do constitucionalismo, sobretudo no Brasil, que não logrou desvencilhar-se do desvio de concentração do poder político na chefia do Executivo. Sob fortes traços patrimonialistas e oligárquicos que marcaram o curso da evolução da sociedade brasileira, é o chefe do Estado que costuma encarregar-se tanto da formulação quanto da implementação de decisões políticas fundamentais, sem sujeitar-se a um controle eficaz dos outros órgãos. No âmbito de respectiva fiscalização, ainda prepondera a mera observância dos contornos formais de competências, além de regras de caráter procedimental.

A organização constitucional do Estado Democrático de Direito da Constituição Federal de 1988 deve ter aptidão para levar a cabo os objetivos primaciais da República Federativa do Brasil, cujo fundamento central reside na proteção da dignidade da pessoa humana. Isso significa regular a produção de decisões políticas inseridas nesse contexto, não havendo como prescindir do funcionamento de mecanismos eficazes de controle sobre a ação dos órgãos que integram a seara dos correspondentes processos decisórios.

Mediante a aplicação do princípio democrático do controle recíproco entre os órgãos estatais, sobressai a distribuição de funções políticas, de modo a advir o equilíbrio ideal entre o poder ativo e o poder impediente, sempre com a participação da sociedade civil em um sistema de controle do poder político pautado pela diretriz de efetividade do conjunto de direitos e garantias fundamentais, incluindo as que se destinam a proteger o funcionamento de uma instituição estatal imediatamente concebida para a tutela de claras densificações do princípio fundamental da dignidade da pessoa humana.

Compete ao Ministério Público brasileiro participar ativamente do controle e da fiscalização de decisões políticas fundamentais, como as do vasto campo das políticas públicas correlatas à efetividade dos direitos sociais, econômicos e culturais. Detém a instituição a titularidade para ações de controle de constitucionalidade sobre a função legislativa estatal, além do dever de agir na esfera de apuração da responsabilidade por atos atentatórios ao bom trato da coisa pública, o que representa a aplicação direta do princípio republicano de prevalência do bem comum do povo sobre todo e qualquer interesse particular. Acrescem ainda as atividades de controle da lisura do processo eleitoral e o monopólio à propositura da ação penal, para alicerçar, sem sombras de dúvidas, a conclusão de se tratar de uma instituição responsável pelo exercício de uma parcela do poder político do Estado. 
O conjunto das funções constitucionalmente atribuídas ao Ministério Público traduz a sua inclusão no sistema de controle recíproco entre os órgãos estatais e, por conseguinte, no campo de incidência do respectivo princípio fundamental de organização política do Estado. Como um de seus desdobramentos, a garantia institucional de independência foi conferida à instituição para salvaguardar um eficiente funcionamento dirigido à concretização do princípio republicano, que sempre há de conviver com o pressuposto da soberania popular, base da democracia, para condicionar a manifestação da vontade estatal ao alcance do bem comum, na produção de decisões políticas fundamentais.

O aperfeiçoamento da estrutura organizacional e do funcionamento do Ministério Público passa pela necessidade da incorporação por seus membros do verdadeiro sentido da garantia de independência funcional, tendo-a consagrada como uma proteção objetiva ao exercício de suas atividades, de maneira a afastá-la da ideia de autonomia da vontade individual. É o que pode provocar, no contexto de um sistema democrático de gestão, a adoção de instrumentos que assegurem a participação de todos os integrantes das carreiras na tomada de decisões coletivas capazes de expressar uma vontade comum da classe. Segue-se, na mesma linha, a necessidade de aprimoramento do regime de representação democrática na composição dos órgãos da administração superior do Ministério Público, responsáveis pelas deliberações sobre todas as políticas institucionais. A garantia do direito de acesso em igualdade de condições a todos os cargos que compõem os vários quadros das carreiras da instituição é também pré-requisito para legitimar as atividades de seus representantes como agentes políticos do Estado Democrático de Direito da República brasileira.

Por outro lado, é imprescindível a apreensão material da dimensão do princípio democrático do controle recíproco entre os órgãos estatais para guiar as relações do Ministério Público com os demais centros de nossa organização política, de sorte a se romperem os vínculos que o prendem ao Executivo do Estado. É essa a maneira de realização das condições objetivas necessárias ao desenvolvimento das elevadas funções que lhe foram reservadas para minorar os efeitos da preeminência daquele órgão no cenário político nacional, o que sempre se apresentou altamente contrastante com a efetiva proteção do conjunto dos direitos fundamentais da pessoa humana. No entanto, um sistema eficaz de controle do poder político também não pode dispensar a existência de mecanismos de fiscalização sobre as decisões institucionais que interfiram diretamente no 
desenvolvimento das atividades do Ministério Público, visando à preservação de seu papel no regime político do Brasil como Estado Democrático de Direito. 


\section{REFERÊNCIAS BIBLIOGRÁFICAS}

ALEXY, Robert. Los derechos fundamentales en el Estado constitucional democrático. In: CARBONELL, Miguel (Ed.). Neoconstitucionalismo(s). 2. ed. Madrid: Trotta, 2005.

. Teoría de los derechos fundamentales. Trad. Ernesto Garzón Valdés. Madrid:

Centro de Estudios Políticos y Constitucionales, 2002.

ALMEIDA, Fernanda Leão de; MAC DOWELL, Claudia Ferreira; LORZA, Flavio Farinazzo; GODOY, Maria Teresa Penteado de Moraes. A democratização na administração superior. In: CONGRESSO DO MINISTÉRIO PÚBLICO DO ESTADO DE SÃO PAULO, 3., 2005, São Paulo. Anais... São Paulo: Páginas \& Letras Ed., 2006. v. 2, p. 789-794.

; MACHADO, Martha de Toledo. A composição dos órgãos superiores do Ministério Público do Estado de São Paulo - na trilha de uma gestão mais democrática. In: CONGRESSO DO MINISTÉRIO PÚBLICO DO ESTADO DE SÃO PAULO, 3., 2005, São Paulo. Anais... São Paulo: Páginas \& Letras Ed., 2006. v. 2, p. 665-675.

; YARD, Anna Trotta. A legitimidade do concurso instaurado pelo critério de merecimento: alguns paradigmas constitucionais. In: CONGRESSO NACIONAL DO MINISTÉRIO PÚBLICO. MINISTÉRIO PÚBLICO E JUSTIÇA SOCIAL, 16., 6-9 nov. 2005. Anais... Belo Horizonte: CONANP - Associação Nacional dos Membros do Ministério Público. Associação Mineira do Ministério Público - AMMP, 2005. p. 701-709.

; MARTINS JUNIOR, Wallace Paiva. O controle externo do Ministério Público e do Poder Judiciário. In: CONGRESSO DO MINISTÉRIO PÚBLICO DO ESTADO DE SÃO PAULO, 3., 2005, São Paulo. Anais... São Paulo: Páginas \& Letras Ed., 2006. v. 2, p. 877-888.

APMP Notícias e Órgão Informativo da Associação Paulista do Ministério Público, São Paulo, ano 3, n. 16, jun. 2009.

ARANTES, Rogério Bastos. Ministério Público e política no Brasil. São Paulo: EDUC: Ed. Sumaré; Fapesp, 2002.

ARENDT, Hannah. Entre o passado e o futuro. Trad. Mauro W. Barbosa. 5. ed. São Paulo: Perspectiva, 2005. 
ARENDT, Hannah. Origens do totalitarismo. Trad. Roberto Raposo. São Paulo: Companhia das Letras, 1999.

ARISTÓTELES. Ética a Nicômaco. Trad. Pietro Nassatti. São Paulo: Martin Claret, 2004. Política. Trad. Therezinha Monteiro Deutsch e Baby Abrão. São Paulo: Nova Cultural, 2000. p. 33-251. (Coleção Os pensadores).

AYARRAGARAY, Carlos A. El Ministerio Público: su historia, organizacíon y funcionamiento em la legislacíon comparada y em la República Argentina seguido de las bases para uma próxima organizacíon. Buenos Aires: J. Lajouane, 1928.

BACHOF, Otto. Normas constitucionais inconstitucionais? Trad. José Manuel Cardoso. Coimbra: Almedina, 2008.

BARBOSA MOREIRA, José Carlos. A ação popular do direito brasileiro como instrumento de tutela jurisdicional dos chamados "interesses difusos". In: Temas de direito processual: primeira série. São Paulo: Saraiva, 1977.

Os deveres para com a comunidade. In: Temas de direito processual: sexta série. São Paulo: Saraiva, 1997. p. 309-317.

. Mandado de injunção. Revista de Processo, São Paulo, n. 56, out./dez. 1989.

BARROSO, Luís Roberto. O direito constitucional e a efetividade de suas normas: limites e possibilidades da Constituição brasileira. 5. ed. Rio de Janeiro: Renovar, 2001. . Interpretação e a aplicação da Constituição. 6. ed. São Paulo: Saraiva, 2004.

BAUMAN, Zigmunt. Em busca da política. Tradução de Marcus Penchel. Rio de Janeiro: Jorge Zahar, 2000.

BENEVIDES, Maria Victoria de Mesquita. A cidadania ativa referendo, plebiscito e iniciativa popular. 3. ed. São Paulo: Ática, 2003.

BERCOVICI, Gilberto. Constituição e estado de exceção permanente. Rio de Janeiro: Azougue Editorial, 2004.

Soberania e Constituição: para uma crítica do constitucionalismo. São Paulo: Quartier Latin, 2008. 
BERNAL PULIDO, Carlos. El principio de proporcionalidad y los derechos fundamentales. 3. ed. Madrid: Centro de Estudios Políticos y Constitucionales, 2007.

BOBBIO, Norberto. Democracia representativa e democracia direta. In: O futuro da democracia. Trad. Marco Aurélio Nogueira. 9. ed. São Paulo: Paz e Terra, 2004. p. 5376.

Governo dos homens ou governo das leis? In: . O futuro da democracia.

Trad. Marco Aurélio Nogueira. 9. ed. São Paulo: Paz e Terra, 2004. p. 165-185.

. Teoria geral da política: a filosofia política e as lições dos clássicos. Org. Bovero Michelangelo. Trad. Daniela Beccaccia Versiani. Rio de Janeiro: Elsevier, 2000.

BONAVIDES, Paulo. Curso de direito constitucional. 11. ed. São Paulo: Malheiros Ed., 2001.

; ANDRADE, Paes de. História constitucional do Brasil. 5. ed. Brasília: OAB Ed., 2004.

BRUGGER, Silvia Maria Jardim. Escolhas de padrinhos e relações de poder: uma análise do compadrio em São João del Rei (1736-1850). In: CARVALHO, José Murilo de (Org.). Nação e cidadania no Império: novos horizontes. Rio de Janeiro: Civilização Brasileira, 2007. p. 313-347.

CANOtilho, J. J. Gomes. Direito constitucional e teoria da Constituição. 7. ed. Coimbra : Almedina, 2003.

CAPPELLETTI, Mauro. Juízes legisladores? Trad. Carlos Alberto Alvaro de Oliveira. Porto Alegre: Sergio Antonio Fabris, 1999.

; GARTH, Bryan. Acesso à justiça. Trad. Ellen Gracie Northfleet. Porto Alegre: Sergio Antonio Fabris, 1988.

CARBONELL, Miguel. Uma historia de los derechos fundamentales. México: UNAN Editorial Porrúa y CNDH, 2005.

CARVALHO, José Murilo de. Cidadania no Brasil: um longo caminho. 5. ed. Rio de Janeiro: Civilização Brasileira, 2004. 
CARVALHO, José Murilo de. A construção da ordem: a elite política imperial. Teatro de sombras: a política imperial. Rio de Janeiro: Civilização Brasileira, 2003.

A formação das almas: o imaginário da República no Brasil. São Paulo: Companhia das Letras, 2005.

CAVALCANTI, Rosângela Batista. O Ministério Público na Paraíba. In: SADEK, Maria Tereza (Org.). Justiça e cidadania no Brasil. São Paulo: Ed. Sumaré, 2000. p. 157-183.

CÉDRIC, Trassard. O Ministério Público em França. In: AZEVEDO, Rodrigo Ghiringhelli de; DIAS, João Paulo (Coords.). O papel do Ministério Público: estudo comparado dos países latino-americanos. Coimbra: Almedina, 2008. p. 125-165.

CERVATI, Angelo Antonio. Le garanzie costituzionali nel pensiero di Costantino Mortati. In: GALIZIA, M.; GROSSI, P. (a cura di). Per la storia del pensiero giuridico moderno: il pensiero giuridico di Costantino Mortati. Milano: Giuffrè, 1990. v. 33, p. 417-469.

CÍCERO, Marco Túlio. Da República. Trad. Amador Cisneiro. Bauru-SP: EDIPRO, 1995. . Dos deveres (De officiis). Trad. Carlos Humberto Gomes. Lisboa: Ed. 70 LDA, 2000.

CINTRA, Antonio Carlos de Araújo; GRINOVER, Ada Pellegrini; DINAMARCO, Candido R. Teoria geral do processo. 11. ed. São Paulo: Malheiros Ed., 1995.

COMPARATO, Fábio Konder. A afirmação histórica dos direitos humanos. 4. ed. São Paulo: Saraiva, 2005.

- Autonomia do Ministerio Público: iniciativa do processo legislativo. Justitia, São Paulo, v. 60, n. esp. (60 anos: 1939-1999), p. 1120-1128, 1999.

. Ética: direito, moral e religião no mundo moderno. São Paulo: Companhia das Letras, 2006.

- Fundamento dos direitos humanos: a noção jurídica de fundamento e sua importância em matéria de direitos humanos. Revista Consulex, ano 4, n. 48, p. 52-61, dez. 2000. 
COMPARATO, Fábio Konder. A garantia institucional contra o abuso de poder. In: BENEVIDES, Maria Victoria et al. (Orgs.). Reforma política e cidadania. São Paulo: Fundação Perseu Abramo, 2003. p. 44-56.

- O Ministerio Público na defesa dos direitos econômicos, sociais e culturais. In:

GRAU, Eros Roberto; CUNHA, Sérgio Sérvulo da (Orgs). Estudos de direito constitucional em homenagem a José Afonso da Silva. São Paulo: Malheiros Ed., 2003. p. 244-260.

. Muda Brasil: uma Constituição para o desenvolvimento democrático. 4. ed. São Paulo: Brasiliense, 1987.

Um quadro institucional para o desenvolvimento democrático. In: JAGUARIBE, Hélio et. al. Brasil: sociedade democrática. Rio de Janeiro: José Olympio, 1985. p. 393432. (Coleção Documentos Brasileiros).

CRUZ, Luis M. Estudios sobre el neoconstitucionalismo. Mexico: Editorial Porrúa y Instituto Mexicano de Derecho Procesal Constitucional, 2006.

DEDIEU, Joseph. As ideais políticas e morais de Montesquieu. In: SADEK, Maria Tereza; QUIRINO, Célia Galvão (Orgs.). O pensamento político clássico: Maquiavel, Hobbes, Locke, Montesquieu, Rousseau. 2. ed. São Paulo: Martins Fontes, 2003. p. 293-340.

DIAS JÚNIOR, Paulo Roberto. Um novo modelo de gestão: reflexos na atuação do Ministério Público. In: CONGRESSO NACIONAL DO MINISTÉRIO PÚBLICO. MINISTÉRIO PÚBLICO E JUSTIÇA SOCIAL, 16., 6-9 nov. 2005. Anais... Belo Horizonte: CONANP - Associação Nacional dos Membros do Ministério Público; Associação Mineira do Ministério Público - AMMP, 2005. p. 710-726.

DI PIETRO, Maria Sylvia. Discricionariedade administrativa na Constituição de 1988. 2. ed. São Paulo: Atllas, 2001.

DIPPEL, Horst. História do constitucionalismo moderno: novas perspectivas. Tradução Antonio Manuel Hespanha e Cristina Nogueira da Silva. Lisboa: Fundação Calouste Gulbenkian, 2007.

DUGUIT, Léon. Fundamentos do direito. Trad. Eduardo Salgueiro. Porto Alegre: Sergio Antonio Fabris, 2005. 
DURKHEIM, Émile. Como Montesquieu classifica as sociedades por tipos e por espécies. In: SADEK, Maria Tereza; QUIRINO, Célia Galvão (Orgs.). O pensamento político clássico: Maquiavel, Hobbes, Locke, Montesquieu, Rousseau. 2. ed. São Paulo: Martins Fontes, 2003. p. 279-292.

. Lições de sociologia. Trad. Monica Stahel. São Paulo: Martins Fontes, 2002.

DWORKIN, Ronald. Freedom's law. Cambridge: Harvard University Press, 1997.

. Taking rights seriously. Cambridge: Harvard University Press, 1977.

ERNST, Cassier. A questão de Jean-Jaques Rousseau. In: SADEK, Maria Tereza; QUIRINO, Célia Galvão (Orgs.). O pensamento político clássico: Maquiavel, Hobbes, Locke, Montesquieu, Rousseau. 2. ed. São Paulo: Martins Fontes, 2003. p. 443-487.

FABBRINI, Renato Nascimento et al. (Coord.). Proposta de revalorização do critério de merecimento nos concursos de promoção e remoção no Ministério Público. São Paulo: Associação Paulista do Ministério Público, 2000.

FABRI, Marco; CAVALLINI, Daniela. O Ministério Público em Itália. In: AZEVEDO, Rodrigo Ghiringhelli de; DIAS, João Paulo (Coords.). O Papel do Ministério Público: estudo comparado dos países latino-americanos. Coimbra: Almedina, 2008. p. 167-221.

FAGUNDES, M. Seabra. O controle dos atos administrativos pelo Poder Judiciário. 7. ed. Rio de Janeiro: Forense, 2005.

O Ministério Público e a preservação da ordem jurídica no interesse coletivo. Justitia, São Paulo, v. 60, n. esp. (60 anos: 1939-1999), p. 237-244, 1999.

FAORO, Raymundo. Os donos do poder: formação do patronato político brasileiro. 3. ed. São Paulo: Ed. Globo, 2001.

FARIA, José Eduardo. As transformações do Judiciário em face de suas responsabilidades sociais. In: (Org.). Direitos humanos, direitos sociais e justiça. São Paulo: Malheiros, 2002. p. 52-67.

FERNANDES, Florestan. Existe uma crise na democracia no Brasil? In: Mudanças sociais no Brasil. 3. ed. Rio de Janeiro: Difel, 1979. p. 93-114. 
FERNANDES, Florestan. A revolução burguesa no Brasil: ensaio de interpretação sociológica. 5. ed. São Paulo: Globo, 2006.

FERRAJOLI, Luigi. Más allá de la soberania y la cidadania: um constitucionalismo global. In: CARBONELL, Carbonell (Comp.). Teoria de la Constitución: ensayos escogidos. 4. ed. México: Editorial Porrúa y Universidad Autónoma de Mexico, 2008. p. 397-410.

FERRAZ, Antonio Augusto Mello de Camargo. Anotações sobre os Ministérios Públicos brasileiro e americano. Justitia, São Paulo, v. 60, n. esp. (60 anos: 1939-1999), p. 1035$1041,1999$.

(Coord.). Um novo modelo de gestão para o Ministério Público: bases de uma necessária reengenharia institucional. São Paulo: Associação Paulista do Ministerio Público - APMP, 2003.

; DIAS JÚNIOR, Paulo Roberto. Aperfeiçoamento do sistema de investidura do Procurador-Geral de Justiça: pressuposto para a afirmação do Ministério Público como defensor do regime democrático. In: VIGLIAR, José Marcelo Menezes; MACEDO JR., Ronaldo Porto (Coords.). Ministério Público II: democracia. São Paulo: Atlas, 1999. p. $115-129$.

FERRAZ, Sergio; DALLARI, Adilson Abreu. Processo administrativo. São Paulo: Malheiros Ed., 2002.

FERRAZ JUNIOR, Tercio Sampaio. Estudos de filosofia do direito: reflexões sobre o poder, a liberdade, a justiça e o direito. 2. ed. São Paulo: Atlas, 2003.

FREYRE, Gilberto. Casa-Grande \& Senzala: formação da família brasileira sob o regime da economia patriarcal. 51. ed. rev. São Paulo: Global, 2006.

FRISCHEISEN, Luiza Cristina Fonseca. Princípio do promotor natural. In: VIGLIAR, José Marcelo Menezes; MACEDO JR., Ronaldo Porto (Coords.). Ministério Público II: democracia. São Paulo: Atlas, 1999. p. 139-148.

GARCÍA DE ENTERRÍA, Eduardo. La Constitucíon como norma y el Tribunal Constitucional. 4. ed. Madrid: Civitas, 2006.

GARCÍA-PELAYO, Manuel. Las transformaciones del Estado contemporâneo. 2. ed. Madrid: Alianza Editorial, 1996. 
GIANNINI, Massimo Severo. L'interpretazione dell'atto amministrativo e la teoria giurica generale dell'interpretazionezi. In: Scritti. Milano: Giuffrè, 2000. v. 1.

. Il podere discrezionale della pubblica amministrazione concetti e problemi. In: Scritti. Milano: Giuffrè, 2000. v. 1.

Lo stato monoclasse: la riflessione della scienza. In: L'amministrazione pubblica dello stato contemporaneo. Padova: CEDAM, 1998. p. 49-59.

GOMES, Angela de Castro. Autoristarismo e corporativismo no Brasil: intelectuais e construção do mito Vargas. In: PINTO, António Costa; MARTINHO, Francisco Palomanes (Orgs.). O corporativismo em português: estado, política e sociedade no salazarismo e no varguismo. Rio de Janeiro: Civilização Brasileira, 2007. p. 79-107.

GOMES, Mauricio Augusto. Ministério Público e Tribunais de Contas na Constituição. Revista dos Tribunais, São Paulo, v. 685, p. 264-267, nov. 1992.

GOMES FILHO, Antonio Magalhães. A motivação das decisões penais. São Paulo: Ed. Revista dos Tribunais, 2001.

GORDILLO, Agustín. En el derecho subjetivo en el derecho de incidencia colectiva. In: . Tratado de derecho administrativo: la defensa del usuario y del administrado. 5. ed. Belo Horizonte: Del Rey; San Paoblo: Fundacíon de Derecho Administrativo, 2003. t. 2.

Tratado de derecho administrativo: la defensa del usuario y del administrado. 5. ed. Belo Horizonte: Del Rey; San Paoblo: Fundacíon de Derecho Administrativo. 2003. t. 2.

Tratado de derecho administrativo: parte general. 7. ed. Belo Horizonte: Del Rey; San Paoblo: Fundacíon de Derecho Administrativo, 2003. t. 1.

GOUGH, J. W. A separação de poderes e a soberania. In: SADEK, Maria Tereza; QUIRINO, Célia Galvão (Orgs.). O pensamento político clássico: Maquiavel, Hobbes, Locke, Montesquieu, Rousseau. 2. ed. São Paulo: Martins Fontes, 2003. p. 219-244.

GOYET, Francisque. Le ministère public en matière civile et en matière répressive et l'exercise de l'action publique. 3. ed. Paris: Sirey, 1953. 
GRINOVER, Ada Pellegrini. A ação popular portuguesa: uma análise comparativa. In: . A marcha do processo. Rio de Janeiro: Forense, 2000. p. 48-61.

. A legislação brasileira em face do crime organizado. In: A marcha do processo. Rio de Janeiro: Forense, 2000. p. 87-99.

As provas ilícitas na Constituição. In: O processo em evolução. Rio de Janeiro: Forense Universitária. 1996. p. 45-53.

. O regime brasileiro das interceptações telefônicas. In: A marcha do processo. Rio de Janeiro: Forense, 2000. p. 100-118.

Significado social, político e jurídico da tutela dos interesses difusos. In:

A marcha do processo. Rio de Janeiro: Forense, 2000. p. 17-23.

; CINTRA, Antonio Carlos de Araújo; DINAMARCO, Candido R. Teoria geral do processo. 11. ed. rev. e atual. São Paulo: Malheiros Ed. 1995.

et al. Código Brasileiro de Defesa do Consumidor: comentado pelos autores do anteprojeto. 8. ed. Rio de Jeneiro: Forense Universitária, 2006.

GROETHYSEN, Bernard. Montesquieu: a razão construtiva. In: SADEK, Maria Tereza; QUIRINO, Célia Galvão (Orgs.). O pensamento político clássico: Maquiavel, Hobbes, Locke, Montesquieu, Rousseau. 2. ed. São Paulo: Martins Fontes, 2003. p. 341-356.

GUARNIERI, Carlo. Pubblico Ministero e sistema político. Padova: CEDAM, 1984.

HAMILTON, Alexander. The Judiciary Department. The Federalist Papers, New York, n. 78, p. 463-471, 2003.

HAURIOU, Maurice. Principios de derecho público y constitucional. Trad. Carlos Ruiz del Castilho. Granada: Editorial Comares, 2003.

La teoria de la institucion y de la fundacion. Trad. Arturo Enrique Sampay. Buenos Aires: Abeledo-Perrot, 1968.

HELLER, Hermann. Teoría del Estado. Trad. Luis Tóbio. 2. ed. México: Fondo de Cultura Económica, 1998.

HESSE, Konrad. Elementos de direito constitucional da República Federal da Alemanha. Trad. Luís Afonso Heck. 20. ed. Porto Alegre: Sergio Antonio Fabris, 1998. 
HOBBES, Thomas. Leviathan. London: Penguin Books, 1985.

HOLANDA, Sérgio Buarque de. Raízes do Brasil. 26. ed. São Paulo: Companhia das Letras, 1995.

IGLÉSIAS, Francisco. Momentos democráticos na trajetória brasileira. In: JAGUARIBE, Hélio et al. Brasil, sociedade democrática. Rio de Janeiro: José Olympio, 1985. p. 125221. (Coleção Documentos Brasileiros).

ITÁliA. Codice di Procedura Penale. Disponível em: <http://www.altalex/com/index.php/?idnot=2011>. Acesso em: 24 nov. 2008.

- Costituzione della Repubblica Italiana. Disponível em: $<$ http://www.edscuola.it/archivio/norme/leggi/costituzione.html>. Acesso em: 24 nov. 2008.

JELLINEK, Georg. Teoría general del Estado. Trad. Fernando de los Rios. México: FCE, 2000.

JHERING, Rudolf von. A finalidade do direito. Trad. Heder K. Hoffmann. Campinas: Bookseller, 2002. t. 1.

KANT, Immanuel. Fundamentação da metafísica dos costumes. Trad. Paulo Quintela. Lisboa: Ed. 70; LDA, 2004.

KAUFMANN, Arthur. Filosofia do direito. 2. ed. Trad. António Ulisses Côrtes. Lisboa: Fundação Calouste Gulbenkian, 2007.

KELSEN, Hans. Teoria pura do direito. Trad. João Batista Machado. 3. ed. São Paulo: Martins Fontes, 1991.

KERCHE, Fábio. Controle democrático e o sistema judicial: o Ministério Público brasileiro em perspectiva comparada. Associação Brasileira de Ciência Política. Niterói, 2002. Disponível em: <http://www.cienciapolitica.org.br/encontro/instpoll.3.doc>. Acesso em: 24 nov. 2008.

KRIELE, Martin. Introdução à teoria do Estado: os fundamentos históricos da legitimidade do Estado constitucional democrático. Trad. Urbano Cervelli. Porto Alegre: Sergio Antonio Fabris, 2009. 
LAFER, Celso. A reconstrução dos direitos humanos: um diálogo com o pensamento de Hannah Arendt. São Paulo: Companhia das Letras, 2001.

LASLETT, Peter. A teoria social e política dos "Dois tratados sobre o governo". In: SADEK, Maria Tereza; QUIRINO, Célia Galvão (orgs.). O pensamento político clássico: Maquiavel, Hobbes, Locke, Montesquieu, Rousseau. 2. ed. São Paulo: Martins Fontes, 2003. p. 245-278.

LEAL, Victor Nunes. Coronelismo, enxada e voto: o município e o regime representativo no Brasil. 3. ed. Rio de Janeiro: Nova Fronteira, 1997.

LIMONGI, Fernando Papaterra. "O Federalista": remédios republicanos para males republicanos. In: WEFFORT, Francisco C. (Org.). Os clássicos da política: Maquiavel, Hobbes, Locke, Montesquieu, Rousseau, “O Federalista”. 13. ed. São Paulo: Ática, 2004. v. 1, p. $243-255$.

LOCKE, John. Segundo tratado sobre o governo. In: Dois tratados sobre o governo. Trad. Julio Fischer. 2. ed. São Paulo: Martins Fontes, 2005. p. 377-601.

LOEWENSTEIN, Karl. The governance of Rome. Netherlands: Martinus Nijhoff, The Hague, 1973.

. Teoria de la Constitucion. 2. ed. Barcelona: Ariel, 1976.

LYRA, Roberto. Theoria e pratica da promotoria pública. Rio de Janeiro: Jacintho, 1937.

MACEDO JÚNIOR, Ronaldo Porto. Carl Schmitt e a fundamentação do direito. São Paulo: Max Limonad, 2001.

Ministério Público brasileiro: um novo ator político: o Ministério Público e as organizações não governamentais sem fins lucrativos: estratégias para o futuro. In: VIGLIAR, José Marcelo Menezes; MACEDO JR., Ronaldo Porto (Coords.). Ministério Público II: democracia. São Paulo: Atlas, 1999. p. 103-114.

O quarto poder e o terceiro setor: o Ministério Público e as organizações não governamentais sem fins lucrativos: estratégias para o futuro. In: VIGLIAR, José Marcelo Menezes; MACEDO JR., Ronaldo Porto (Coords.). Ministério Público II: democracia. São Paulo: Atlas, 1999. p. 248-263. 
MACEDO JÚNIOR, Ronaldo Porto. Vinculatividade dos planos de atuação do Ministério Público. In: VIGLIAR, José Marcelo Menezes; MACEDO JR., Ronaldo Porto (Coords.). Ministério Público II: democracia. São Paulo: Atlas, 1999. p. 130-138.

MACHADO, J. Baptista. Participação e descentralização democratização e neutralidade na Constituição de 76. Coimbra: Almedina, 1982.

MADISON, James. The structure of the government must furnish the proper checks and balances between the different departments. The Federalist Papers, New York, n. 51, p. 317-322, 2003.

. The union as a safeguard against domestic faction and insurrection. The Federalist Papers, New York, n. 10, p. 71-79, 2003.

MÁRTENS, João Baptista Ferrão de Carvalho. O Ministério Público e a ProcuradoriaGeral da Coroa e da Fazenda: história, natureza e fins. Boletim do Ministério da Justiça, n. 233, p. 5-33, fev. 1974.

MARTINELLI, Jaqueline Lorenzetti et al. Promotoria comunitária: a experiência do júri de Santo Amaro. In: CONGRESSO DO MINISTÉRIO PÚBLICO DO ESTADO DE SÃO PAUlO, 3., 2005, São Paulo. Anais... São Paulo: Páginas \& Letras Ed., 2006. v. 2, p. 989 998.

MARUM, Jorge Alberto de Oliveira. Ministério Público Eleitoral. In: VIGLIAR, José Marcelo Menezes; MACEDO JR., Ronaldo Porto (Coords.). Ministério Público II: democracia. São Paulo: Atlas, 1999. p. 150-176.

MASSACHESETTS (USA). Constitution of the Commonwealth of Massachusetts. Disponível em: <http://www.mass.gov/legis/const.htm>. Acesso em: 18 nov. 2008.

MAZZILLI, Hugo Nigro. Regime jurídico do Ministério Público. 6. ed. São Paulo: Saraiva, 2007.

MCILWAIN, Charles Howard. Constitucionalism: ancient and modern. Ithaca, New York: Cornell University Press, 1940.

MELlo, Celso Antonio Bandeira de. Curso de direito administrativo. 18. ed. São Paulo: Malheiros Ed., 2005. 
MELLO, Celso Antonio Bandeira de. Discricionariedade e controle jurisdicional. 2. ed. São Paulo: Malheiros Ed., 1996.

MONTESQUIEU, Charles de. De l'esprit des lois. Paris: Gallimard, 2003. t. 1 e 2.

MURA, Virgilio. Diritti dell'uomo e diritti del cittadino. In: TARANTINO, Antonio (a cura di). Filosofia e politica dei diritti umani nel terzo millennio: atti del V Congresso dei Filosofi Politici Italiani, Lecce, 13-14-15, apr. 2000. Milano: Giuffrè, 2003. p. 17-43.

NABUCO, Joaquim. O abolicionismo. Brasília: Ed. da UnB, 2003.

NERY JUNIOR, Nelson. Defesa do patrimônio público em juízo - o sistema do processo coletivo e o interesse público. In: SUNDFELD, Carlos Ari; BUENO, Cássio Scarpinella (Coords.). Direito processual público: a Fazenda Pública em juízo. São Paulo: Malheiros Ed., 2000. p. 252-263.

Princípios do proceso civil na Constituição Federal. 4. ed. São Paulo: Ed. Revista dos Tribunais, 1997.

ORTEGA Y GASSET, José. Obras completas. (1926-1931). Fundación José Ortega y Gasset, 2005. t. 4.

PASSOS, Joaquim José Calmon de. Democracia, participação e processo. In: GRINOVER, Ada Pellegrini et al. (coords.). Participação e processo. São Paulo: Ed. Revista dos Tribunais, 1988. p. 83-97.

PEREZ LUÑO, Antonio Enrique. Derechos humanos, Estado de derecho y Constitución. 6. ed. Madrid: Tecnos, 1999.

PIOVESAN, Flavia. Direitos humanos e o direito constitucional internacional. 5. ed. São Paulo: Max Limonad, 2002.

POCOCK, J. G. A. Linguagens do ideário político. São Paulo: Ed. da Universidade de São Paulo, 2003.

. 1776: a Revolução contra o Parlamento. In: . Linguagens do ideário político. São Paulo: Ed. da Universidade de São Paulo, 2003.

PRADO JUNIOR, Caio. Formação do Brasil contemporâneo: Colônia. 23. ed. São Paulo: Brasiliense, 2007. 
PRIETO SANCHÍS, Luis. El constitucionalismo de los derechos. In: CARBONELL, Miguel (Ed.). Teoría del neoconstitucionalismo: o ensayos escogidos. Madrid: Editorial Trotta; Instituto de Investigaciones Jurídicas - UNAM, 2007. p. 213-235.

. Neoconstitucionalismo y ponderacíon judicial. In: CARBONELL, Miguel (Ed.). Neoconstitucionalismo(s). 2. ed. Madrid: Trotta, 2005. p. 123-158.

RASSAT, Michele-Laure. Le ministère public entre son passé et son avenir. Paris: Librairie Générale de Droit et de Jurisprudence, 1967.

REALE, Miguel. Teoria do direito e do Estado. 5. ed. São Paulo: Saraiva, 2000.

RECASENS SICHES, Luis. Filosofía del derecho. 19. ed. Mexico: Editorial Porrúa, 2008.

ROCHA, Carmem Lúcia Antunes. Ação afirmativa: conteúdo democrático do princípio da igualdade jurídica. Revista Trimestral de Direito Público, São Paulo, n. 15, p. 85-99, 1996.

ROUSSEAU, Jean-Jacques. Du contrat social. Paris: Gallimard, 2002.

SACCO, Ricardo Ferreira. Constitucionalismo e Ministério Público: uma visão panorâmica. Belo Horizonte: Mandamentos, FHC/FUMEC, 2008.

SADEK, Maria Tereza. Cidadania e Ministério Público. In: SADEK, Maria Tereza (Org.). Justiça e cidadania no Brasil. São Paulo: Ed. Sumaré, 2000. p. 11-37.

. Judiciário: mudanças nem sempre à vista Brasil o que resta fazer? Rio de Janeiro: Fundação Konrad Adenauer, set. 2006. p. 139-155. (Caderno Adenauer VII, n. 3).

SALGADO, J. A. César. O Ministério Público e os atributos de sua dignidade. Justitia, São Paulo, v. 60, n. esp. (60 anos: 1939-1999), p. 877-885, 1999.

SALLES, Carlos Alberto. Entre a razão e a utopia: a formação histórica do Ministério Público. In: VIGLIAR, José Marcelo Menezes; MACEDO JR., Ronaldo Porto (Coords.). Ministério Público II: democracia. São Paulo: Atlas, 1999. p. 13-43.

SANCHES FILHO, Alvino Oliveira. Ministério Público e controle externo da polícia na Bahia. In: SADEK, Maria Tereza (Org.). Justiça e cidadania no Brasil. São Paulo: Ed. Sumaré, 2000. p. 185-208.

SÁNCHEZ MORÓN, Miguel. Discrecionalidad admnistrativa y control judicial. Madrid: Editorial Tecnos, 1994. 
SANTIAGO NINO, Carlos. Derecho, moral y política. II. Fundamentos del liberalismo político. Derechos humanos y democracia deliberativa. Buenos Aires: Gedisa, 2007.

SANTOS, Boaventura de Souza. A crítica da razão indolente: contra o desperdício da experiência. 4. ed. São Paulo: Cortez, 2002. v. 1.

SANTOS, Wanderley Guilherme dos. O ex-Leviatã brasileiro: do voto disperso ao clientelismo concentrado. Rio de Janeiro: Civilização Brasileira, 2006.

SARLET, Ingo Wolfgang. A eficácia dos direitos fundamentais. 3. ed. Porto Alegre: Livr. do Advogado, 2003.

SCHMITT, Carl. La defensa de la Constitución. Trad. Manuel Sanches Sarto. 2. ed. Madrid: Tecnos, 1998.

. Teoría de la Constitución. Trad. Francisco Ayala. Madrid: Alianza Editorial, 2003.

SIEYÈS, Emmanuel-Joseph. Qu'est-ce que le tiers État? Paris: Au Siège de la Société, 1888 .

SILVA, José Afonso da. Comentário contextual à Constituição. São Paulo: Malheiros Ed., 2005 .

SKINNER, Quentin. As fundações do pensamento político moderno. Trad. Renato Janine Ribeiro e Laura Teixeira Motta. São Paulo: Companhia das Letras, 1996.

SKOCPOL, Theda. Bringing the State back in: strategies of analysis in current research: ntroduction. In: EVANS, Peter B. RUESCHEMEYER, Dietrich; SKOCPOL, Theda (Eds.). Bringing the State back in. Cambridge: Cambridge University Press. 1998. p. 3-37.

SMEND, Rudolf. Costituzione e diritto costituzionale. Trad. F. Fiore e J. Luther. Milano: Giuffrè, 1988.

SOLON, Ari Marcelo. Teoria da soberania como problema da norma jurídica e da decisão. Porto Alegre: Sergio Antonio Fabris, 1997.

SOUZA, Jessé. A construção social da subcidadania: para uma sociologia política da modernidade periférica. Belo Horizonte: Ed. UFMG, 2003. 
STERN, Klaus. Derecho del Estado e la Republica Federal Alemana. Trad. Javier Perez Royo y Pedro Cruz Villalón. Madrid: Centro de Estudios Constitucionales, 1987.

SUNDFELD, Carlos Ari. Motivação dos atos administrativos como garantia dos administrados. Revista de Direito Público, São Paulo, v. 18, n. 75, p. 118-127, jul./set. 1985.

SWERDBERG, Richard. Max Weber e a idéia de solciologia económica. Trad. Dinah Abreu Azevedo. Rio de Janeiro: Ed. UFRJ; São Paulo: Beca Produções Culturais, 2005.

TÁCITO, Caio. Poder de polícia e seus limites. In: Temas de direito público (estudos e pareceres. Renovar, 1997. v. 1, p. 521-534.

- Poder de polícia e polícia do poder. In: Temas de direito público (estudos e pareceres. Renovar, 1997. v. 1, p. 545-555.

TAYLOR, C. C. W. Politics. In: BARNES, Jonathan (Ed.). The Cambridge companion to Aristotle. New York: Cambridge University Press, 2006. p. 233-258.

THELEN, Kathleen; STEINNO, Sven. Historical institutionalism in comparative politcs. In: (Eds.). Structurin politcs historical institutionalism in comparative politcs. Cambridge: Cambridge University Press, 1992. Reprinted 1998. p. 1-32.

TOCQUEVILLE, Alexis de. A democracia na América (1835). In: Igualdade social e liberdade política: uma introdução à obra de Alexis de Tocqueville. Trad. Cícero Araújo. São Paulo: Nerman, 1998. p. 31-65.

TOURINHO, Rita. O controle jurisdicional da promoção por merecimento do membro do Ministério Público. In: CONGRESSO NACIONAL DO MINISTÉRIO PÚBLICO. MINISTÉRIO PÚBLICO E JUSTIÇA SOCIAL, 16., 6-9 nov. 2005. Anais... Belo Horizonte: CONANP - Associação Nacional dos Membros do Ministério Público. Associação Mineira do Ministério Público - AMMP, 2005.

VALADÉS, Diogo. Constitución y control político. In: CARBONELL, Miguel (Comp.). Teoria de la Constitución: ensayos escogidos. 4. ed. México: Editorial Porrúa y Universidad Autónoma de Mexico, 2008. p. 343-370. 
VERNIÈRE, Paul. Dois planos e duas leituras. In: SADEK, Maria Tereza; QUIRINO, Célia Galvão (Orgs.). O pensamento político clássico: Maquiavel, Hobbes, Locke, Montesquieu, Rousseau. 2. ed. São Paulo: Martins Fontes, 2003. p. 357-409.

VIRGINIA (USA). Constitution of Virginia. Disponível em: <http://legis.state.va.us/laws/search/constitution.htm>. Acesso em: 18 nov. 2008.

. The Constitution of Virginia, June 291 (1), 1776. Disponível em: <http://www.nhinet.org/ccs/docs/va-1776.htm>. Acesso em: 18 nov. 2008.

WATANABE, Kazuo et al. Código Brasileiro de Defesa do Consumidor: comentado pelos autores do anteprojeto. 7. ed. Rio de Janeiro: Forense Universitária, 2001.

WEBER, Max. A política como vocação. In: Ciência e política: duas vocações. Trad. Leônidas Hegenberg e Octany Silveira da Mota. 19. ed. São Paulo: Cultrix, 2000. p. 54124.

ZAGREBELSKY, Gustavo. El derecho dúctil: ley, derechos, justicia. Trad. Marina Gascón. 8. ed. Madrid: Trotta, 2008.

. Jueces constitucionales. In: CARBONELL, Miguel (Ed.). Teoría del neoconstitucionalismo: o ensayos escogidos. Madrid: Editorial Trotta; Instituto de Investigaciones Jurídicas - UNAM, 2007. p. 91-104.

ZANON, Nicolò. Pubblico Ministero e Costituzione. Padova: CEDAM, 1996.

ZOLO, Danilo. Teoria e crítica do Estado de direito. In: COSTA, Pietro; ZOLO, Danilo (Orgs.). O Estado de direito: história, teoria, critica. Tradução de Carlos Alberto Dastoli, São Paulo: Martins Fontes, 2006. p. 3-94. 